\title{
MASTER
}

\section{Progress Report 12}

for the Period January 1979 to April 1979

\section{and Proceedings of the \\ 12th Project Integration Meeting}

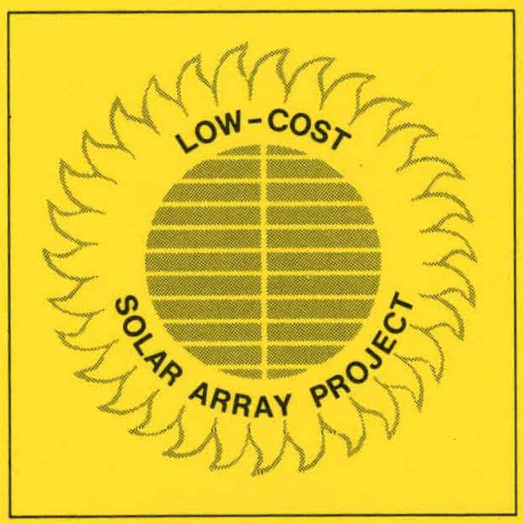

Piepared tor

U.S. Department of Energy

Through an agreement with

National Aeronautics and Space Administration

by

Jet Propulsion Laboratory

California Institute of Technology

Pasadena, California 


\section{DISCLAIMER}

This report was prepared as an account of work sponsored by an agency of the United States Government. Neither the United States Government nor any agency Thereof, nor any of their employees, makes any warranty, express or implied, or assumes any legal liability or responsibility for the accuracy, completeness, or usefulness of any information, apparatus, product, or process disclosed, or represents that its use would not infringe privately owned rights. Reference herein to any specific commercial product, process, or service by trade name, trademark, manufacturer, or otherwise does not necessarily constitute or imply its endorsement, recommendation, or favoring by the United States Government or any agency thereof. The views and opinions of authors expressed herein do not necessarily state or reflect those of the United States Government or any agency thereof. 


\section{DISCLAIMER}

Portions of this document may be illegible in electronic image products. Images are produced from the best available original document. 


\section{Progress Report 12}

for the Period Januariy 1979 to April 1979

\section{and Proceedings of the 12th Project Integration Meeting}
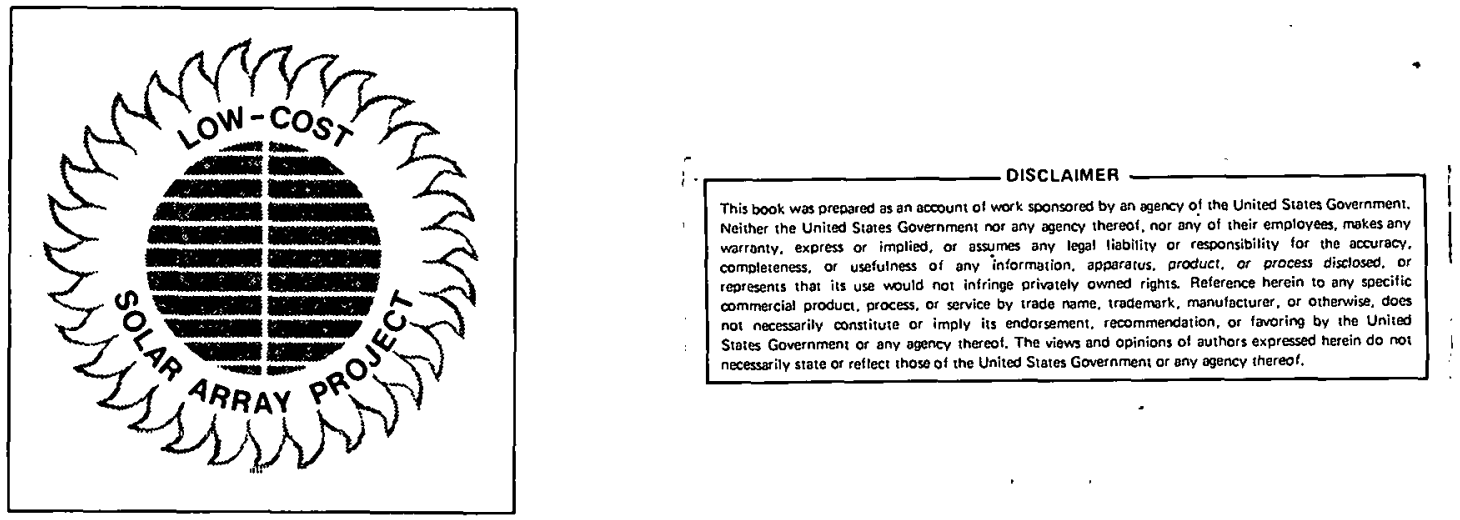

Prepared tor

U.S. Department of Energy

Through an agreement with

National Aeronautics and Space Administration

by

Jet Propulsion Láboratory

Califorria Inislitute of Technology

Pasadena, California 
Prepared by the Jet Propulsion Laboratory, California Institute of Technology, for the Department of Energy through an agreement with the National Aeronautics and Space Administration.

1

The JPL Low-Cost Solar Array Project is sponsored by the Department of Energy (DOE) and forms part of the Solar Photovoltaic Conversion Program to initiate a major effort toward the development of low-cost solar arrays.

- This report was prepared as an account of work sponsored by the United States Government. Neither the United States nor the United States Department of Energy, nor any of their employees, nor any of their contractors, subcontractors, or their employees, makes any warranty, express or implied, or assumes any legal liability or responsibility for the accuracy, completeness or usefulness of any information, apparatus, product or process disclosed, or represents that its use would not infringe privately owned rights. 


\section{ABSTRACT}

This report describes progress made by the Low-Cost Solar Array Project during the period January through April 1978. It includes reports on project analysis and integration; technology development in silicon material, large-area sheet silicon, and encapsulation; production process and equipment development; engineering and operations, and a discussion of the steps taken to integrate these efforts. It includes a report on, and copies of viewgraphs presented at, the Project Integration Meeting held April 4-5, 1979. 
THIS PAGE

\section{WAS INTENTIONALLY \\ LEFT BLANK}




\section{ABBREVIATIONS AND TERMS}

AR

BSF

B-T

$\mathrm{B}-\mathrm{T}-\mathrm{H}$

CLF

CSA

CVD

$\mathrm{CZ}$

DCF

DLTS

DS/RMS

EB

EFG

EPR

EPSDU

E3B

EVA

FPUP

GRC

HEM

IPEG

$I_{8 \mathrm{C}}$

$\mathrm{I}-\mathrm{V}$
Antireflective

Back-surface field

$\mathrm{Bias} /$ temperature

Bias/temperature/humidity

Continuous liquid feed

Department of Energy Office of Conservation and Eolar Applicationo

Chemical vapor deposition

Czochralski (classical silicon crystal growth method)

Discounted cash flow

Deep-level transient spectroscopy

Directionally solidified/refined metallurgical silicon

Electron beam

Edge-defined film-fed growth (silicon ribbon growth method)

Ethylene propylene rubber

Experimental process system development unit

Electrostatic bonding

Ethylene vinyl acetate

Federal Photovoltaics Utilization Program

Glass-reinforced concrete

Heat exchanger method (silicon crystal ingot growth method)

Interim Price Estimation Guidelines

Short-circuit current

Current-voltage 


\begin{tabular}{|c|c|}
\hline LAPSS & Large-area pulsed solar simulator \\
\hline LCP & Lifetime cost and performance \\
\hline LSA & Low-Cost Solar Array \\
\hline MBS & Multiblade sawing \\
\hline MWS & Multiwire sawing \\
\hline NDE & Nondestructive evaluation \\
\hline NOCT & Nominal operating cell temperature \\
\hline PDU & Process development unit \\
\hline $\mathrm{P} / \mathrm{FR}$ & Problem/failure report \\
\hline PIM & Project Integration Meeting \\
\hline PMMA & Polyme thylmethacrylate \\
\hline$P_{\max }$ & Maximum power \\
\hline ppba & Parts per billion atoms \\
\hline ppma & Parts per million atoms \\
\hline PRDA & Program Research and Development Announcement \\
\hline PVB & Polyvinyl butyral \\
\hline$\underline{P V C}$ & Polyvinyl chloride. \\
\hline RFP & Request for propnent \\
\hline $\mathrm{RFQ}$ & Request for quotation \\
\hline KMS & Refined metallurgical-grade silicon \\
\hline RTR & $\begin{array}{l}\text { Ribbon-to-ribbon (silicon crystal growth } \\
\text { melhod) }\end{array}$ \\
\hline SAMICS & $\begin{array}{l}\text { Solar Array Malufacturing Industry Costing } \\
\text { Standardo }\end{array}$ \\
\hline SAMIS & Solar Array Manufacturing Industry Simulation \\
\hline SERI & Solar Energy Research Institute \\
\hline soc & Silicon on ceramic (crystal growth method) \\
\hline TD\&A Lead Center & $\begin{array}{l}\text { Photovoltaics Program Technology Development } \\
\text { and Applications Lead Center }\end{array}$ \\
\hline
\end{tabular}




\section{CONTENTS}

I. PROJECT SUMMARY - 1

A. INTRODUCTION - 1 -

B. OVERVIEW -

II. AREA REPORTS -

A. PROJECT ANALYSIS AND INTEGRATION AREA - 2-1

1. Planning and Integration

2. Array Technology Cost Analysis - 2-1

3. Economics and Industrialization

B. TECHNOLOGY DEVELOPMENT AREA - 2-2

1. Silicon Material Task - 2-2

2. Large Area Silicon Sheet Task - 2-13

3. Encapsulation Task - 24

C. PRODUCTION PROCESS AND EQUIPMENT AREA -

1. Process Sequence Development - 2-35

2. Junction Formation - 2-33

3. Metallization - 2-35

4. Surface Preparation - 2-36

5. Assembly and Test $2-38$

6. Module Development

7. Advanced Equipment Development - 2-38

D. ENGINEERING AREA - 2-43

1. Array Design/Engineering - 2-43

2. Reliability-Durability Requirements - 
3. Array Standards and Specifications $2-44$

E. OPERATIONS AREA - 2-44

1. Large Scale Production Task

2. Module Test and Evaluation - 2-43

III. PIM REPORT - 3-1

A. INTRODUCTION -- 3-1

B. THEME TOPICS -

1. Ingot Technology - 3-2

2. Refractory Materials Studies - 3-3

3. Material Characterization

4. Shaped-Sheet Technology -

C. PRESENTATIONS - 3-5

1. Project Analysis and Integration Area -- 3-5.

2. Technology Development Area - 3-20

a. Silicon Material Task - 3-20

b. Large-Area Silicon Sheet Task-_..

c. Encapsulation Task

3. Production Process and Equipment Area -

4. Engineering Area - 3-229

5. Operations Area - 3-276

Figures

2-1. Edge-Defined Film-Fed Growth - 2-17

2-2. Laser Zone Regrowth - 2-17

2-3. Schematic Section of Web Growth - 2-18 
2-4. Crystal Growth Using the Heat Exchanger Method

2-5. Continuous CZ Crystal Growth Machines -- 2-20

2-6. Production Process and Equipment Area Schedule ----- 2-32

2-7. Increase in Short-Circuit Current After Cel1 Processing With RCA's Anti-Reflective Coating ------ 2-37

2-8. Distribution of Short-Circuit Current vs Film Thickness - 2-37

2-9. ARCO Solar Module Design - 2-39

2-10. ARCO Solar Cell Assembly Prototype -

2-11. ARCO Solar Module Lamination Prototype -------- 2-41

2-12. Kulicke and Soffa's Machine Concept for Assembly of Solar Modules by Solder Interconnection----- 2-42

$\underline{\text { Tables }}$

2-1. Organization of the Silicon Material Task Effort --- 2-3

2-2. Silicon Material Task Contractors - 2-5

2-3. Large-Area Silicon Sheet Task Contractors ------- 2-14

2-4. Production Process and Equipment Area

Contractors - 2-33

2-5. Summary of P/FR Activity.- 2-48 


\section{SECTION I}

PROJECT SUMMARY

\section{A. INTRODUCTION}

This report describes the activities of the Low-Cost Solar Array Project during the period December 1978 through March 1979, including the 12th LSA Project Integration Meeting (PIM) held April 4-5, 1979.

The LSA Project is assigned responsibility for advancing solar array technology while encouraging industry to reduce the price of arrays to a level at which photovoltaic electric power systems will be competitive with more conventional power sources early in the next decade. Set forth here are the goals and plans will which the Project intends to accomplish this, and the progress that has been made during the period.

The Project objective is to develop the national capability to produce low-cost, long-life photovoltaic modules at a rate greater than $500 \mathrm{MW} / \mathrm{yr}$ and at a price of less than $\$ 500$ (in 1975 dollars) per peak kilowatt by 1986 . The array performance goals include an efficiency greater than $10 \%$ and an operating lifetime in excess of 20 years.

\section{B. OVERVIEW}

In the analysis and integration area, the Solar Array Manufacturing Industry Costing Standards (SAMICS) methodology was applied to several contractor production processes in support of Production Process and Equipment Area activities. Review of the SAMICS indirect requirements matrix was initiated, also in cooperation with PP\&E. A major presentation was made at Department of Energy describing SAMICS. Later, at the 12th Project Integration Meeting, projections of potential module prices for the late 1980 s and late 1990 s were shown (see Section III). The results of the first verification runs of the lifetime Cost and Yerformance (LCP) model were also presented at the PIM.

The planning and costing of Battelle Memorial Institute's process development unit was carried out for its fabrication, procurement, installation, startup and developmental operation. Union Carbide's process design-phase activities concluded during this reporting period, and contract negotiations began for the $100 \mathrm{MT} / \mathrm{yr}$ experimental process support development unit phase. Union Carbide's free-space reactor was operated at five times the design output rate to produce about $30 \mathrm{~kg}$ of $\mathrm{Si}$ powder, which was two to three times as dense as powder produced at the design output rate. Impurity levels were less than $10 \mathrm{ppba}$. Westinghouse's arc heater equipment for the reduction of $\mathrm{SiCl}_{4}$ by $\mathrm{Na}$ neared completion, and shakedown tests at 
reduced power levels were successful. At the end of the reporting period, work was stopped because of cost overruns and efforts were being made to fund the program to completion. The final report on J.C. Schumacher's investigation into the production of $\mathrm{Si}$ from bromosilanes indicated that two closed-1oop $\mathrm{SiHBr}_{3}$ processes demonstrated by laboratory-scale experiments were feasible. The Schumacher contract lapsed in February due to lack of available funds.

In ingot technology, Kayex Corporation (Hamco) completed its chunk silicon feeder and a 100-kg multiple ingot run using a $30 \mathrm{~cm}$ dia. crucible was made. Ingot diameter was $12 \mathrm{~cm}$, with an average growth rate of $8 \mathrm{~cm} / \mathrm{h}$. Loss of crystal structure remains a problem. A melt transfer/crystal-growth run was attempted by Siltec Corp., yielding ingots of $21 \mathrm{~kg}$ to $70 \mathrm{~kg}$. Maximum growth rate achieved was $1.29 \mathrm{~kg} / \mathrm{h}$.

In shaped sheet investigations, Mobil Tyco's EFG process was modified to achieve a greater width of $10 \mathrm{~cm}$ at a slower speed of 5 $\mathrm{cm} / \mathrm{h}$ than in previous demonstrations. Westinghouse, using its web dendritic approach, made more than 40 experimental growth runs, demonstrating a throughput of $22 \mathrm{~cm} / \mathrm{min}$. Melt replenishment, with simultaneous web growth, was used for a period of more than one hour. Motorola obtained significant improvements in material quality in 7.5 $\mathrm{cm}$ wide ribbons using the RTR process. Solar cell efficiencies of $>10 \%$ at AMl with areas of $>1 \mathrm{~cm}^{2}$ were achieved.

Candidate encapsulation material systems and fabrication processes having the potential of meeting the Project cost, performance and lifetime goals have been identified, and during this period intensive experimental evaluation and system development was begun. A 12 in $x 16$ in minimodule effort will examine the effectiveness of a large variety of materials in many component combinations. Materials and processes that were the subject of major special investigations included ethylene/vinyl acetate, electrostatic bonding, silicone-based materials, glass-reinforced concrete, and antireflective coatings.

In junction formation, Sensor Technology demonstrated the ability of spray-on doping techniques to produce both boron- and phosphorus-doped junctions. Spire Corp. has determined reproducible and uniform beam parameters intended for post-inn-implantation electron-beam annealing of $7.6-\mathrm{cm}$ dia. wafers with a single pulse. Westinghouse reports that most consistent back-surface field result.s have been achieved by sputtering deposition of aluminum.

Kinetic Coatings, Inc., and Spectrolab, Inc., have optimized or defined process sequences they are developing, and a contract was awarded to Sensor Technology to establish a processing sequence for polysilicon cells.

Bernd Ross Associates has compounded fritless inks to produce metal contacts using base metals or base metal dilutions or noble 
metals, and OCLI is continuing investigation of the use of copper in contact formation. Sol/Los, Inc., investigated a metallization system that will produce a molybdenum-tin contact. Westinghouse has found deterioration in all properties when an electroless palladium-nicke1conductive layer is substituted for the standard titanium-palladiumsilver system.

In surface preparation, Motorola has constructed a module made entirely of cells whose front-surface ohmic contact grid pattern was etched through the silicon nitride dielectric by plasma technique through a mechanical mask.

OCLI is in the process of developing a $p-o n-n, 14 \%$ efficient module. Most recently, $15.6 \%$ efficient cells have been reported. ARCO Solar is designing machines that will solder interconnects at a rate of 12 per minute and produce 12 laminaces per huik. A final design review has been completed of OCLI's four-fold tooling, which provides semi-automation of the antireflective coating application, cell testing, back contact soldering, and vacuum pick-up.

During this reporting period, $44.4 \mathrm{~kW}$ of photovoltaic modules were shipped to JPL under Block III procurement. This represented $89 \%$ of the contracted total of $214 \mathrm{~kW}$, and completed the requirement for three of the five manufacturers contributing to the procurement. Proposals for the Block IV module design contracts were evaluated and negotiations with eight potential contractors were begun. Most testing done during this period was on flat-plate PRDA-38 modules. Significant findings were that 1) most modules showed excellent hailstone survivability and 2) hipot tests during environmental exposure showed a high incidence of failure of electrical resistance to ground. Reference cells were delivered to the PRDA test program at JPL and MIT/LL. Testing during this period resulted in a modification of test procedures using reference cells. JPL assumed responsibility this period for 12 module test sites originally established by Lewis Research Center. These sites, located in diverse locations between Alaska and Panama, will be the subject of visits and an updated test plan by JPL personnel. 


\section{SECTION II}

AREA REPORTS

\section{A. PROJECT ANALYSIS AND INTEGRATION}

\section{Planning and Integration}

A critique of, and response to, the American Physical Society's report on photovoltaics was submitted to Project management and to the Technology Development and Applications Lead Center. This 'was combined with the Lead Center's response and forwarded to the APS and DOE. As a result, a dialogue has developed between LSA, Lead Center, DOE and APS that should be very helpful in dispelling misconceptions and keeping all parties informed.

Support of the Lead Center continued with reviews of the supplyside economic assessment implementation plan and contributions to the Program planning and integration plans as well as the Multiyear Program Plan. In addition, LSA contributed support to the Lead Center in the effort to develop a system-level price allocation methodology and breakdown structure for Program-wide application.

The Project Analysis and Integration area has been exploring ways to aid Project management in decision-making by applying some decision analysis methods to the LSA planning process. The application of these methods shows promise for clarifying Project goals and identifying appropriate action to attain those goals.

\section{Array Technology Cost Analysis}

The SAMICS methodology was applied to the evaluation of several contractor production processes in support of Production Processes and Equipment Area activities. Several runs were made on CdS processes in connection with discussions at JPL with a CdS module manufacturer.

A major presentation was made at DOE describing the EAMICS methodology, validation and working experience. Although the stated purpose of the presentation was a SAMICS methodology review, the subject shifted to several other items including the credibility of the $\$ 0.50 /$ Wp strawman candidate factory.

A review of the SAMICS indirect requirements matrix was initiated and is continuing in close cooperation with the Production Processes and Equipment Area. The results of this review will be more realistic algorithms for computing indirect requirements.

The development of a replacement algorithm for IPEG was initiated. The new algorithm should permit greater flexibility in calculating rough estimates of product prices. 
Projections of potential module prices for the late 1980 s and late 1990s were presented at the 12 th Project Integration Meeting and are shown in the PA\&I section of the PIM portion of this report. These prices were not SAMICS analyses, but were based on estimates of what would be possible in that time frame.

A revised SAMICS Input Data Preparation document has been issued. It contains examples of excellent Format A preparation and a checklist of items to consider in Format A preparation.

\section{Economics and Industrialization}

The results of the first verification runs of the lifetime cost and performance (LCP) model were presented at the 12th Project. Integration Meeting. Viewgraphs of this presentation are included in the PIM section of this report. The I.C.P model developmont wnn initiated in the LSA Project and is now being developed jointly by LSA Project and the Lead Center.

Documents of interest published during this reporting period include the Gnostics Concepts, Inc., "Industrialization Study" final report and JPL Document 5101-102, "Energy Systems Economic Analysis (ESEA) Methodology and Users Guide." The latter describes a computer program that has been developed for the rank ordering of alternative energy systems in terms of cost.

\section{B. TECHNOLOGY DEVELOPMENT AREA \\ 1. Silicon Material Task}

The objective of the Silicon Material Task is to establish by 1986 an installed plant capability of producing silicon ( $\mathrm{Si}$ ) suitable for solar cells at a rate pquivalent to $500 \mathrm{MWp}$ of oolar arrays per year and at a price of less than $\$ 10 / \mathrm{kg}$ (1975 dollars; $\$ 14 / \mathrm{kg}$ in 1980 dollars). One means of meeting this requirement is to devise a process for producing $\mathrm{Si}$ material that is less pure than semiconductor-grade $\mathrm{Si}$ material.

a. Technical Goals. Solar cells are presently fabricated from semiconductor-grade $\mathrm{Si}$, which has a market price of about $\$ 65 / \mathrm{kg}$. A drastic reduction in the price of material is necessary to meet the economic objectives of the T.SA Project. One meano for meeting this requirement is to devise a process for producing $\mathrm{Si}$ material that is less pure than semiconductor-grade Si. However, the allowance for the cost of $\mathrm{Si}$ material in the overall economics of the solar arrays for the Project is dependent on optimization trade-offs, which roncomitantly treat the price of $3 i$ material and the effects of material properties on the performance of solar cells. Accordingly, the program of the Silicon Material Task is structured to provide information for the optimization trade-offs concurrently with the development of high-volume, $1 \mathrm{ow}$-cost processes for producing $\mathrm{Si}$. 
b. Organization and Coordination. As Table 2-1 indicates, the Silicon Material Task effort is organized into four phases. Phase I. is divided into four parts. In Part I the technical feasibility and practicality of processes for producing semiconductor-grade $\mathrm{Si}$ are being demonstrated. In Part II the effects of impurities and of various processing procedures on the properties of single-crystal Si material and the performance characteristics of solar cells are being investigated. This body of information will serve as a guide in developing and assessing processes (in Part III) for the production of solar-cell-grade $\mathrm{Si}$. The process developments in

Table 2-1. Organization of the Silicon Material Task Effort

\begin{tabular}{|c|c|c|c|}
\hline$a$ & Phase/ & /Part & Objective \\
\hline & Phase & I & $\begin{array}{l}\text { Demonstrate the technical feasibility and } \\
\text { practicality of processes for producing } \mathrm{Si} \text {. }\end{array}$ \\
\hline & & Part I & $\begin{array}{l}\text { Establish the practicality of processes } \\
\text { capable of high-volume production of } \\
\text { semiconductor-grade Si. }\end{array}$ \\
\hline & & Part II & $\begin{array}{l}\text { Investigate the effects of impurities and } \\
\text { of various processing procedures on the } \\
\text { properties of single-crystal si material } \\
\text { and the performance characteristics of } \\
\text { solar cells. }\end{array}$ \\
\hline & & Part III & $\begin{array}{l}\text { Establish the practicality of processes } \\
\text { capable of high-volume production of } \\
\text { solar-cell-grade Si. }\end{array}$ \\
\hline & & Part IV & $\begin{array}{l}\text { Evaluate the relative commercial } \\
\text { potential of the Si-production processes } \\
\text { developed under Phase I. }\end{array}$ \\
\hline & Phase & II & Obtain process scale-up information. \\
\hline & Phase & III & $\begin{array}{l}\text { Conduct EPSDU operations to obtain technical } \\
\text { and economic evidence of large-scale production } \\
\text { potential. }\end{array}$ \\
\hline & Phase & IV & $\begin{array}{l}\text { Design, install, and operate a full-scale } \\
\text { comercial plant capable of meeting the } \\
\text { production objective. }\end{array}$ \\
\hline
\end{tabular}


Parts I and III are being accomplished through chemical reaction, chemical engineering, energy-use, and economic studies. In Part IV of Phase I, the relative commercial potentials of the various Si-production processes developed under Parts I and III are being evaluated. Thus, at the end of Phase I a body of information will have been obtained for optimization trade-off studies, and the most promising processes will have been selected.

Phase II is for obtaining process scale-up information. This is being derived from experiments and analyses involving mass and energy balances; process flows; kinetics; mass transfer; temperature and pressure effects, and operating controls. The basic approach is to provide fundamental scientific and engineering information from which valid extrapolations usable for plant design can be made; applicable scale-up correlations are also being used. This body of ecalc-up data will then provide the necessary basis for the design, construction, and operation of experimental prosese oyntem developinenl units (EPSDUs).

Since the installation and operation of a commercial chemical process plant that incorporates a new process involves high risks, EPSDUs will be used to obtain technical and economic evidence of large-scale production potential. In the EPSDU phase (i.e., Phase III) there will be opportunities to correct design errors, to determine energy consumption, to establish practical operating procedures and production conditions for process optimization and steady-state operation, and to evaluate more realistically the requirements for instrumentation, controls, and on-line analyses.

In the final phase of the Silicon Material Task (i.e., Phase IV), a full-scale commercial plant capable of meeting the production objective will be designed, installed, and operated. The EPSDU and the commercial plant will be operated concurrently for some time so as to permit the use of the EPSDU for investigations of plant operations; i.e., for problem-solving and for studies of process optimization.

Additional basic chemical and engineering investigations to respond to problem-solving needs of the Silicon Material Task are being conducted in supporting efforts. These supporting subtasks are accomplished under contract and by an in-house JPL program.

c. Silicon Material lask Contracts. Fifteen contracts are in progress and are listed in Table 2-2.

d. Silicon Material Task Technical Background

1) Processes for Producing Semiconductor-Grade Si

a) Production of $\mathrm{Si}$ by $\mathrm{Zinc}(\mathrm{Kn})$ Reduction of $\mathrm{SiCl}_{4}$ Battelle. The contract with Battelle Columbus Laboratories is for development of the reaction for the $\mathrm{Zn}$ reduction of silicon 
tetrachloride $\left(\mathrm{SiCl}_{4}\right)$ using a fluidized bed reactor as an economical means for producing $\mathrm{Si}$.

Table 2-2. Silicon Material Task Contractors

Technology Area.

AeroChem Research

Princeton $\mathrm{NJ}$ :

(JPL Contract No. 954777)

(JPL Contract No. 954862)

Aerospace Corporation

E1 Segundo CA

(JPL Contract No. 955201)

Battelle Columbus Laboratories

Columbus $\mathrm{OH}$

(JPL Contract No. 954339)

Lamar University

Beaumont TX

(JPL Contract No. 954343)

Lawrence Livermore Laboratories

Livermore CA

(NASA Defense Purchase

Request No. W08626)

Materials Research

Salt Lake City UT

(JPL PO No. JR-672583)

National Bureau of Standards

Washington DC

(NASA Defense Purchase

Request No. WO 8604)

Sah, C. T. Associates

Urbana IL

(JPL Contract No. 954685)

Schumacher, J.C.

Oceanside CA

(JPL Contract No. 954914)
Investigation of $\mathrm{Si}$ halide-alkali

metal flames process

Model of silicon hydride and

lialide ieactions

Impurity concentration

measurements

$\mathrm{Zn} / \mathrm{SiCl}_{4}$ fluid bed reactor process

Technology and economic analyses

Measurements of impurity

concentrations in $\mathrm{Si}$

$\mathrm{X}$-ray analysis of $\mathrm{Si}$ wafers

Measurements of impurity

concentration in $\mathrm{Si}$

Effects of impurities

on cell performance

Production of $8 i$

from bromosilanes 
Table 2-2. Silicon Material Task Contractors (Continued)

\begin{tabular}{|c|c|}
\hline Contractor & Technology Area \\
\hline $\begin{array}{l}\text { Solarex } \\
\text { Rockville MD } \\
\text { (JPL Contract No. 955307) }\end{array}$ & $\begin{array}{l}\text { Effects of impurities on } \\
\text { performance of solar cells }\end{array}$ \\
\hline $\begin{array}{l}\text { SRI International } \\
\text { Menlo Park CA } \\
\text { (JPL Contract No. 954471) }\end{array}$ & $\begin{array}{l}\text { Sodium (Na) reduction of } \mathrm{SiF}_{4} \\
\text { process }\end{array}$ \\
\hline $\begin{array}{l}\text { Union Carbide } \\
\text { Sisterville WV } \\
\text { (JPL Contract No. 954334) }\end{array}$ & Silane/silicon process \\
\hline $\begin{array}{l}\text { Westinghouse } \\
\text { Pittsburgh PA } \\
\text { (JPL Contract No. 954331) }\end{array}$ & $\begin{array}{l}\text { Effects of impurities on } \\
\text { performance of solar cells }\end{array}$ \\
\hline (JPL Contract No. 954589) & Plasma arc heater process \\
\hline
\end{tabular}

b) Production of $\mathrm{Si}$ from $\mathrm{SiH}_{4}$ Prepared by Redistribution of Chlorosilanes -- Union Carbide. The Union Carbide contract is for the development of processes for the production of silane $\left(\mathrm{SiH}_{4}\right)$ and for the subsequent deposition of $\mathrm{Si}$ from $\mathrm{SiH}_{4}$. The $\mathrm{SiH}_{4}$ process includes systems for the redistribution of chlorosilanes and the hydrogenation of metallurgical-grade $\mathrm{Si}$ and the by-product $\mathrm{SiCl}_{4}$ to trichlorosilane $\left(\mathrm{SiHCl}_{3}\right)$, which can be used as a feed for redistribution. The free-space reactor and the fluidized bed reactor are techniques being investigated as the means for si deposition.

2) Effects of Impurities and Processing on Solar Ce11 Performance

a) Determination of the Effects of Impurities and ProcessSteps on Properties of $\mathrm{Si}$ and the Performance of Solar Cells -Westinghouse/Dow Corning. The objective of this program is to obtain a data base for performing cost tradeoff analyses for polycrystalline $S i$ processes and for defining the purity requirements for solar-cell-grade Si.

b) Effeets of Impurities -- C. T. Sah Associates. The objective is to develop a model for solar-cell performance, including 
the effects of recombination centers. The parameters of the recombination centers are being determined.

c) X-Ray Analysis of Si Wafers -- Materials Research Inc. This is for a non-destructive study of the crystallographic structure defects in $\mathrm{Si}$ wafers deliberately doped with impurities.

d) Analysis of the Effects of Impurities in Si -- Solarex. This effort consists of measuring and analyzing the performance of solar cells that have been fabricated from impurity-doped $\mathrm{Si}$ ingots.

c) Impurity Concentration Measurements in Si -- Lawrence Livermore Laboratories. By means of neutron activation analyses, impurity concentrations in $\mathrm{Si}$ materials from process development contractors are being measured.

f) Impurity Concentration Measurements in Si -- National Bureau of standards. Procedures are being developed for measuring impurity concentrations in the ppba range in $\mathrm{Si}$ using neutron activation analysis and spark-source mass spectroscopy.

g) Composition Measurements by Analytical Photon Catalysis - Aerospace. The purpose of this work is to establish the capabilities of analytical photon catalysis for the measurement of impurity concentrations in $\mathrm{Si}$ in the ppba range.

3) Processes for Producing Solar-Ce11-Grade Si

a) Production of $\mathrm{Si}$ from $\mathrm{H}_{2} \mathrm{SiF}_{6}$ Using $\mathrm{Na}$ Reduction of $\mathrm{SiF}_{4}$ Process -- SRI International. This contract is for the development of a two-step process for the production of $\mathrm{Si}$ from $\mathrm{SiF}_{4}$, which can be made from $\mathrm{H}_{2} \mathrm{SiF}_{6}$, a byproduct from the fertilizer industry. The steps are (1) the reduction of silicon tetrafluoride $\left(\mathrm{SiF}_{4}\right)$ by $\mathrm{Na}$ to produce high-purity $\mathrm{Si}$ and (2) the further purification of this product.

b) Production of Si Using Arc Heater Process for Reduction of $\mathrm{SiCl}_{4}$ by $\mathrm{Na}$-- Westinghouse. This contract is for the development of a process for the production of $\mathrm{Si}$ using the reduction of $\mathrm{SiCl}_{4}$ by. $\mathrm{Na}$, employing elcctric-arc heaters.

c) Production of $\mathrm{Si}$ from Bromosilanes -- J. C. Schumacher. The objective of this contract is to determine the feasibility of using bromosilanes as the appropriate intermediates to produce si. 


\section{4) Supporting Contracts}

a) Evaluation of $\mathrm{Si}$ Production Processes -- Lamar University. The objective of this contract is to evaluate the potentials of the processes being developed in the program of the Silicon Material Task. The economic evaluations will be based upon analyses of process-system properties, chemical engineering characteristics, and costing economics. The evaluations will be performed during all phases of the Task, using information that becomes available from the various process-development contracts.

b) Development of a Model and Computer Code to Describe Si Production Processes -- AeroChem Research. This contract is for the formulation of a model and a computer cude for the description of several of the $\mathrm{Si}$ processes now under development.

c) Investigation of Si Halide/Alkali Metal Flames -- AeroChem Research. The objective is to study high-temperature reactions of alkali metals with $S i$ halides, evaluating product separation and collection processes, measuring heat release parameters for scaling purposes, and determining the effects of the reactants and products on materials of construction.

e. Summary of Progress

1) Production of $\mathrm{Si}$ by $\mathrm{Zn}$ Reduction of $\mathrm{SiCl}_{4}$-- Battelle Columbus Laboratories. The planning and costing of the Process Development Unit (PDU) was carried out and a proposal was prepared for the PDU fabrication, procurement, installation, start-up, and developmental operation. The PDU conoists of the critical portions of the Experimental Process System Development Unit (EPSDU), and it will be operuted in a batch mode to prove out its principal items ( $\mathrm{Zn}$ vaporizer, reactor byproduct condenser, and $\mathrm{ZnCl}_{2}$ electrolysis cei1). Development continued on these three items. The power efficiency of the eler.trolysis coll was raised lu $42.5 \%$ from a level of about $32 \%$.

2) Production of $\mathrm{Si}$ from $\mathrm{SiH}_{4}$ Prepared by Redistribution of Chlorosilanes -- Union Carbide. The Phase II (Process Design) activities ended on March 31 , and the final report on this work waa compleeed. Cunlract negotiations for Process Support R\&D for Phase III (100. MT/yr EPSDU program) were started. A unilateral contract modification was issued by JPL to cover the period between the two phases.

The free-space reactor was operated at five times the design output rate to produce about $30 \mathrm{~kg}$ of $\mathrm{Si}$ powder. This powder was two to three times as dense as powder produced at the design output 
rate. Analysis of electrical resistivity data for Si crystals made by melting the powder produced in the free-space reactor indicates electrically active impurity levels of less than 10 ppba.

3) Determination of the Effects of Impurities and Process Steps on Properties of $\mathrm{Si}$ and the Performance of Solar Cells -Westinghouse/Dow Corning. Deep-level transient spectroscopy (DLTS) and detailed I-V measurements made on gettered, Ti-doped solar cells indicate that as cell performance improves, bulk lifetime increases and the density of $\mathrm{Ti}$ recombination centers $\left(\mathrm{E}_{\mathrm{V}}+0.3 \mathrm{eV}\right.$ level)

diminishes. Thus, in this case gettering deactivates the recombination centers rather than changing the level of the recombination center. The Ti trap density fell by about a factor of four after gettering for five hours at $1100^{\circ} \mathrm{C}$.

Studies of potential impurity anisotropy in 3-inch-dia. $\mathrm{Mn}$-doped and $\mathrm{Ti}$-doped wafers were extended to provide detailed edge-to-center and seed-to-tang maps of cell performance. No systematic or preferential impurity distribution was noted except a slight seed-to-tang buildup due to impurity segregation during crystal growth. Performance variation across or along the ingots was within $\pm 10 \%$ of the average ingot cell efficiency. This was consistent with the map of ingot bulk lifetime, which indicated that the maximum variation of impurity content is less than a factor of 2 in both types of ingots.

Initial studies of impurity aging effects on solar cells were done for temperatures up to $800^{\circ} \mathrm{C}$ and times as long as $100 \mathrm{~h}$. For uncontacted cells, no cell performance degradation due to aging effects in Mo-doped or Ti-doped cells was noted even at the longest times and highest temperatures. However, cell efficiency reduction occurred in contacted cells after 10 hours at $500^{\circ} \mathrm{C}$ due to interdiffusion of the contact metals and $\mathrm{Si}$ base material.

4) Effects of Impurities -- C.T. Sah Associates. Computer model studies were made of the effects of phosphorus-vacancy recombination centers in the phosphorus-diffused back-surface field (BSF) region, of boron-defect complex centers in the diffused emitter, and of surface recombination at the front and back surfaces in BSF cells. These recombination mechanisms are not as important as recombination at the $\mathrm{Ti}$ center in the base region. Computer calculations showed that to get AMl efficiency of $16 \%$ in the $\mathrm{Si}$ $\mathrm{P}^{+} / \mathrm{N} / \mathrm{N}+$ cell, which is less sensitive to $\mathrm{Ti}$ than the corresponding $\mathrm{P}$-base cell, the $\mathrm{Ti}$ concentration must be smaller than about $6 \times 10^{12}$ atoms/cc.

The second technical report, covering the past year's work, was completed for distribution in May. 
5) X-ray Analysis of Si Wafers -- Materials Research. Samples from Al-doped and Mn-doped ingots were examined by the Lang transmission technique and the results were correlated with the performance of solar cells made from other slices of the same materials. The Al-doped samples were by far the cleanest with respect to dislocations. However, there were varying amounts of precipitate clusters scattered at random in the samples. Correlations with the cell performance indicate that the Al-doped $\mathrm{Si}$ solar cell behavior is not structure-defect-sensitive but rather is affected by electronic properties.

6). Effects of Impurities on Solar Cells -- Solarex. This effort was started in this period. A draft program plan, including quality assurance provisions, for the cell fabrication program was prepared and submitted to JPL.

7) Composition Measurements by Analytical Photon Catalysis -Aerospace Corp. Analysis of NBS standard Si (Standard Reference Material \#57) by the analytical photon catalysis method indicates that the composition of the vapor reflects the composition of the original solid sample; these results demonstrate the validity of the method. The following impurities were identified in this material: $\mathrm{Al}, \mathrm{Ca}, \mathrm{Cr}$, $\mathrm{Cu}, \mathrm{Fe}, \mathrm{Mn}, \mathrm{Mg}$, and $\mathrm{Na}$. For $\mathrm{Ti}$ analysis, sensitivity was found to be $10^{4}$ atoms $/ \mathrm{cc}$, or $1 \mathrm{ppb}$.

8) Production of $\mathrm{Si}$ from $\mathrm{H}_{2} \mathrm{SiF}_{6}$ Source Material Using $\mathrm{Na}$ Reduction of $\mathrm{SiF}_{4}$-- SRI International. For the process using $\mathrm{Na}$ (s) and $\operatorname{SiF}_{4}(\mathrm{~g})$, the effects of various sizes, geometries, and feed rates of $\mathrm{Na}$ slices on reaction efficiencies were investigated. It was found that the presence of $\mathrm{Na}$ in the reaction product was minimized when the slice thickness was $\leq 3 \mathrm{~mm}$. All impurities in the $S i$ product were below the limits of detection by emission spectroscopy.

9) Production of Si Using Arc Heater Process for Reduction of $\mathrm{SiCl}_{4}$ by $\mathrm{Na}=-$ Westinghouse. Assembly and installation of test system equipment for the process demonstration continued and neared completion. Shakedown tests were conducted on several subsystems, including cooling water, electrical, and effluent disposal. The first reactor shakedown tests, made at reduced power levels, were successful. In the first test, only argon (Ar) gas was employed as the worling fluid (no $\mathrm{H}_{2}$, Na, or $\mathrm{EiCl}_{4}$ being introdueed). In the second test a mixture of $\mathrm{H}_{2}$ and $\mathrm{Ar}$ was used, and a power level of 750 $\mathrm{kW}$ (about half of the normal operating power) was attained.

In mid- February JPL was notified by Westinghouse that the contract funding would be exhausted by about the end of February because of a projected overrun. Consequently, after the second test was done on March 2 the work was stopped. Efforts are under way to 
reach a suitable contracting agreement to assure completion of the effort while still limiting the additional funding required.

10) Production of Si from Bromosilanes -- J.C. Schumacher. Tests were performed on the synthesis of tribromosilane ( SiHBr$_{3}$ ), which is used as feedstock for $\mathrm{Si}$ production in this process. The yield was found to be sensitive to such variables as residence time of the reactants in the hot $z$ one, $\mathrm{H}_{2}$-to-SiBr4 feed ratio, catalytic agents, and temperature. In other tests the production of $\mathrm{Si}$ by the $\mathrm{H}_{2}$ reduction of $\mathrm{SiHBr}_{3}$ was studied.

The final report was issued. The study indicates that two closed-1oop SiHBr3 processes (the thermal decomposition process and the hydrogen reduction process) for the production of pure $S i$ were demonstrated by laboratory-scale experiments to be technically. feasible. These processes appear to have some significant advantages, such as reductions in both homogeneous nucleation and wall deposition of $\mathrm{Si}$, over chlorosilane-based processes.

This contract was allowed to lapse in February because of lack of available funds.

11) Silicon Halide/Alkali Metal Flames -- AeroChem Research. A larger-scale reactor system was designed, built, and tested. Experiments on the compatibility of pyrolytic graphite-coated graphite with $\mathrm{Na}$ vapor were completed. Tests were made at $1700 \mathrm{~K}$ and $1200 \mathrm{~K}$, a $\mathrm{Na}$ pressure of $0.5 \mathrm{~atm}$, and flow velocities ranging from $3 \mathrm{~m} / \mathrm{sec}$ to $10 \mathrm{~m} / \mathrm{sec}$. At $1200 \mathrm{~K}$, tests showing that the coated graphite samples were extensively damaged and lost their structural strength were consistent with earlier tests with refluxing Na. The experiments at $1700 \mathrm{~K}$ showed no substrate damage, but the coating peeled and cracked.

12) Development of a Modei and Computer Code to Describe Si Production Processes -- AeroChem Research. Coefficients needed to. describe the transport of $\mathrm{Si}$ vapor and droplets from the interior to the walls of reactors, such as those in the Westinghouse arc heater process and in the AeroChem flame process, were calculated. It was found that for extremely large temperature gradients near the wall (conditions that occur in some of the reactors to be used in producing $\mathrm{Si}$, particularly the Westinghouse reactor), the deposition of $\mathrm{Si}$ droplets in the diameter range $0.01 \mu \mathrm{m}$ to $1.0 \mu \mathrm{m}$ within a viscous sublayer region close to the wall will be controlled by thermal diffusion (thermophoresis or Soret diffusion). Work also proceeded on debugging and developing the modified LAPP (Low Altitude Plume Program) code and the boundary layer code. 
13) JPL In-House Si Processing Technologies. Initial testing of the modified continuous-flow pyrolyzer (CFP) system was conducted. The particle feed subsystem was tested successfully at particle temperatures up to $840^{\circ} \mathrm{C}$ and at feed rates of about $5 \mathrm{~g} / \mathrm{min}$. Tests were then made with the CFP system. One test lasted $1.7 \mathrm{~h}$, during which particles were fed for $0.7 \mathrm{~h}$ at temperatures as high as $850^{\circ} \mathrm{C}$. The results indicate that the difficult problem of continuously feeding fine $\mathrm{Si}$ powder at elevated temperature has been solved.

Tests were conducted in the one-inch-diameter quartz fluidized bed reactor (FBR) to determine the concentration and temperature dependence for homogeneous nucleation of $\mathrm{Si}$ from silane $\left(\mathrm{SiH}_{4}\right)$. The conditions ranged from $700^{\circ} \mathrm{C}$ to $850^{\circ} \mathrm{C}$ in the bed and $1 \%$ to $6 \%$ $\mathrm{SiH}_{4}$ in $\mathrm{H}_{2}$, at about 6.5 times the minimum fluidization velocity. For these conditions, less than $1 \%$ of the $\mathrm{Si}$ formed in the reactor was collected at the outlet as fines, indicating that reasonably high concentrations of $\mathrm{SiH}_{4}$ can be employed in the FBR without producing excessive quantities of fines.

\section{Large Area Silicon Sheet Task}

The objective of the Large-Area Silicon Sheet Task is to develop and demonstrate the capability of several processes to produce large areas of $\mathrm{Si}$ sheet material suitable for low-cost, high- efficiency solar photovoltaic energy conversion. To meet the objectives of the LSA Project, sufficient technology development must be accomplished on these processes to allow the capability of producing large areas of silicon sheet. The final sheet growth configurations must be suitable for direct incorporation into an automated solar-array processing scheme.

a. Technical Goals. Current solar cell technology is based on the use of si wafers obtained by slicing large Czochralski ( $\mathrm{Cz}$ ) or float-zone ingots (up to $12.5 \mathrm{~cm}$ in diameter), using single-blade inner-diameter (ID) diamond saws. This method of obtaining single crystalline $\mathrm{Si}$ wafers is tailored to the needs of large-volume semiconductor products (i.e., integrated circuits plus discrete power and control devices other than solar cells). Indeed, the small market offered by present solar cell users does not justify the development of Si high-volume production techniques that would result in low-cost electrical energy.

Growth of si crystalline matcrial in a gcomctry that doco not require cutting to achieve proper thickness is an obvious way to eliminate costly processing and material waste. Growth techniques such as edge-defined film-fed growth (EFG), web-dendritic growth (WEB), etc., are possible candidates for the growth of solar cell material. The growth of large ingots requiring less consumables would also appear plausible. However, it appears that to meet productivity requirements in cutting large ingots into wafers it wil be necessary to increase throughput; one way to achieve this is by multiple-cutting techniques. 
Technology development on ribbon, film and ingot growth plus multiple-blade, multiple-wire and enhanced ID cutting initiated in $1975-76$ is in progress.

b. Organization and Coordination. At the time the LSA Project was initiated (January 1975) a number of methods potentially suitable for growing $\mathrm{Si}$ crystals for solar cell manufacture were known. Some of these were under development; others existed only in concept.

Development work on the most promising methods is now being funded. After a period of accelerated development, the various methods will be evaluated and the best selected for advanced development. As the growth methods are refined, manufacturing plants will be developed from which the most cost-effective solar cells can be manufactured. The Large-Area Silicon Sheet Task effort is organized into four phases: leasibility demonstration of sheet growth methods (1975-77); advanced development of selected growth methods (1977-80); prototype production development (1979-82); development, fabrication, and operation of production growth plants (1981-86).

c. Large-Area Silicon Sheet Task Contracts. Advanced development contracts awarded for growing Si crystaline material for solar cell production are shown in Table 2-3.

d. Large-Area Silicon Sheet Task Technical Background

1) Shaped Ribbon Technology: EFG Method -- Mobil-Tyco Solar Energy Corp. The EFG technique is based on feeding molten Si through a slotted die as illustrated in Figure 2-1. In this technique, the shape of the ribbon is determined by the contact of molten Si with the outer edge of the die. The die is constructed from material that is wetted by molten $\mathrm{Si}$ (e.g., graphite). Efforts under this contract are directed toward extending the capacity of the EFG process to a speed of $5 \mathrm{~cm} / \mathrm{min}$ and a width of $10 \mathrm{~cm}$. In addition to the development of EFG machines and the growing of ribbons, the program includes economic analysis, characterization of the ribbon, production and analysis of solar cells, and theoretical analysis of thermal and stress conditions.

2) Shaped Ribbon Technology: Laser Zone Growth in a Ribbon-to-Ribbon (RTR) Process -- Motorola. The ribbon-to-ribbon process is basically a float-zone crystal growth method in which the feedstock is a polycrystalline $\mathrm{Si}$ ribbon (Figure 2-2). The polysilicon ribbon is fed into a preheated region that is additionally heated by a focused laser beam, melted, and crystallized. The liquid $S i$ is held in place by its own surface tension. The shape of the resulting crystal is defined by the shape of the feedstock and the orientation is determined by that of a seed single-crystal ribbon. 
3) Shaped Ribbon Technology -- Westinghouse. Dendritic web is a thin, wide ribbon form of single-crystal Si. "Dendritic" refers to the two wire-like dendrites on either side of the ribbon, and "web" refers to the silicon sheet that results from the freezing of the liquid film supported by the bounding dendrites. Dendritic web is particularly suited for fabrication into photovoltaic converters for a number of reasons, including the high efficiency of the cells that can be fabricated from it, the excellent packing factor of the cells into subsequent arrays, and the cost-effective conversion of raw $\mathrm{Si}$ into substrates (Figure 2-3). 
Table 2-3. Large-Area Silicon Sheet Task Contractors

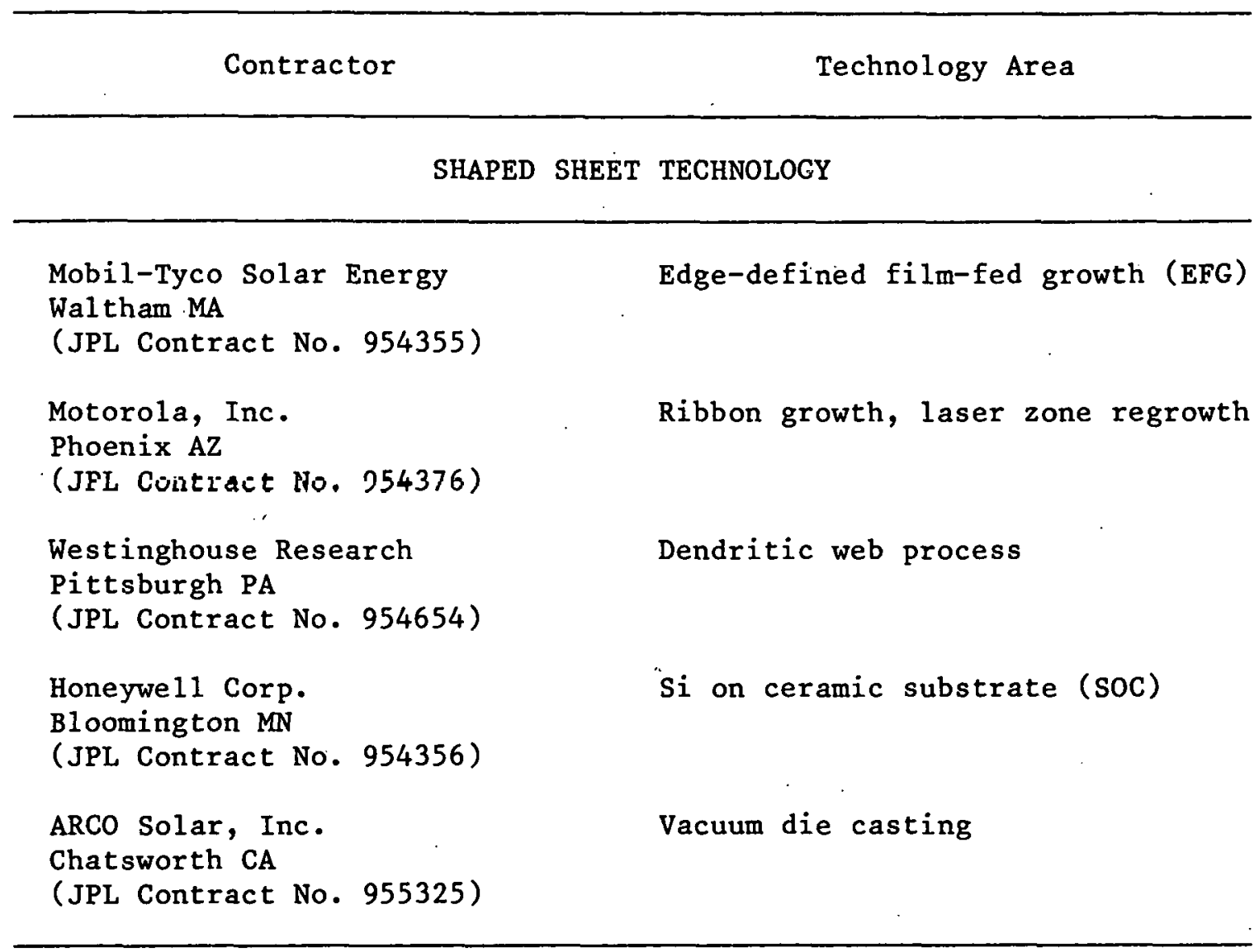

INGOT TECHNOLOGY

Crystal Systems, Inc.

Salem MA

(JPL Contract No. 954373)

Kayex Corp. (Hamco)

Rochester $\mathrm{NY}$

(JPL Contract No. 954888)

(JPL Contract No. 955270)

Siltec Corp.

Menlo Park CA

(JPL Contract No. 954886)

(JPL Contract No. 955282 )

Varian Vacuum Division

Lexington MA

(JPL Contract No. 954374)

(JPL Contract No. 954884)
Heat exchanger method (HEM) of cast ingot and multiwire fixed abrasive slicing technique (FAST)

Advanced. $\mathrm{Cz}$ growth

Advanced $\mathrm{Cz}$ growth

Advanced $\mathrm{Cz}$ growth

Enhanced ID slicing

Multiblade slurry sawing

Advanced $\mathrm{Cz}$ growth 
Table 2-3. Large-Area Silicon Sheet Task Contractors (Continued)

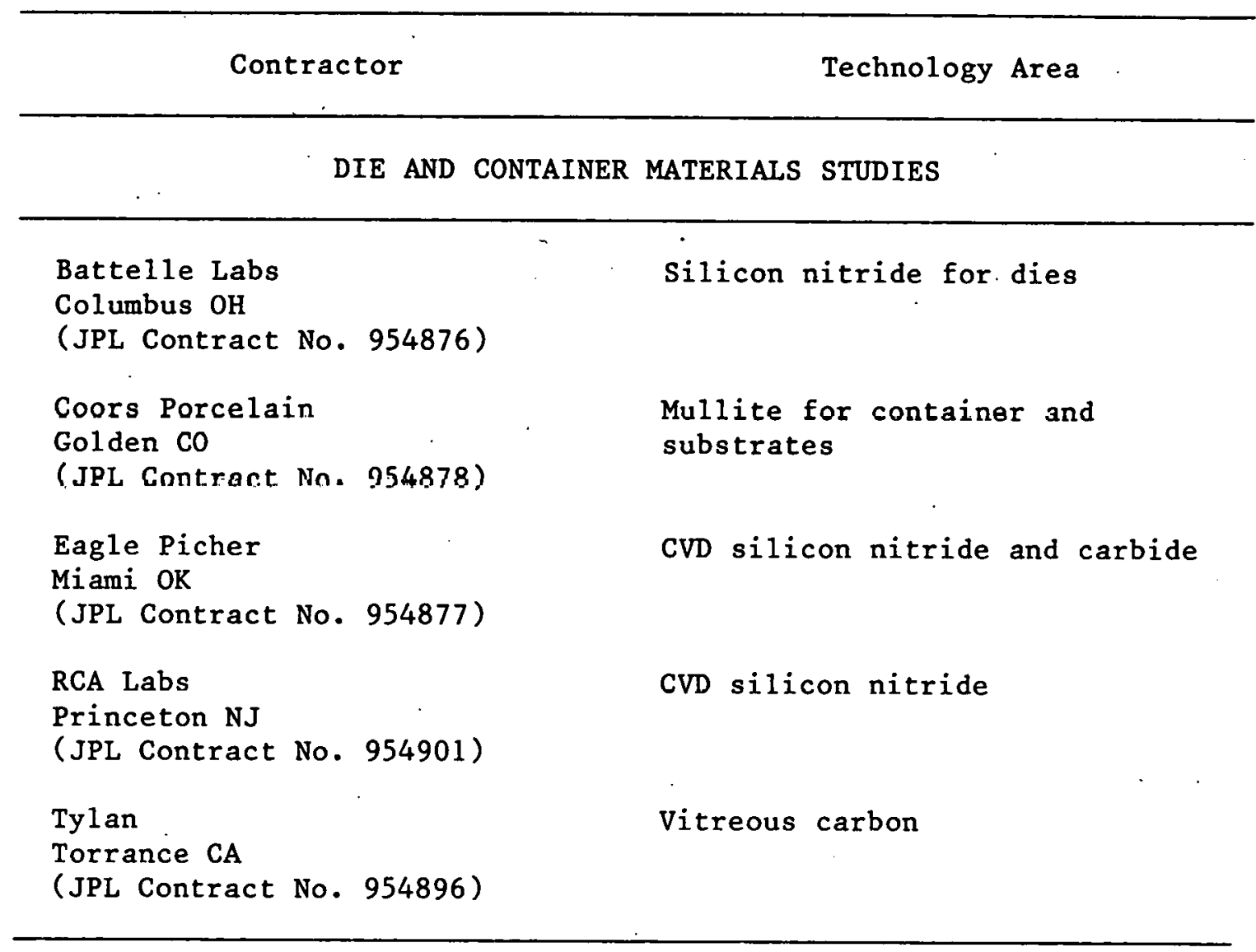

MATERIAL EVALUATION

Optical Coating Laboratory

City of Industry CA

(JPL Contract No. 955089)

Spectrolab

Sylmar CA

(JPL Contract No. 055055)

UCLA

Los Angeles CA

(JPL Contract No. 954902)

Materials Research Inc.

Centerville UT

(JPL Contract No. 957977)

Cornell University

Ithaca NY

(JPL Contract No. 954852)
Cell fabrication and evaluation

Cell fabrication and evaluation

Material evaluation

Quantitative analysis of defects and impurity technique evaluation

Characterization--Si properties 


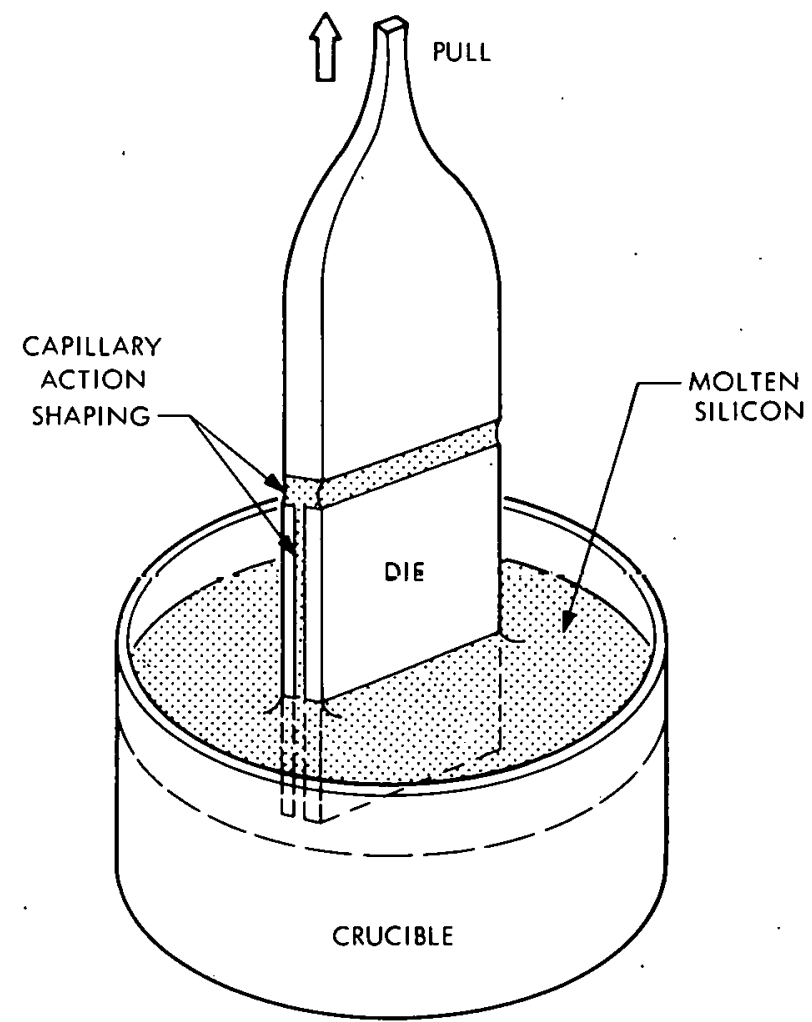

Figure 2-1. Edge-Defined Film-Fed Growth (EFG) -- Mobil-Tyco

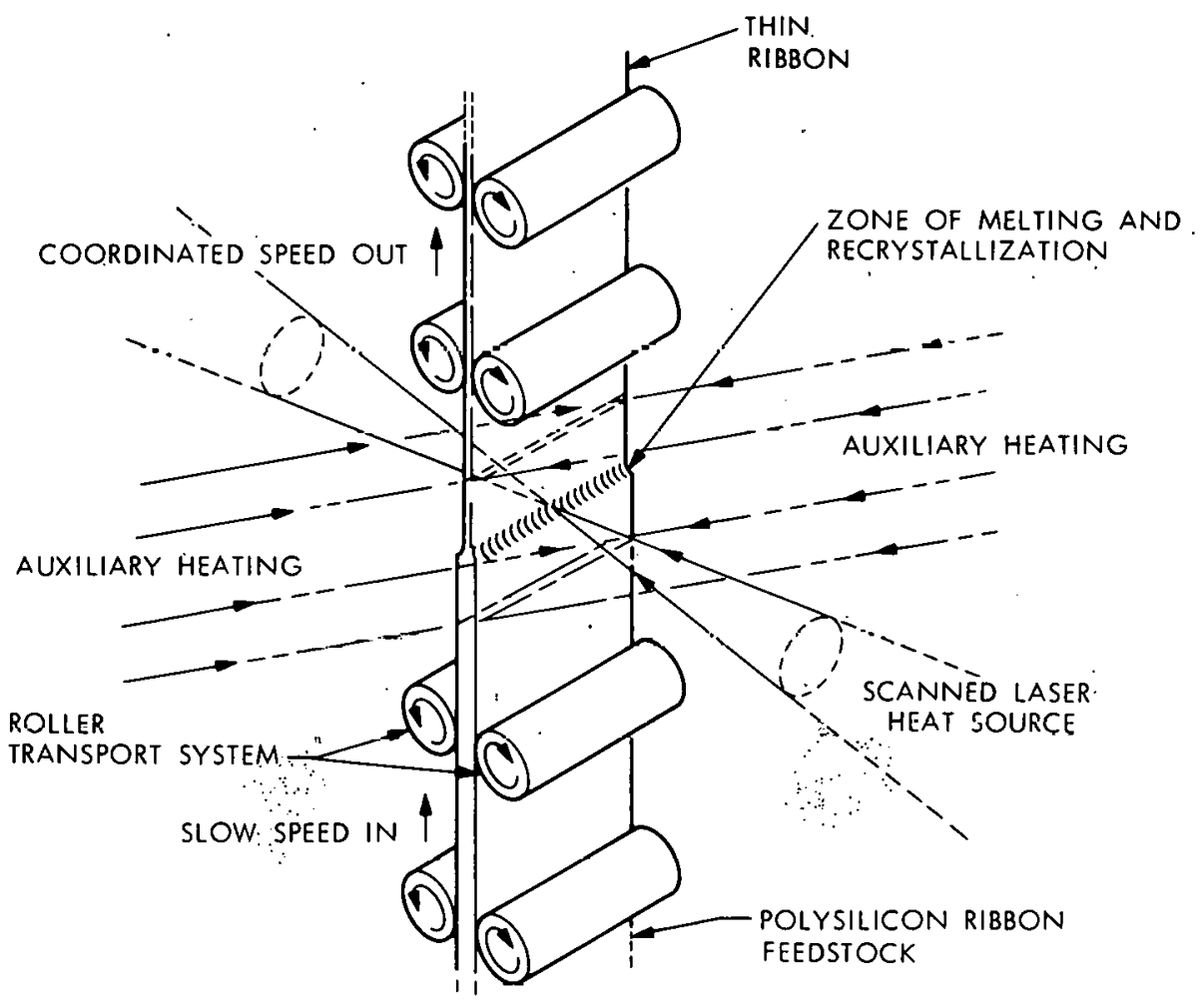

Figure 2-2. Laser Zone Regrowth -- Motorola 


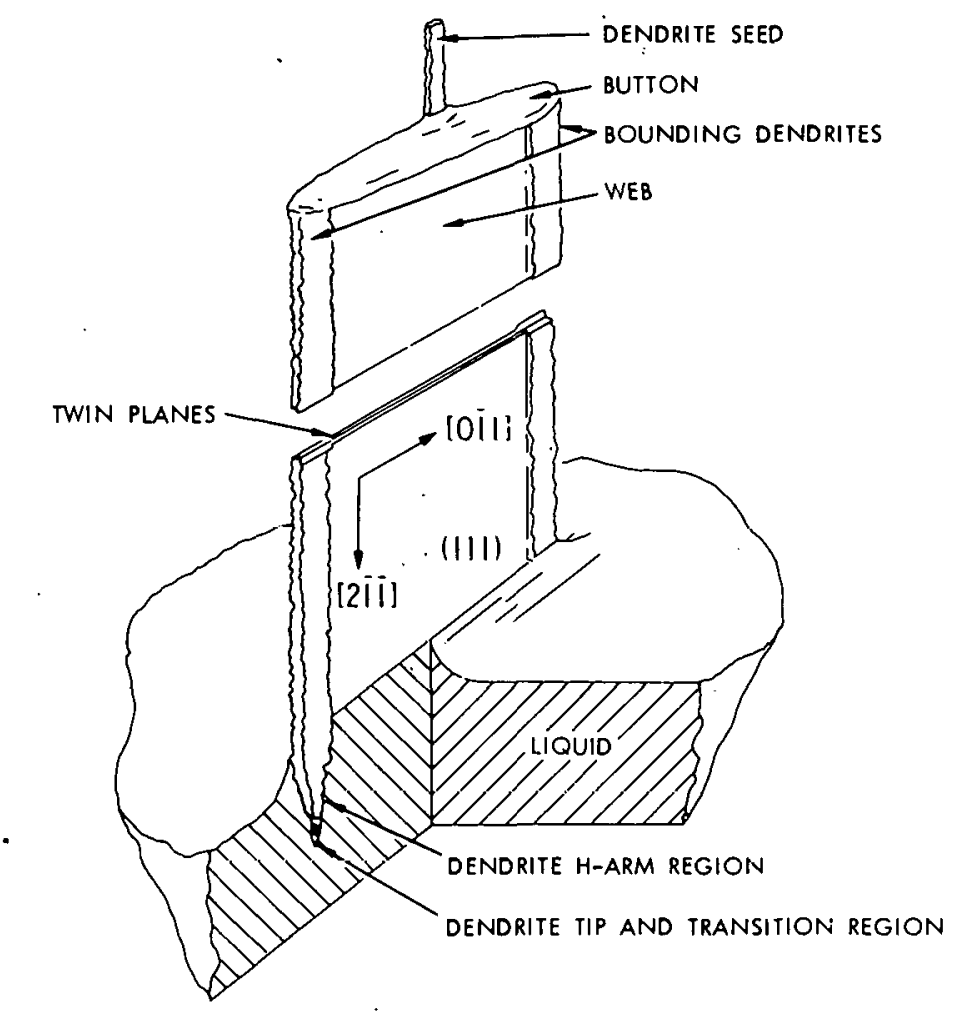

Figure 2-3. Schematic Section of Web Growth --Westinghouse

4) Supported Film Technology -- Honeywell. The purpose of this program is to investigate the technical and economic feasibility of producing solar-celi quality ohcet $\delta i$ by coating inexpensive ceramic substrates with a thin layer of polycrystalline Si. The coating methods to be developed are directed toward a minimum-cost process for producing solar cells with a terrestrial conversion efficiency of $12 \%$ or greater. By applying a graphite coating to one face of a ceramic substrate, molten $\mathrm{Si}$ can be caused to wet only that graphite-coated face and produce uniform thin layers of large-grain polycrystalline $\mathrm{Si}$; thus, only a minimal quantity of $\mathrm{Si}$ is consumed.

5) Ingot Technology: Heat Exchanger Method (HEM) -- Crystal Systems. The Schmid-Vicchnicki technique (heat exchanger methnd) has been developed to grow large single-crystal sapphire (Figure 2-4). Heat is removed from the crystal by means of a high-temperature heat exchanger. The heat removal is controlled by the flow of He (the cooling medium) through the heat exchanger. This obviates motion of the crystal, crucible, or heat zone. In essence this method involves directional solidification from the melt where the temperature gradient in the solid might be controlled by the heat exchanger and the gradient in the liquid controlled by the furnace temperature. 


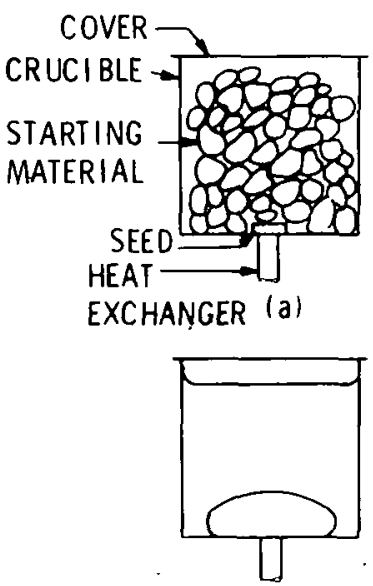

(e)
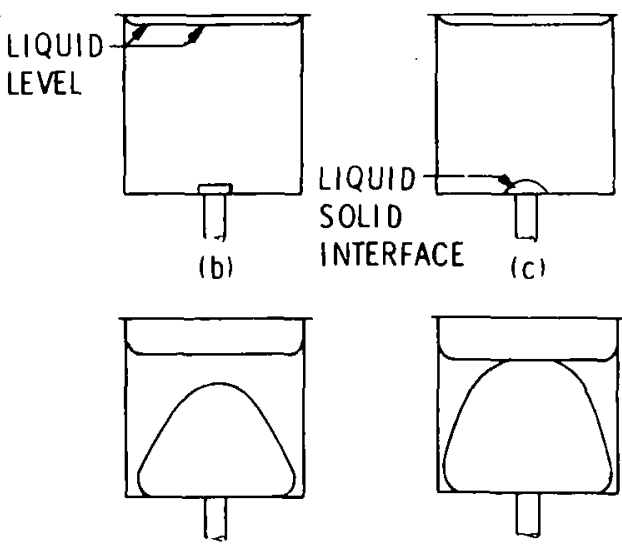

(f)

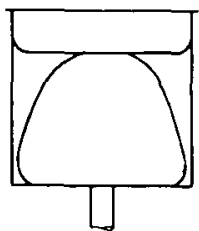

(g)

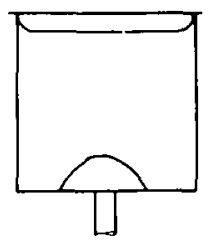

(d)

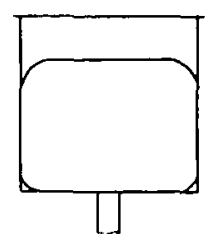

(h)

Growth of a crystal by the heat exchanger method:

(a) Crucible, cover, starting material, and seed prior to melting.

(b) Starting material melted.

(c) Seed partially melted to insure good nucleation.

(d) Growth of crystal commences.

(e) Growth of crystal covers crucible bottom.

(f) Liquid-solid interface expands in nearly ellipsoidal fashion.

(g) Liquid-solid interface breaks liquid surface.

(h) Crystal growth completed.

Figure 2-4. Crystal Growth Using the Heat

Exchanger Method -- Crystal Systems

The goal of this program is to determine if the heat- exchanger ingot casting method can be applied to the growth of large shaped Si crystals ( $30 \mathrm{~cm}$ cube) in a form suitable for the eventual fabrication of solar cells. This goal is to be accomplished by the transfer of sapphire-growth technology (50-1b ingots have already been grown), and theoretical considerations of seeding, crystallization kinetics, fluid dynamics, and heat flow for Si.

6) Ingot Technology: Advanced $\mathrm{Cz}$-- Varian, Texas

Instruments, Siltec, and Kayex. In the advanced $\mathrm{Cz}$ contracts efforts are geared toward developing equipment and a process to achieve the cost goals and demonstrate the feasibility of continuous $\mathrm{Cz}$ solar-grade crystal production (Figure 2-5). Varian will modify an existing furnace for continuous growth using granular $S i$ for recharging (molten Si will also be considered), and a new puller is to be designed. Siltec's approach is to develop a furnace with continuous liquid replenishment of the growth crucible accomplished by a meltdown system and a liquid transfer mechanism with associated automatic feedback controls. Kayex will demonstrate the growth of $100 \mathrm{~kg}$ of single crystal material using only one crucible by periodic melt replenishment. 

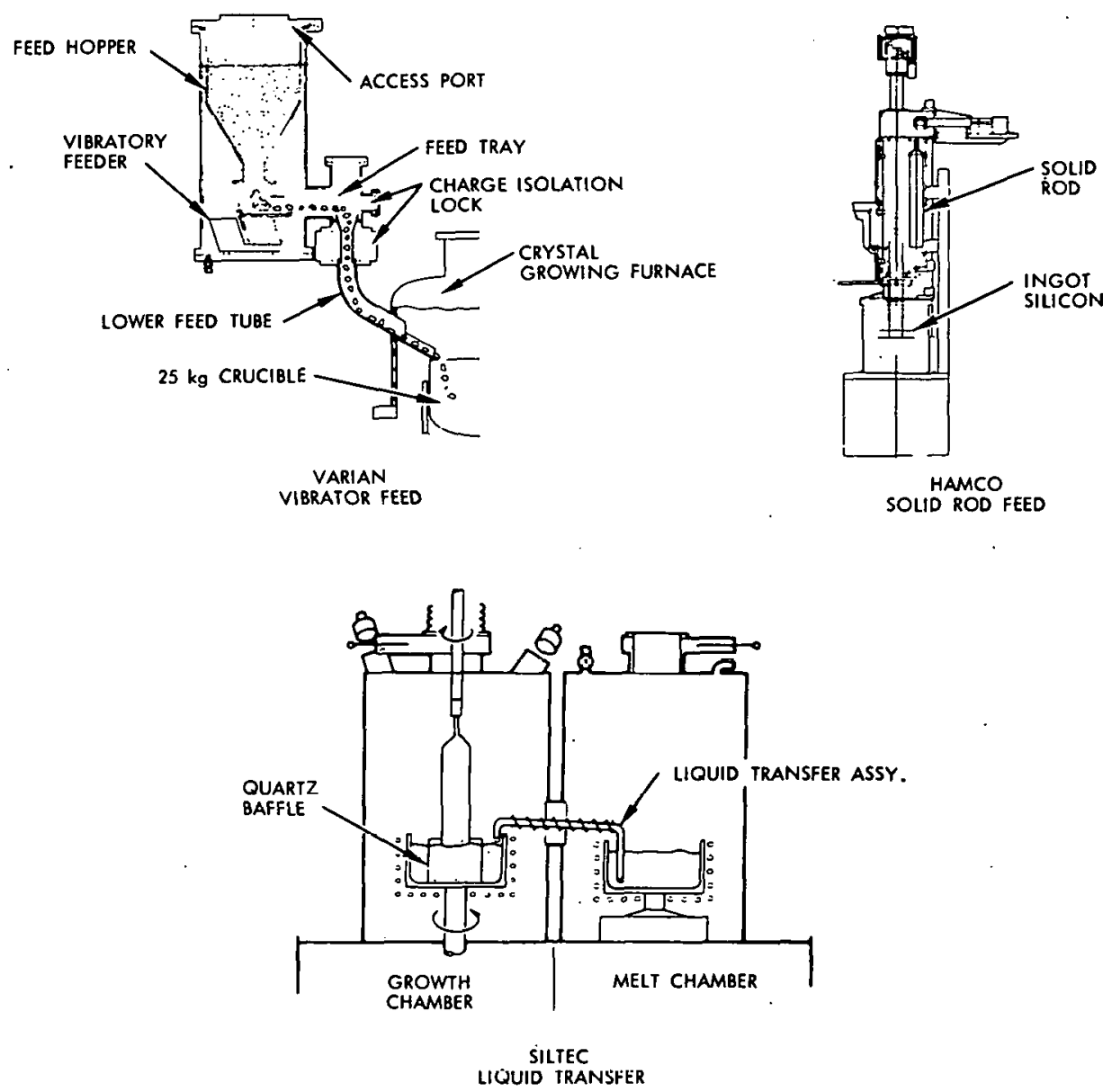

Figure 2-5. Continuous $\mathrm{Cz}$ Crystal Growth Machines

7) Ingut Téhiulugy: Mulliwice Süing (Mws) -- Crybtal Systems; Multiblade Sawing (MBS).-- Varian. Today most Si is sliced into wafers with an inside diameter saw, one wafer at a time being cut from the crystal. This is a large cost factor in producing solar cells. The multiblade and multiwire slicing operations employ similar reciprocating blade-head motion with a fixed workpiece. Multiblade slicing is accomplished with a slurry suspension of cutting fluid and silicon carbide abrasive and tensioned steel blades of $6 \mathrm{~mm}$ height and $0.2 \mathrm{~mm}$ thickness. Multiwire slicing uses $0.5 \mathrm{~mm}$ steel wires surrounded by a $0.25 \mathrm{~mm}$ copper sheath, which is impregnated with diamond as an abrasive.

8) Contact Material -- Battelle Labs, Coors Porcelain, Eagle Picher, RCA Labs, and Tylan. In the crystal-growing processes, a refractory crucible is required to hold the molten $\mathrm{Si}$, while in the ribbon processes an additional refractory shaping die is needed. The objective of these contracts is to develop and evaluate cost-effective refractory die and container materials. The material must be 
mechanically stable to temperatures above the melting point of $\mathrm{Si}$, must not excessively contaminate the $S i$ processed through it, be amenable to the fabrication of dies and containers with close tolerances and of varying geometries, and be cost-effective. Two of the contracts in this area, RCA and Tylan, are to develop a substrate material for supported film growth and a coating for substrates, dies, and containers.

9) Material Evaluation -- Optical Coating Lab (OCLI), Spectrolab, UCLA and Materials Research Inc. Proper assessment of potential low-cost $\mathrm{Si}$ sheet materials requires the fabrication and testing of solar cells using reproducible, reliable processes and standardized measurement techniques. Wide variations exist, however, in the capability of sheet growth organizations to fabricate and evaluate photovoltaic deviobs. It therefore is logical and essential that the various forms of low-cost $\mathrm{Si}$ sheet be impartially evaluated in solar cell manufacturing environments with well- established techniques and standards. Two solar cell manufacturers, OCLI and Spectrolab, have been retained to satisfy this need.

A small ongoing effort is being supported at UCLA to provide evaluation of $\mathrm{Si}$ sheet by device fabrication and electrical characterization.

Materials Research Inc. (MRI) is currently under an expanded effort to survey techniques best capable of providing impurity characterization with desired spatial and chemical impurity resolution. This assessment program will be an extension of the current MRI sheet-defect structure assessment effort, thus permitting a correlation of impurity distributions with the defect structures.

e. Summary of Progress

1) Ingot Technology

a) Kayex Corporation (Hamco). The design for the chunk Si feeder was completed and the fabrication work was initiated. A 100-kg multiple-ingot run using a $30 \mathrm{~cm}$ (12") dia. crucible was made. Ingot diameter was $12 \mathrm{~cm}$, with an average growth rate of $8 \mathrm{~cm} / \mathrm{h}$. The total run time was $80 \mathrm{~h}$. Another run totaling $50 \mathrm{~kg}$ ( 2 ingots) was made using a $35.5 \mathrm{~cm}\left(14^{\prime \prime}\right)$ dia. crucible. Loss of crystal structure remains a major problem.

b) Siltec Corporation. The recharging of solid Si particles into the melt-down chamber during a melt transfer/crystal growth run was attempted. Recharging was slow, crystal removal was difficult and an excessive oxide build-up in the meltdown chamber obscured the view inside the furnace. Several growth runs were tried for $100 \mathrm{~kg}$ multiple-ingot growth using the liquid transfer system. Yields varying 
from $21 \mathrm{~kg}$ to $70 \mathrm{~kg}$ were obtained. Maximum growth rate achieved was $1.29 \mathrm{~kg} / \mathrm{h}$ (contract goal $>2.0 \mathrm{~kg} / \mathrm{h}$ ). Major problems were the erratic heat control because of Sio deposition on the sensor surface and the melt transfer tube failure. An add-on phase is currently being negotiated.

c) Varian Associates. After detailed discussions between Varian and JPL it was decided that the work on the prototype construction would continue. No further development work or growth runs will be funded under this phase of the contract.

d) Crystal Systems (HEM). Design work on modifications of the present furnace was completed. Construction of a larger heat zone is under way. Several $20 \mathrm{~cm}$ dia. ingots ( $5 \mathrm{~kg}, 6.5 \mathrm{~kg}$, etc.) were cast at growth rates of $1 \mathrm{~kg} / \mathrm{h}$ (contract goal is $2.5 \mathrm{~kg} / \mathrm{h}$ ), with single crystal yield of $80 \%$. Delivery of a $15 \mathrm{~cm} \times 15 \mathrm{~cm}$ shaped crucible is awaited by CSI. Uniformity of the graded crucibles is affecting growth yield.

e) Crystal Systems (FAST). A $10 \mathrm{~cm} \times 10 \mathrm{~cm} \times 5 \mathrm{~cm}$ ingot (cut from a $15 \mathrm{~cm}$ dia. HEM ingot) was cut in the high-speed slicer using commercial (impregnated and plated diamonds) Lastec variety blades at 20 slices/cm spacing. Yields dropped rapidly (to 50\%) at the latter half of the run because of binding in the ingot-feed mechanism. Modification for 25 slices/cm is being planned. Blade development work will continue. Another run on an older Varian 686 machine yielded 100\% of $4 \mathrm{~cm} \times 4 \mathrm{~cm}$ wafers cut at 25 wafers $/ \mathrm{cm}$. Blade pack with 100 blades was used for five runs, giving good blade life.

f) Varian Associates (MBS). A new 1,000-blade package was assembled and tried, but the run was aborted due to bearing trouble. Complete overhaul is planned. Mineral oil slurries with and without lubricity additive (lard) have been studied. Runs on a Varian 686 (standard machine) with 300-blade pack, $100 \mathrm{~m}$ thick blades and $300 \mathrm{~m}$ spacers (25 wafers/cm) gave low yields due to sample holder rocking and blade breakage. A water-based slurry run with additives is showing some promise. A recycled abrasive run is also planned.

g) Siltec (Advanced ID). Work has been started on design and hardware fabrication. Operation is anticipated to start by late May.

2) Shaped-Sheet Technology.

a) Mobil Tyco (EFG). The effort directed to increase throughput has been modified to achieve greater width $(10 \mathrm{~cm})$ at a slower speed $(5 \mathrm{~cm} / \mathrm{min}$ ) (instead of $7.5 \mathrm{~cm}$ width $\times 7.5 \mathrm{~cm} / \mathrm{min}$ ). A multiple ribbon growth effort yielded 10 meters of material per cartridge system. Cell processing is planned. 
b) Westinghouse (Web). More than 40 experimental growth runs were made. A throughput of $22 \mathrm{~cm}^{2} / \mathrm{min}$ was demonstrated. Direction of Ar flow was found to be critical for web quality. Initial problems with cold after-trimmers were eliminated. Melt replenishment, with simultaneous web growth, was used for a period of more than $1 \mathrm{~h}$.

c) Motorola (RTR). The modified furnace for RTR growth of 7.5-cm-wide ribbons was made functional. Several CVD poly feedstock runs were made. Solar cell efficiencies of $>10 \%$ at AMl with area 1 $\mathrm{cm}^{2}$ have been achieved. Rigid-edge RTR growth was demonstrated. significant improvement in material quality was obtained.

d) Honeywell ( $\mathrm{SOC}$ ). Some progress was made in thermal-fluid flow configuration in the 8 CIM coator. Coatings of $30-50 \mathrm{~cm}^{2}$ with apparent1y reasonable structure and thickness were produced. Evaluation for improvement of material quality as evidenced by low values of solar cell short-circuit current was in progress. The best SOC cell has shown $10.1 \%$ cell efficiency at AMl.

3) Contact Material.

a) Battelle Labs. Study of Sibeon and Sialon was continued. Effort is in final stage and a completion report is being prepared.

b) Eagle Picher. Si sessile drop studies were extended to higher temperatures (up to $1490^{\circ} \mathrm{C}$ ), longer times (up to $12 \mathrm{~h}$ ), and lower $\mathrm{O}_{2}$ partial pressures (down to $10^{-20} \mathrm{~atm}$. $\mathrm{P}_{02}$ ). Final die and crucible blanks were submitted to Chemetal for coating. Program effort is being completed.

c) Coors Porcelain Company. About 400 slotted and 300 unslotted mullite substrates have been delivered to Honeywell. Two new compositions were also formulated and test parts delivered to Honeywe11. The p'üidail effort has been completed.

d) RCA. Difficulties in EFG-type die development were encountered. Capillary rise was accomplished under vacuum conditions.

4) Material Evaluation.

a) OCLI. Solar cells were fabricated and tested using the following materials: 
Material

EFG (RH) displaced die
EFG (RH) standard die
WEB
SOC
HEM $(3 \Omega-\mathrm{cm})$
$\quad(0.5 \Omega-\mathrm{cm})$

Avg. Efficiency at AMO

$$
\begin{array}{r}
6.0 \%(4.3-7.5 \%) \\
5.4 \%(2.9-7.4 \%) \\
9.6 \% \\
6.8 \% \\
10.0 \% \\
9.2 \%
\end{array}
$$

BSF cell processing was not successful.

b) Spectrolab. Material and efficiencies are reported as listed below:

Material

Wacker

EFG

Web
Efficiency AMO (\%)

$9-10$

5-7

$8.5-9.7$

HEM and RTR material were in the process of fabrication. Similar efforts in process optimization are under way.

c) Materials Research. Good progress was made in sample defect characterization. $200 \mathrm{~cm}^{2}$ of ribbon were evaluated using $a$ QTM (Quantimet). No cost extension of the contract may be needed for upgrading the image-analyzer QTM720 data-acquisition system by adding a PDP-1103. It will be possible to analyze Honeywell samples now.

\section{Encapsulation Task}

\section{a. General Progress}

Candidate encapsulation material systems and fabrication processes having the potential of meeting the LSA Project cost, performance and lifetime goals have been identified and are undergoing intensive experimental evaluation and system development. The Encapsulation Task now has two major goals: 1) the development and evaluation of candidate encapsulation material systems and 2) the development and validation of a module life prediction method. Current progress and testing results give increasing confidence that the LSA 1986 cost and performance goals can be met and technology readiness can be demonstrated by 1982 .

An experimental mini-module (12 in $x 16$ in) dcmonstration and evaluation task is being conducted to qualify and optimize the several candidate low-cost encapsulation systems. Four basic material system concepts have been defined for the purpose of detailed analysis and 
experimental evaluation during the coming year. These, with their functional element variations, are summarized below:

--Glass superstrate design

--Wood product (e.g. Super Dorlux) substrate design

--Metal substrate design

--Concrete substrate design.

Within these design concepts the following potential variations may be examined within the mini-module task:

Superstrate glass

-Soda lime (window glass)

Borosilicate

-Low-iron (tempered/untempered)

Pottant/Adhesives -Ethlene vinyl acetate

-Aliphatic urethane

-Polyvinyl butyral

-Ethylene propylene rubber

-Poly N-butyl acrilate

-Silicone/acrylic blend

-Low-cost silicone elastomer

-Polyvinyl chloride plastisol

Front cover films $\quad$-Korad 201/R

-Tedlar UT

-Tailored UV screening

-Films of acrylic

-UV screening films of

silicone resin

-Abrasion resistant

coatings

Substrate panels

-Wood fiber hardboard (costed)

-Glass reinforced

concrete

-Steel, galvanized or organic coating

Back-cover films and insulators

-Mylar

- Tedlar

-Acrylics

-Aluminum foil

(plus flexible

laminates of the above) 
Current R\&D experience and test results with the low-cost encapsulant candidates show that thermal-expansion differences between single-crystal $\mathrm{Si}$ solar cells and the structural panel materials such as glass, steel, hardboard, and concrete can be accommodated by a low-modulus adhesive pottant of reasonable thickness (e.g., less than $0.015 \mathrm{in})$. Excellent adhesive bonding of these different system materials appears practical with the application of selected primers and coupling agents. The prospect is good for incorporating the coupling agent directly into the pottant formulation.

A major new two-year Encapsulation Task subcontract will be awarded in the next quarter with the goal of integrating and optimizing encapsulation system candidates relative to cost, performance and durability. Studies to determine the thermal, optical, electrical and structural characteristics of candidate 1986 material systems will be performed and experimentally validated by the contractor.

The photodegradation and environmental stability of these materials are being determined at the material specimen level as well as at the system level with encapsulated solar cells. The corrosion protection provided and the corrosion sensitivity of different solar cell strings is being investigated under a current contract.

A critical question relative to the long-term stability of the low-cost pottants is the ability of UV screening covers and backsurface covers to protect them for 20 years or more. The short-term outdoor exposures and accelerated UV radiation tests have shown strikingly the protective potential of UV and oxygen barriers.

Achievement of a $3,000 \mathrm{~V}$ DC insulation to ground can be realized with current candidate material systems. Critical breakdown locations appear to be at terminations, electrical leads and gas bubbles left by the lamination process. Current field testing of degradation of this dielectric property has indicated this may not he a serinus problem for long-term utility. Work in this area is continuing. The insertion of a low-cost dielectric scrim of glass or polymeric woven material between the solar cell strings and any conducting surface will be incorporated into selected mini-module designs for evaluation.

An abrasion-resistant organic coating applied to the acrylic UV screening film is being evaluated both for abrasion resistance and ease of dust removal. Glass appears to be almost self-cleaning in contrast to the development of a sticky dark film on some of the current silicone-covered solar modules. The soiling characteristics of several commercial abrasion-resistant coatings are being determined.

The progress of individual LSA subcontracts is presented in the following section. Selected viewgraphs from the 12 th PIM contract review sessions on encapsulation are appended in Section III.3.c. 
b. Contract Status

1) Materials and Processes

a) Springborn. A detailed plan for the optimization of ethylene/vinyl acetate (EVA) was worked out, and the experimental program begun. This program is being carried out with the cooperation of Dupont, the manufacturer of the base EVA resin. Dupont will report to Springborn on both Dupont's and other industrial experience with regard to the reliability and concerns of employing EVA in engineering applications.

Another major phase of experimental testing was initiated, including the following: 1) accelerated UV exposure of candidate UV screening films and candidate pottants overcoated with the films, 2) corrosiun assesswent of EVA enoapsulated copper, mi.ld steel, galvanized steel, etc.,.3) modification of Korad 201/R with long-life UV screening agents, and 4) EVA optimization. Springborn will also initiate development of a second candidate encapsulation pottant, ethylene-propylene rubber.

The EVA optimization program has been divided into two phases, designated as system-readiness and life-readiness. Systemreadiness relates to the selection of its base EVA polymer, curing agents and cure conditions, whiting for pigmented EVA versions, and general qualities of chemical inertness, ease of handling and fabricability, adhesion, and optical transparency. Life-readiness relates to selection of anti-oxidants, UV stabilizers, and outer-cover requirements; module assembly, design techniques, and approaches to maximizing EVA service life. A system-ready EVA formulation should be achieved by early May.

Dr. Plueddemann of Dow Corning Corp., in his capacity as consultant to the Encapsulation Task, will develop an adhesive/primer system that can be physically incorporated into EVA. It is expected that the primer system will be sufficiently general to promote chemical coupling with all surfaces contacted by the EVA in a typical module. The development of such a system would eliminate the need for separate priming steps during module processing.

b) SPIRE. Activities at SPIRE were limited in this quarter pending approval of an 18-month contract extension.

Design modifications to the electrostatic bonder were studied. These included the use of a ylass flattencr in the post-bonding annealing chamber (which showed significant improvements), a cell alignment fixcure incorpurating beryllium pine that worked satisfactorily, and a general strengthening of the bonder. 
One hundred fifty 5.7 in $\times 7.7$ in hand-rolled Type 7070 glass panels have been completed by Corning. This is the first order of hand-rolled Type 7070 glass. Cast pieces of glass had been used in the past.

Borosilicate glasses from both Owens Corning and Schott Glass have been found satisfactory for electrostatic bonding. Work on these materials will be continued so that competition in the glass field can be increased.

Special evaporation masks for vacuum-depositing contacts have been fabricated. These masks are of a: special design for use with square cells intended for future modules.

c) Dow Corning. An interim report has been reviewed by JPL and approved. It should be distributed by Dow Corning within a few weeks.

Phase II of the contract began March 1. This phase is primarily concerned with the fabrication and assessment of large-area modules using silicone-based encapsulation materials identified in Phase I. Phase II includes consideration of automated processing techniques that are applicable for the encapsulation materials. The details of the Phase II program plan were worked out at a joint meeting with Dow Corning, JPL, and Spectrolab. Two Phase II modules were displayed at the April Project Integration Meeting.

Activities to reformulate silicone/acrylic blends were begun. Blends of these polymers are cost-effective, but the selection of the basic polymers and compositions must result in a blend that can survive the JPL qualification tests and outdoor stresses mechanically. The first blend made by Dow Corning rracked during thcrmal cycling from $=10^{\circ} \mathrm{C}$ to $190^{\circ} \mathrm{C}$.

Dow Corning has successfully deposited its anti-abrasion coating ( $A \Lambda C$ ) onto 3 -inch square modules having Korad surfaces. The AAC layer could not be abraded by a steel-wool pad; the Korad surface was readily abraded. Dow Corning will. now attempt to deposit AAC on an 11 in $\times 16$ in module with a Korad surface.

Dr. Plueddemann of Duw Curning has ldentitied his first candidate adhesive/primer system that can be physically incorporated into EVA, which is to function as a general purpose bonding system for all module interfaces in contact with EVA. Springhorn will uvaluatc the candidate system.

Dr. Plueddemann is preparing a report on the subject of adhesion and primers for LSA application. 
d) Endurex ITW. A statement-of-work for a new contract to develop ion-plated metal patterns in the same process as the AR coatings has been approved. Patent considerations may cause a delay in the planned contract start of late April or early May.

e) MB Associates. Equipment for spraying glass-reinforced concrete (GRC) was received and assembled, and application was begun. Three types of specimens and samples are produced by the GRC equipment: 1) 12 in $\times 24$ in specimens for compression testing to determine optimum mix ratios, thickness, cure rates, etc.; 2) samples for the development of inserts, and 3) samples for the development of molds.

Four point flexure sperimens ( 12 in $\times 24$ in) for characterization of glass-reinforced concrete formulations were prepared and tested after 7,28 , and 56 days of room-temperature curing. A report on the results of these tests is in preparation.

Substrate design was completed and drawings signed off by JPL. The design will be updated periodically to reflect latest thinking and as more data become available.

A visit was made to Springborn Laboratories to get up-to-the minute data on encapsulation materials. Latest thinking is that encapsulated cell subassemblies will be fabricated (e.g., 24 in $\times 48$ in) then adhesively bonded to the substrate. The subassemblies will have top covers, pottant, and bottom covers only --no substrate or superstrate -- as the most cost-effective approach.

A small module approximately 12 in $x 12$ in that successfully demonstrated this approach was fabricated. The cells were encapsulated between layers of 3-mil-thick Korad 201/R acrylic film using ethylene/vinyl acetate as adhesive/pottant. Laminated assemblies of this type with dimensions approximately 24 in $\times 48$ in would be secondarily bonded to the GRC substrate with an adhesive to be selected. Because of the relative unavailability of Korad 201/R, it is planned to use Tedlar for fabrication of five mini-modules required by contract to be delivered to JPL in early June. Either Korad or Tedlar could be used on prototype modules to be delivered in December, depending upon availability.

f) Motorola. Two contracts were initiated with Motorola to develop an antireflective (AR) cooting for spia-lime glass. The first of these is a Near-Term Cost Reduction contract to develop an AR coating suitable for automated production of $15 \mathrm{MW} /$ year by acid development of a sodium silicate coating. The second is an LSA-funded contract to improve the state of art of producing an improved AR coating on soda lime glass by an acid-leaching process. 
g) In-House. Report No. DOE/JPL1012-79/8 (John Repar)

"Experience with Silicones in Photovoltaic Modules", dated February 15 , 1979, was released.

A draft of a JPL report, "Automated Polymer Processing in Encapsulation," was sent to approximately 20 polymer/automation companies for comment. Some of the companies have expressed an interest in exploring the subject further.

Contacts were made with the Metal-Polymer Laminate Company for encapsulation back-cover film products. A variety of samples were received and placed in test including vapor deposited (VD) aluminum on polyester (Mylar) film, polyester film/aluminum foil/polyester film laminate, VD aluminum on polyester film/paper laminate, and VD aluminum on polyester film/white pigmented PVC laminate.

A permeation cell was designed and tests begun to compare the above materials for resistance to moisture permeation.

2) Life Prediction and Material Degradation

a) Battelle. The Study 5 final report draft entitled "Measurement Techniques and Instruments Suitable for Life-Prediction Testing of Photovoltaic Arrays" was approved. Publication is scheduled for early May.

As discussed in the most recent Project Progress Report, it is desirable to develop a simple method of measuring small changes in electrical characterization of modules at field sites to avoid transportation problems. Series resistance was selected for investigation. Three methods were used to determine values of series resistance of modules taken from the Mead, Nebraska site. These were 1) the Wolf/Rauschenbach (W/R) method (under two levels of illumination), 2) a forward bias ( $F / B$ ) method (forward bias without illumination), and 3) a two-diode model. While the two-diode model appeared to offer the most potential, the scope of the investigation was limited and the problem too complex for the development of a viable test method within the contract cost and time constraints. To develop a method with the required precision would require extensive development work that is beyond the scope of this contract.

b) Rockwe1l Science Center. Future work will be on the development and validation of modeling of corrosiun ao a life-liumiling process in encapsulated modules. The effort is in the planning stage, with a follow-on contract in negotiation.
c) Case Western Reocrve University.
A follow-on contract is in negotiation. 
d) California Institute of Technology/In-House. Work has begun in-house to establish a thermomechanical computer model for solar cell modules. A coarse model has been completed and reviewed by Professor W. Knauss of Caltech. Four cases, two boundary conditions simulating winter and summer conditions were run. From these coarse models a high-stress area within the solar module has been identified and chosen for further analyses. A detailed model is being constructed and coded for an ANSYS computer analysis.

e) In-House. Seventeen mini-modules consisting of 11 different designs were subjected to temperature and humidity cycling tests per JPL specification Document 5101-65. These results and the results of other mini-module tests will be given in a forthcoming LSA Project report.

\section{PRODUCTION PROCESSES AND EQUIPMENT AREA}

During the reporting period, the PP\&E Area directed 17 contractor organizations in 25 efforts in pursuit of economical processes for the fabrication of solar cells and modules. The Area's overall schedule is shown in Figure 2-6. A listing of the contractors appears in Table 2-4.

One of the primary functions of the Area is dissemination of process information and procedures evolved as a result of its activities. To obtain such information, contact Mr. Brian Gallagher at (213) 577-9225 or by mail at JPL's Mail Station 512-103. There is no charge for this service; industry is encouraged to make use of it. 


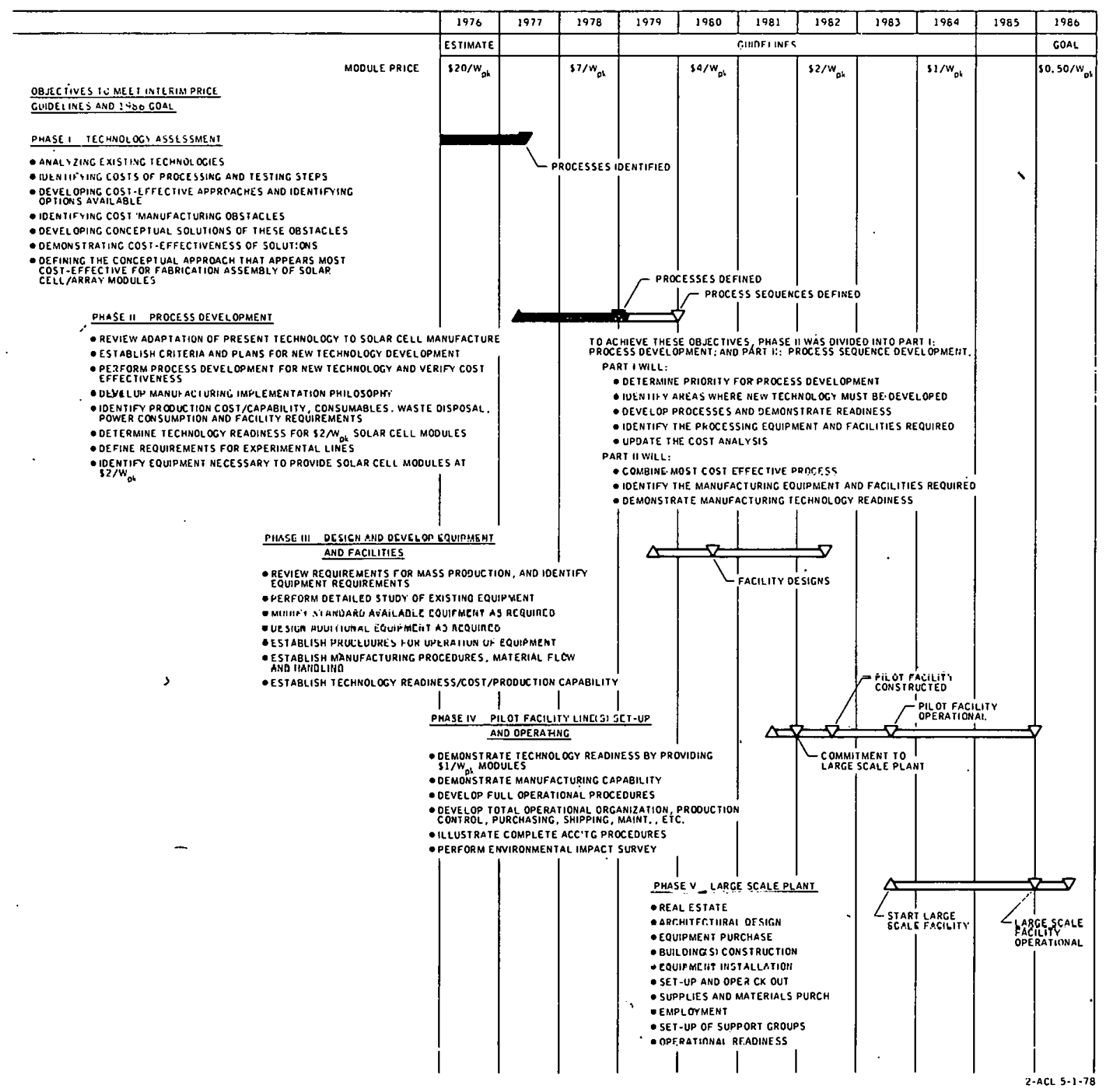

Figure 2-6. Production Processes and Equipment Area Schedule 
Table 2-4. Production Process and Equipment Area Contractors

Contractor

ARCO Solar, Inc.

Chatsworth CA

(JPL Contract No. 955278)

Bernd Ross Associates

San Diego CA

(JPL Contract No. 955164)

Kinetic Coatings, Inc.

Burlington MA

(JPL Contract No. 955079)

Kulicke \& Soffa Ind. Inc. Horsham PA

(JPL Contract No. 955287)

Mobil Tyco Solar

Waltham MA

(JPL Contract No. 954999)

MB Associates

San Ramon CA

(JPL Contract No. 954882)

Motorola, Inc.

Phoenix AZ

(JPL Contract No. 954689)

(JPL Contract No. 955328)

(JPL Contract No. 955324)

(JPL Contract No. 954847)

Optical Coating Laboratory City of Industry CA

(JPL Contract No. 955217)

(JPL Contract No. 955244)

RCA Corporation

Princeton NJ

(JPL Contract No. 954868)

(JPL Contract No. 955342)

Sensor Technology

Chatsworth CA

(JPL Contract No. 955265)

(JPL Contract No. 954865)

(JPL Contract No. 955266)
Contract

Type

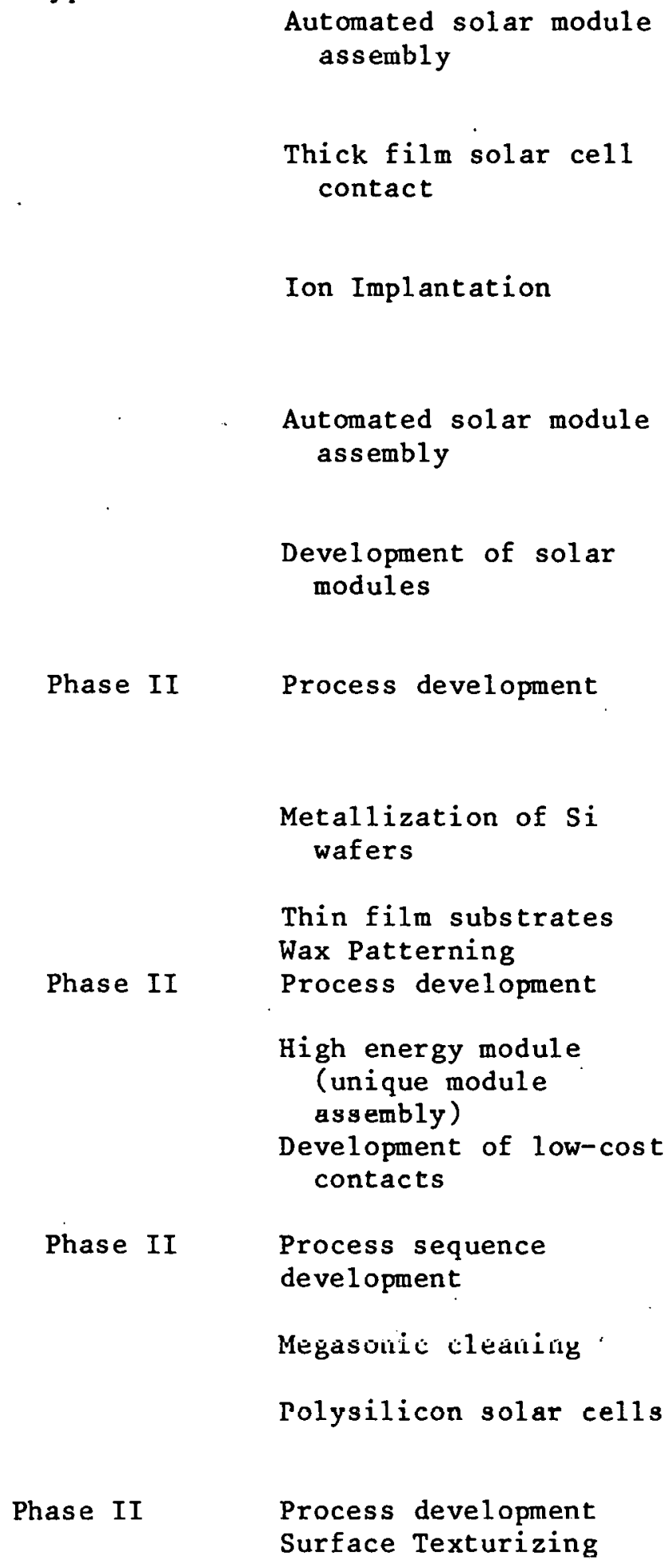

Automated solar module assembly

Thick film solar cell contact

Ion Implantation

Automated solar module assembly

Development of solar modules

Phase II Process development

Metallization of $\mathrm{Si}$ wafers

Thin film substrates

Wax Patterning

Phase II Process development

High energy module (unique module assembly)

Development of low-cost contacts

Phase II Process sequence

development

Megasonic cleanilay

Polysilicon solar cells

Phase II

Process development

Surface Texturizing

Technology Area 
Table 2-4. Production Process and Equipment Area Contractors (Continued)

Solarex Corporation

Rockville MD

(JPL Contract No. 954854)

(JPL Contract No. 955077)

Sol/Los Incorporated

Los Angeles CA

(JPL Contract No. 955318)

Spectrolab, Inc.

Sylmar CA

(JPL Contract No. 954853)

SPIRE Corporation

Bedford MA

(JPL Contract No. 954786)

Texas Instruments

Dallas TX

(JPL Contract No. 954881

University of Pennsylvania

Philadelphia PA

(JPL Contract No. 954796)

Westinghouse Research

Pittoburgh PA

(JPL Contract No. 954873)
Phase II Process development

Wafer thickness

evaluation

Metallization

Phase II Process sequence

development

Ion implanter

Phase II Process development

Phase II Process sequence development 


\section{Process Sequence Development}

Kinetic Coatings, Inc. has been able to optimize the implantation parameters and those associated with front-contact formation in their Integral Structure-Simplified Process Sequence. Earlier the combined antireflective/hermetic seal/implantation oxide coating and the back contact were optimized.

Sensor Technology has recently been awarded a contract to establish a processing sequence for polysilicon cells. The intent is to process fibrously oriented crystal-grain-structure wafers through a modified sequence. No wafers have been processed to date.

Spectrolab, Inc., has defined a process sequence with only three processes currently having alternate options. These involve the use of plasma etching for diffusion oxide removal, aluminum removal and junction cleaning. Investigation of these options will be done soon and a final process will be evolved. Copies are available for those processes that have been made final.

\section{Junction Formation}

Sensor Technology has demonstrated the ability of spray-on doping techniques to produce both boron- and phosphorus-doped junctions. Currently efforts are being directed toward spray-on application of antireflective coatings and aluminum for back surface field formation.

SPIRE Corp. has determined reproducible and uniform beam parameters intended for post ion implantation electron beam annealing of $7.6 \mathrm{~cm}$ diameter wafers with a single pulse. This has been done for both the junction and back surface field sides of the wafer. There are 500 ion-implanted wafers being processed for characterization and distribution of values. A step and repeat technique has been demonstrated for sheet materials up to $10 \mathrm{~cm}$ square.

A new furnace annealing cycle has been evolved by Spire for $10 \Omega \cdot \mathrm{cm}$ material that reduces the processing time from $255 \mathrm{~min}$. to 75 min.

Westinghouse reports that aluminum that has been deposited by sputtering has yielded the most consistent back-surface field results. Open circuit voltages of $0.585 \mathrm{~V}$ and efficiencies of $15.2 \%$ have been achieved. When $10-12 \Omega \cdot \mathrm{cm}$ dendritic web was used instead of the $12 \Omega \cdot \mathrm{cm}$ float zone reported above, the average open-circuit voltage reported is $0.570 \mathrm{~V}$ and the efficiency averages $14.8 \%$.

\section{Metallization}

Bernd Ross Associates has been compounding fritless inks to produce metal contacts using base metals or base metal dilutions of noble metals. To verify the general capability of the technique a 
silver/silver fluoride system was tried with some success. The recent experiments have shown that use of a Ge powder fraction gives better electrical properties than pastes using $\mathrm{B}, \mathrm{Al}, \mathrm{Ga}, \mathrm{In}, \mathrm{Sb}$ and $\mathrm{Ti}$ as dopants. To date 55 pastes have been formulated.

OCLI is continuing investigation of the use of copper in contact formation. The most promising system to date has been one in which an initial layer of palladium is laid down electrolessly by the bath developed by Motorola under PP\&E Area contract. Subsequent electro-deposited layers of chromium and copper are then applied. Good adhesion and conductivity have been shown but some problems have occurred with copper migration after elevated temperature exposure. Work is currently being directed toward improved masking methods.

Sol/Los, Inc., has been investigating a metallization system that will produce a molybdenum-tin contact. The underlying theory is that molybdenum matches the coefficient of expansion of $\mathrm{Si}$ closely and tin will provide an easy interconnection system. The fritless ink formed is to be printed and fired in the $800^{\circ} \mathrm{C}-900^{\circ} \mathrm{C}$ range. This is deemed possible because the molybdenum will be applied as a trioxide.

Initial investigations by Westinghouse have indicated to them that there is a deterioration in all properties when an electroless palladium-nickel conductive layer is substituted for the standard titapium-palladium-silver system.

In addition, optimum grid size and spacing has been determined for a variety of cells by Westinghouse.

4. Surface Preparation

Motorola hes constructcd a modulc made cntircly of cclla whooc front-surface ohmic contact grid pattern was etched throughout the silicon nitride dielectric by plasma technique through a mechanical mask. The module produced about $18 \mathrm{~W}$ with an open-circuit voltage of $20 \mathrm{~V}$ and a short-circuit current of $1.2 \mathrm{~A}$.

RCA has further investigated its in-house formulation of spray-on antireflective coating and has tound that the coating, after processing, produced a typical $35 \%$ increase in short-circuit current (Figure 2-7). The distribution of short-circuit current vs film thiaknoes is chown in Figuro $3-8$.

Solarex Corp. has ascertained that wafers sawn with a wire saw and $5 \mu \mathrm{m}$ abrasives needed very little saw damage removal. The wafering time rose however, and cost trade-offs are going to be analyzed. A wire diameter of at least 0.006 in. was needed for cost effective use of Solarex's saw. 


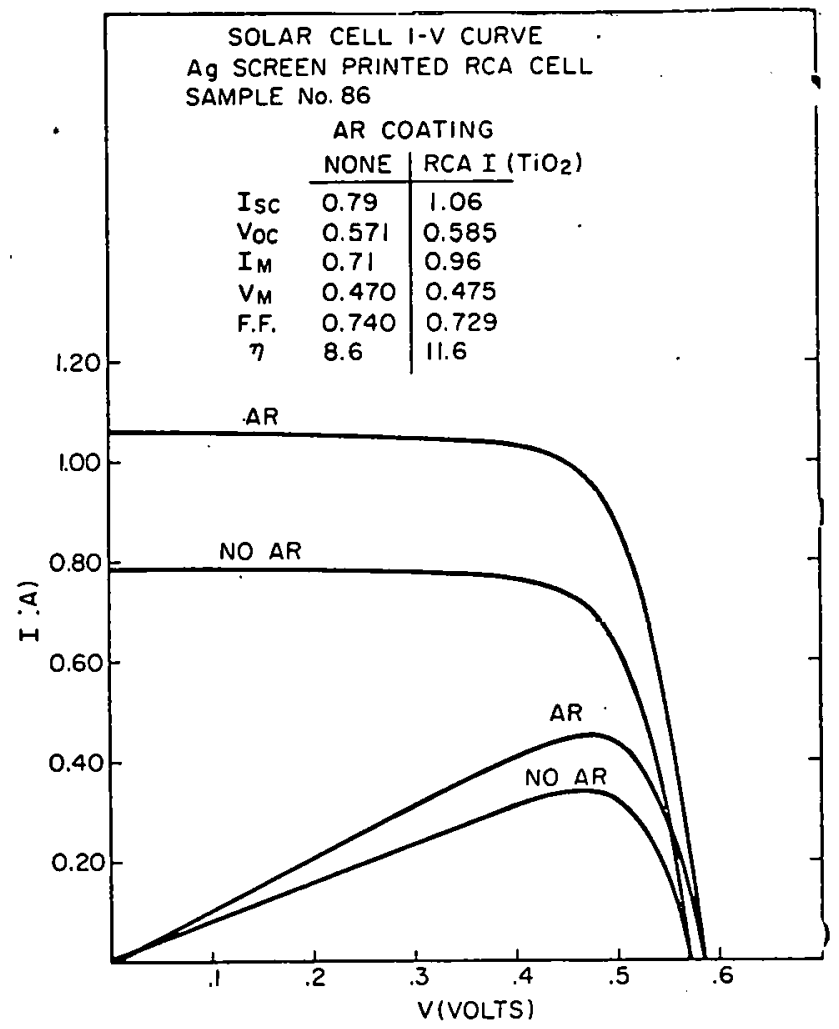

Figure 2-7. Increase in Short-Circuit Current After Cell Processing with RCA's Anti-Reflective Coating

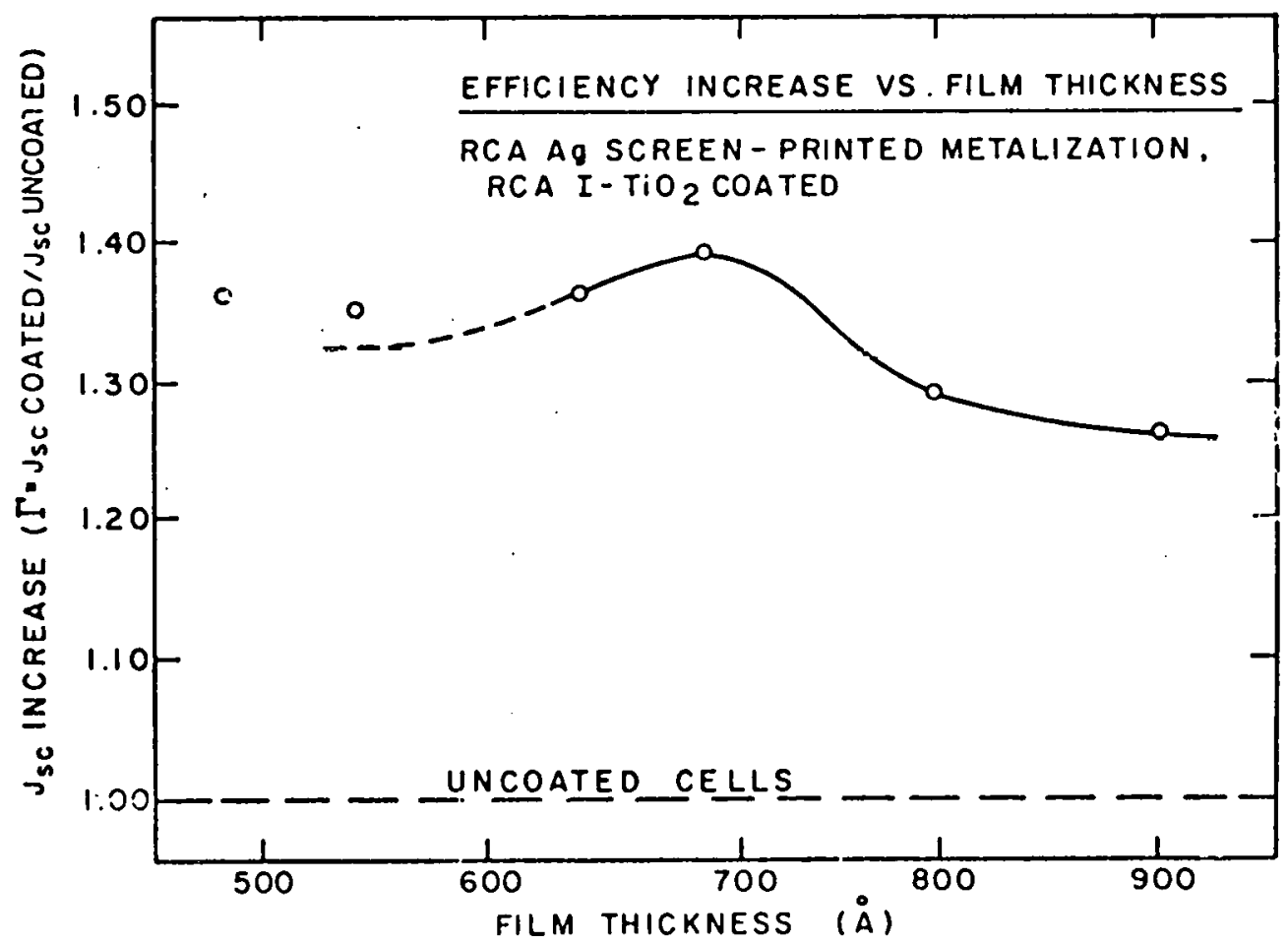

Figure 2-8. Distribution of Short-Circuit Current vs Film Thickness. 
5. Assembly and Test

The Unimate industrial robot is now operational at MB Associates and is being programmed for automation of cell placement and interconnection.

A SAMICS analysis of MB's entire production sequence now indicates a module selling price of $\$ 0.489 / \mathrm{Wp}$. This is predicated upon a price of $\$ 34.90 / \mathrm{m}^{2}$ for the input $\mathrm{si}$.

Sensor Technology has discovered a computational error in its laser scribing and holing SAMICS costing. The current calculation brings the cost down to $\$ 0.00777 / \mathrm{Wp}$ for the combined operation. This is in line with the 1986 target goals for Sensor Tech's process sequence. Its current overall SAMICS analysis shows a selling price of $\$ 0.6994 / \mathrm{Wp}$.

6. Module Development

OCLI is in the process of developing a P-on-N, $14 \%$ efficient module. Most recently, $15.6 \%$ efficient cells have been reported. Work is proceeding on further improvement and currently efforts are directed at production of a back-surface field. The module design size is 22-1/4 in. $x 48$ in. Sunadex glass, 3/16 in., is being used. The 120 cells will be connected in a four-parallel 30-series system to produce $96.4 \mathrm{~W}$ at $15 \mathrm{~V}$. These values are at AMl and $28^{\circ} \mathrm{C}$. OCLI estimates that a gain of $7 \%$ is expected from the combined effect of the Sunadex glass and the zero-depth concentrator developed by General Electric under PP\&E Area contract.

\section{Advanced Equipment Development}

ARCO Solar io designing wachiues to solder interconnects at a rate of 12 per minute and produce 12 laminates per hour. A prototype lamination system has been built and operated. The Contractor Module Design Review was completed in mid-March and the design selected is illustrated in Figure 2-9. Figure 2-10 shows the schematic representation of the Solar Cell Assembly Prototype while the Solar Panel Lamination Prototype is shown in Figure 2-11 with the operating sequellet.

Kulicke and Soffa, Inc., presented a design review in the latter part of March and the resultant machinc concept is shown in Figure 2-12. The plan is to produce strings of cells by solder interconnection. A vacuum lance will be used to position the string within the module. The cycle target is to process one cell every five seconds.

OCLI has completed a final design review at JPL. The tooling is four-fold in function. It is to cover semi-automation of the antireflective coating application, cell testing, back contact soldering and vacuum pickup. 

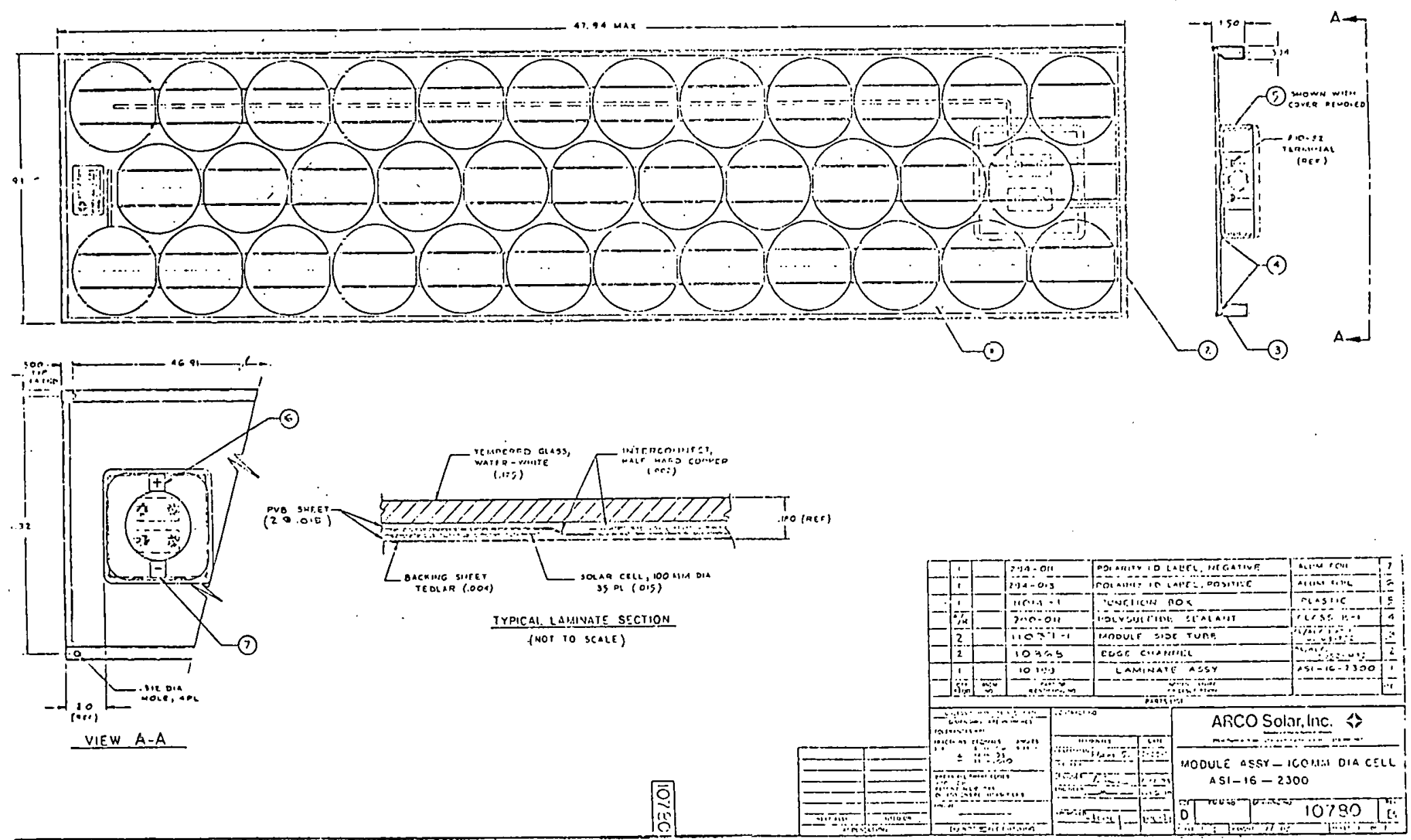

Figure 2-9. ARCO Solar Module Design 


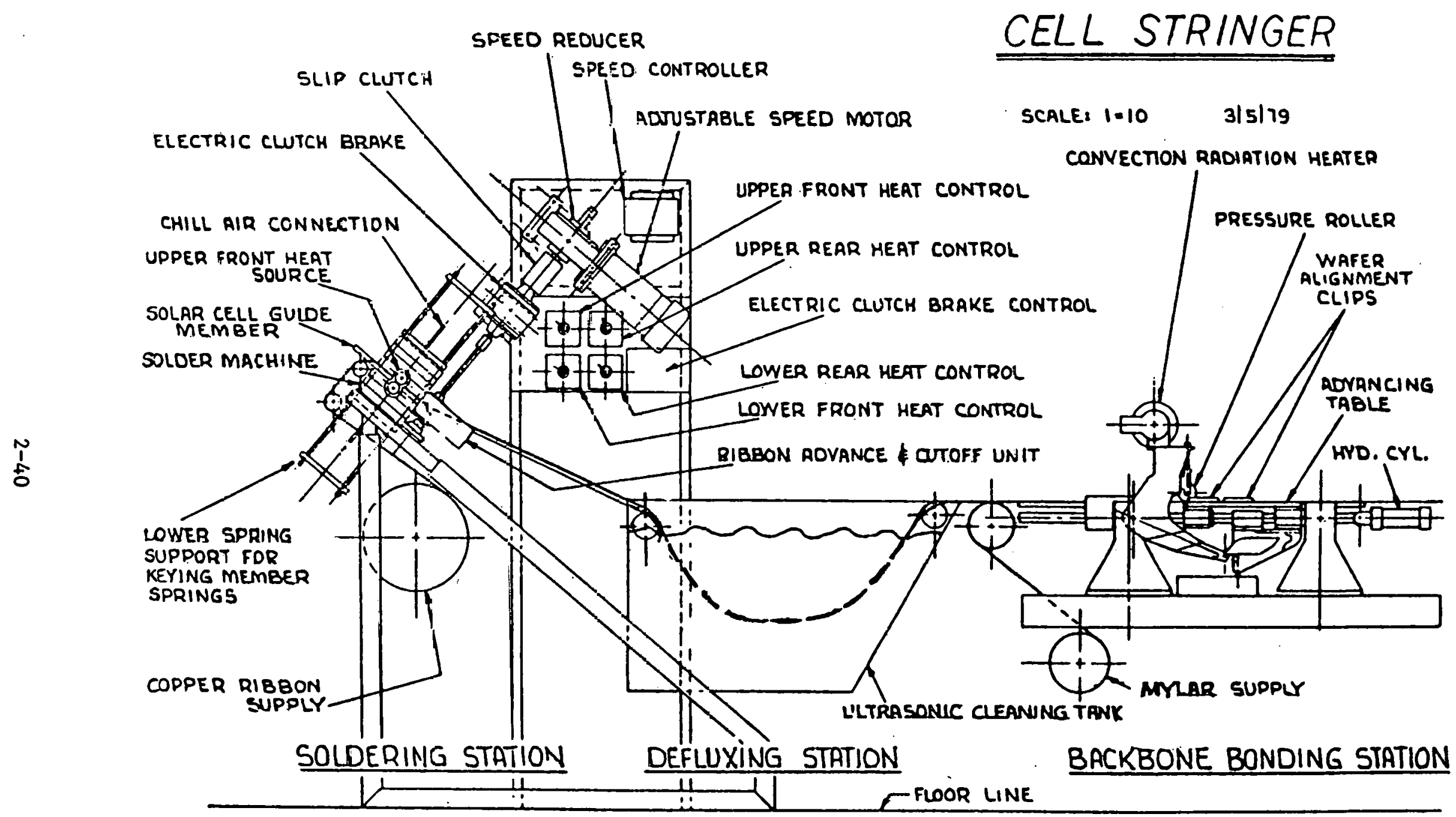

Figure 2-10. ARCO Solar Cell Assembly Prototype 


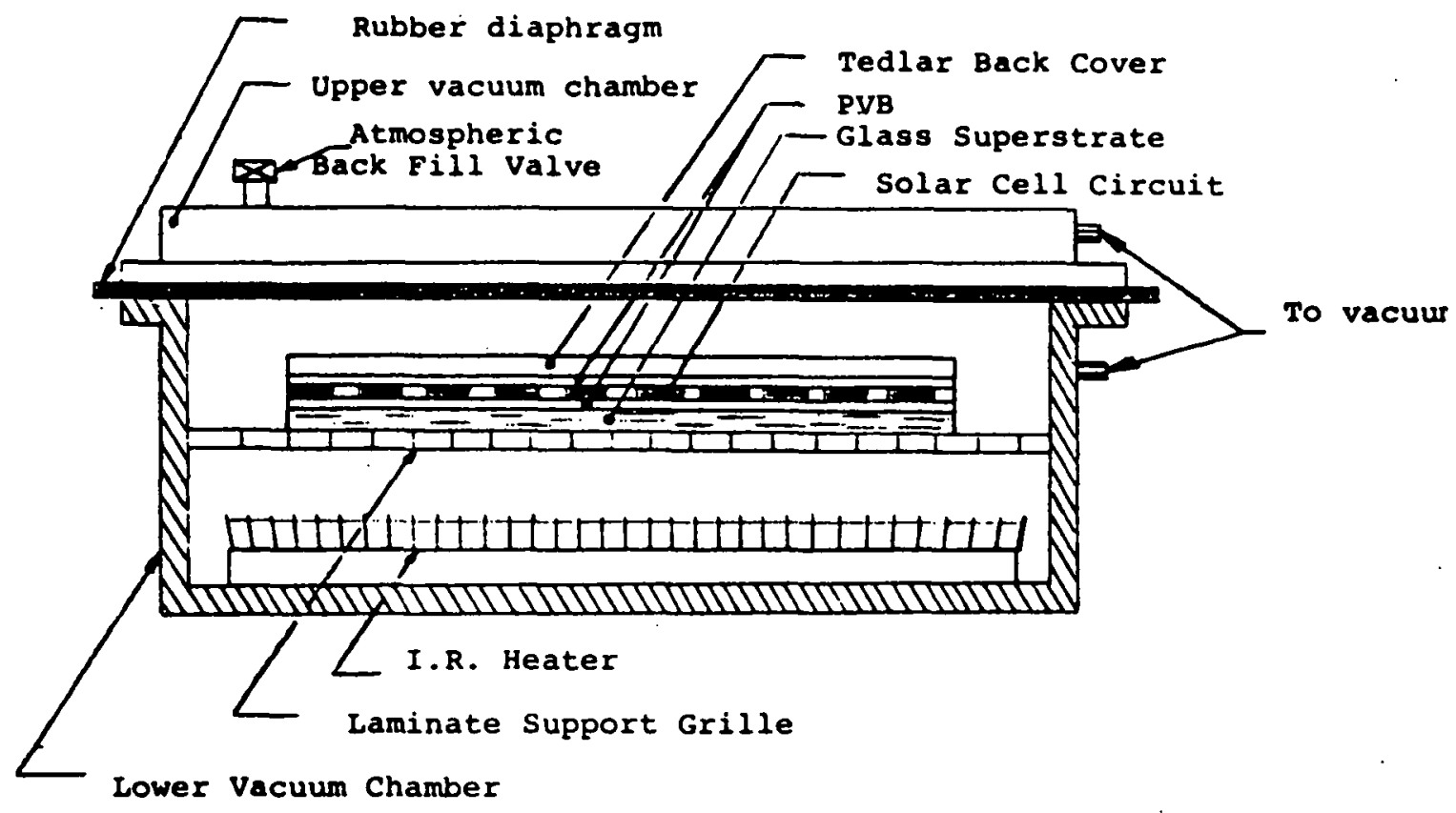

Figure 2-11. ARCO Solar Module Lamination Prototype. 


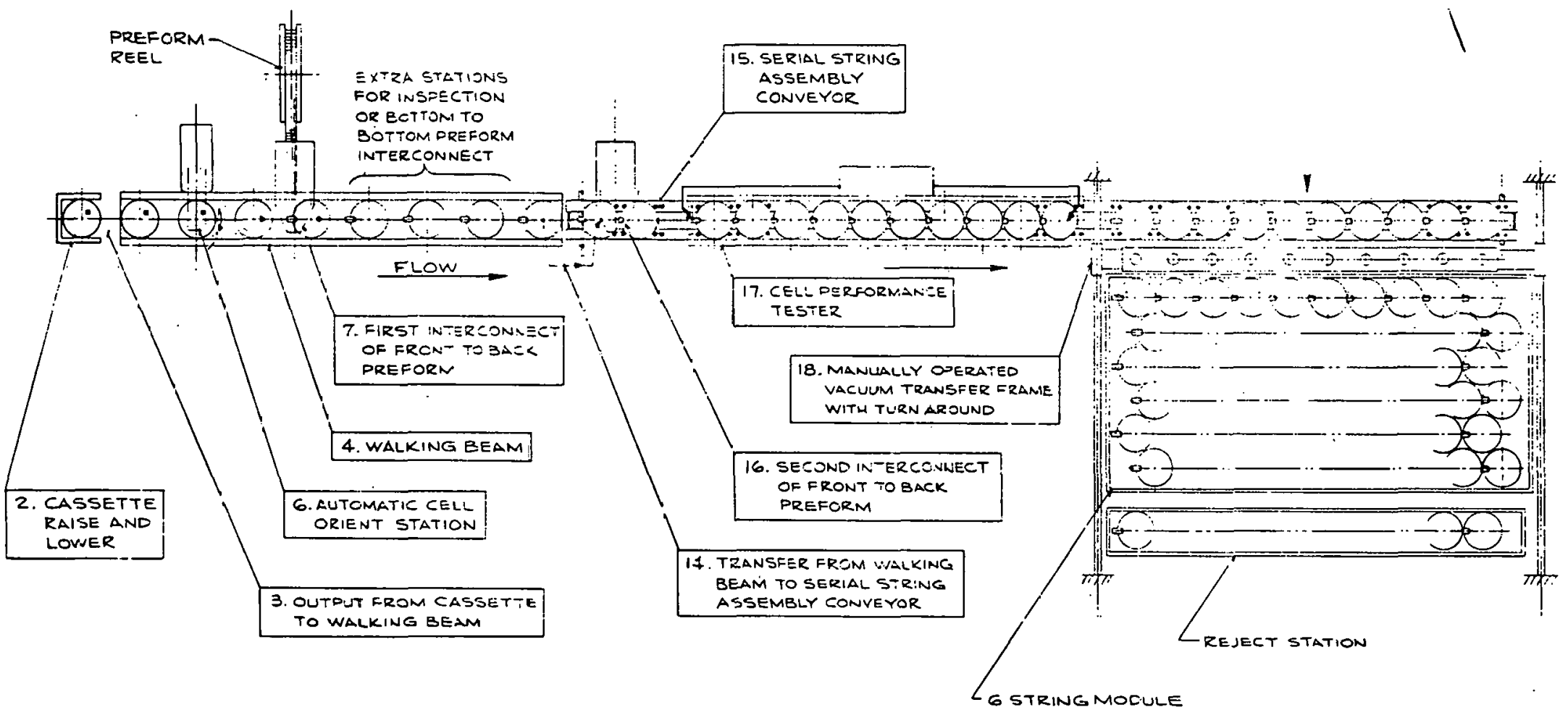

APPRCXX SCALE: $1 / 8^{\circ}=1^{\circ}-1$

1 meter 
During this reporting period work has been focused on array design/engineering, reliability-durability requirement development, and array standards.

\section{Array Design/Engineering}

Principal in-house work has been upgrading and application of series/paralleling computer programs to perform various analyses. The program. was expanded to include cell-failure rates an order of magnitude above and below those previously reported. A statistical method was developed for determining the distribution of failures in an array field based on given expected failure rates. A Monte Carlo technique for analyzing non-uniform location of hot-spot heating cells resul Ling from distribution of col1 shunt resistance was incorporated in the program. An analysis was performed to optimize placement of diodes in module circuits. The module mean environmental operating condition studies reported before are being extended to apply to concentrator systems in response to SERI standards activity. Computer model input parameters for cell characteristics are being modified to include spectral response and theoretical solar spectrum data.

Contractor reports for the Bechtel array-structure study, Boeing wind-loading study, Burt Hill Kosar Rittleman Associates residential requirements study and a recently initiated Motorola module electrical termination requirements study appear in Section III of this report. A contract has been initiated with Underwriters Laboratory to develop photovoltaic module safety-related design criteria.

\section{Reliability-Durability Requirements}

In-house efforts in the area of cell-fracture mechanics have continued. The four-point twist loading fixture developed by JPL was employed in loading tests of wafers and cells removed from Motorola's cell fabrication line at successive process steps. Results indicate that significant changes in cell fracture resistance can be detected as a result of specific coll fabrication process steps.

Phase I activities were completed and planning for Phase II was initiated in module soiling. Purchase of candidate materials for the outdoor material-soiling experiment, a cooperative effort with the Encapsulation Task, was accomplished and sample preparation and baseline transmission and reflectance measurements made. Deployment of samples to llie field is planned for mid-April. The 1500-V electrical stress test of Block II minimodules is continuing at the JPL Ci.eld site. Corona and leakage courrent measurements are continuing to be made on a periodic basis. The instrumentation for this test is being modified to detect and count corona or leakage transients with voltage applied. Procurement of an Inframetrics infrared camera for use in hot-spot investigations and field failure detection was initiated. Preliminary results of the use of the camera 
to scan the Mead, Nebraska site were discussed at this Project

Integration Meeting. Contracted efforts in the Reliability-Durability activity continued on schedule. Current status of the clemson University cell-reliability study and the DSET Labs module accelerated solar-exposure tests are detailed in the attached summaries.

\section{Array Standards and Specifications}

A principal activity has been support of the SERI-led Performance Criteria and Test Standards Project. The Task Group I (Array Subsystems) met at JPL in January; Dr. Ron Ross was chairman. Participants included government and industry. The first meeting was addressed to array performance and reliability-durability criteria. A second meeting took place the week before the 12th PIM. Engineering area personnel also participated in Task Group II, which currently addresses itself to the balance of system interface requirements and to system overview requirements. During this period Engineering Area personnel have participated in and provided support to proposal review and assessment for concentrator and flat-plate PRDAs, an Encapsulation Task RFP, and Block IV procurement. Review of designs with respect to applicable specifications was accomplished.

\section{E. OPERATIONS AREA}

1. Large Scale Production Task

a. Block III. From December 1978 through March 1979, $44.4 \mathrm{~kW}$ of modules were provided to JPL by Block III contractors. The totals delivered by the end of March represented $89 \%$ of the requirement. ARCO Solar completed delivery of modules in January. Production detail for the four months ending March 1979 io diaplayed beluw.

\begin{tabular}{|c|c|c|c|c|}
\hline Contractor & $\begin{array}{c}\text { Alloca- } \\
\text { tion } \\
\mathrm{kW} \\
\end{array}$ & $\begin{array}{c}\text { Shipped } \\
\text { Dec.-Mar } \\
\mathrm{kW}\end{array}$ & $\begin{array}{c}\text { Shipped } \\
\text { Total } \\
\text { kW. }\end{array}$ & $\underset{\%}{\text { Complete }}$ \\
\hline ARCO Solar. & 37.15 & 10.00 & 37.28 & 100 \\
\hline Motorola & 50.00 & 21.52 & 43.82 & 80 \\
\hline \multicolumn{5}{|l|}{ Sensor } \\
\hline Technology & 42.73 & 10.46 & 24.44 & 57 \\
\hline Solar Power & 53.07 & 2.34 & 53.51 & 100 \\
\hline Solarex & 31.91 & 0 & 31.11 & 100 \\
\hline Totals & 214.86 & 44.32 & 190.77 & 89 \\
\hline \multicolumn{5}{|c|}{$\begin{array}{l}\text { Significant modifications to contracts with Sensor Technology, Inc., } \\
\text { and Motorola, Inc., that compensated for various changes in the } \\
\text { reference cell calibrations used in measuring module power output and } \\
\text { for changes in the average power output per module, were negotiated and } \\
\text { implemented. In the case of Motorola, the actual power output of an } \\
\text { average module was } 10 \% \text { larger than the nominal average oower predicted }\end{array}$} \\
\hline
\end{tabular}


at the outset of the contract and the number of modules required to deliver the $50 \mathrm{~kW}$ on order was reduced from 2381 to 2156.

A continuing shortage of 2-inch dia. Si wafers prevented achievement of the planned module delivery schedule from Sensor Technology, Inc.

\section{b. Block IV}

Proposals for Block IV module design contracts were evaluated during this reporting period and negotiations with eight potential contractors were begun. Module designs sought in this procurement were to be for intermediate load applications or for residential applications. Companies submitting proposals for module designs regarded as uniquely residential. were ARCO Solar, Inc., GE, and Solarex Corp. Module designs characterized as primarily adapted to intermediate-load applications were submitted by ARCO Solar, Motorola, OCLI, Sensor Technology, Solar Power, Solarex and SPIRE.

The contracts to be negotiated call for the design, fabrication and qualification of modules that incoporate advancements in design and/or processing. Under these contracts, design and processing documentation is to be completed including inspection plans and criteria, the modules are to be subjected to qualification testing, and the SAMICS/SAMIS costing and price analysis demonstrated.

Approximately $1 \mathrm{~kW}$ of modules will be obtained of each model for qualification testing and limited field testing.

After the successful completion of the design contracts it is expected that purchase orders for limited quantities of each module type, up to $10 \mathrm{~kW}$, will be placed.

\section{Module Test and Evaluation}

a. Environmental Testing. Most of this period's testing effort was on the PRDA-38 modules. Testing has been completed on some of the 12 types; completion of all test.s is expected by the end of April. Details of results will be available after Phase 2 awards are made by DOE. Several general comments about these tests can be made:

1) Hail testing was initiated as one of the qualification tests for this procurement. Most modules had little trouble meeting the requirements except when the field application called for unusually large hailstones.

2) Monitoring of modules for resistance to ground during environmental exposure was also done for the first time during these tests. A considerable number of modules failed this check; this problem was confirmed in most cases by failures in hipot tests after environmental exposure. Poor electrical isolation is a serious problem because it represents a safety hazard in field installations. 
Other test results from this period are summarized briefly below:

(1) ARCO Solar Block III Production Samples: Minor shrinking, cracking and lifting of plastic end channels has continued.

(2) Sensor Tech Block III Production Samples: Satisfactory.

(3) Motorola Developmental Module with Multiple Back

Contacts: Satisfactory

(4) Mobil Tyco Developmental Module with Improved Terminals: Many cover glass cracks from cyclic pressure loading.

(5) Texas Instruments Developmental Module: Cell cracking and one cover glass crack in temperature; more cell cracking in humidity; encapsulant (an oil) leak; one electrical degradation of $12 \%$ after cyclic pressure loading.

(6) OCLI Commercial with PVB Encapsulant: Cover glass crack from temperature cycling.

The Block II Test Report, JPL Document 5101-98, has been issued.

b. Performance Measurements. Reference cells were fabricated, calibrated and delivered to the flat-plate PRDA Program for the JPL test program and to MIT/LL for its field test program. Procurement and fabrication of components for the Block IV reference cells was initiated. It is anticipated that vendor cells will arrive starting in mid-July for the generation of Block IV reference cells.

A need was identified for a higher current capacity dynamic load for the LAPSS system. The present system, though rated at 20 amps, will not function over about 13 amps. Spectrolab was contracted to build a new unit with current capacity to 50 amps. The new unit will be completed in four to six months at a cost of $\$ 25,000$. The second LAPSS facility construction is now scheduled for completion in June. The second LAPSS is scheduled to become operational in July. The integration of both LAPSS systems to the central computer system is scheduled for completion in August. Interface hardware and software development for the system integration is continuing.

c. Field Tests. The effort in this period centered on improving the accuracy of the endurance data at the JPL Field Test Site and initiating an inspection tour of the newly acquired Lewis Research Center remote sites.

Two exploratory tests have been performed to provide some basic information regarding the use of reference cells. First, an examination of the influence of the incidence angle (angle between the module normal and the sun) on data accuracy was performed by 
collecting $\mathrm{I}_{S C}$ and reference cell output data on a large number of modules around solar noon at different tilt angles. A comparison of the ratios of the $I_{S C}$ values and the reference cell values as a function of tilt angle indicated that: 1) there is an angle-ofincidence effect for angles greater than $10^{\circ} ; 2$ ) the effect can be as great as $2 \%$ to $3 \%$ at large angles, around $30 \%$; and 3 ) there is a time-of-day effect, i.e., the results were different in the morning and afternoon.

The second test entailed performing field calibrations of reference cells. A small group of modules was removed from the field, flashed with the LAPSS system and then re-installed. These modules then provided a baseline for performing a calibration of the reference cells in situ. Over a period of about two weeks data was taken at solar noon on this group of modules. These results provided the data necessary to apply corrections to the roforence-cell. constants.

At the end of April, as a result of those tests, a revised testing procedure will be implemented. The principal changes will be: 1) the acquisition of the basic daily data will take place at solar noon instead of at some minimum insolation threshold; 2) more module tilt angles will be used throughout the year to ensure that the incidence angles do not exceed $10^{\circ}$; and, 3) in-field reference cell correction constants will be used.

During February, JPL assumed the responsibility for data collection at the 12 remote endurance test sites originally established by NASA Lewis about a year ago. The sites are located in such diverse spots as Alaska and the Panama Canal Zone and collectively cover virtually all climatic conditions. Each site is the same, having four test stands and the same inventory of modules, four of each of the Block II types. The Area's plan calls for site visits to obtain electrical performance and physical change data on each module, then to generate an updated test plan by the end of FY79. During mid-March, the two high desert sites at Albuquerque, NM, and Dugway, UT, were visited and data taken. A report summarizing these results will be made at the end of April.

d. Failure Analysis. During this reporting period 80 new Problem/Failure Reports were filed and 80 P/FRs were closed out. A summary of this activity is given in Table 2-5. 
Table 2-5. Summary of PFR Activity: Module/Problem/Failure Experience for the Period Jan.-Mar. 1979

\begin{tabular}{|c|c|c|c|c|c|c|}
\hline MFG & $\begin{array}{c}\text { Procure- } \\
\text { ment } \\
\text { Block } \\
\end{array}$ & $\begin{array}{c}\text { New } \\
\text { PFR's } \\
\end{array}$ & $\begin{array}{l}\text { Closed } \\
\text { PFR's } \\
\end{array}$ & $\begin{array}{c}\text { Environ- } \\
\text { mental } \\
\text { Test } \\
\end{array}$ & $\begin{array}{l}\text { Field } \\
\text { Test }\end{array}$ & $\begin{array}{c}\text { Application } \\
\text { Centers } \\
\end{array}$ \\
\hline \multirow[t]{3}{*}{ V } & I & & 5 & & 1 & 4 \\
\hline & II & 6 & 7 & & & 7 \\
\hline & III & & 8 & 8 & & \\
\hline W & I & 4 & & & & \\
\hline $\mathrm{Y}$ & II & 2 & 2 & 2 & & \\
\hline \multirow[t]{2}{*}{$z$} & $I$ & & 3 & & & 3 \\
\hline & III & & 11 & 10 & 1 & \\
\hline $\mathbf{R}$ & & & 13 & 13 & & \\
\hline $\mathrm{U}$ & & 7 & 9 & 9 & & \\
\hline Task 4 & & 10 & 13 & 10 & 3 & \\
\hline Taok 5 & & & 9 & y & & \\
\hline PRDA & & 51 & & 51 & & \\
\hline
\end{tabular}



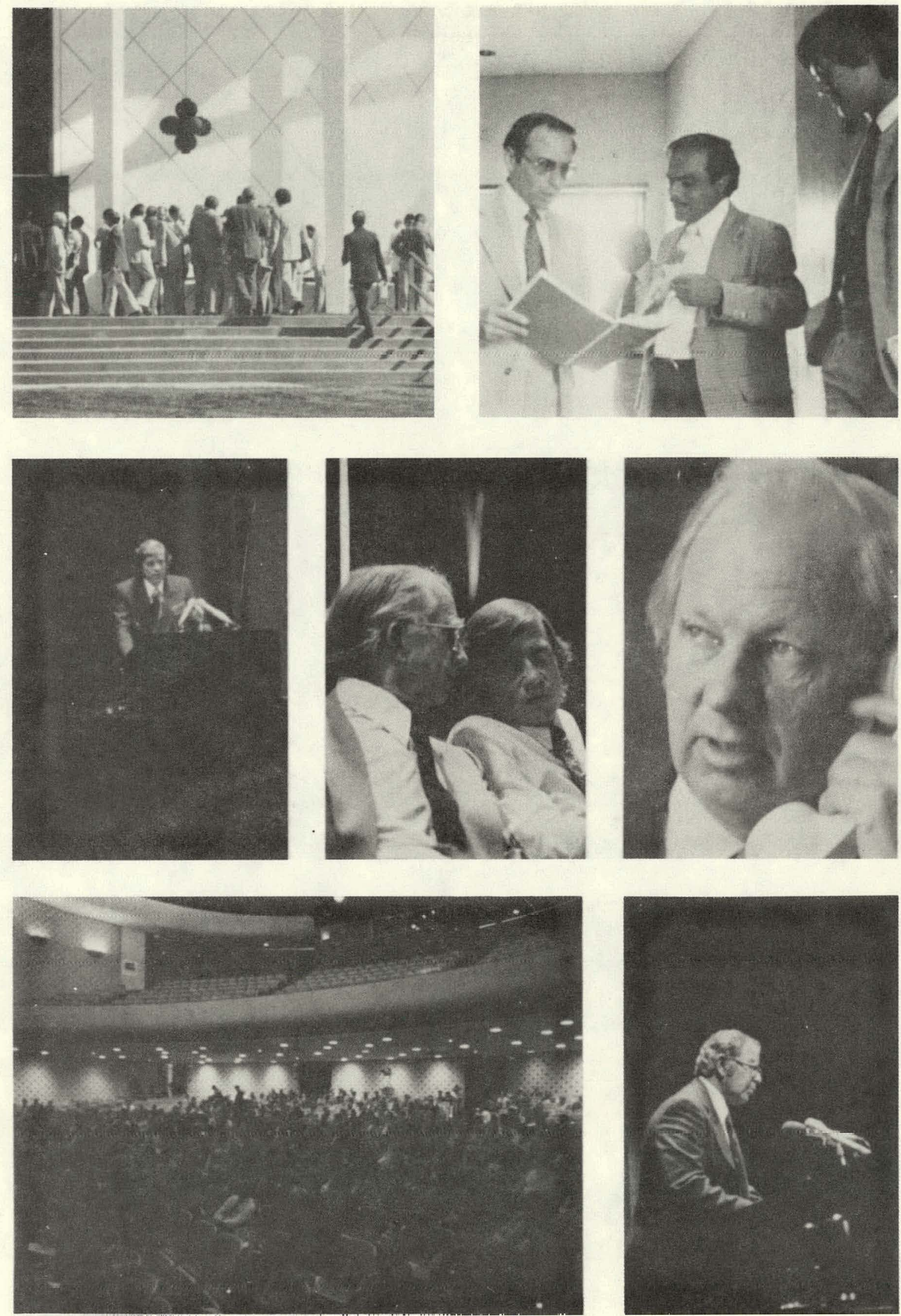

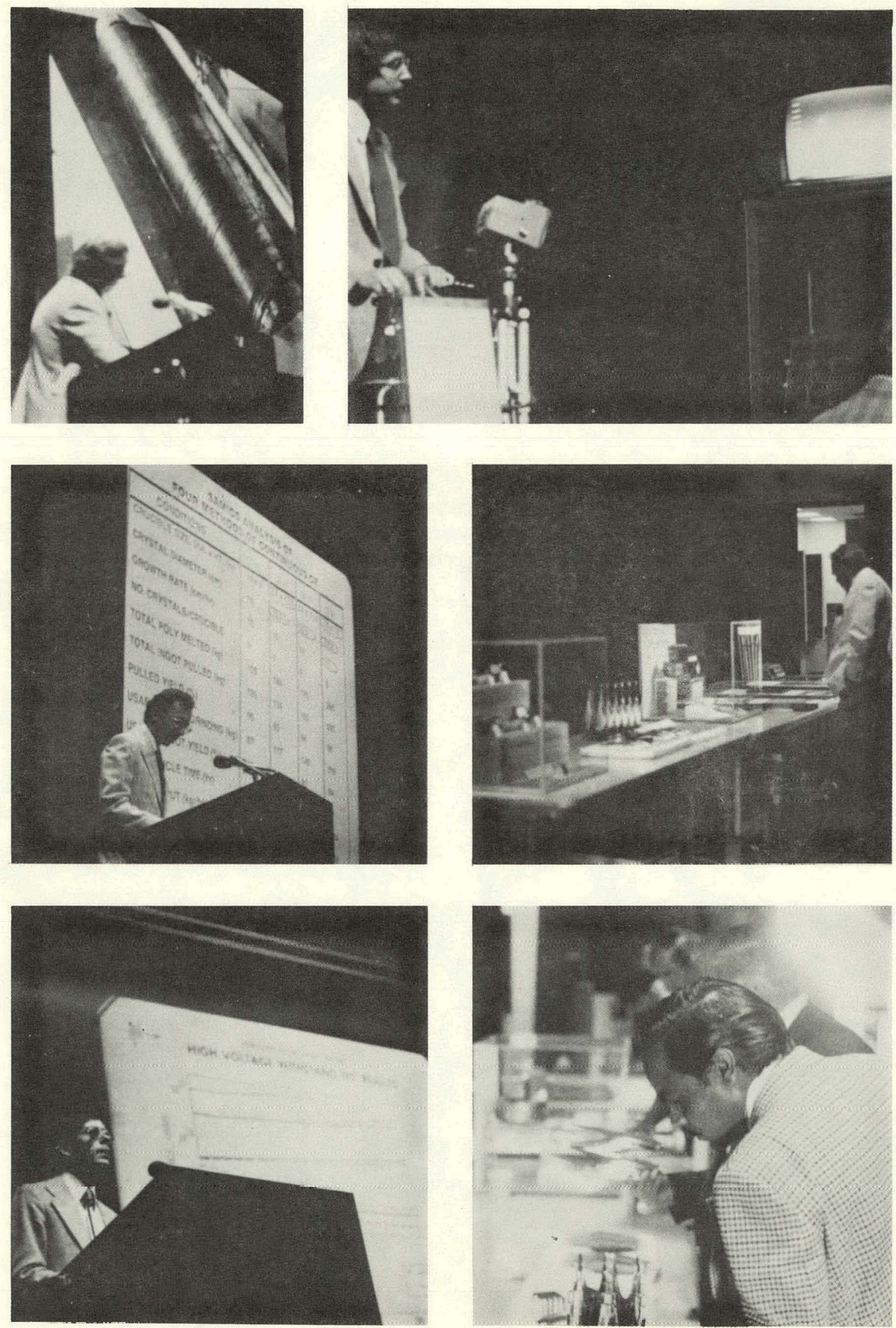
SECTION III

PROCEEDINGS OF THE 12TH PROJECT INTEGRATION MEETING

The 12th LSA Project Integration Meeting (PIM) was held April $4-5,1979$, on the campus of the California Institute of Technology. Invitation-controlled attendance included Project participants from JPL and LSA Project contractors, together with representatives of the DOE Division of Solar Technology and other agencies participating in the Photovoltaic Program.

\section{A. INTRODUCTION}

Dr. Marshall E. Alper, Manager of Solar Projects at JPL, opened the 12th PIM by announcing two permanent appointments: Mr. Robert G. Forney as Manager, Photovoltaics Technology Development and Applications (TD\&A) Lead Center, and Dr. William T. Callaghan as Manager, Low-cost Solar Array Project.

Announcements were continued by Mr. Paul Maycock, Chief of the Photovoltaics Systems Branch of the Department of Energy, regarding the upcoming DOE Semi-Annual meeting to be held May 15-17, 1979, at Gatlinburg, Tennessee, and the importance of the TD\&A Lead Center role at JPL. In addition, budgetary prospects for FY80 were also discussed briefly. Dr. Leonard Magid, Senior Program Manager, also of DOE, reported briefly on the status of the Photovoltaics Standards work currently underway and the recent American Physical Society report on photovoltaic energy conversion.

Welcoming comments to attendees of the PIM were continued by $\mathrm{Dr}$. Callaghan. He noted that the 12 th PIM was being held jointly with the 3rd Sandia Laboratory Concentrator Technology PIM, managed by Dr. Donald J. Schueler.

The main theme of the LSA Project PIM was presented as consisting of two major thrusts: ingot growth and slicing, and automated process equipment. The status of ingot growth and slicing was chosen as an important theme because of the general advances made over the past two-year period. Specific advances in recent months give strong support for the achievement of $\$ 0.50 / \mathrm{Wp}$ (1975 dollars) by the ingot technologies. Presentations detailing these advances, to be given by Dr. James Liu and JPL contractors in the Large Area sheet Task, were announced.

Likewise, automated process equipment was chosen as a timely and important theme because of recent advances by JPL contractorc. Presentations by $\mathrm{Mr}$. Donald Bickler and contractors in the Production Process and Equipment Area were announced to present both narrative and graphic (motion picture and slides) development of notable achievements. Technologies thus covered included cell junction formation, metallization, surface preparation and module fabrication. 
After summarizing the importance of the two themes with respect to the demonstration of LSA Project Technical Readiness by FY82, the opening announcements were concluded and the 12th PIM proceeded.

\section{B. THEME TOPICS}

\section{Ingot technology}

The morning plenary session focused on both ingot growth the ingot slicing efforts.

Crystal Systems reported on developments of the heat exchange method and casting of shaped ingots by the HEM process. Current status and Project goals were outlined. Data on solar cell performance with AMl etticiencies of $13.4 \%$ to $15 \%$ were presented. Economic analysis was given to show an add-on cost of $\$ 4.46 / \mathrm{m}^{2}$ for the ingnt grnwth,

Hamco (Kayex) reported on its advanced Czochralski approach. Crystal growth equipment design data were presented, and goals were compared with status to show that almost all goals in the present effort were achieved. $100 \mathrm{~kg}$ ingot growth particulars were given. Solar cell analysis and economic analysis of the process with four alternatives were presented. The effect of number of crystals per crucible as well as recharge and ingot growth times on cost were discussed. Future effort and primary areas of concern were outlined.

Siltec Corp. reported on the continuous liquid-feed Czochralski approach. Furnace-design aspects were illustrated and discussed showing the transfer tube, the furnace hardware, the melt level monitor, etc. Current progress and economic analysis was presented. An add-on cost of $\$ 21.3 / \mathrm{m}^{2}$ for ingot growth at the present state of operation was shown, which can be reduced to $\$ 9.92 / \mathrm{m}^{2}$ by 1986 . Data on the effect of run size on crystal add-on cost was also presented both for the batch recharge as well. as continuous recharge.

Crystal Systems, Inc., reported on multiwire slicing by the fixed abrasive slicing technique. Machine hardware and achievements were shown. Economic analysis was presented to show an add-on cost of $\$ 4.63 / \mathrm{m}^{2}$ by 1986 .

Varian Associates described its progress on the multi-blade slurry sawing effort. An economic summary, as well as technical summaries, was presented to show an add-on cost of $\$ 8.53 / \mathrm{m}^{2}$ for the s1icing operation by 1986 .

Siltec Corp. described enhanced ID slicing, emphasizing the three key elements: a) ingot rotation, with minimum exposed blade area; b) dynamic cutting edge control; and c) use of prefabricated insert blades. Goale wcre presented and the approach was outlined. Economic analysis showed a slice add-on cost $\$ 6.97 / \mathrm{m}^{2}$. Schematics and process hardware were shown. 
During the subsequent intertask meeting, progress on refractory material studies, material characterization studies and shaped sheet technology was reviewed.

\section{Refractory Materials Studies}

Battelle Columbus Labs reported development efforts on die and container materials. Silicon aluminum oxynitride (Sialon) and silicon beryllium oxynitride (Sibeon) were two materials found to be resistant to molten $\mathrm{Si}$ attack. Comparative impurity analysis of $\mathrm{Si}_{3} \mathrm{~N}_{4}$ and Sibeon as well as thermodynamic data were presented.

Coors Porcelain Co. is developing mullite substrates (compatible with $\mathrm{Si}$ coating of ceramic) and molten $\mathrm{Si}$ containers. Extensive data on oxide composition and thermal properties of slotted substrates were presented. Sessile drop test data were also displayed. "K" modification mullite matches the average expansion of $S i$ and is being used by Honeywell for silicon-on-ceramic coating.

Eagle Picher's effort for die and container material development is shared by Miami Research Labs (MRL), University of Missouri-Rolla (UMR) and Chemetal Corp., Pacoima, CA. Their presentation was directed toward study of thermal properties of ceramic substrates and effect of oxygen pressure upon silicon/ceramic contact angle and reactivity. Sessile drop-test setup and results were presented for varying oxygen partial pressures. Three CNTD $\mathrm{Si}_{3} \mathrm{~N}_{4}$-coated hot-pressed crucibles were delivered to JPL.

RCA's development program of die materials for use in its inverted ribbon-growth process was reported. Various types of die materials have been evaluated, and resulting Si samples grown using those dies were shown to yield up to $8 \%$ solar cell efficiency (without AR coating). Oxygen and carbon content, sheet resistance, diffusion length and solar cell data were presented. Problems of substrate thermal mismatch, edge effects and slag formation were highlighted. Tylan Corp. reported on the study of processing parameters of Vitre-Graf (a glass-like carbon glaze) for application to mullite and graphite. Failure mechanisms of silicon-graphite were discussed. The baseline process was described and Series 1 through 8 test plans with results were shown.

\section{Material Characterization}

OCLI reported on its effort in solar cell fabrication and evaluation of various JPL-supplied low-cost. Si sheets. Data on CSI's HEM material, Mobil Tyco's EFG ribbon and Honeywell's SOC material was presented.

Spectrolab similarly presented data on Wacker polycrystalline material, Mobil Tyco's EFG ribbons and Westinghouse's web material. It also described the baseline cell fabrication process. 
4. Shaped-Sheet Technology

Progress of the various sheet-growth options was presented. ARCO Solar outlined the vacuum die-casting effort that is just starting. Honeywe 1l, in its silicon-on-ceramic process, outlined the goals for 1979 and the present status. A steady-state vertical growth model for SOC was presented and a film thickness-growth speed relation was discussed. It was shown that production yields for dip-coated substrates have improved to $85 \%$ and cell efficiencies around $8 \%$ to $10 \%$ have been obtained. In the continuous coating machine, however, meniscus instability problems still remain to be solved.

Mobil Tyco presented its EFG Si growth experiments with unsymmetrical dies to show that high meniscus side ribbon was virtually clear of SiC particles. Extensive spreading resistance data and details of die design were presented. Some selected solar cells showed efficiencies from $12.9 \%$ to $14.1 \%$ for ribbons grown in JPL machines 12 and 13 .

Motorola reviewed its progress on RTR silicon. Cell efficiency improvement from $6 \%$ to $9 \%$ has been achieved by Mo removal by etching and a $\mathrm{PH}_{3}$ gettering step. Purgeable furnace experiments have not given consistent results. Some solar cell data and the purge furnace design was presented. Polyribbon formation was described. The technique of rigid-edge RTR growth was also highlighted; it allows better material efficiencies, relaxes polyribbon formation requirements and reduces ribbon breakage. Motorola's program plan for high area growth and cell fabrication was also presented.

Westinghouse presented the progress of web dendritic Si growth. Area throughput of $19.8 \mathrm{~cm}^{2} / \mathrm{min}$, melt replenishment and highest cell efficiency of $15.5 \%$ AMl was their technology status. Analysis of thermal stress vs dislocations was presented. Growth data, cell data, furnace hardware and web solar cell module were illustrated. Program plans for 1986 goals were outlined. 


\section{PRESENTATIONS}

\section{Project Analysis and Integration Area}

\section{POTENTIAL LSA MODULE PRICES}

TOPICS COVERED:

- IMPORTANCE OF THE YEAR 2000

- INGOT TECHNOLOGY POTENTIAL

- NON-INGOT TECHNOLOGY POTENTIAL

\section{R.W. ASTER}

LSA PROJECT PA \& I

APRIIL 4, 1979

THE YEAR 2000

- THE YEAR 2000 HAS BEEN TREATED AS AN "IMPORTANT" YEAR IN.SOME RECENT STUDIES

- THIS IS A YEAR WHEN PV COULD BE PRODUCING A "SIGNIFICANT" AMOUNT OF ELECTRICITY IN THE U.S.

- BY 2000, THE MORE ADVANCED PV CONCEPTS OF TODAY MIGHT HAVE ACHIEVED COMMERCIAL READINESS

- THE LONG TERM PROSPECTS OF FLAT PLATE SILICON ARRAYS ARE SOMETIMES EQUATED WITH INTERMEDIATE (1986) LSA PROJECT GONLS. THIS IS NOT $\Lambda$ GOOD WAY TO COMPARE SILICON WITH ALTERNATIVE TECHNOLOGIES IN THE YEAR 2000 


\section{INGOT TECHNOLOGY \\ (LATE 1980's)}

\begin{tabular}{lcccc} 
PROCESS & YIELD & $\begin{array}{c}\text { REQUIRED } \\
\text { P.RICE } \\
\text { (VALUE ADDED) }\end{array}$ & $\begin{array}{c}\text { YIELDED PRICE } \\
\text { PER UNIT MODULE } \\
\text { AREA }\end{array}$ & $\begin{array}{c}\text { REQUIREO } \\
\text { PRICE PER } \\
\text { PEAK WATT }\end{array}$ \\
\hline SILICON & - & $10 \$ / \mathrm{kg}$ & $11.6 \$ / \mathrm{m}^{2}$ & $0.091 \$ / \mathrm{W}$ \\
INGOT & 0.85 & $12 \$ / \mathrm{kg}$ & 11.8 & 0.093 \\
SLICE & 0.95 & $10 \$ / \mathrm{m}^{2}$ & 9.3 & 0.073 \\
CELL & 0.93 & $15 \$ 1 \mathrm{~m}^{2}$ & 13.0 & 0.102 \\
MODULE & 0.98 & $18 \$ / \mathrm{m}^{2}$ & 18.0 & 0.141 \\
\hline
\end{tabular}

BASED ON THESE ASSUMPTIONS:

- ENCAPSULATED CELL EFFICIENCY $=15 \%$

- PACKING EFFICIENCY $=85 \%$

- INGOTS YIELD $1 \mathrm{~m}^{2}$ WAFER PER kg OF INGOT

\section{INGOT TECHNOLOGY (LATE 1990's)}

\begin{tabular}{lcccl} 
PROCESS & YIELD & $\begin{array}{c}\text { REQUIRED } \\
\text { PRICE } \\
\text { (VALUE ADDED) }\end{array}$ & $\begin{array}{c}\text { YIELDED PRICE } \\
\text { PER UNIT } \\
\text { MODULE AREA }\end{array}$ & $\begin{array}{l}\text { REQUIRED } \\
\text { PRICE PER } \\
\text { PEAK WATT }\end{array}$ \\
\hline SILICON & - & $8 \$ / \mathrm{kg}$ & $8.9 \$ / \mathrm{m}^{2}$ & $0.062 \$ / \mathrm{W}_{P}$ \\
INGOT & 0.85 & $10 \$ / \mathrm{kg}$ & 9.4 & 0.065 \\
SI.ICE & 0.95 & $5 \$ / \mathrm{m}^{2}$ & 4.5 & 0.031 \\
CELL & 0.96 & $15 \$ \mathrm{~m}^{2}$ & 12.9 & 0.089 \\
MODULE & 0.99 & $18 \$ \mathrm{~m}^{2}$ & 18.0 & 0.125 \\
\hline & & & $54.0 \$ / \mathrm{m}^{2}$ & $0.37 \$ / \mathrm{W}_{\mathrm{P}}$
\end{tabular}

BASEO ON THESE AS SUMPTIONS:

- ENCAPSULATED CELL EFFICIENCY $=17 \%$

- PACKING. EFFICIENCY $=85 \%$

O INGOTS YIELU I $\mathrm{m}^{2}$ WAFER PER $\mathrm{kg}$ OF INGOT 


\section{NON-INGOT TECHNOLOGY}

(LATE 1980's)

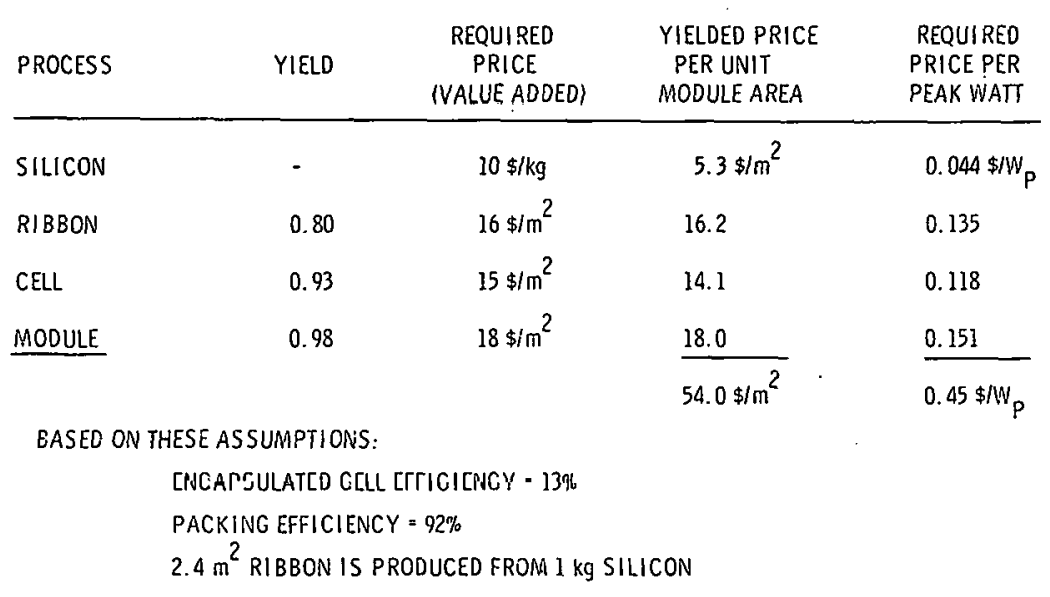

\section{NON-INGOT TECHNOLOGY \\ (LATE 1990's)}

\begin{tabular}{lcccc} 
PROCESS & YIELD & $\begin{array}{c}\text { REQUIRED } \\
\text { PRICE } \\
\text { (VALUE ADDED }\end{array}$ & $\begin{array}{c}\text { YIELDED PRICE } \\
\text { PER UNIT } \\
\text { MODULE AREA }\end{array}$ & $\begin{array}{c}\text { REQUIRED } \\
\text { PRICE PER } \\
\text { PEAK WATT }\end{array}$ \\
\hline SILICON & - & $8 \$ / \mathrm{kg}$ & $2.1 \$ / \mathrm{m}^{2}$ & 0.014 \\
RIBBON & 0.90 & $15 \$ / \mathrm{m}^{2}$ & 15.0 & 0.102 \\
CELL & 0.96 & $15 \$ / \mathrm{m}^{2}$ & 14.4 & 0.098 \\
MODULE & 0.99 & $18 \$ / \mathrm{m}^{2}$ & 18.0 & 0.122 \\
\hline
\end{tabular}

BASED ON THESE ASSUMPTIONS:

ENCAPSULATED CELL EFFICIENCY $=15.5 \%$

PACKING EFFICIENCY $=95 \%$

$4.25 \mathrm{~m}^{2}$ RIBBON IS PRODUCED FROM $I \mathrm{~kg} S I ! I C O N$ 


\section{DEFINITIONS AND RELATIONSHIPS}

REQUIRED PRICE - THE VALUE ADDED IN THAT PROCESS AREA, INCLUDING THE CAPITAL AND INDIRECT COSTS. UNITS ARE $\$ / \mathrm{kg}$ SILICON, $\$ / \mathrm{m}^{2}$ CELL, ETC. THUS, THE YIELDS OF SUBSEQUENT PROCESS AREAS ARE NOT FACTORED IN . (RP)

YIELDED PRICE PER UNIT MODULE AREA - THE YIELDS OF SUBSEQUENT PROCESS AREAS AND THE PACKING EFFICIENCY IS FACTORED IN HERE. (YP)

YIELD - THE AMOUNT OF INPUT FROM PREVIOUS PROCESS AREAS THAT MAKES IT THROUGH THE NEXT PROCESS AREA $(Y)$

RELATIONSHIPS

$$
\begin{aligned}
& Y P P=\text { (RP } \cdot \eta_{p} / Y Y \text { (EXCEPT FOR THE MODULE PROCESS) } \\
& \left.\$ / W_{p}=Y P / / \eta_{\mathrm{e}} \cdot \eta_{p} \cdot 1000\right)
\end{aligned}
$$

\section{IMPACTS ON PROJECT GOALS EQUIVALENT ENERGY PRICES}

- THIS WILL IMPACT PRICE GOALS FOR SYSTEMS WITH DIFFERENT MODULE. EFFICIENCIES (Higher efficiency modules will have an advantage. The extent of this advantage wil! depend upon area-related cosis.)

- thIS WILL IMPACT PRICE GOALS FOR SYSTEMS WITH DIFFERENT LIFETIMES

IMPACTS ON PROJECT GOALS THREE APPLICATION CLASSES

\begin{tabular}{|l|cc|}
\hline \multicolumn{1}{|c|}{ APPLICATION } & $\begin{array}{c}|c| \\
\text { YLCIINOLOCY } \\
\text { READINESS }\end{array}$ & $\begin{array}{c}\text { COMMERCINL } \\
\text { READINESS }\end{array}$ \\
\hline $\begin{array}{l}\text { RESIDENTIAL } \\
\text { INTERMEDIATE LOAD CENTERS }\end{array}$ & 1982 & 1986 \\
CENTRAL SIATIION & 1982 & 1986 \\
\hline
\end{tabular}

PROJECT PAGS HAVE ADDRESSED COMMERCIAL READINESS TARGETS FOR 1986 


\section{IMPACTS ON PROJECT GOALS \\ BASE YEAR CHANGE}

\begin{tabular}{|l|cc|cc|}
\cline { 2 - 5 } \multicolumn{1}{c|}{} & \multicolumn{2}{|c|}{ 1975 DOLLARS } & \multicolumn{2}{c|}{1980 DOLLARS } \\
\hline SILICON & 10 & $\$ / \mathrm{kg}$ & 14 & $\$ / \mathrm{kg}$ \\
INGOT SHEET & 18 & $\$ / \mathrm{m}^{2}$ & 25.2 & $\$ / \mathrm{m}^{2}$ \\
NON -INGOT SHEET (12\%) & 17.4 & $\$ / \mathrm{m}^{2}$ & 24.4 & $\$ / \mathrm{m}^{2}$ \\
NON-INGOT SHEET (14\%) & 11.1 & $\$ / \mathrm{m}^{2}$ & 15.5 & $\$ / \mathrm{m}^{2}$ \\
CELLS & 22 & $\$ / \mathrm{m}^{2}$ & 30.8 & $\$ / \mathrm{m}^{2}$ \\
ENCAPSULATION MATERIALS & 8 & $\$ / \mathrm{m}^{2}$ & 11.2 & $\$ / \mathrm{m}^{2}$ \\
MODULE & 15.5 & $\$ / \mathrm{m}^{2}$ & 21.7 & $\$ / \mathrm{m}^{2}$ \\
& & & & \\
\multicolumn{1}{|c|}{ TOTAL } & 0.50 & $\$ / \mathrm{w}_{\mathrm{p}}$ & 0.70 & $\$ / \mathrm{w}_{\mathrm{p}}$ \\
\hline
\end{tabular}

\section{SOME PRELIMINARY ASPECTS OF THE PV LEAD CENTER PGA}

- 1980 dollars are USed ICONVERT 1975 dollars INTO 1980 DOLLARS BY MULTIPLYING BY 1.40 )

- thrEE APPLICATION CLASSES ARE ADDRESSED:

- residential

- inTERmediate load CEnters

- central station

- DIFFERENT SYSTEMS WITHIN THE SAME APPLICATION CLASS SHOULD PROVIDE APPROXIMATELY EQUIVALENT ENERGY PRICES $(\$ / k W h)$

PRICE ALLOCATION GUIDELINE STATUS

- A SYSTEM-WIDE PRICE GOAL ALLOCATION (PGA) IS BEING PRODUCED BY THE PV LEAD CENTER

D MODULES ARE A COMPONENT OF A SYSTEM WHICH WILL. RECEIVE A PGA ALLOCATION

? THE LSA PROJECT WILL CONTINUE TO ALLOCATE SUDGOALS TO PROJECT ELEMENTS IN THE FORM OF PRICE ALLOCATION GUIDELINES (PAG)

- LSA pRojecit pacs WILl be CONSIStent WITH THE PV LEAD CENTER PGA FOR MODULES 


\author{
SAMIS \\ TOPICS COVERED: \\ - ReLEASE 2 OF SAMIS III \\ - FORMAT "A" ASSISTANCE
}

\title{
RELEASE 2 OF SAMIS III
}

- ReleASE 2 WILL PROVIDE BetTer REPORTS

- all PAST IMPROVEMENTS ARE DOCUMENTED

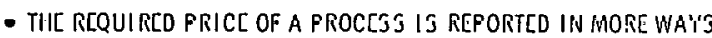

- REQUIRED PRICE PER UNIT OF OUTPUT

- Value added IN $\$ / W_{\text {pk }}$

- value lost due to the yield loss of each step

- COST OF PROCESS

- YIELD SENSITIVITY ANALYSIS

- Release 2 WILl be easier to operate

- RELEASE 2 WILL CONTAIN SEVERAL MODIFICATIONS OF THE INDIRECT REQUI REMENT RELATIONSHIPS

\section{FORMAT A ASSISTANCE}

- FORMAT A's ARE IMPQRTANT TO SAMIS AND TO LSA

- THERE IS A NEW VERSION OF 5101-44, SAMICS INPUT DATA PREPARATION

- THERE IS NOW A FORMAT A CHECKLIST

- an ATTACHMEnt to ench format a is requestcd, dejcridino KEY ASSUMPTIONS THAT LEAD TO FORMAT A DATA 


\title{
LIFETIME COST AND PERFORMANCE MODEL FOR \\ PHOTOVOLTAIC POWER SYSTEMS
}

\author{
C. BORDEN \\ D. SCHWARTZ
}

\begin{abstract}
MOTIVATION FOR THE LIFETIME COST AND PERFORMANCE (LCP) MODEL
\end{abstract}

- TO PROVIDE a "BOTTOM-UP" DESCRIPTION OF ALl tHE ACTIVITIES ASSOCIATED WITH INSTALLING, OPERATING, AND MAINTAINING A PHOTOVOLTAIC POWER PLANT IN TERMS OF COSTS AND ELECTRICAL PERFORMANCE OVER ITS LIFETIME

- to PROVIDE a FRAMEWORK FOR MAKING TRADE-OFFS bETWEen ALTERNATIVE INITIAI. AND RECURRENT POLICY OPTIONS

- to create a general model Which CAN eVAluate paramitrically a wide range OF POWER plant DESIGNS AND APPLICATIONS

- to fill in the analytical gap between the solar array manufacturing INDUSTRY SIMULATION ( SAMIS) AND THE UTILITY-OWNED SOLAR ELECTRIC SYSTEMS (USES) F.CONOMIC MODCL

THE LIFETIME COST AND PERFORMANCE (LCP) MODEL IS

- a management tool useful to system designers and operators for decioing BETWEEN ALTERNATIVE

- SYSTEM CONFIGURATIONS

- installation activities

- level of efFort and timing of operations/maintenance actions

- replacement options

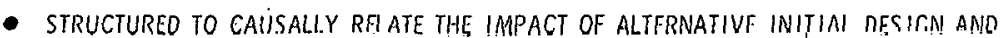
RECURRENT POLICY DECISIONS ON BOTH COST AND ENERGY OUTPUT OVER THE LIFETIME OF $\wedge$ PHOTOVOLTAIC POWERPLANT

- designed to make trageoffs on the bases of minimizing busbar energy cost AND MAXIMIZING THE NET PRESENT VALUE OF THE INVESTMENT 


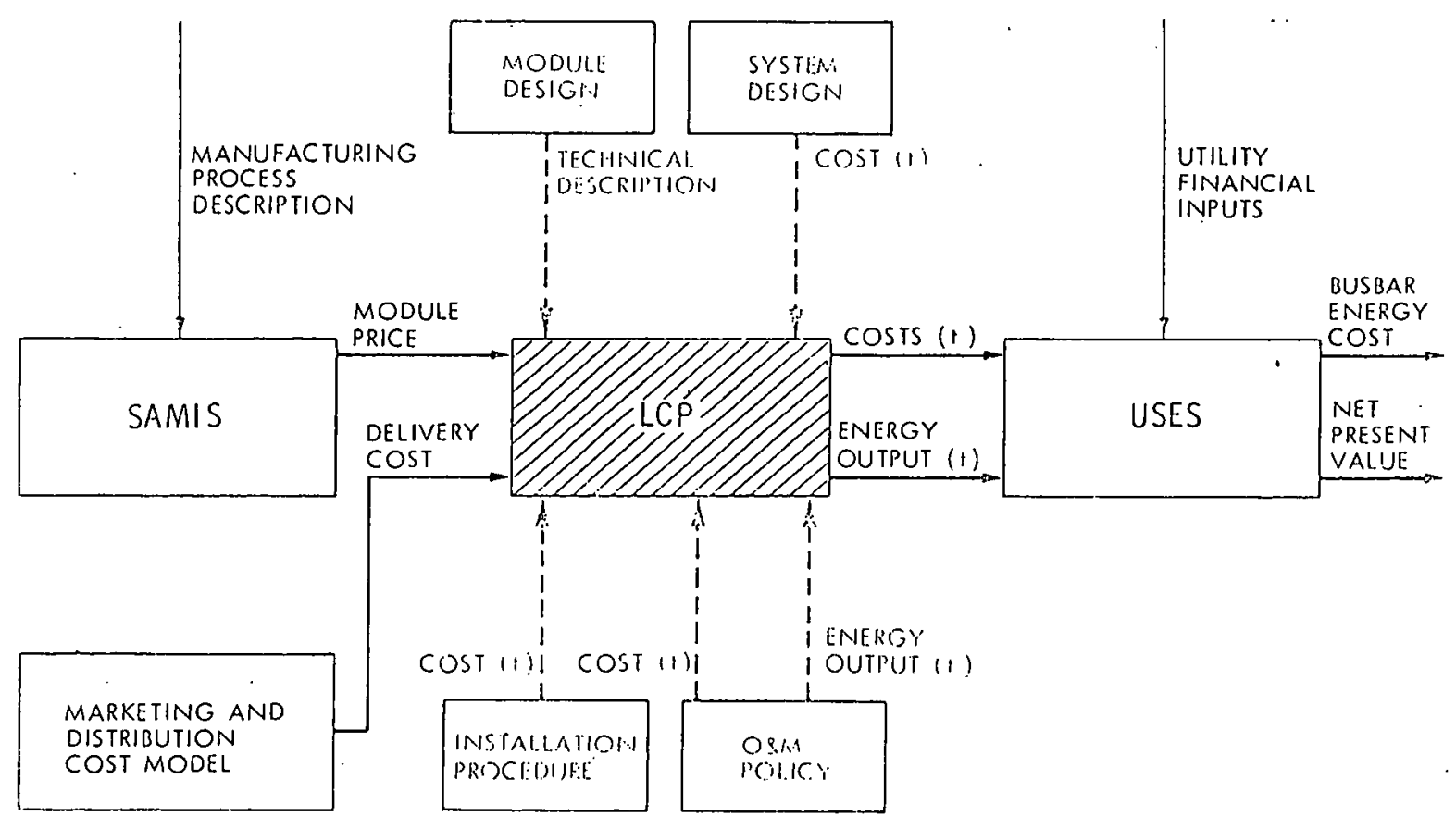

VALUE OF PHOTOVOLTAICS TO THE UTILITY

- photovoliaic punek plants are grid-connected and their yaluls are GRID-SPFCIFIC.

- hourly electricity generation calculations are reguired to determine the tRue ValiJf of PHITtOVDITAICS

- lcp incorporatej filotovoltaic production cost values ahd capacity valuts

- there is no dedicated storage fon grin-CONnected photovoltaic systems

\section{LCP ENERGY OUTPUT OBJECTIVES}

- hourly plant output (kHh)

- MODEL THE EFFECTS OF

INSOLNTION

TEMPERATURE:

MOIJULE PERI-OIKNAANCE TIEGRADATION

ELECTRICAL MISIMTCH

MODULE FNILURES

DIRT ACCUMULATION/CLEANING

MODULE REPLACEMENTS

COMPONENT EFFICIENCES 


\section{RESULTS REFLECT PRELIMINARY INPUT DATA FOR TESTING OF LCP MODEL}

- system design is based upon $n 184$ min central poner station

(TANDEM ARRAY hITIIOUT REFLECTORS) DESIGNED by BECHTEL CORPORATION

- several potential opernting nlternatives are illustrated

\section{PRELIMINARY INPUT DATA}

PONER PLANT LOCATION — PHOENIX

YEAR FOR SOLMET INSOLATION/TEMPERATURE $=1953$

PLANT PEAK CAPACITY

$=184 \mathrm{MW}$

BASE YEAR FOR CONSTANT DOLLARS $=1975$

YEAR OF CAPACITY OPERATION . $=1995$

CONSTPUCTION.SSTARTUP PERIOD $\quad=5$ YEABS

PLANT OPERATING LIFETIME $\quad=30$ VEARS

REAI. AFTER-TAX DISCOINT RATE $=0.026$

NUF̈BER OF PCU'S

$=36$

NUFPEER OF MODULES PER PCU $\quad=12960$

MODULE EFFICIEISCY

BALANCE OF SYSTEM EFFICIENCY

NUNBER OF CLEANIHGS

MODULE COST

MODULE FAILURE RATE

MODULE DEGRADATION RATE

$=0.1 / 14$

$\approx 0.85$

$=9$ PER YEAR (DURING HON-HIHTER HONTHS)

$=\$ 0.50 /$ NATT $(=\$ 214 /$ itonth.F. $)$

$=0.002 / Y E A R$

$=0.03 / Y E A R$

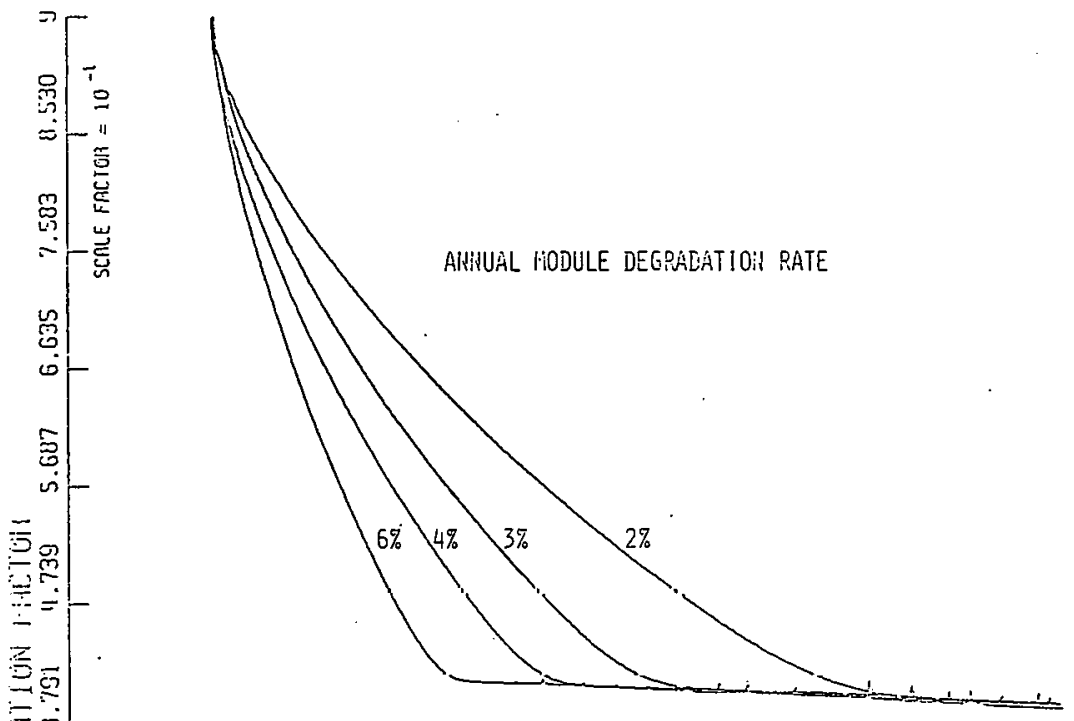


MONTHLY EFFECTS OF DIRT ACCUMULATION AND CLEANING
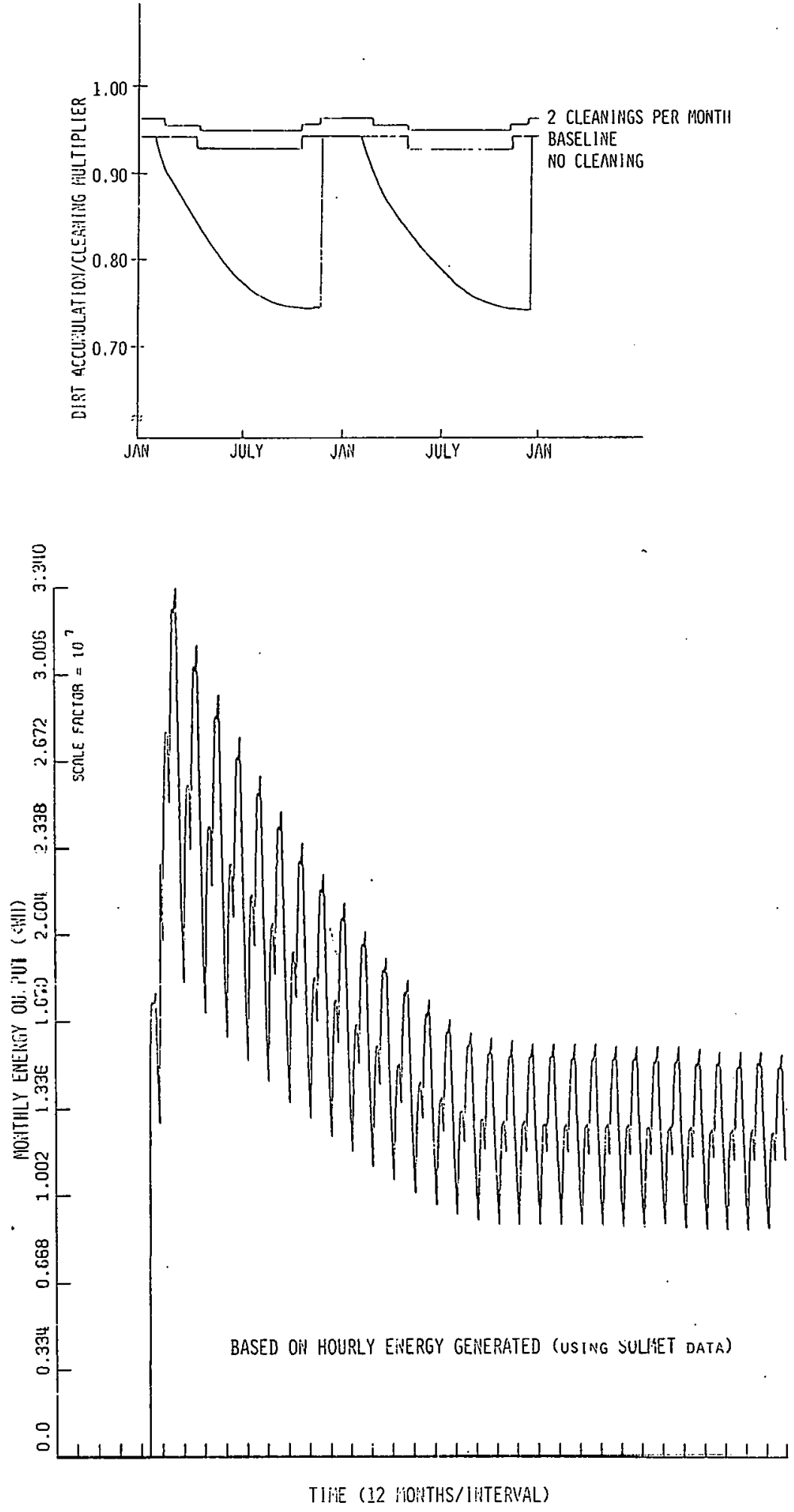


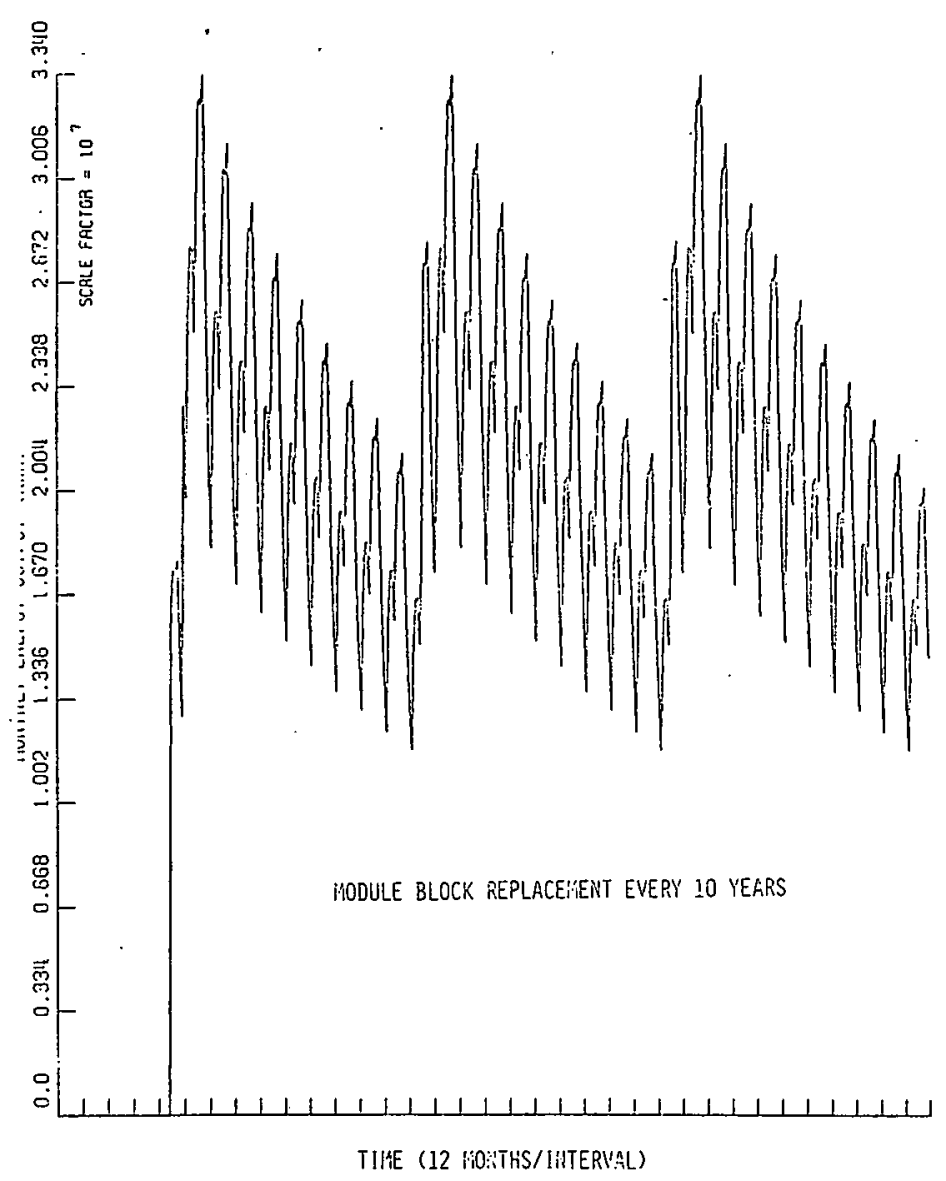

LIFETIME COST AND PERFORMANCE MODEL

- all costs are input and olitput in base year dollars (1975)

- busbar energy costs are levelized in constant dollirs (bBec c $_{0}$ RATHER THAN IN CURRENT DOLLARS (BBBEC)

- IN THE FOLLONING EXAMPLES $\overline{\mathrm{BBEC}} \approx 1.8 \cdot$ BBEC $_{0}$ 
LIFETIME COST AND PERFORMANCE MODEL

BASELINE CASE WITH ZERO DEGRADATION

$\mathrm{BBEC}_{0} \approx 4.7 \xi / \mathrm{K} H \mathrm{H}$

$\overline{\mathrm{BDEC}} \approx 8.5 \% / \mathrm{kWH}$

BASELINE CASE WITH $3 \%$ GEGRADATION

$\mathrm{BBEC}_{0} \approx 7 \mathrm{~s} / \mathrm{K} \mathrm{KH}$

$\overline{\mathrm{BBEC}} \approx 12.5 \% / \mathrm{KHH}$

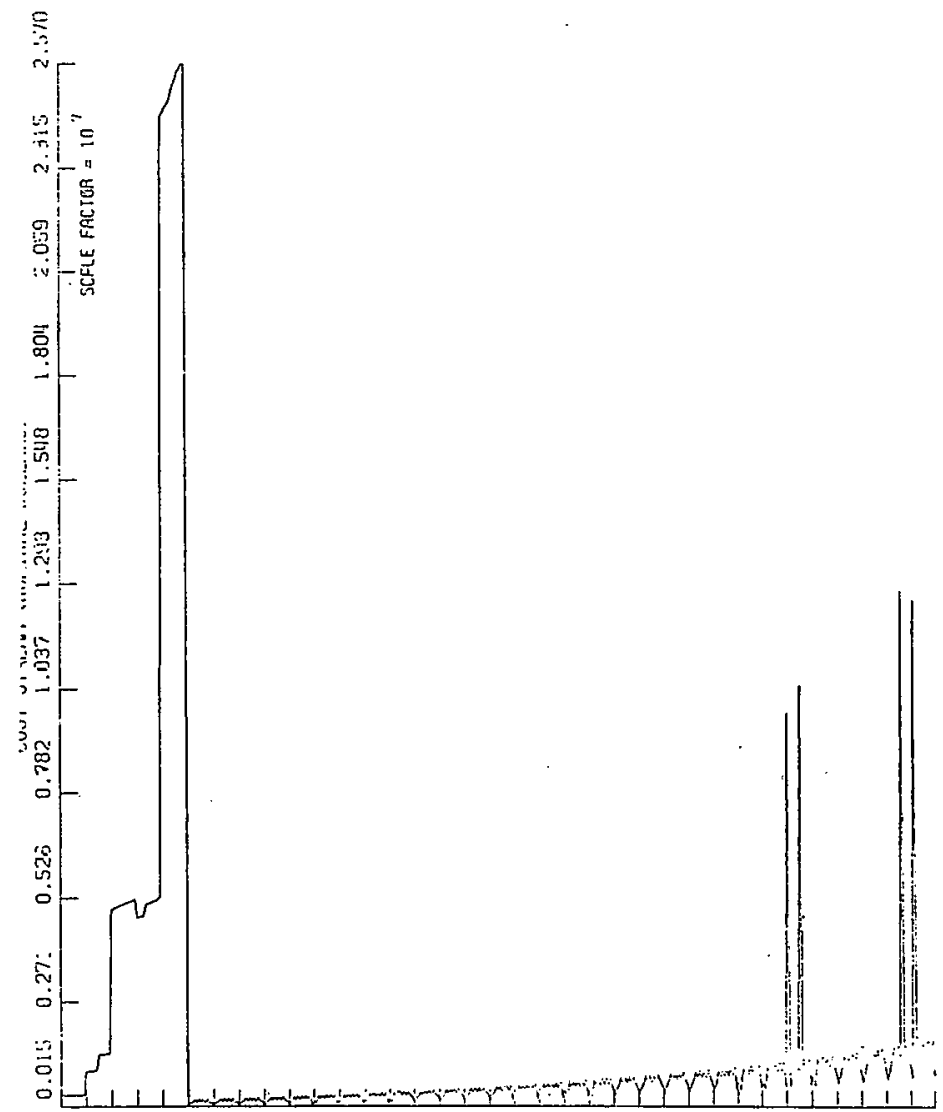

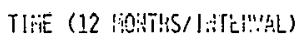




\section{SENSITIVITY OF BUSBAR ENERGY COST TO CLEANING POLICY}

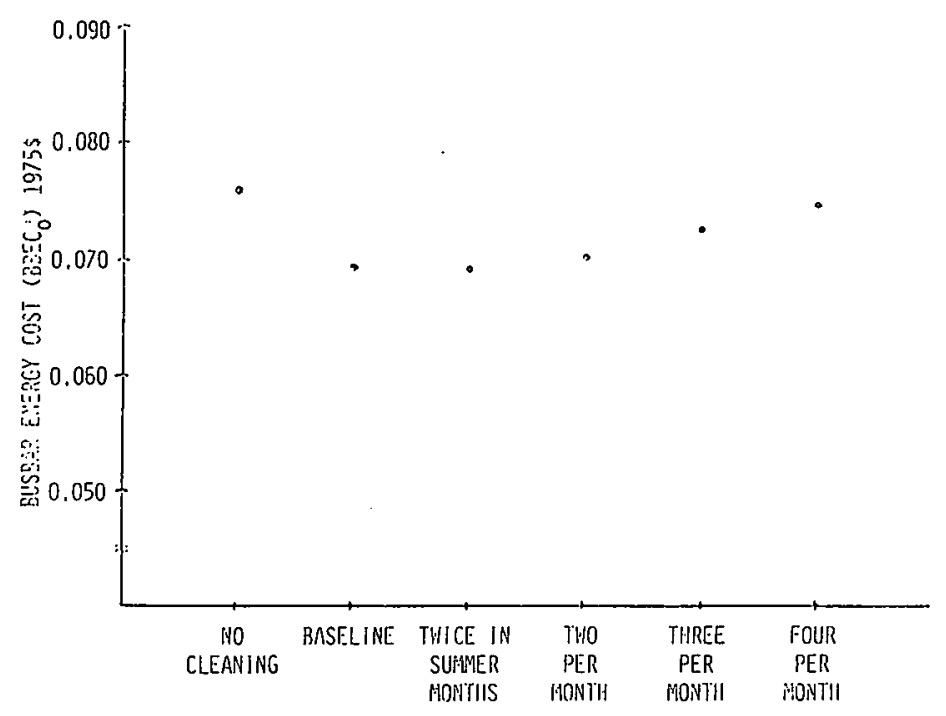

\section{SENSITIVITY OF SYSTEM COSTS TO MODULE PRICE}

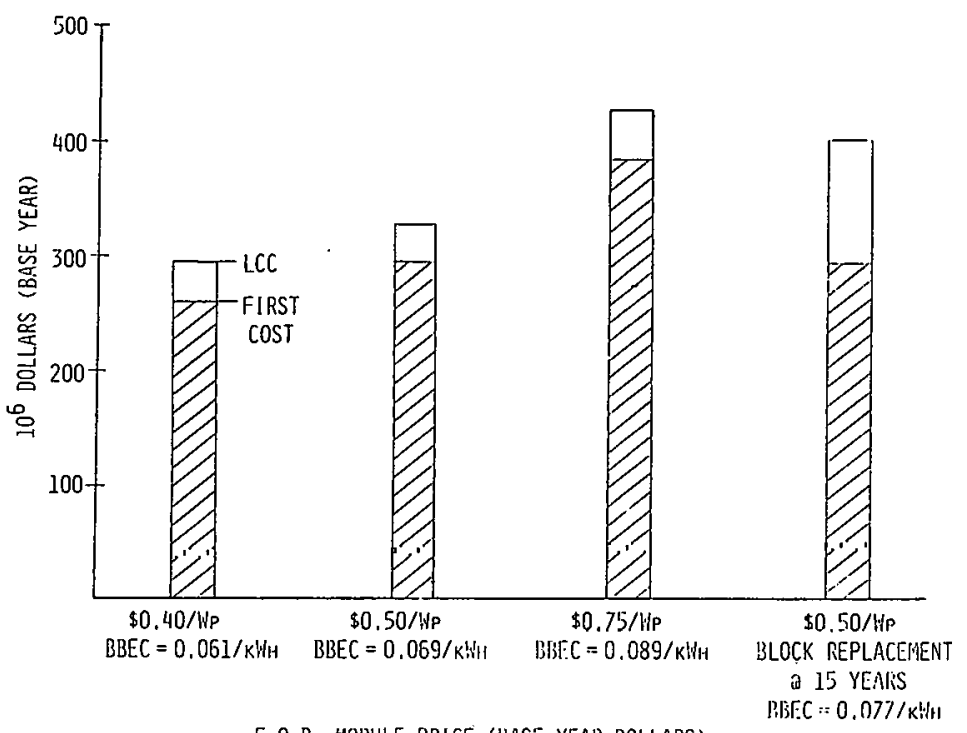


MODULE REPLACEMENTS DUE TO DEGRADATION

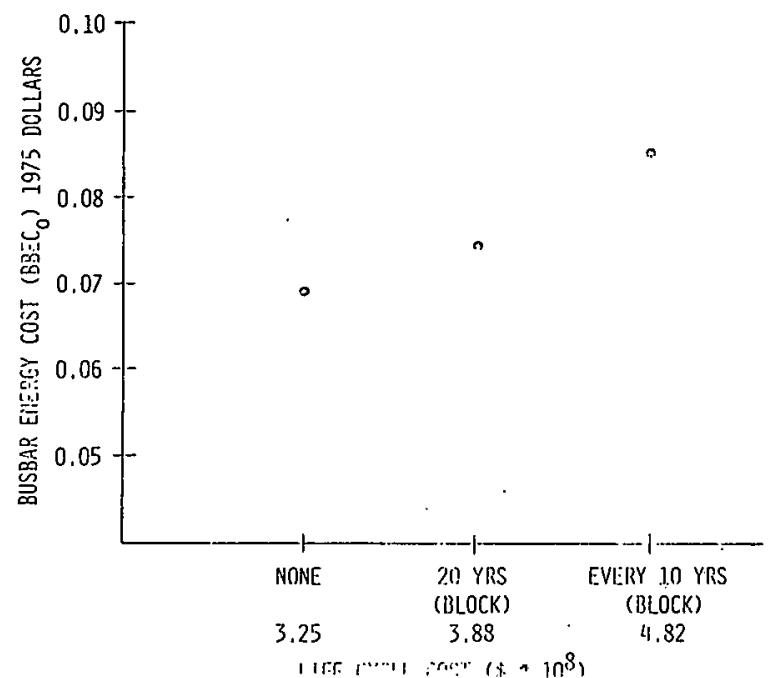

VARIOUS OPTIONS

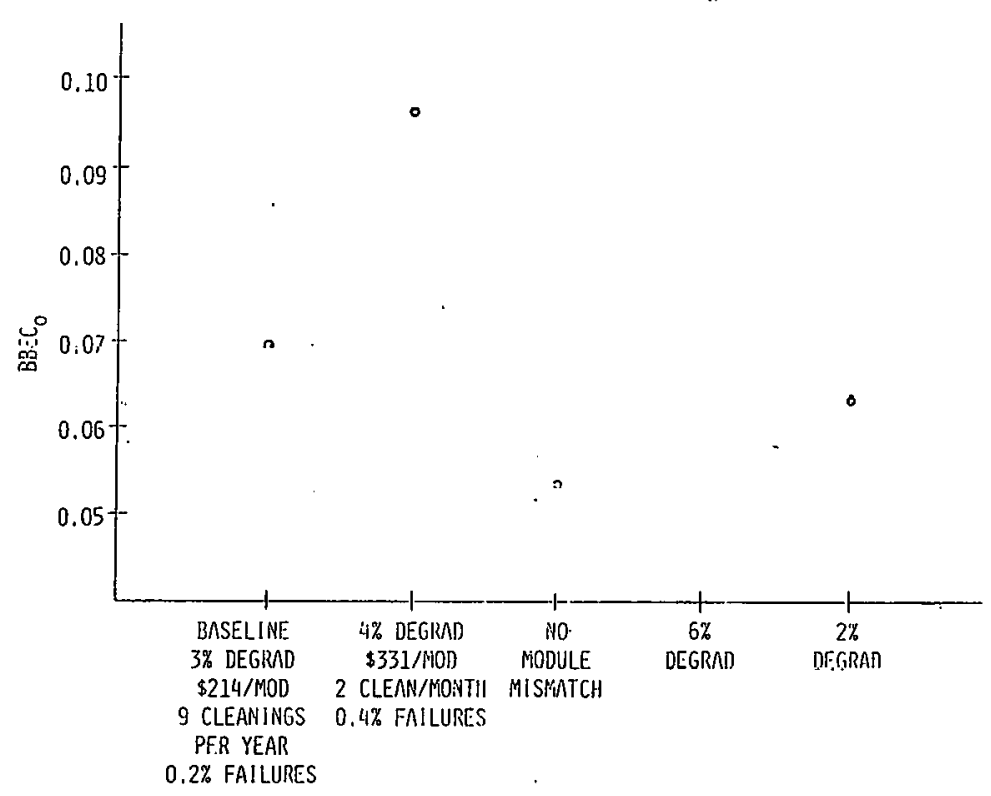




\section{FOR THE ASSUMED SYSTEM DESIGN, COMPONENT COST AND OPERATING CONDITIONS}

- cleanings nRe shoHn to be cost efFective.

- block replacements are hot economicnlly attractive either in A BUSBAR ENERGY COST OR NET PRESFNT VALUE SENSE.

- degradation rate has an important linfluence on energy output AND BUSBAR ENERGY COST.

\section{CURRENT STATUS/PLANNED ACTIVITIES}

- cunRreni sialus

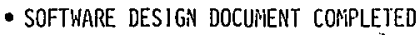

- exterinal reView/CRItique by tileodore liarry and associates is conpleted

- initial runs of the computer model have begun

- planNed activities

- continuting model and inPUt validotion both interinal nitd exterinal to jal

- in the future, lcp nill evaluate resideittial applicat loils nind interface HITII A UTILITY GRID SIHULATION MODEL 


\title{
2. Technology Development Area
}

\author{
a. Silicon Material Task
}

AEROCHEM RESEARCH LABORATORIES, INC.

\section{SILICON HALIDE-ALKALI METAL FLAMES \\ AS A SOURCE OF \\ SOLAR GRADE SILICON}

\section{OBJECTIVES}

TO DETERIIIE T!IE FEASIBILITY OF USING HIGH

TEHPERATURE REACTIOAS OF ALKALI METALS AND

SILICOA HALIIIES TO PRODUEE SOLAR-GRADE SILICON

1. MEASUIE HEAT RELEASE/RENCTION RATE parnie:TCRS for scaling purposes.

2. eValuaite product separation ant COLLECTION PROCESSES.

3. DETERHIHE EFFECTS OF REACTANTS AND/OR PRODUCTS ON REACTOR MRTERIALS:

\section{INITIAL RESULTS}

1. SMALL-SCALE DEMGNSTRATION OF: VAPOR-PHASE REAGENT SYSTEMS SILICON PRODUCTION PRODUCT PURITY

2. SCALED-UP REACTOR DEMONSTRATION OF: SILICON PRODUCTION AT $0.5 \mathrm{KG} / \mathrm{HR}$ SEPARATION OF SILICON FROM BYPRODUCT SALT IN HEATED REACTOR 


\section{CURRENT WORK}

1. EXTEND RUN TJME AND PRODUCE LARGER QUANTITIES OF SILICON.

2. INVESTIGATE EXTENT OF REACTION, HEAT RELEASE RATE, SILICON COLLECTION EFFICIENCY, AND SKULL HALL DEVELOPMENT IN WELL-STIRRED REACTOR.

3. SEED REAGENTS HITH B AND P AND TEST PRODUCT PURITY

4. DETERMINE EFFECTS OF REAGENTS AND PRODUCTS ON MATERIALS OF CONSTRUCTION

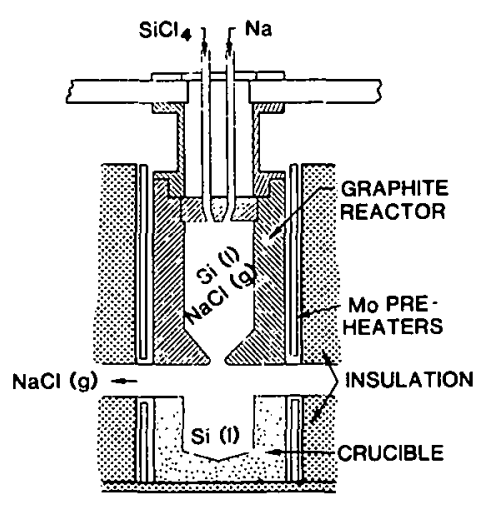

\section{Na/GRAPHITE TEST APPARATUS}

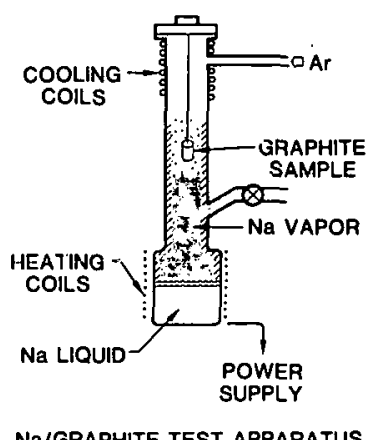




\section{FLOW TUBE FOR Na/GRAPHITE TESTS}

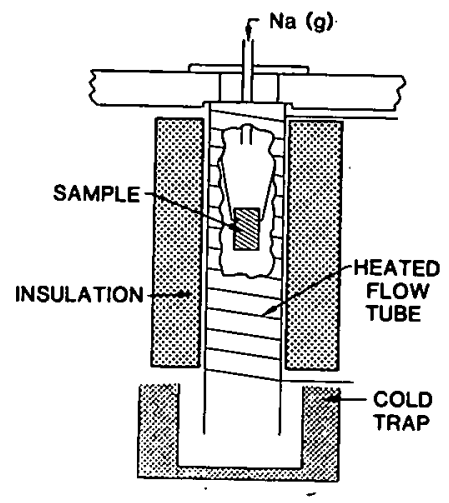

FLOW TUBE FOR Na/GRAPHITE TESTS

\section{Na/GRAPHITE FLOW TUBE TESTS}

CONDITIONS:

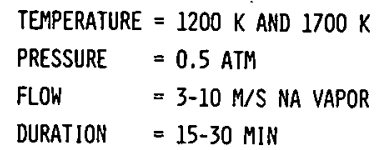

C AIRCO-SPEER, 5 Sִ GQ GRADE

\section{TEST RESULTS}

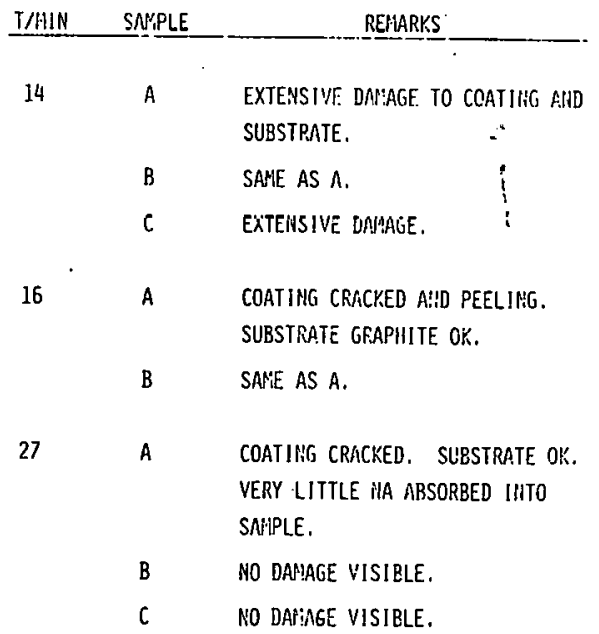




\title{
CONCLUSIONS
}

1. ALL SAMPLES AND COATINGS RAPIDLY DEGRADED AT NA DEW POINT.

2. AT $1700 \mathrm{~K}$ NO DAMAGE OBSERVED TO SUBSTRATE GRAPHITES. PYROLYTIC GRAPHITE COATINGS CRACKED.

\section{BATTELLE COLUMBUS LABORATORIES}

\author{
ZINC REDUCTION OF SILICON \\ IETRACHLORIDE IN A FLUIDIZED BED TO \\ PRODUCE SILICON GRANULES
}

JPL CONTRACT No. 954339

SILICON MATERIAL TASK

LOW-COST SOLAR ARRAY PROJECT

\section{BACKGROUND}

- FEASIBILITY - 1975 TO 1976

- MINIPLANT AND ECONOMICS - 1976 TO 1977

- PRELIMINaRY EPSDU (50 MTMEAR) DESIGN. ECONOMICS, AND SUPPORT STUDIES - 1977 TO 1978

- finalization of epsdu design, CONSTRUCTION, AND SUPPORT - 1978 TO 1979

- DESIGN, CONSTRUCTION AND OPERATION OF PDU -- AT PRESENT 


\section{SCHEMATIC DRAWING OF EPSDU FOR PREPARATION \\ OF SILICON BY THE ZINC REDUCTION OF SiCl 4}

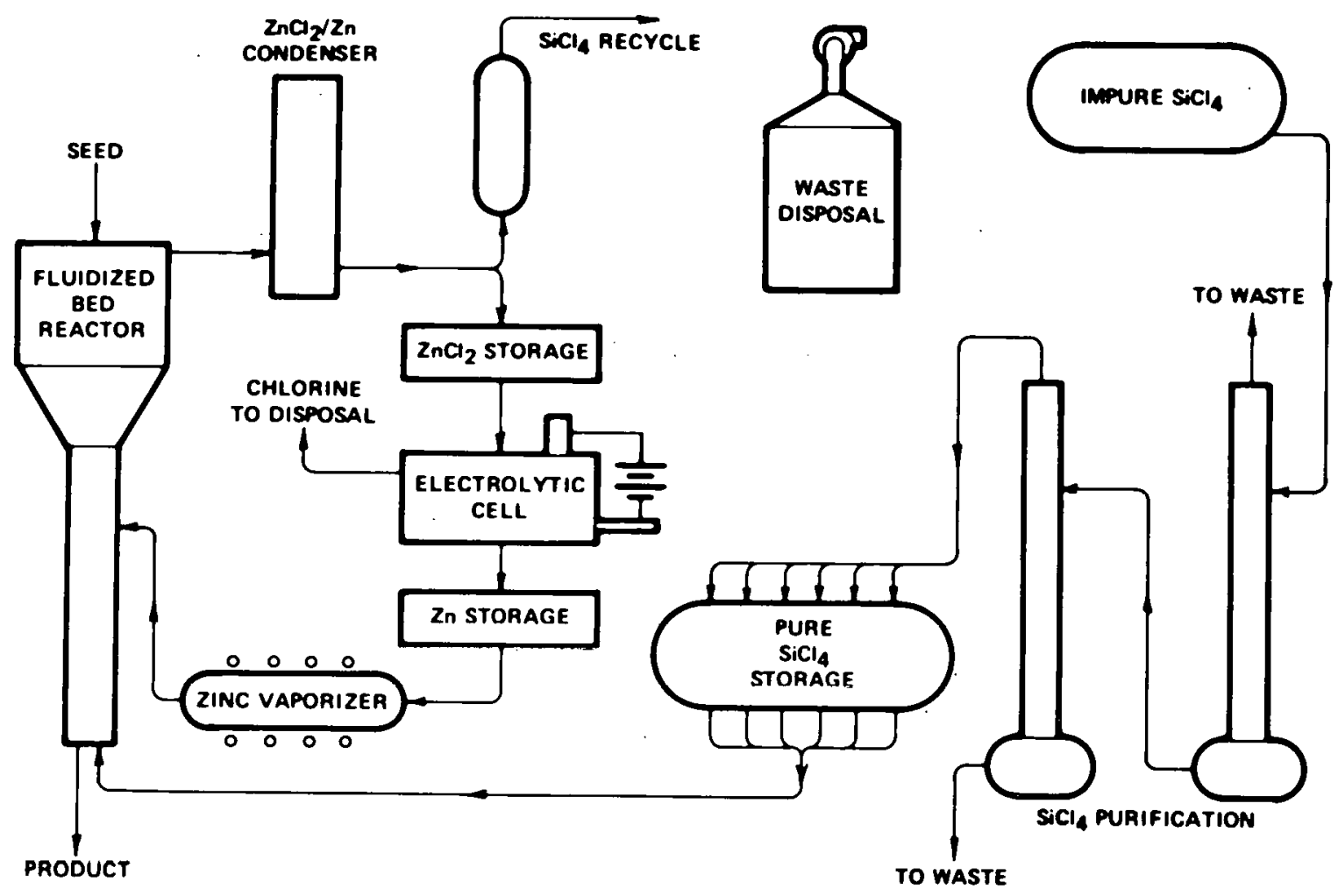

COST ANALYSIS

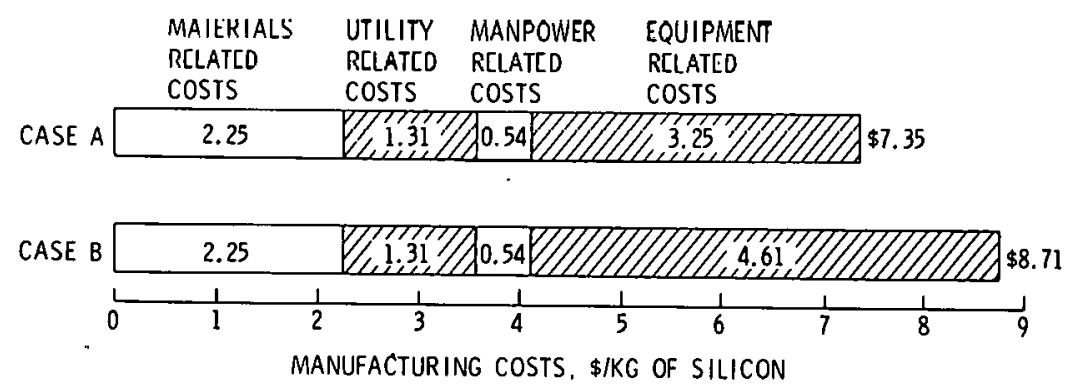

\$/KG OF SILICON - 1.19 (MATERIAL COSTS + UTILITY COSTS) + 2.37 (MANPOWER COSTS)

+1.92 (EQUIPMENT COSTS)

CASE A l-4l-IN REACTOR

1-720,000-AMP ELECTROLYTIC CELL

CASE B 2-29-IN REACTORS

12-60.000-AMP ELECTROLYTIC CELLS 


\section{SUPPORT STUDIES}

- zinc vaporization

-- Design

-- PURITY

- Fluidized-Bed Modelling

- Electrolytic Cell Design

- Reactor-Condenser Design

\section{FLOW DIAGRAM FOR EPSDU}

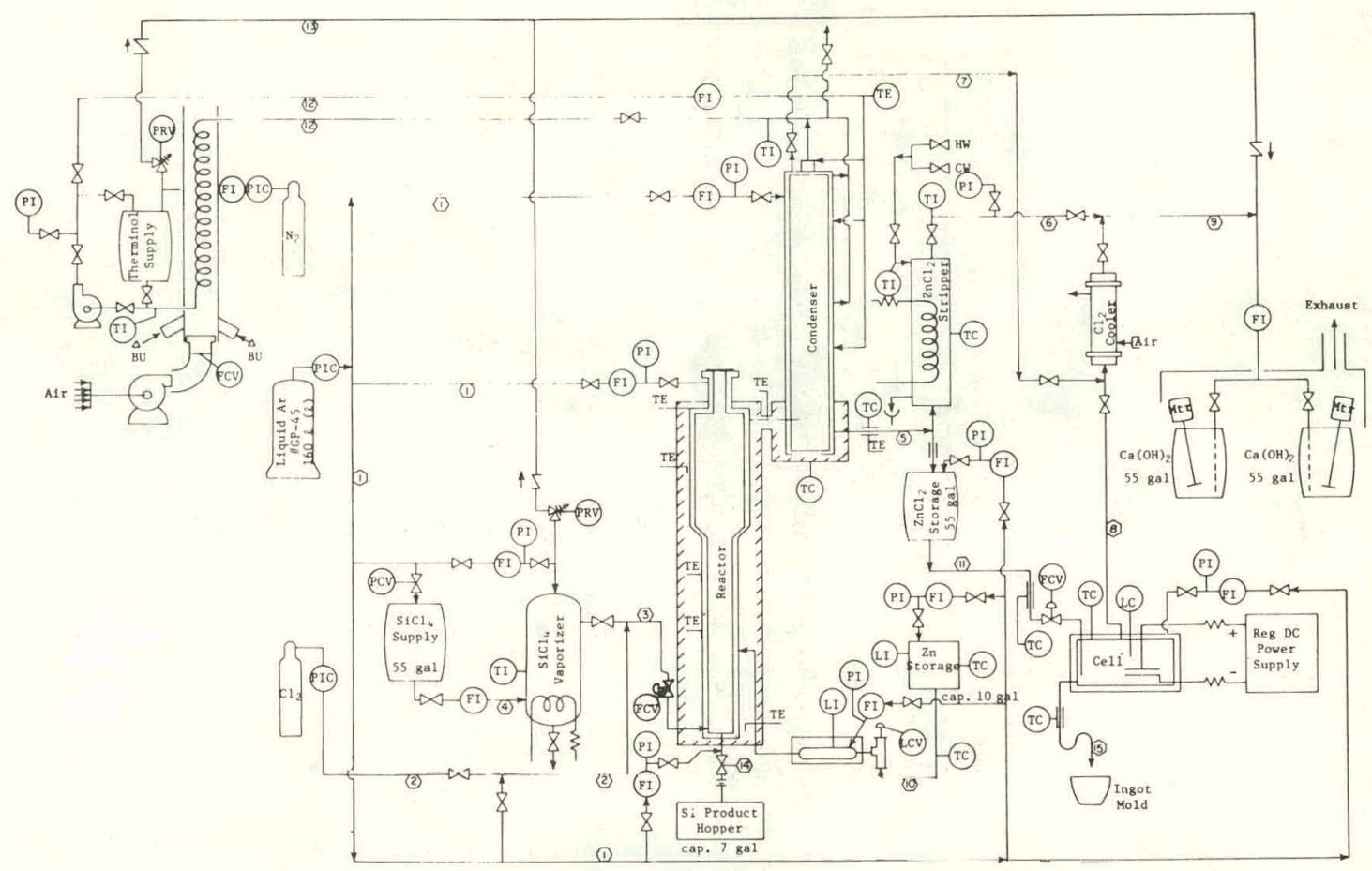




\subsection{IN. ID FLUIDIZED-BED REACTOR}

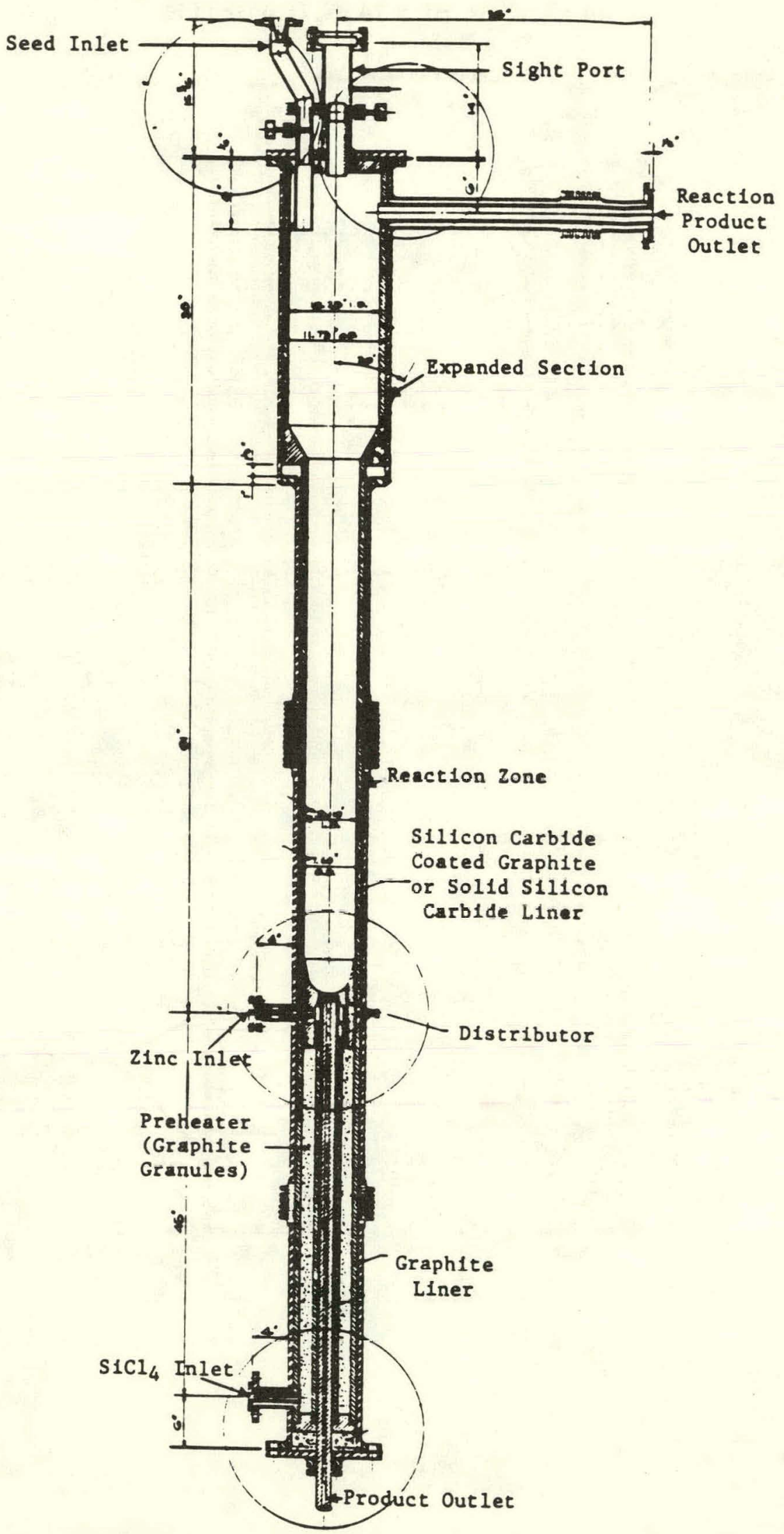


REACTOR CONDENSER

14 FT 10 IN. HI. x 14 IN. DIAMETER

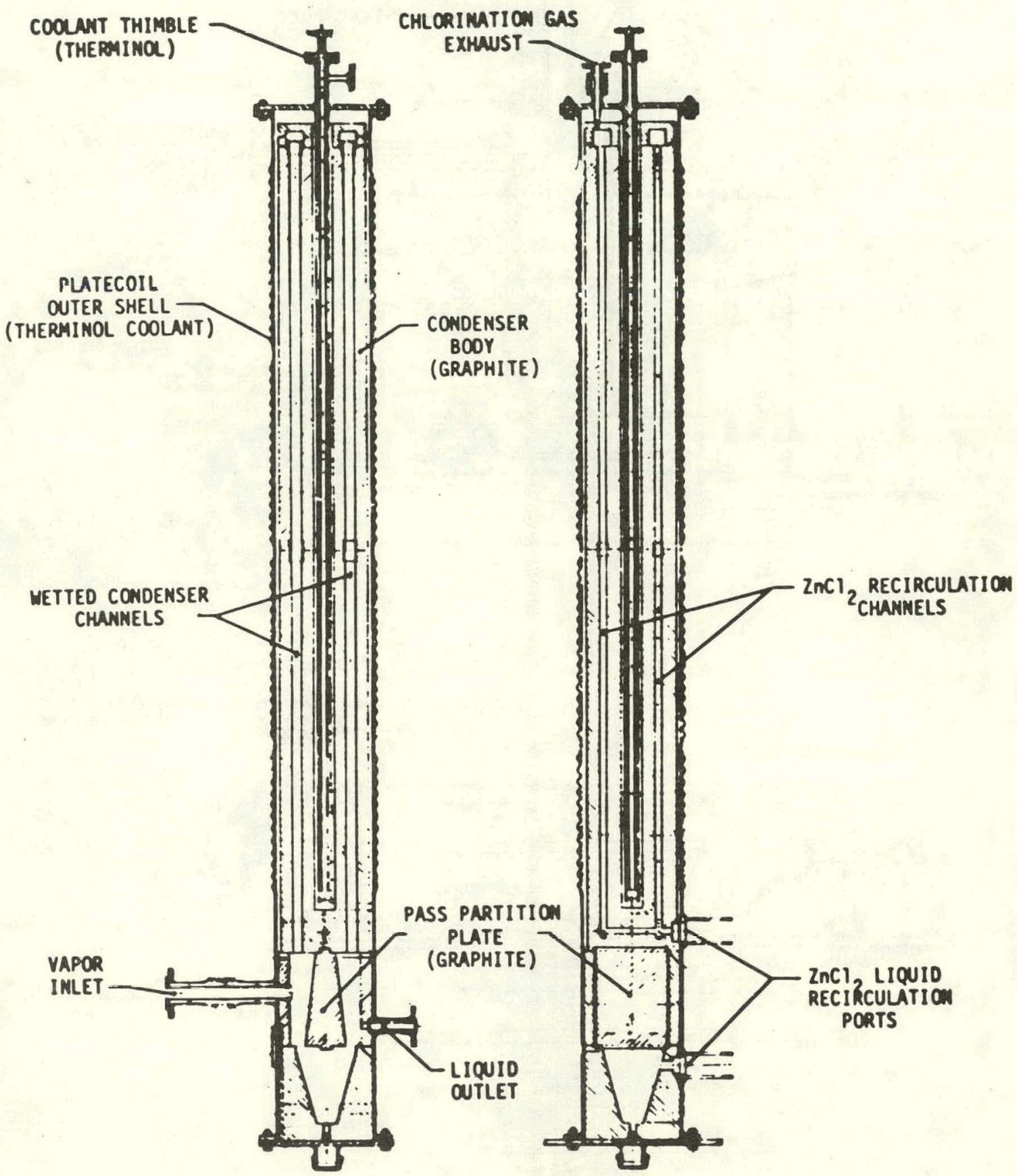




\section{ELECTROLYTIC CELL}

36 IN. x 50 IN. x 33 IN. HI.

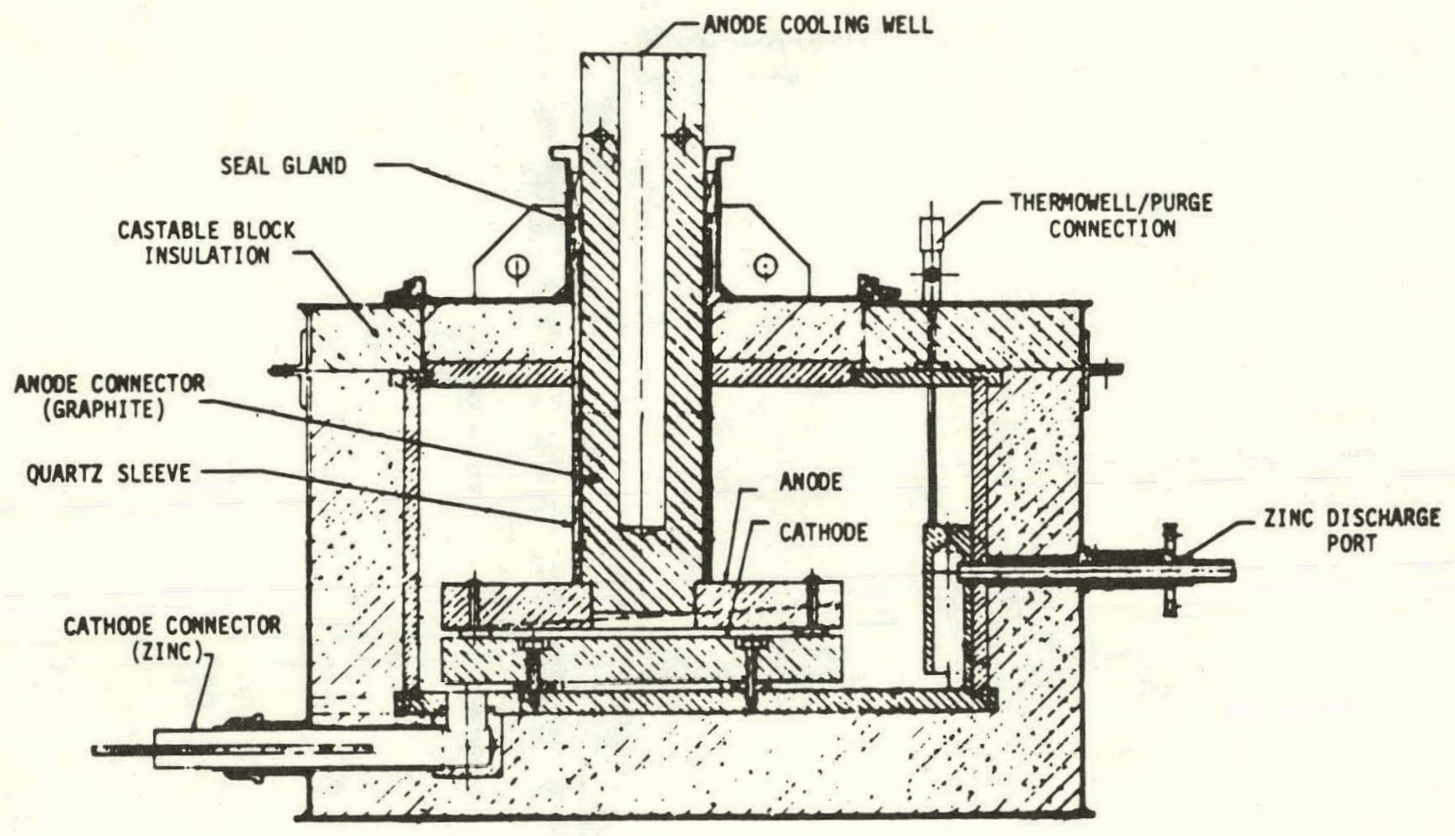

ZINC VAPORIZER

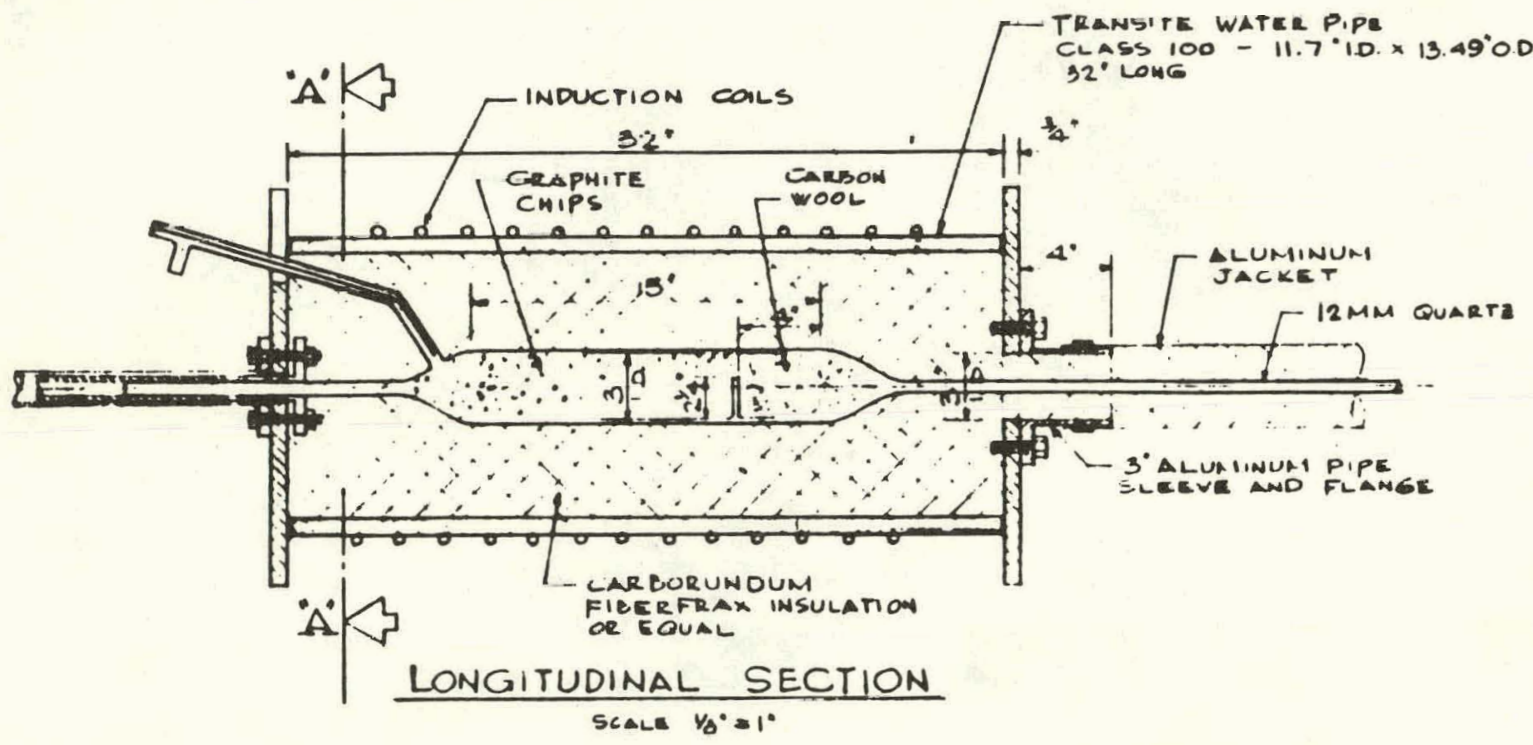




\section{DESIGN PARAMETERS - 50 MT/YEAR EPSDU}

- On-stream factor

- zn/siclla stoichiometry

- Conversion of Sicla

- Phujuction rate

- Seed renuirement (5 percent)

- fluidized bed reactors (two)

- siclly purification by dist ILLATION

- Zinc recycle by electrolysis

- Zinc recovery

- Clz disposal by conversion TO NAOCL
80 PERCENT

$2 / 1$

63 PERCENT PER PASS

$7.20 \mathrm{~kg} /$ HOUR $(16.8 \mathrm{G} / \mathrm{HOUR} /$ CH2 CROSS SECTION)

$0.36 \mathrm{KG} /$ HOUR

$16.5 \mathrm{cM}$ DIAMETER

92 PERCENT CENTER CUT SIX 5000-6000 AMP CELLS 95 PERCENT

\section{WESTINGHOUSE R\&D CENTER}

- Characterize the efFlcts of impulitiles on silicon solar celle

- Provide a basis for evaluating the cost-benefit trade-ofts BETWEEN SILIEON PURITY, CELL FABRICATION TET.HNOLOGY AND GEll performance.

\section{IMPURITY EFFECTS}

+ Carstal gnowth

CONSTITUTIONAL SUPER-COOLING AND CRYSTAL BREAKDOWN

GRAIN BOUNDARY DECORATION

MON-UNIFORM IMPURITY DISTRIBUTION

+ RESISTIVITY

COMPENSATION

NON-UNI.FORMITY

IMPURITY-DOPANT COMPLEXING

$+\quad$ LIFETIME/DIFFUSION LENGTH

ELECTRICALLY ACTIVE RECOMBINATION CENTERS

$+\quad$ JUNCTION RELATED

PRECIPITATES/CLUSTERS

SWUNTIMG/EXCESS CURRENTS

+ IMPURITY-IMPURITY

STIERGY/ANT IS YMERGY

+ SURFACE AMD BOUMDARY RELATED

PILE-UP

passivation/DCTaOsivation

CONTACT DEGRADATION

$+\quad$ PROCESS RELATED

GETTERIMG

REDISTRIBUTION

+ TIMe dependent

AGING/PERMANENCE 


\section{EFFICIENCY VERSUS METAL CONTENT; P-BASE DEVICES MODEL-DERIVED CURVES}

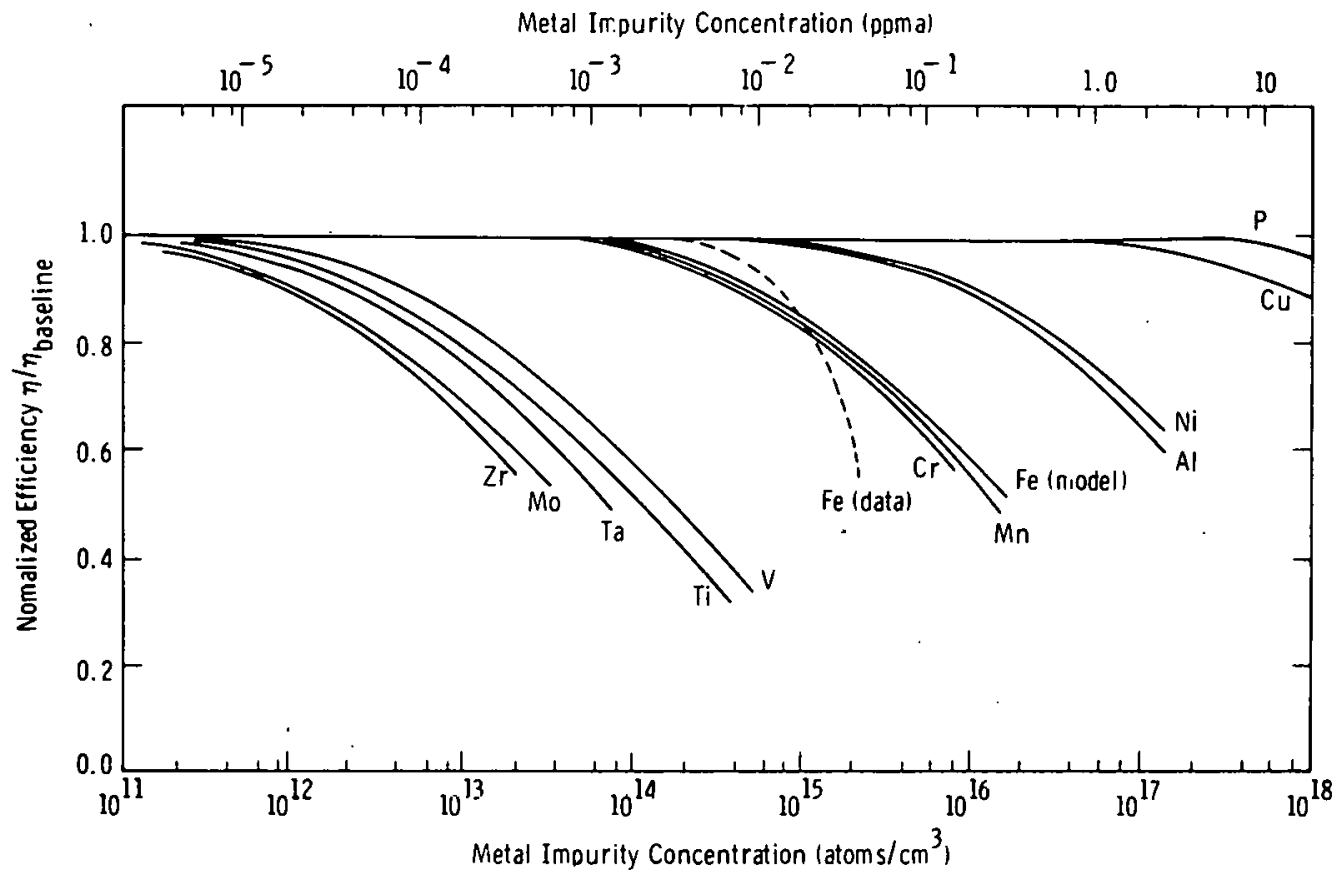

OCD LIFETIME MAP, INGOT W-093 MN $=2.75 \cdot 10^{15} \mathrm{CM}^{-3}$

(75 MAFER, 4 OHM-TM P-TYPE, .030" MESA DIODES)

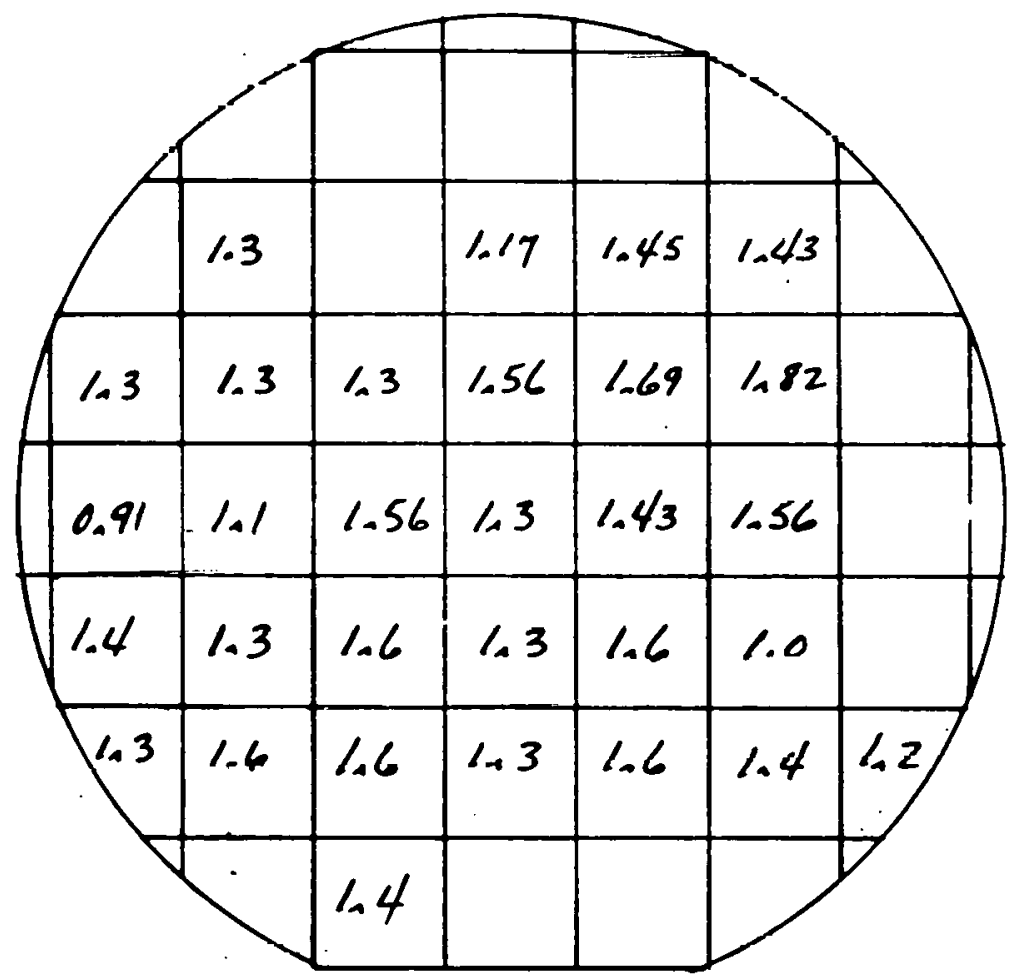




\section{EFFICIENCY VERSUS METAL CONTENT}

SOLID CURVES ARE N-BASE;

\section{DASHED CURVES ARE COMPARABLE P-BASE DATA}

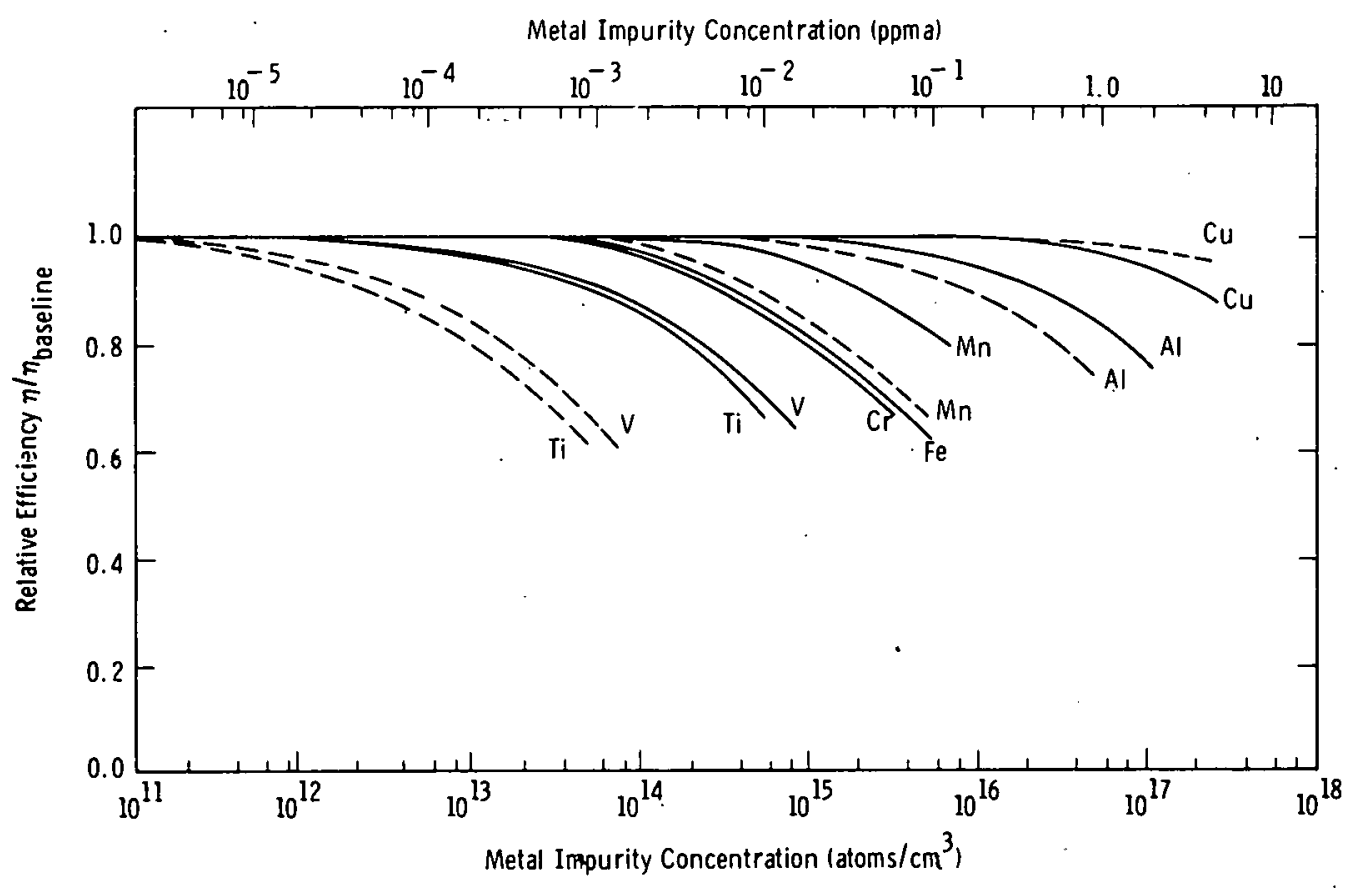

POCL $_{3}$ GETTERING OF TITANIIUM

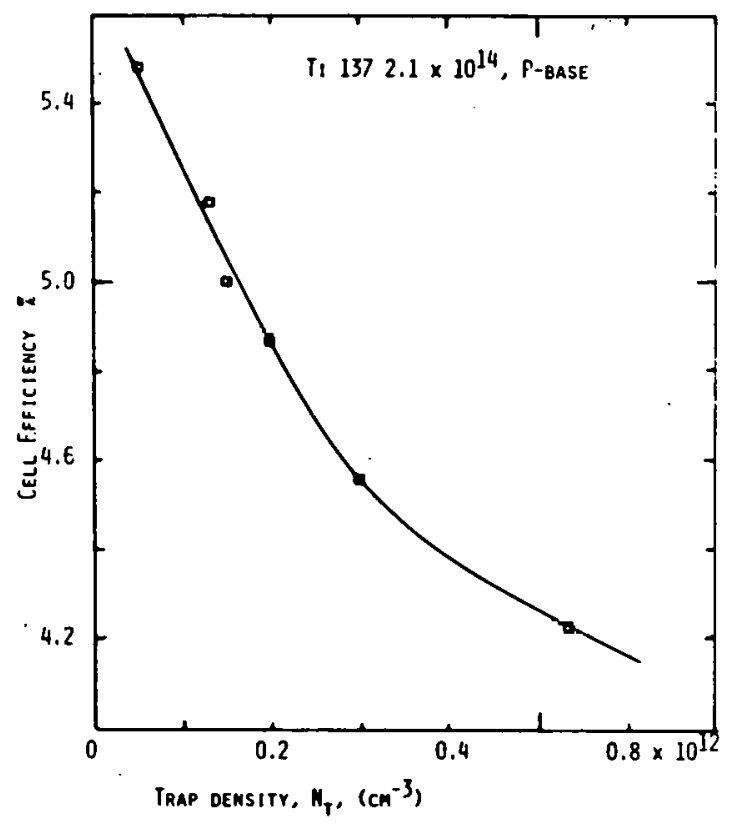


RECIPROCAL TRAP DENSITY VERSUS MINORITY CARRIER LIFETIME ( $\mu$ S)

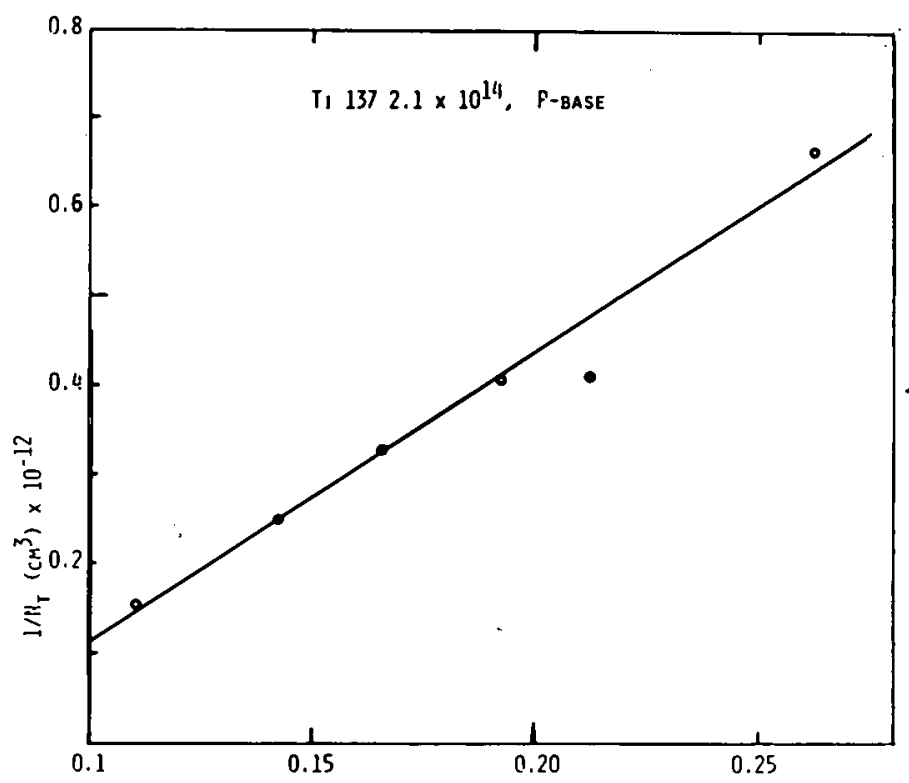

CALCULATED AND MEASURED PERFORMANCE FOR INGOTS USED TO MODEL "SOLAR GRADE" FEEDSTOCK

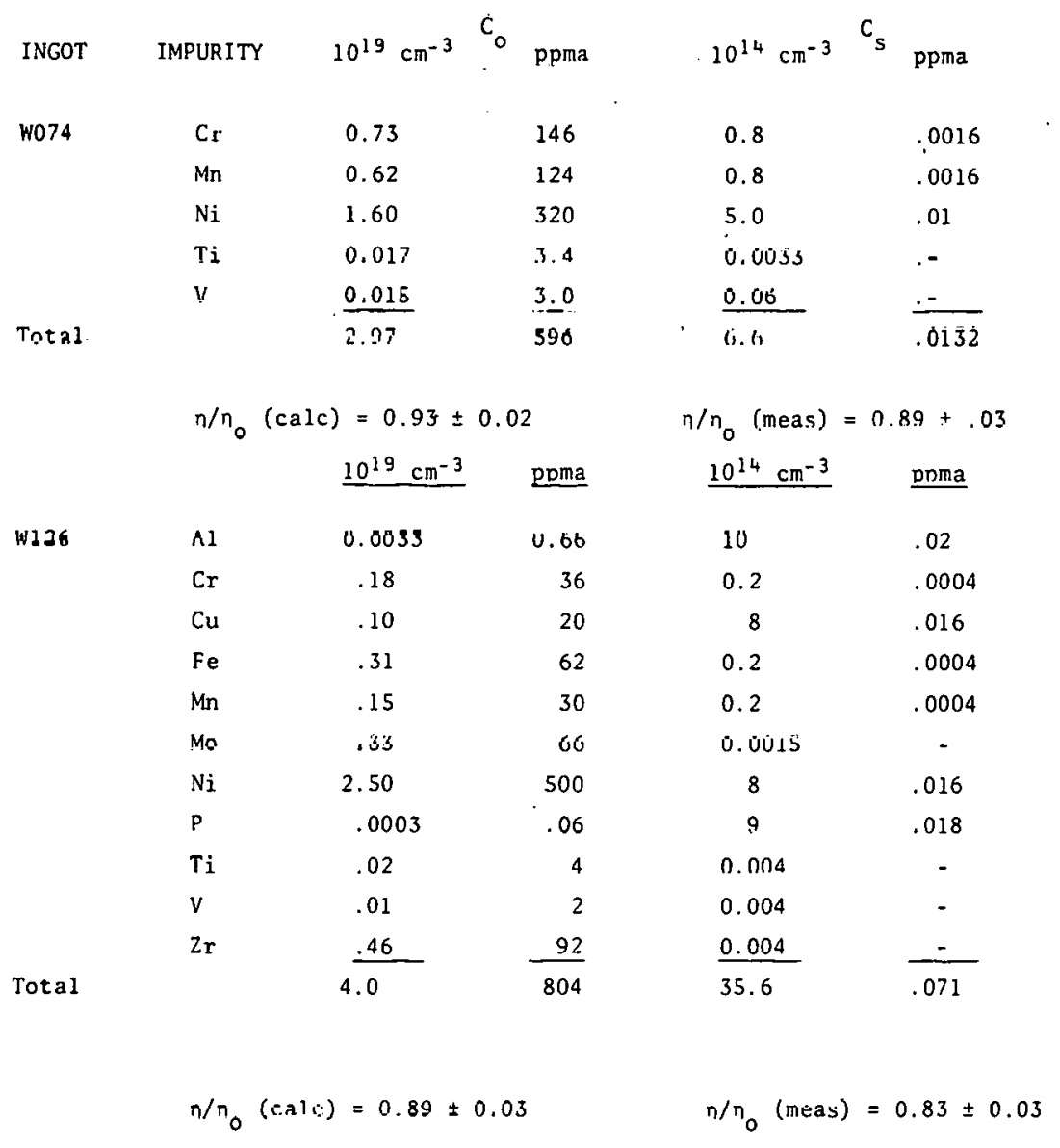




\title{
DEVELOPMENT OF MODELS AND COMPUTER CODES TO DESCRIBE SOLAR GRADE SILICON PRODUCTION PROCESSES
}

\author{
PROGRAM OBJECTIVES \\ OVERALL: \\ TO DEVELOP COMPUTATIONAL TOOLS TO \\ TREDICT PERFORMANCE-OF METHODS OF \\ PRODUCING SILICON FROM GAS PHASE \\ REACTIONS OF SILICON HALIDES OR \\ HYDRIDES.
}

IFMEDIATE:

DESCRIBE $\mathrm{SiC}_{4} / \mathrm{Na}$ PROCESSES

\section{APPROACH}

1. TREAT GAS PHASE CHEMISTRY AND PARiICLE FORMATION AND GRONTH IN DETAIL

2-PHASE MIXING CODE

2. TREAT TRANSFER OF hEAT AND MATERIAL TO WALLS - BOUNDARY LAYER CODE

\section{STATUS}

1. BOUNDARY LAYEP. CODE - BEGINNIIIG PRODUCTION RUNS - VAPOR DEPOSITION

2. 2.PHASE MIXING CODE IINDERSOING FINAL TESTING 

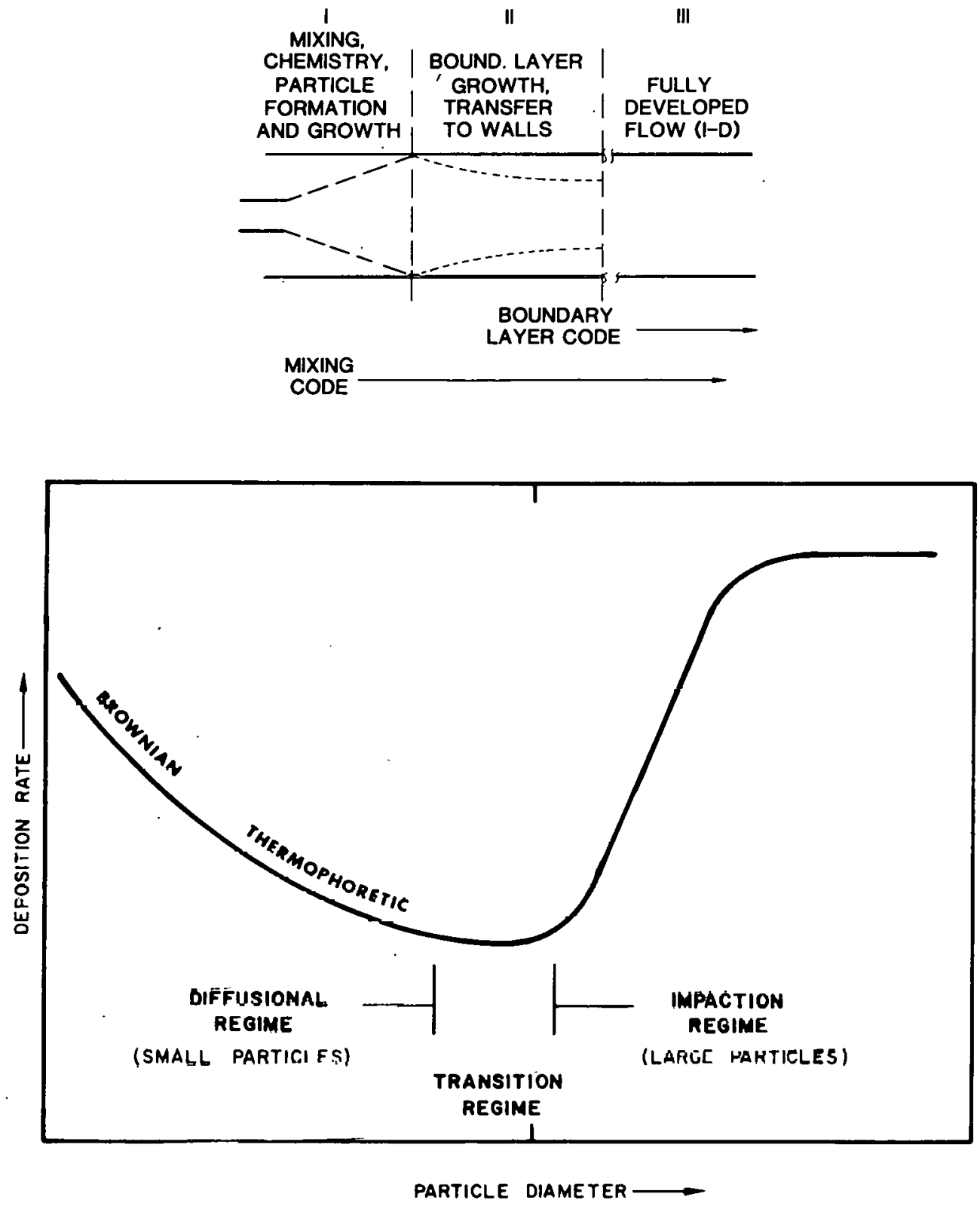


\section{PLANS}

1. ADD BOUHDARY LAYER CONDENSATION (PARTICLES) TO BOUNDARY LAYER CODE.

2. PRODUCTION RUNS FOR $\mathrm{SICL}_{4} /$ HA FLOW REEACTOPS USING BOUNDARY LAYER CODE.

3. PRODUCTION RUNS USING 2-PHASE MIXING CODE - GET PARTICLE SIZE DIŚTRIBUTION.

4. COMPARE WALL FLUX PREDICTIONS FRR THF MODELS,

\section{SRI INTERNATIONAL}

\section{GAS REACTOR}

STEP

$1 \mathrm{SiF}_{4}$ PREPARATION

$\mathrm{H}_{2} \mathrm{SiF}_{6}(\mathrm{aq}) \longrightarrow \mathrm{SiF}_{4}(\mathrm{~g})+2 \mathrm{HF}(\mathrm{aq})$

2 REACTION

$\mathrm{SiF}_{4}(\mathrm{~g})+4 \mathrm{Na}(\ell) \longrightarrow \mathrm{Si}(\mathrm{s})+4 \mathrm{NaF}(\mathrm{s})$

$\mathrm{SiF}_{4}(\mathrm{~g})+2 \mathrm{NaF}(\mathrm{s}) \longrightarrow \mathrm{Na}_{2} \mathrm{SiF}_{6}(\mathrm{~s})$ (SIDE REACTION)

REACTION PRODUCTS - Si, NaF, $\mathrm{Na}_{2} \mathrm{SiF}_{6}$

3 SILICON RECOVERY FROM REACTION PRODUCTS

FUSIÓN AT TEMP $>1410^{\circ} \mathrm{C}$

SILICON (MELT)

$\mathrm{NaF}$ (MELT)

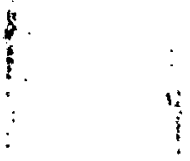




\section{GAS REACTOR SILICON ANALYSIS}

SPARK SOURCE MASS SPECTROMETRIC AND EMISSION SPECTROGRAPHIC

\begin{tabular}{|c|c|c|c|c|c|c|c|}
\hline ELEMENT & $\begin{array}{l}\text { PPM } \\
\text { Wt. }\end{array}$ & ELEMENT & $\begin{array}{c}\text { PPM } \\
\text { Wt. }\end{array}$ & ELEMENT & $\begin{array}{l}\text { PPM } \\
\text { We. }\end{array}$ & ELEMENT & $\begin{array}{l}\text { PPM } \\
\text { Wt. }\end{array}$ \\
\hline B & 0.1 & $v$ & 0.04 & $F$ & 0.1 & Mn & 0.1 \\
\hline Al & 0.8 & $\mathrm{Cr}$ & $<3.5$ & $\mathrm{Na}$ & 1.0 & $\mathrm{Ni}$ & 2.0 \\
\hline Ga & 0.06 & $\mathrm{Ti}$ & 2.0 & Nb & 0.02 & Co & 0.5 \\
\hline$\cdot p$ & 0.2 & $\mathrm{Zr}$ & 2.0 & $\mathrm{Ta}$ & 0.4 & $\mathrm{Fe}$ & $<7$ \\
\hline As & $\begin{array}{l}\text { Not } \\
\text { Obs. }\end{array}$ & & & Mo & 0.3 & $\mathrm{Cu}$ & $<4$ \\
\hline & & & & $w$ & 0.2 & $\mathrm{Zn}$ & 0.01 \\
\hline
\end{tabular}

- Chem. Analysis - 0.09 PPM

\section{ESTIMATION OF PRODUCT COST
(LAMAR UNIVERSITY FACTORS)}

\begin{tabular}{ccc}
\multicolumn{2}{c}{ Mollars } & Per Kilngram Si \\
\hline SRI & SRI & SRI/Thermite \\
(Leach) & (Melt) & (Melt) \\
\hline
\end{tabular}

1. Direct Manufacturing Cost (Direct Cost)
1. Raw materials
2. Direct operating labor
3. Utilities
4. Supervision and clerical
5. Maintenance and repairs
b. Uperating supplies
7. Laboratory charge

2. Indirect Manufacturing Cost (Fixed Cost)
i. Uepreciation
2. Lonal taxes
3. Insurance

3. Plant Overhead

4. By-Product Credit

1a. Total Manufacturing Cost, $1+2+3+4$

$\begin{array}{rrr}\mathbf{5 . 7 2 5} & 4.876 & 4.784 \\ .674 & .674 & .674 \\ .714 & 1.021 & 1.021 \\ .101 & .101 & .101 \\ .901 & .699 & .663 \\ .180 & .140 & .133 \\ .101 & .101 & .101\end{array}$

5. General Expenses

1. Administration

2. Distribution and Sales

3. Hesearch and Development

6. Product Cost Without Profit, $4 a+5$

7. $25 \%$ ROI (Profit)

8. Cost $+25 \%$ ROI (Profit), $6+7$

$\begin{array}{lll}.901 & .699 & .663 \\ .180 & .140 & .133\end{array}$

$.090 \quad .070 \quad .066$

$\begin{array}{lll}.735 \quad .675 & .664\end{array}$

(4.910) (4.987) (5.051)

$5.393 \quad 4.209 \quad 3.952$

SRI INTERNATIONAL/LSA-JPL 


\section{GAS REACTOR}

REACTOR FOR THE $\mathrm{SIF}_{4}$-Na REACTION: SOLID Na FEEDING TECHNIQUE

STEP 2 REACTION

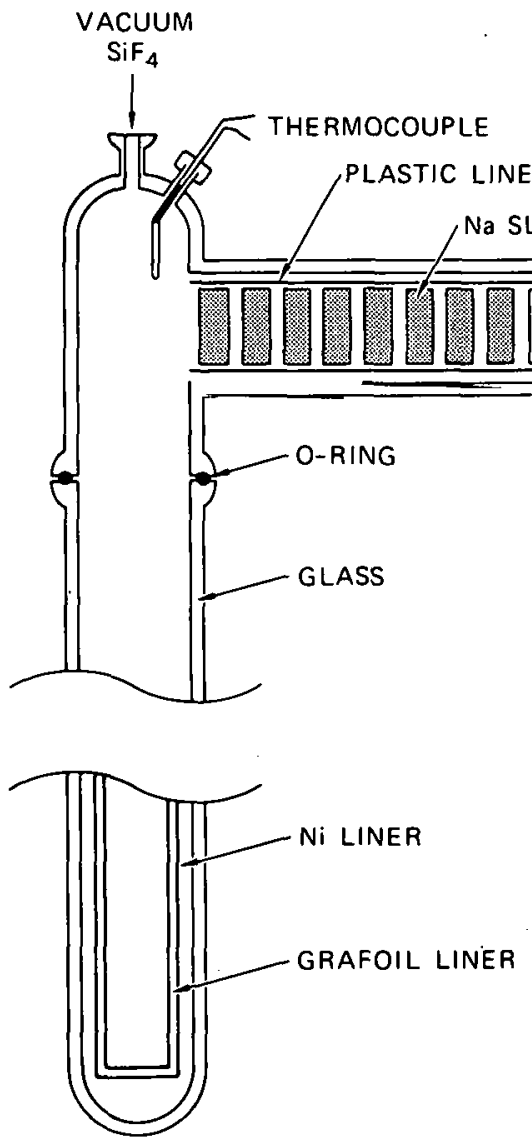

STEP 2 REACTION

$\mathrm{SiF}_{4}(\mathrm{~g})+4 \mathrm{Na}(l) \rightarrow \mathrm{Si}(\mathrm{s})+4 \mathrm{NaF}(\mathrm{s})$ HIGHLY EXOTHERMIC

$\mathrm{SiF}_{4}(\mathrm{~g})+2 \mathrm{NaF}(\mathrm{s})-\mathrm{Na}_{2} \mathrm{SiF}_{6}(\mathrm{~s})$ SIDE REACTION

- REACTION CONDITIONS

- SOLID SODIUM DROPPED INTO A HOT REACTOR CONTAINING $\mathrm{SiF}_{4}$ GAS

- AVERAge ReACTION TEMP $\sim 500^{\circ} \mathrm{C}$

- $P_{\text {Sif }_{4}}=0.7-1.0$ ATM

- NICKel liNer material

- inNer liner grafoil

- REACTION PRODUCTS

- SILICON ABOUT 11\% WEIGHT OF MAXIMUM POSSIBLE

- $\mathrm{Na}_{2} \mathrm{SiF}_{6}$ 5-40\% WEIGHT

- UNREACTED SODIUM 1-10\% WEIGHT

- silicon particle size

$150 \mu \mathrm{m}$ 


\section{GAS REACTOR}

STEP 3 SILICON RECOVERY BY FUSION

- REACTION PRODUCTS MELTED AT T > $1410^{\circ} \mathrm{C}$

- graphite crucibles, argon atmosphere

- separation of phases

MOLTEN NaF ABOVE MOLTEN SILICON

- NaF Wets graphite, PREVENTS Si CONTACt

\section{EFFECT OF SURFACE TO VOLUME RATIO OF CYLINDRICAL} (6 CM DIAMETER) Na SLICES ON AMOUNT OF Na UNREACTED

\begin{tabular}{|c|c|c|}
\hline $\begin{array}{c}\text { SLICE } \\
\text { THICKNESS } \\
\text { CM. } \\
\end{array}$ & $\begin{array}{l}\text { SURFACE } \\
\text { VOLUME } \\
\text { CM } 2 / \mathrm{CM}^{3}\end{array}$ & $\begin{array}{l}\text { ME GHT PERCENT NA } \\
\text { IN REACTION PRODUCTS }\end{array}$ \\
\hline 0.3 & 5.7 & $2-4,3-5,2-8$ \\
\hline 0.6 & 3.5 & $5-7,3-5,2-18,9-20,5-11$ \\
\hline 1.3 & 1.9 & $>20$ \\
\hline
\end{tabular}

EFFECT OF SURFACE TO VOLUME RATIO OF QUADRANT SHAPED Na SLICES (3 CM EDGE) ON AMOUNT OF Na UNREACTED

SLICE
THICKNESS
CM.

SURFACE
VOLUME
CM2lCM3
3.9
2.9
2.1

WEIGHT PERCENT NA
IN REACTION PRODUCIS
$3-9$
$1-10,5$
$\geqslant 20$




\section{MEASUREMENT OF IMPURITY CONCENTRATIONS IN SILICON}

\section{IRRADIATION FACILITIES}

Livermore Pool type Reactor is a Research Reactor.

THREe of the access tUBes are used for activation amalysis.

\begin{tabular}{|c|c|c|c|c|}
\hline Pesuruar & IHERMAL ELUXX & $\begin{array}{l}\text { EPIIHF DMAL } \\
\text { IHERIAAL }\end{array}$ & $\begin{array}{l}\text { IRRADIATION } \\
\text { JلlC (CM) }\end{array}$ & $\begin{array}{l}\text { CONTAINER } \\
\text { L. HI. (CM) }\end{array}$ \\
\hline$S-2$ & $.5 \times 10^{13}$ & .022 & (PoLY) 6.35 & 13.03 \\
\hline$E-1$ & $2.5 \times 10^{13}$ & .042 & $(A L)$ & 4.27 \\
\hline (RABBIT) & $2.0 \times 10^{13}$ & .045 & (POLY) 2.38 & 6.99 \\
\hline
\end{tabular}

JPL NUCLIDE LIST BY HALF-LIFE

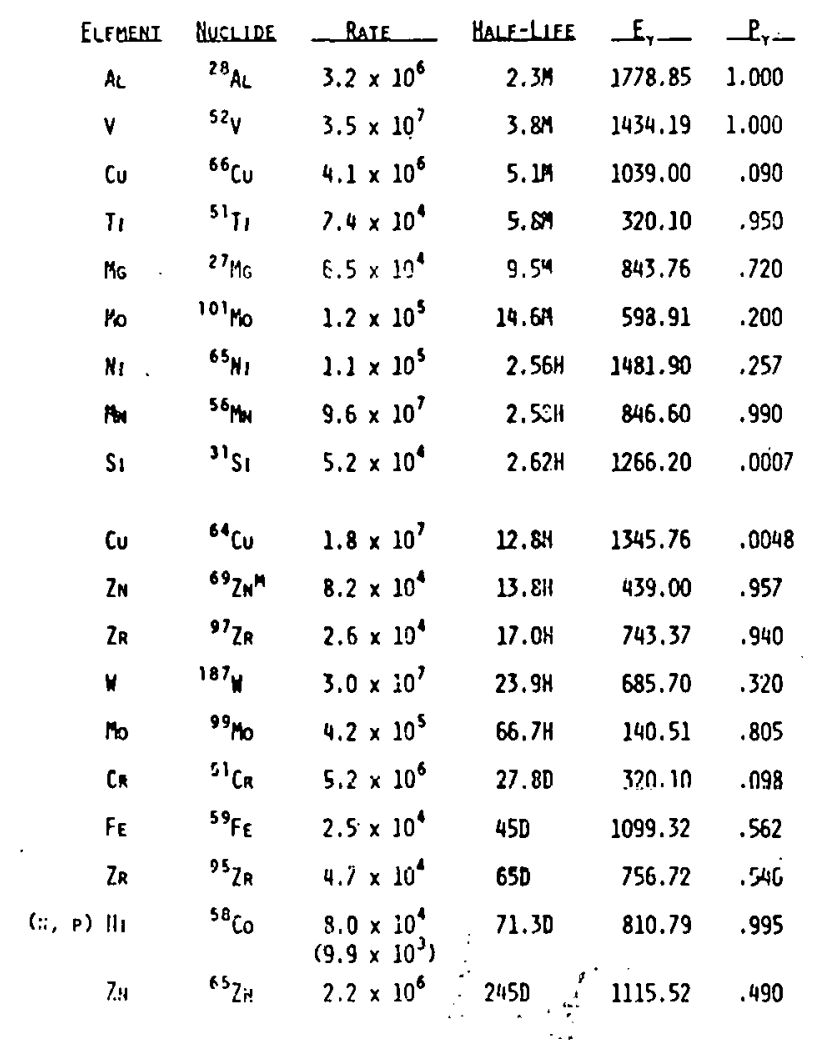




\section{${ }^{31}$ SI ACTIVITY - 2.62 HOUR HALF-LIFE}

\begin{tabular}{|c|c|}
\hline Cooluts LuE (Hours) & 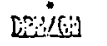 \\
\hline 0 & $1 \times 10^{10}$ \\
\hline 24 & $7 \times 10^{7}$ \\
\hline 36 & $3 \times 10^{6}$ \\
\hline 48 & $1 \times 10^{5}$ \\
\hline 60 & 5300 \\
\hline 72 & 220 \\
\hline
\end{tabular}

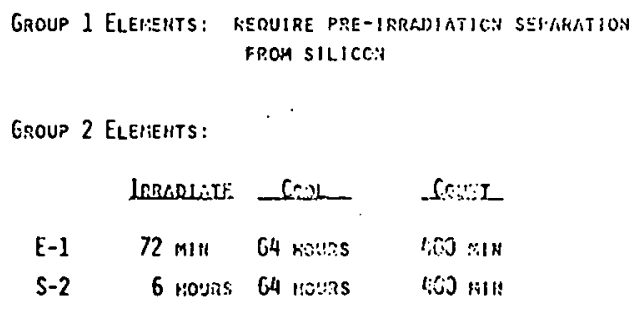

\begin{tabular}{|c|c|c|c|}
\hline & IRRBRLELFت & Cr.jL & Ser:I \\
\hline$E-1$ & $72 \mathrm{mlt1}$ & 04 xงurs & $1,00 \mathrm{~N}$ \\
\hline$s-2$ & 6 rorsts & 64 1:0!?s & (:0) \\
\hline
\end{tabular}

- [P: $=$ Tisintegrations fer limute

\section{DETECTION LIMITS - GROUP 1 ELEMENTS}

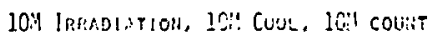

\begin{tabular}{|c|c|c|c|}
\hline & nEii(l): & [? & 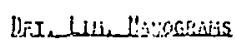 \\
\hline $20 / \mathrm{L}$ & 5.1 & 47 & .05 \\
\hline${ }^{27} 7_{16}$ & 10.0 & 11 & .45 \\
\hline${ }^{51} \mathrm{~T}_{1}$ & 3.5 & 9 & .14 \\
\hline${ }^{52} v$ & 4.9 & 2180 & .001 \\
\hline${ }^{35} \mathrm{H} / \mathrm{N}$ & 4.3 & 3930 & .0005 \\
\hline${ }^{65} \mathrm{ml}$ & 16.0 & 4 & 1.8 \\
\hline${ }^{66} \mathrm{Cu}$ & 51.9 & 430 & .051 \\
\hline
\end{tabular}

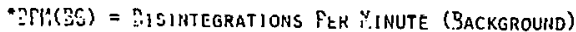


: UNION CARBIDE CORPORATION

UNION CARBIDE SILANE PROCESS

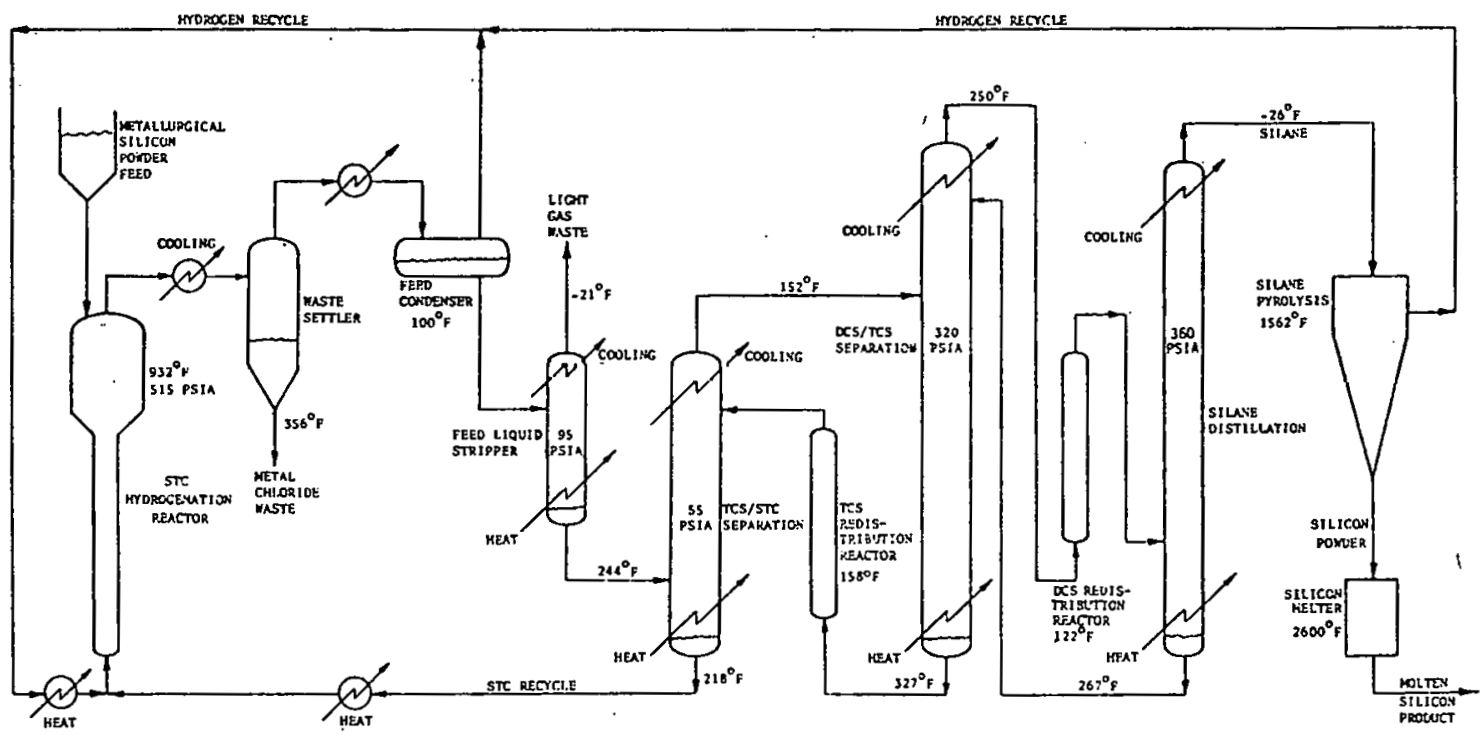


ECONOMIC PERFORMANCE OF COMMERCIAL UCC SILANE/SILICON PLANTS

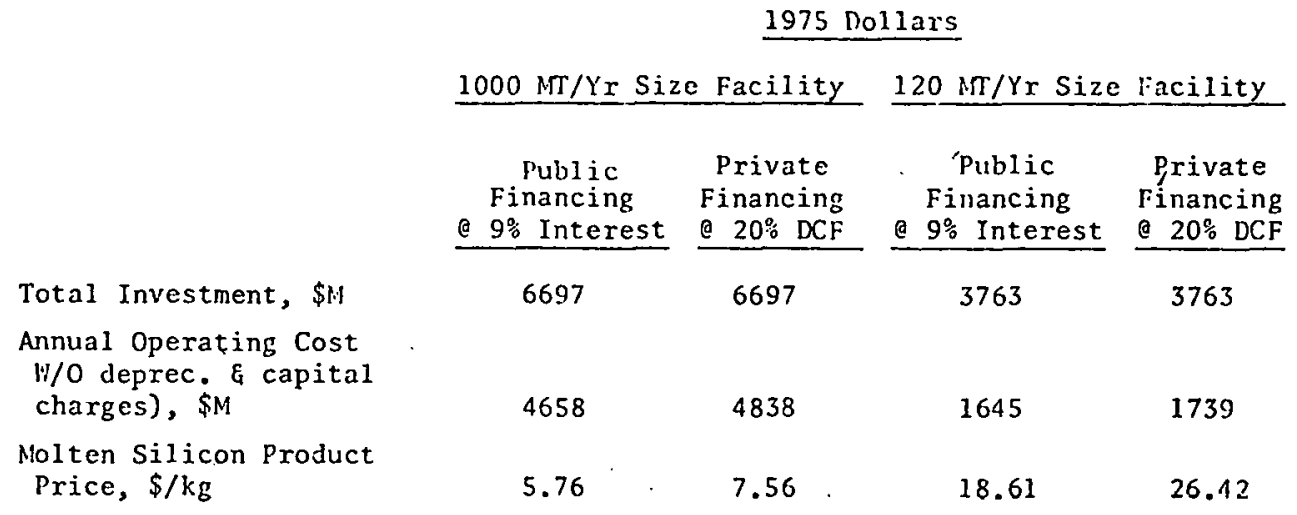

Price Breakdom $(1975$ Do 17 ars $/ \mathrm{kg})$

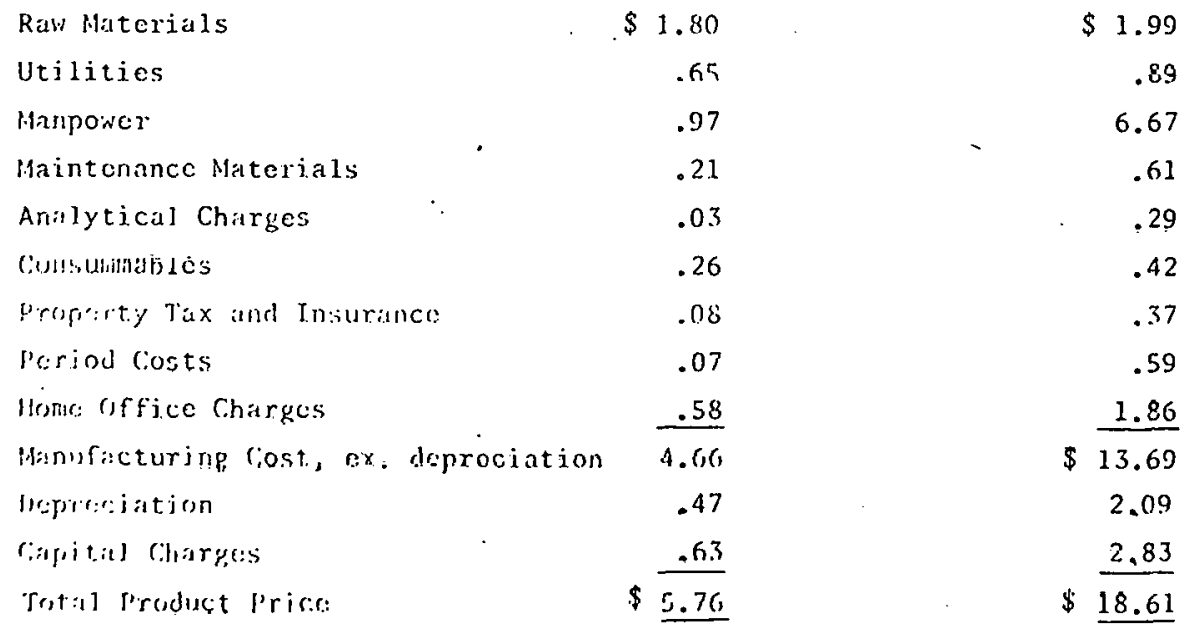


FLUID BED SILANE PYROLYSIS SCHEMATIC DIAGRAM

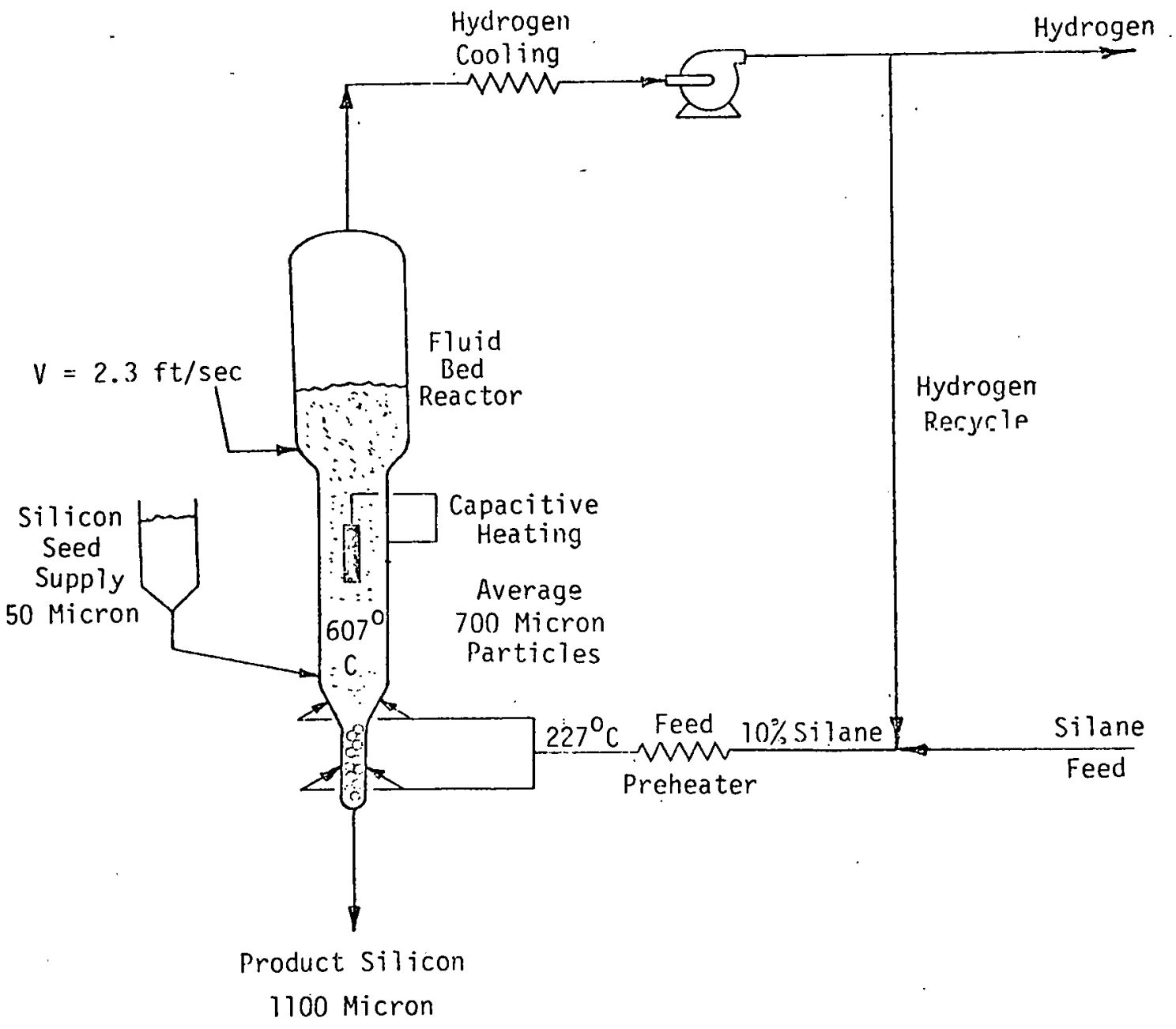


FLUID BED PYROLYSIS OF SILANE

CRITICAL MOLE FRACTION OF SILANE AS A FUNCTION OF TEMPERATURE.

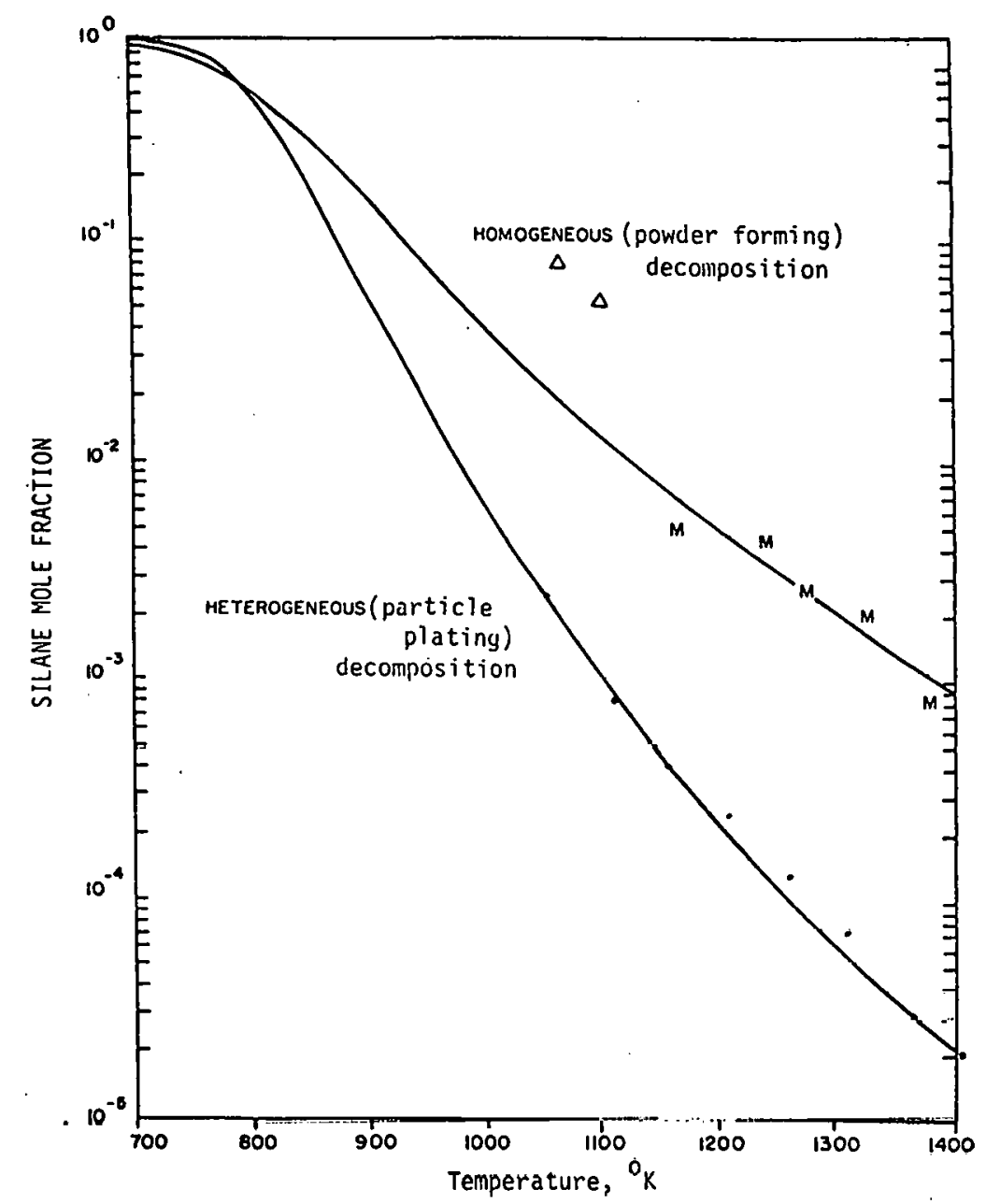


HETEROGENOUS SILANE DECOMPOSITION, SURFACE REACTION RATE VS $T^{-1}\left(K^{-1}\right)$

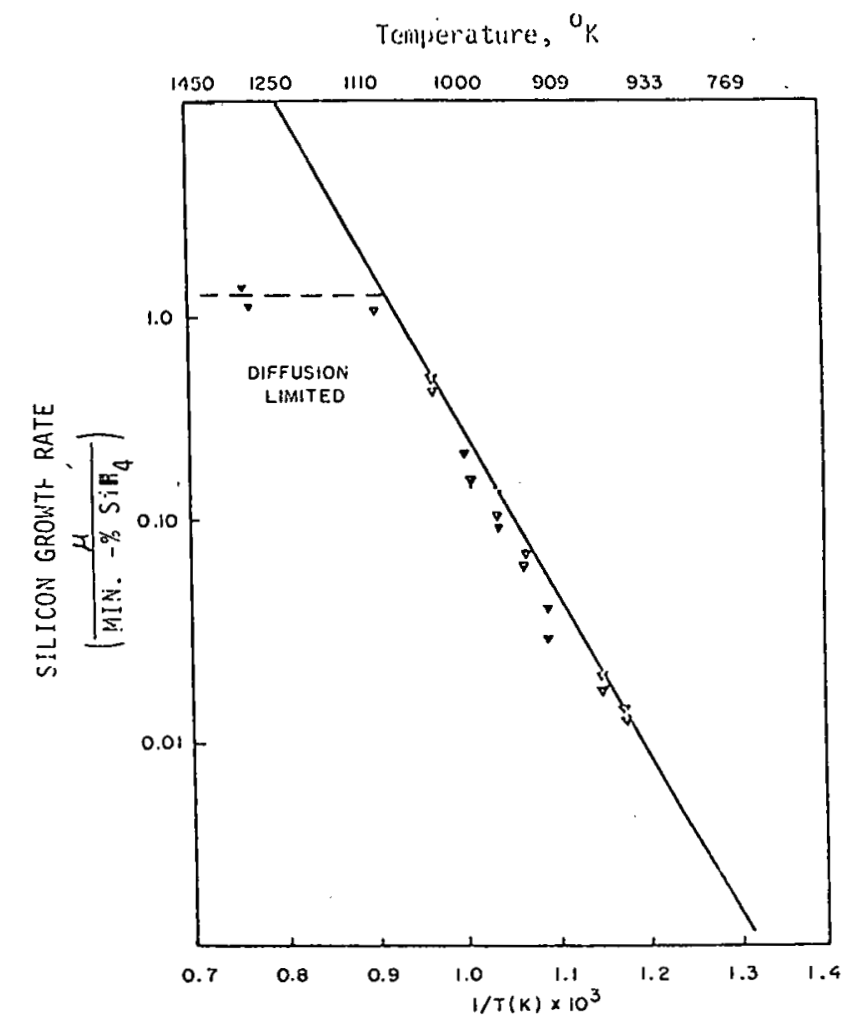




\section{CHEMICAL REACTIONS \\ UCC SILANE/SILICON PROCESS}

STR: Ilydrogenation

$\mathrm{Si}+2 \mathrm{H}_{2}+3 \mathrm{SiCl}_{4} \pm 4 \mathrm{HSiCl}_{3}$

(1)

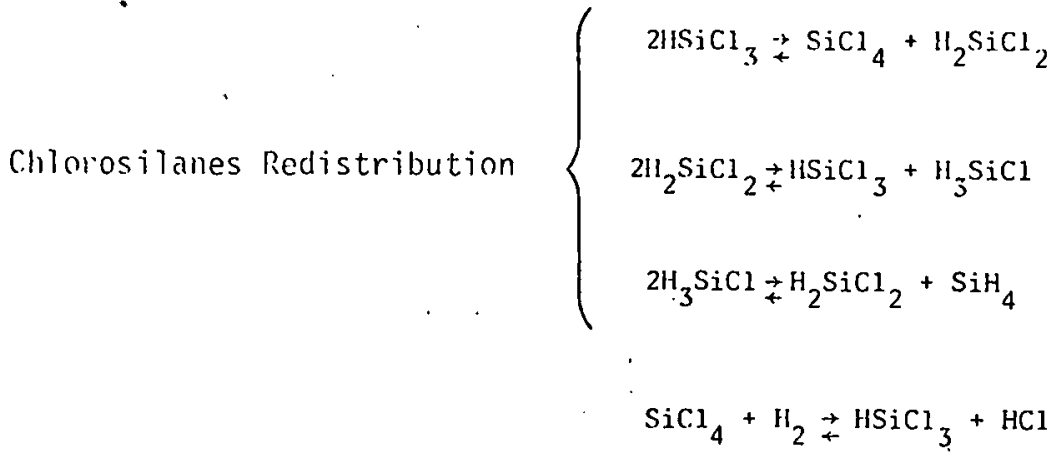

$$
\begin{aligned}
& \text { Silane Pyrolysis } \\
& \mathrm{SiH}_{4}+\mathrm{Si}+2 \mathrm{H}_{2}
\end{aligned}
$$

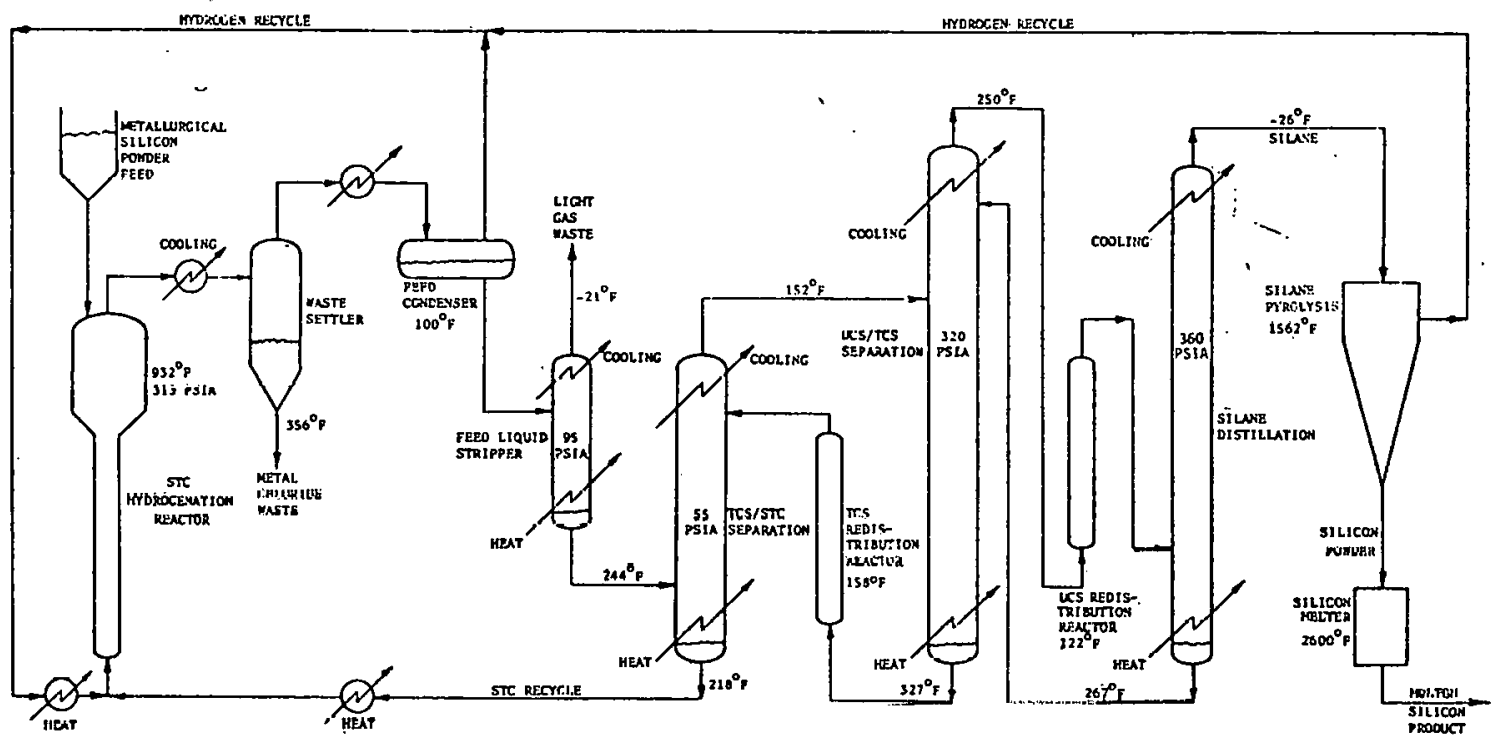




\section{EFFLUENT PRODUCT COMPOSITION FROM TCS REDISTRIBUTION \\ REACTOR AT $81^{\circ} \mathrm{C}$ CONTAINING A-21 RESIN CATALYST}

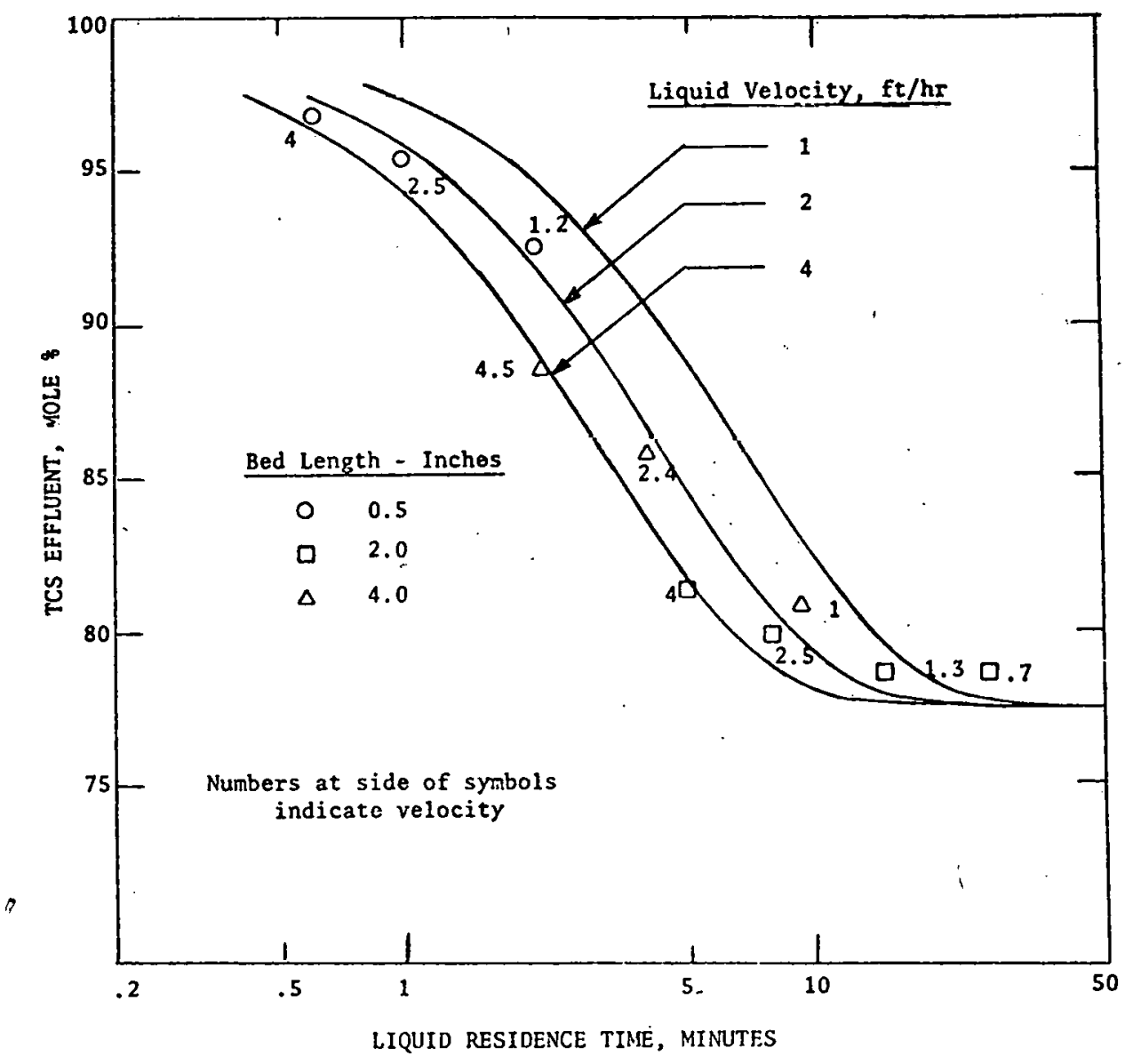

BED DINMETER $=0.43$ INCHES

$\begin{array}{ccc}\text { velocity, ft/hr } & \underline{k}_{3} & \underline{k}_{3} \\ 1 & .0210 & .01370 \\ 2 & .0210 & .02162 \\ 4 & .0210 & .03041\end{array}$




\section{EFFLUENT PRODUCT COMPOSITION FROM LIQUID DCS REDISTRIBUTION REACTOR AT $56^{\circ} \mathrm{C}$ CONTAINING A-21 RESIN CATALYST}

BED DIAMETER $=0.43$ INCHES

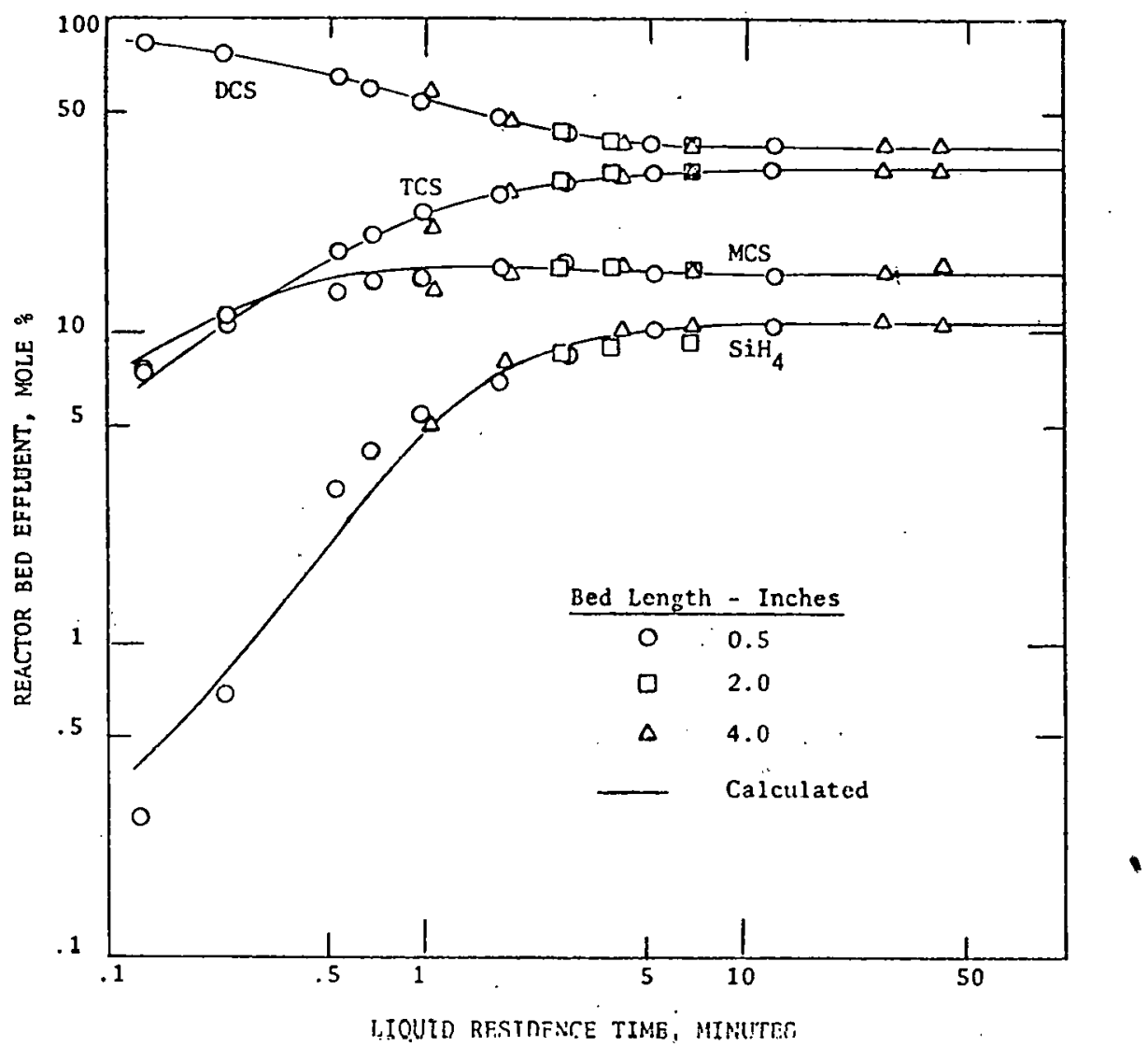




\section{PROCESS FEASIBILITY STUDY IN SUPPORT OF SILICON TASK 1}

- CHEMICAL E:IGIHEERING GiIALYSIS

- ECONOMIC A:SALYSIS

\section{PRELIMINARY PROCESS DESIGN ACTIVITIES FOR SILANE PROCESS-CASE C (UNION CARBIDE)}

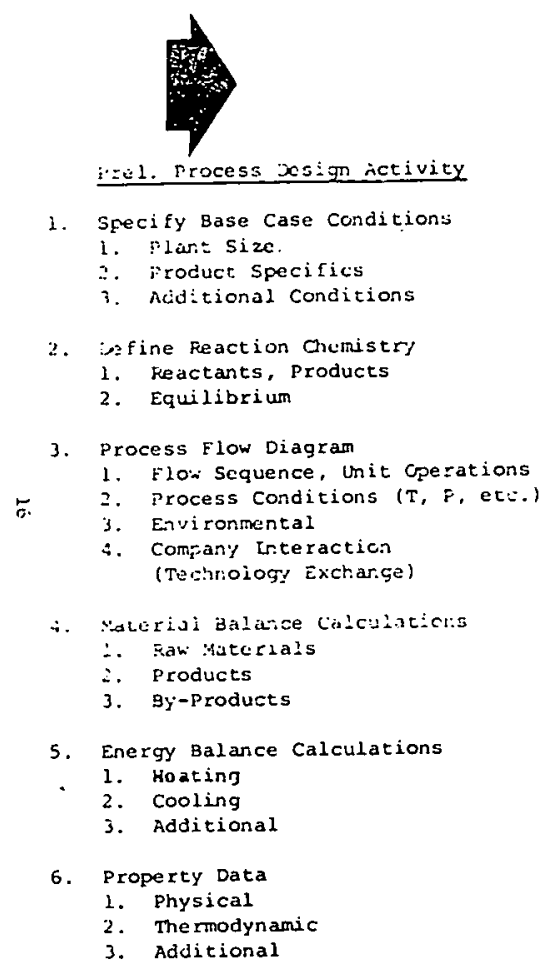

7. Equipment Design Calculations

1. Storage Vessels

2. Unit Operations Equipment

3. Process Data (P, $T$, rate, etc.)

4. Additional

8. List of Major Process Equipment

1. Size

2. Type

2. Type

8á. Major Technical Factors

(Potential Problem Areas)

1. Materials Compatibility

2. Process conditions Limitations

3. Additioral

9. Production Labor Requi rements

1. Process Technology

2. Production volume

10. Forward for Economic Analysis

$$
\begin{aligned}
& \text { - Plan } \\
& \text { - In Progress } \\
& \text { - Complete }
\end{aligned}
$$




\section{BASE CASE CONDITIONS FOR SILANE PROCESS-CASE C (UNION CARBIDE)}

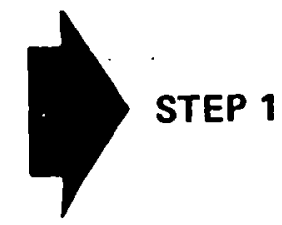

1. Plant Size

-silicon produced from silane

-1000 metric tons/year of silicon

2. Hydrogenation Reaction

- Metallurgical grade silicon, hydrogen, and recycle silicon tetrachloride

(TET) used to produce trichlorosilane (TCS)

- Copper catalyzed

-Fluidized bed

$-500^{\circ} \mathrm{C}, 514.7$ psia

-208 to 22.58 conversion of $\mathrm{SiCl}_{4}$ (example)

3. TCS Redistribution Reaction

-TCS from hydrogenation produces dichlorosilarie (DCS)

- Catalytic redistribution of TCS with tertiary amine ion exchange resin

-Liquid phase 85 psia, $140^{\circ} \mathrm{F}$.

- Conversion a function of inlet concentration (Union Carbide equilibrium)

- Conversion from pure TCS feed is about 9.5 to DCS (example)

4. DCS Redistribution Reactior.

-DCE produces $\mathrm{Sill}_{4}$ ( 511 iane)

- Catalytic redistribution of DCS with tertiary amine exchange resin

-Liquid phase 510 psia, $140^{\circ} \mathrm{F}$

- Culversion a tunction nf inlet conccntratioil (Union carbide equilibrium)

-Convcrgion lium pure'uxis teed is about 148 to Silane (example)!

5. Recycles

-Unreactcd chlorosilanes separated by distillation and recycled

6. Silane Purification

-Final purification by distillation

-Designed to remove trace impurities $\left(\mathrm{B}_{2} \mathrm{H}_{6}\right.$, example)

7. Operating Ratio

-Approximately 858 utilization (on stream time)

-Approximately 7445 hour'year production

8. Utorage Cunslderátion

-Feed materials (several week supply, approx. 1 month)

-Product (two shifts storage)

-Process (several hours to 1 shift) 


\section{Step 1 base case conditions \\ MAJOR ITEMS SUMMARY}

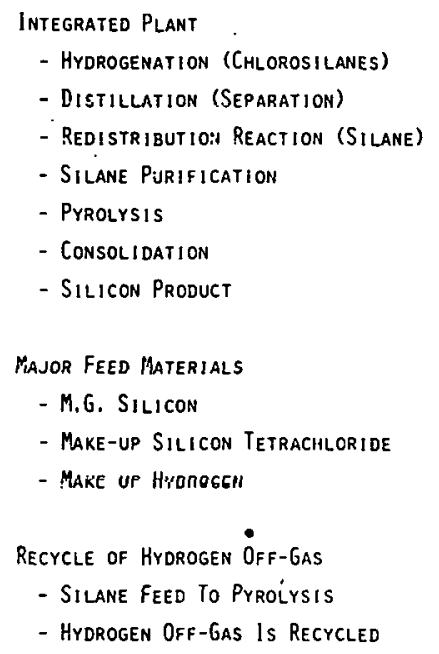




\section{CASE C (REVISED PROCESS)}

1. Hydrogenation Reaction

$3 \mathrm{SiCl}_{4}+\mathrm{Si}+2 \mathrm{H}_{2} \rightleftarrows 4 \mathrm{SiHCl}_{3}$

2. Trichlorosilane Redistribution Reaction

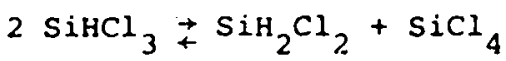

3. Dichlorosilane Redistribution Reaction

$3 \mathrm{SiH}_{2} \mathrm{Cl}_{2} \stackrel{\text { Distillation }}{\longrightarrow} 2 \mathrm{SiHCl}_{3}+\mathrm{siH}_{4}$

4. Waste Treatment (representative)

$$
\begin{aligned}
& \mathrm{SiH}_{2} \mathrm{Cl}_{2}+\mathrm{Ca}(\mathrm{OH})_{2} \stackrel{\mathrm{aq} .}{\longrightarrow} \mathrm{SiO}_{2}+\mathrm{CaCl}_{2}+2 \mathrm{H}_{2} \mathrm{O} \\
& \mathrm{SiHCl}_{3}+1.5 \mathrm{Ca}(\mathrm{OH})_{2} \stackrel{\mathrm{ag} .}{\longrightarrow} \mathrm{SiO}_{2}+1.5 \mathrm{CaCl}_{2}+2 \mathrm{H}_{2} \mathrm{O} \\
& \mathrm{SiCl}_{4}+2 \mathrm{Ca}(\mathrm{OH})_{2} \stackrel{\mathrm{aq} .}{\longrightarrow} \mathrm{SiO}_{2}+2 \mathrm{CaCl}_{2}+2 \mathrm{H}_{2} \mathrm{O}
\end{aligned}
$$

5. Silane Pyrolysis Reaction

$$
\mathrm{SiH}_{4} \longrightarrow \mathrm{Si}+2 \mathrm{H}_{2}
$$

Note

1. Reaction 1 product contains $\mathrm{H}_{2}, \mathrm{HCl}, \mathrm{SiCl} \mathbf{l}_{4}, \mathrm{siHCl}_{3}, \mathrm{si}:-{ }_{2}$ (trace), uller riace chlorides

2. Reaction 2 Product contains $\mathrm{SiHCl}_{3} \mathrm{SiCl}_{4}, \mathrm{SiH}_{2} \mathrm{Cl}_{2} \cdot \mathrm{SiH}_{3} \mathrm{Cl}$

3. Reaction 3 Product contains $\mathrm{SiH}_{2} \mathrm{Cl}_{2}, \mathrm{SiHCl}_{3}, \mathrm{SiCl}_{4}, \mathrm{SiH}_{3} \mathrm{Cl}, \mathrm{SiH}_{4}$ 


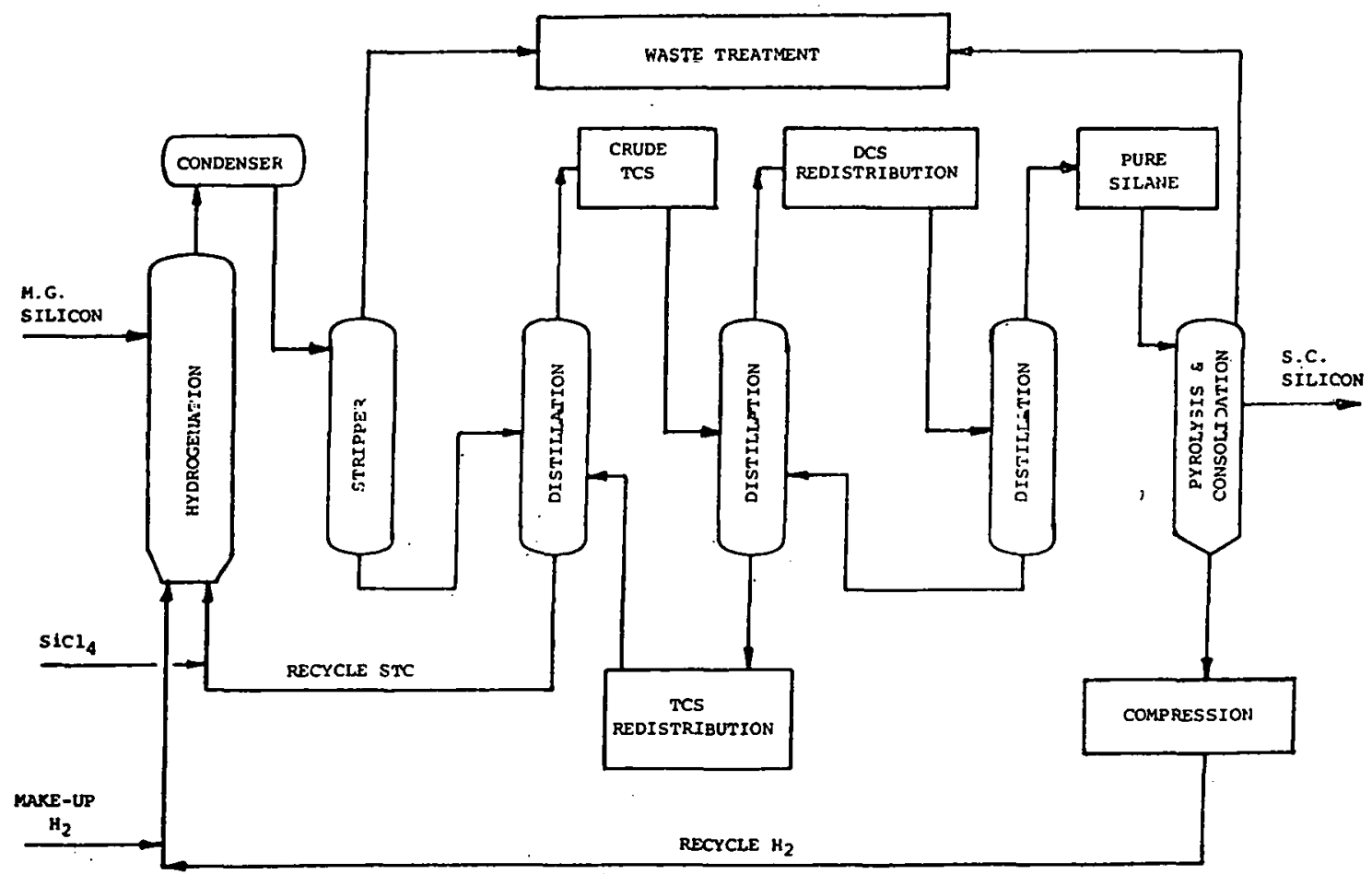

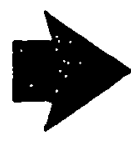

Prel. Process Economic Activity

1. Process Design Inputs

1. Raw Material Requirements

2. VLillty lequl rement

3. Equipment List.

4. Labor Requi rements

2. Specify Base Case Conditions

1. Base Year for costs

2. Appropriate Indices for costs

3. Additional

3. Raw Material Costs

1. Base Cost/lb, of Material

2. Material cost/kg of silicon

3. Total cost/xs of silicon

4. Utility Costs

1. Bage cost for Eacn ueility

2. Utility cost/Kg of silicon

3. Toral cost/ig of silicon

5. Major Process Equipment Costs

1. Individual Equipment cost

2. Cost Index adjustment
CASE C

ECONOMIC ANALYSES:

MIC ANALYSIS ACTIVITIES FOR SILANE PROCESS CASE C (UNION CARBIDE).

Statis
$:$
$:$
$:$
$:$
$:$
$:$
$:$

6. Production Labor costs

1. Base Cost Per Man Hour

2. Cost/Kg Silicon Per Area

3. Total Cost/Kg Silican

7. Estimation of Plant Investment

1. Battery Limits direct Costs

2. Other Direct costs

3. Indirect costs

4. Contingercy

5. Total Plant Investment (Fixed Capital)

8. Estimation of Total Prodict Cost

1. Di rect Manufacturing Cost

2. Indirect ranufacturing Cost

3. Plant Overhead

6. By-Protist: Credit

5. General kxpenses

6. Total cost of Product

- Plan

- In Progress

- complete
Prel. Process Ecchomic netivity 
1. Capital Equipment

-January 1975 Cost.Index for Capital Equipment cost -January 1975 cost Index value $=430$

2. Utilities

-Electrical, Steam, Cooling water, Nitrogen

-January 1975 cost Index (U. S. Dept. Labor)

- Values determined by literature search and summarized in cost

standardization work

3. Law Material cost

-Chemical markcting Reporter

- Jaruary 1975 value

- Ruw Material cost Index for Industrial Chemicals

-3975 cost index value $=206.9$ (Wholestale price Index, yroducer

price Index)

4. Labor Cost

-average for Chenical petroleum, Coul and allied Industrics (1975)

-Skilled $\$ 6.90 / \mathrm{mr}$

-semiski1100 \$4.90/hr 


\section{CASE C \\ STEP 7 ESTIMATION OF PLANT INVESTMENT FOR SILANE PROCESS CASE C (UNION CARBIDE).}

\author{
1. Major Process Equipment Cost \\ 2. Installation of Major Process Equipmirt \\ 3. Process Piping, Installed \\ 4. Instrumentation, Installed \\ 5. Electrical, Installed \\ 6. Process Buildings, Installed
}

1a. SUBTOTAL FOR DIRECT PLANT INVESTMENT COSTS (PRIMARILY BATTERY LIMIT FACILITIES)

2. OTHER DIRECT PLANT INVESTMENT COSTS

1. 1!ilitips. Installed

2. General Services, Sile Development, Fire Protection, etc.

3. General Buildings, offices, Shups, etc.

4. Receiving, Shipping Facilities

Investment

$\$ 1000$

2a. SUBTOTAL FOR OTHER DIRECT PLANT INVESTMENT COSTS (PRIMARILY OFFSITE FACILITIES OUTSIDE BATTER' 'LIMITS)

3. TOTAL DIRECT PLANT INVESTMENT COST, +3

$1,481.9$

637.2

1.096 .6

281.6

148.2

148.2

$3,793.7$

. INDIRECT PLAHT INVESTMENT COSTS

1. Engineering, Overhead, etc.

2. Normal Cont. for Floods, Strikes, etc.

177.6

207.5

311.2

1.407 .8

$5,201.5$

815.0

$1,052.1$

4a. TOTAL INDIRECT PLANT INVESTMENT COST

$1,867.1$

5. TOTAL DIRECT AND INDIRECT PLANT INVESTMENT COST,

$7,068.6$ $3+40$

c. ONEPALI CONTINGEncy, of 5

$2,120.6$

7. FIXED CAPITAL INVESTMENT FUR PLAITT, $5^{-}+6$

B. WORKING CAPITAL INVESTMENT FOR RLANT

9. TOtal PLANT IINESTMENT, $7+8$

Not:

Custs are 1975 Dollars. 


\title{
CASE C \\ STEP 8 ESTIMATION OF TOTAL PRODUCT COST FOR SILANE PROCESS - CASE C (UNION CARBIDE)
}

\author{
$\$ / K G$ of $S i$
}

1. Direct Manufacturing Cost (Direct Charges)

1. Raw Materials

2. Direct Operating Labor

3. Utilities

4. Supervision and Clerical

5. Maintenance and Repairs

6. Operating Supplies

7. Laboratory Charge

0.184

0.083

2. Indirect Manufacturing Cost (Fix $(\cdot)$ ( thill me:i)

1. Depreciation

0.919

2. Local Taxes

0.134

3. Insurance

0.092

3. Plant Overhead

0.6 .56

4. By-praduct credit

1a. Total Manufacturing Cost, $1+2+3+4$

6.003

5. General Expenses
1. Naministration
2. Distribution and sales
0.360
(3. 180

3. Rescurch and Development

6. Total cost of Product, $4 a+5$

基

Note:

Costs are 19\%5 Dullits

\section{UCC SILANE PROCESS}

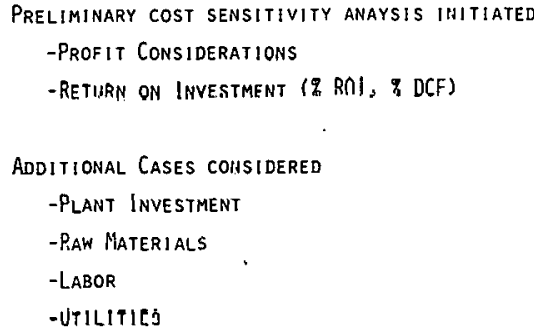




\section{STEP 1 COST AND PROFITABILITY ANALYSIS}

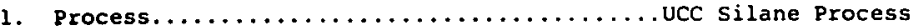

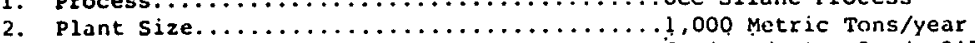

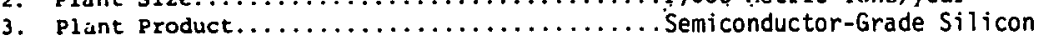

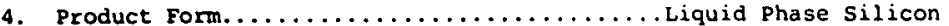

5. Plant Irvestment.................. $\$ 10,570,000$

(1975 dollars)

$$
\begin{aligned}
& \text { Fixed Capital } \$ 9.19 \text { Mega } \\
& \begin{array}{cr}
\text { Working Capital } \\
\text { (158) } & \text { Total } \$ 1.38 \text { Mega } \\
\hline 10.57 \text { Mega }
\end{array}
\end{aligned}
$$

1) 6. Return on Original Investment, after taxes (8ROI)

$$
\begin{aligned}
& \text { Sales Price } \\
& \$ / \mathrm{Kg} \text { of Silicon }
\end{aligned}
$$$$
\text { (1975 dollars) }
$$

Os nor.......: : : : $\quad$ C.90

S8 ROI .......... 7.92

108 ROI ........... 8.93

15 ROI ............... 9.95

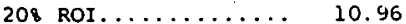

258 ROI ........... 11.98

308 ROI.......... 13.00

408 ROI......... 15.03

(1) Uiscounted Cash Flow Rate of Return, after taxes (8 DCF)

$$
\begin{aligned}
& \text { Sales Price } \\
& \$ / \mathrm{Kg} \text { of Silicon } \\
& \text { (1975 dollars) }
\end{aligned}
$$

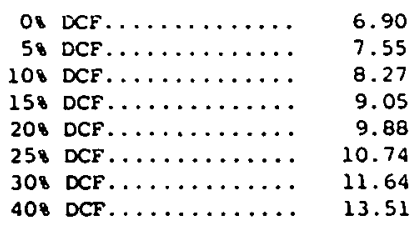

Based on io year project life and 10 year straight line depreciation. 


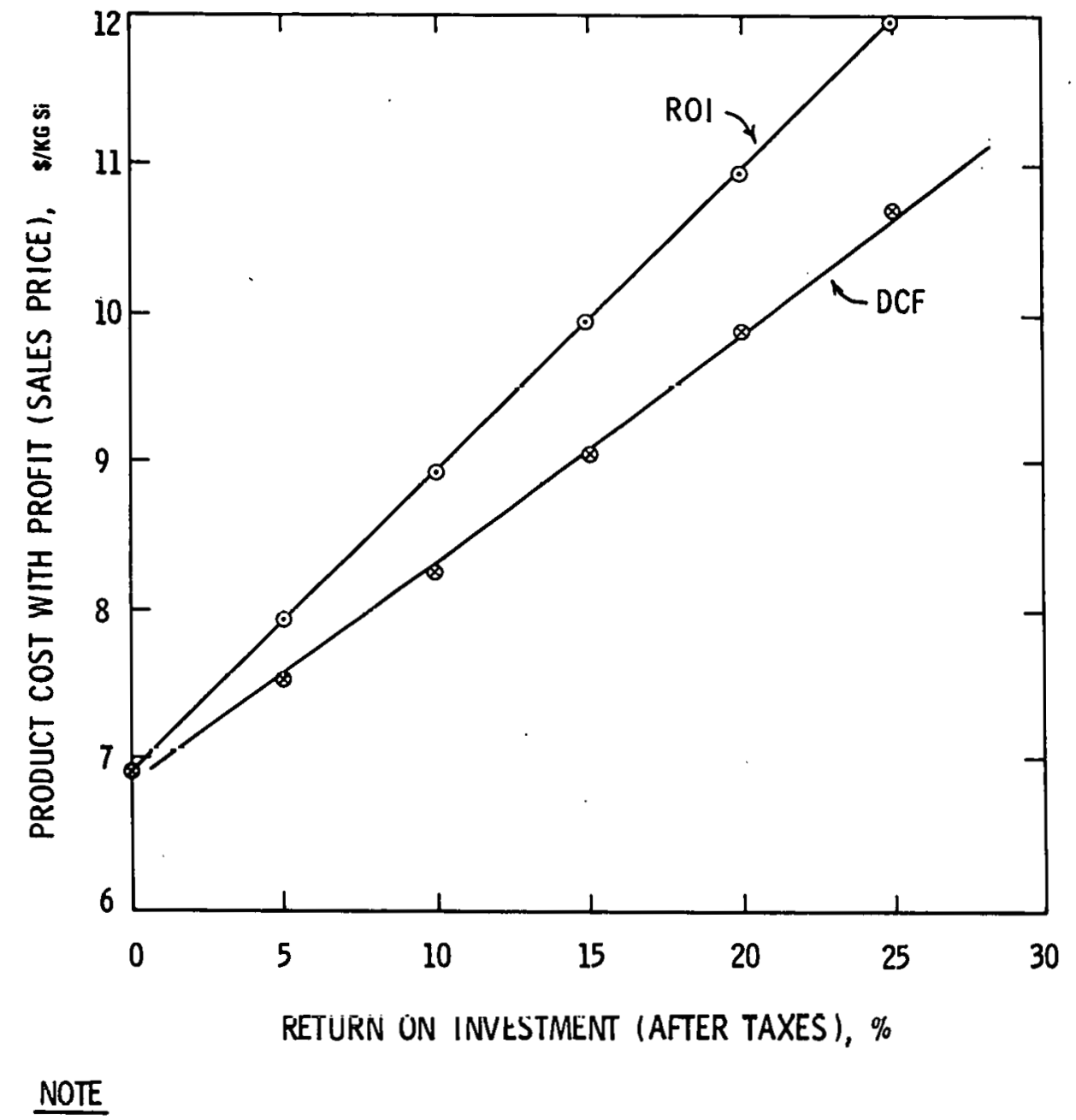

COSTS ARE 1975 DOLLARS 


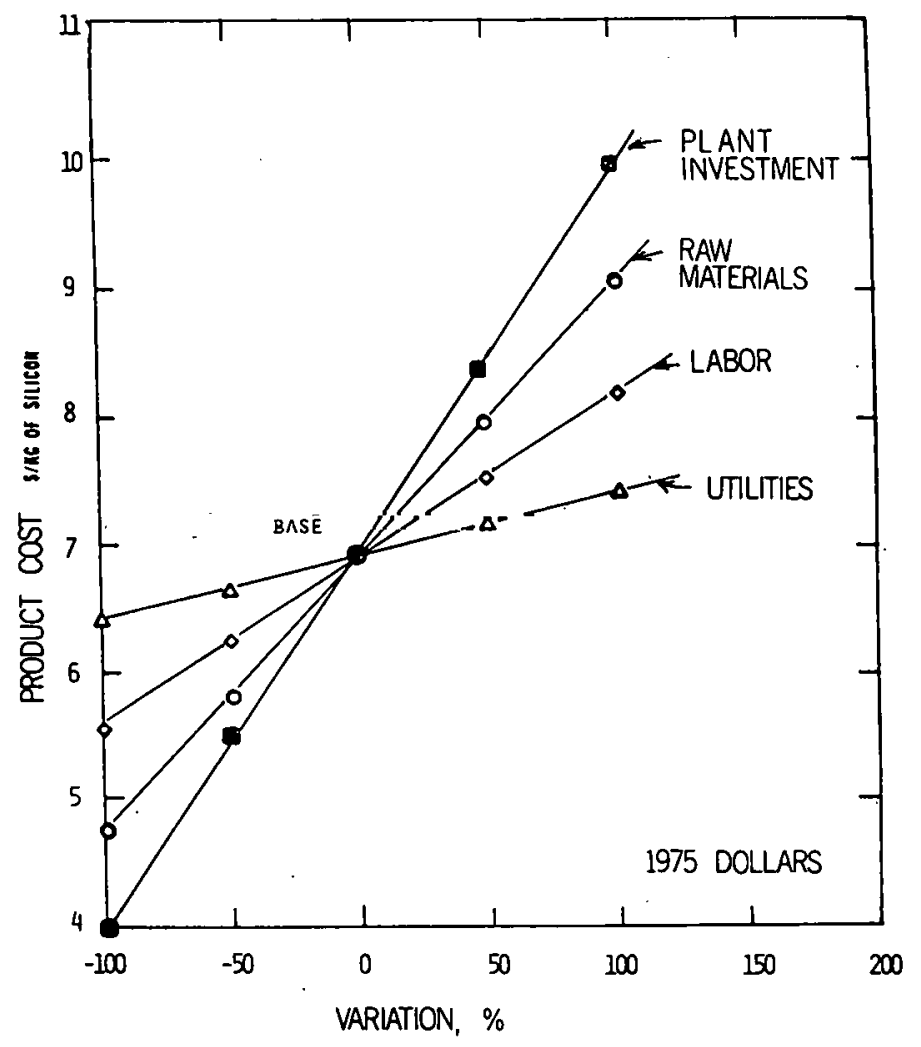

COST AND PROFITABILITY ANALYSIS SUMMARY

1. Process......................ucc silane Process

2. Plant size..................... 000 Metric Tons/year

3. Plant Product................... silicon

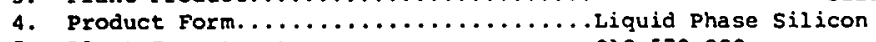

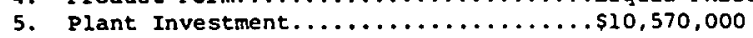

(1975 Dollars)

Fixed Capital

\$ุ. 19 Mr:g.

working Capital

$\$ 1.38$ Mega

(158) Total \$10.57 Mega

(1.975 Dollars)

6. Product Cost Without Profit........6.90 $\$ / \mathrm{kg}$ of silicon

7. Sales Price with Profit...........9.88 $\$ / \mathrm{kg}$ of Silicon at 208 DCF 


\section{CONVENTIONAL POLYSILICON PROCESS}

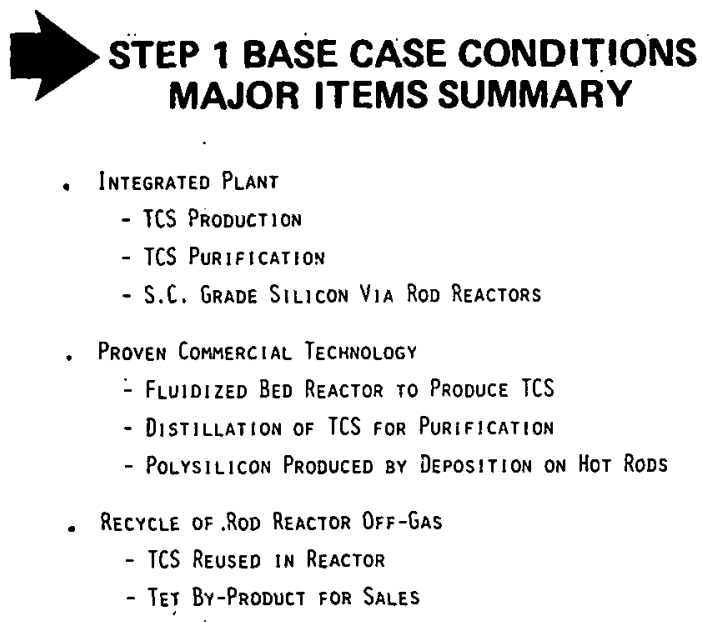
POLYSILICON PROCESS

1. res keactor

$$
\begin{aligned}
& \mathrm{Ci}+3 \mathrm{HCl}+3 \mathrm{HCl}_{3}+\mathrm{H}_{2} \\
& \mathrm{Si}+4 \mathrm{HCl}+\mathrm{SiCl}_{4}+2 \mathrm{H}_{2} \\
& \mathrm{si}+2 \mathrm{ICl}+\mathrm{SiH}_{2} \mathrm{Cl},+\cdot
\end{aligned}
$$

2: kisd keactor

$$
\begin{aligned}
& \mathrm{SiHCl}_{3}+\mathrm{H}_{2}+\mathrm{Si}+3 \mathrm{HCl} \\
& \mathrm{SiHCl}_{3}+\mathrm{HCl}+\mathrm{SiCl}_{4}+\mathrm{H}_{2} \\
& \mathrm{SiHCl}_{3}+\mathrm{H}_{2} \rightarrow \mathrm{SiH}_{2} \mathrm{Cl}_{2}+\mathrm{HCl}
\end{aligned}
$$

3. Waste Treatment

$$
\begin{aligned}
& \mathrm{SiHCl}_{3}+2 \mathrm{H}_{2} \mathrm{O} \cdot \mathrm{SiO}_{2}+3 \mathrm{HCl}+\mathrm{H}_{2} \\
& \mathrm{SiCl}_{4}+2 \mathrm{H}_{2} \mathrm{O} \cdot \mathrm{SiO},+4 \mathrm{HCl} \\
& \mathrm{SiH} \mathrm{Cl}_{2}+2 \mathrm{H}_{2} \mathrm{O} \cdot \mathrm{SiO} 2+2 \mathrm{HCl}+2 \mathrm{H}_{2} \\
& \mathrm{HCl}+\mathrm{NaOH} \cdot \mathrm{NaCl}+\mathrm{H}_{2} \mathrm{O}
\end{aligned}
$$




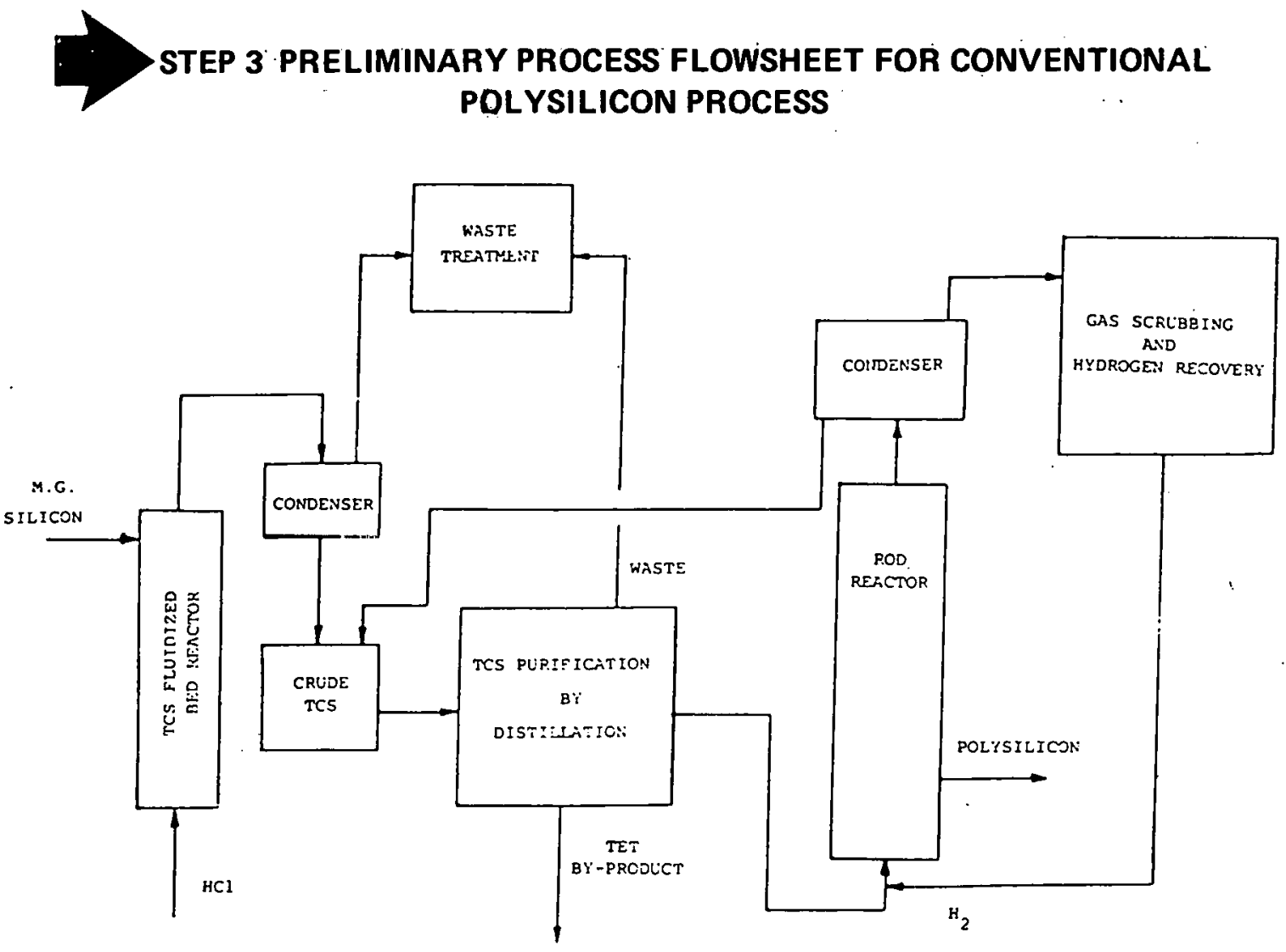



POLYSILICON PROCESS: CASE B

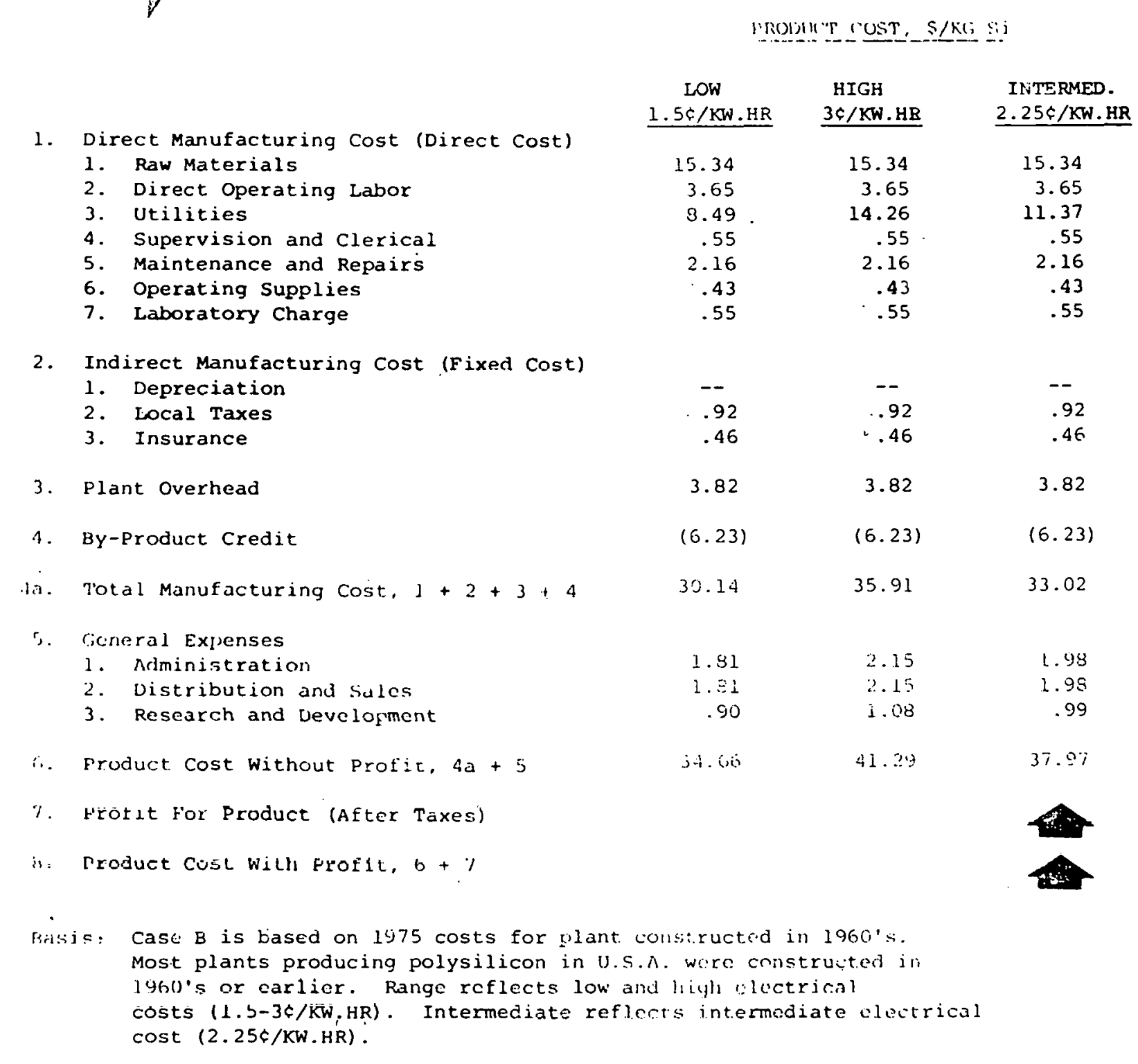


STEP 5 PRODUCT COST VS. PARAMETER VARIATION COST SENSITIVITY FOR CONVENTIONAL POLYSILICON PROCESS: CASE B

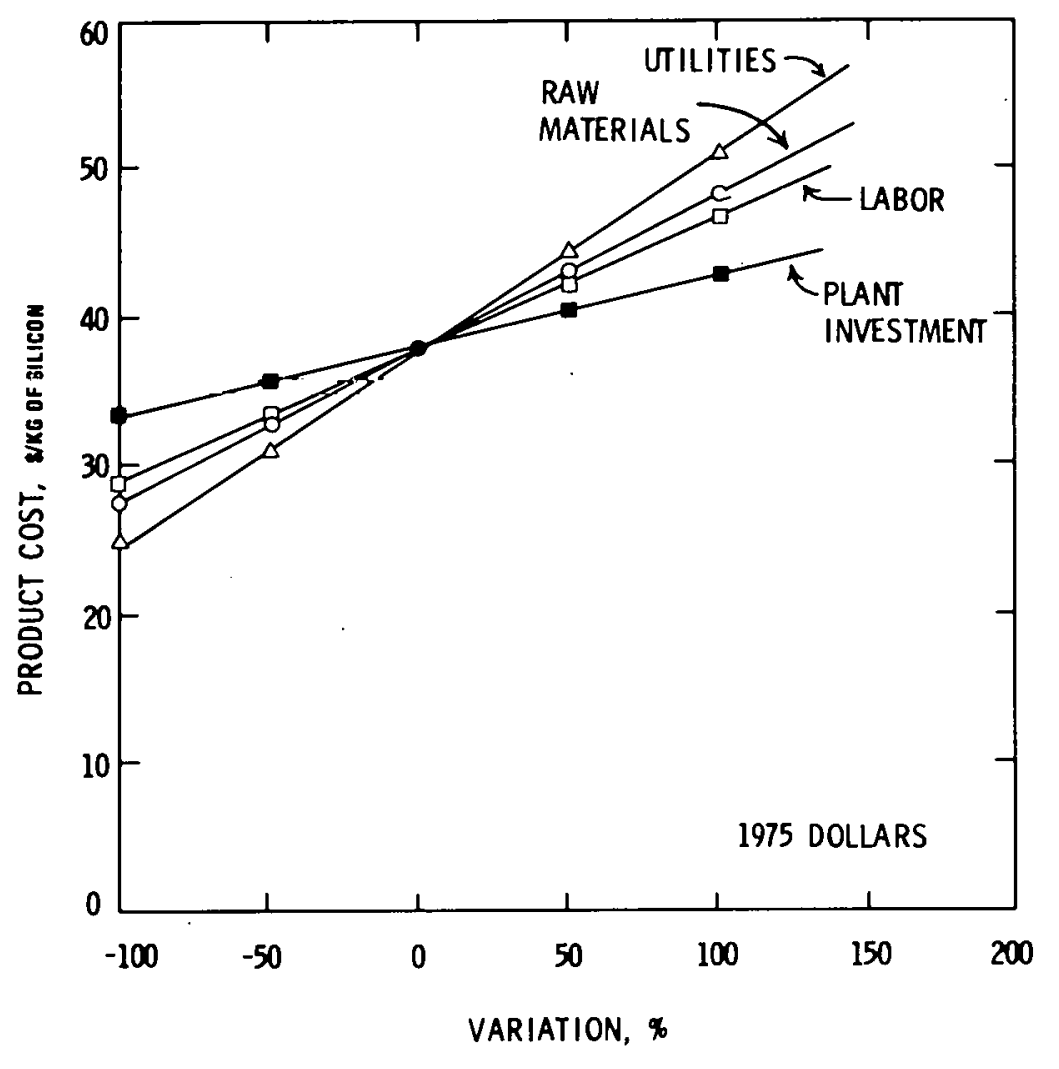




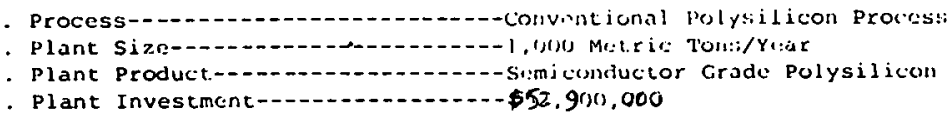

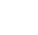

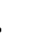

108

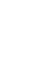

8

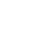

8

08


STEP 8 SALES PRICE VS. YEAR (CONVENTIONAL POLYSILICON PROCESS, CASE B, 15\% ROI)

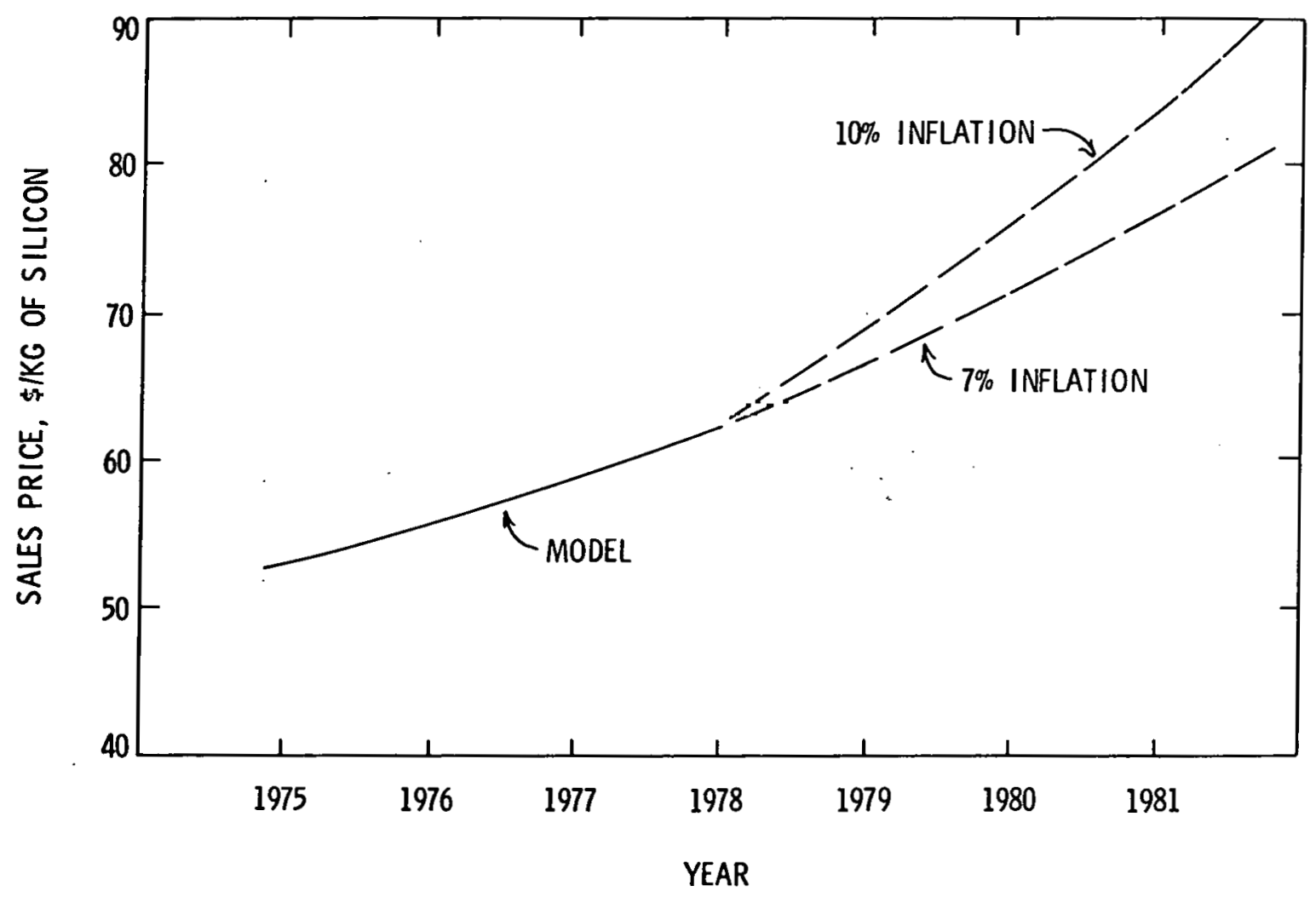



PROCESS: CASE B

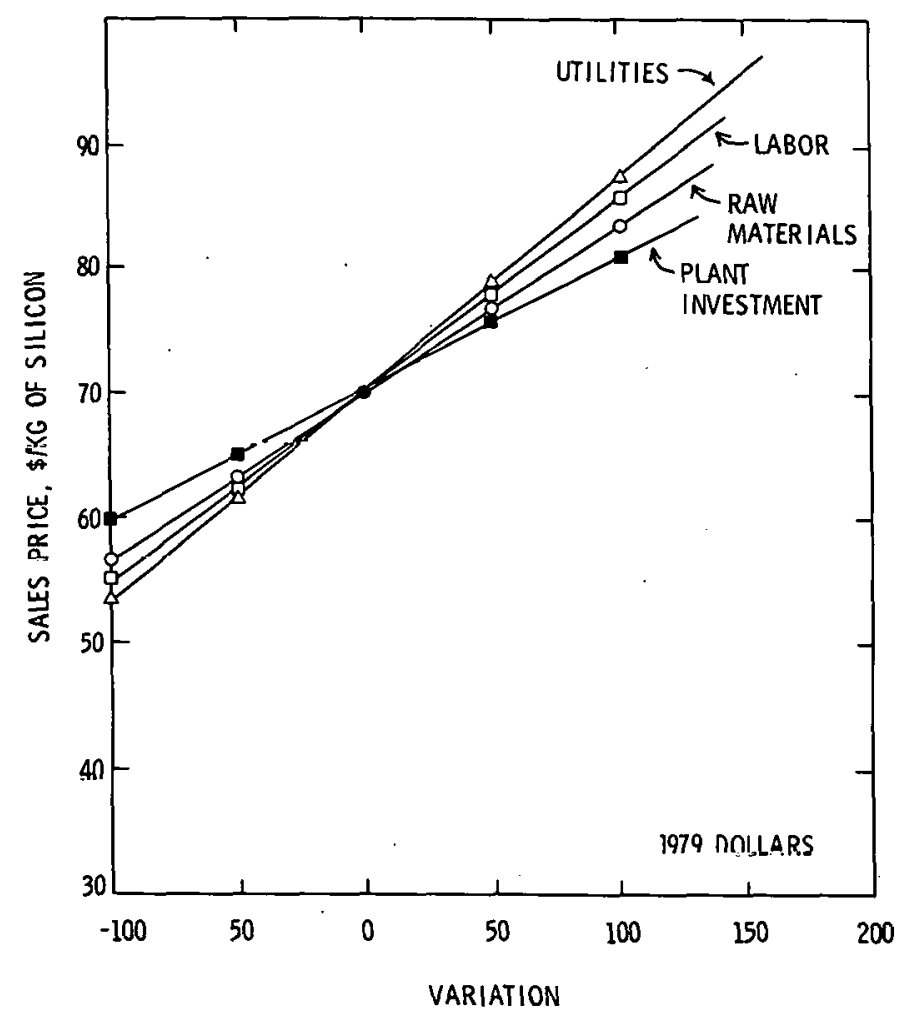

C. BCL PROCESS

STEP 1 BCL PROCESS: INITIAL ECONOMIC ANALYSIS RESULTS REPORTED IN 1977

1. Process.................... PCL Process

2. Plant Size................1,000 Metric Tons/year

3. Plant Product................ Silicon

4. Hroduct Funı................. Solid Phase Silicon (Granules)

5. Plant Investment........... \$10,510,000 (Fixed Capital) (1975 Dollars)

6. Product Cost Without Profit....8.79 $\$ / \mathrm{kg}$ of Silicon

7. Product Cost With $8 \%$ Interest...9.63 $\$ / \mathrm{kg}$ of Silicon 


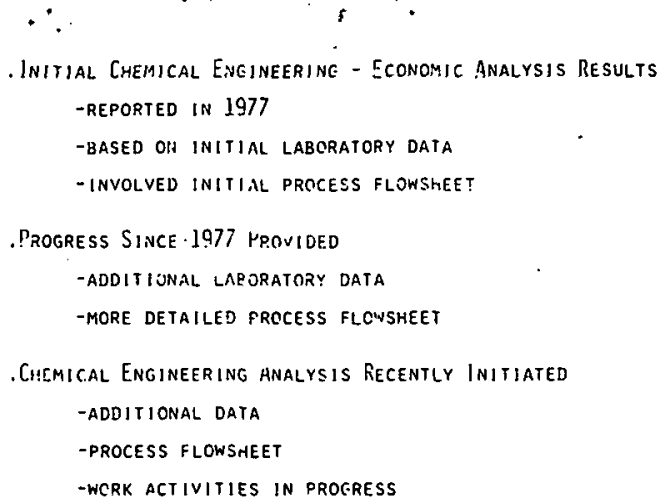

\section{STEP 3 BCL PROCESS (BATTELLE COLUMBUS LABORATORIES): STATUS}

$\begin{array}{ll}\text { 1. Base Case Conditions } & 95 \% \\ \text { 2. Reaction Chemistry } & 95 \% \\ \text { 3. Process Flow Diagram } & 90 \% \\ \text { 4. Material Balance } & 90 \% \\ \text { 5. Energy Balance } & 90 \% \\ \text { 6. Property Data } & 90 \% \\ \text { 7.-8. Equipment Design } & 90 \% \\ \text { 9. Production Labor } & 80 \%\end{array}$

\section{STEP 4 BCL PROCESS (BATTELLE COLUMBUS LABORATORIES): PLANS}

1. Chemical Engieering Analysis

Continue preliminary process desing of the $\mathrm{BCL}$ process based

on additional laboratory data and more detailed process flowsheet.

2. Economic Analys is

Perform cost analysis of BCL. process as results issue from chemical engineering analysis. 


\section{CHEMICAL ENGINEERING AND ECONOMIC ANALYSIS: SUMMARY}

\section{PROCESS}

1. BCL Process-Case A $\left(Z_{N} / S_{I} C L_{4}\right)$

2. BCL Process-Case $B$ $\left(S_{I} I_{4}\right.$ Decomp.)

3. Conventional Polysilizon Process-Case a

4. Conventional Polysilicicon Process-Case B

5. Conventional Polysilicon Process-Case $C$

6. UCC Sillane ProcessCASE A

7. ucc Sillane ProcessCase B

8. ucC. Silane ProcessCASE C

\section{\$/KG OF SILICON \\ 8.79}

42.0

48.43

37.97

42.30

$12.21 \$ / \mathrm{KG}$ OF $\mathrm{SIH}_{4}$

$10.12 \% / K G$ OF $\mathrm{SIH}_{4}$

6.90
CoMinENTS

SHOWS Prolitse

Too Expensive (Nlew Plant)

Too Expensive (Exist, Plant)

Too Expensive (Exist, Plant)

Too Expensive (New Plant)

Too Expensive-Silane Cost Gilly

Too Expensive-Silane Cost Cili ShOWS PROMISE 


\section{b. Large Area Silicon Sheet Task}

CRYSTAL SYSTEM, INC.

\section{DEVELOPMENTS OF HEAT EXCHANGER METHOD (HEM)}

- HISTORICAL INGOT CRACKING PROBLEM SOLVED

- IT IS NOW POSSIBLE TO PROCESS SILICON IN vacium

- HEM IS ONLY METHOD WHICH PRODUCES

SINGLE CRYSTAL IN SQUARE SHAPE

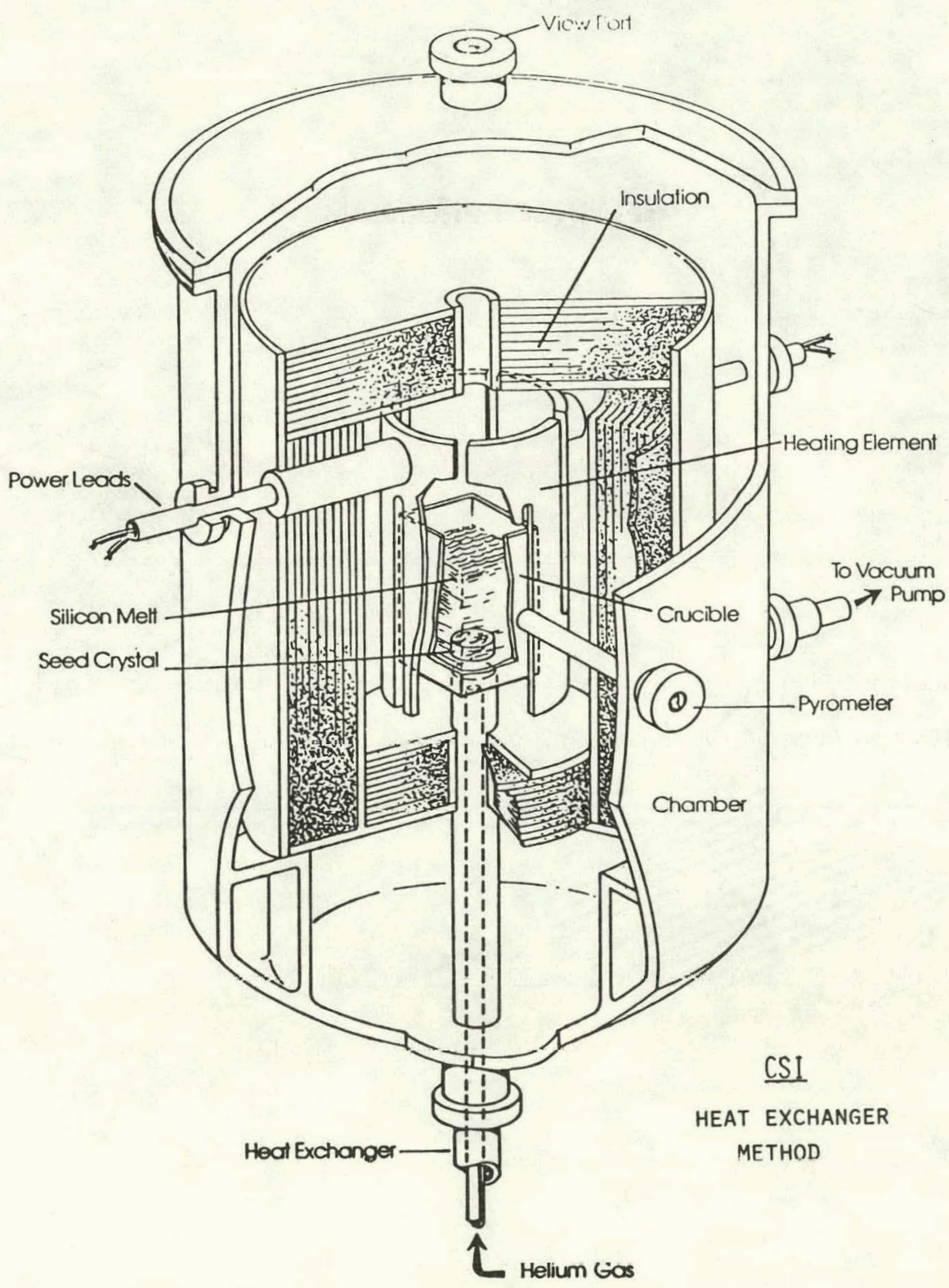




\section{SQUARE INGOTS CAST BY HEM}

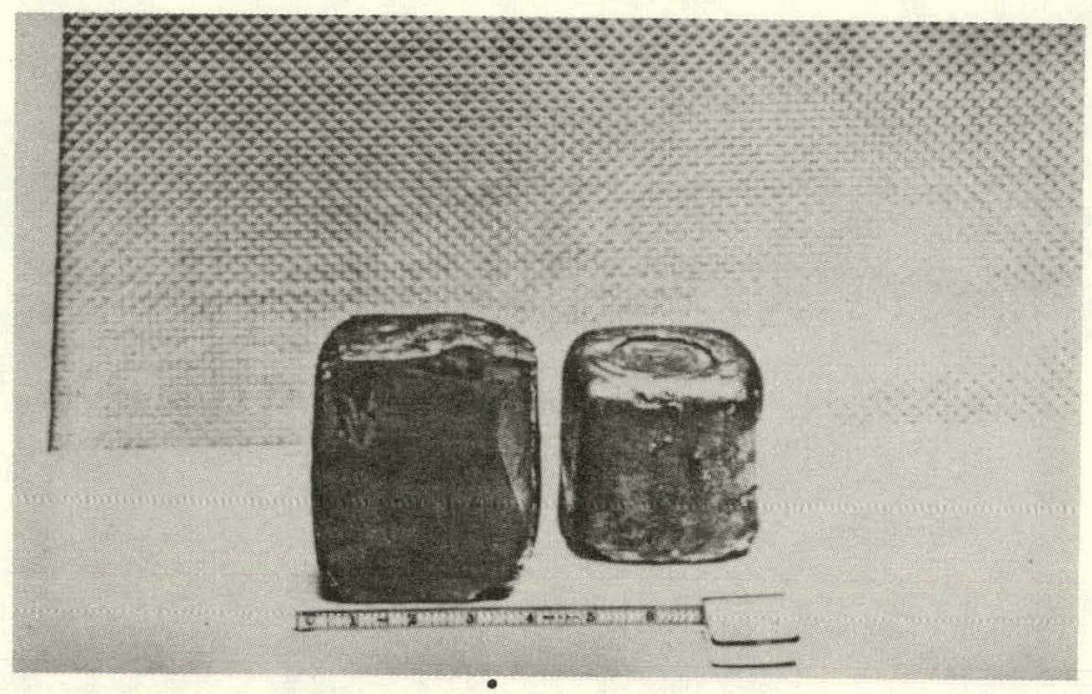

\section{HEM INGOT PROGRAM}

1978

$10 \times 10 \times 12.5 \mathrm{~cm}$

(3.0kg)

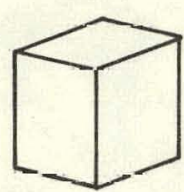

$20 \times 20 \times 20 \mathrm{~cm}$

(18.6kg)

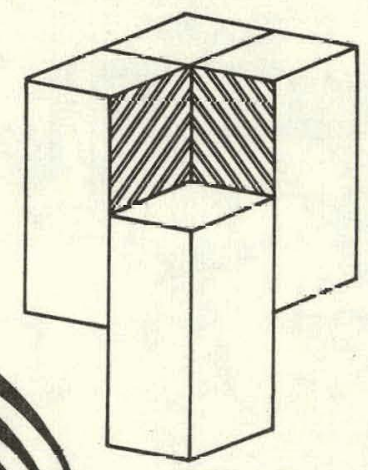

$4(10 \mathrm{~cm} \times 10 \mathrm{~cm} \times 20 \mathrm{~cm})$

$9(10 \mathrm{~cm} \times 10 \mathrm{~cm} \times 30 \mathrm{~cm})$
1986

$30 \times 30 \times 30 \mathrm{~cm}$

$(62.9 \mathrm{~kg})$

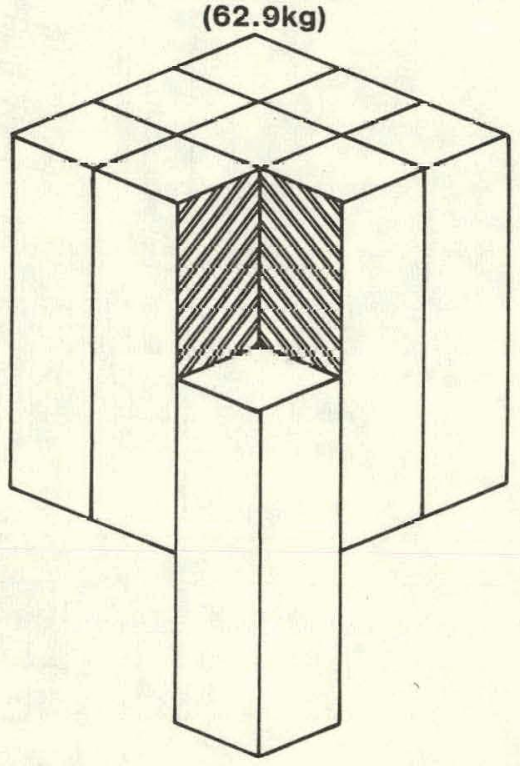

FAST Slicing 


\section{HEM CURRENT STATUS AND GOALS}

\begin{tabular}{lccc}
\hline & 1978 & 1979 & 1986 \\
\hline SIZE & $10 \times 10 \times 12.5 \mathrm{~cm}$ & $20 \times 20 \times 20 \mathrm{~cm}$ & $30 \times 30 \times 30 \mathrm{~cm}$ \\
CRYSTALLINITY,\% & 95 & 90 & 90 \\
GROWTH RATE, KG/HR & 1.2 & 1.0 & 2.5 \\
EFFICIENCY,\% & 15 & 12 & 15 \\
\hline
\end{tabular}

\section{SOLAR CELL PERFORMANCE OF 2 CM $\times 2$ CM CELLS}

HEM CAST SILICON (RUN 2-049-C)

\begin{tabular}{cccccc}
\hline \hline $\begin{array}{r}\text { Ce11 } \\
\text { No. }\end{array}$ & $\begin{array}{c}\text { AMO } \\
I_{\text {sc }} \\
(\mathrm{mA})\end{array}$ & $\begin{array}{c}\text { AMO } \\
\mathrm{v}_{\text {oc }} \\
(\mathrm{mV})\end{array}$ & $\begin{array}{c}\text { AMO } \\
n\end{array}$ & CFF & $\begin{array}{c}\text { AMI } \\
n\end{array}$ \\
\hline 1 & 148 & 583 & 12.2 & 0.77 & 14.2 \\
2 & 156 & 591 & 12.8 & 0.75 & 15.0 \\
3 & 156 & 587 & 11.6 & 0.69 & 13.5 \\
4 & 156 & 587 & 12.5 & 0.74 & 14.6 \\
5 & 157 & 591 & 12.4 & 0.72 & 14.5 \\
6 & 148 & 577 & 11.5 & 0.73 & 13.4 \\
7 & 149 & 583 & 12.0 & 0.75 & 14.0 \\
\hline
\end{tabular}




\section{SOLAR CELL DATA ON \\ 2 CM $\times 2$ CM HEM CAST SILICON}

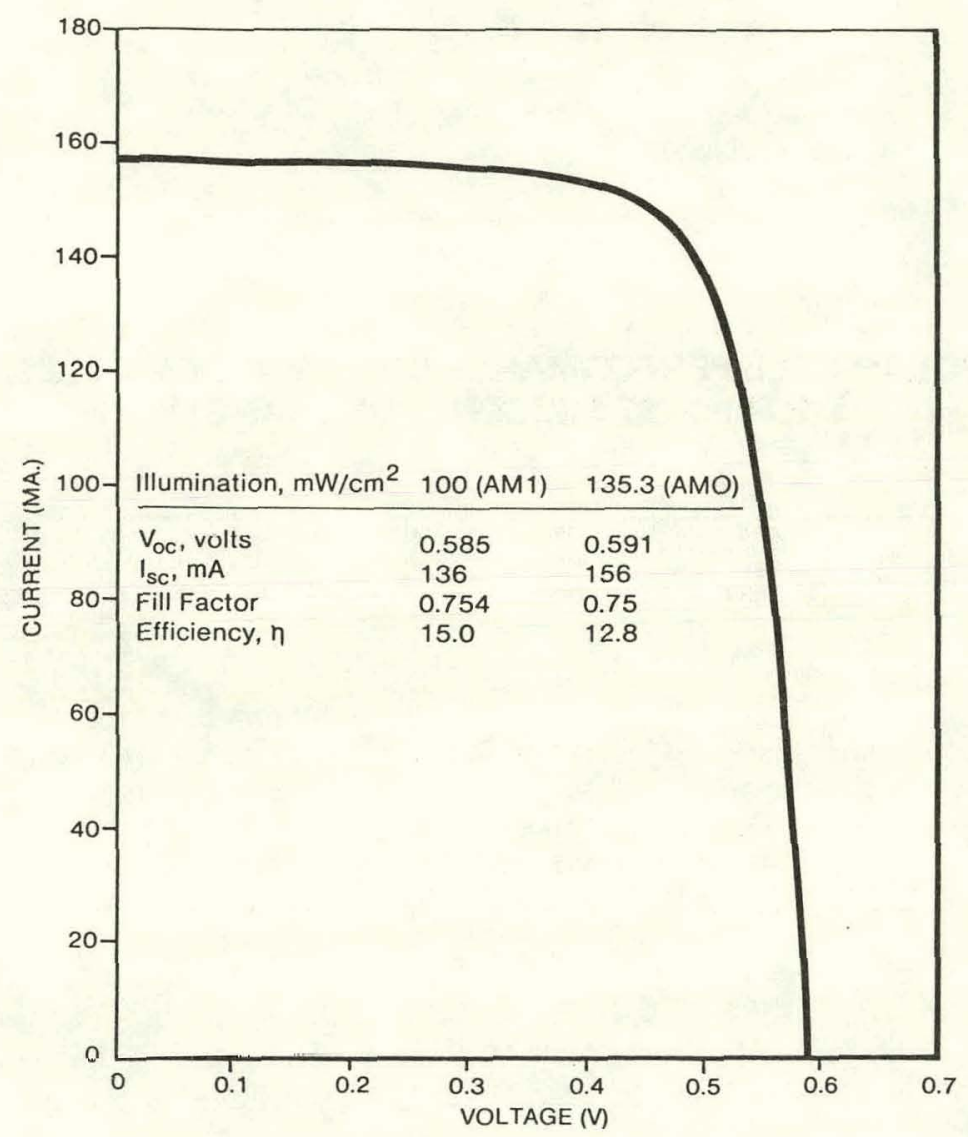

\section{HEAT EXCHANGER METHOD (HEM)}

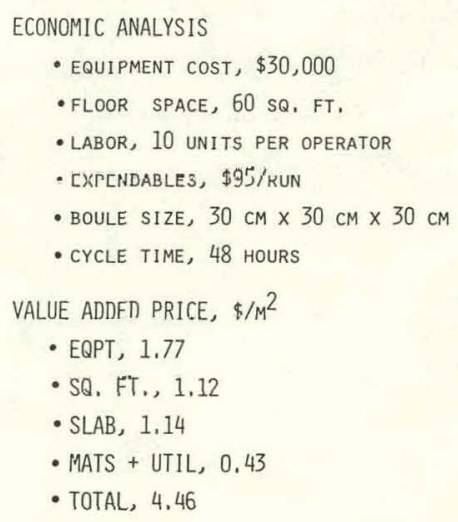




\section{EQUIPMENT DESIGN AND CONSTRUCTION}

\begin{tabular}{llr} 
GOALS & \multicolumn{2}{c}{ STATUS } \\
1. RECHARGEABLE CHAMBERS WITH VACUUM-TIGHT & 1. COMPLETE & $11 / 77$ \\
ISOLATION VALVE & & \\
2. POLY WE1GHT/RECHARGE SYSTEM & 2. COMPLETE & $6 / 78$ \\
3. POLY-ROD FEEDSTOCK RECHARGE DEVICE & 3. COMPLETE & $12 / 77$ \\
4. LUMP POLYSILICON RECHARGE DEVICE & 4. COMPLETE & $1 / 79$ \\
5. CRYSTAL/POLY TRANSFER EQUIPMENT & 5. COMPLETE & $3 / 78$ \\
6. DOPANT FIXTURE & 6. COMPLETE & $1 / 78$ \\
7. 35 KG HOT ZONE (14" DIA CRUCIBLE) & 7. COMPLETE & $11 / 79$ \\
8. MELT LEVEL CONTROL VIA WEIGHT & 8. INCOMPLETE
\end{tabular}

PROCESS DEVELOPMENT

GONLS

1. HOT-FILL METHOD WITH POLY ROD

2. HOT FILL WITH LUMP SILICON

3. 100 KILOGRAMS FROM ONE 12 -INCH CRUCIBLE

4. 100 MM DIAMETER OR GREATER

5. $10 \mathrm{cM} /$ HR GROWTH RATE

6. 35 KG HOT ZONE $(14-1$ NCH $)$

7. $14 \%$ EFFICIENCY AM-1

8. $1.2 \mathrm{KG} / \mathrm{HR}$ THROUGHPUT

\section{STATUS}

1. COMPLETE $2 / 78$

2. COMPLETE $1 / 79$

3. COMPLETE $2 / 79$

4. 130 MM ACHIEVED

5. $9.1 \mathrm{cM} / \mathrm{HR}$ ON CONTINUOUS RUNS

$10 \mathrm{CM} /$ HR FOR $2-3$ HOURS

6. 28 KG INGOT PRODUCED FROM HOT ZONE

7. $9,3-10.4 \%$ MM-O

$=13-14,6 \% \quad A M-1$

8. $1,2 \mathrm{KG} / \mathrm{HR}$

SAMPLES FROM RUN NO. 11 SELECTED FOR SOLAR CELL AND IMPURITY ANALYSES

\begin{tabular}{|clc|}
\hline $\begin{array}{c}\text { SAMPLE } \\
\text { NUMBER }\end{array}$ & \multicolumn{1}{c}{ DESCRIPTION } & $\begin{array}{c}\text { SOLAR CELL EFFICIENCY (z) } \\
\text { AT AM-0 }\end{array}$ \\
\hline 101 & $\begin{array}{l}\text { First Ingot, top section } \\
\text { All single crystal }\end{array}$ & 10.4 \\
103 & $\begin{array}{l}\text { Second Ingot, top section } \\
\text { All single crystal }\end{array}$ & 9.7 \\
105 & $\begin{array}{l}\text { Second Ingot, bottom section } \\
\text { All single crystal }\end{array}$ & $\begin{array}{l}\text { Third Ingot, top section } \\
\text { All single crystal }\end{array}$ \\
106 & $\begin{array}{l}\text { Fourth Ingot, top section } \\
\text { All single crystal }\end{array}$ & 10.1 \\
107 & $\begin{array}{l}\text { Fourth Ingot, bottom section } \\
\text { Dislocated material }\end{array}$ & 9.3 \\
\hline
\end{tabular}


SUMMARY OF RUN NO. 30
CRYSTAL INGOT DIAMETER
$13,3 \mathrm{~cm}$
AVERAGE GROWTH RATE
$8.7 \mathrm{cM} / \mathrm{HR}$
RUN TIME
79 HRS
THROUGHPUT
$1.2 \mathrm{KG} / \mathrm{HR}$
PULLED YIELD
$99 \%$
ZERO DISLOCATION
$27 \%$
TOTAL INGOT PULLED
$99.1 \mathrm{kc}$

\section{SAMICS ANALYSIS OF FOUR METHODS OF CONTINUOUS CZ}

\begin{tabular}{|l|l|l|l|l|}
\hline \multicolumn{1}{|c|}{ CONDITIONS } & $\mathrm{CZ} \# 1$ & $\mathrm{CZ} \# 2$ & $\mathrm{CZ} \# 3$ & $\mathrm{CZ} \# 4$ \\
\hline CRUCIBLE SIZE, DIA. $\times \mathrm{HT}$. (in) & $12 \times 9$ & $14 \times 10.5$ & $14 \times 11.5$ & $15 \times 12$ \\
\cline { 2 - 4 } CRYSTAL DIAMETER $(\mathrm{cm})$ & 10 & 12.5 & 15.2 & 17.8 \\
GROWTH RATE $(\mathrm{cm} / \mathrm{hr})$ & 10 & 10 & 10 & 11 \\
NO. CRYSTALS/CRUCIBLE & 5 & 4 & 4 & 5 \\
TOTAL POLY MELTED $(\mathrm{kq})$ & 105 & 144 & 170 & 260 \\
TOTAL INGOT PULLED $(\mathrm{kg})$ & 100 & 134 & 160 & 250 \\
PULLED YIELD $(\%)$ & 95 & 93 & 94 & 96 \\
USABLE AFTER GiHINUING $(\mathrm{kg})$ & 87 & 117 & 140 & 219 \\
USABLE INGOT YIELD $(\%)$ & 83 & 81 & 82 & 81 \\
TOTAL CYCLE TIME $(\mathrm{hr})$ & 75 & 73 & 75 & 80 \\
THROUGHPUT $(\mathrm{kg} / \mathrm{hr}),\left(\mathrm{m}^{2} / \mathrm{hr}\right)$ & 1.2 & 1.6 & 1.86 & 2.74 \\
ADD-ON COST, $1975 \$ / \mathrm{m}^{2}$ & 19.24 & 14.63 & 12.97 & 8.56 \\
\hline
\end{tabular}

\section{IPEG PRICE EQUATION INPUT DATA}

$\begin{array}{lcccc} & C 71 & C Z 2 & C Z 3 & \text { CZ 4 } \\ \text { EQUIPMENT COST (\$) } & 124,700 & 124,700 & 124,700 & 128,000 \\ \text { FLOOR SPACE (sO FT) } & 100 & 100 & 100 & 100 \\ \text { LABOR (\$) } & 13,353 & 13,353 & 13,353 & 13,373 \\ \text { MATERINLS (\$) } & 43,110 & 49,000 & 49,000 & 45,000 \\ \text { UTILITIES (\$) } & 10,848 & 10,848 & 10,848 & 13,350 \\ \text { OUANT (KG/YR) } & 8,602 & 11,932 & 13,423 & 20,357\end{array}$

(ALL COSTS IN 1975 \$) 


\section{EFFECT OF MULTIPLE USE OF CRUCIBLES ON CZ ADD-ON COST}

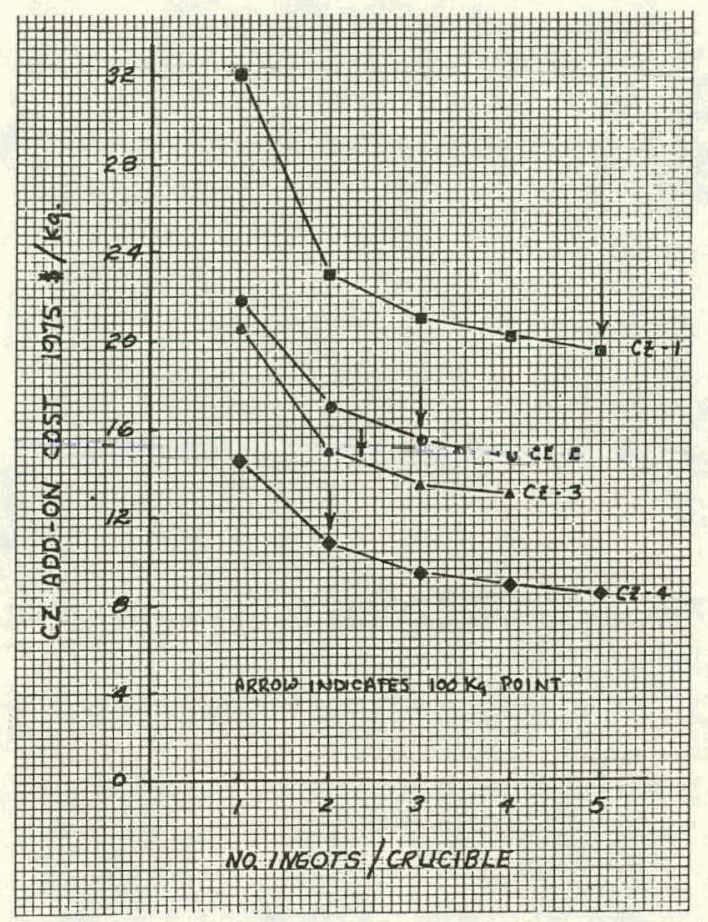

\section{RECHARGE AND INGOT GROWTH TIME (RUN 30)}

\begin{tabular}{|c|c|c|c|}
\hline MELT NO, & RECHARGE TIME (HR) & COMMENTS & $\begin{array}{l}\text { CRYSTAL GRONTH (3) } \\
\text { TIME (HR) }\end{array}$ \\
\hline 1 & $3.5^{(2)}$ & 6.5 KG LUMP HOT FILLED & 5.5 \\
\hline 2 & 4,0 & ROD MATERIAL, ONLY $12.1 \mathrm{KG}$ & 7.5 \\
\hline 3 & 3.0 & 5.0 KG LUMP PLUS $11.7 \mathrm{KG}$ ROD & 7.0 \\
\hline 4 & 3.4 & $5.0 \mathrm{KG}$ LUMP PLUS $11.0 \mathrm{KG}$ ROD & 7.0 \\
\hline 5 & 3,0 & 6.2 KG LUMP PLUS $10.4 \mathrm{KG}$ ROD & 6.5 \\
\hline 6 & $\frac{2.0}{18.9 \mathrm{HR}}$ & 15.8 KG LUMP & $\frac{3,1}{39.2 H R}$ \\
\hline
\end{tabular}

(1) RECHARGE TIME INCLUDES: REMOVAL OF GROWN CRYSTAL

INSERTION OF POLY

HOT FILL

MELT DOWN

SEED PREPARATION UP TO SEEDING THE MELT

(2) INCLUDES COLD FILL AND HOT FILL TIME ON FIRST MELT

(3) AT 125 MM DIAMETER 


\title{
CONCLUSIONS
}

1. 100 KG RUN HAS BEEN DEMONSTRATED,

2. SOLAR EFFICIENCY GOAL HAS BEEN MET WITH A FOUR-MELT RIN,

3. MAJOR COST REDUCTION IN FUTURE WILL BE AS A RESULT OF INCREASED THROUGHPUT.

4. FUTURE PROGRAMS WILL EMPHASIZE FASTER RECHARGING,

5. PRIMARY AREA OF CONCERN IS INGOT QUALITY AND ITS EFFECT ON SOLAR EFFICIENCY,

\section{SILTEC CORP (ADVANCED CZ.)}

\section{CONTINUOUS CZOCHRALSKI PROCESS}

\author{
- CURRENT CONTRACT GOALS
}

DESIGN, FABRICATE, AND DEVELOP EQUIPMENT AND PROCESSES TO DEMONSTRATE CONTINUOUS CZ GROWTH, DEFINED AS $100 \mathrm{KG}$ OF SINGLE SILICON CRYSTAL, $10 \mathrm{cM}$ IN DIAMETER GROWN FROM ONE CONIAIIIER.

$$
\text { - APPROACH TO ACHIEVE THOSE GOALS }
$$

DEVELOP A DUAL CHAMBER FURNACE WITH CONTINUOUS LIQUID REPLENISHMENT OF THE GROWTH CRIICIBLE, ACCOMPLISHED BY A MELT-DOWN AND MELT TRANSFER SYSTEM WITH ASSOCIATFD FFFMBACK. CONTROLS.

\section{- PRESENT STATUS RELATIVE TO GOALS}

FURNACE WAS DESIGNED AND TABRICATED; SEVERAL $100 \mathrm{Kg}$ THROUGHPUT RUNS WERE ATTFMPTFT. TO DATE THE BESI EHHORT WAS 71 KG THROJGHPUT IN ONE CONTINUOUS RUN.

- ECONOMICS OF SYSTEM AT PRESENT STATE

CRYSTAL ADD-ON COST $\$ 21.30 / \mathrm{m}^{2}$ IN 1975 DOLLARS

KEY ASSUMPTIONS

25 SLICES/CM 100 MM DIAMETER CRYSTALS 1 In MM/HOUR GROWTH VELOCITY

BATCH RECHARGING 


\section{CONTINUOUS CZOCHRALSKI PROCESS}

ACHIEVABLE ECONOMIC GOAL FOR 1986

|CRYSTAL ADD-ON COST $\$ 9.92 / \mathrm{M}^{2}$ IN 1975 DOLLARS

KEY ASSUMPTIONS

$\begin{array}{ll}\text { FURNACE RUNSIZE } & 150 \mathrm{KG} \\ \text { CRI'3TAL DIAMLTCR } & 150 \mathrm{mM} \\ \text { CRYSTAL GROWTH VELOCITY } & 100 \mathrm{mM} / \mathrm{HR}, \\ \text { INGOTS PER RUN } & 3 \\ \text { CRYSTAL YIELD } & 85 \% \\ \text { RUN CYCLE TIME } & 52 \mathrm{HOURS} \\ \text { PULLERS PER OPERATOR } & 3 \\ \text { DIRECT LABOR COST } & \$ 6.20 / \mathrm{HR}, \\ \text { OPERATING SUPPLIES COST } & \$ 567.00 / \text { RUN } \\ \text { EQUIPMENT COST } & \$ 140,000 \\ \text { EQUIPMENT FLOOR SPACE } & 150 \mathrm{SQ}, \mathrm{FT}, \\ \text { EQUIPMENT UTILIZATION } & 90 \% \\ \text { ENERGY RERUIREMENTS } & 3552 \mathrm{KWH} / \mathrm{RUN} \\ \text { ENERGY COST } & \$ 0.04 / \mathrm{KWH} \\ \text { SILICON/SLICE CONVERSION } & 25 \mathrm{SLICES/CM}\end{array}$

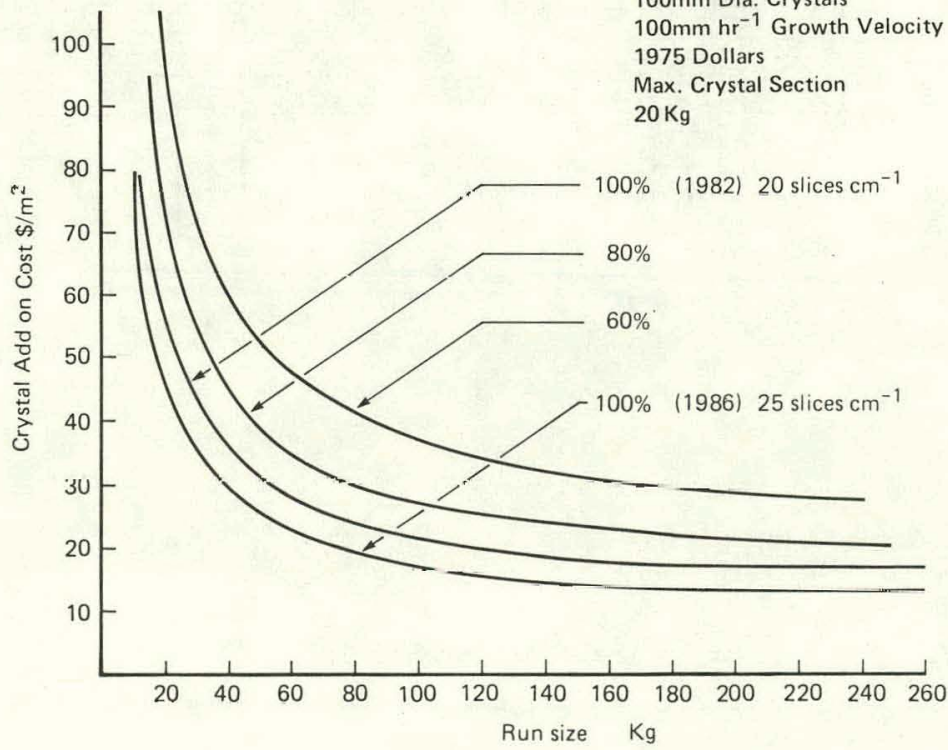

Effect of run size on continuous Czochralski Add-on cost 


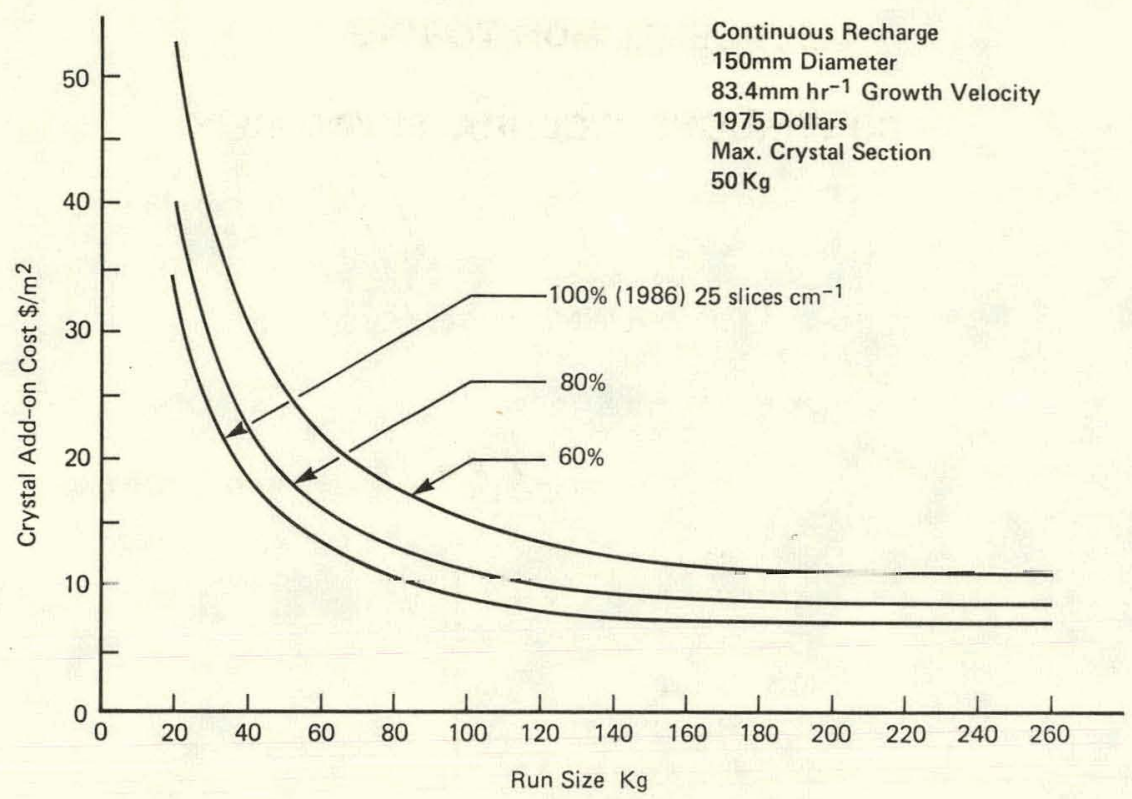

Effect of run size on continuous Czochralski Add-on cost

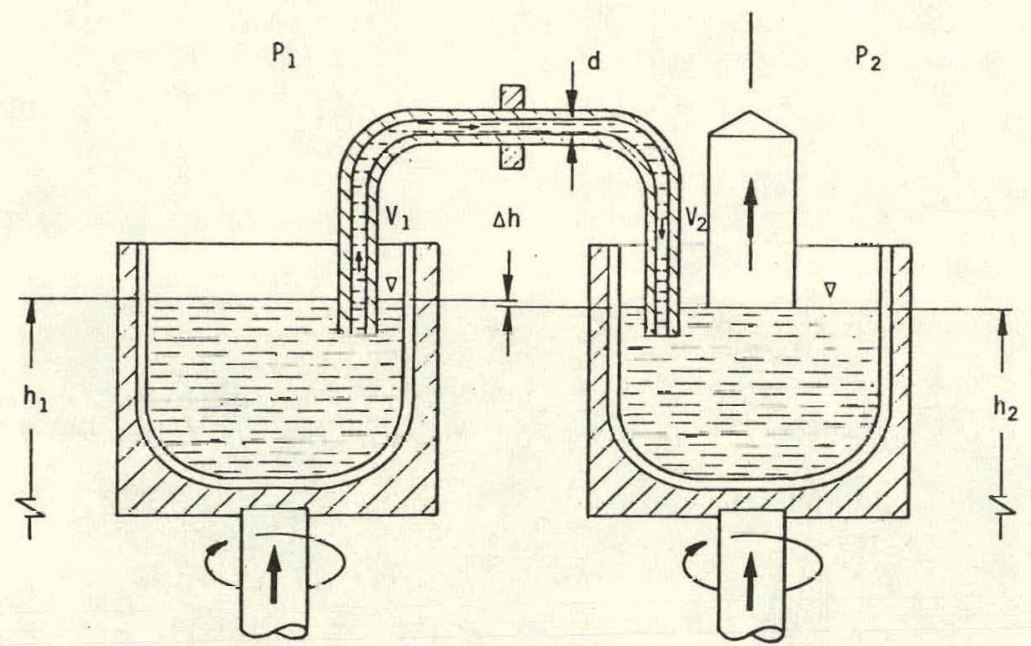

(1) $\frac{V_{1}{ }^{2}}{2 g}+\frac{P_{1}}{\gamma}+h_{1}=\frac{V_{2}{ }^{2}}{2 g}+\frac{P_{2}}{\gamma}+h_{2}+5 \frac{V^{2}}{2 g}$

$$
V_{1}=V_{2} \quad P_{1}=P_{2} \text { for CLI }
$$

(2) Iff $\frac{Q}{d} \leqq 5.6 \times 10^{-4} \frac{\mathrm{m}^{2}}{\mathrm{~s}} \Rightarrow \Delta \mathrm{h}=\frac{128 \mathrm{~L}, \mathrm{v} \cdot 0}{\mathrm{~d}^{4} \mathrm{~g} \cdot \pi}$

$\begin{array}{lll}\Delta h & \text { head differential } & \{\mathrm{m}\} \\ L & \text { tube length } & \{\mathrm{m}\} \\ \nu & \text { kinematic viscosity } & \left\{\frac{\mathrm{m} 2}{\mathrm{~s}}\right\} \\ Q & \text { replenishment rate } & \left.i \frac{\mathrm{m} 3}{\mathrm{~s}}\right\} \\ \text { d } & \text { I.D. of transfer tube } & \{\mathrm{m}\}\end{array}$




\section{MELT-LEVEL MONITORING}
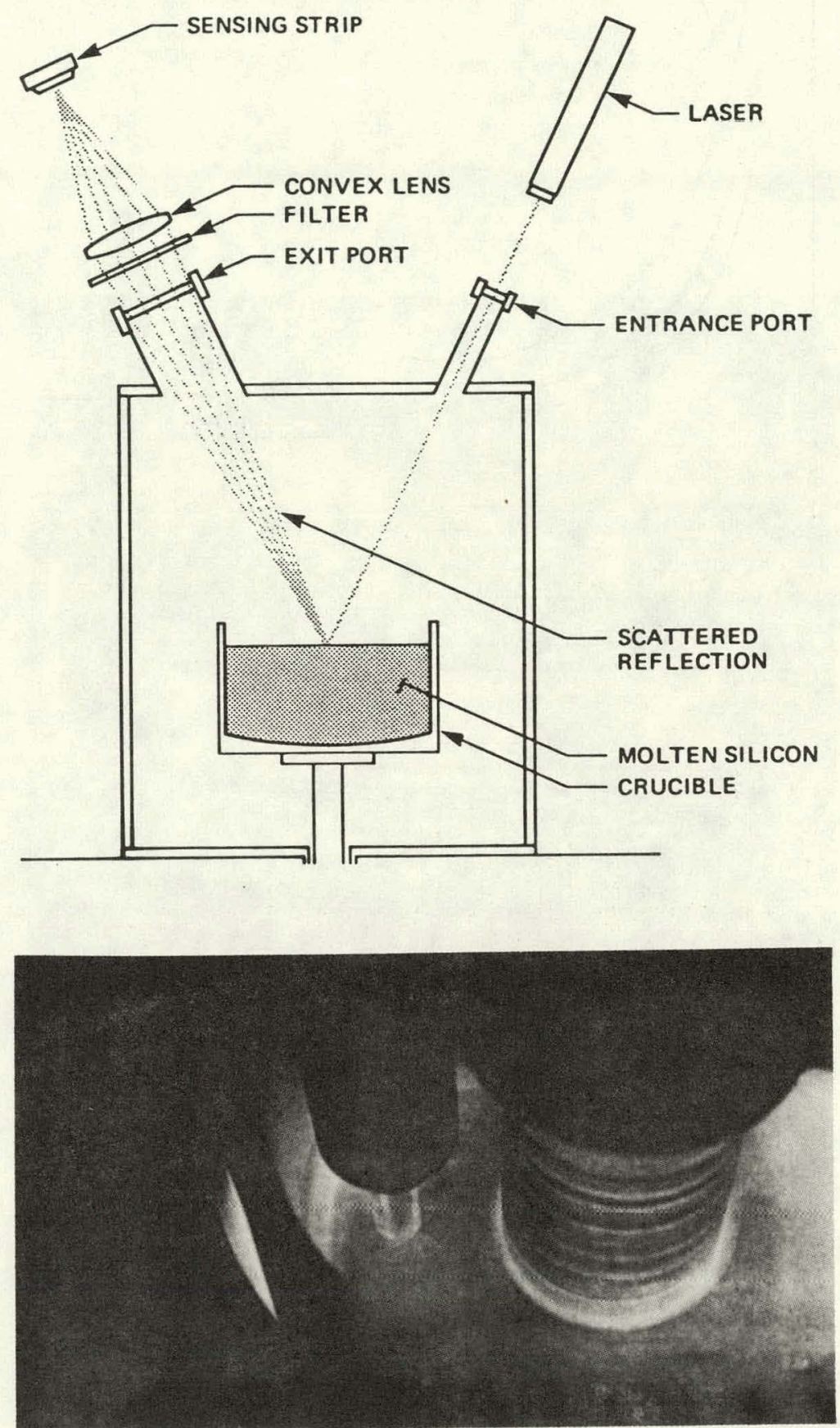

CRYSTAL SYSTEMS, INC, (FAST)

\section{ESSENTIAL REQUIREMENTS FOR SLICING}

1. LOW-COST PROCESS

2. HIGH MATERIAL UTILIZATION

3. LOW EXPENDABLE MATERIAL COSTS 
FIXED ABRASIVE SLICING TECHNIQUE (FAST)

ACHIEVEMENTS:

- 64 wafers per inch, 25 wafers per cm

- Conversion ratio: $1.08 \mathrm{~m}^{2} / \mathrm{kg}$

- Slice + Kerf: 15.6 mils, 0.40 mm

- Low kerf: E.2 mils, 0.16 mM

- Thin wafers: 4 mils, 0.10 mM

- Low surface damage: 3-5 um

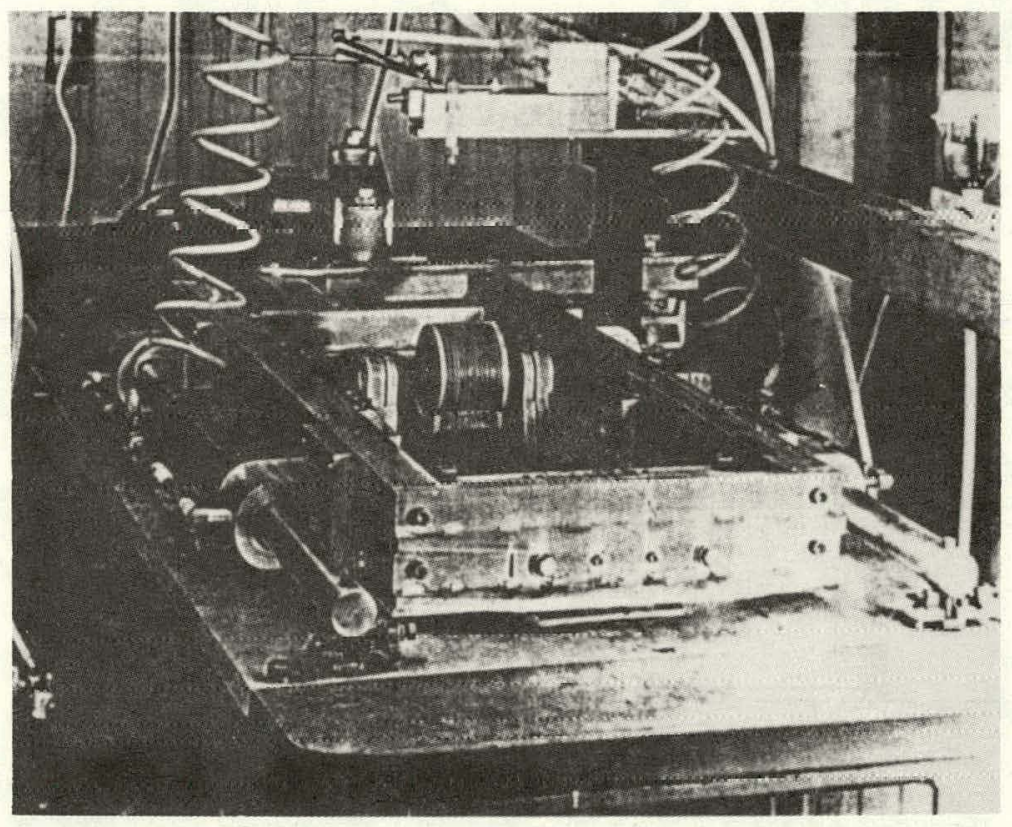

FAST CURRENT STATUS AND GOALS

\begin{tabular}{lccc}
\hline & 1978 & 1979 & 1986 \\
\hline WAFER SIZE & 10CM DIAMETER & $10 \times 10 \mathrm{cM}$ & $10 \times 10 \mathrm{cM}$ \\
NO. OF SLICES & 120 & 300 & 750 \\
SLICING RATE, MM/MIN. & 0.06 & 0.1 & 0.1 \\
YIELD,\% & 97 & 95 & 95 \\
WAFERS/CM & 20 & 25 & 25 \\
CONVERSION RATIO, M $/$ KG & 0.86 & 1 & 1 \\
\hline
\end{tabular}


FIXED ABRASIVE SLICING TECHNIQUE (FAST)

ECONOMIC ANALYSIS

- Equipment costs, $\$ 25,000$

- Floor space, 80 sq. ft.

- Labor, 10 units per operator

- 25 WAFERs/CM

- $30 \times 10 \times 10 \mathrm{~cm}^{3}$ WORKPIECE

- YIELD, $95 \%$

VALUE ADDED PRICE, $\$ / M^{2}$

- EQPT, 1.32

- SQFT, 0.52

- SLAB, 0.76

- MATS + UTIL, 2.04

- TOTAL, 4.63

VARIAN ASSOCIATES (MBS)

\section{MULTIBLADE SLURRY SLICING OF SILICON}

\begin{tabular}{|c|c|c|c|}
\hline YEAR & $\begin{array}{l}\operatorname{COST} \text { GOAL } \\
\left(\$ / M^{2}\right)^{*}\end{array}$ & KEY ASSUMPTIONS ** & $\begin{array}{l}\text { PROJECTED COST } \\
\left(\$ / \mathrm{M}^{2}\right)\end{array}$ \\
\hline 1979 & 130.5 & NONE & 81.8 \\
\hline 1980 & 122.5 & $\begin{array}{l}\text { IN-PLANT BLADE PACKS *** } \\
0.30 \mathrm{~m}^{2} / \mathrm{KG} * * * \\
\text { LOWER COST SLURRY } \\
\text { VEHICLE }(\$ 0.31 / \mathrm{KG} / \text { RUN })\end{array}$ & 49.8 \\
\hline 1982 & 64 & $\begin{array}{l}\text { LARGE CAPACITY SAW (1000 } \\
\text { SLICES/RUN) } \\
0.89 \mathrm{M}^{2} / \mathrm{KG} \\
\text { PARTIAL ( } 35 \%) \text { ABRASIVE } \\
\text { RECLAMATION }\end{array}$ & 30.1 \\
\hline 1984 & 19 & $\begin{array}{l}\text { LOW-COST BLADES }(\$ 4,25 / \mathrm{KG}) \\
1.0 \mathrm{~m}^{2} / \mathrm{KG} \\
\text { LOWEST COST SLURRY } \\
\text { VEHICLE }(0.09 / \text { L/RUN }) \\
\text { EXTENDED ABRASIVE } \\
\text { RECLAMAIIUN (GS\%) }\end{array}$ & 19.3 \\
\hline 1985 & 9.1 & $\begin{array}{l}0.5 \text { WAFER/MIN } \\
15 \mathrm{cM} \text { DIAMETER }\end{array}$ & 8.53 \\
\hline $\begin{array}{l}* \\
* * \\
* * *\end{array}$ & $\begin{array}{l}1 / 2 \text { OF INGOT AND } \\
\text { NOTE ASSUMPTIONS } \\
\text { ROUTINE WITH CURR }\end{array}$ & $\begin{array}{l}\text { SLICING ADD-ON } \\
\text { ACCUMULATE FROM YEAR TO YEAR } \\
\text { RENT TECHNOLOGY }\end{array}$ & \\
\hline
\end{tabular}




\section{MULTIBLADE SLURRY SLICING OF SILICON}

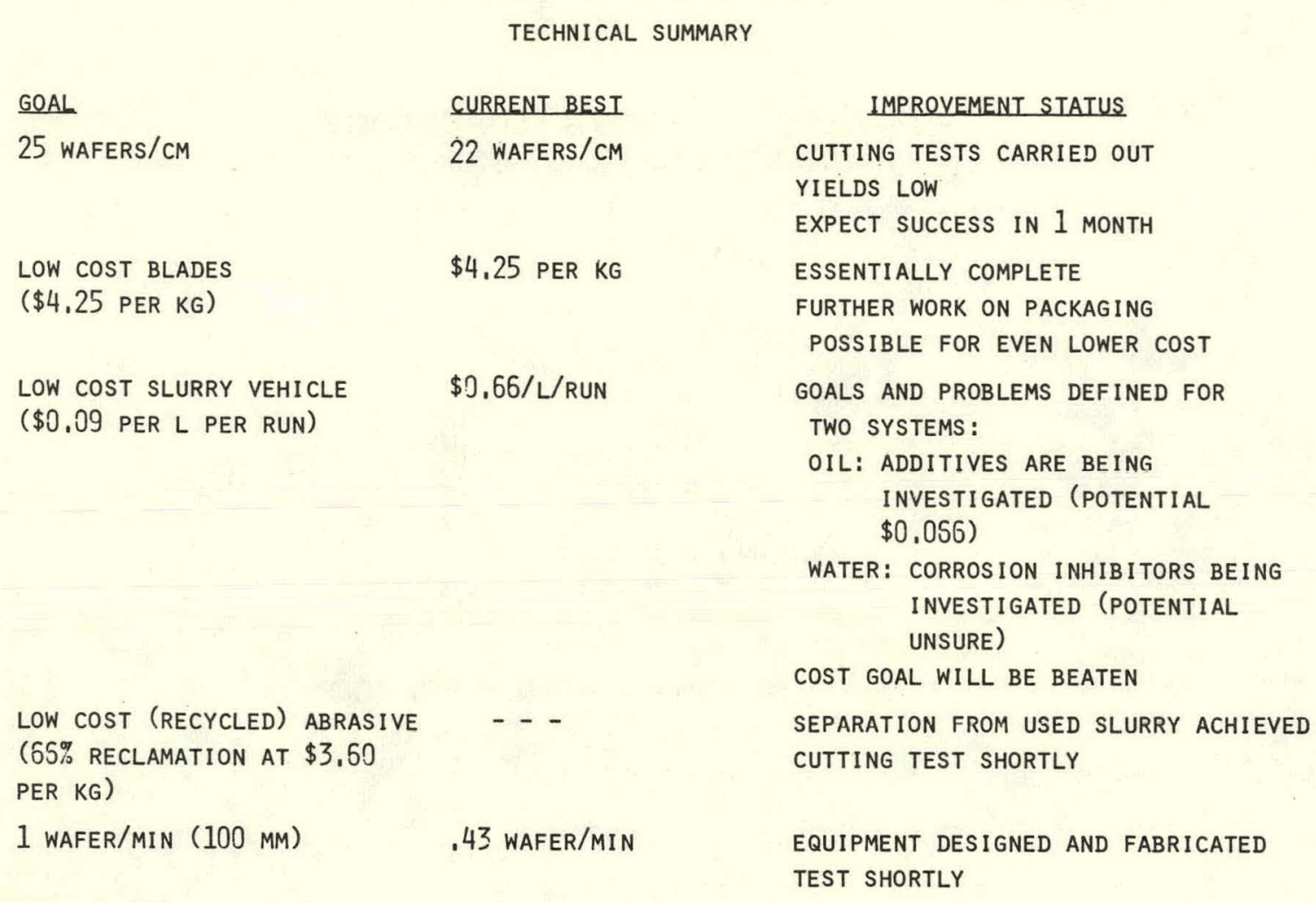


SILTEC CORP.

(ADVANCED ID SLICING)

\section{ENHANCED I.D. SLICING TECHNOLOGY CURRENT CONTRACT GOALS}

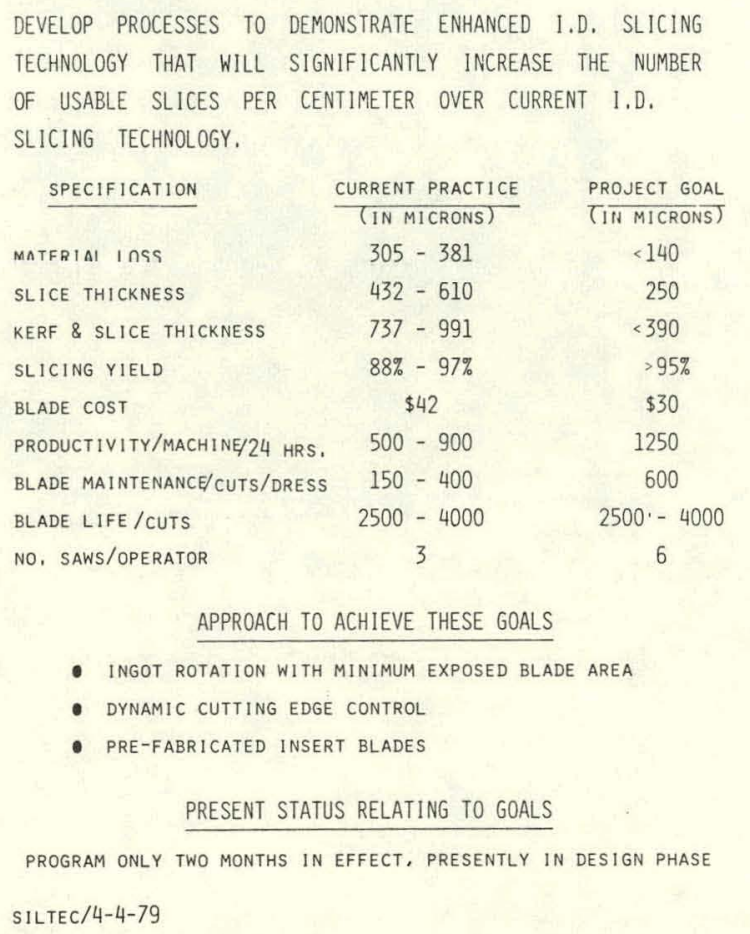

\begin{tabular}{cc}
$\frac{\text { CURRENT PRACTICE }}{\text { (IN MICRONS) }}$ & PROJECT GOAL \\
\hline $305-381$ & (IN MICRONS) \\
$432-610$ & $<140$ \\
$737-991$ & 250 \\
$88 \%-97 \%$ & $<390$ \\
$\$ 42$ & $>95 \%$ \\
& $\$ 30$ \\
$500-900$ & 1250 \\
S. & 600 \\
$2500-4000$ & $2500-4000$ \\
3 & 6
\end{tabular}

APPROACH TO ACHIEVE THESE GOALS

- ingot rotation with minimum exposed blade area

- dynamic cutting edge control

- pre-fabricated insert blades

PRESENT STATUS RELATING TO GOALS

PROGRAM ONLY TWO MONTHS IN EFFECT, PRESENTLY IN DESIGN PHASE

SILTEC/4-4-79

\section{ENHANCED I.D. SLICING TECHNOLOGY}

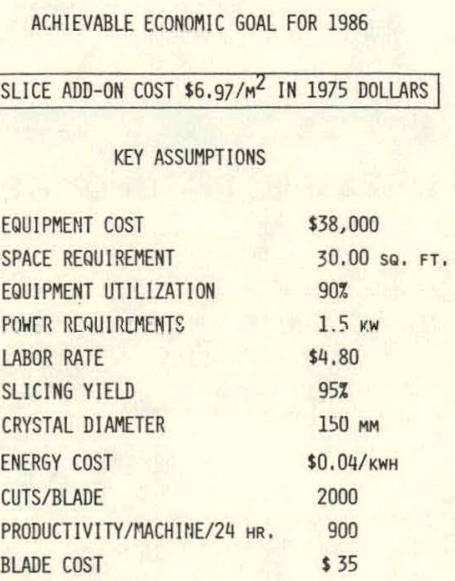




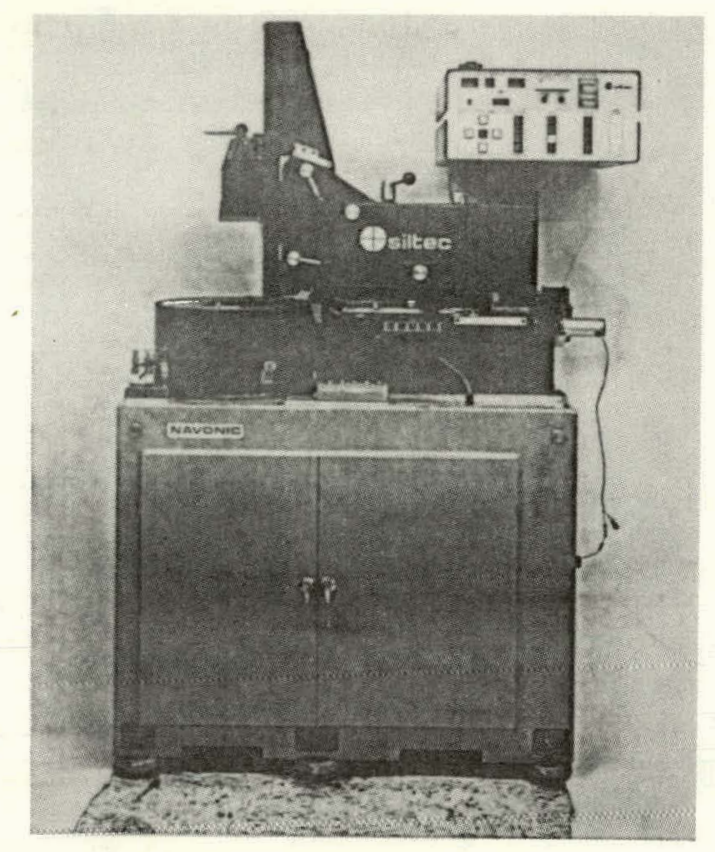

\section{BLADE HEAD CONFIGURATION}

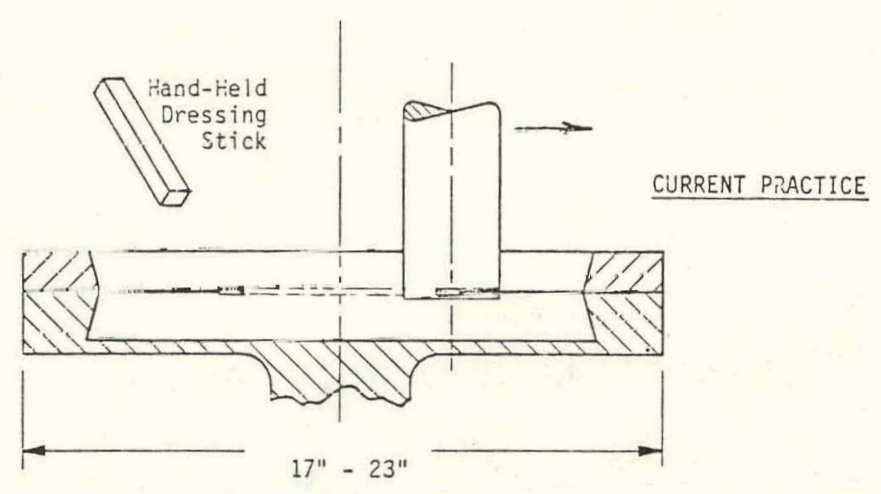

\section{BLADE DRESSING PROCEDURE (SIDES)}

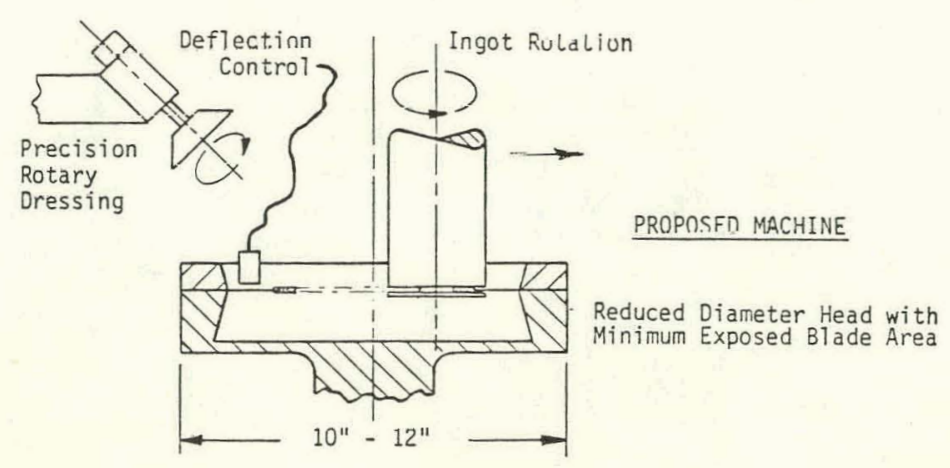




\section{BLADE DRESSING PROCEDURE (SIDES)}

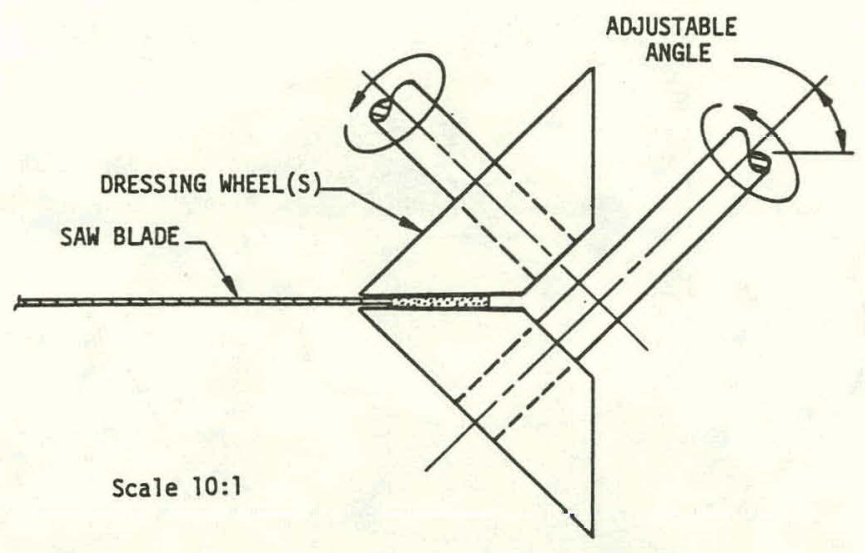

\section{CLOSED LOOP BLADE POSITION CONTROL SYSTEM}

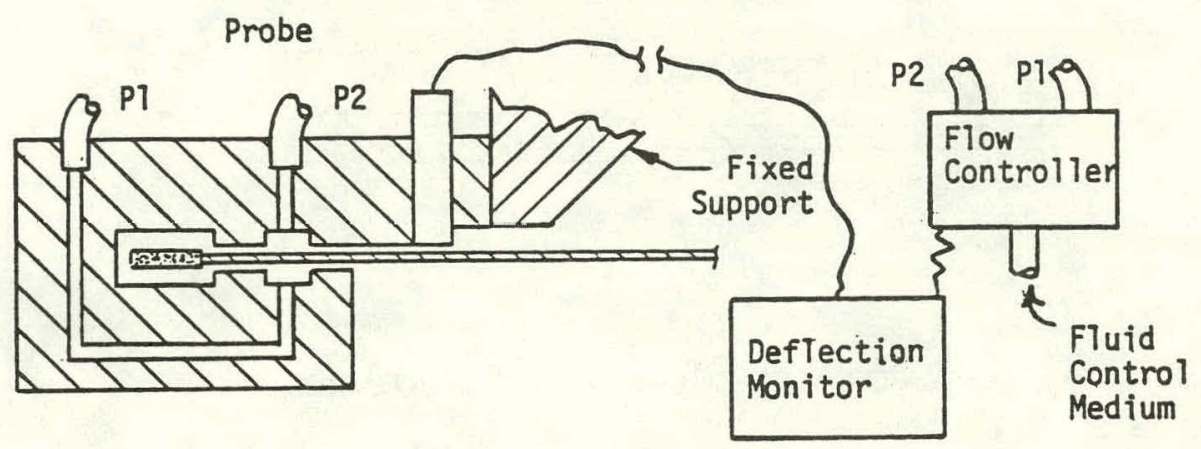

CONVENTIONAL ID BLADES

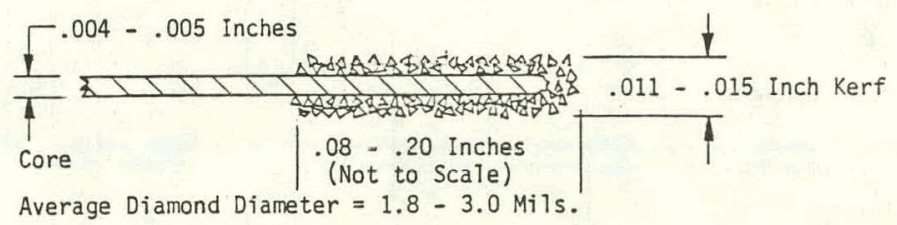




\section{PERSPECTIVE VIEW: PREFABRICATED INSERT BLADE}

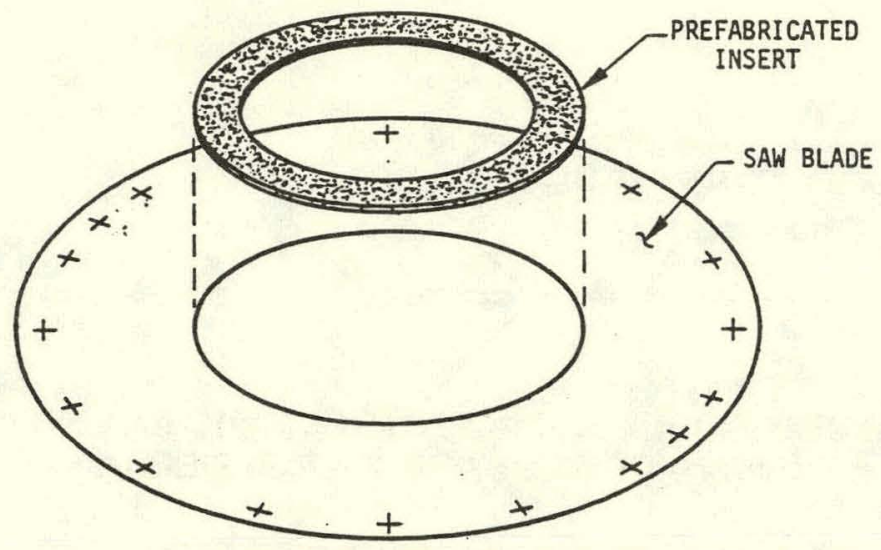

BLADE CROSS-SECTION AFTER BONDING

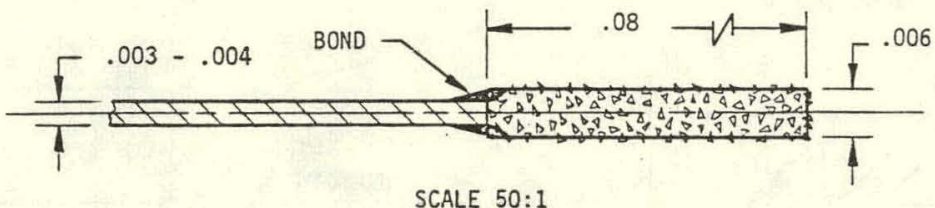

BATTELLE'S COOLUMBUS LABORATORIES

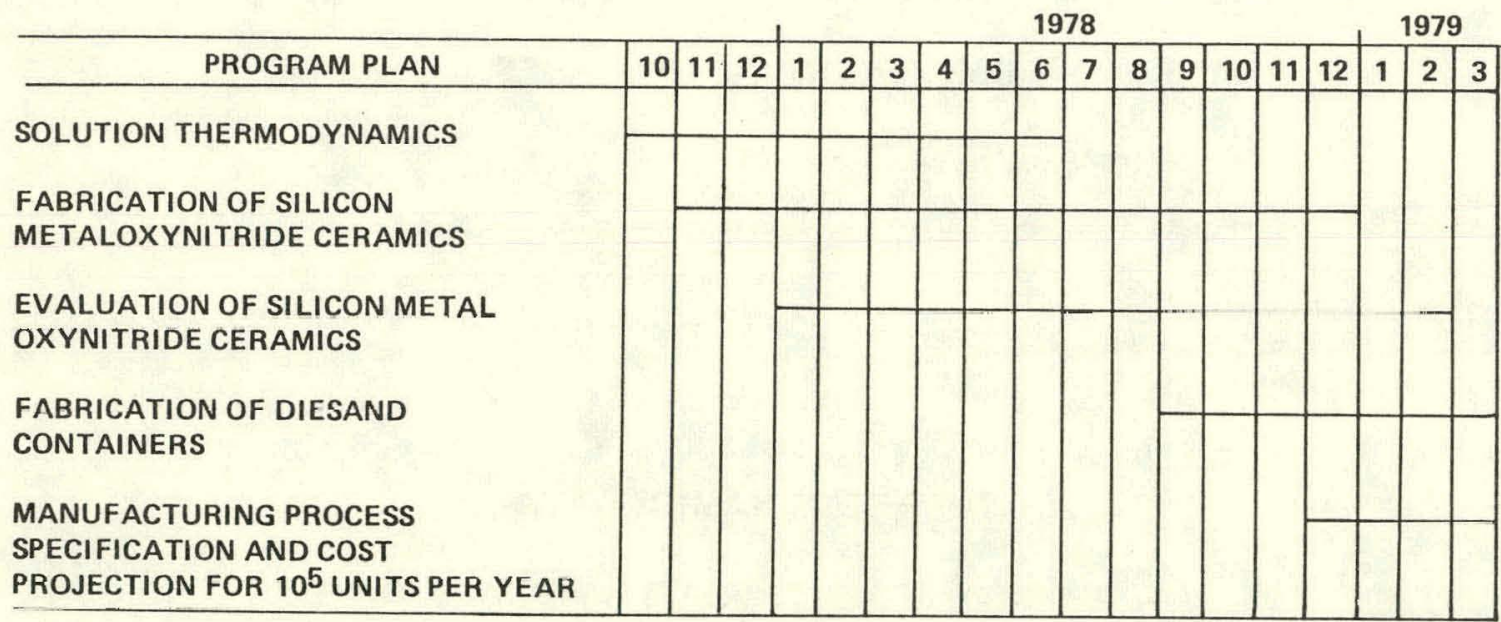




\section{SUMMARY OF ACCOMPLISHMENTS}
(1) DEVELOPMENT OF WELL CONTROLLED PROCESSING SCHEDULES FOR FABRICATING HIGH QUALITY MATERIALS
(2) DEVELOPMENT OF PROMISING MATERIALS
(3) FABRICAIION OF SHAPING DIE
(4) THERMODYNAMICS DATA

\section{SPARK SOURCE MASS SPECTROSCOPIC ANALYSIS (PPMW) OF $\mathrm{Si}_{3} \mathrm{~N}_{4}$ AND $X=0.35$ SIBEON}

\begin{tabular}{|c|c|c|}
\hline Element & $\begin{array}{l}\mathrm{SN} 502 \\
\mathrm{Si}_{3} \mathrm{~N}_{4}\end{array}$ & $\begin{array}{r}\text { Hot Pressed } \\
X=0.35 \text { Sibeon }\end{array}$ \\
\hline $\mathrm{Li}$ & 0.1 & 0.005 \\
\hline $\mathrm{Be}$ & 0.003 & High \\
\hline B & 0.2 & 0.2 \\
\hline $\mathrm{F}$ & 0.1 & 0.5 \\
\hline $\mathrm{Na}$ & 5 & 3 \\
\hline $\mathrm{Mg}$ & 5 & 10 \\
\hline $\mathrm{Al}$ & 60 & 100 \\
\hline Si & Major & Major \\
\hline$P$ & 0.2 & 0.5 \\
\hline S & 0.6 & 1 \\
\hline $\mathrm{Cl}$ & 500 & 7 \\
\hline K & 0.6 & 1 \\
\hline $\mathrm{Ca}$ & 12 & 3 \\
\hline Sc & 0.3 & 0.2 \\
\hline $\mathrm{Ti}$ & 7 & 1 \\
\hline V & 0.2 & 0.3 \\
\hline $\mathrm{Cr}$ & 10 & 1 \\
\hline $\mathrm{Mr}$ & 0.2 & 0.1 \\
\hline $\mathrm{Fe}$ & 10 & 5 \\
\hline Co & 0.4 & 0.3 \\
\hline $\mathrm{Ni}$ & 0.2 & 1 \\
\hline $\mathrm{Cu}$ & 0.7 & 5 \\
\hline $\mathrm{Zn}$ & 0.5 & 0.1 \\
\hline $\mathrm{Ga}$ & 0.4 & 0.5 \\
\hline $\mathrm{Ge}$ & 0.1 & 0.3 \\
\hline As & 0.02 & 0.03 \\
\hline $\mathrm{Se}$ & 2 & 0.5 \\
\hline $\mathrm{Br}$ & 0.2 & 0.1 \\
\hline$R b$ & 0.2 & 0.3 \\
\hline Sr & 0.3 & 0.1 \\
\hline Y & 3 & 1 \\
\hline $\mathrm{Zr}$ & 60 & 10 \\
\hline $\mathrm{Nb}$ & 0.2 & 0.05 \\
\hline Mo & 400 & 30 \\
\hline
\end{tabular}

\section{THERMODYNAMICS DATA}

(1) DEVELOPMENT OF WELL CONTROLLED PROCESSING SCHEDULES FOR FABRICATING HIGH QUALITY MATERIALS

(2) DEVELOPMENT OF PROMISING MATERIALS

(3) FABRICATION OF SHAPING DIE

(4) THERMODYNAMICS DATA 


\section{MATERIALS PERFORMANCE}

(1) SIALON AND SIBEON MORE RESISTANT TO MOLTEN SiliCON ATTACK THAN ANY OTHER METAL CATION CONTAINING MATERIALS

(2) Sibeon MORE Stable than Sialon

(3) LOW WETTING ANGLES

\section{ORIGINAL ONE-PIECE DIE DESIGN SUPPLIED BY JPL}

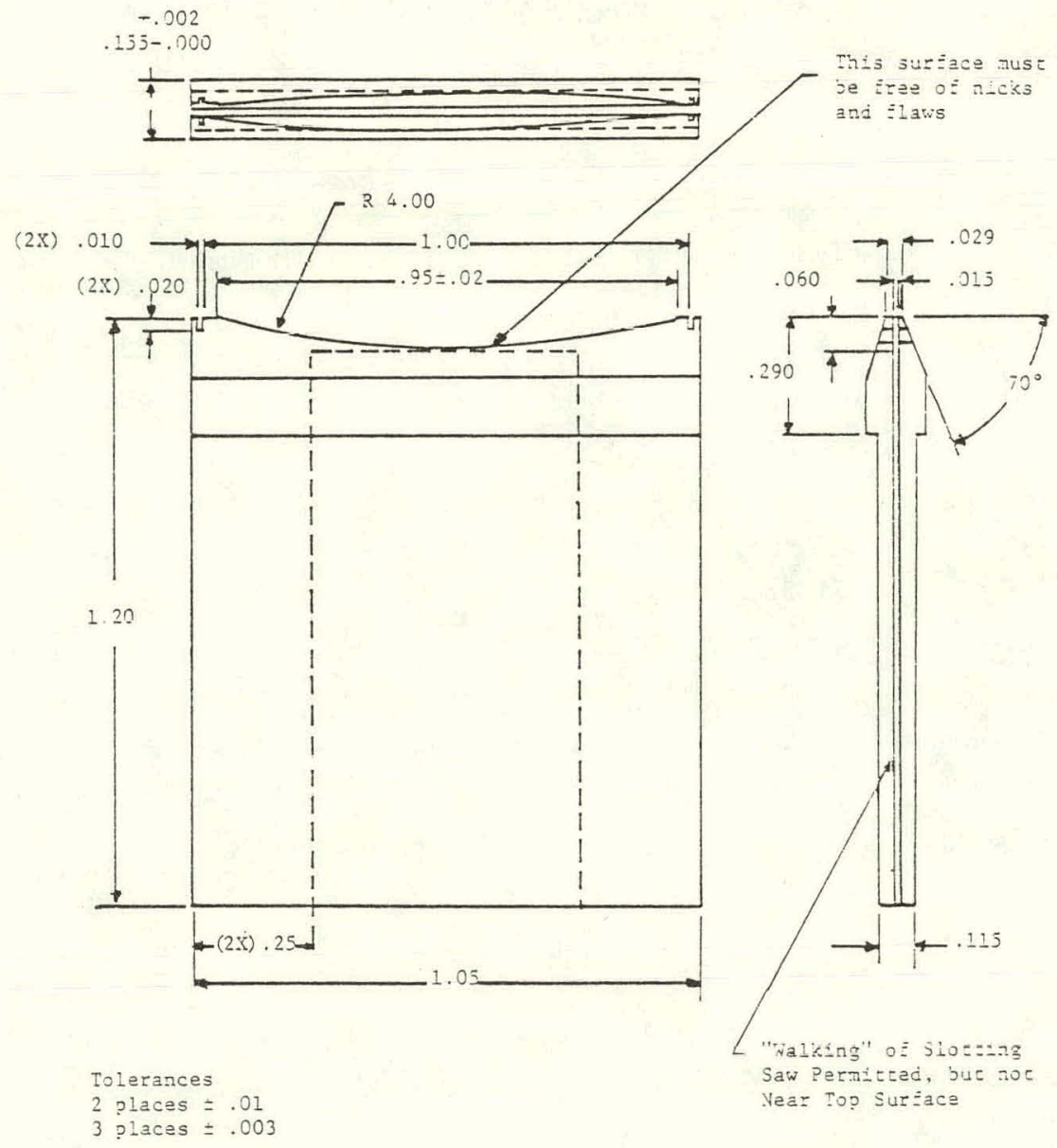




\section{INTRODUCTION}

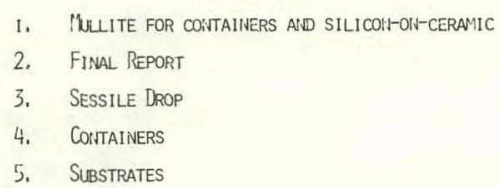

\section{SESSILC DIOP}

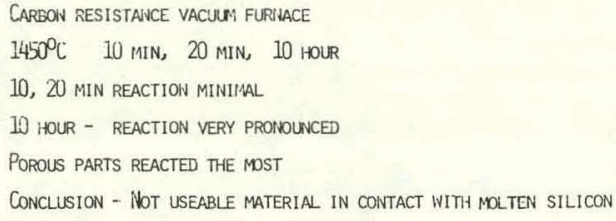

\section{SUBSTRATES}

1. Manufacture
A. DRY PRESS
B. ROLL COMPACTION
C. SLOTted SUBSTRATES - SANING
D. SLOTTED SUBSTRATES - PUIFCHING
E. $1.75 \times 3 \times .040$ INCHES, $2 \times 20 \times .040$ INCHES, $4 \times 40 \times .040$ INCHES

2. THERMAL EXPANSION
A. DECREASE $\mathrm{Al}_{2} \mathrm{O}_{3} / \mathrm{SiO}_{2}$ RATIO DECREASES THERMAL EXPA'ISION
B. "K" MODIFICATION MATCHES SILICUN THLRMAL EXPANSION
C. " $K$ " MODIFICATION CAN BE MADE IN ALL SHAPES 
TABLE II

\begin{tabular}{|c|c|c|c|c|c|c|c|c|c|c|c|}
\hline \multirow[t]{2}{*}{$\underline{\text { TASK }}$} & \multirow[t]{2}{*}{ BODY } & \multicolumn{2}{|c|}{1} & \multicolumn{7}{|c|}{ APPROXIMATE \% OXIDE COMPOSITION } & \multirow{2}{*}{ Th. Ex. $800^{\circ} \mathrm{C}$} \\
\hline & & $\overline{\mathrm{A}}] \mathrm{2}_{3}$ & $\mathrm{SiO}_{2}$ & $\mathrm{Fe}_{2} \mathrm{O}_{3}$ & $\mathrm{CaO}$ & MgO & $\mathrm{K}_{2} \mathrm{O}$ & $\mathrm{Na}_{2} \mathrm{O}$ & $\mathrm{TiO}_{2}$ & $\mathrm{SiO}_{2}^{\mathrm{A}_{3}}$ & \\
\hline A & $\begin{array}{l}\text { Std S-1-SI } \\
\text { Coors Compositi }\end{array}$ & $\begin{array}{l}5 \% .6 \\
\text { on }\end{array}$ & 38.9 & 0.62 & 0.13 & 0.25 & 0.92 & 0.25 & 1.12 & 1.48 & 0.375 \\
\hline \multirow[t]{4}{*}{ C } & $\begin{array}{l}996 \text { HPM } \\
\text { High Silica }\end{array}$ & 52.2 & 44.7 & 0.56 & 0.13 & 0.22 & 0.83 & 0.22 & 1.01 & 1.17 & 0.35 \\
\hline & $\begin{array}{l}117 \mathrm{HPM} \\
\mathrm{S}-1-\mathrm{SI}+10 \% \mathrm{Si}\end{array}$ & 52.3 & 44.7 & 0.56 & 0.14 & 0.23 & 0.83 & 0.22 & 1.02 & 1.17 & 0.37 \\
\hline & $\begin{array}{l}118 \mathrm{HPM} \\
\mathrm{S}-1-\mathrm{SI}+12.5 \%\end{array}$ & $\mathrm{SiO}_{2}^{51.1}$ & 46.0 & 0.55 & 0.14 & 0.22 & 0.81 & 0.22 & 0.99 & 1.11 & 0.36 \\
\hline & $\begin{array}{l}119 \mathrm{HPM} \\
\mathrm{S}-1-\mathrm{SI}+15 \% \mathrm{Si}\end{array}$ & 149.9 & 47.2 & 0.54 & 0.14 & 0.22 & 0.80 & 0.21 & 0.97 & 1.07 & 0.38 \\
\hline \multirow[t]{2}{*}{$\begin{array}{l}\mathrm{s} t \\
\mathrm{~J}\end{array}$} & $\begin{array}{l}120 \mathrm{HPM} \\
\mathrm{S}-1-\mathrm{SI}+17.5 \%\end{array}$ & $\begin{array}{l}48.8 \\
\mathrm{SiO}_{2}\end{array}$ & 48.3 & 0.53 & 0.14 & 0.21 & 0.78 & 0.21 & 0.85 & 1.01 & 0.37 \\
\hline & $\begin{array}{l}121 \mathrm{HPM} \\
\mathrm{S}-1-\mathrm{SI}+20 \% \mathrm{Si}\end{array}$ & 147.8 & 49.4 & 0.52 & 0.14 & 0.21 & 0.76 & 0.20 & 0.93 & 0.97 & 0.33 \\
\hline $\begin{array}{l}1 \mathrm{st} \\
\mathrm{K}\end{array}$ & $\begin{array}{l}134 \mathrm{HPM} \\
5-1-\mathrm{SI}+27.2 \% \\
\end{array}$ & $\begin{aligned} 45.0 \\
\mathrm{SiO}_{2}\end{aligned}$ & 52.4 & 0.49 & 0.14 & 0.20 & 0.72 & 0.19 & 0.87 & 0.86 & 0.32 \\
\hline $\begin{array}{l}\text { 2nd } \\
\mathrm{J}\end{array}$ & $\begin{array}{l}183 \mathrm{HPM} \\
80 \% \frac{\mathrm{S}}{\mathrm{S}}-\mathrm{I}-\mathrm{SI}+20\end{array}$ & $\begin{array}{r}45.8 \\
0 \quad \text { SiO }\end{array}$ & 51.5 & 0.50 & 0.14 & 0.20 & 0.73 & 0.19 & 0.89 & 0.89 & \\
\hline $\begin{array}{l}2 \mathrm{nd} \\
\mathrm{K}\end{array}$ & $\begin{array}{l}184 \mathrm{HPM} \\
72.5 \% \text { S-1-SI + }\end{array}$ & $\begin{array}{r}41.4 \\
27.5 \% \\
\end{array}$ & $\mathrm{SiO}_{2}$ & 0.45 & 0.14 & 0.18 & 0.66 & 0.18 & 0.81 & 0.74 & 0.292 \\
\hline L & $\begin{array}{l}71.43 \% \mathrm{~S}-1-\mathrm{SI} \\
28.57 \% \mathrm{SiO}_{2}\end{array}$ & 40.7 & 56.9 & 0.45 & 0.14 & 0.18 & 0.66 & 0.18 & 0.79 & 0.715 & 0.287 \\
\hline$M$ & $\begin{array}{ll}69 \% & \mathrm{~S}-1-\mathrm{SI} \\
218 & \mathrm{HPM} \\
31 \% \mathrm{SiO}_{2} \\
\end{array}$ & 39.2 & 58.4 & 0.43 & 0.14 & 0.17 & 0.64 & 0.17 & 0.77 & 0.67 & 0.315 \\
\hline$M_{A}$ & $\begin{array}{l}\text { By Chem Lab } \\
\text { Analysis }\end{array}$ & 44.6 & 54.2 & $\mathrm{NA}$ & $\mathrm{NA}$ & $\mathrm{NA}$ & NA & NA & $\mathrm{NA}$ & 0.82 & 0.315 \\
\hline$\vec{M}_{R}$ & $\begin{array}{ll}69 \% & \text { S-1-SI } \\
304 & \text { HPM } \\
31 \% & \text { SiO., } \\
\end{array}$ & 39.2 & 58.4 & 0.43 & 0.14 & 0.17 & 0.64 & 0.17 & 0.77 & 0.67 & 0.290 \\
\hline & $\begin{array}{l}66.8 \% \mathrm{~S}-1-\mathrm{SI} \\
307 \mathrm{M} \\
33.2 \% \mathrm{SiO}_{2}\end{array}$ & 38.1 & 59.7 & 0.42 & 0.14 & 0.17 & 0.61 & 0.16 & 0.74 & 0.64 & 0.285 \\
\hline & $\begin{array}{l}63.65 \% \mathrm{~s}-1-\mathrm{SI} \\
308 \mathrm{M} \\
36.35 \% \mathrm{SiO}_{2}\end{array}$ & 36.2 & 51.6 & 0.40 & 0.14 & 0.16 & 0.58 & 0.15 & 0.76 & 0.59 & 0.277 \\
\hline & $\begin{array}{l}56.7 \% \mathrm{~S}-1-\mathrm{SI} \\
3 \mathrm{n} 9 \mathrm{M} \\
43.3 \% \mathrm{SiO}_{2}\end{array}$ & 32.2 & 55.9 & 0.36 & $0.14 \mid$ & 0.14 & 0.51 & 0.14 & 0.63 & 0.49 & 0.330 \\
\hline
\end{tabular}

$56.7 \% \mathrm{~S}-1-\mathrm{SI}+43.3 \% \mathrm{SiO}_{2}$

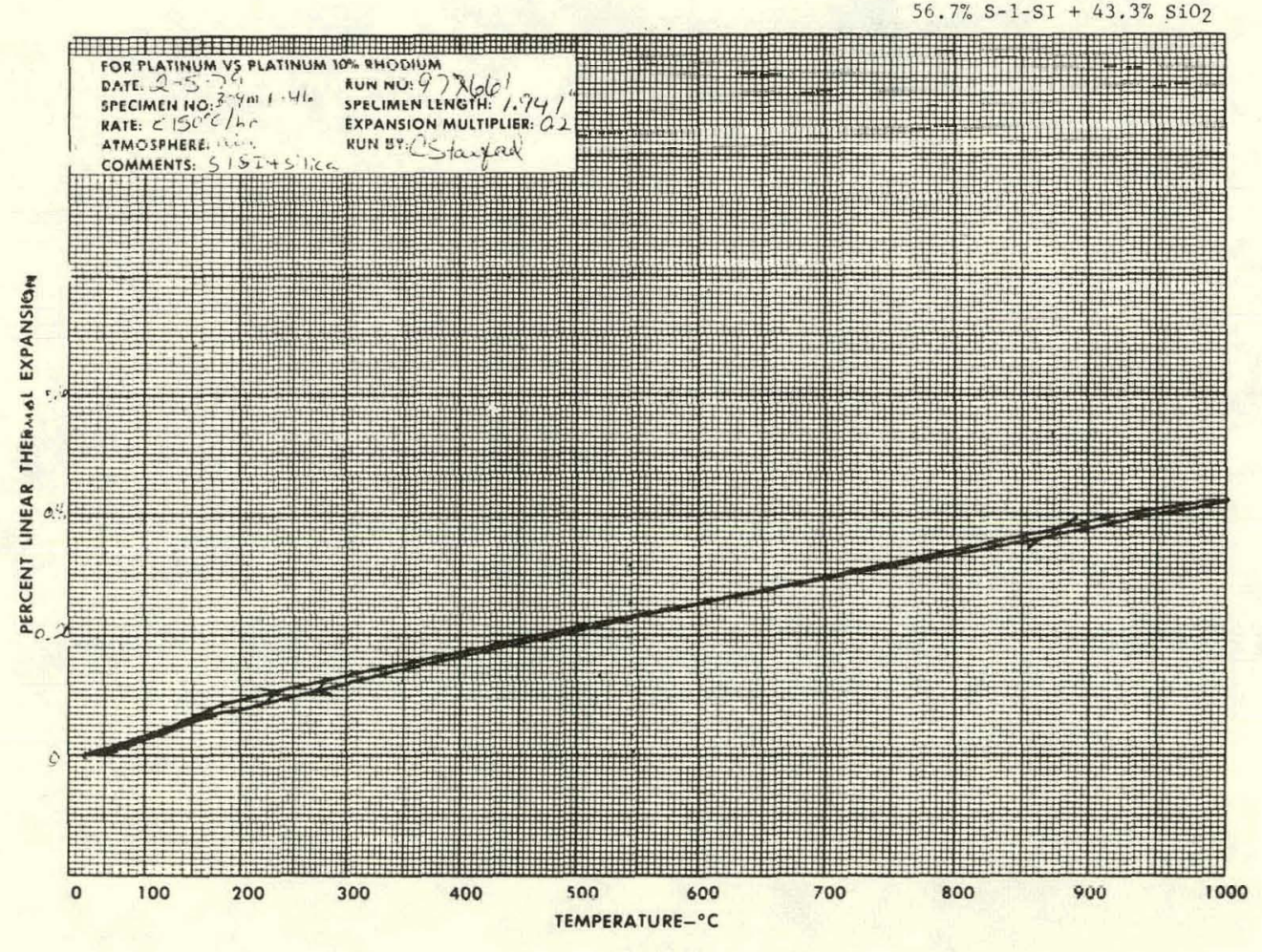


EAGLE.PICHER, INC.

1. MATERIALS W/O PRESSING ADDITIVES AS COATINGS

2. COMPATIBLE SUBSTRATES - LIKE CERAMIC

A. COEFFICIENT OF THERMAL EXPANSION

B. $\mathrm{P}_{2}$ NOT FIXED BY SUBSTRATE

3. $\mathrm{P}_{\mathrm{O}_{2}}$ EFFECTS UPON CONTACT ANGLE AND REACTIVITY

4. CHARACTERIZATION - BEFORE AND AFTER SESSILE DROP TESTS

5. HARDWARE DELIVERY TO JPL

\section{MAIN ASPECTS OF EAGLE-PICHER/UMR/CHEMETAL EFFORT}
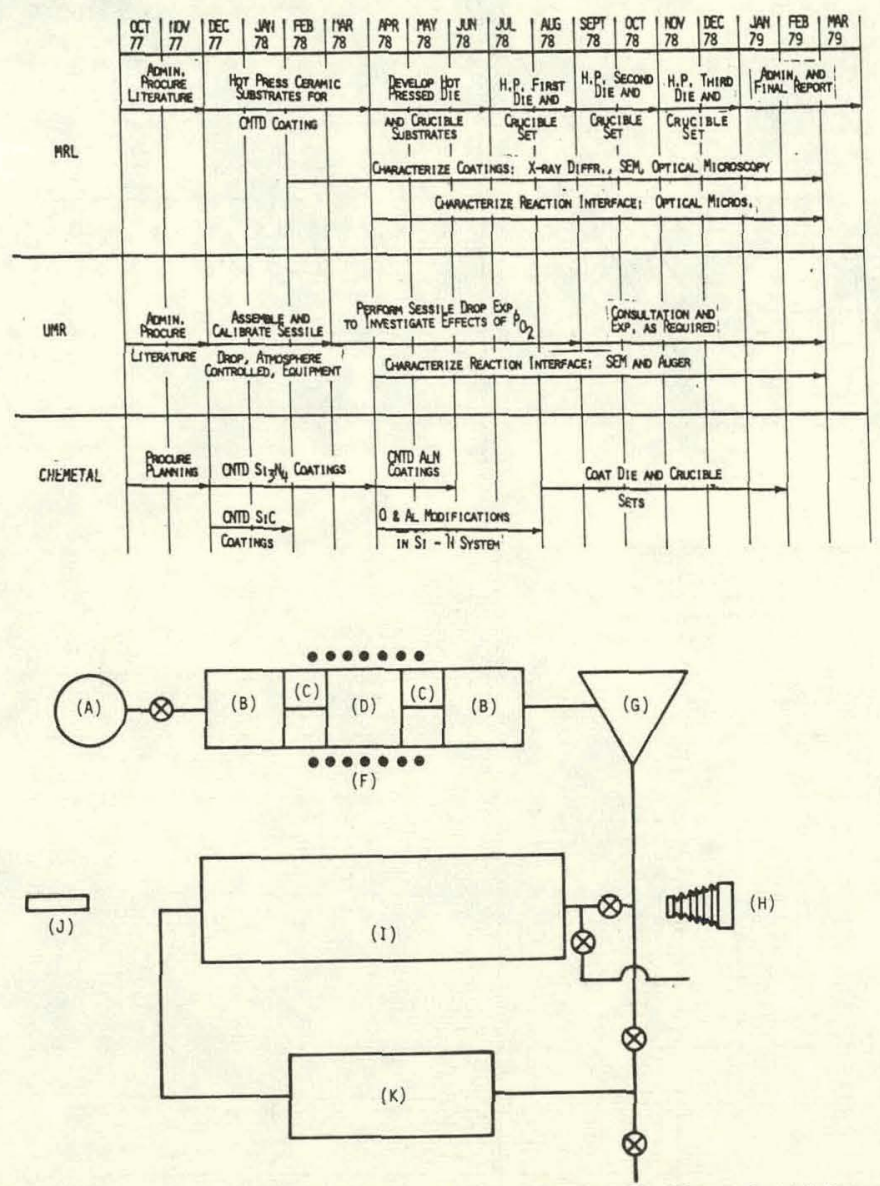

Scherlatic Illustration of Sessile Drop Experiment Under Preciseiy Defined Oxyyen Partiol Pressuro (A) Hydrogen gas, (B) Platinized asbestos, (C) $\mathrm{Al}_{2} \mathrm{O}_{3}$ separator, (D) Titanium powder, (E) Heat ing element, (G) Cold-trap-chiller, (H) Camera, (I) Sessile drop test furnace, (J) Optical pyrometer, (K) Oxide cell 
RELATIONSHIP BETWEEN LOG P02 AND GALVANIC EMF OUTPUT AT $1000^{\circ} \mathrm{C}$ AND $1100^{\circ} \mathrm{C}$

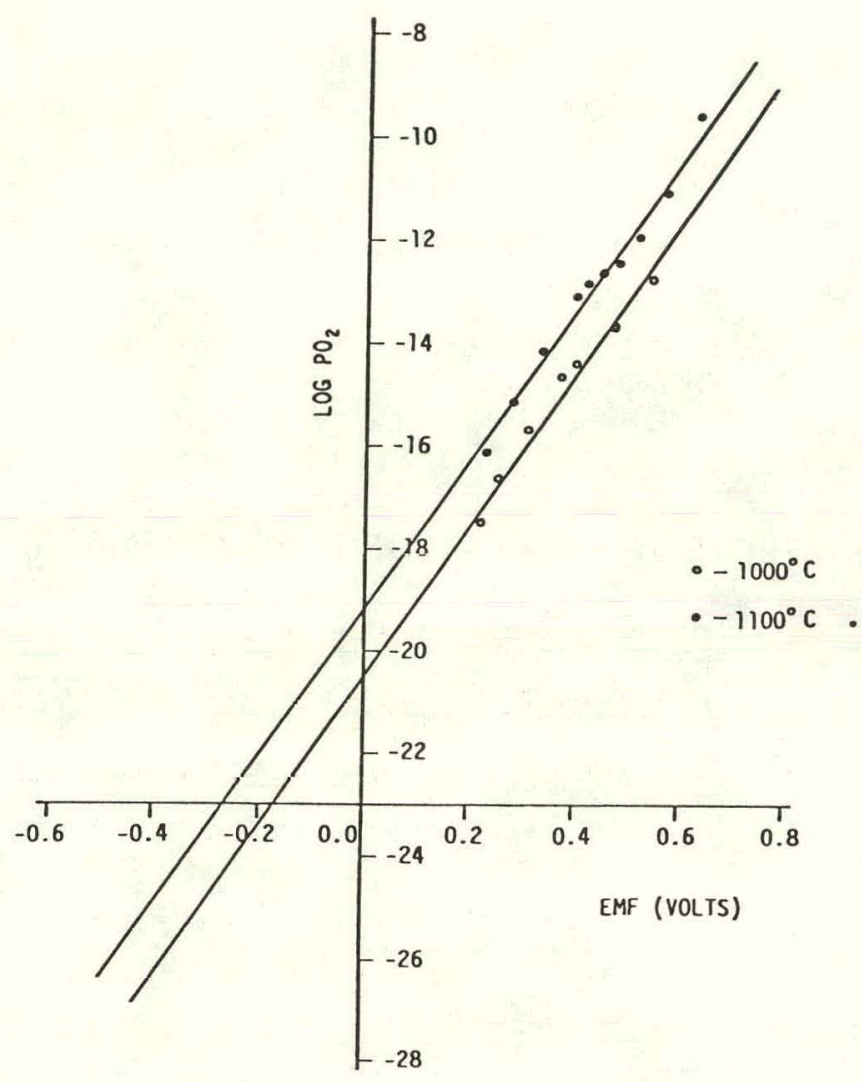


TIME AND $\mathrm{P}_{2}$ DEPENDENCE OF MOLTEN SILICON CONTACT ANGLE ON CNTD $\mathrm{Si}_{3} \mathrm{~N}_{4}$ AT $1420^{\circ} \mathrm{C}$

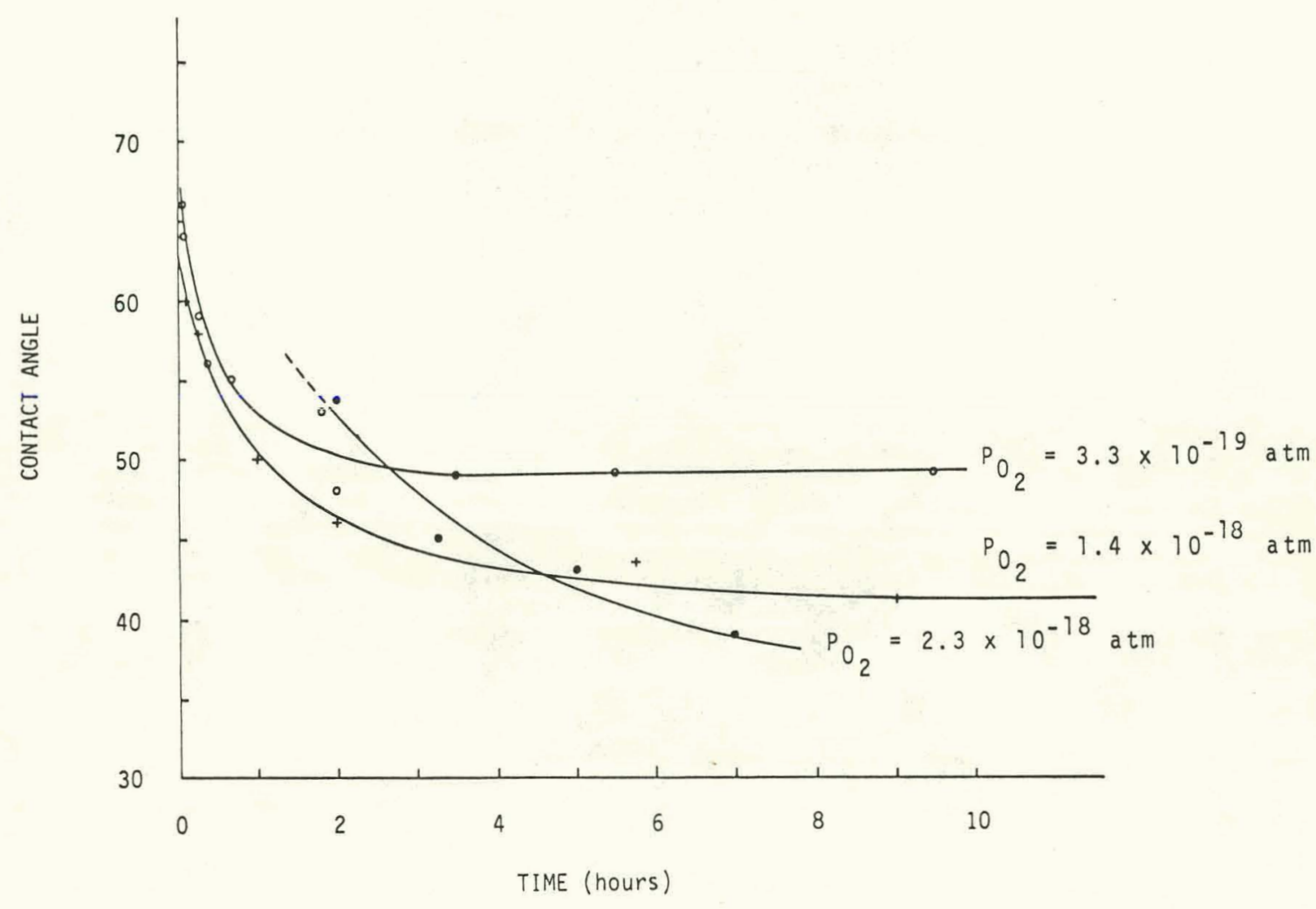

DECREASING OXIDATION EFFECTS WITH DECREASING OXYGEN PARTIAL PRESSURE, $1420^{\circ} \mathrm{C}, \mathrm{CNTD} \mathrm{Si}{ }_{3} \mathrm{~N}_{4}$

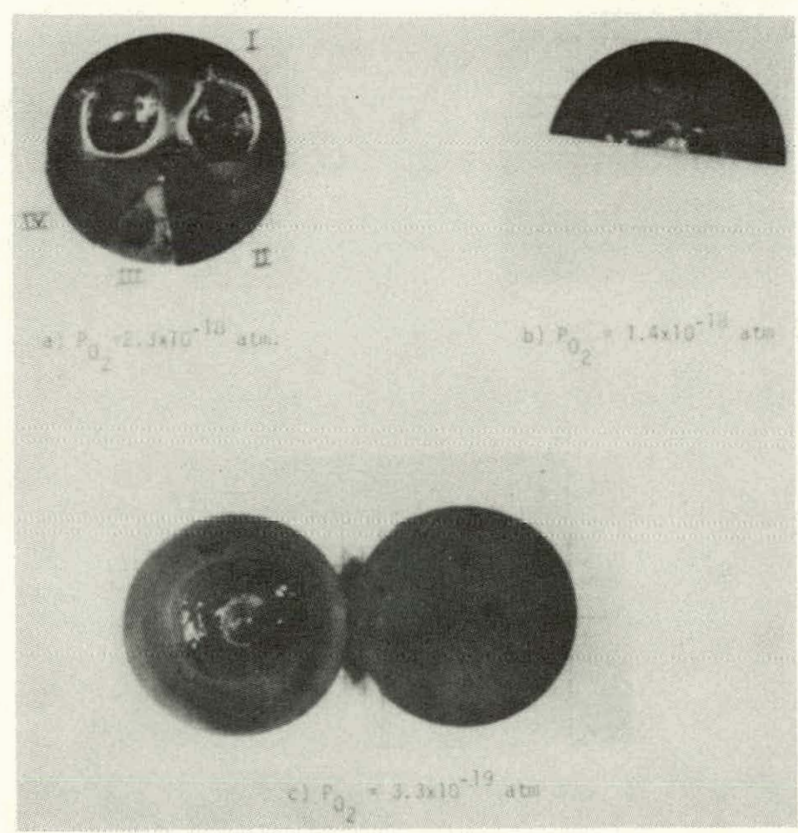



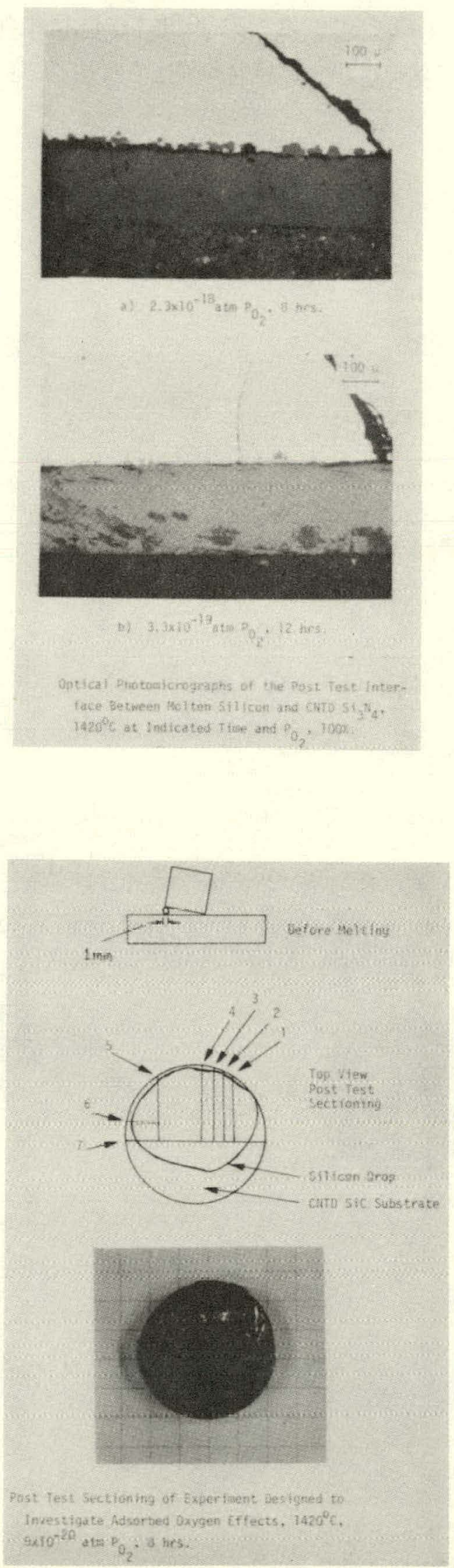
RCA CORP.

Sample

(SDE) $\mathrm{S}_{1} / \mathrm{S} \mathrm{O}_{\mathrm{x}} \mathrm{N} y / \mathrm{RS}-\mathrm{Si}_{3} \mathrm{~N}_{4}$ (ctched)

(SDC) $S 1 / \mathrm{S}_{x} \mathrm{~N}_{\mathrm{y}} / \mathrm{RS}-\mathrm{SI}_{3} \mathrm{~N}_{4}$ (etched)

(SDC) S1/S10 ${ }_{x} \mathrm{~N}_{y} / \mathrm{RS}-\mathrm{SI}_{3} \mathrm{~N}_{4}$ (etched)

$\begin{array}{ccl}\frac{\text { Approximate Content }}{\alpha-\mathrm{Si}_{3} \mathrm{~N}_{4}} & \beta-\mathrm{Si}_{3} \mathrm{~N}_{4} & \\ 28 \% & 72 \% & \text { Treatment } \\ 22 \% & 78 \% & 4 \mathrm{hr} \text { in lle at } 1450^{\circ} \mathrm{C} \\ 10 \% & 90 \% & 20 \mathrm{hr} \text { in He at } 1450^{\circ} \mathrm{C} \\ & 9 t 1450^{\circ} \mathrm{C}\end{array}$

Oxygen (ppma) Carbon (ppma)

Seed

$\sim 35$

$\sim 30-40$

Ribbon

$<5$

$<25$

Sheet Resistance $(\Omega / 0)$
60

57

48

49

48

\begin{tabular}{l|c|c} 
Sample & Lifetime $\tau(\mu s)$ & $\begin{array}{c}\text { Diffusion Length } \\
(L=\sqrt{D T})(u m)\end{array}$ \\
\hline$R \quad 2-1-78$ & 0.6 & 39 \\
$R 2-10-78$ & 0.9 & 48 \\
Control & 3.6 & 95
\end{tabular}

Sample R $\quad 2-10-78$

$\begin{array}{lll} & \text { No AR } & \frac{\text { AR }}{18} \\ J_{S C}\left(\mathrm{~mA} / \mathrm{cm}^{2}\right) & 18.5 & 27.0 \\ v_{o C}(\mathrm{mV}) & 550 & 562 \\ \eta(\%) & 8.0 & 11.8 \\ \dot{F} . \mathrm{F} . & 0.767 & 0.769\end{array}$




\section{CAFILLARY DIE}

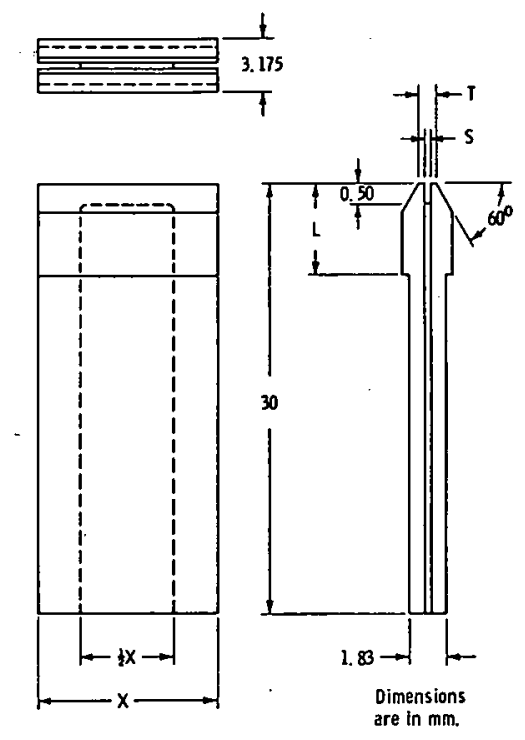

\section{EFG DIE FABRICATION - PROBLEM AREAS}

EFG DIE FABRICATION - PROBLEM AREAS

- SUBSTRATE MATERIALS

a) Tiermal Exṕdis Lù Momatch

b) Thermal Stab111ty

c) Purity

- SUBS'RATE EUEE EFFETIS UN CVU

a) Enhanced CVD Rate at Kdges

b) CVD Layer Cracking at Bdges

- CAPILIARY RISE IN CVD COATED DIES

a) Oxygen Content in System

b) Transport Reactions - Slag Formation

\section{DIES FABRICATED AND FILLED WITH SILICON}

$$
\begin{aligned}
& \text { CVD } \mathrm{Si}_{3} \mathrm{~N}_{4} / \mathrm{H} . \mathrm{P} . \mathrm{Si}_{3} \mathrm{~N}_{4} \\
& \text { CVD SiO } \mathrm{Ny} / \mathrm{H}, \mathrm{P} . \mathrm{Si}_{3} \mathrm{~N}_{4} \\
& \operatorname{CVD~Si} \\
& \mathrm{N}_{4} / \mathrm{Si}_{2} \mathrm{~N}_{2} \mathrm{O} \\
& \text { CVD SiO } \mathrm{Ny}_{\mathbf{4}} / \mathrm{Si}_{2} \mathrm{~N}_{2} \mathrm{O}
\end{aligned}
$$




\section{IMPURITY CONTENT (PPM) OF MATERIALS IN SILICON SESSILE DROP EXPERIMENT}

\begin{tabular}{|c|c|c|c|c|c|}
\hline Element & $\begin{array}{c}\text { S13N4 } \\
\text { (Powder) }\end{array}$ & $\begin{array}{c}\mathrm{SI}_{3} \mathrm{~N}_{4} \\
\text { (Hot-Pressed) }\end{array}$ & $\begin{array}{l}\mathrm{S1}_{3} \mathrm{~N}_{4} \\
\text { (Under Sillcon } \\
\text { Sessile Drop) }\end{array}$ & $\begin{array}{c}\text { S1 } \\
\text { (Segsile Drop) }\end{array}$ & $\begin{array}{c}\text { S1 } \\
\text { (Source) }\end{array}$ \\
\hline AI & $600-6000$ & $600-6000$ & $600-6000$ & $30-300$ & $3-30$ \\
\hline $\mathbf{B a}$ & $10-100$ & $10-100$ & $10-100$ & & \\
\hline B & $30-300$ & $100-1000$ & $100-1000$ & $60-600$ & $50-500$ \\
\hline $\mathrm{Ca}$ & $30-300$ & $30-300$ & $100-1000$ & & $3-30$ \\
\hline $\mathrm{Cu}$ & $5-50$ & $6-60$ & $3-30$ & $3-30$ & \\
\hline $\mathbf{F e}$ & $10-100$ & $15-150$ & $20-200$ & $10-100$ & $0.6-6$ \\
\hline 48 & $15-150$ & (s) & (s) & $3-30$ & $1-10$ \\
\hline m & $5-50$ & $10-100$ & $10-100$ & $1-10$ & $10-100$ \\
\hline $\mathrm{Na}$ & $20-200$ & & & & \\
\hline Mi & & $3-30$ & $6-60$ & $\cdot$ & \\
\hline SI & & $0.3-3$ & $1-10$ & & \\
\hline $\mathbf{T} 1$ & $10-100$ & 20200 & $50-580$ & & $2-20$ \\
\hline $\mathbf{z r}$ & & $1-10$ & $3-30$ & & \\
\hline
\end{tabular}

\section{RESULTS OF X-RAY ANALYSIS ON "Si2 $\mathrm{N}_{2} \mathrm{O}$ " BOTH BEFORE AND AFTER IMMERSION IN MOLTEN SILICON}

\begin{tabular}{|c|c|c|c|c|}
\hline Saruple & & App & ximate $C$ & tent \\
\hline Region & Treatment & $\mathrm { Si } _ { 2 } \longdiv { \mathrm { N } _ { 2 } \mathrm { O } }$ & $\alpha-\mathrm{SI}_{3} \mathrm{~N}_{4}$ & $\mathrm{~B}-\mathrm{S} 1_{3} \mathrm{~K}$ \\
\hline Bulk & As received & $90 \%$ & 57 & 57 \\
\hline Surface & $\begin{array}{l}\text { After immerston in molten silicon } \\
\text { for } 1 \text { h at } \sim 1440^{\circ} \mathrm{C} \text { in } \mathrm{Ar}\end{array}$ & $25 \%$ & $30 \%$ & $45 \%$ \\
\hline Subaurface & After tmersion as otated & $70 \%$ & $10 \%$ & $20 \%$ \\
\hline
\end{tabular}

TYLAN CORP.

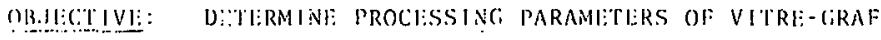

(a glass-like carbon glaze) I:OR OPTIMAI. PI:R-

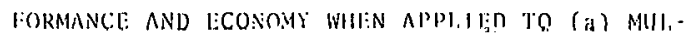

LITI: AND (b) GRAPHITI:

TI:SI PI.AN:

\begin{tabular}{|c|c|c|c|}
\hline SI:RII:S & 1. & - I:VAIUATI: & PREPARATION OF SUBSIRAIE \\
\hline SLERII:S & 2. & LVALIATE & APPLICATION METHODS \\
\hline SERII:S & 3. & - IEVALUATE & CONTING: THICKNIESS \\
\hline SERI I:S & 4. & BVMLUATI: & CURE: TEMPERATURE \\
\hline SERILES & 5. & - EVALUATE & IIEATING RATE \\
\hline SERIES & 6. & EVALUNTE & NLTIERNATI: GAS ATMOSIHERES \\
\hline SERIES & 7 & DISCRETIO & ONARY \\
\hline
\end{tabular}




\section{FAILURE MECHANISMS BETWEEN MOLTEN SILICON AND GRAPHITE/GLASSY CARBON}

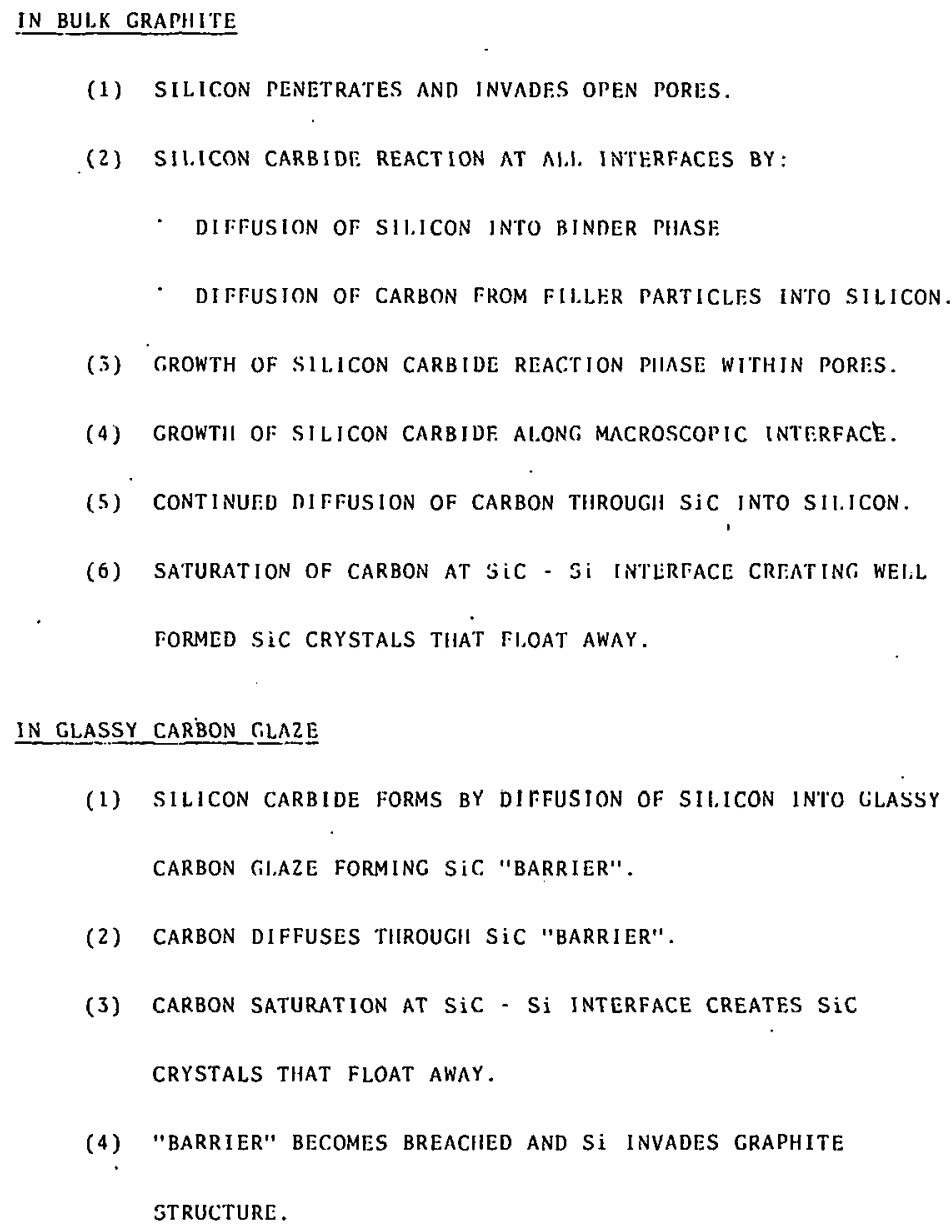

(1) SILICON PENETRATES AND INVADES OPEN PORISS.

(2) SIIICON CARBIDI: REACTION AT Al. INTERFACES BY:

- DIFFUSION OF SII.ICON INTO BINDER PHASE

- DIFFUSION OF CARBON FROM FIILLR PARTICLES INTO SILICON.

(3) GROWTH OF SILICON CARBIDE REACTION PIIASE WITHIN PORIS.

(4) GROWTII OF SILICON CARBIDF. ALONG MACROSCOPIC INTERFACE.

(5) CONTINUFD DIFFUSION OF CARBON THROUGH SiC INTO SII.ICON.

(6) SATURATION OF CARBON AT SiC - Si INI'LRTACE CRTATTING WEIL FORMED SIC CRYSTALS THAT FI,OAT AWAY.

\section{IN GLASSY CARBON CILAZE}

(1) SILICON CARBIDE FORMS BY DIFFUSION OF SIIIICON INTO GLASSY CARBON GI.AZE FORMING SIC. "BARRIER".

(2) CARBON DIFFUSES TIIROUGII SiC "BARRIER".

(3) Carbon Saturation at SiC - Si interface creates SiC CRYSTALS THAT FLOAT AWAY.

(4) "BARRIER" BECOMES BREACHED AND Si INVADES GRAPHITE STRUCTURE .

\section{BASELINE PROCESS}

A SOLUTION OF DECOMPOSED POLYMERIC RESIN IN AN ORGANIC SOLVENT IS PREPARED HAVING CHARACTERISTICS OF LACQUER.

- THE SOLUTION IS APPLIED TO POROUS GRAPHITE BY USING TYPICAI. PAINT TFRHNInUFS AND CURED AT ELEVATED TEMPERATURE.

- the coating material fills and seals surface pores to

RENDER THE SURSTRATE IMPERVIOUS TO GAS OR LIQUID PENETPATION.

- COATINC THICKNESSES (5 1ayers) ARF TYPICALlY 5-10 $\mu \mathrm{m}$ AND CLOSELY MATCHES THE THERMAL EXPANSION OF GRAPHITE. 
OCLI

\section{OBJECTIVE}

The objective of this program is to investigate, develop

and ut llize technologies appropriote and necessory for

improving the performonce of solor cells made from vorious

unconventional sillicon sheets.

\section{SCOPE}

1. Moteriol Evaluoted

- Cost Sllicon by HEM (Crystol System)

o EFG SH (Mobil TrCo)

o SOC (Honeywell)

2. Performance characterization

- Illumination Characterístics (AMO)

- Dark I-V Choracteristics

- Spectral Response

- Minority Corrier Diffusion Lenoth

o Srall Light Spot Scanning A.cross Cell

3. Problem Areas Reloted to Process and Performance 


\section{SUMMARY OF PARAMETERS OF SOLAR CELLS FABRICATED FROM CAST SILICON BY HEM; STANDARD PROCESS}

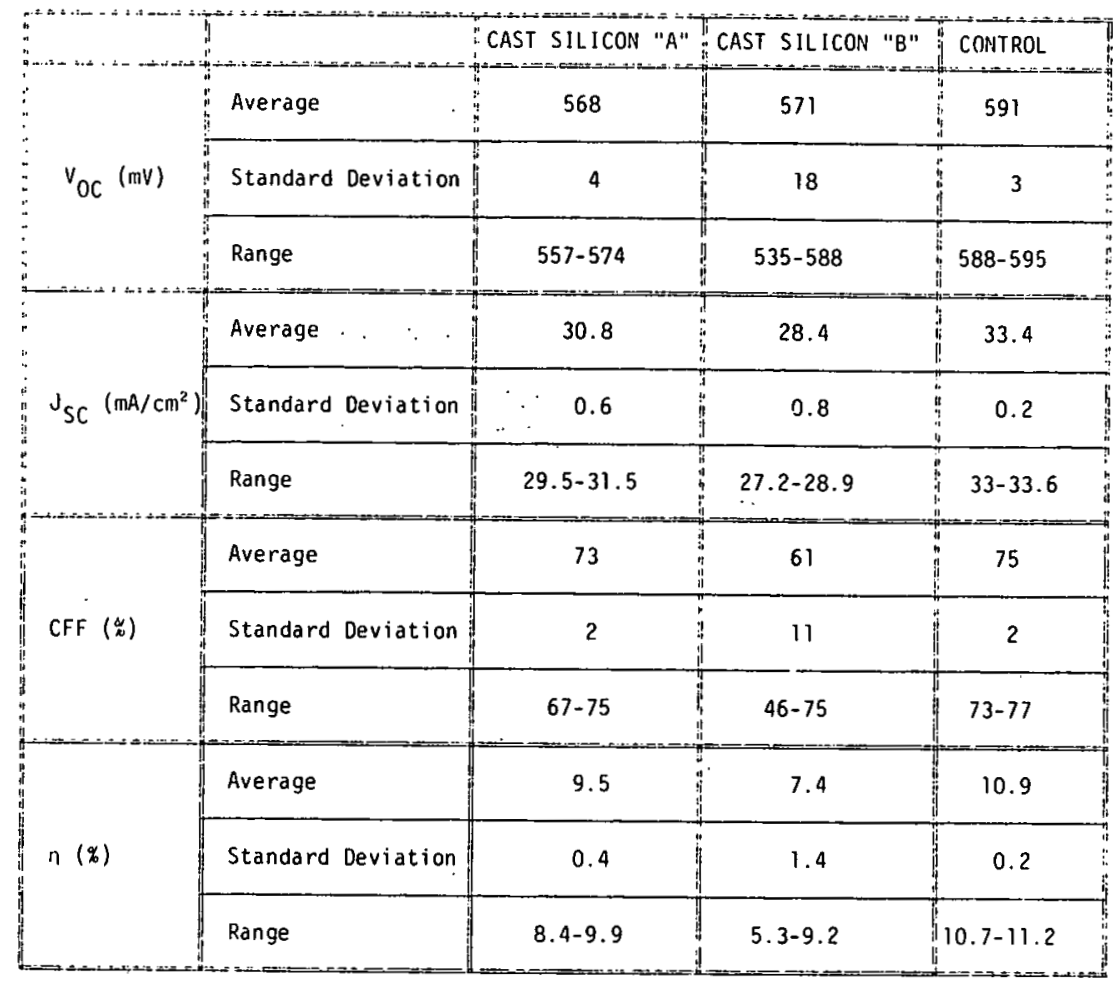

NOTE: 1. Measured at $25^{\circ} \mathrm{C}$ under AMO conditons (with SiD AR)

2. Cast silicon "A": 3 ohm- $\mathrm{cm}$

Cast Silicon "B": $0.5 \mathrm{ohm}-\mathrm{cm}$

3. Number of Samples: Cast Silicon "A" - 18

Cast Silicon "B" - 12

Control Cells $\quad 6$ 

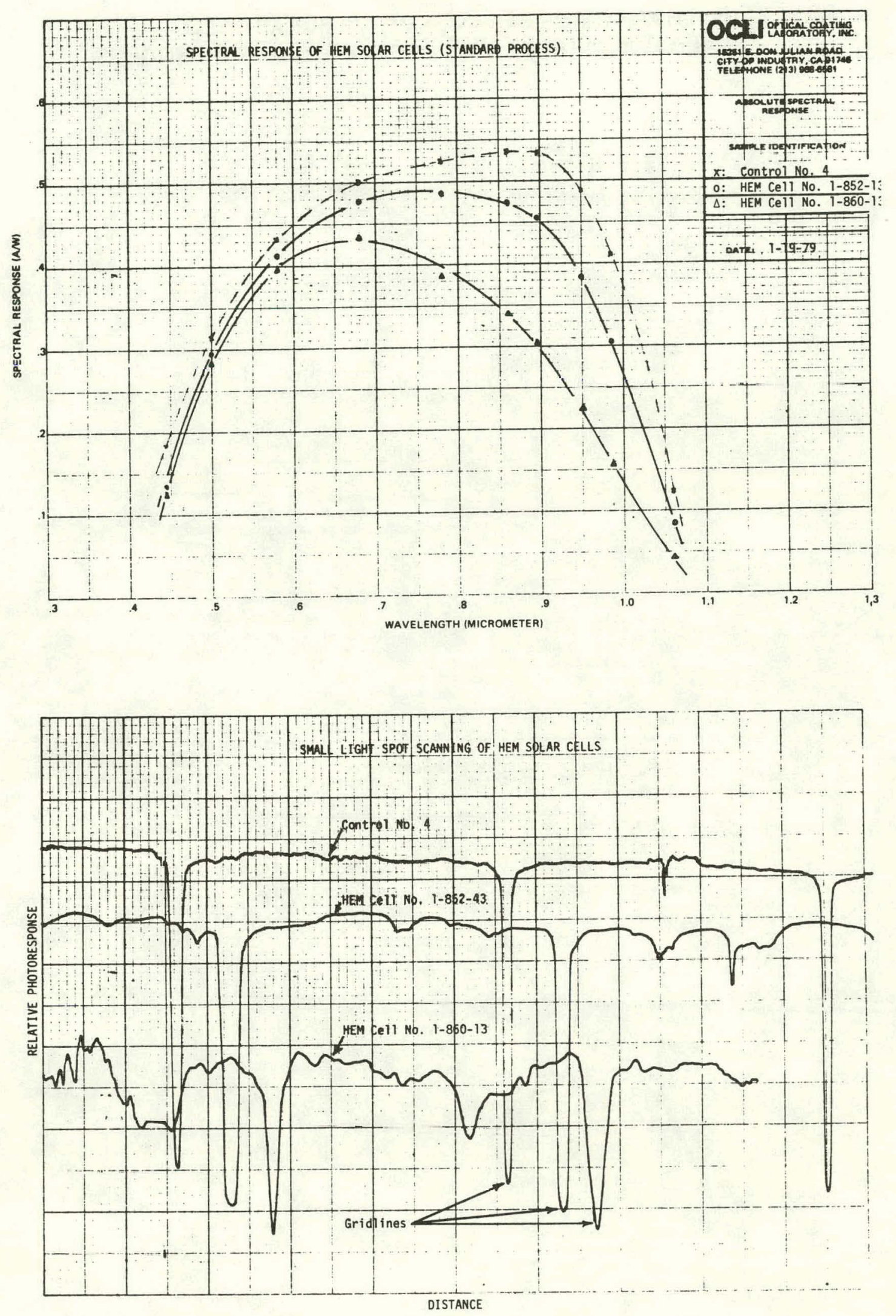


\section{SUMMARY OF PARAMETERS OF SOLAR CELLS FABRICATED FROM EFG RH RIBBON: STANDARD PROCESS}

\begin{tabular}{|c|c|c|c|c|c|}
\hline & & $E F G$ " $A$ " & $E F G$ "B" & EFG "C" & CONTROL \\
\hline \multirow{3}{*}{$V_{O C}(m V)$} & Average & $\begin{array}{c}517 \\
(492)\end{array}$ & $\begin{array}{c}515 \\
(502) \\
\end{array}$ & $\begin{array}{c}508 \\
(500)\end{array}$ & 580 \\
\hline & $\begin{array}{l}\text { Standard } \\
\text { Deviation }\end{array}$ & $\begin{array}{c}9 \\
(19)\end{array}$ & $\begin{array}{c}2 \\
(2)\end{array}$ & - & - \\
\hline & Range & $\begin{array}{c}490-526 \\
(464-510)\end{array}$ & $\begin{array}{c}510-508 \\
(498-506)\end{array}$ & $\begin{array}{c}480-527 \\
(492-514)\end{array}$ & $576-588$ \\
\hline \multirow{3}{*}{$\mathrm{J}_{\mathrm{SC}}\left(\mathrm{mA} / \mathrm{cm}^{2}\right)$} & Average & $\begin{array}{l}25.2 \\
(17.9)\end{array}$ & $\begin{array}{c}24.9 \\
(17.6) \\
\end{array}$ & $\begin{array}{l}25 \\
(18)\end{array}$ & 33.5 \\
\hline & $\begin{array}{l}\text { Standard } \\
\text { Deviation }\end{array}$ & $\begin{array}{c}0.6 \\
(0.3)\end{array}$ & $\begin{array}{c}0.7 \\
(0.6)\end{array}$ & - & - \\
\hline & Range & $\begin{array}{c}24.8-26.1 \\
(17.5-18.4)\end{array}$ & $\begin{array}{c}23.5-25.5 \\
(16.5-18.2)\end{array}$ & $\begin{array}{r}24-25.5 \\
(17.2-18.6)\end{array}$ & $33-33,8$ \\
\hline \multirow{3}{*}{$\operatorname{CFF}(\%)$} & Average & $\begin{array}{c}64 \\
(60)\end{array}$ & $\begin{array}{c}73 \\
(72)\end{array}$ & $\begin{array}{c}56 \\
(60)\end{array}$ & 73 \\
\hline & $\begin{array}{l}\text { Standard } \\
\text { Deviation }\end{array}$ & $\begin{array}{l}12 \\
(14)\end{array}$ & $\begin{array}{c}1 \\
(2)\end{array}$ & - & - \\
\hline & Range & $\begin{array}{c}47-74 \\
(42-73)\end{array}$ & $\begin{array}{r}71-74 \\
(69-74) \\
\end{array}$ & $\begin{array}{c}34-75 \\
(\Delta 9-72)\end{array}$ & $67-73$ \\
\hline \multirow{3}{*}{$n_{1}(\%)$} & Average & $\begin{array}{c}6.2 \\
(4.0)\end{array}$ & $\begin{array}{c}6.9 \\
(4.8)\end{array}$ & $(4)^{4}$ & 10.5 \\
\hline & $\begin{array}{l}\text { Standard } \\
\text { Deviation }\end{array}$ & $\begin{array}{l}1.4 \\
(1.1) \\
\end{array}$ & $\begin{array}{l}0.2 \\
(0.2) \\
\end{array}$ & - & - \\
\hline & Range & $\begin{array}{c}4.3-7.5 \\
(2.6-5.1)\end{array}$ & $\begin{array}{c}6.6-7.2 \\
(4.5-5.0)\end{array}$ & $\begin{array}{c}2.9-7.4 \\
(3.6-4.9) \\
\end{array}$ & $9.7-11.2$ \\
\hline
\end{tabular}

NOTE: $\quad$ I. Measured at $25^{\circ} \mathrm{C}$ under AMO Condilions (cells with SiO AR). Parenthesis Numbers are for the Parameters Before AR coating.

2. Identification and Sample Numbers of EFG RH Ribbon Cells:

"A": $5-866$

"B": $\quad 5-868$

-5 Cells

"C". 5-870 Uncontrolled Sic- 3 Cells

Control: 1-3 ohm-cm Czochralski-3 Cells

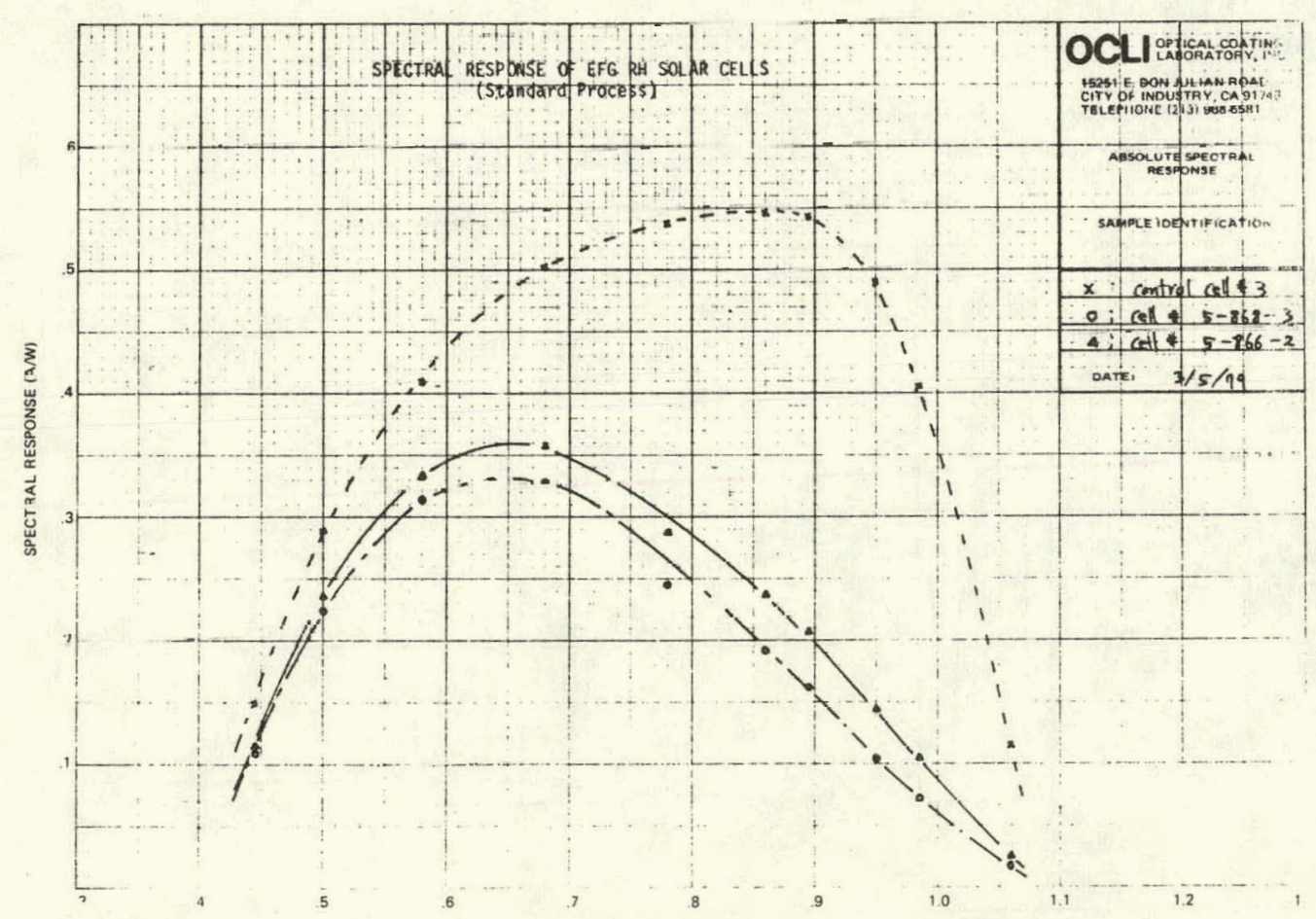




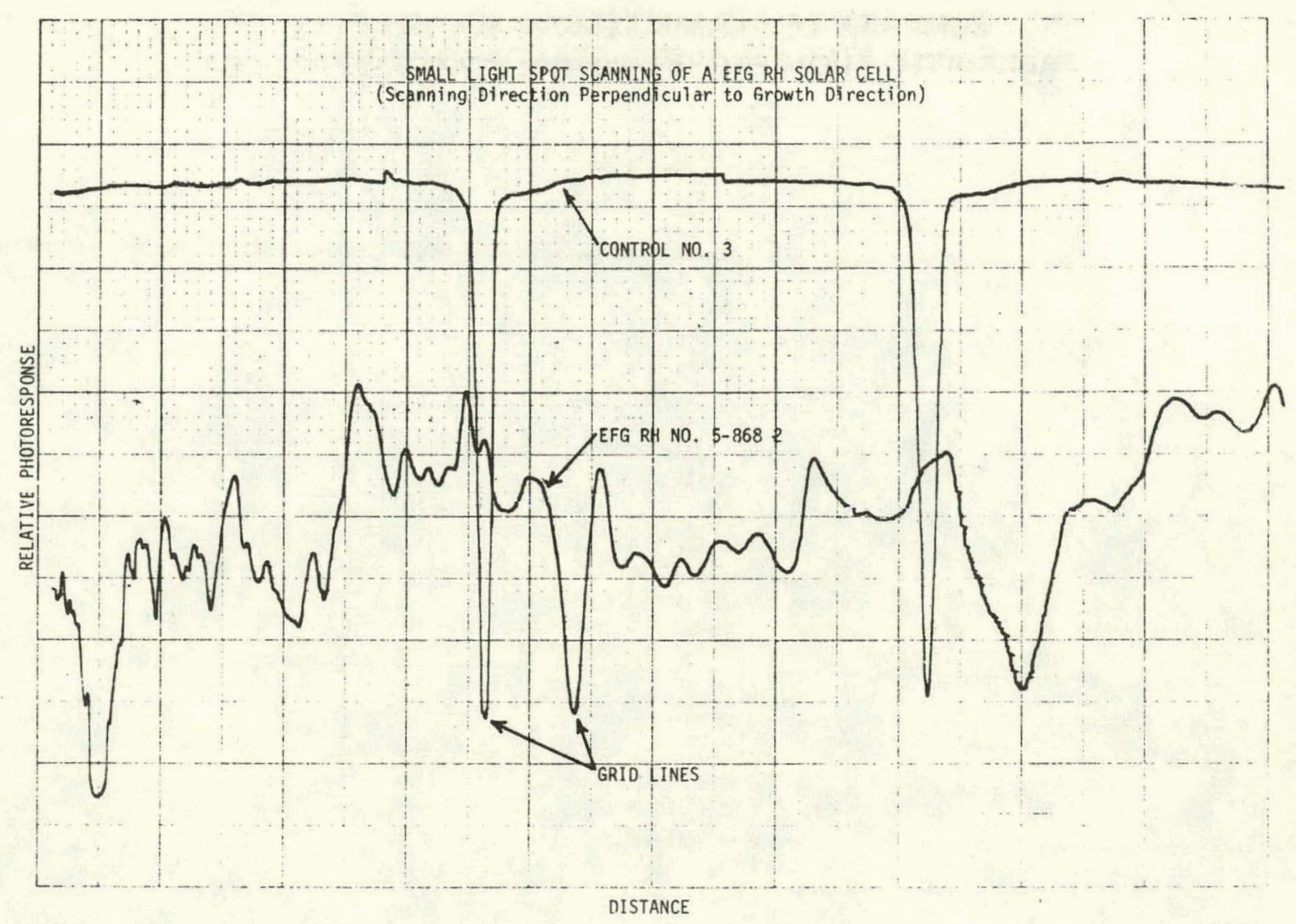

3-103 


\section{SUMMARY OF PARAMETERS OF SOLAR CELLS FABRICATED FROM SOC; STANDARD PROCESS}

\begin{tabular}{|c|c|c|c|}
\hline & & SOC & CONTROL \\
\hline \multirow{3}{*}{$V_{O C}(m V)$} & Average & 547 & 589 \\
\hline & $\begin{array}{l}\text { Standard } \\
\text { Deviation }\end{array}$ & 3.7 & 4 \\
\hline & Range & $541-553$ & $581-592$ \\
\hline \multirow{3}{*}{$J_{S C}\left(\mathrm{~mA} / \mathrm{cm}^{2}\right)$} & Average & 24.1 & 33.8 \\
\hline & $\begin{array}{l}\text { Standard } \\
\text { Deviation }\end{array}$ & 1.4 & 0.8 \\
\hline & Range & $22-26.3$ & $32.4-34.8$ \\
\hline \multirow{3}{*}{ CFF $(\%)$} & Average & 60 & 72 \\
\hline & $\begin{array}{l}\text { Standard } \\
\text { Deviation }\end{array}$ & 6 & 3 \\
\hline & Range & $52-69$ & $67-77$ \\
\hline \multirow{3}{*}{$n(\%)$} & Average & 5.9 & 10.6 \\
\hline & $\begin{array}{l}\text { Standard } \\
\text { Deviation }\end{array}$ & 0.6 & 0.5 \\
\hline & Range & $5.1-6.8$ & $10-11.3$ \\
\hline
\end{tabular}

NOTE: 1. Measured Under AMO Condition.

2. SOC Solar Cells:

$\begin{array}{ll}\text { Average Cell Size: } & 15.1 \mathrm{~cm}^{2} \\ \text { Number of Cells Evaluated: } & 7 \\ \text { Active Area: } & 80-85 \% \\ \text { AR Coating: } & \text { Si } 0\end{array}$

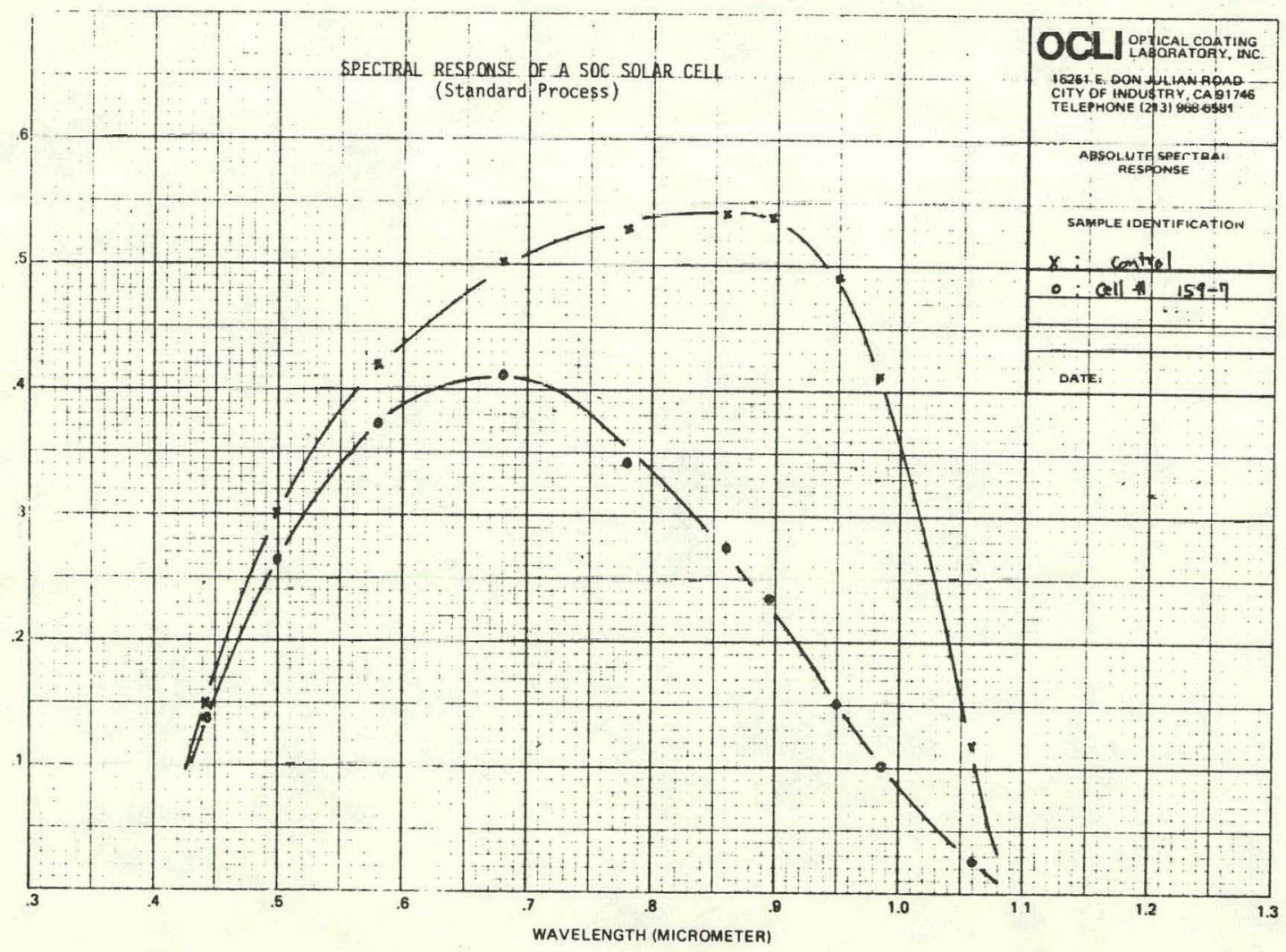




\section{PROBLEM AREAS RELATED TO PROCESS AND PERFORMANCE}

\begin{tabular}{|c|c|c|}
\hline SHEETS & PROCESS & CELL PERFORMANCE \\
\hline EFG (RF AND RH) & $\begin{array}{l}\text { Netallization \& Measurement; } \\
\text { Non-Flat and Non-Uniform } \\
\text { Thickness }\end{array}$ & $\begin{array}{l}\text { Shunting (Low Fill Factor); } \\
\text { Surface Inclusion (SiC) }\end{array}$ \\
\hline RTR & $\begin{array}{l}\text { Metallization \& Measurement; } \\
\text { Wavy Surface }\end{array}$ & $\begin{array}{l}\text { Low Lifetime } \\
\text { Low Fill Factor }\end{array}$ \\
\hline DENDRITIC WEB & $\begin{array}{l}\text { Removal of Surface Deposit } \\
\text { (SiO) } \\
\text { Handling; Fragile (Thin Web) }\end{array}$ & No Major Problem \\
\hline SILSO (WACKER) WAFEK & No Majur prublem & Shunting; Inrlusinn \\
\hline CAST SILICON BY HEM & No Major Problem & Shunting; Microcrack \\
\hline SOC & $\begin{array}{l}\text { Metallization \& Measurement; } \\
\text { Warpage and Back Slot }\end{array}$ & $\begin{array}{l}\text { Shunting; Surface Inclusion } \\
\text { Series Resistance; Small } \\
\text { Area Back Slot Contact (?) }\end{array}$ \\
\hline
\end{tabular}

\section{CONCLUSION}

- Back up measurements confirm the solar cell performance (efficiency) and minority carrier diffusion lenath will be the ultimate limiting factor.

0 Inclusion caused shunting problem.

0 Non-flat and non-uniform surface introduced process and measurement problems.

- Need close interaction between cell processor and sheet producer. 


\section{SPECTROLAB}

\section{SOLAR CELL.FABRICATION}

(BASELINE PROCESS)
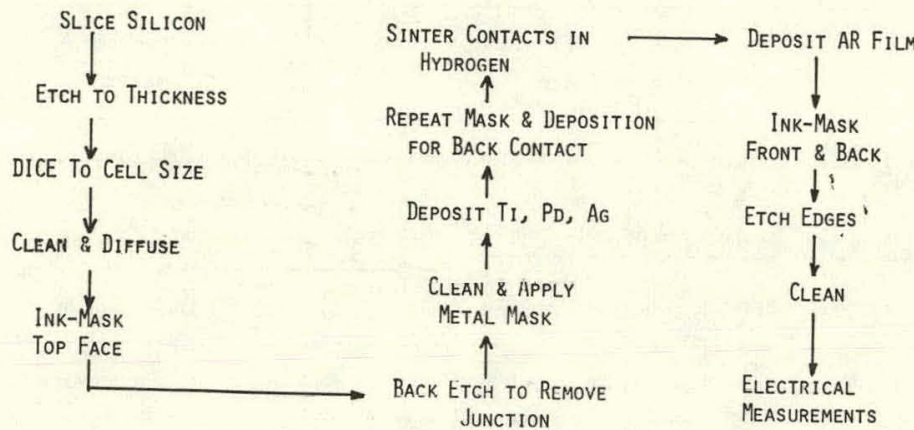

CONTROL FLOW CHART

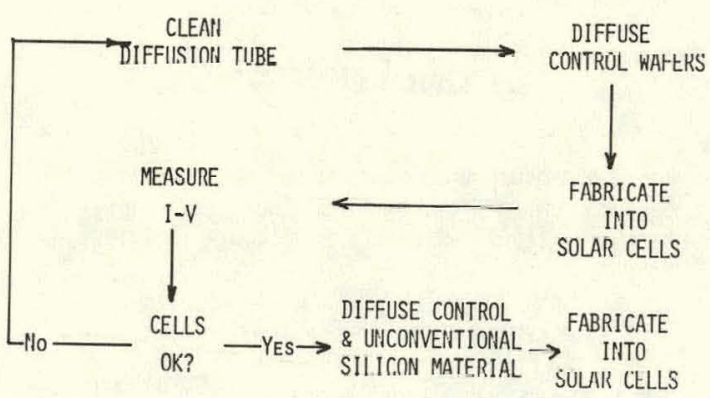

CURRENT - VOLTAGE CURVE WACKER SILSO AND CONTROL CELL

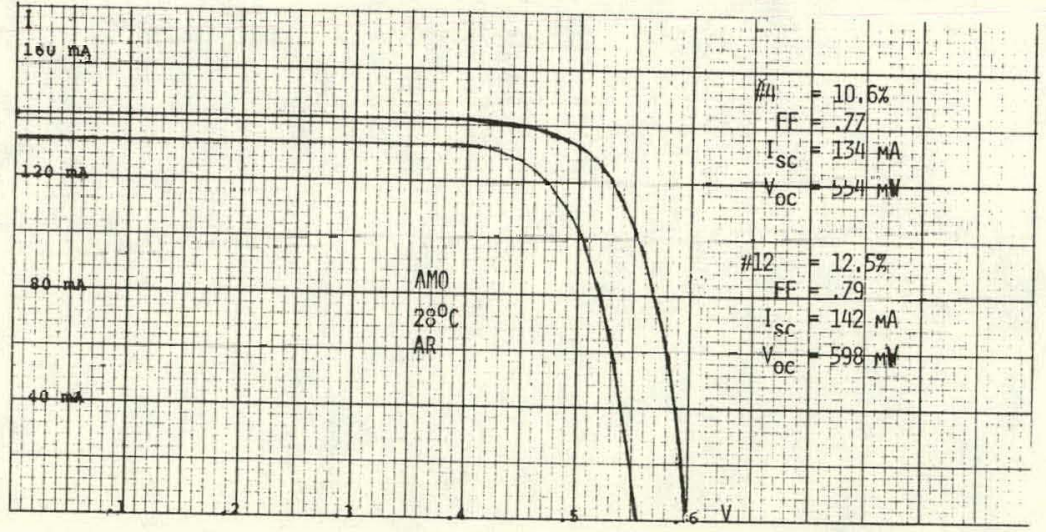


SOLAR CELLS, WACKER SILSO, SINGLE SHEET

\begin{tabular}{|c|c|c|c|c|}
\hline $\begin{array}{c}9.0 \\
1 \\
.73\end{array}$ & 2 & 3 & $\begin{array}{c}9.0 \\
4 \\
.73\end{array}$ & 5 \\
\hline $\begin{array}{c}8.8 \\
6 \\
.70 \\
\end{array}$ & $\begin{array}{l}9.8 \\
7 \\
.74 \\
\end{array}$ & $\begin{array}{l}9.8 \\
8 \\
\quad .75 \\
\end{array}$ & 9 & 10 \\
\hline $\begin{array}{l}9.0 \\
11 \\
.73\end{array}$ & $\begin{array}{c}10.0 \\
12 \\
.74 \\
\end{array}$ & $\begin{array}{c}10.0 \\
13 \\
.75 \\
\end{array}$ & $\begin{array}{l}9.9 \\
14 \\
.75 \\
\end{array}$ & 15 \\
\hline $\begin{array}{l}9.0 \\
16 \\
.74 \\
\end{array}$ & $\begin{array}{c}9,4 \\
17 \\
.74 \\
\end{array}$ & $\begin{array}{c}10,0 \\
18 \\
.75 \\
\end{array}$ & $\begin{array}{l}9.6 \\
19 \\
.74 \\
\end{array}$ & 20 \\
\hline $\begin{array}{l}8,5 \\
21 \\
.74\end{array}$ & $\begin{array}{l}9,0 \\
22 \\
.72\end{array}$ & $\begin{array}{l}9,0 \\
23 \\
.75\end{array}$ & 24 & $\begin{array}{l}7.6 \\
<0\end{array}$ \\
\hline
\end{tabular}

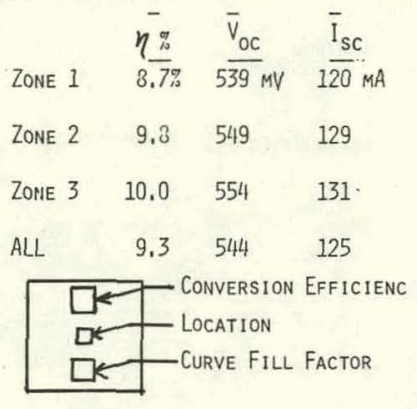

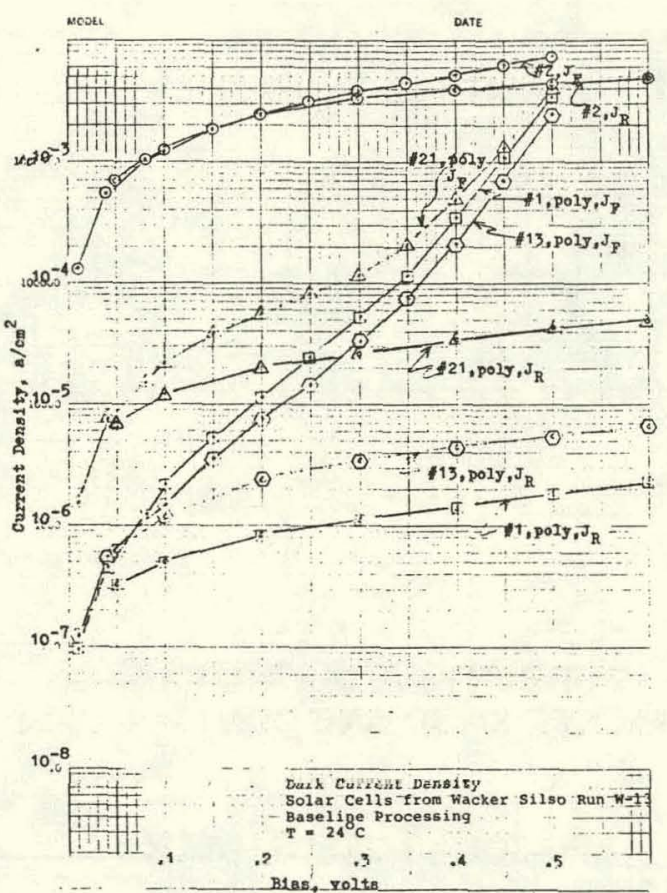




\section{SOLAR CELLS, WACKER SILSO}

\begin{tabular}{|c|c|c|c|c|c|}
\hline & & & SELINE PF & & \\
\hline & $\mathrm{N}$ & $\mathrm{I}_{\mathrm{SC} M A}$ & $V_{O C}, M V$ & $\mathrm{FF}$ & $\eta \%$ \\
\hline POLY & 4 & 133 & 554 & .76 & 10.4 \\
\hline Control & 8 & 142 & 597 & .78 & 12.2 \\
\hline POLY & 23 & 130 & 546 & .74 & 9.7 \\
\hline CONTROL & & 139 & 598 & .75 & 11.6 \\
\hline PoLy & 16 & 123 & 546 & .74 & 9.2 \\
\hline CONTROL & 5 & 133 & 599 & .76 & 11.2 \\
\hline POLY & 16 & 125 & 545 & .74 & 9.4 \\
\hline CONTROL & 8 & 137 & 595 & .73 & 11.2 \\
\hline POLY & 59 & 127 & 546 & .74 & 9.5 \\
\hline CONTROL & 20 & 139 & 598 & .76 & 11.6 \\
\hline
\end{tabular}

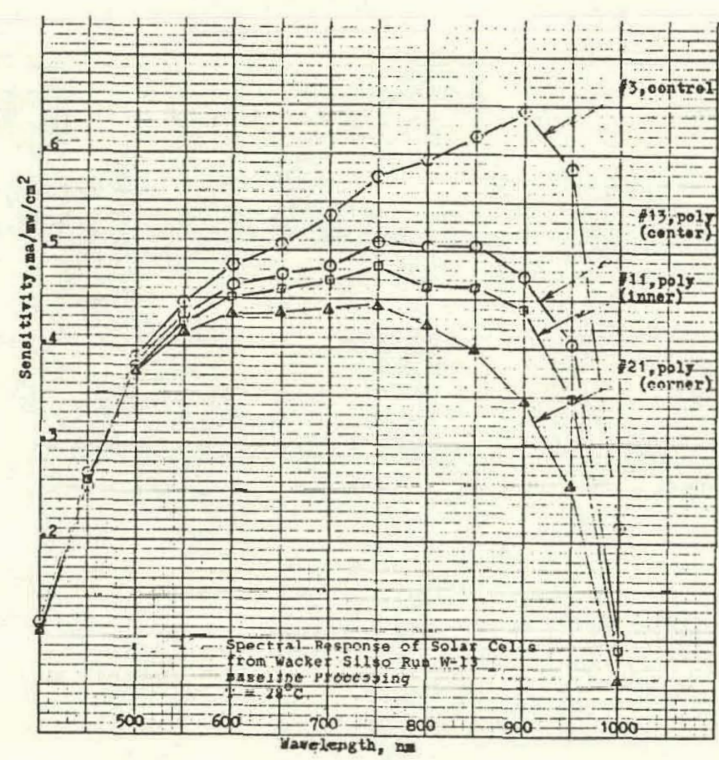

\section{EFG SOLAR CELLS - 1 " $\times 1 "$}

PRELIMINARY

$\begin{array}{rrrrr}\frac{S / N}{3} & \frac{I_{S C}}{177} & \frac{V_{\text {OC }}}{535} & \frac{\text { CFF }}{.57} & \frac{\eta}{6.2} \\ 6 & 159 & 529 & .64 & 6.1 \\ 7 & 174 & 539 & .69 & 7.4 \\ 8 & 154 & 534 & .48 & 4.6 \\ 9 & 159 & 535 & .66 & 6.1 \\ 13 & 179 & 541 & .59 & 6.4 \\ 15 & 174 & 528 & .65 & 6.3\end{array}$

I-V Data Measured at amo, $28^{\circ} \mathrm{C}$ 


\section{CURRENT - VOLTAGE WEB MATERIAL 2 CM X 2 CM}

\begin{tabular}{|c|c|c|c|c|}
\hline \multirow[b]{2}{*}{$\underline{S / N}$} & \multirow[b]{2}{*}{$\underline{V_{O C} M V}$} & \multicolumn{3}{|c|}{ (Very Preliminary) } \\
\hline & & $\mathrm{I}_{\text {SC }} \mathrm{MA}$ & CFF & $\%$ \\
\hline B & 494 & 131 & .73 & 3.7 \\
\hline C & 485 & 131 & .72 & 8.4 \\
\hline D & 475 & 132 & .72 & 8.3 \\
\hline$E$ & 490 & 132 & .71 & 8.4 \\
\hline $\mathrm{F}$ & 514 & 144 & .71 & 9.7 \\
\hline H & 501 & 131 & .72 & 3.8 \\
\hline J & 513 & 129 & .72 & 8.8 \\
\hline Cont. & $\begin{array}{r}601 \\
\sim \text { AMO }\end{array}$ & 141 & .76 & 11.9 \\
\hline
\end{tabular}

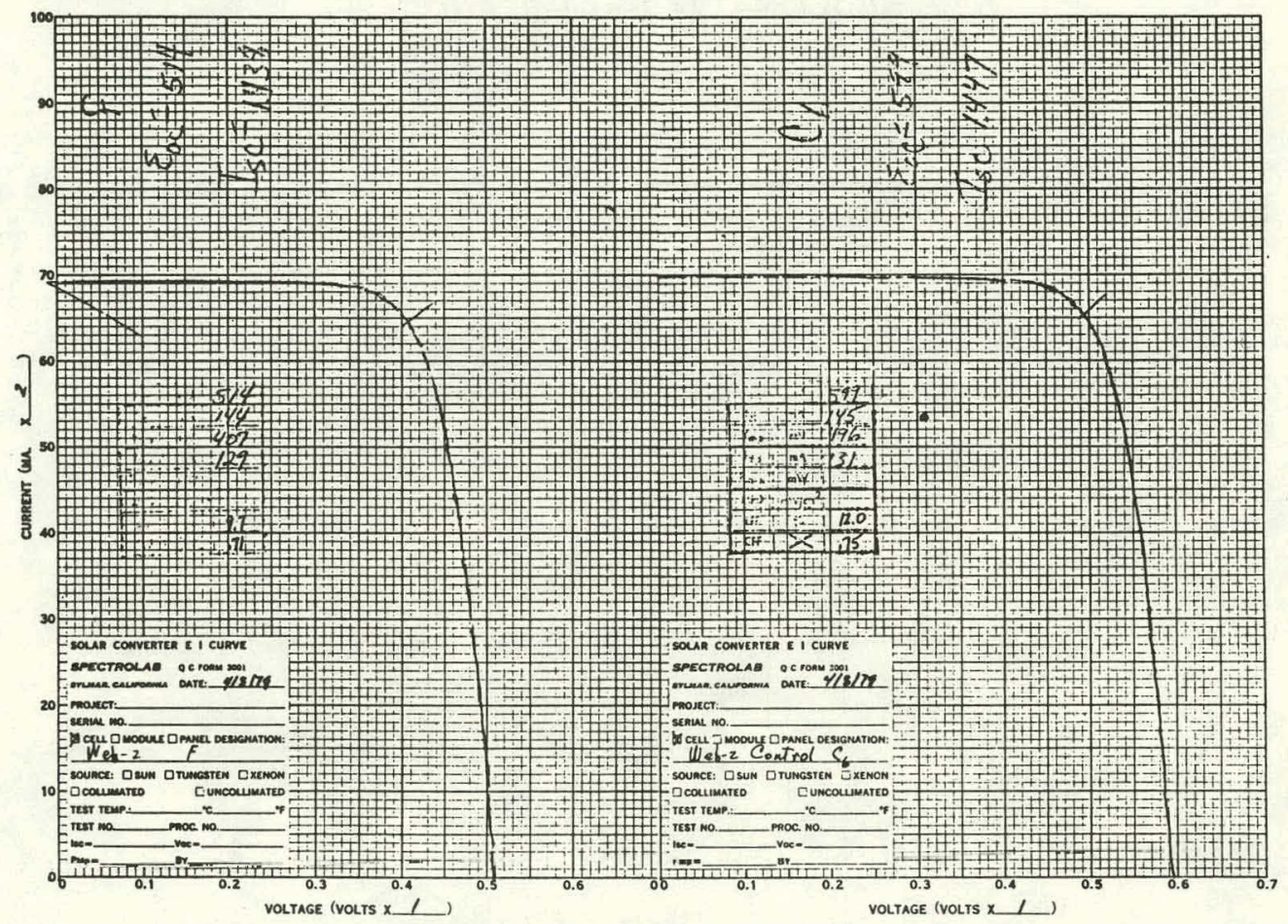




\section{ARCO SOLAR}

\section{VACUUM DIE CASTING}

The vacuum die casting program is a joint effort between ARCO Solar and SRI International to cast thin sheet silicon and fabricate that material into $12 \%$ efficient solar cells. The program was just funded two weeks ago.

In the casting process liquid silicon is forced by argon or another inert gas to enter an evacuated die consisting of rigid parallel flat plates forming slots sandwiched between the plates.

\section{SILICON-ON-CERAMIC PROCESS}

Honeywell Material Sciences Center

1979 GOALS

- Determine Maximum Dip-Coating Growth Speed

- Demonstrate 11\% SoC Solar Cells

Status

- $10.1 \%$ on $4 \mathrm{~cm}^{2}$

- $9.2 \%$ ON $10 \mathrm{~cm}^{2}$

a $0.06 \mathrm{~cm} / \mathrm{sEC}$.

- Thick Dendritic Growth at , $2-, 3 \mathrm{~cm} / \mathrm{sec}$,

INVESTIGATURS:

D. Zook, B. Crung, D. Hearg, S, Schuldt, B. Koepk.e

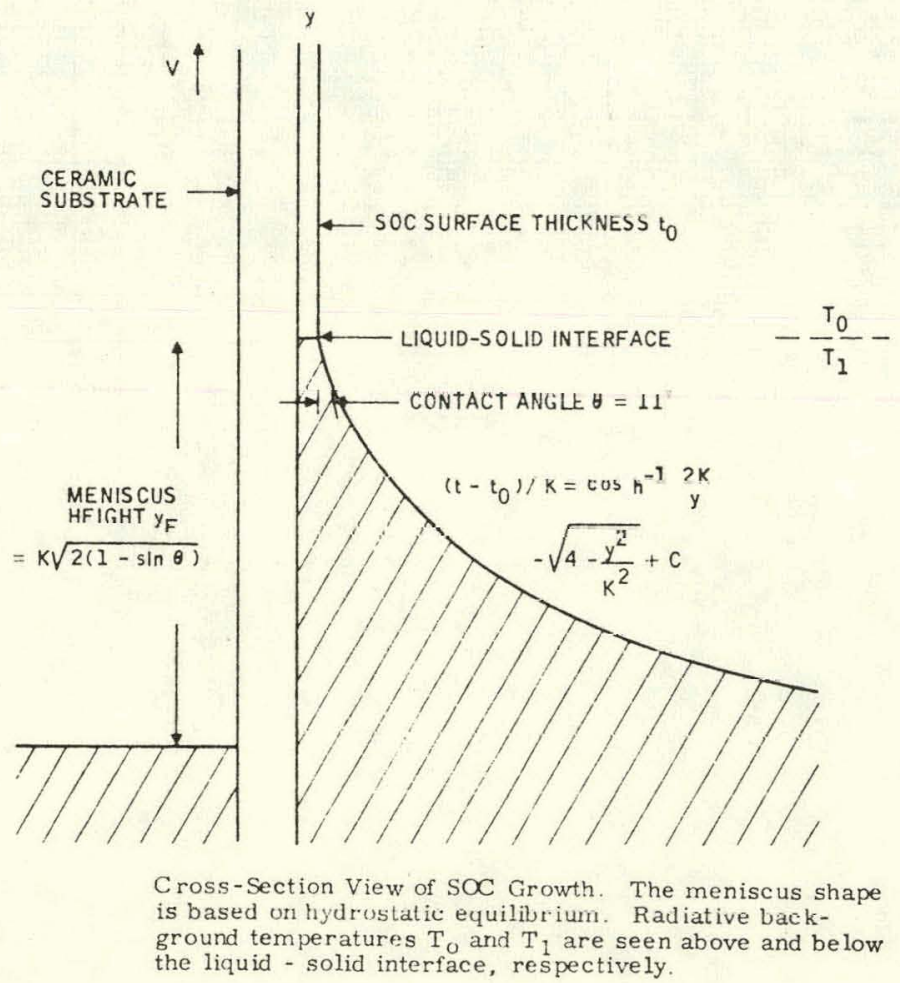



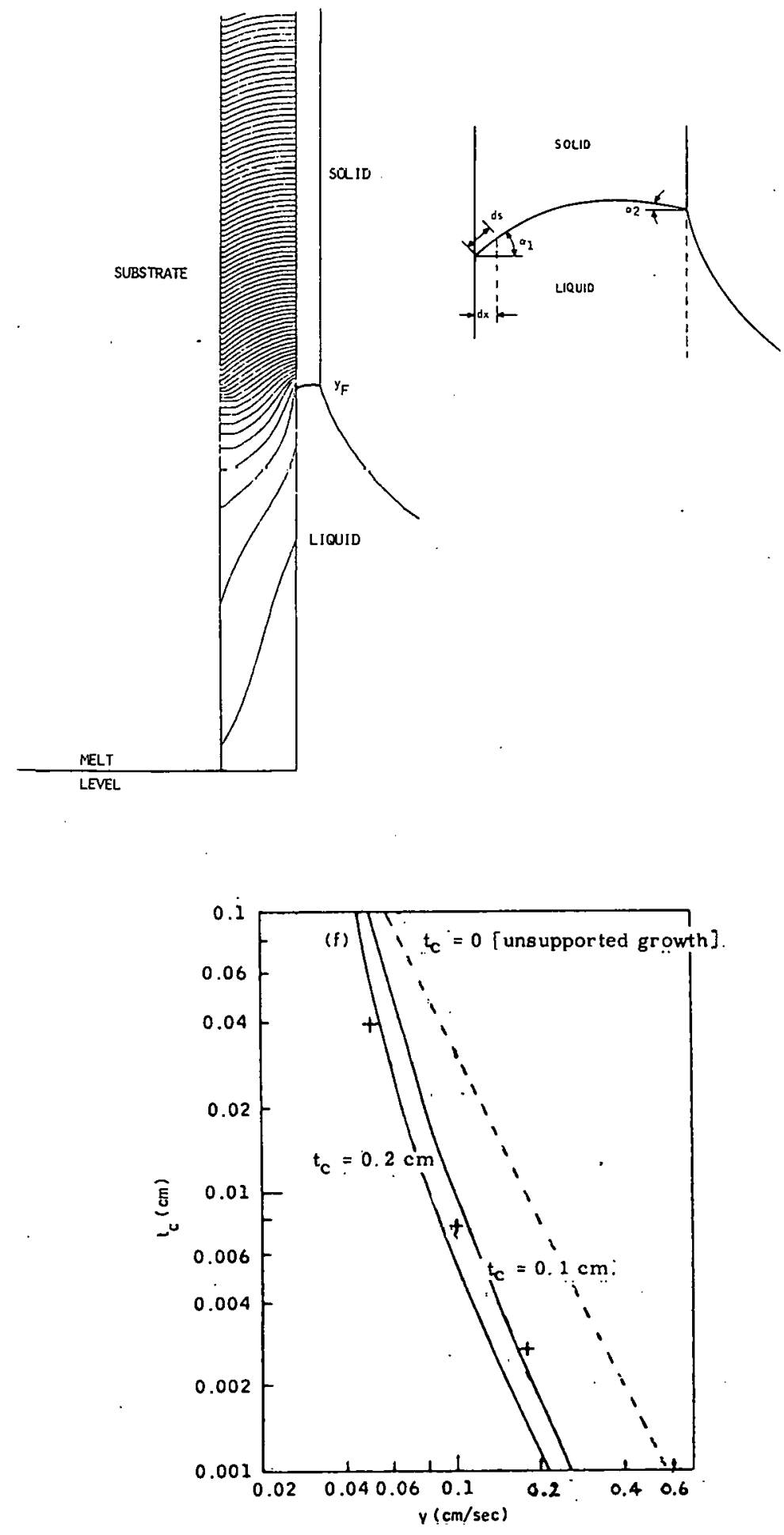


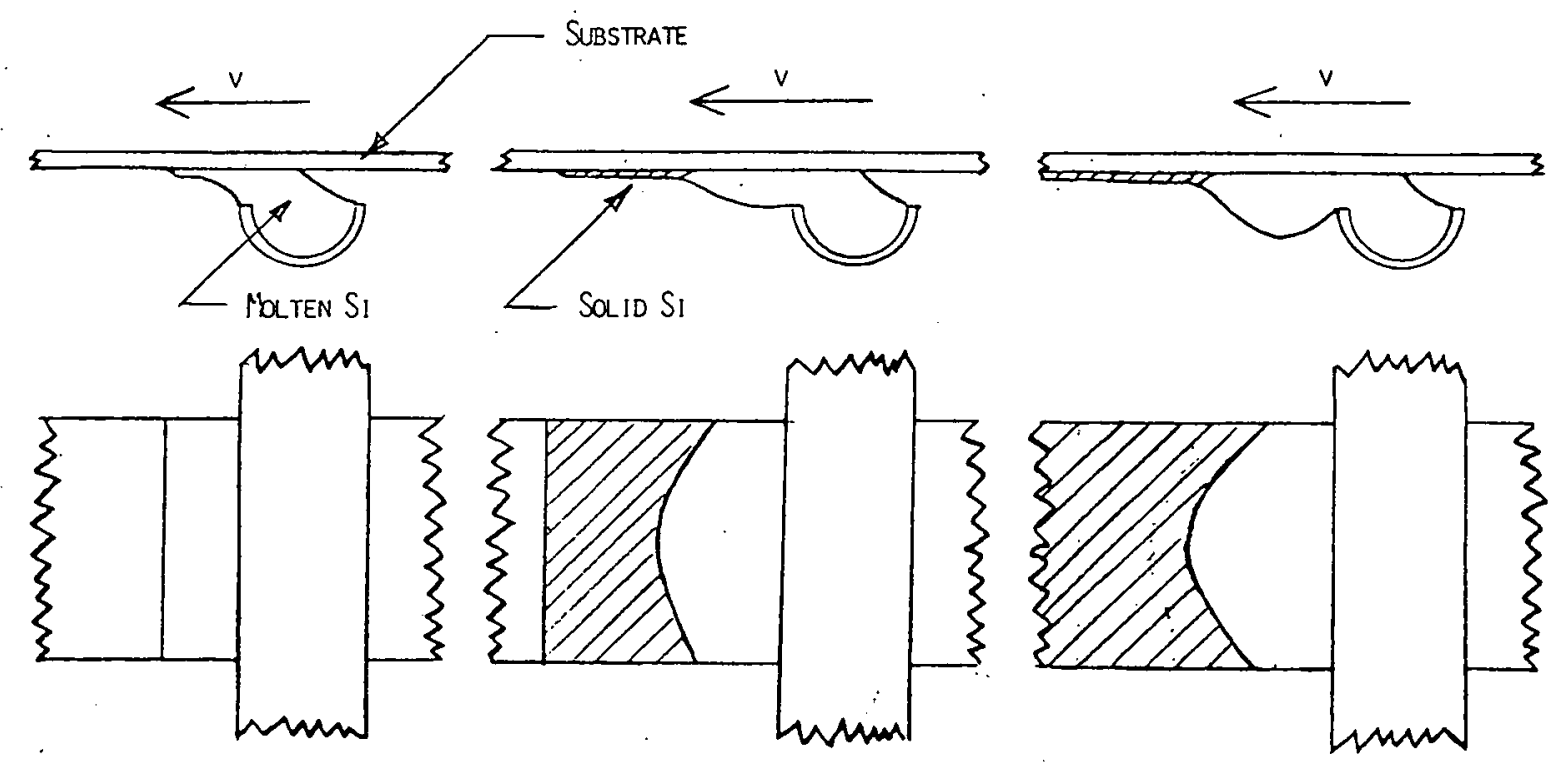

Meniscus Instability

- Temperature Depentent Sirrfare temsion

- Gravitational effects

Coater Modifications

- Inclined Subsirate

- top coating 
DIP-COATING PROGRESS

- Production Yteld Improved

- UP TO $85 \%$ in Recent RUNS

- Cooling Sholes hith X-Y Motion

in EXPErimental System

\section{CHARACTERISTICS OF RECENT SOC CELLS}

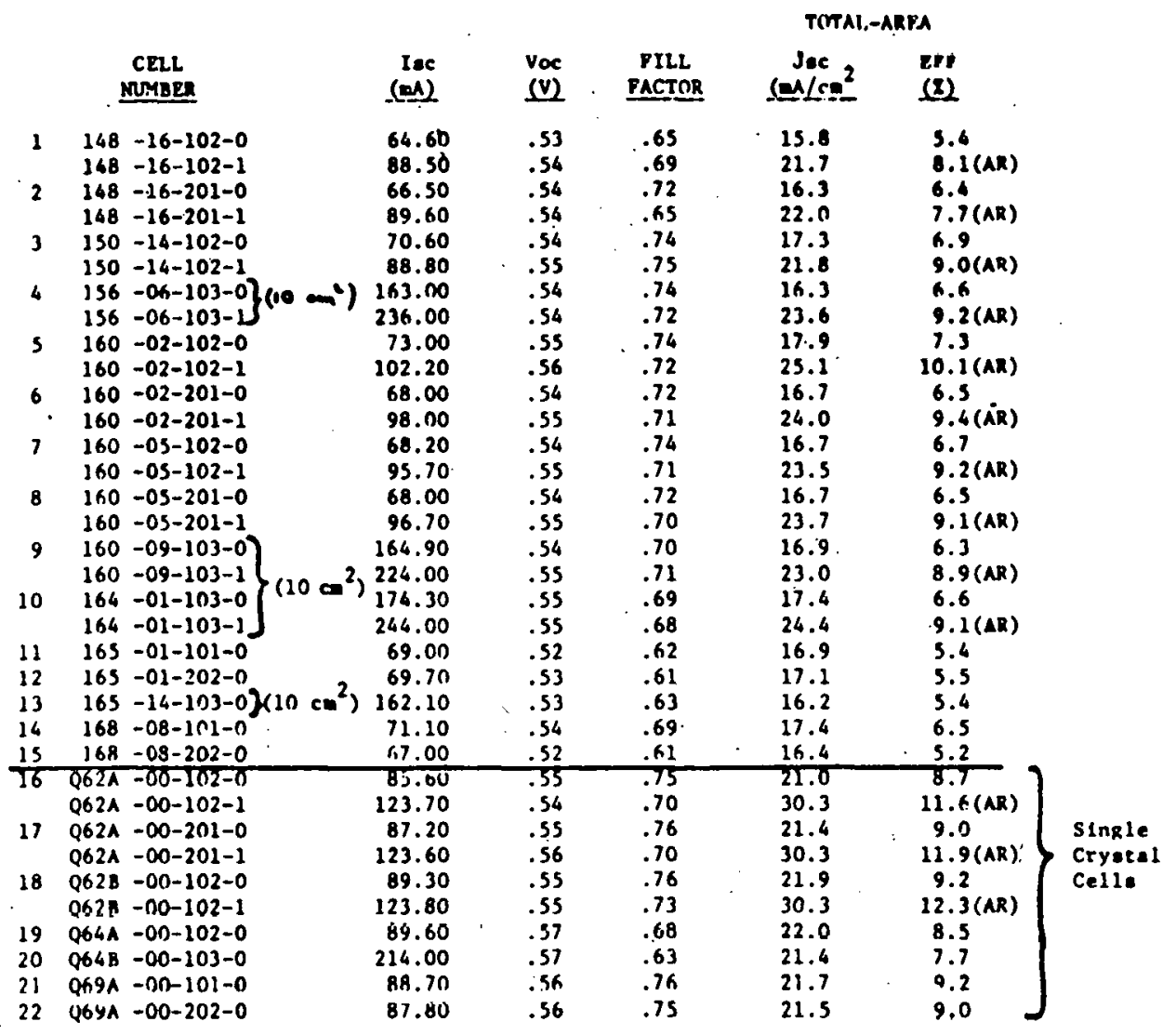




\section{SLOTTED SOC CELL}
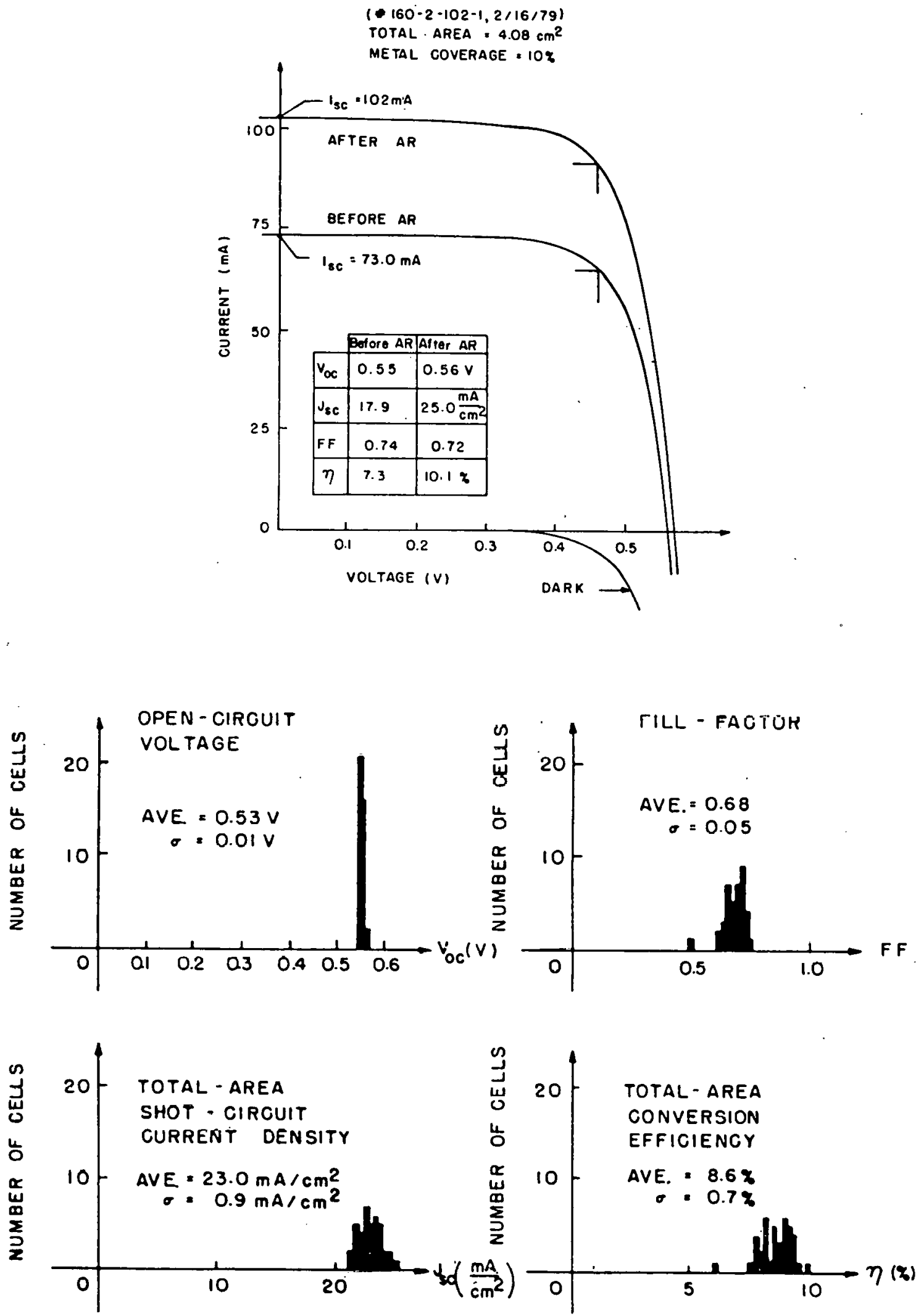


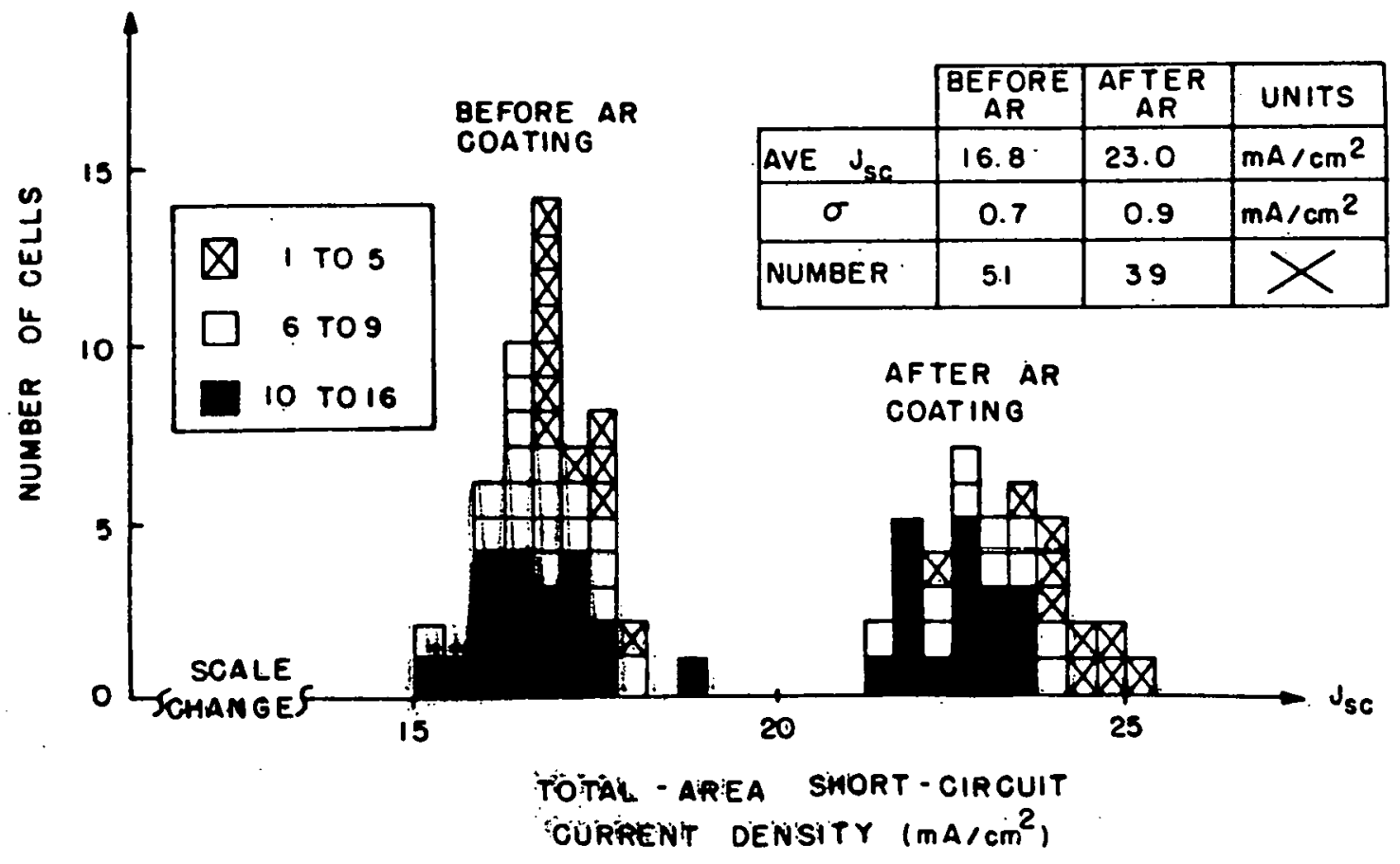

SUMMARY OF PROGRESS

\begin{tabular}{|c|c|}
\hline Thermal Amalysis & $\begin{array}{l}\text { - Effect of Ceramic on Grohth } \\
\text { - Shape of Liouid-Solid Interface- } \\
\text { - Thickness vs. Velocity Trade-Off }\end{array}$ \\
\hline CONTINUOUS COATING & $\begin{array}{l}\text { - Good Structure } \\
\text { - Metiscus Instability Problem } \\
\text { - Proposed Solutions }\end{array}$ \\
\hline Dip-Coating & $\begin{array}{l}\text { - InCREased Yield - Up To } 852 \\
\text { - CoOLINo Shoes IN EXPerimental Dipper }\end{array}$ \\
\hline Material Evaluation & $\begin{array}{l}-L_{N}=25 \text {-50um - Avg. Within Grains } \\
\text { - ST.ATtered Laser L Light Counts GB }\end{array}$ \\
\hline Cell Performance & $\begin{array}{l}\text { - Reproducible Pesults: Loh Variabilitiy } \\
\text { - Nem JPI. Stamdard Cell } \\
\text { - } 10.13 \text { Oin } 4 \mathrm{~cm}^{2} \\
-9.28 \text { on } 10 \mathrm{~cm}^{2}\end{array}$ \\
\hline
\end{tabular}




\section{MTSÉC (EFG)}

Solar Cell Datá For Ribbon Material Grown from Kun 18-103. Cells are $2.5 \times 7.5 \mathrm{~cm}^{2}$, cut across

the ribbon width.

$100 \mathrm{~mW} / \mathrm{cm}^{2}$, ELH 1 ight, $28^{\circ} \mathrm{C}$, AR coated

\begin{tabular}{|l|c|c|c|c|}
\hline Ce11 No. & $I_{s c}\left(\mathrm{~mA} / \mathrm{cm}^{2}\right)$ & $V_{o c}(\mathrm{~V})$ & $F F$ & $P\left(\mathrm{~mW} / \mathrm{cm}^{2}\right)$ \\
\hline 1031 & 25.78 & 0.539 & 0.663 & 9.22 \\
1032 & 25.30 & 0.544 & 0.668 & 9.20 \\
1033 & 24.45 & 0.532 & 0.672 & 8.74 \\
1034 & 24.89 & 0.535 & 0.656 & 8.73 \\
1035 & 24.50 & 0.532 & 0.670 & 8.73 \\
1036 & 24.88 & 0.541 & 0.671 & 9.03 \\
1037 & 25.13 & 0.538 & 0.636 & 8.60 \\
1038 & 26.64 & 0.546 & 0.653 & 9.50 \\
1039 & 26.57 & 0.550 & 0.685 & -0.02 \\
10310 & 24.66 & 0.544 & 0.697 & 9.36 \\
\hline Mean Value & 25.28 & 0.540 & 0.667 & 9.11 \\
\multicolumn{2}{|l}{ Standard Error 0.254} & 0.0019 & 0.0054 & 0.132 \\
\hline
\end{tabular}

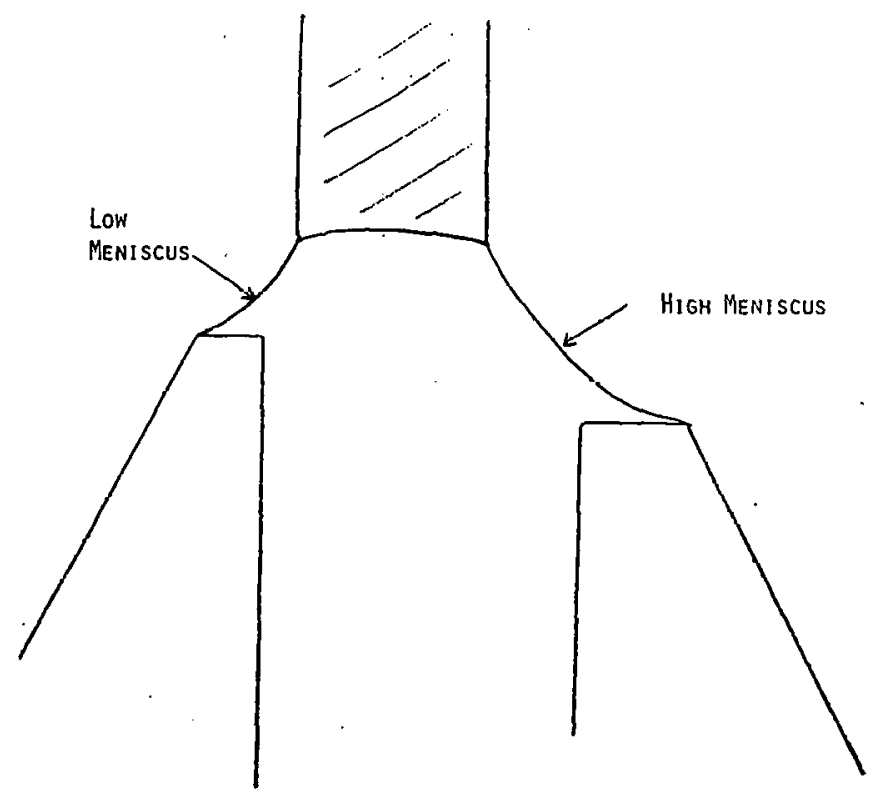

1. Low Meniscus Side has Usual Sic Particle Density 1 - in PartiCLES $1 \mathrm{~cm}^{2}$.

2. Hiah Mfniscus Side ic Virtualli Clear Or 3ic Particles ando EXCEPTIONALLY SMOOTH.

3. Growth Stability Excellent For 0,005" Displacement on 0,020" TOP SLOT FOR SFEEdS 2 - $3.5 \mathrm{~cm} / \mathrm{MIN}$

4. Higher Speeds, Greater Displacements Allow Harrow Ribbon Growth ONLY, 

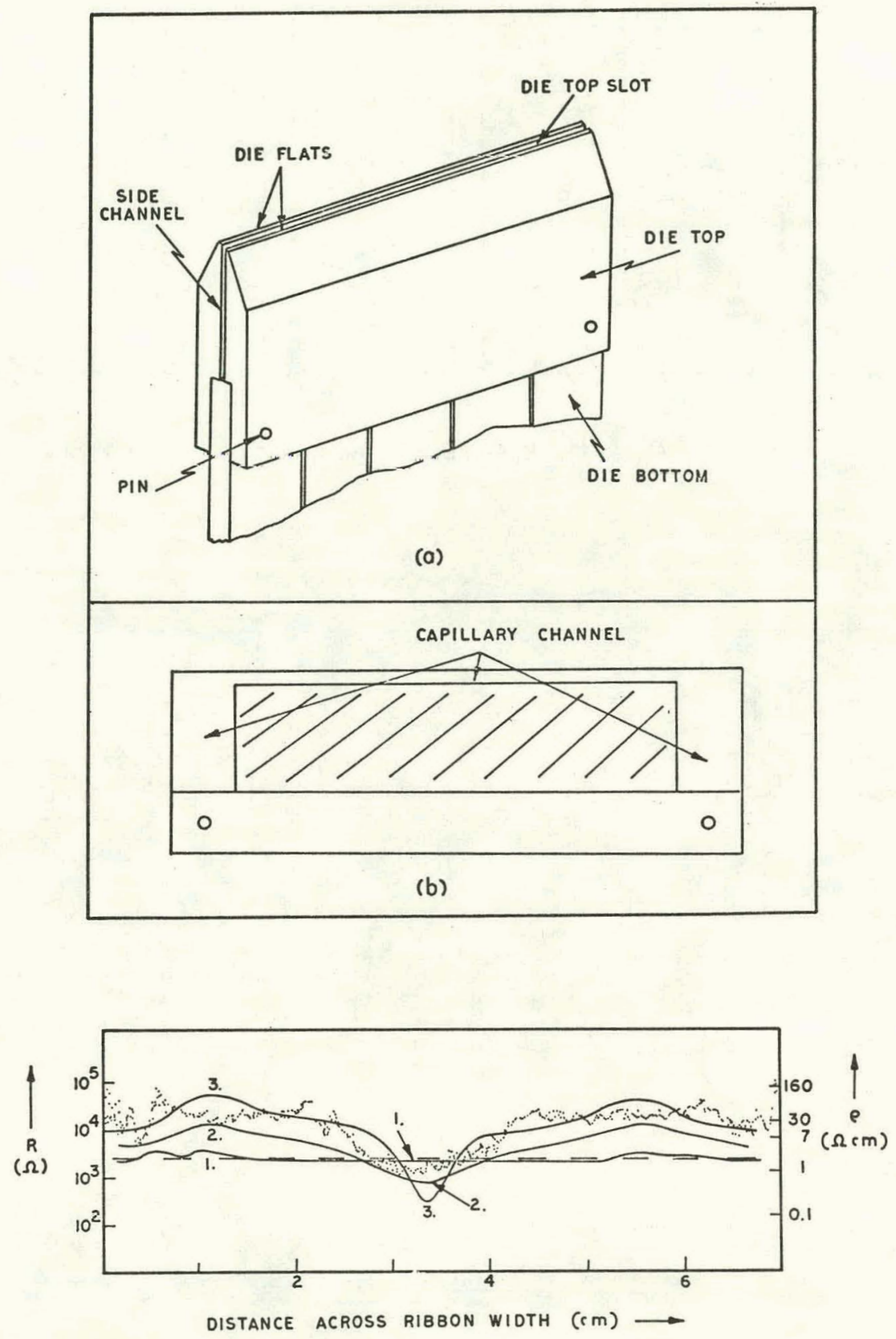

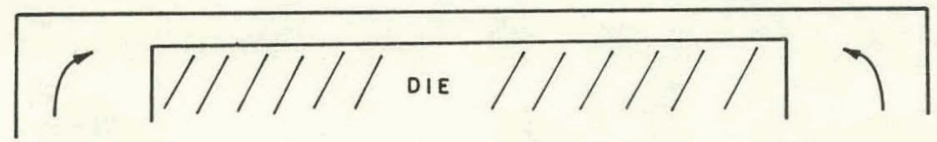



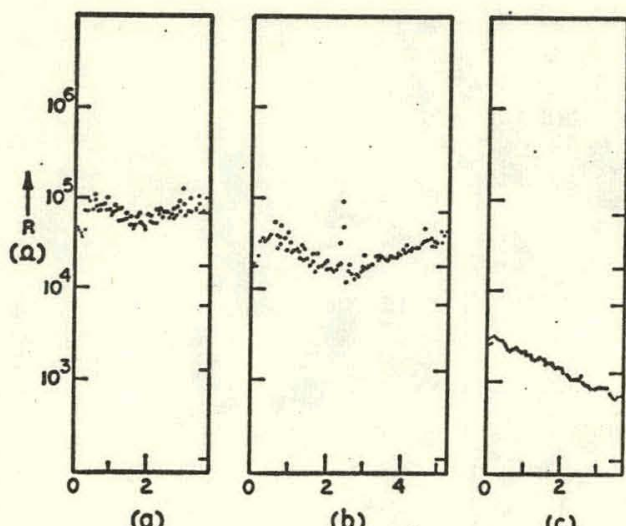

(b)

(c)

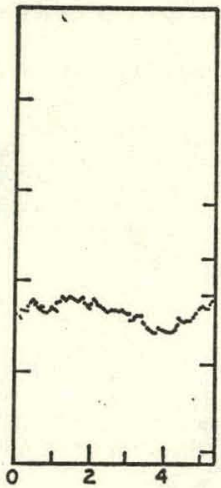

(d)

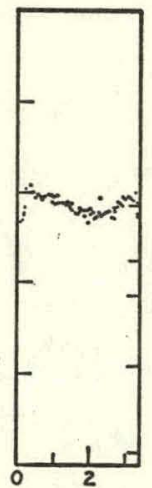

(e)

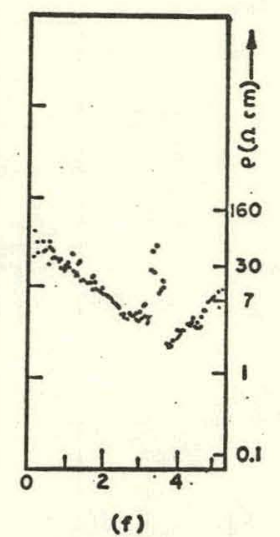

Distance DOWN Bevel $(\mathrm{mm})$

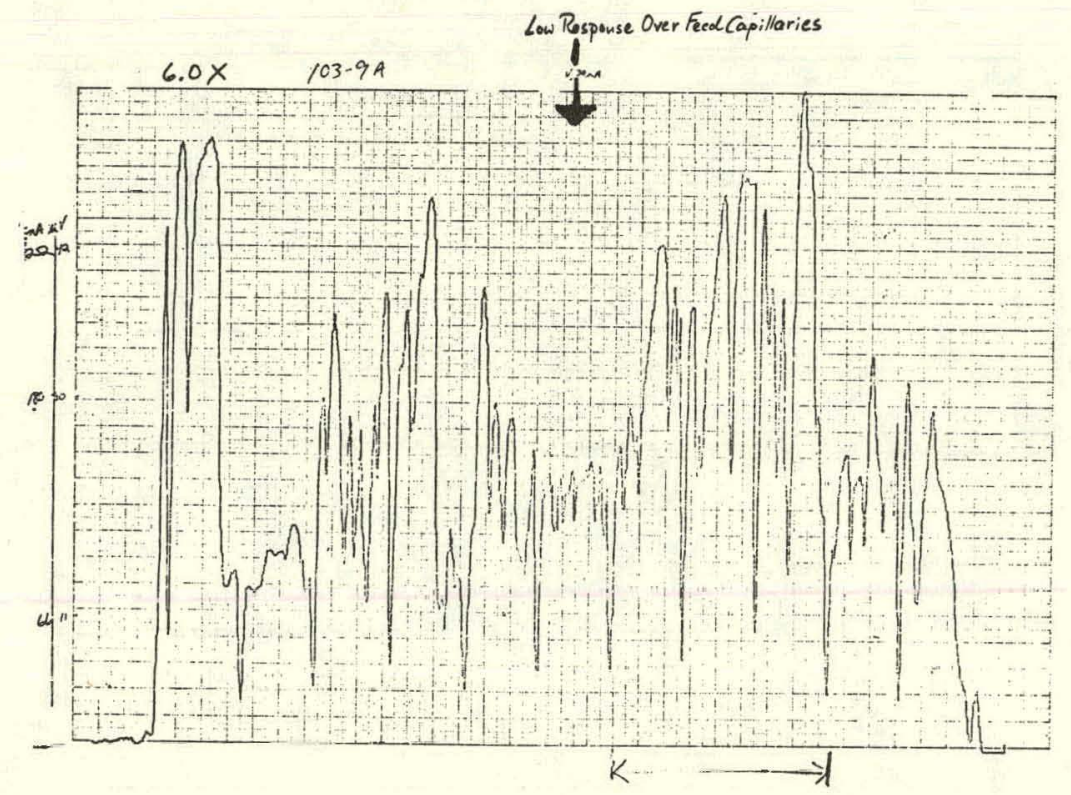

Performance of Selected Solar Cells from Ribbon Grown in Machines 12 and 13 . Grown at $2.5 \mathrm{~cm} / \mathrm{MIN}, 2.5 \mathrm{~cm}$ WidE, RF HEATING.

\begin{tabular}{|c|c|c|c|c|}
\hline $\begin{array}{l}\text { AREA } \\
\left(\mathrm{CM}^{2}\right)\end{array}$ & $\begin{array}{l}V_{\text {OC }} \\
\text { (MV) }\end{array}$ & $\begin{array}{c}\mathrm{I}_{\mathrm{SC}} \\
\left(\mathrm{MA} / \mathrm{cm}^{2}\right)\end{array}$ & FF & $\begin{array}{c}n \\
(y)\end{array}$ \\
\hline 4.20 & 564 & 29.8 & .730 & 13.0 \\
\hline 4.2 & 567 & 29.1 & .737 & 12.9 \\
\hline 4.0 & 580 & 29. & .774 & 14.1 \\
\hline 4.2 & 574 & 29.9 & .742 & 13.5 \\
\hline 4.13 & $5 \in 2$ & 30.0 & .736 & 13.6 \\
\hline
\end{tabular}

Light Intensity $94.5 \mathrm{mk} / \mathrm{Cm}^{2}$. Calibration Based on JPL, TerresTRIAL SECONDARY STANDARD 004. 
Performance of Selected Solar Cells Made from Ribbon Grown in Machine \#l. GRown at $3.5 \mathrm{~cm} / \mathrm{MIN}, 7.5 \mathrm{~cm}$ Wide, Resistance Hieating.

\begin{tabular}{|r|c|c|c|c|}
\hline $\begin{array}{r}\text { AREA } \\
\left(\mathrm{cM}^{2}\right)\end{array}$ & $\begin{array}{c}\mathrm{V}_{\text {OC }} \\
(\mathrm{MV})\end{array}$ & $\begin{array}{c}\mathrm{I}_{\mathrm{SC}} \\
\left(\mathrm{MA} / \mathrm{CM}^{2}\right)\end{array}$ & $\begin{array}{c}\mathrm{FF} \\
(\%)\end{array}$ & $\begin{array}{c}n \\
(\%)\end{array}$ \\
\hline 4.76 & 553 & 27.1 & .714 & 11.3 \\
4.86 & 553 & 26.3 & .761 & 11.7 \\
7.23 & 547 & 25.2 & .751 & 11.0 \\
10.29 & 550 & 25.8 & .749 & 11.2 \\
10.92 & 552 & 24.8 & .754 & 10.9 \\
\hline
\end{tabular}

Light Intensity $94.5 \mathrm{mH} / \mathrm{cm}^{2}$. Calibration Based on JPL, TerresTRIAL SECONDARY STANDARD 004.

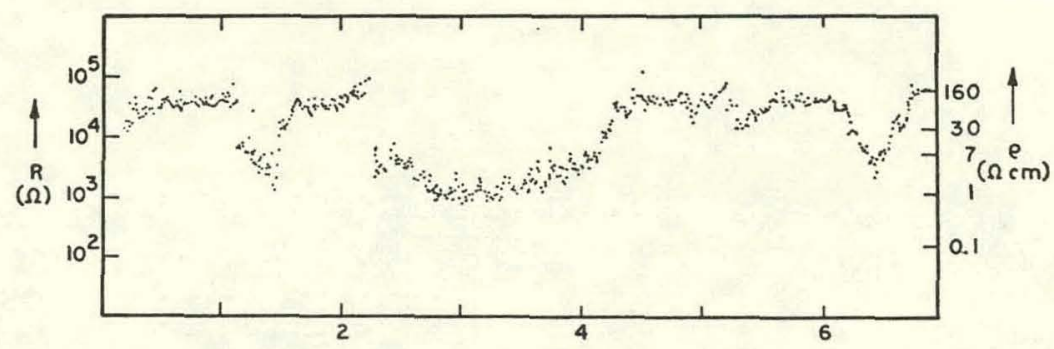

(a)

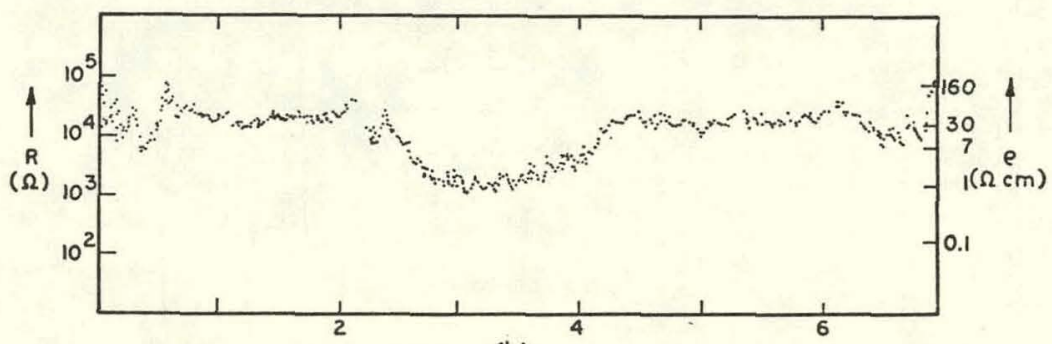

(b)

DISTANCE ACROSS RIBBON WIDTH $(\mathrm{cm}) \longrightarrow$

( P/III/ or IIII/ ) 

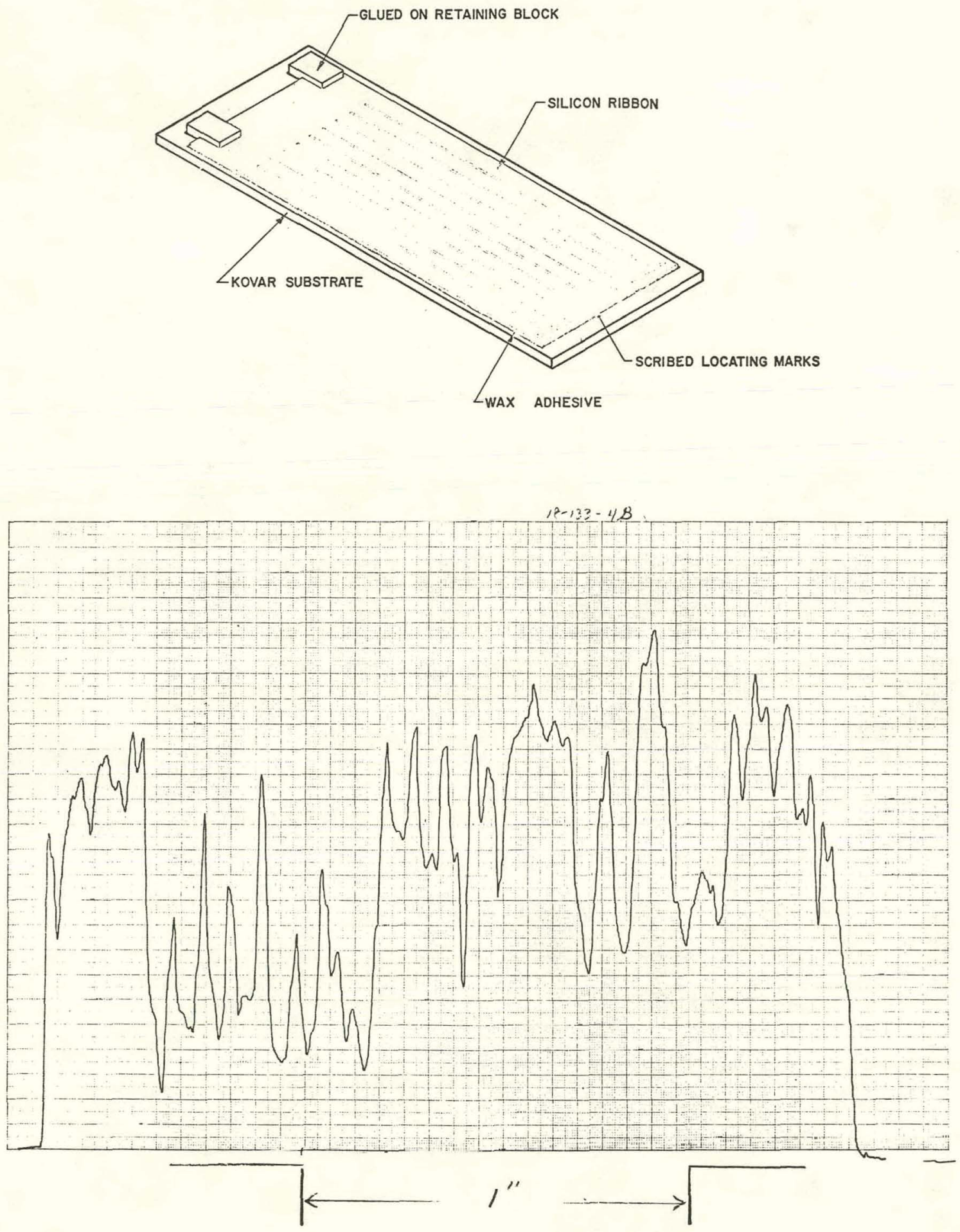


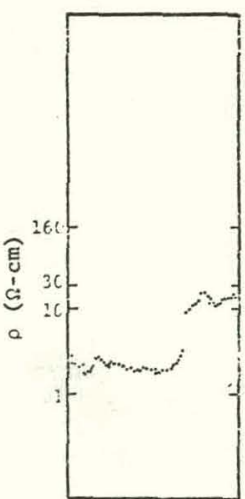

(a)

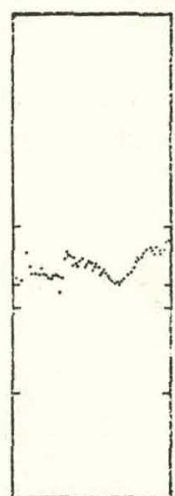

(3)

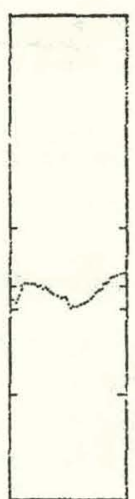

(c)

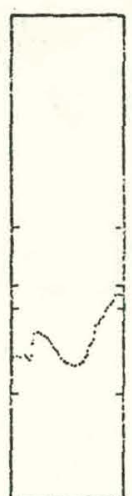

(d)

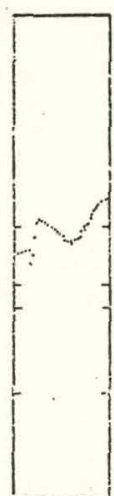

(e)

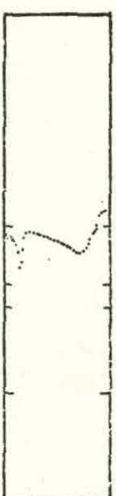

(5)

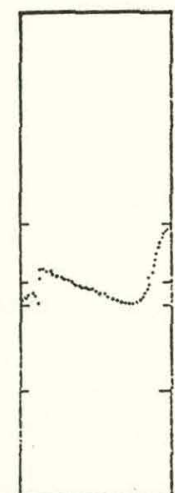

(g)

Eprasing resistance data from displaced die run 18-90. Traces are taken on a beveled surface willilil Llic eroerfsertinn of the ribbon at locations indicated in Fig. 7. The traces go from the low menlscus surface on the left to the high meniscus surface on the right.

MOTOROLA, INC.

\title{
PROGRESS HIGHLIGHTS
}

\author{
Progress has been demonstrated on all aspects of the RTR \\ DEVELOPMENT EFFORT: \\ CELLEFFICIENCY \\ - Cells fabricated on RTR substrates grown fRom CVD \\ FEEDSTOCK HAVE DEMONSTRATED AN AVERAGE EFFICIENCY \\ OF OVER $9 \%$ WITH A. 'BEST' CELL EFFICIENCY OF $11.3 \%$. \\ POLYRIBBON FORMATION \\ - SEQUENTIAL SEPARATION OF LARGE $\left(2^{\prime \prime} \times 24^{\prime \prime}\right)$ POLYRIBBON \\ SUBSTRATES HAS BEEN ACHIEVED IN A SEMI-CONTINUQUS \\ MANNER, WITH A TOTAL OF ALMOST $10^{\prime}$ IN A SINGLE RUN. \\ RTR GROWTH \\ - An alternative growth mode has beEn demonstrated \\ WHICH WILL ALLOW MATERIAL-EFFICIENT RTR GROWTH \\ UTILIZING SHORT SUBSTRATES, THUS ELIMINATING THE \\ NEED FOR NEAR-CONTINUOUS SHEETS OF POLYSILICON \\ FEEDSTOCK,
}

\section{EFFICIENCY AND CONTAMINATION PROBLEMS}

CELL EFFICIENCY IMPROVEMENTS

CEL.I EFFICIENCY IMPROVEMENTS FROM $\pi \leq 6 \%$ TO $\pi \geq 9 \%$ ATTRIBUTED TO:

- Etch removal of Mo contaminatfo surface ( 115 um removen).

- EFFECTIVE GETtERING OCCURRING DURING PH 3 DifFusion.

- GROWTH Without a FURNACE,

PURgeable FurNaCe EXPERIMENTS

GROWTH EXPERIMENTS WITH PURGEABLE FURNACE HAVE NOT GIVEN

REPEATABLE RESULTS. GOOD QUALITY RIBBONS HAVE BEEN GROWN, BUT NOT CONSISTENT.

- Pt eliminated from vicinity of melt.

- Stray beam vaporization does not appear to be a problem IN THESE EXPERIMENTS, 
CVD SOLAR CELLS

\begin{tabular}{|c|c|c|c|c|c|c|c|}
\hline$n$ & L & VOC & JSC & FF & RIBBON \# & LOT $\frac{u}{t}$ & COMMENTS \\
\hline * & & & & & $967 J-1$ & G113 & $\begin{array}{l}\text { SHADINE METAL } \\
\text { FILM ON FRONT }\end{array}$ \\
\hline * & & & $26.3^{*}$ & & $967 J-2$ & ${ }_{3} 113$ & " $" ~ " ~$ \\
\hline & & .515 & 26.2 & & $967 P-1$ & G114 & $\begin{array}{l}\text { BROKEN; } \\
\text { BAD METAL }\end{array}$ \\
\hline 9.4 & & .52 & 27. & 67 & $967 P-2$ & G114 & \\
\hline 6.8 & & .50 & 24.8 & & $967 P-3$ & G114 & \\
\hline 8.9 & & .522 & 27.8 & 62 & $967 U-2$ & 6114 & \\
\hline 8.9 & & .52 & 26.8 & 64 & $967 U-3$ & $611^{4}$ & \\
\hline $10.1^{*}$ & & .517 & 28. * & 70 & $967 R-1$ & 6114 & \\
\hline $11.3^{*}$ & & .533 & $29.4^{*}$ & 72 & $9 \in 7 R-2$ & G.114 & \\
\hline $10.7^{*}$ & & .53 & 27.8 * & 72 & $9 \in 7 R-3$ & f114 & \\
\hline $8.5^{*}$ & & .51 & 26.3 * & 63 & $9670-2$ & fi114 & \\
\hline $7.0^{*}$ & & .486 & 21. " & 69 & $9670-3$ & 6114 & \\
\hline
\end{tabular}

\section{PURGED FURNACE DESIGN}

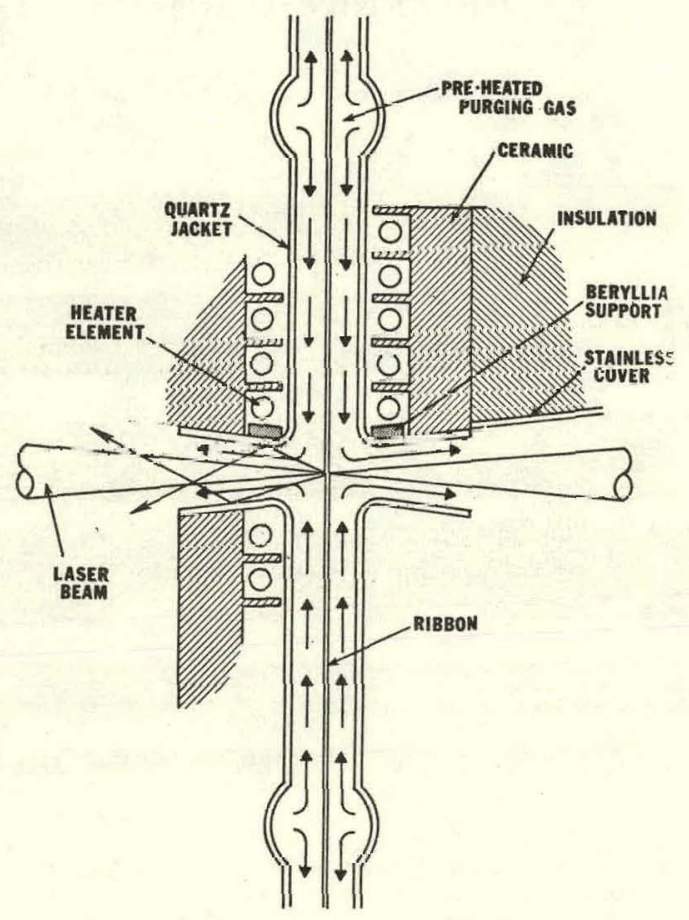




\section{POLYRIBBON FORMATION}

- Problems with end seals have been resolved.

- Good QUALITY Silicon DEPOSitS ARE obTAINED BUt DO NOT ALWAYS SEPARATE.

- Temperature and temperature gradient CONTROL APPEAR CRUCIAL. HIGH YIELD IN BATCH OPERATION HAS NOT CARRIED OVER TO SEMI-CONTINUOUS MODE.

- SUCCESSFUL DEPOSITION AND SEPARATION HAS BEEN DEMONSTRATED IN A SEMI-CONTINUOUS MANNER BUT CONDITIONS NEED TO BE OPTIMIZED.

\section{MULTILAYER SUBSTRATES}

- $\mathrm{Si}_{3} \mathrm{~N}_{4}$ COATEd Mo substrates PROVide goOd nUCLEATION AND RESULT IN POLYRIBBON FEEDSTOCK WITH AN ORDER-OFMAGNITUDE REDUCTION IN MO CONTENT AS MEASURED BY NEUTRON ACTIVATION ANALYSIS.

- OXide coated Mo substrates provide good isolation Between Si and Mo SUbStrate but nuCleation is POOR, AND SEPARATION WILL NOT OCCUR. ADDITION OF A THIN (5000A) COATING OF MO PROVIDES GOOD NUCLEATION, GOOL SEPARATION, AND GOOD ISOLATION.

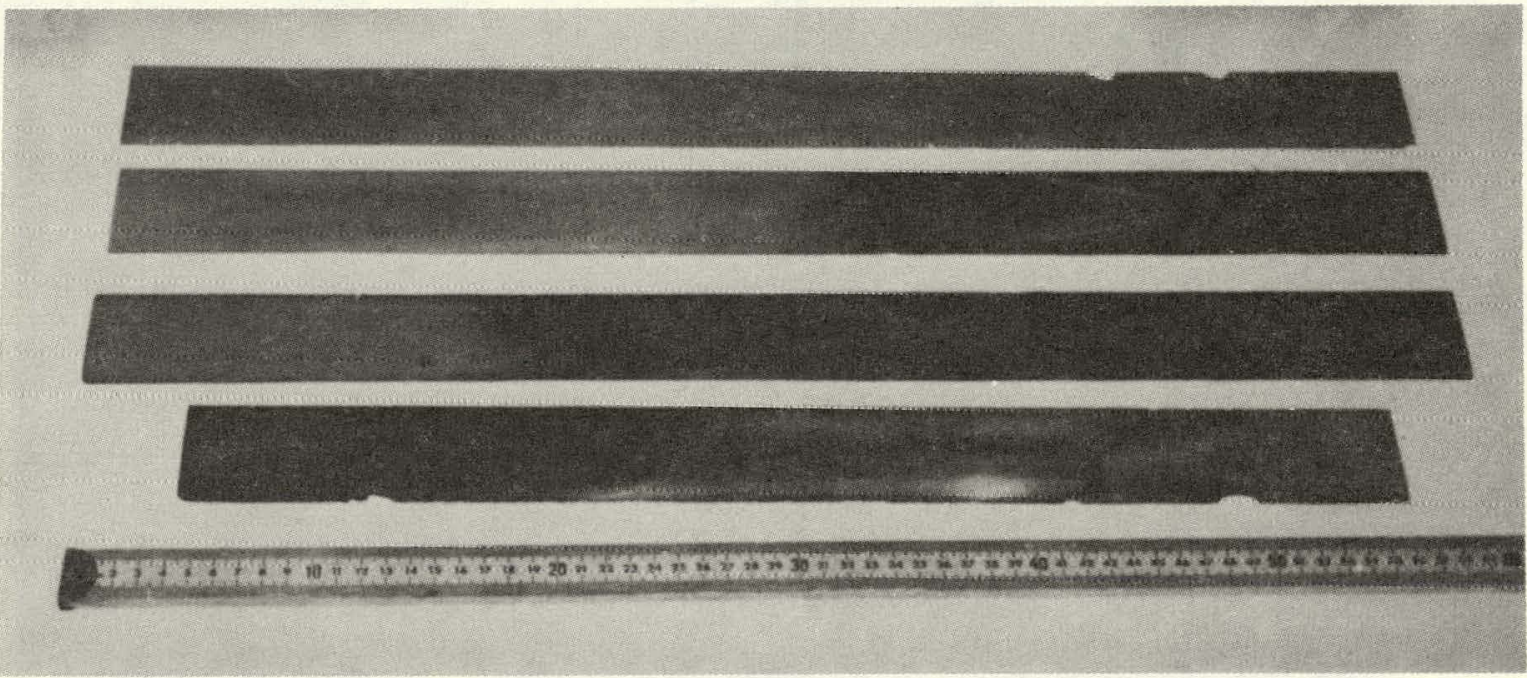

\section{HIGH THROUGHPUT RTR GROWTH}

\footnotetext{
- Multiple ribBon growth has already been demonstrated BY GROWTH OF 4 RIBBONS SIMULTANEOUSLY. AREA GROWTH RATE IS LIMITED BY FURNACE ZONE WIDTH.

- Fabrication IS NEARLY COMPLETE ON A FURNACE WHICH WILL ALLOW $15 \mathrm{CM}$ WIDE GROWTH (TWO $7.5 \mathrm{cM}$ OR THREE $5 \mathrm{cM}$ WIDE RIBBONS) \& AN AREA GROWTH RATE OF $100 \mathrm{~cm}^{2} / \mathrm{MIN}$ SHOULD BE ATTAINABLE.
} 


\section{RTR GROWTH}

A TECHNIQUE hAS BEEN DEMONSTRATED WHICH ALLOWS USE OF SHORT SUBSTRATES FOR RTR GROWTH, THIS TECHNIOUE, BASED ON RIGID EDGE RTR GROWTH, WILL:

- Allow material efficiencies in excess of 90\% even IN A $5 \mathrm{CM} \times 25$ CM SAMPLE SIZE.

- RELAX REQUiREMENTS ON POLYRIBBON FORMATION.

- REDUCE THE IMPACT OF POLYRIBBON BREAKAGE DURING RTR GROWTH.
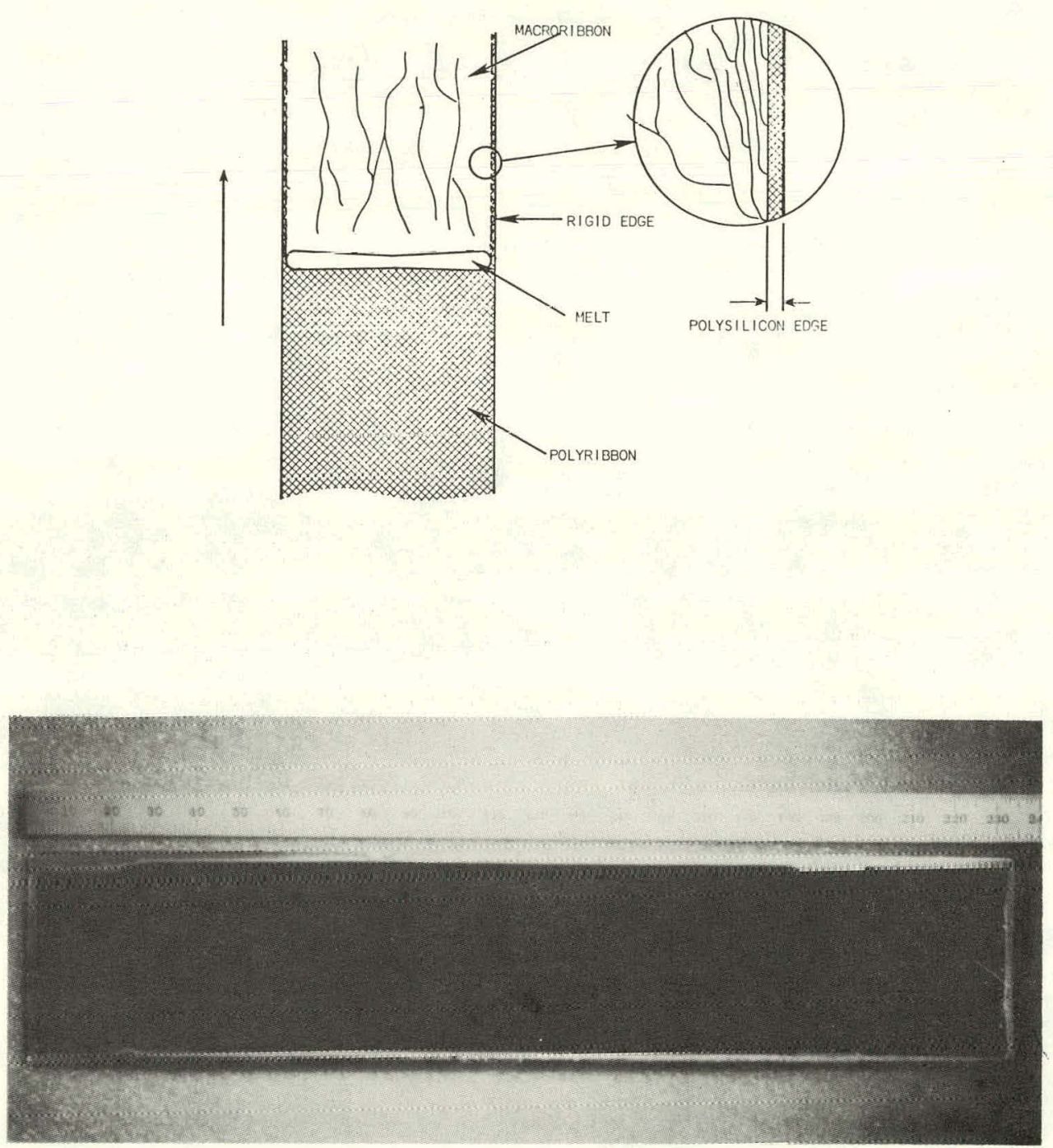


\section{PROGRAM PLANS}

1. Continue efforts to resolve furnace contamination problem.

2. Perform high area growth rate experiments with new furnace.

3. Complete fabrication of large area cells.

WESTINGHOUSE (WEB)

\section{SILICON WEB}

\begin{tabular}{|c|c|}
\hline & IECHNOLOGY STATUS \\
\hline AREA THROUGHPUT & Maximum Demonstrated $19.8 \mathrm{~cm}^{2} /$ Min \\
\hline MELI REPLENLSHMENI & $\begin{array}{l}\text { Polysilicon Fed Simultaneously with } \\
\text { Growth of High Quality Web }\end{array}$ \\
\hline CELL EFEICIENCY & $\begin{array}{l}\text { Average } \sim 13 \% \text { AMI } \\
\text { MaXImuM } 15.5 \% \text { AM1 }\end{array}$ \\
\hline
\end{tabular}

Curve 713010-A

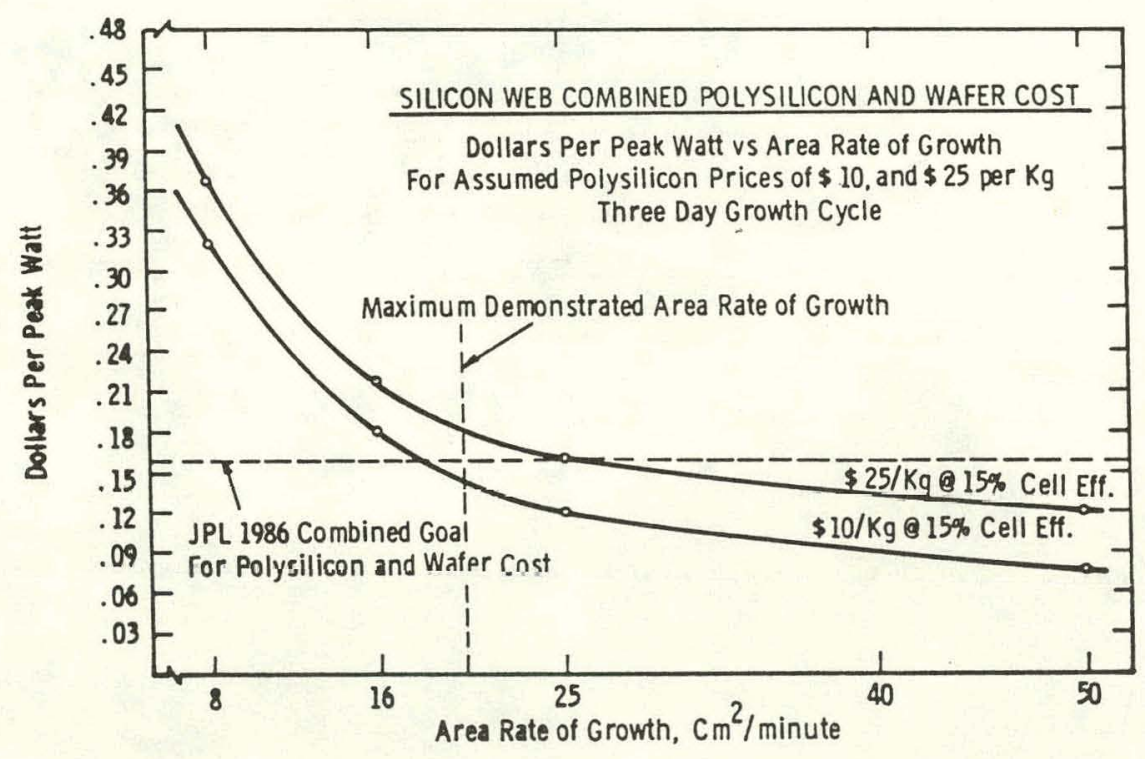




\section{SILICON WEB}

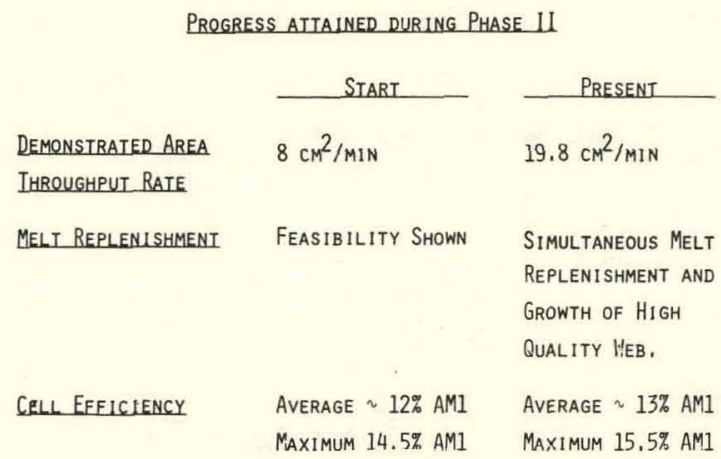

\section{REGIONS OF THERMALLY GENERATED STRESS}

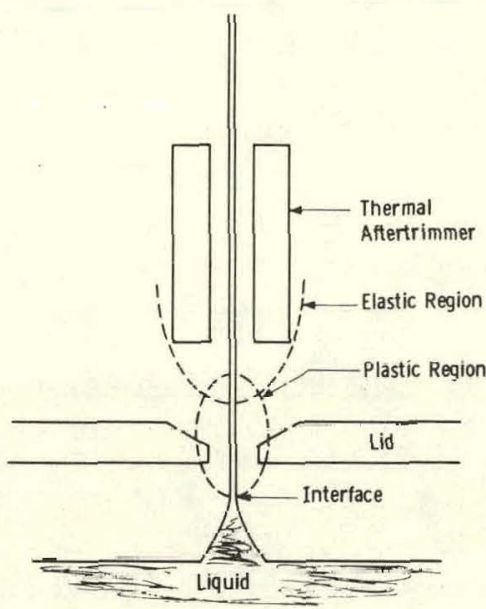


RELATIONSHIP BETWEEN ETCH PIT (DISLOCATION) DENSITY AND RESIDUAL STRESS

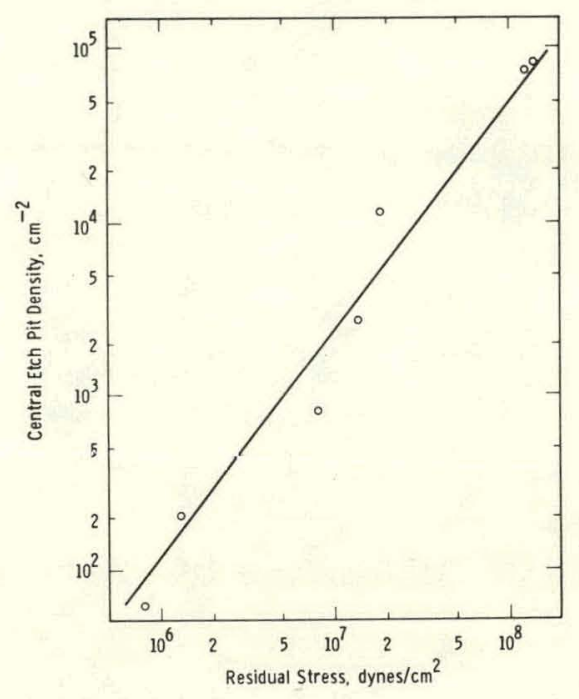

R. Seidensticker

c. m. - 1. r. $2-15-79$

COLD AFTERTRIMMER FOR CONTROL OF THERMALLY GENERATED STRESS

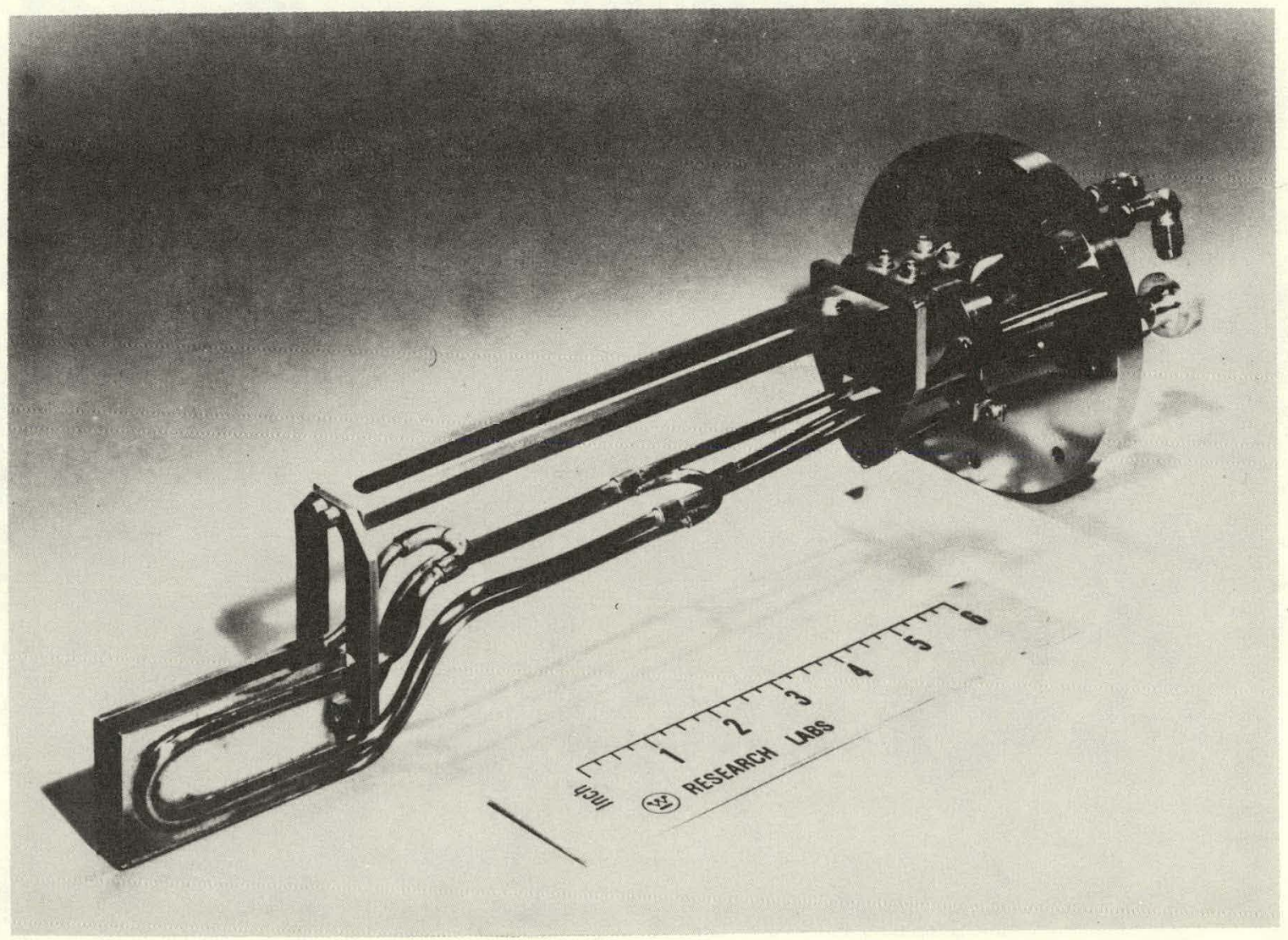




\section{RECENT THROUGHPUT RESULTS}

\begin{tabular}{|c|c|c|c|}
\hline RUN NO. & $\begin{array}{c}\text { THROUGHPUT RATE } \\
\mathrm{cm}^{2} / \mathrm{min}\end{array}$ & $\begin{array}{c}\text { WIDTH } \\
\mathrm{mm}\end{array}$ & $\begin{array}{c}\text { GROWTH VELOCITY } \\
\mathrm{cm} / \mathrm{min}\end{array}$ \\
\hline J -95 & 12.3 & 23.0 & 5.35 \\
\hline$J-123$ & $\begin{array}{r}11.4 \\
8.8\end{array}$ & $\begin{array}{l}22.4 \\
30.8\end{array}$ & $\begin{array}{l}5.1 \\
2.9\end{array}$ \\
\hline $\mathrm{J}-125$ & 14.7 & 25.0 & 5.9 \\
\hline$J-126$ & 12.2 & 14.7 & 8.3 \\
\hline RE-98 & $\begin{array}{l}11.2 \\
12.7\end{array}$ & $\begin{array}{l}26.2 \\
25.5\end{array}$ & $\begin{array}{l}4.3 \\
5.0\end{array}$ \\
\hline$. T-129$ & 12.3 & 24.2 & 5.1 \\
\hline RE-99 & $\begin{array}{l}12.7 \\
14.8\end{array}$ & $\begin{array}{l}23.2 \\
27.9\end{array}$ & $\begin{array}{l}5.5 \\
5.3\end{array}$ \\
\hline RE-100 & $12: 8$ & 21.3 & 6.0 \\
\hline$J-131$ & $\begin{array}{l}12.7 \\
13.7 \\
14.3 \\
12.3\end{array}$ & $\begin{array}{l}26.5 \\
29.3 \\
26.0 \\
24.2\end{array}$ & $\begin{array}{l}4.8 \\
4.7 \\
5.5 \\
5.1\end{array}$ \\
\hline RE-101. & 10.4 & 27.5 & 3.8 \\
\hline RE-102 & $\begin{array}{l}11.9 \\
13.4\end{array}$ & $\begin{array}{l}23.9 \\
26.7\end{array}$ & $\begin{array}{l}5.0 \\
5.0\end{array}$ \\
\hline$J-133$ & $\begin{array}{l}15.7 \\
13.9\end{array}$ & $\begin{array}{l}29.1 \\
32.3\end{array}$ & $\begin{array}{l}5.4 \\
4.3\end{array}$ \\
\hline$J-135$ & 12.2 & 24.0 & 5.1 \\
\hline RF $-10 b$ & 19.8 & 33.0 & 0.0 \\
\hline RF -107 & 15.1 & 35.5 & 4.25 \\
\hline $\mathrm{RE}-108$ & 16.4 & 31.6 & 5.2 \\
\hline RE-113 & 14.3 & 30.4 & 4.7 \\
\hline
\end{tabular}

\section{SILICON WEB}

Continuous Melt Replenishment is a Critical Requirement

- Provides long periods of unintfrrupted growtil.

- Pruvides sustainfod growth at minimum thermal STRES3 -- PERMIIS INCREASED WIDTH.

- Provides sustained growth at maximum speed. 
SIMPLIFIED SCHEMATIC OF MECHANIZED MELT REPLENISHMENT SYSTEM
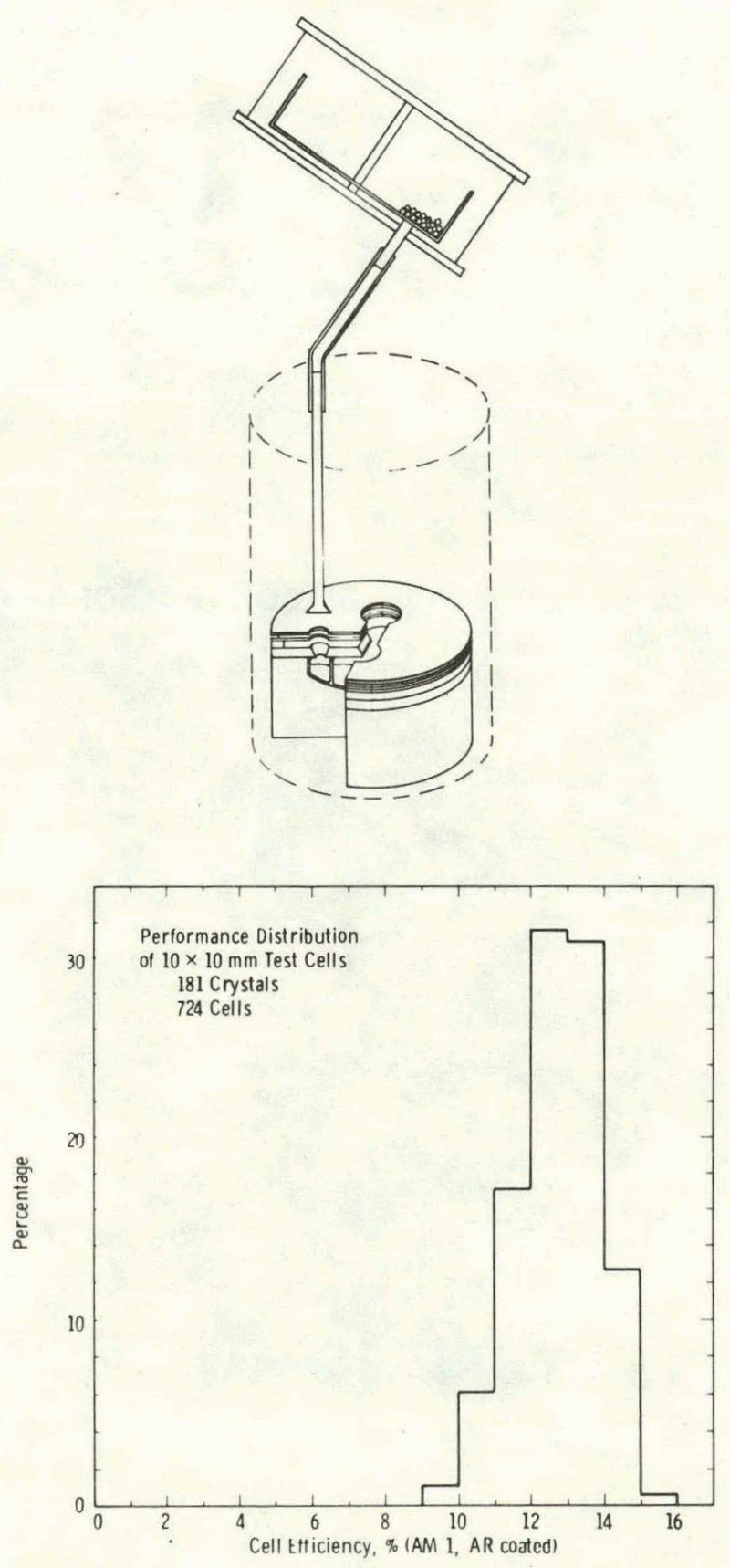

3-129 
WEBQUAL $20=$ DATA SUMMARY

$$
A=1.039 \mathrm{~cm}^{2}, A M 1 \odot 91.6 \mathrm{~mW} / \mathrm{cm}^{2}
$$

\begin{tabular}{|c|c|c|c|c|c|c|c|c|}
\hline CRYSTAL & NO. CELLS & $\begin{array}{l}{ }_{\mathrm{mA}}^{\text {I }} \\
\text { f }^{2}\end{array}$ & $\begin{array}{l}\text { VoC } \\
\text { voLtT }\end{array}$ & $\mathrm{FF}$ & $n_{0}$ & ${\underset{\delta}{\alpha}}_{A R}^{n_{n}}$ & $\begin{array}{l}\tau_{O C D} \\
{ }_{\text {usec }}\end{array}$ & NOTES \\
\hline RE12-3.2 & 4 & 22.18 & .548 & .737 & 9.47 & 13.5 & 11.4 & STD. \\
\hline RE102-2.2 & 4 & 20.18 & .520 & .734 & 8.15 & 11.7 & 3.8 & \\
\hline $\mathrm{J} 131-2.2$ & 4 & 20.98 & .537 & .746 & 8.88 & 12.7 & 6.3 & \\
\hline $\mathrm{J} 131-3.4$ & 4 & 19.40 & .513 & .733 & 7.73 & 11.1 & 2.8 & \\
\hline $\mathrm{J} 134-2.2$ & 4 & 21.70 & .536 & .749 & 9.21 & 13.2 & 6.7 & \\
\hline W141-1.2 & 4 & 21.90 & .569 & .738 & 9.73 & 13.9 & 6.3 & \\
\hline W151-1.2 & 4 & 22.18 & .543 & .738 & 9.35 & 13.4 & 8.6 & FEED EXPT. \\
\hline W154-1.4 & 4 & 21.58 & .542 & .722 & 8.92 & 12.8 & 7.5 & FEED EXPT. \\
\hline W154-2.3 & 4 & 21.35 & .531 & .734 & 8.79 & 12.6 & 5.4 & FEED EXPT. \\
\hline
\end{tabular}

\section{SOLAR PANEL MADE WITH SILICON WEB SOLAR CELLS}

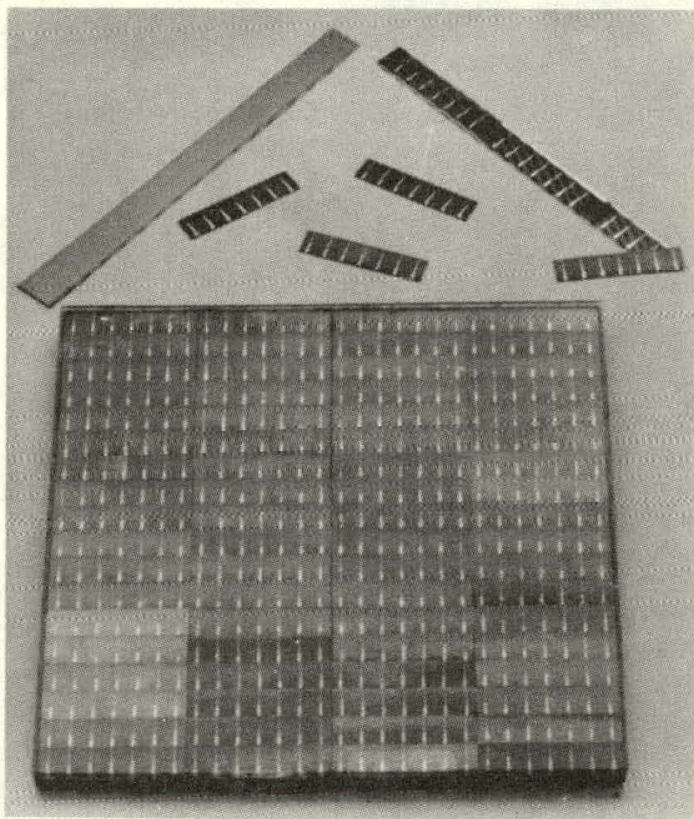




\section{SILICON WEB}

Major Technical. Requirements for 1986 Goal HAVE NOW BEEN DEMONSTRATED.

- $20 \mathrm{~cm}^{2} /$ minute Web throughput rate.

- Simultaneous melt replenishment with WEB GROWTH OF HIGH QUALITY ( $\cap$ WITH REPLENISHMENT $=n$ W/O REPLENISHMENT).

- Cell efficiency $\geq 15 \%$ aml.

Necessary Developments to Reach 1986 Sheet Goals

- Sustained melt replenished high THROUGHPUT GROWTH (TO $25 \mathrm{~cm}^{2} / \mathrm{MIN}$ ).

- Mean cell efficiency $\geq 15 \%$.

- Automated growth. 


\section{c. Encapsulation Task}

\section{OBJECTIVES:}

1. DEFINE, UEVELUP, DEMONSTRATE ENCAPSULATION SYSTEMS, MATER IALS, AND PROCESSES TO MEET THE LSA PROJECT LIFE, COST, ANE PERFGRMANCE GOALS

2. DEVELOP AND VALIDATE A MODUILE LIFE PREDICTION IMETHODOLOGY BASED ON MODELING LIFE-LIMITING FAILURE. MODES AND ON CONDUCTING ANO ANALYZING ACCELERATEO AGING TESTS

\section{TECHNOLOGY READINESS}

1. NARRDA LIST OF CAMIDATE EICAPSULATICH YYSTE:S LYITRIALS, AMD PROCESSES CAPABLE OF IETING 1986 COST AND PEPFRPATE CMLLS

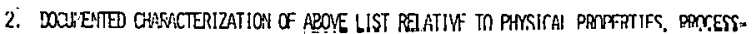

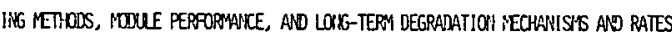

3. TEOHIOLDGY TRAHSFER TO INDLSTRY VIA PPBORTS, PINS, AND DIRECT PATTIIIPATION IN . DESLEN, ANVLYSES, AN TESTINO 


\section{FLAT-PLATE PHOTOVOLTAIC ENCAPSULATION SYSTEM DESIGN}

SUPERSTRATE BONDED

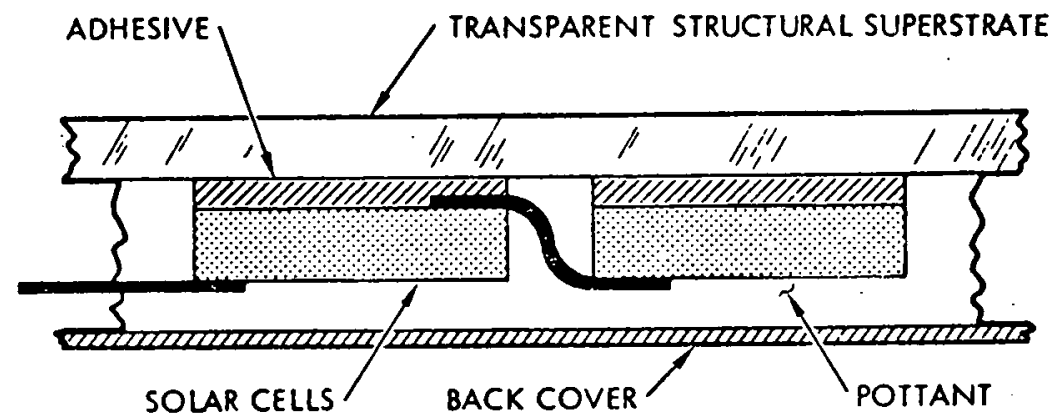

SUBSTRATE BONDED

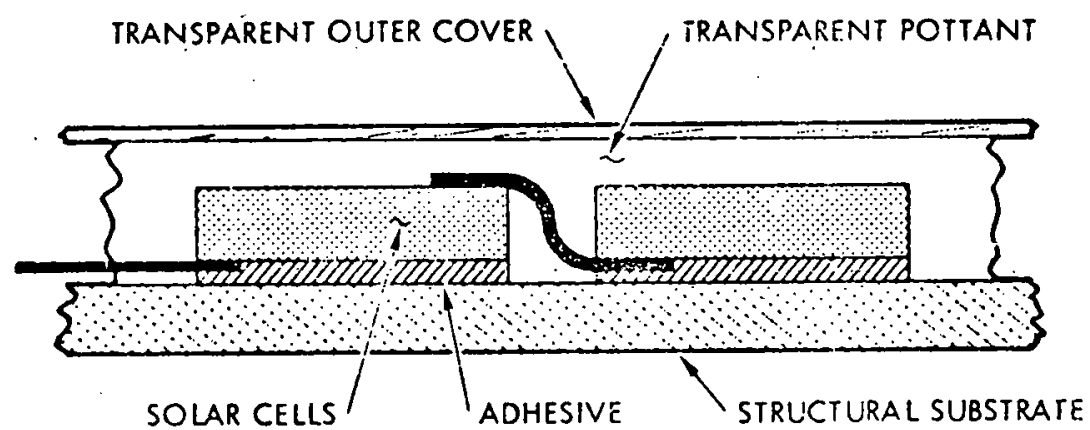

LAMINATED

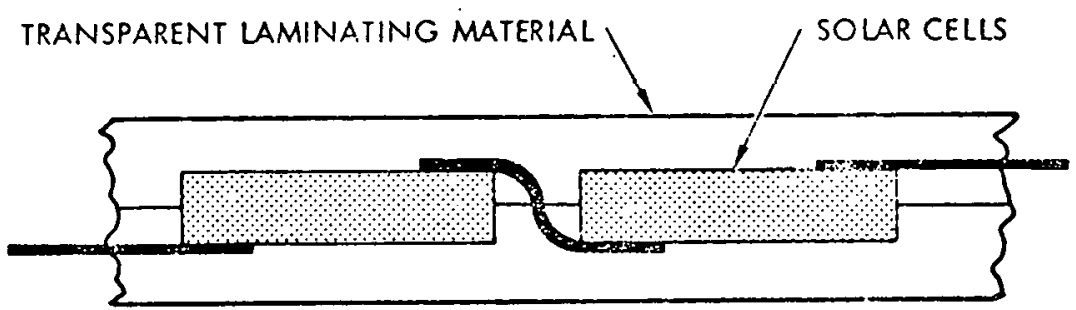


COST COMPARISON FOR SUPERSTRATE AND SUBSTRATE MATERIALS (APPROXIMATELY 1978 DOLLARS)

\begin{tabular}{|c|c|c|c|}
\hline Materials & $\begin{array}{c}\text { Buik Cost } \\
\$ / \mathrm{kg}\end{array}$ & $\begin{array}{c}\text { Panel Thickness } \\
\mathrm{cm}\end{array}$ & $\begin{array}{c}\text { Panel } \\
\$ / m^{2}\end{array}$ \\
\hline \multicolumn{4}{|l|}{ Iransparent Superstrates } \\
\hline Soda Lime Glass & 0.51 & 0.25 & 3.15 \\
\hline Low-iron Tempered Glass & -- & 0.32 & 7.50 \\
\hline Borosilicate Glass & $\cdots$ & 0.32 & $5.00-15.00$ \\
\hline Acrylic (PMPAA) & 3.12 & 0.80 & 19.00 \\
\hline Polycarbonate & 4.00 & 0.80 & 37.00 \\
\hline \multicolumn{4}{|l|}{ Structural substrates } \\
\hline Epoxy/Fiberglass & 6.17 & 0.35 & 44.00 \\
\hline Kraft paper honeycomb & $\cdots$ & 2.5 & 1.00 \\
\hline Plywood & -- & 0.54 & 1.61 \\
\hline Hardboard & -- & 0.58 & 1.44 \\
\hline Mild Steel & 0.34 & 0.17 & 4.53 \\
\hline Aluminum & 1.88 & 0.25 & 12.44 \\
\hline Stainless Steel & 2.50 & 0.17 & 34.00 \\
\hline Glass ReInforced Concrete & 0.18 & 0.64 & 3.00 \\
\hline
\end{tabular}




\section{COST COMPARISON FOR TRANSPARENT POTTANT MATERIALS (APPROXIMATELY 1978 DOLLARS)}

\begin{tabular}{lcc} 
Material Candidate & $\begin{array}{c}\text { Module Cost } \\
\text { Bulk Cost } \\
\$ / \mathrm{kg}\end{array}$ & $\begin{array}{c}\text { (cents } / \mathrm{m}^{2} \\
\text { per } 0.025 \mathrm{~mm} \\
\text { thickness }\end{array}$ \\
\hline $\begin{array}{l}\text { Weatherable } \\
\text { Acrylics }\end{array}$ & 3.30 & 10.7 \\
$\quad$ Silicone gels & 8.25 & 21.5 \\
Silicone elastomers & 19.80 & 53.8 \\
Fluorocarbons and & 14.85 & $>53.8$ \\
Halocarbons & $>\mathrm{tn}$ & \\
Requires uv protection & $>44.00$ & \\
Ethylene propylene rubber & 1.10 & 2.4 \\
Ethylerie vinyl acetate & 1.10 & 2.6 \\
Polyvinyl chloride plastisol & 1.32 & 4.0 \\
Polyvinyl Butyral & $\ldots$ & 12.3
\end{tabular}

BATTELLE MEMORIAL INSTITUTE

SUMMARY OF MODULE $R_{S}$ MEASUREMENTS: $R_{S}$ IN OHMS

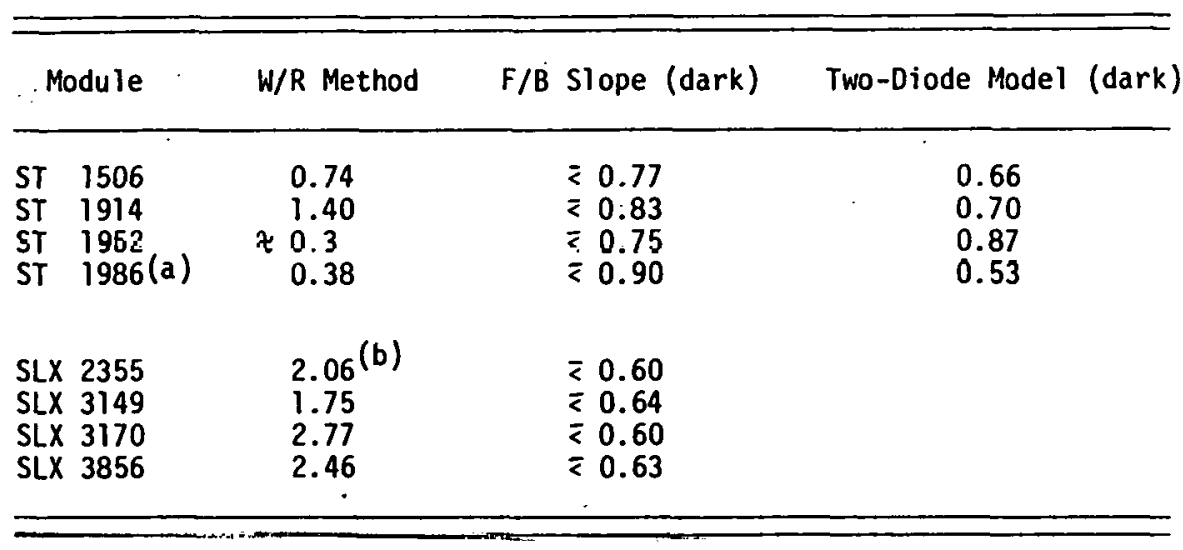

a. No field exposure

b. Non-uniform illumination effects to some degree 
PHYSICAL PROPERTIES GLASS FIBER REINFORCED CONCRETE
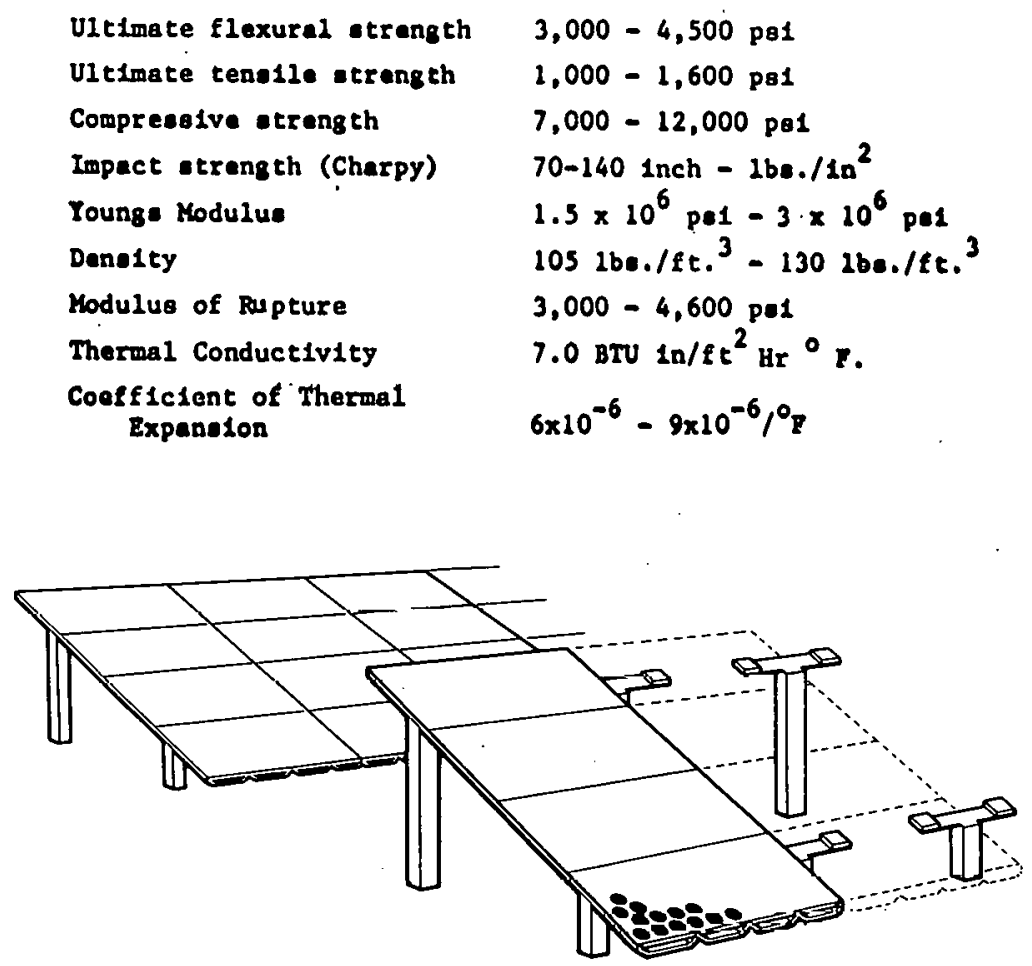

A POSSIBLE FIELD ARRAY CONCEPT INDICATING POSTS AND BRACKETS SUPPORTS

SPIRE

\section{INTEGRAL GLASS ENCAPSULATION FOR SOLAR ARRAYS PHASE III PROGRAM OBJECTIVES}

- LOW leVFI PRODUCtION OF STANDARD ESB MODULES

- DEMONSTRATF PROMIITTIION RATE AND YIELD OF ESB MODULES

- INSURE READINESS FOR PROCESS SCALE UP

- incorporation of eSB mOdULES INTO JPL MINIMODULES CONFIGURATION

- development and production of adVAnCed modules

- PREFORMED WIRE MESH CONTACTS

- hIGH EFFICIENCY CELls

- develop engineering concepts for large AREA BONDER 
ETHYLENE - VINYL ACETATE COPOLYMER SURVEY

\begin{tabular}{|c|c|c|c|}
\hline $\begin{array}{c}\text { EVA } \\
\text { Compound }\end{array}$ & $\begin{array}{c}\text { Total } \\
\text { Integrated } \\
\text { Transmission } \\
\text { (Visible) } \\
\text { Tq }\end{array}$ & $\begin{array}{l}\text { Average } \\
\text { (g/lo min) } \\
\text { Equivalent } \\
\text { Melt Index }\end{array}$ & $\begin{array}{l}\text { Cost } \\
(\$ / 1 b .)\end{array}$ \\
\hline EY 901-25 & 86 & 7.5 & $\$ 0.64$ \\
\hline UE $654-35$ & 84 & 48.0 & $\$ 0.645$ \\
\hline UE $638-35$ & 86 & 24.0 & $\$ 0.635$ \\
\hline UE 646-04 & 85 & 25.0 & $\$ 0.615$ \\
\hline Elvax $150^{(a)}$ & 91 & 43 & $\$ 0.575$ \\
\hline Elvax 240 & 89 & 43 & $\$ 0.545$ \\
\hline Elvax 250 & 91 & 25 & $\$ 0.545$ \\
\hline Elvax 260 & 86 & 6 & $\$ 0.545$ \\
\hline Elvax 420 & 82 & 151 & $\$ 0.545$ \\
\hline Elvax 350 & 87 & 19 & $\$ 0.505$ \\
\hline Elvax $4260^{(b)}$ & 87 & 6.0 & $\$ 0.675$ \\
\hline Elvax $4320^{(b)}$ & 91 & 150 & $\$ 0.635$ \\
\hline Elvax $4355^{(b)}$ & 91 & 6.0 & $\$ 0.665$ \\
\hline
\end{tabular}
(a) Presently used compound.
(b) Acid Terpolymer.

\section{CURRENT EVA PIGMENTED FORMULATION(1)}

\begin{tabular}{lcr} 
MATERIAL & \multicolumn{1}{c}{ DESCRIPTION } & PARTS \\
\cline { 2 - 2 } ELVAX 150 & - & 100.0 \\
LUPERSOL 101 & ZINC OXIDE & 1.5 \\
KADOX 15 & TITANIUM DIOXIDE & 4.0 \\
TITANOX RF-3 & .UV ABSORBER & 1.5 \\
FERRO AM-105 & & 0.25
\end{tabular}

(1) $8320 \mathrm{~B}$ 


\section{EVA REFORMULATION}

ELIMINATION OF SR-350 CROSSLINKING AGENT

ADVANTAGES :

- BETTER CURE - HIGHER GEL CONTENT

- ELIMINATION OF A VOLATILE COMPONENT

- COST REDUCTION IN TOTAL FORMULATION

- ONE LESS VARIABLE

DISADVANTAGES :

. HIGHER EXTRUSION TEMPERATURES DEVELOPED

- POOR PIGMENT DISPERSION IN WHITE COMPOUND

PIGMENT DISPERSION MAY BE SOLVED BY PRECOMPOUNDING SMALL VOLUMES OF RESIN WITH HIGH PIGMENT LOADINGS AND BLENDING PRIOR TO EXTRUSION.

\section{VACUUM BAG PROCESS}

1. ASSEMBLE MATERIALS AND SEAL EDGES.

2. PI.ACE MATERIAL ASEEMBLY DETWEEN PLATEAND-FRAME / DIAPHRAGM,

3. PLACE FRAME/DIAPHRAGM ON SUPPORT PLATE.

4. APPLY VACUUM : REMOVE AIR AND COMPRESS ASŚËMBLY.

5. POSITION VACUUM BAG BETWEEN HEATED PLATENS OF HYDRAUI.T.C. PRESS.

6. CURE FOR 20 MINUTES, ABOVE $140^{\circ} \mathrm{C}$. 
KORAD 201R UV STABILIZED ACRYLIC OUTER COVER

$\begin{array}{lc}\text { Tensile strength, psi } & 4400 \\ \text { Yield strength, psi } & 4200 \\ \text { Elongation, \% } & 130 \\ \text { Light transmission, \% } & 92 \\ \text { Haze, \% } & 1.3 \\ \text { Gloss at } 60^{\circ} & 92 \\ \text { Glass transision }\left(\mathrm{T}_{\mathrm{g}}\right) & 88^{\mathrm{U}} \mathrm{C}\end{array}$

SCRIM MATERIAL SURVEY

\begin{tabular}{|c|c|c|c|}
\hline Manufacturer & $\begin{array}{c}\text { Cell Size } \\
\text { (Mils x Mils) }\end{array}$ & $\begin{array}{c}\text { Scrim } \\
\text { Thickness } \\
\text { (Mil) }\end{array}$ & Cost $\left.\$ / f t^{2}\right)$ \\
\hline \multirow{6}{*}{$\begin{array}{l}\text { Burlington } \\
\text { Glass } \\
\text { Fabrics } \\
\text { (Glass Fiber) }\end{array}$} & $50 \times 100$ & 5 & $\$ .038$ \\
\hline & $33 \times 63$ & 4.5 & $\$ .027$ \\
\hline & $50 \times 50$ & $\cdot 4$ & $\$ .017$ \\
\hline & $33 \times 71$ & 6.2 & $\$ .025$ \\
\hline & $50 \times 100$ & 4 & $\$ .013$ \\
\hline & $50 \times 100$ & 4.7 & $\$ .014$ \\
\hline \multirow{3}{*}{$\begin{array}{l}\text { Bay Mills } \\
\text { (Bayex) } \\
\text { (Polyester) }\end{array}$} & $500 \times 1000$ & $\sim 10$ & $\$ .005$ \\
\hline & $125 \times 125$ & $\sim 10$ & $\$ .022$ \\
\hline & $2000 \times 1000$ & $\sim 6$ & $\$ .003$ \\
\hline \multirow{5}{*}{$\begin{array}{l}\text { Apex } \\
\text { Mills } \\
\text { Corp. } \\
\text { (Nylon) }\end{array}$} & $50 \times 50$ & $\sim 5$ & $\$ .028$ \\
\hline & $125 \times 125$ & $\sim 12$ & $\$ .042$ \\
\hline & $63 \times 63$ & $\sim 8$ & $\$ .041$ \\
\hline & $438 \times 438$ & $\sim 14$ & $\$ .047$ \\
\hline & $34 \times 34$ & $\sim 5$ & $\$ .04$ \\
\hline
\end{tabular}




\section{MODULE NUMBER 5 \\ SUBSTRATE DESIGN - SUPER DORLUX}

MATERIAL ASSEMBLY

. KORAD 201-R OUTER COVER

- Clear eVa potTant

- solar cells (FACE UP)

- SCRIM SPACER

- WHITE EVA

- SUPER DORLUX SUBSTRATE

- WHITE EVA

- OLASS FIBEK CLUIH-HEAT RADIATION

\section{CORROSION TESTING}

\begin{tabular}{lll} 
SALT & SALT & HIGH \\
SPRAY & SPRAY & HUMIDITY \\
2.4 HRS & 450 HRS & 450 HRS \\
\hline
\end{tabular}

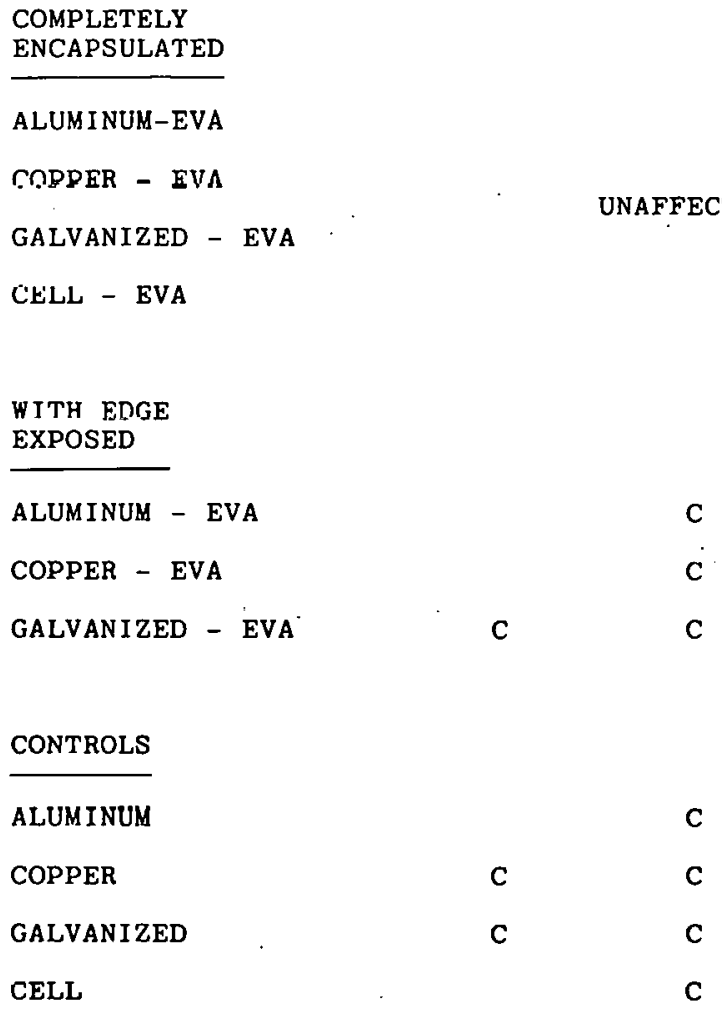

CELL 
ABRASION (AND DIRT?) RESISTANT COATINGS

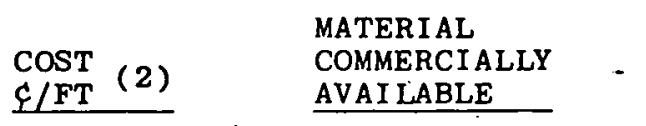

\section{SILICATES}

DOW CORNING

GENERAL ELECTRIC

9 (0.2 MILS)

(1)

COMMERCI ALLY

AVAI LABLE

E. I. DUPONT

NO

BERG INDUSTRIES

YES

AMERICAN OPTICAL

No

$3 M$

No

OWENS ILLINOIS

$2.3(0.3$ MILS $)$

YES

ROHM \& HAAS

NO \& YES

URETH'ANES

DEXTER MIDLAND

YES

HUGHSON

4.8

YES

BEE CHEMICAL

3.5 (MIL)

YES

ACRYLIC

BEE CHEMICAL

2.26 (MIL)

YES

ORGANIC

ROHM \& HAAS

YES

FLUOROCARBON FILM

DUPONT (TEDLAR)

9 (MIL) (2)

YES

PENNWALT (KYNAR)

YES

(1) INCLUDES PRIMER AND UV ABSORBER

(2) TEDLAR UT 


\section{ADHESION TESTING \\ SODA - LIME GLASS \\ AVERAGE BOND STRENGTH (PSI)}

SIDE A IS AIR SIDE

SIDE B IS TIN SIDE OF FLOAT GJAASS

\begin{tabular}{ccc} 
& 2 HOURS & 24 HOURS \\
CONTROL & BOILING WATER & BOILING WATER \\
\hline
\end{tabular}

$\begin{array}{lrrrr}\text { EVA } & \text { SIDE A } & 2 & - & - \\ & \text { SIDE B } & 4 & - & - \\ \begin{array}{l}\text { EVA, SS4179 } \\ \text { PRIMER SIDE A }\end{array} & 21 \text { (c) } & 2.2 & 13 \\ & \text { SIDE B } & 18 \text { (c) } & 2.5 & - \\ \begin{array}{l}\text { *EVA, A8330B B SIDE A } \\ \text { PRIMER }\end{array} & 22 \text { (c) } & 30 \text { (c) } & 17 \text { (c) } \\ & \text { SIDE B } & 20 \text { (c) } & 25 \text { (c) } & 9.6\end{array}$

EVA, SS 4179

PRIMER BLENDED

INTO POLYMER

$\begin{array}{rrrrr}\text { SIDE } & \text { A } & 9.9 & 2.3 & 2.2 \\ \text { SIDE B } & 30 \text { (c) } & 25 \text { (c) } & 10 \text { (c) }\end{array}$

EVA, A89212

PRIMER BLENDED

INTO POLYMER

\begin{tabular}{|c|c|c|c|}
\hline $\begin{array}{l}\text { SIDE } A \\
\text { SIDF }\end{array}$ & $32(c)$ & $\begin{array}{l}10 \\
30\end{array}$ & 10 (c) \\
\hline
\end{tabular}

×BE3T PERFORMAIVLE FUUND IN 'IIJE'SE' S̈PECIMENS

(c) COHESTVE FAILURF IN POIIMTR.

S\$4179 - proprietary folmula, General Fiectrie Co.

A8330-B- hydrolyzed Dow Corning Z-6030 primer

A8921-2- mixture of $90^{\%} \mathrm{Z}-6030$ and $10^{\%} \mathrm{Z}-6020$ 


\section{POTTANTS CHOSEN FOR FURTHER STUDY}

POTTANT

ETHYLENE/VINYL ACETATB COPOLYMER (EVA) ETHYLENE/PROPYLENE ELASTOMER
(EPR)

POLYVINYL CHLORIDE PLASTISOL (PVC)

ACRYLIC HOT MELT

ALIPHATIC URETHANE
DEGREE OF:

UV PRO-

TECTION

COST NEEDED

LOW HIGH

LOW HIGH

LOW HIGH

MODER- LOWER

ATE

MODER- MEDIUM ATE

DOW CORNING

\section{ADHESION OF KRATON 1102 TO PRIMED GLASS}

(PRESSED 1 MIN. AT $150^{\circ} \mathrm{C}$ )

\begin{tabular}{|c|c|c|c|c|}
\hline $\begin{array}{l}\text { SILANE }(10 \%) \text { ADDED } \\
\text { TO RESIN IN PRIMER }\end{array}$ & $\begin{array}{l}\text { PICCC } \\
\text { DRY }\end{array}$ & $\begin{array}{l}X \text { LC } \\
\text { WET } \\
\end{array}$ & $\begin{array}{l}\text { PICCO } \\
\text { DRY }\end{array}$ & $\begin{array}{r}\text { LTP-135 } \\
\text { WET } \\
\end{array}$ \\
\hline NONE & 1 & - & 1 & - \\
\hline $\mathrm{CH}_{2}=\mathrm{CHSi}\left(\mathrm{OCH}_{3}\right)_{3}$ & 1 & - & 1. & - \\
\hline $\mathrm{HSCH}_{2} \mathrm{CH}_{2} \mathrm{CH}_{2} \mathrm{Si}\left(\mathrm{OCH}_{3}\right)_{2}$ & 1 & - & 1 & - \\
\hline $\mathrm{ClCH}_{2} \mathrm{CH}_{2} \mathrm{CH}_{2} \mathrm{Si}\left(\mathrm{OCH}_{3}\right)_{3}$ & 1 & - & 1 & - \\
\hline $\mathrm{C}_{6} \mathrm{H}_{5} \mathrm{Si}\left(\mathrm{OCH}_{3}\right)_{3}$ & 1 & - & 1 & - \\
\hline$\left(\mathrm{CH}_{3}\right)_{2} \mathrm{NCH}_{2} \mathrm{CH}_{2} \mathrm{CH}_{2} \mathrm{Si}\left(\mathrm{OCH}_{3}\right)_{3}$ & 1 & - & 2 & 1 \\
\hline $\mathrm{CH}_{3} \mathrm{NHCH}_{2} \mathrm{CH}_{2} \mathrm{CH}_{2} \mathrm{Si}\left(\mathrm{OCH}_{3}\right)_{3}$ & 3 & 1 & 3 & 3 \\
\hline $\mathrm{H}_{2} \mathrm{NCH}_{2} \mathrm{CH}_{2} \mathrm{CH}_{2} \mathrm{Si}\left(\mathrm{OC}_{2} \mathrm{H}_{5}\right)_{3}$ & 4 & 3 & 4 & 2 \\
\hline $\left.\mathrm{H}_{2} \mathrm{NCH}_{2} \mathrm{CH}_{2} \mathrm{NH}\left(\mathrm{CH}_{2}\right)_{3} \mathrm{SilOCH}_{3}\right)_{3}$ & 4 & 3 & 4 & 4 \\
\hline
\end{tabular}




\section{ORGANOFUNCTIONAL SILANE COUPLING AGENTS}

\begin{tabular}{|c|c|c|}
\hline $\begin{array}{l}\text { ORGANOFUNCTIONAL } \\
\text { GROUP } \\
\end{array}$ & $\begin{array}{l}\text { DOW CORNING } \\
\text { PRODUCT } \\
\end{array}$ & $\begin{array}{l}\text { STRUCTURE OF } \\
\text { ORGANOFUNCTIONAL GROUP }\end{array}$ \\
\hline AMINE & LAB & $-\mathrm{CH}_{2} \mathrm{CH}_{2} \mathrm{CH}_{2} \mathrm{NH}_{2}$ \\
\hline DIAMINE & $Z-6020$ & $-\mathrm{CH}_{2} \mathrm{CH}_{2} \mathrm{CH}_{2} \mathrm{NHCH}_{2} \mathrm{CH}_{2} \mathrm{NH}_{2}$ \\
\hline POLYAMINO & $Z-6050$ & DOW POLYETHYLENEIMINE \\
\hline EPOXY & $Z-6040$ & $-\left(\mathrm{CH}_{2}\right)_{3} \mathrm{OCH}_{2} \mathrm{CH}-\mathrm{CH}_{2}$ \\
\hline MERCAPTAN & $z-6062$ & $-\mathrm{CH}_{2} \mathrm{CH}_{2} \mathrm{CH}_{2} \mathrm{SH}$ \\
\hline CATIONIC STYRYL & QZ8-5069 & $-\mathrm{CH}_{2} \mathrm{CH}_{2} \mathrm{CH}_{2} \mathrm{NH}-\mathrm{CH}_{2} \mathrm{CH}_{2}$ \\
\hline METHACRYLATE ESTER & LAB & $-\mathrm{CH}_{2} \mathrm{CH}_{2} \mathrm{CH}_{2}$ M.A. ${ }^{2}$ \\
\hline METHACRYLATE QUAT. ESTER & A-6031 & $-\left(\mathrm{CH}_{2}\right)_{3} \stackrel{\oplus}{\mathrm{N}} \underset{\left(\mathrm{CH}_{3}\right)_{2}}{\left(\mathrm{CH}^{-}\right.}-\mathrm{CH}_{2} \mathrm{CH}_{2}$ M.A. ${ }^{2}$ \\
\hline SATURATED QUAT. ALCOHOL & $X Z 8-5061$ & $-\left(\mathrm{CH}_{2}\right)_{3} \underset{\oplus}{\mathrm{N}} \mathrm{Cl}^{\left.-\mathrm{CH}_{3}\right)_{2}}-\mathrm{CH}_{2} \mathrm{CH}_{2} \mathrm{OH}$ \\
\hline
\end{tabular}

\section{OUTDOOR VS ATLAS SUNSHINE CARBON ARC WEATHER-OMETER (WOM) STRESSING: EFFECTS ON PROPERTIES}

\begin{tabular}{|c|c|c|c|}
\hline KESIN UK ELASIUPTEK & FURM UF SAMPLE & SITE \& DURATION OF EXPOSURE & CONDITION OF SAMPLE \\
\hline $\begin{array}{l}\text { 1. DOW CORNING } \\
808 \text { Res in }\end{array}$ & $\begin{array}{l}\text { 3-4 mil coating on aluminum } \\
\text { panels }\end{array}$ & 6 years Florida, $45^{\circ}$ south & $\begin{array}{l}36 \% \text { loss } 60^{\circ} \text { gloss, no checking or dirt } \\
\text { retention } \\
33 \% \text { loss } 60^{\circ} \text { gloss, } 7 \text { check rating, no } \\
\text { dirt retention }\end{array}$ \\
\hline $\begin{array}{l}\text { 2. DOW CORNINGO } \\
\text { 901 Resin }\end{array}$ & $\begin{array}{l}6 \text { mil coating on fine weave } \\
\text { fiberglass }\end{array}$ & $\begin{array}{l}\text { 4_years Arizona } 45^{\circ} \text { south. } \\
48 . \text { Langleys . E Emtiagua } \\
3.524 \text { hours filtered wom }\end{array}$ & $\begin{array}{l}\text { 99\% of original } 350-2400 \text { NM transmissinn } \\
\text { 944 of original } 350-2400 \text { NM transmissinn } \\
\text { Resin flaked off of substrate. }\end{array}$ \\
\hline $\begin{array}{l}\text { 3. B66 Acrylic/ } \\
\text { DCO } 840 \text { 8lend }\end{array}$ & $\begin{array}{l}\text { 3-4 mil coating on aluminum } \\
\text { and steel panels }\end{array}$ & $\begin{array}{l}13 \text { ypars Texas } \\
7 \text { years Florida } 45^{\circ} \text { south } \\
3,750 \text { hours f } f 1 \text { tered wOM }\end{array}$ & $\begin{array}{l}\text { Slight dirt retention, no loss gloss } \\
\text { or checking } \\
\text { High corrosion protection } \\
\text { 100\% cooting off. No measurement }\end{array}$ \\
\hline $\begin{array}{l}\text { 4. OOW CORNINGO } \\
996 \text { Res in }\end{array}$ & $\begin{array}{l}2 \text { mil coating on al uminum } \\
\text { panel }\end{array}$ & 10 years Midland & $\begin{array}{l}\text { No loss gloss, no color change, } \\
\text { checking rating. } 6 \text {. } \\
69 \% \text { loss } 20^{\circ} \text { gloss (spots from water } \\
\text { spray). } 37 x \text { loss of } 60^{\circ} \text { gloss; } \\
\text { checking } 2 \text {, no dirt retentlon. }\end{array}$ \\
\hline 5. LS 53 Rubber & $\begin{array}{l}1 / 8^{\prime \prime} \text { thick strips-folded, } \\
\text { stretched } 20 \% \text {, unstressed }\end{array}$ & 20 years Florida & $\begin{array}{l}\text { Slight dirt \& mildew, no cracking or } \\
\text { checking } \\
\text { No change }\end{array}$ \\
\hline
\end{tabular}




\section{OUTDOOR VS ATLAS SUNSHINE CARBON ARC WEATHER-OMETER (WOM)}

STRESSING: EFFECTS ON PROPERTIES

\begin{tabular}{|c|c|c|c|}
\hline RESIN OR ELASTOMER & FORM OF SAMPLE & SITE : OURATION OF EXPOSURE & CONDITION OF SAMPLE \\
\hline \multirow[t]{2}{*}{$\begin{array}{l}\text { 5. RTV } 132 \mathrm{U} \\
\text { Elastomer }\end{array}$} & \multirow[t]{2}{*}{$\begin{array}{l}1 / 8^{\prime \prime} \text { thick strips-foided, } \\
\text { stretched } 20 \% \text {, unstressed }\end{array}$} & 20 years Florida & $\begin{array}{l}\text { Some } 1055 \text { of tensile and Elongation, } \\
\text { Same as } L S 53\end{array}$ \\
\hline & & 4,234 hours filtered wON & Slight trace dirt \\
\hline \multirow{2}{*}{$\begin{array}{l}\text { 7. RTV } 501 \\
\text { Elastomer }\end{array}$} & \multirow{2}{*}{$\begin{array}{l}\text { 1/8" thick strips-folded, } \\
\text { stretched } 20 \% \text {, unstressed }\end{array}$} & 16 years Florida & Slight dirt retention and mildew \\
\hline & & 4,019 hours filtered wOM & No checking \\
\hline \multirow{2}{*}{$\begin{array}{l}\text { 8. 5EU Silastico } \\
\text { Rubber }\end{array}$} & \multirow{2}{*}{$\begin{array}{l}1 / 8^{\prime \prime} \text { thick strips-folded, } \\
\text { stretched } 20 \% \text {, uns tressed }\end{array}$} & 19 years Elorida & Slight dirt retention and mildew. \\
\hline & & 4,234 hours filtered woM & No change \\
\hline \multirow[t]{2}{*}{$\begin{array}{l}\text { 9. Silastico } 675 \\
\text { Rubber }\end{array}$} & \multirow[t]{2}{*}{$\begin{array}{l}1 / 8 " \text { thick strips-foided, } \\
\text { stretched } 20 \% \text {, unstressed }\end{array}$} & 19 years Florida & $\begin{array}{l}\text { Slight decrease in durometer, tensile } \\
\text { and elongation, some surface.cracking. }\end{array}$ \\
\hline & & 4,234 hou:s filtered wOM & No change \\
\hline III, KIV $\mid \mathrm{HI}$ & $\begin{array}{l}\text { b mil coaring on a luminuid } \\
\text { pane! }\end{array}$ & ¿ú yed"s ."Iscuis lı & $\begin{array}{l}\text { B } 1, L \text { plck up, } \mathrm{s} \text { liglil lumiring in } \\
\text { durometer }\end{array}$ \\
\hline $\begin{array}{l}\text { Building } \\
\text { Sealant }\end{array}$ & $\begin{array}{l}6 \text { mi }) \text { coating on aluminum } \\
\text { pane? }\end{array}$ & 3,679 hours filtered woy & No loss $20^{\circ}$ gloss, some blisters \\
\hline
\end{tabular}

\section{$132 U$ EXPOSED IN WOM (FILTERED III)}

\begin{tabular}{ccc|c} 
UV EXPOSURE & & TENSILI & $\Delta$ \\
\hline 0 & & 517 PSI & \\
$290 \mathrm{HR}$. & & $503 \mathrm{PSI}$ & $-2.7 \%$ \\
$641 \mathrm{HR}$. & & $454 \mathrm{PSI}$ & $-12.2 \%$ \\
$900 \mathrm{HR}$. & & $437 \mathrm{PSI}$ & $-15.5 \%$ \\
$1200 \mathrm{HR}$. & & $485 \mathrm{PSI}$ & $-6.2 \%$ \\
$1500 \mathrm{HR}$. & & $402 \mathrm{PSI}$ & $-22.2 \%$ \\
$2000 \mathrm{HR}$. & & $475 \mathrm{PSI}$ & $-8.1 \%$ \\
$2510 \mathrm{HR}$. & & $471 \mathrm{PSI}$ & $-8.9 \%$ \\
$3009 \mathrm{HR}$. & & $438 \mathrm{PSI}$ & $-15.2 \%$ \\
$3260 \mathrm{HR}$. & & $395 \mathrm{PSI}$ & $-23.6 \%$ \\
$3481 \mathrm{HR}$. & & $461 \mathrm{PSI}$ & $-10.8 \%$ \\
$3786 \mathrm{HR}$. & & $362 \mathrm{PSI}$ & $-30.0 \%$
\end{tabular}

\begin{tabular}{|c|c} 
ELONGAT ION & $\Delta$ \\
\hline $580 \%$ & \\
$540 \%$ & $-6.9 \%$ \\
$500 \%$ & $-13.8 \%$ \\
$470 \%$ & $-19.0 \%$ \\
$590 \%$ & $-1.7 \%$ \\
$480 \%$ & $-17.2 \%$ \\
$570 \%$ & $-1.7 \%$ \\
$570 \%$ & $-1.7 \%$ \\
$520 \%$ & $-10.3 \%$ \\
$495 \%$ & $-14.6 \%$ \\
$560 \%$ & $-3.4 \%$ \\
$450 \%$ & $-22.0 \%$
\end{tabular}

PULL RATE 2"/MIN. 
OUTDOOR EXPOSURE PANELS (DC 184)

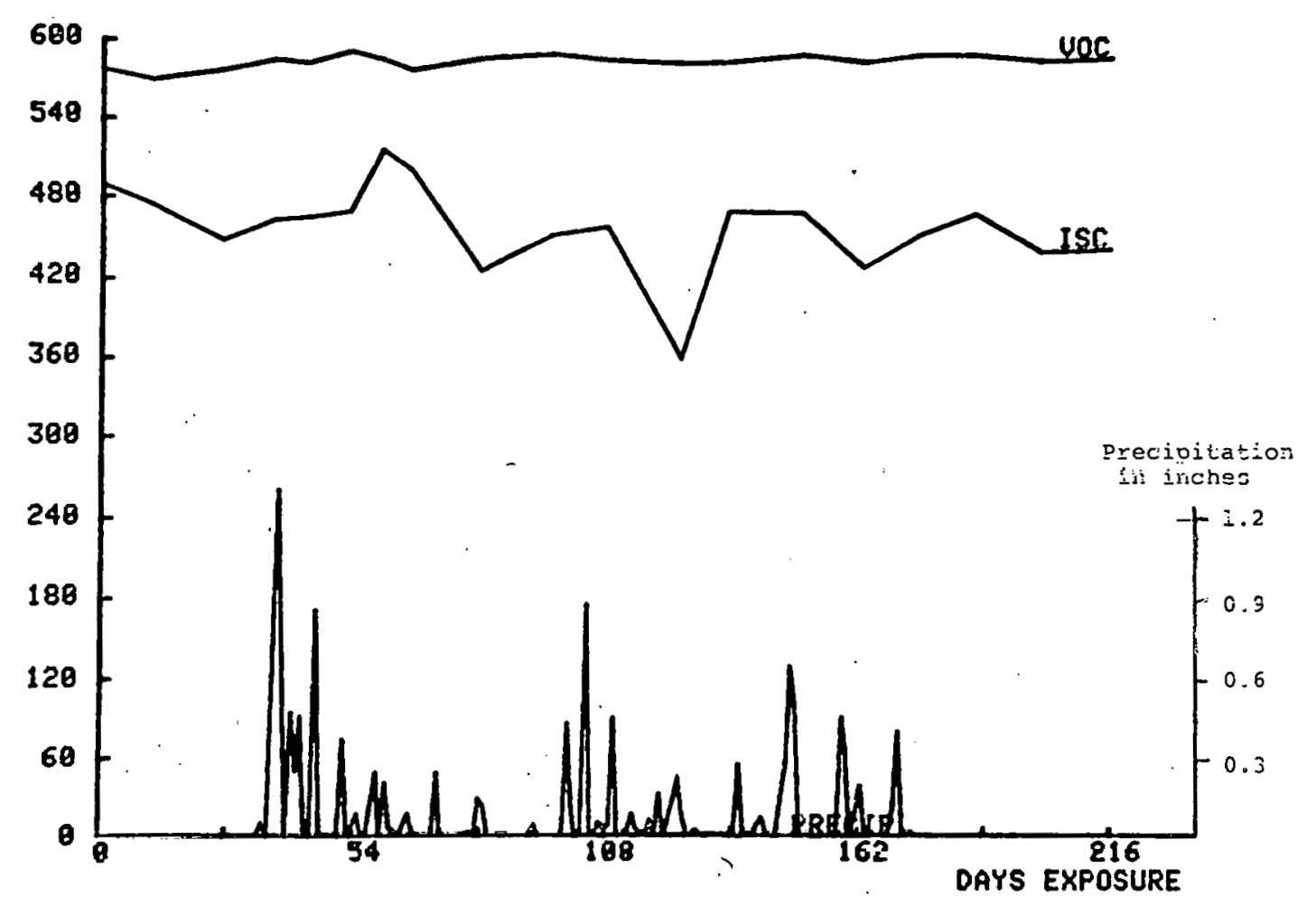




\section{SUBSTRATE DISPLAY MODULE}

Twenty-four holes were countersunk to a depth of $15 \mathrm{mils}$ in a 12" x 16" panel of tempered Masonite** using a 2-1/8" arill bit. Grooves for interconnects were cut between the recessed openings. Holes were drilled and countersunk for the terminals. The front, back and edges of the panel were then sprayed with DOW CORNING* Q1-2577 Conformal coating pigmented with $30 \%$ titanium dioxide and allowed to air dry.

The 24-cell circuit string was bonded to the panel with Q1-2577 and the leads soldered to two flathead bolts which serve as torminals.

The front of the pariel and cells were then sprayed with a thin coating of clear Q1-2577 and the module allowed to air dry.

Cost of this mini-module (in 1978 dollars):

Super Dorlux@ Masonite Thickness - 0.125 inches $\left(1 / 8^{\prime \prime}\right)$....... $\$ 0.11 / \mathrm{ft}^{2}$

DOW CORNING@ Q1-2577 Conformal Coating

Pigmented with $\mathrm{TiO}_{2}$
Front and back .002 inches $(2 \cdot \mathrm{mils}) . . . .+\$ 0.19 / \mathrm{ft}^{2}$

DOW CORNING@ Q1-2577 Conformal Coating

Clear adhesive .002 inches $(2 \mathrm{mils})$. . . . $\$ 0.09 / \mathrm{ft}^{2}$

(Assuming 100\% cell 'coverage).

DOW CORNING(9) Q1-2577 Clear Conformal Coating

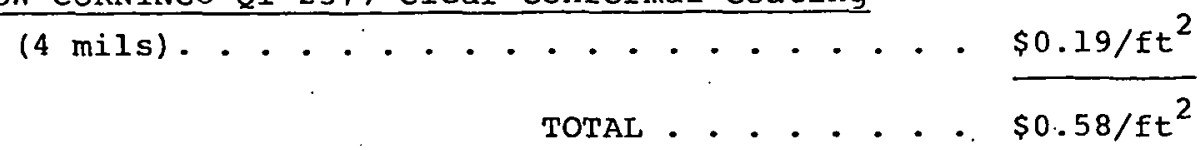

*Tempered Masonite was used to simulate Super Dorlux@. 


\section{NEW ENCAPSULATION CONCEPT}

This novel encapsulation concept was prepared in the following manner:

A flat surface is first covered with polyethylene coated paper which serves as a release coating.

A thin coating of DOW CORNING( Q1-2577 Conformal coating is applied to the polyethylene coated paper and a 24-cell circuit string is placed front side up on this coating. A sheet of woven giass cloth is placed over the cells and additional Q1-2577 is flow coated over the glass cloth and the excess removed with a straight edge.

The resin is allowed to air dry and removed from the polyethylene release paper.

Alternatively, the 24-cell circuit string can be placed front side down and the woven glass cloth placed on the back of the cells.

Both of these concepts provide only encapsulation protection and additional superstrate or substrate mechanical support is required.

Cost:

Woven gl.ass cloth

DOW CORNING@ QI-2577 Conformal coating

$10 \mathrm{mils}=$

TOTAL COST

$\$ .03-.05 / \mathrm{ft}^{2}$

$\$ .05 \% \mathrm{mil}_{\mathrm{ftet}}{ }^{2}$

$\$ .50 / \mathrm{tt}^{2}$

$\$ .53 / \mathrm{tt}^{2}$ 


\section{Production Process and Equipment Area}

\section{AUTOMATED PROCESSING EQUIPMENT CURRENT PERFORMANCE}

\begin{tabular}{|c|c|c|}
\hline SPEAKER & COMPANY & SUBJECT \\
\hline W. KERN & RCA & SPRAY ANTIREFLECTION COATING \\
\hline R.V. D'AIELLO & $\mathrm{RCA}$ & THICK FILMI AETALLIZATION \\
\hline S. CHITRE & SENSOR TECH & LASER SCRIBER \\
\hline S. CHITRE & SENSOR TECH & SPRAY-ON JUNCTION \\
\hline R. D. CAMTOCLL & WESTIMCIIOUSE & DIP AMIIRFFIFCTION SMATING \\
\hline
\end{tabular}

\section{PLANS}

- HOLLOW-CATHOde PARAMETRIC STUDY

- NEW CATHODES ARRIVING SOON

- RETROFIT SPIRE-LIKE SOURCE WITH HOLLOW CATHODE

- NON-MASS-ANALYZED IMPLANT WITH SOLIO SOURCE

\section{CALTECH \& JPL IN-HOUSE}

- CALTECH STUDY: EFFECTS OF NON-MASS-ANALYZED ION IMPLANTATION (SOLID PHOSPHORUS SOURCE)

- molecular phos phorus $\left(\mathrm{P}_{4}, \mathrm{P}_{3}, \mathrm{P}_{2}\right)$

- IMPURITIES (O, N, H, ETC)

- JPL IN-HOUSE

- hOLLOW-CATHOde TESTING

- SOLID PHOSPHORUS SOURCE DEVELOPMENT

- FUTURE WORK 
- hollow-Cathode test Set-up IN Ofiration

- TEST FLOW CHARACTERISTICS

- optIMIZE DISCHARGE PARAMETERS

- tentative hollow-Cathode results

- OPERATES at low FlOW $(<20 \text { ma EOUIVALENT })^{\circ}$

- hydrogen appears to degrade cathodes

- DISCharge operates at lower voltage, hIGHer CURRent

- SOLID PHOSPHORUS SOURCE DEVELOPMENT

- CAN PRODUCE - $8 \mathrm{ma}$ at $10 \mathrm{keV}$

- discharge 35V, 3a

- SAMPLE CAROUSEL READY FOR NON-MASS ANALYZED IMPLANT

- PROBLEMS

- consumption of solid phosphorus too high "

- better understanding of CONTrol parameters needeo

\section{OBJECTIVES}

- DEVELOP CELL HANDLING END EFFECTORS FOR PLACEMENT AND INTERCONNECTION OF CELLS

- DEVELOP TECHNIQUES FOR AUTOMATED INTERCONNECTION OF CELLS USING ROBOTICS

- oETERMINE TOLERANCE REQUirementS for PLACEMENT OF CELLS

- STUDY METALIZATION PATERN RECOGNITION FOR ORIENTATION

- ASSESS PROC.FSS SERUENCE FOR FURTHER APPLICATION OF ROBOTICS 


\section{MODULE FRAMING OPERATION}

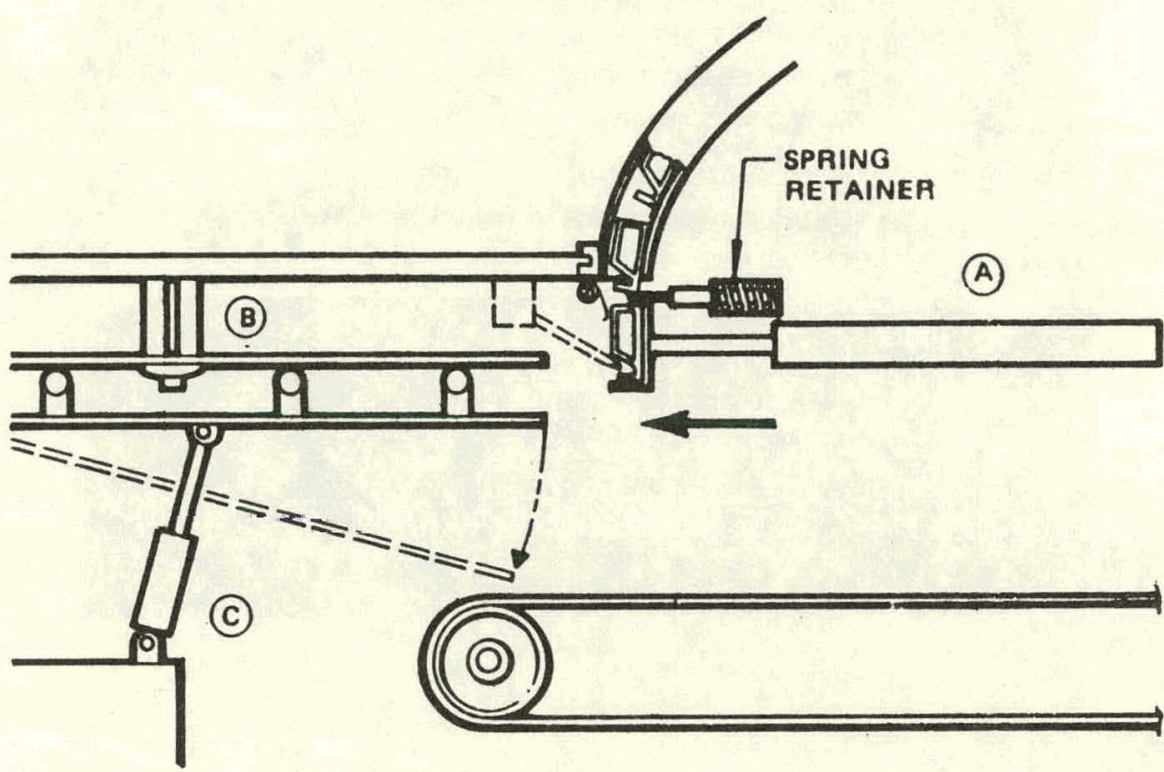

(A) PNEUMATIC RAM KEYED to Location OF EXTRUSION HEAD, INITIATED BY TRAVELING BEAM.

(B) TRAVELING BEAM WITH SUCTION GRIP POSITIONS PANEL IEXTRUSION HEAD POSSIBLY MOUNTED HERE TO APPLY ADHESIVE TO FRAME).

(C) PNEUMATIC RAM KEYED BY RETRACTION OF FRAME POSITIONING RAM LOWERS TABLE, ALLOWING THE PANEL TO SLIDE ONTO THE NEXT CONVEYOR.

\section{MODULE EDGE SEALING STATION}

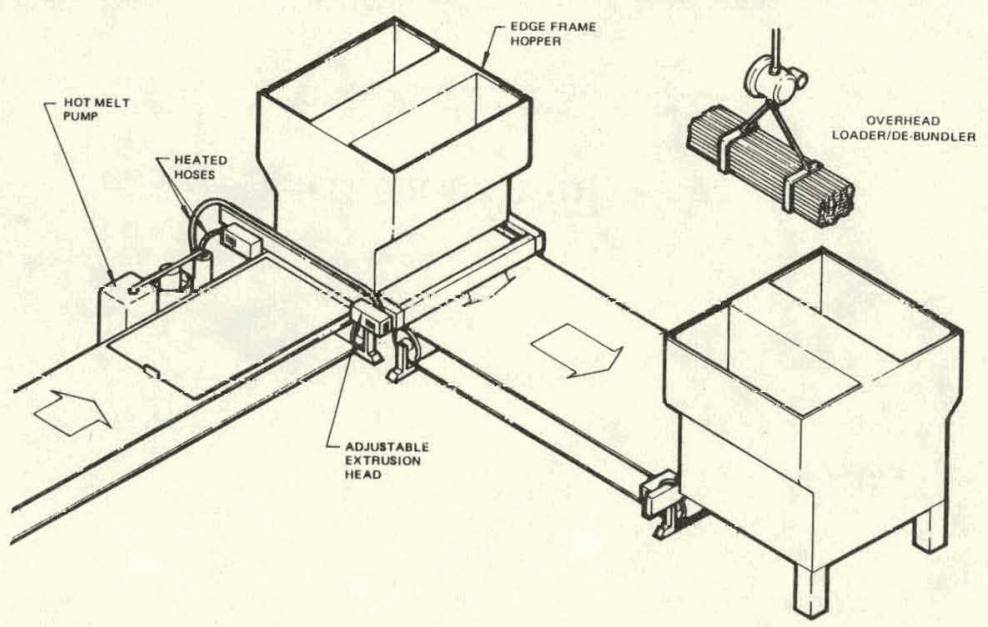



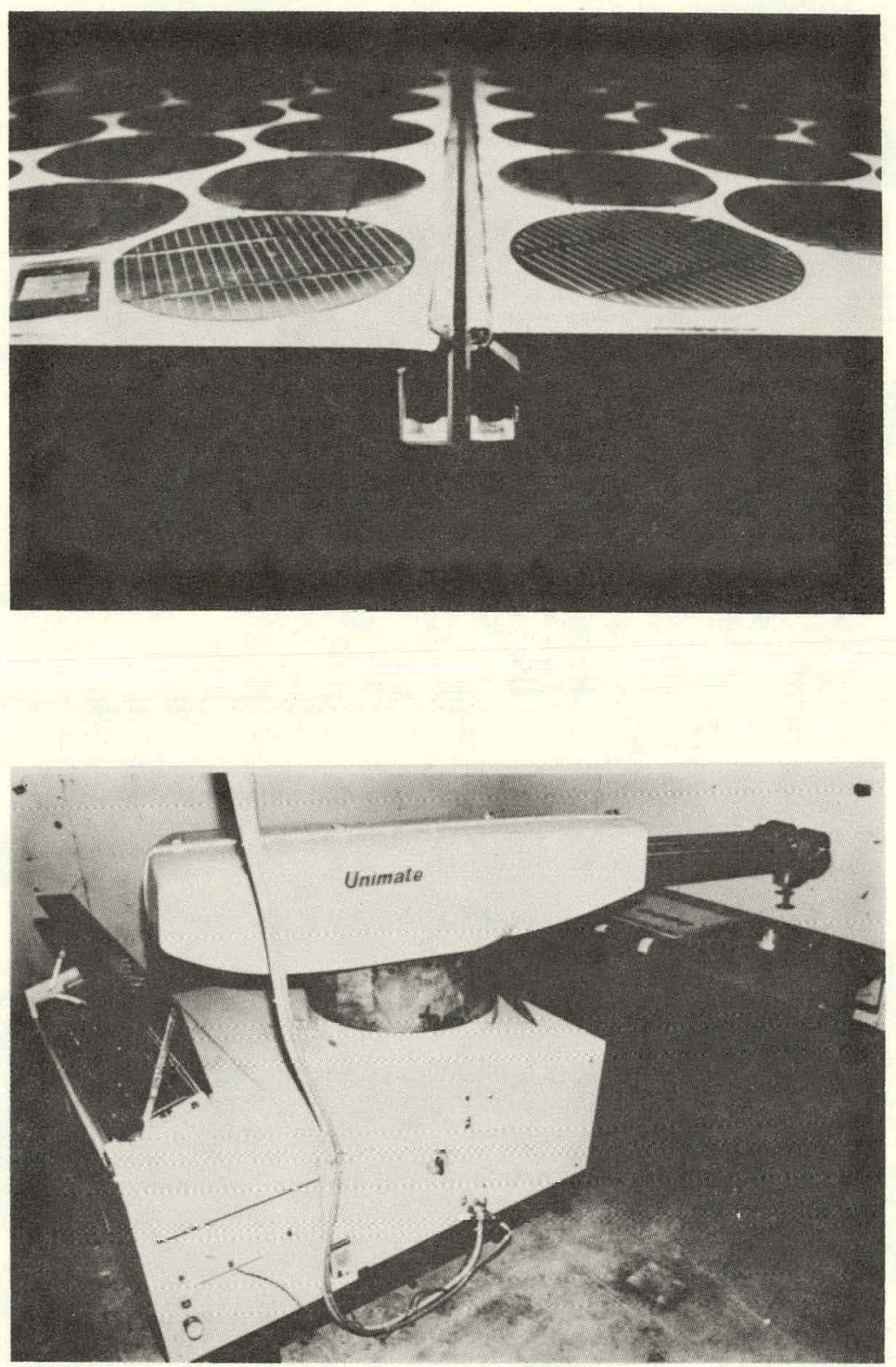

MATERIAL PROPERTIES

\begin{tabular}{|c|c|c|c|}
\hline & Mo & Si & $\underline{\mathrm{MoO}_{3}}$ \\
\hline MELTING POINT $\left({ }^{\circ} \mathrm{C}\right)$ & 2622 & 1420 & 795 \\
\hline BOILING FOINT $\left({ }^{\circ} \mathrm{C}\right)$ & 4510 & & SUBLIME \\
\hline DENSITY (G/CM $\left.{ }^{3}\right)$ & 10.2 & 2.33 & 4.5 \\
\hline $\begin{array}{l}\text { COEF. OF THERMAL EXP. } \\
\left(\mathrm{CM} / \mathrm{CM} /{ }^{\circ} \mathrm{C}\right) 10^{-6}\end{array}$ & 3.1 & 4.2 & \\
\hline $\begin{array}{l}\text { ELECTRICAL RESISTIVITY } \\
\text { (MICRO OHM-CM) }\end{array}$ & 5.17 & & \\
\hline
\end{tabular}




\section{CONVERSION OF $\mathrm{MOO}_{3}$ TO MO \\ (TEMPERATURE - TIME - ATMOSPHERE CYCLE)}

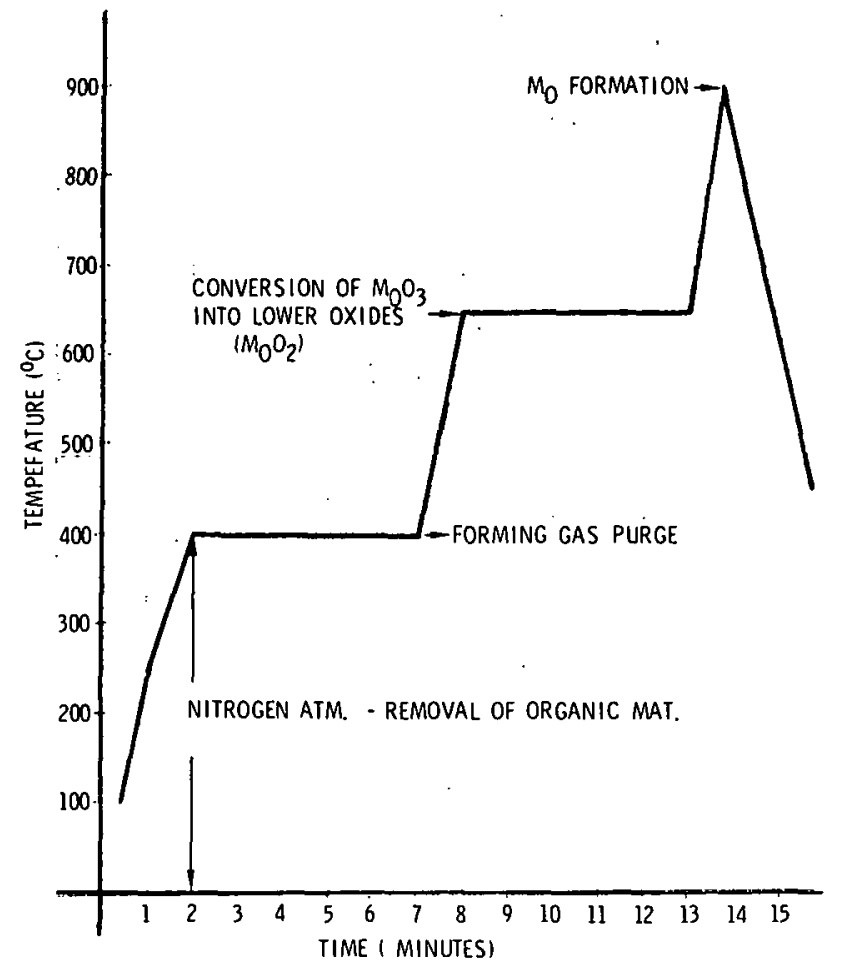

RCA LABORATORIES

SPRAY-ON ANTIREFLECTION COATINGS FOR SILICON SOLAR CELLS

WERNER KERN

WORK PERFORMED AS PART OF "AUTOMATED ARRAY ASSEMBLY" FOR JET PROPULSION LABORATORY, CALIFORNIA INSTITUTE OF TECHNOLOGY, UNDER NASA CONTRACT NAS 7.100 DOE/JPL-954868.

\section{OBJECTIVE}

TO DEVELOP A LOW-COST, HIGH-SPEED MASS PRODUCTION PROCESS FOR DEPOSITING SINGLE-LAYER THIN FILM ANTIREFLECTION (AR) COATINGS ON METALLIZED SINGLE. CRYSTAL SILICON SOLAR CELLS FOR TERRESTIAL APPLICATIONS. 
- MATERIALS FOR THIN FILM AR COATINGS ON SILICON

COMPOUND

\begin{tabular}{l}
\hline $\mathrm{Ta}_{2} \mathrm{O}_{5}$ \\
$\mathrm{TiO}_{2}$ \\
$\mathrm{Si}_{2} \mathrm{~N}_{y} \mathrm{H}_{2}$ \\
$\mathrm{ZrO}_{2}$ \\
$\mathrm{HrO}_{2}$ \\
$\mathrm{SnO}_{2}$ \\
$\mathrm{In}_{2} \mathrm{O}_{3}$ \\
$\mathrm{Si}_{3} \mathrm{~N}_{4}$ \\
$\mathrm{SiO}$ \\
$\mathrm{Al}_{2} \mathrm{O}_{3}$ \\
$\mathrm{SiO}_{2}$
\end{tabular}

REFRACTIVE INDEX

$(n)^{\circ}$

$2.4-2.8$

$2.2-2.7$

$2.1-2.4$

$1.7-2.2$

2.0

$1.9-2.3$

$1.7-2.4$

$1.9-2.1$

2.0

$1.6-1.8$

$1.4-1.5$
ABSORPTION BELOW

$(\lambda \sim \mu \mathrm{m})$

310

380

380

340

220

350

420

300

380

340

205

Dopending on method of formation and crystallographic form.

\section{OPTICAL CONSIDERATIONS}

\begin{tabular}{|c|c|}
\hline REFLECTANCE & - $\mathbf{R}$ \\
\hline I HAIVSWHITTANCE & $-\cdot T$ \\
\hline REFRACTIVE INDEX & - $\mathbf{N}$ \\
\hline$N_{\text {air }}$ & $=1.0$ \\
\hline$N_{\text {cover }}$ & -1.5 \\
\hline$N_{S i} A T \lambda=6000 A$ & - 3. \\
\hline
\end{tabular}

- T OF SUNLIGHT INTO CELE WITHOUT AR COAT. ING IS THUS 65\%.

- A 100\% - EFFECTIVE AR COATING (R=0, T=100\%) SHOULD RESULT IN A 54\% GAIN IN ELECTRICAL OUTPUT.

- optimal $N_{\text {bI }}$ at QUAATER WaVet, ENGTH thick. NESS FOR $R_{\min }$ AT .6000 A IS 2.0 IN AIH ANU 2.4 UNDER COVER. 


\section{SUMMARY OF PROCESS AND COST COMPARISON FOR PRODUCING AR COATINGS ON SILICON SOLAR CELLS}

\begin{tabular}{|c|c|c|c|}
\hline \multicolumn{4}{|c|}{ (per $100 \times 10^{6}$ cells per year) } \\
\hline PROCESS & SPRAYING & $L P$ - CVD & $P E$ - CVD \\
\hline - FILM TYPE & $\mathrm{SiO}_{2}-\mathrm{TiO}_{2}$ & $\mathrm{Si}_{3} \mathrm{~N}_{4}$ & $\mathrm{Si}_{x} \mathrm{~N}_{y} \mathrm{H}_{z}$ \\
\hline - THICKNESS, $\dot{\AA}$ & $700^{\circ}$ & 700 & 700 \\
\hline - REACTANTTS & Ti-Si "C" & $\mathrm{SiCl}_{2} \mathrm{H}_{2}+\mathrm{NH}_{3}$ & $1.5 \% \mathrm{SiH}_{4}-\mathrm{Ar}, \mathrm{N}_{2}$ \\
\hline - CONDITIONS & NTP & $750^{\circ} \mathrm{C} 0.25$ TORR & $250^{\circ} \mathrm{C}, 1.0$ TORR \\
\hline - MACHINE & $\begin{array}{l}\text { ZICON RECIPRO- } \\
\text { CATING SPRAYER }\end{array}$ & $\begin{array}{l}\text { HORIZONTAL } \\
\text { TUBE FURNACE }\end{array}$ & $\begin{array}{l}\text { GLOW DISCHARGE } \\
\text { CONTINUOUS REACTOR }\end{array}$ \\
\hline $\begin{array}{l}\text { - THROUGHPUT, } \\
\text { CELLS/MACHINE }\end{array}$ & $33.5 \times 10^{6} /$ YEAR & $7.1 \times 10^{6} /$ YEAR & $2.0 \times 10^{6} /$ YEAR \\
\hline - SYSTEM3 NCEDED & 3 & 15 . & 50 \\
\hline - SYSTEM COST, & & & 78.000 \\
\hline $\begin{aligned} & \$ / \text { UNIT } \\
\text { - } & \text { /TOTAL UNITS }\end{aligned}$ & $\begin{array}{l}110,000 \\
330,000\end{array}$ & $\begin{array}{l}134,000 \\
2,016,000\end{array}$ & $\begin{array}{l}78,000 \\
3,900,000\end{array}$ \\
\hline $\begin{array}{l}\text { - POWER REQUIRE- } \\
\text { MENTS, KW TOTAL. } \\
\text { - MATERIAL COST, }\end{array}$ & .75 & 80 & 250 \\
\hline $\begin{array}{l}\text { \$/TOTAL } \\
\text { - MANPOWER COST, }\end{array}$ & 268,000 & 34,000 & 612,000 \\
\hline $\begin{array}{l}\text { \$/TOTAL } \\
\text { - TOTAL COST. }\end{array}$ & 36,000 & 90,000 & 210,000 \\
\hline \$/TOTAL & 634,000 & $2,134,000$ & $4,722,000$ \\
\hline COST RATIO & 1.0 & 3.4 & 7.5 \\
\hline
\end{tabular}




\section{SUMMARY OF RESULTS FROM ZICON SPRAY TESTS FOR AR COATING(1)}

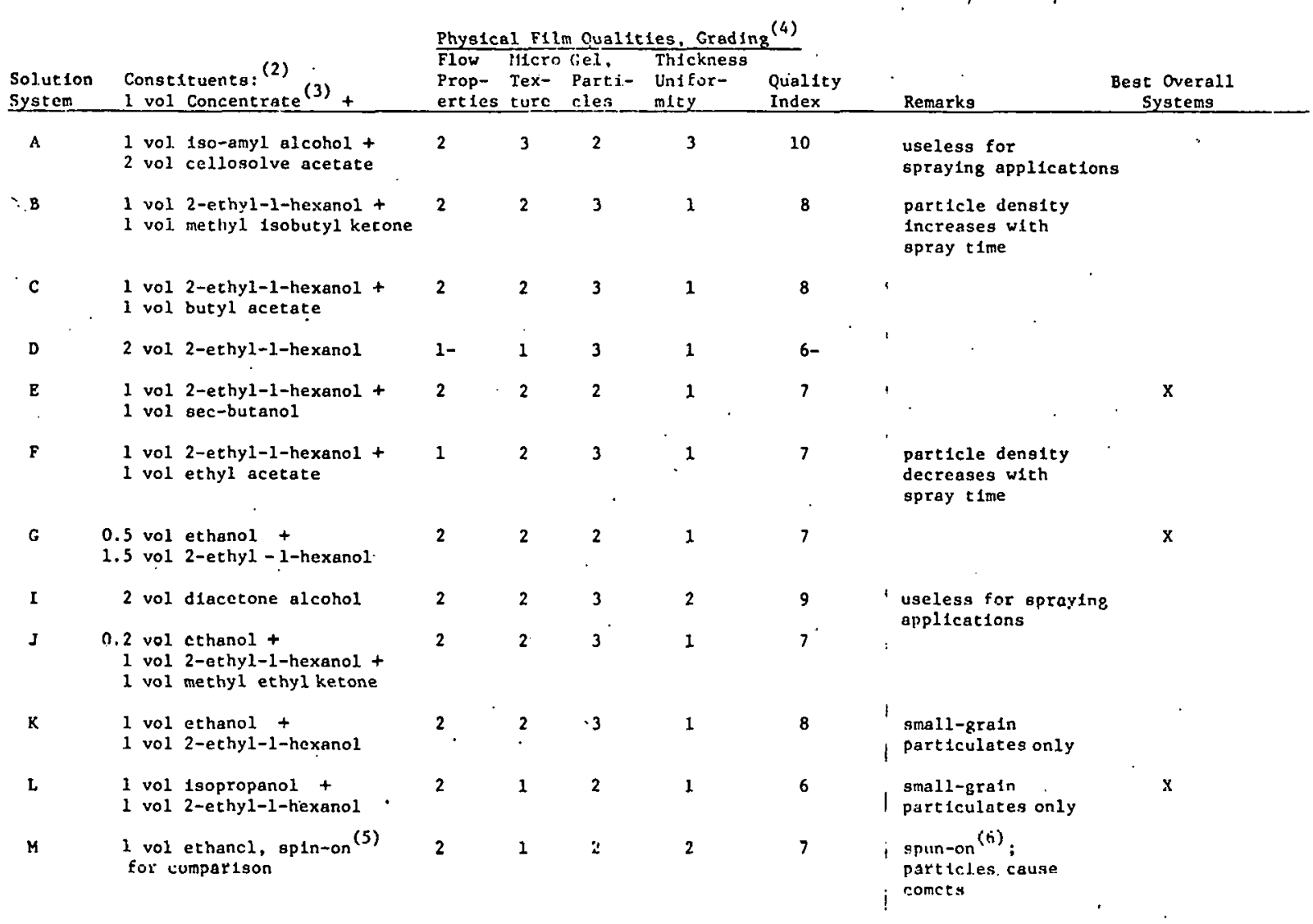

(1) Standard Model, Zicon Series 11000 Autocodter. Substrates were Si wafers and

(2) In the sequence of addition. solar cell structures.

(3) Titania-Silica Film "C", special concentrate (Organometallic Composite)by Emulsitone

4) Grading as follows: 1-good, 2-fair, 3-poor. Evaluation after standard, immediate post-deposition heat treatments in room air 60 s drying in IR oven at $200^{\circ} \mathrm{C}, 60 \mathrm{~s}$ curing at $200^{\circ} \mathrm{C}$ and 600 densiflual fon at $400^{\circ} \mathrm{C}$ on hot plates).

(5) Titania-Silica Film "C", formulation for spin-on applications by Emulsitone Co.

(6) Spun on at 3300r/min, 30s: (for rnmparioot with spedy-on deposils). 


\section{EFFECTIVENESS OF AR FILMS FROM THREE SOURCE SOLUTIONS}

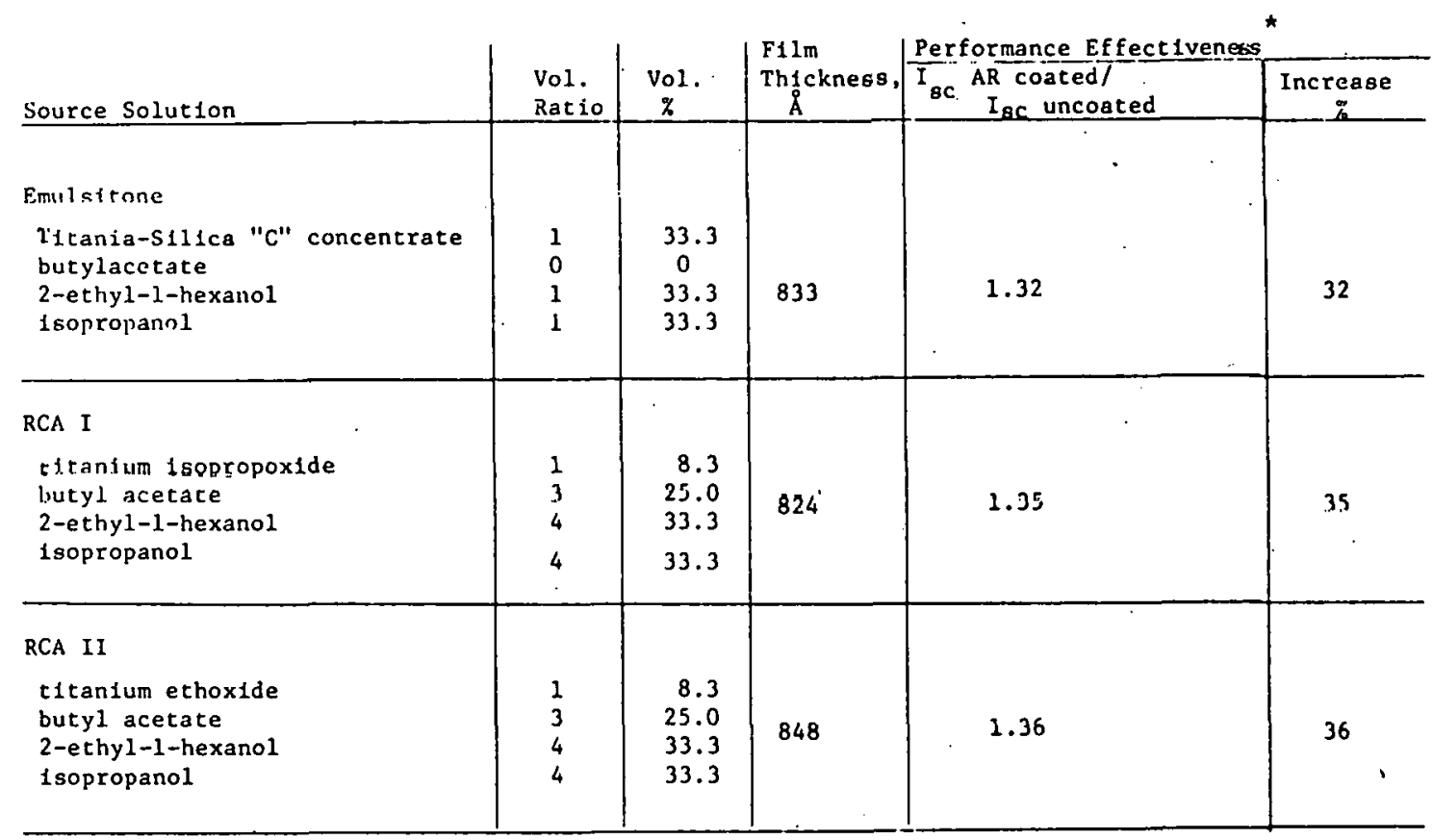

* These ratios indicate the increase in short circuit current of the cells

"after AR coating; they can be considered essentially equivalent of the increase in efficlency, since $v_{\text {oc }}$ remains unchanged after coating.

\section{COMPOSITION AND COST OF AR CÓATING SPRAY SOURCE SOLUTION FOR RCA I TIO 2}

\begin{tabular}{|c|c|c|c|}
\hline COMPONENT & VOL & VOL\% & FUNCTION \\
\hline TITANIUM (IV) ISPRROPOXIDE, TIIOCH$\left.\left(\mathrm{CH}_{3}\right)_{2}\right]_{4}$ & 1 & 8.3 & $\mathrm{TiO}_{2}$ SOURCE \\
\hline n-BUTYL ACETATE, $\mathrm{CH}_{3} \mathrm{CO}_{2}\left(\mathrm{CH}_{2}\right)_{3} \mathrm{CH}_{3}$ & $\sim 3$ & $\sim 25$ & DILUENT SOLVENT \\
\hline 2-ETHYL-1-HEXANOL, $\mathrm{CH}_{3}\left(\mathrm{CH}_{2}\right)_{3} \mathrm{CH}\left(\mathrm{C}_{2} \mathrm{H}_{5}\right) \mathrm{CH}_{2} \mathrm{OH}$ & $>4$ & $>33$ & SPRAYABILITY AGENT \\
\hline ISOPROPANOL, ANHYDROUS, $\left(\mathrm{CH}_{3}\right)_{2} \mathrm{CHOH}$ & $<4$ & $<33$ & LEVELING AGENT \\
\hline COMPOSITE & $\sim 12$ & $\sim 100$ & \\
\hline MATERIALS CUSI & & & \\
\hline
\end{tabular}




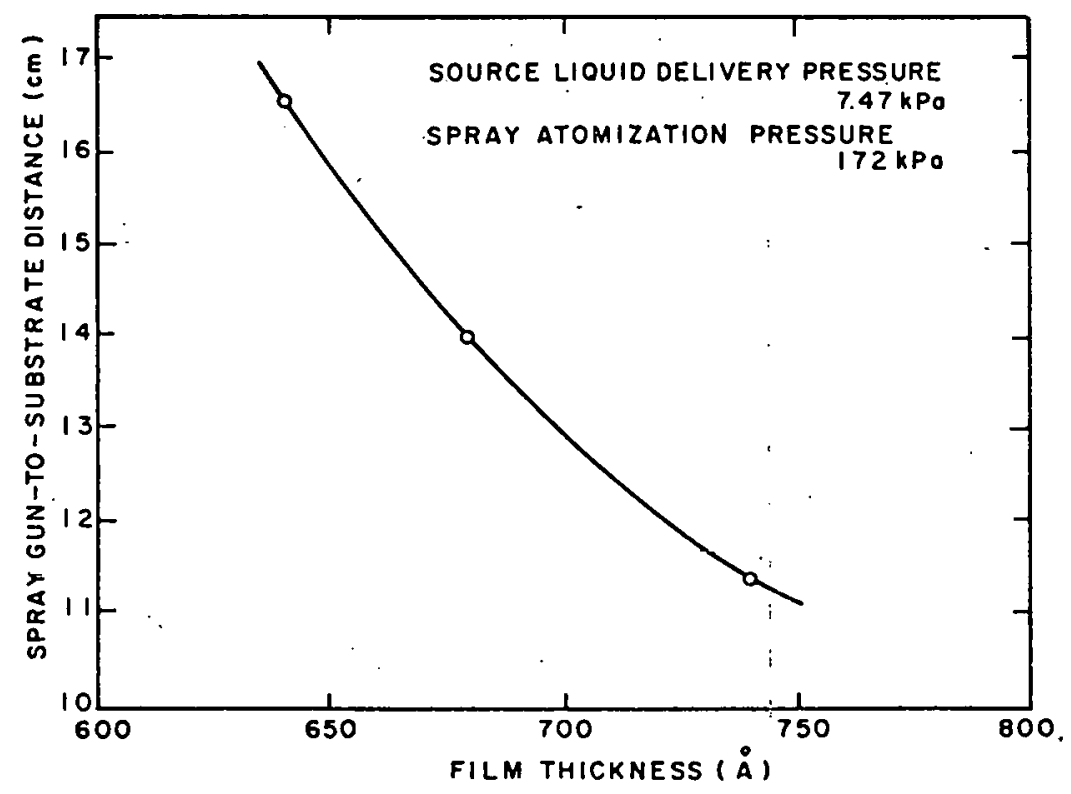

-

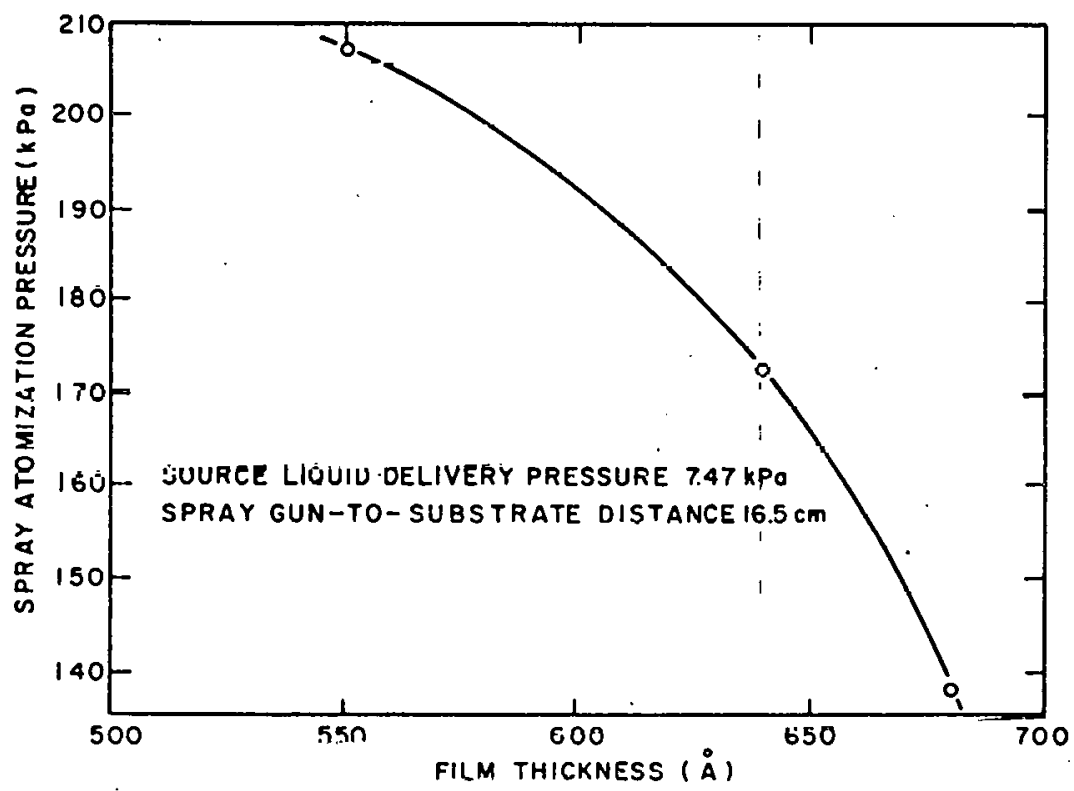



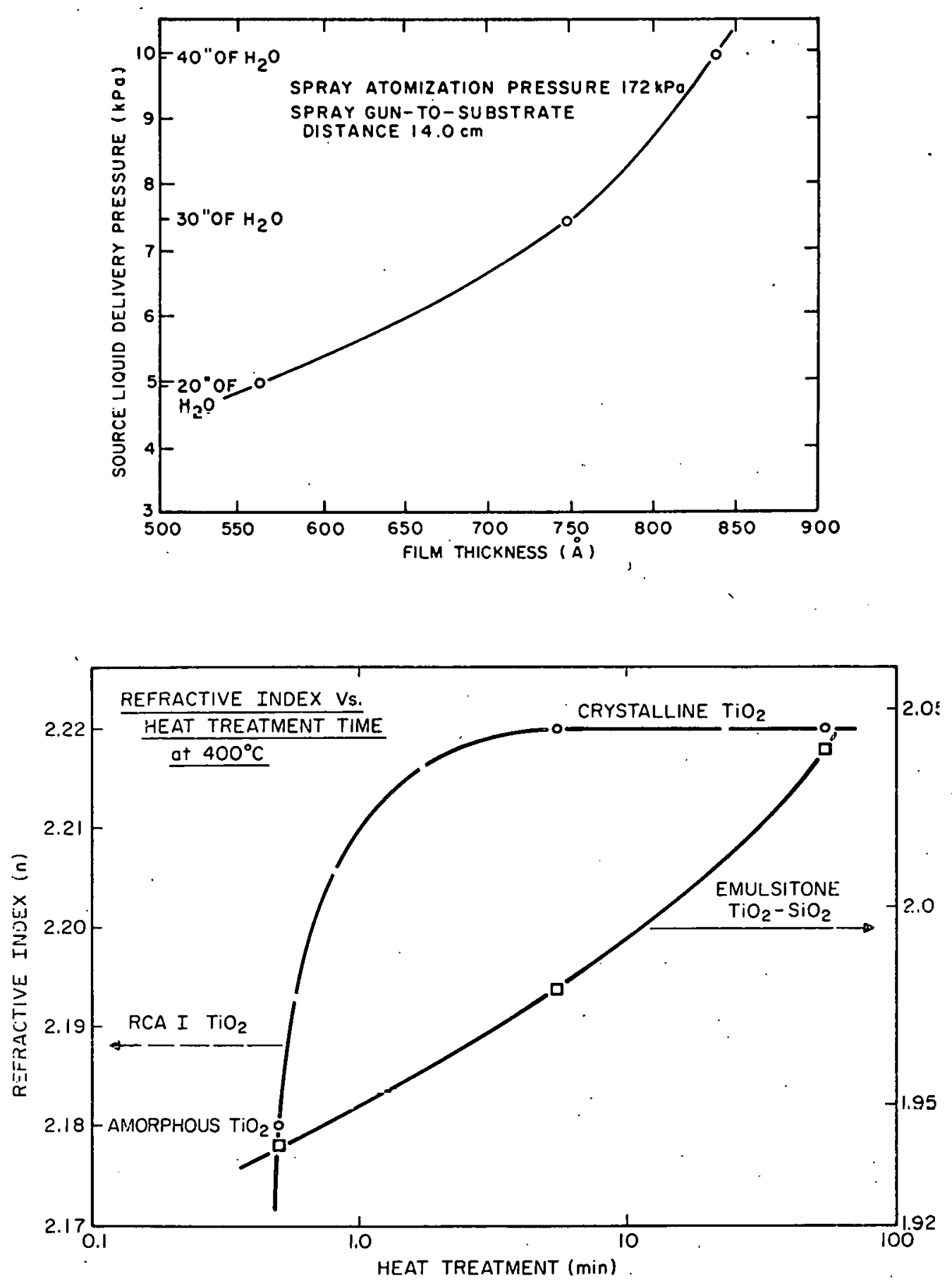

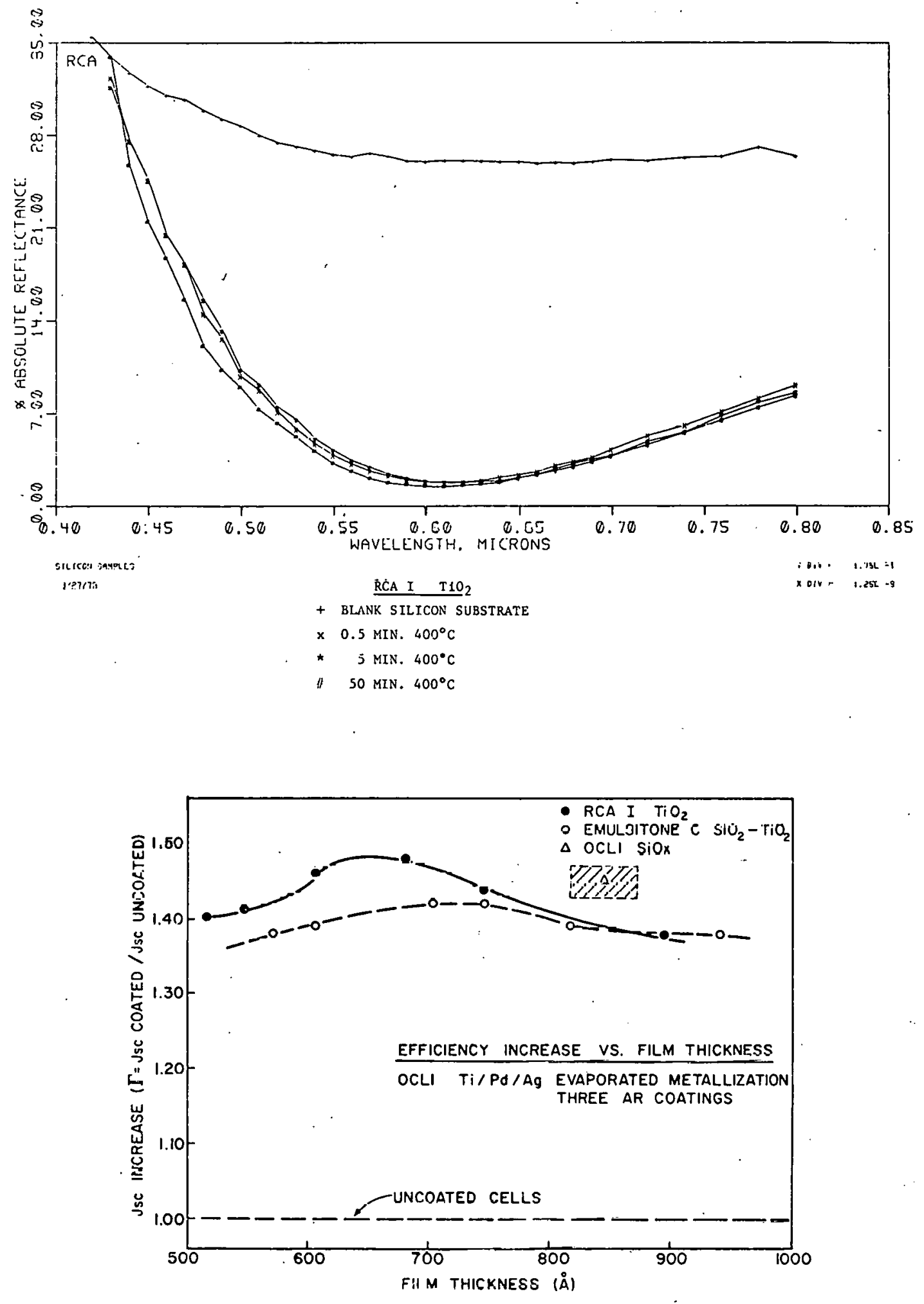


\section{CONCLUSIONS}

1. A HIGH.SPEED AUTOMATED SPRAYING PROCESS HAS BEEN DEVELOPED FOR DEPOSITING A LOW-COST AR COATING ON SILICON SOLAR CELLS:

2. THE OPTIMIZED SPRAY SOLUTION CONSISTS OF TITANIUM (IV) ISOPROPOXIDE, N-BUTYL ACETATE, 2.ETHYL-1-HEXANOL, AND ISOPROPANOL.

3. OXIDATIVE HYDROLYSIS AND HEAT TREATMENTS OF THE SPRAY FILM YIELDS A STABLE AR COATING OF CRYSTALLINE $\mathrm{TiO}_{2}$ (ANASTASE) OF $n=2.2$.

4. AR COATING THICKNESS IN THE RANGE OF 600-750 $\AA$ IS NON.C.RITISAL.

5. THE INCREASE OF ELECTRICAL OUTPUT EFFICIENCY ACHIEVED BY OUR AR COATING APPROACHES THE THEORETICAL MAXIMUM.

SPECTROLAB, INC.

\section{ARRAY AUTOMATED ASSEMBLY \\ PHASE 2}

WILLIAM E. TAYLOR

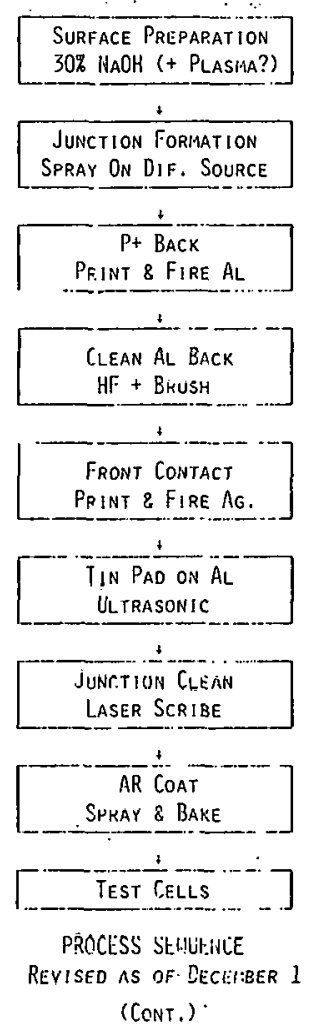




\title{
PRINTED ALUMINUM $\mathbf{P}^{+}$
}

PROBLEM SOURCES:

- SPIKE firing REQUIRED

- edge and front surface contamination

- incomplete coverage (wetting) of back surface

- aluminum powder

- SENSITIVITY OF FIRING CYCLE TO THERMAL MASS

- INTERACTIONS WITH DIFFUSION PROCESS

EFFECT OF THERMAL MASS ON OPTIMUM

FIRING CYCLE

\begin{tabular}{|l|c|c|}
\multicolumn{1}{c}{} & \multicolumn{1}{l}{ Round } & \multicolumn{1}{l}{ SOUARE } \\
\multicolumn{1}{c}{} & 2.125 INCH & \multicolumn{1}{l}{2.125 INCH } \\
\hline TEMPERATURE & $825^{\circ} \mathrm{C}$ & $850^{\circ} \mathrm{C}$ \\
\hline TIME & $40 \mathrm{seC}$ & $80 \mathrm{sEC}$ \\
\hline
\end{tabular}

DIFFERENT FIRING FIXTURES

\section{SPRAY ON DIFFUSION}

\author{
TEXTURI ZLI $\longrightarrow$ SMOOTH
}

\section{N250 OBSERVED TO GIVE 'ERAATIC}

SHEET REȘISTIYITY:

- run to run

- hafer to hafer?

- hithin wafers 


\title{
SPRAY ON DIFFUSION
}

\author{
TEXTURIZED $\longrightarrow$ SHOOTH
}

$\$ 250$

- operator dependent

- DILUTED $\longrightarrow$ FULL STRENGTH

- requires sheet resistance of 15 ohms/square vs, 30-35 FOR PHOSPHINE

$$
\begin{aligned}
& \text { PX-10 } \\
& \text { - MORE CONSISTEnt Results } \\
& \text { - } 30-35 \text { Ohms/SQUare SUItable }
\end{aligned}
$$

\begin{tabular}{|c|c|c|c|c|c|c|c|}
\hline \multicolumn{4}{|c|}{ BARE } & \multicolumn{4}{|c|}{ AR COATED } \\
\hline $\begin{array}{l}\text { VoC } \\
\text { MV }\end{array}$ & $\begin{array}{l}\text { Isc } \\
\text { MA }\end{array}$ & $\begin{array}{l}I_{500} \\
M A\end{array}$ & $\begin{array}{l}\text { RsH } \\
\text { OHMS }\end{array}$ & $\begin{array}{l}\text { Voc } \\
M V\end{array}$ & $\begin{array}{l}\text { Isc } \\
\text { MA }\end{array}$ & ${ }_{\text {MA }}$ & $\begin{array}{l}7 \\
\% .\end{array}$ \\
\hline & & 607 & 12.9 & 614 & 982 & 819 & 14.2 \\
\hline 603 & 721 & 618 & 15.4 & (1) & 967 & 823 & 14.2 \\
\hline $\begin{array}{l}505 \\
506\end{array}$ & $\begin{array}{l}723 \\
722\end{array}$ & $\begin{array}{l}\text { 354 } \\
629\end{array}$ & $\begin{array}{l}23.6 \\
23.9\end{array}$ & & & & \\
\hline $\begin{array}{l}803 \\
603\end{array}$ & $\begin{array}{l}723 \\
723\end{array}$ & 622 & 14.7 & & & & \\
\hline 604 & 735 & $\begin{array}{l}631 \\
632\end{array}$ & 17.7 & & & & \\
\hline $\begin{array}{l}604 \\
602\end{array}$ & $\begin{array}{l}732 \\
730\end{array}$ & $\begin{array}{l}630 \\
630 \\
630\end{array}$ & $\begin{array}{l}18.8 \\
22.4\end{array}$ & 614 & 994 & 836 & \\
\hline $\begin{array}{l}606 \\
603\end{array}$ & $\begin{array}{l}707 \\
747\end{array}$ & $\begin{array}{l}622 \\
630\end{array}$ & $\begin{array}{l}21.5 \\
22.9\end{array}$ & $\begin{array}{l}512 \\
611\end{array}$ & $\begin{array}{l}966 \\
999\end{array}$ & $\begin{array}{l}829 \\
812\end{array}$ & $\begin{array}{l}14.3 \\
14.0\end{array}$ \\
\hline $\begin{array}{l}604 \\
606\end{array}$ & $\begin{array}{l}736 \\
773\end{array}$ & $\begin{array}{l}628 \\
628\end{array}$ & $\begin{array}{l}20.3 \\
24.2\end{array}$ & 614 & 952 & 820 & 14.1 \\
\hline $\begin{array}{l}606 \\
604\end{array}$ & $\begin{array}{l}713 \\
707\end{array}$ & $\begin{array}{l}668 \\
617\end{array}$ & $\begin{array}{l}17.8 \\
18.4\end{array}$ & 613 & 956 & 817 & 14.1 \\
\hline 604.2 & 720 & 674.4 & 19.49 & 6125 & 7 & 822 & 14.19 \\
\hline 1.3 & 11.2 & 7.3 & 3.56 & 1.6 & 18.3 & 7.99 & 0.13 \\
\hline
\end{tabular}

\section{CELL PERFORMANCE}

RUN 3.18.9-C

SENSOR TECHNOLOGY, INC.

AUTOMATED ARRAY ASSEMBLY TASK DEVELOPMENT OF LOW-COST POLYSILICON SOLAR CELLS 


\section{AIM AND OBJECTIVES}

1. POLYSILICON SOLAR CELL PROCESS SEQUENCE.

2. FRONT SURFACE GRID PATTERN OPTIMIZATION.

3. - SURFACE MACROSTRUCTURE PROCESS.

4. JUNCTION FORMATION.

5. ANTI-REFLECTION COATINGS.

6. OTHER PROCESSES.

\section{PROJECT STATUS}

POLYSILICON MATERIAL HAS BEEN ORDERED FROM THE FOLLOWING COMPANIES:

1) WACKER

2) CRYSTAL SYSTEMS

3) EXOTIC MATERIALS

OTHER COMPANIES ALL BEING SOUGHT FOR POLYSILICON MATERIAL.

BHASE?

ARRAY AUTOMATED AEEEMDLY TASIK

GREGORY T. JONES

SANG S. RHEE

KIMBERLY ALLISON 


\title{
DESCRIPTION OF INDUSTRY
}

1) WAFERCO SUPPLIES WAFERS TO CELLCO AT THE PRICE OF 22 CENTS/WATT IN 1975 CENTS.

2) CELLCO AND MODULCO ARE VERTICALLY INTEGRATED COMPANIES.

3) CELLCO AND MODULCO REQUIRE 4.7 SHIFTS PER DAY, 24 HOURS PER DAY, 7 DAYS A WEEK, 345 OPERATING DAYS.

4) CELLCO AND MODULCO WILL SHARE 40\% OF THE 500 MW MARKET IN 1986.

\section{CELLCO}

1) PRODUCi

$90 \mathrm{~mm}$ DIAMETER HEXAGONAL SOLAR CELLS

CELL EFFICIENCY: $14.7 \%$

PEAK POWER: 0.76 WATTS/CELL

USABLE SILICON PER WAFER: $81 \%$

2) PRODUCTION YIELD

COMPANY YIELD IS $96.31 \%$

3) PRODUCTION SIZE

$278 \times 10^{6}$ CELLS/YEAR OR $210.3 \times 10^{6}$ WATT/YEAR

4) PROCESS STEPS

9 PROCESS STEPS

\section{CELLCO PRODUCTION LINE}

\author{
10 MEgawatT PER YeaA CAPACIT \\ 7200 WAFERS PER HOUR \\ CELLCO NEEOS SIX LINES FOR 200 MEGAWATT PER YEAR PLANT
}

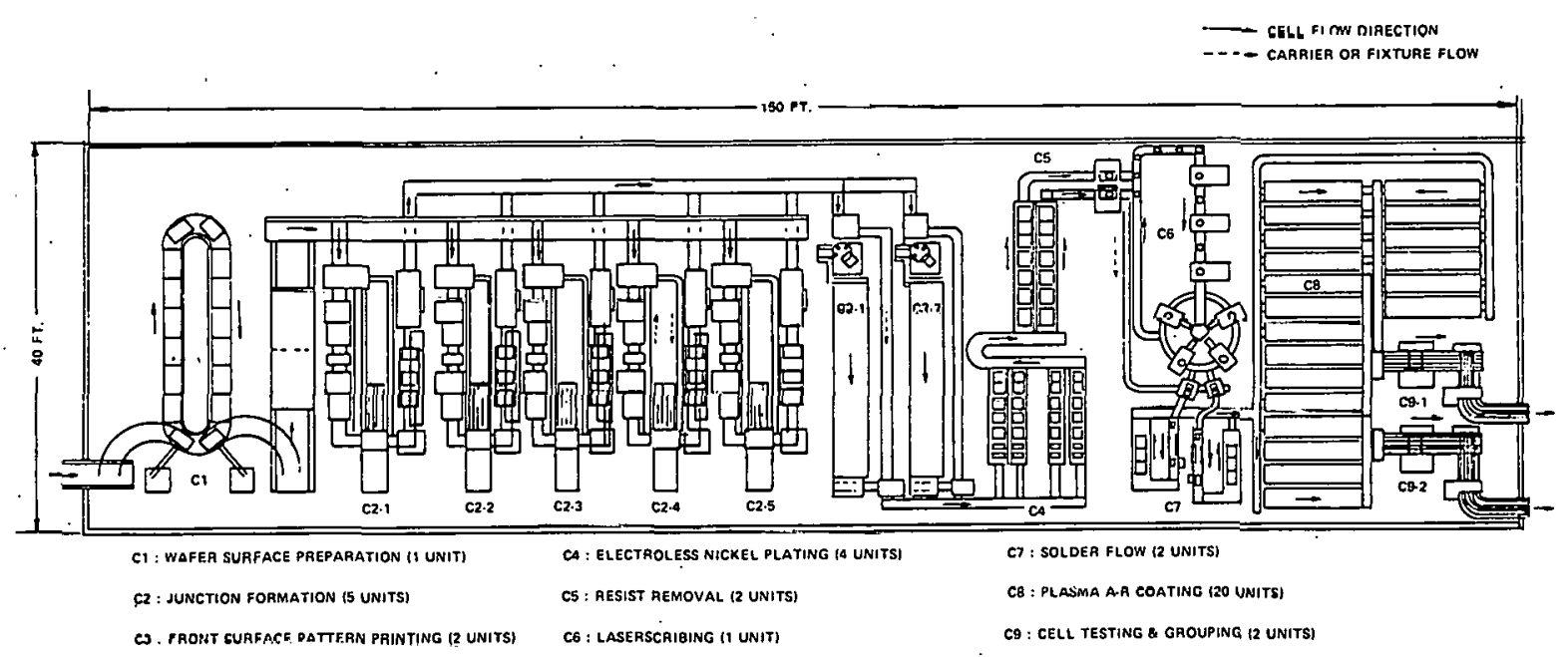




\section{MODULCO}

11 PRODUCI

MODULE SIZE: $2 \cdot \times$ ' NOMINAL

NUMBER OF SOLAR CELLS: 119 fULL HEXAGONAL SOLAR CELLS

PACKING RATIO: $87 \%$

ENCAPSULANT MATERIALS: GLASS/PVB/CELLS/PVB/MYLAR

PEAK POWER: 90 WATT/MODULE AT NOTC, $100 \mathrm{MW} / \mathrm{cm}^{2}$

2) PRQDUGTION YIELD

COMPANY YIELD IS $95.13 \%$

3) PRQQUCTION SIZE

$2.222 \times 10^{6}$ MODULES/YEAR -OR-

$200 \times 10^{6}$ WATTSIVEAR

4) PROCESS STEPS

7 PROCESS STEPS

\section{CELLCO PROCESS COST SUMMARY}

(COST PER PEAK WATT IN 1975 CENTS)

\begin{tabular}{|c|c|c|c|c|c|c|c|}
\hline $\begin{array}{l}\text { PROC. } \\
\text { NO. }\end{array}$ & $\begin{array}{l}\text { PROCESS } \\
\text { REFERENT }\end{array}$ & EQUIP. & $\begin{array}{l}\text { FL. } \\
\text { SPACE }\end{array}$ & LABOR & $\begin{array}{l}\text { MAT. \& } \\
\text { BY. PROP. }\end{array}$ & UTIL. & TOTAL \\
\hline C. 1 & WFSURPR & .200 & .072 & .440 & .780 & 190 & 1.602 \\
\hline C-2 & JUNF & .660 & .974 & ט/ט. & 1.200 & .641 & 3,735 \\
\hline$c .-3$ & FSPP & .128 & .110 & .270 & .424 & .050 & .882 \\
\hline $\mathrm{C}-4$ & ELNIPL & .084 & .038 & .430 & $3.810^{*}$ & .138 & $4.500^{*}$ \\
\hline C-5 & RESREM & .027 & .017 & .220 & 1.636 & .109 & 2.009 \\
\hline C-6 & HEXLS & .270 & .030 & .350 & .004 & 123 & .777 \\
\hline C.7. & SDFLW & .050 & .021 & .210 & 1.900 & .213 & 2.394 \\
\hline$C-8$ & ARCT & $1.861^{*}$ & .124 & .940 & .800 & .274 & $3.999^{*}$ \\
\hline C.9 & CELLTEST & .100 & .018 & .185 & 9 & .090 & .321 \\
\hline & TOTAL & 3.270 & .604 & 3.615 & 10.554 & 1.756 & 19.800 \\
\hline
\end{tabular}

- HIGHEST COST ELEMENT 


\section{MODULCO PROCESS COST SUMMARY (PLAN A)}

\begin{tabular}{|c|c|c|c|c|c|c|c|}
\hline $\begin{array}{l}\text { PROC. } \\
\text { NO. }\end{array}$ & $\begin{array}{l}\text { PROCESS } \\
\text { REFERENT }\end{array}$ & EQUIP. & $\begin{array}{l}\text { FL, } \\
\text { SPACE }\end{array}$ & LABOR & $\begin{array}{l}\text { MAT. \& } \\
\text { BY. PROP. }\end{array}$ & UTIL. & TOTAL \\
\hline$M \cdot 1$ & INTCON & 0.118 & 0.370 & 0.240 & $85.35^{*}$ & 1.766 & $87.84^{*}$ \\
\hline M-2 & MDLAYUP & 0.081 & 0.113 & 0.235 & $18.31^{*}$ & 0.004 & $18.743^{*}$ \\
\hline$M-3$ & DEGAS & 0.089 & 0.038 & 0.313 & 0 & 0.067 & · $\quad .507$ \\
\hline$M-4$ & AUTOCLAV & 0.228 & 0.073 & 0.083 & 0 & 0.380 & .764 \\
\hline M-5 & FRMASEM & 0.007 & 0.110 & 0.055 & $7.581^{*}$ & 0.002 & 7.755* \\
\hline$M \cdot 6$ & MDLTFST & 0.074 & 0.016 & 0.189 & & 0.003 & .282 \\
\hline M-7 & PICDMDL & 0.010 & 0.017 & 0.348 & 0.536 & 0 & .911 \\
\hline & TOTAL & 0.607 & 0.737 & 1.463 & $111.777^{*}$ & 2.222 & 116.806 \\
\hline
\end{tabular}

* highest cost element

MODULE SELLING PRICE (PLAN A)

(1975 CENTS PER PEAK WATT)

$\begin{array}{lc}\text { WAFERCO } & 22 . \varangle \\ \text { CELLCO } & 19.84 \\ \text { MODULCO } & 116.84 \\ \text { MODULE SELLING PRICE } & 158.6 ₫ / \text { WATT } \\ \text { MODULCO COST REDUCTION RECOMMENDATIONS } \\ \text { FROM PLAN A TO PLAN B }\end{array}$

1) FLEXIBLE PRINTED CIRCUIT SHEET IS REPLACED BY A STAMPED COPPER STRIP ON KAPTON.

PRICE CHANGE: $\$ 5 / \mathrm{FT}^{2}$ TO $\$ 0.25 / \mathrm{FT}^{2}$

2) LAMINATION MATERIAL PVB IS REPLACED BY EVA.

PRICE CHANGE: $\$ .34 / F^{2}$ TO $\$ 0.086 / F^{2}$

3) ALUMINUM FRAME IS MODIFIED BY CHANGING THE SPECIFICATIONS AS FOLLOWS: 3 INCH HEIGHT AND 1/8 INCH THICINESS CHANGED TO 2 INCH HEIGHT and 3/32 INCH THICKNESS.

PRICE CHANGE: $\$ 0.38 / F T$ TO $\$ 0.19 / F T$ 


\title{
MODULCO PROCESS COST SUMMARY (PLAN B) POTENTIAL FUTURE MODULE
}

(COST PER PEAK WATT IN 1975 CENTS)

\begin{tabular}{|c|l|l|c|c|c|c|c|}
\hline $\begin{array}{c}\text { PROC. } \\
\text { NO. }\end{array}$ & $\begin{array}{c}\text { PROCESS } \\
\text { REFERENT }\end{array}$ & EQUIP. & $\begin{array}{c}\text { FL. } \\
\text { SPACE }\end{array}$ & LABOR & MAT. & UTIL. & TOTAL \\
\hline M-1 & INTCON & 0.118 & 0.370 & 0.240 & 4.268 & 1.766 & 6.762 \\
M-2 & MDLAYUP & 0.081 & 0.113 & 0.235 & 14.08 & 0.004 & 14.513 \\
M-3 & DEGAS & 0.089 & 0.038 & 0.313 & 0 & 0.067 & .507 \\
M-4 & AUTOCLAV & 0.228 & 0.073 & 0.083 & 0 & 0.380 & .764 \\
M-5 & FRMASEM & 0.007 & 0.110 & 0.055 & 4.23 & 0.002 & 4.404 \\
M-6 & MDLTEST & 0.074 & 0.016 & 0.189 & 0 & 0.003 & .282 \\
M-7 & PKDMDL & 0.01 & 0.017 & 0.348 & 0.536 & 0. & .911 \\
\hline
\end{tabular}

\section{MODULE SELLING PRICE (PLAN B)}

\author{
MODULE SELLING PRICE (PLAN B)
}

(1975 C.FNTS PER PEAK WATT)

\begin{tabular}{|c|c|}
\hline WAFERCO & $22.00 \$$ \\
\hline CELLCO & $19.80 \leftarrow$ \\
\hline MODULCO & 28.144 \\
\hline
\end{tabular}

\section{CONCLUSIONS}

1) THE SOLAR CELL AND MODULE PROCESS COSTS ARE FEASIBLE AND WILL MEET. THE 1986 LSA COST GOALS.

2) THE MODULE FABRICATION MATERIAL COSTS ARE HIGH. FOUR MAJOR PROBLEM AREAS ARE:

LAMINATION MATERIAL

FRAME MATERIAL

SEALANTS

TERMINALS 


\section{AUTOMATED ARRAY ASSEMBLY TASK INDEPTH STUDY OF SILICON WAFER SURFACE TEXTURIZING}

\section{AIM AND OBJECTIVES}

1. LOW.COST WAFER CLEANING.

2. LOW-COST WAFER DRYING.

3. TWO-STAGE TEXTURIZING PROCESS.

4. GETTERING PROCESS.

\section{PROJECT STATUS}

1. EFFECT OF GETTERING AND TEXTURIZING ON POOR TO FAIR QUALITY 1.406 INCH, SQUARE SILICON MATERIAL.

2. EFFECT OF GETTERING AND TEXTURIZING ON FAIR TO GOOD QUALITY 3 INCH DIAMETER ROUND SILICON MATERIAL.

\section{COST OF POC1 $1_{3}$ JUNCTION FORMATION IN CENTS PER PEAK WATT}

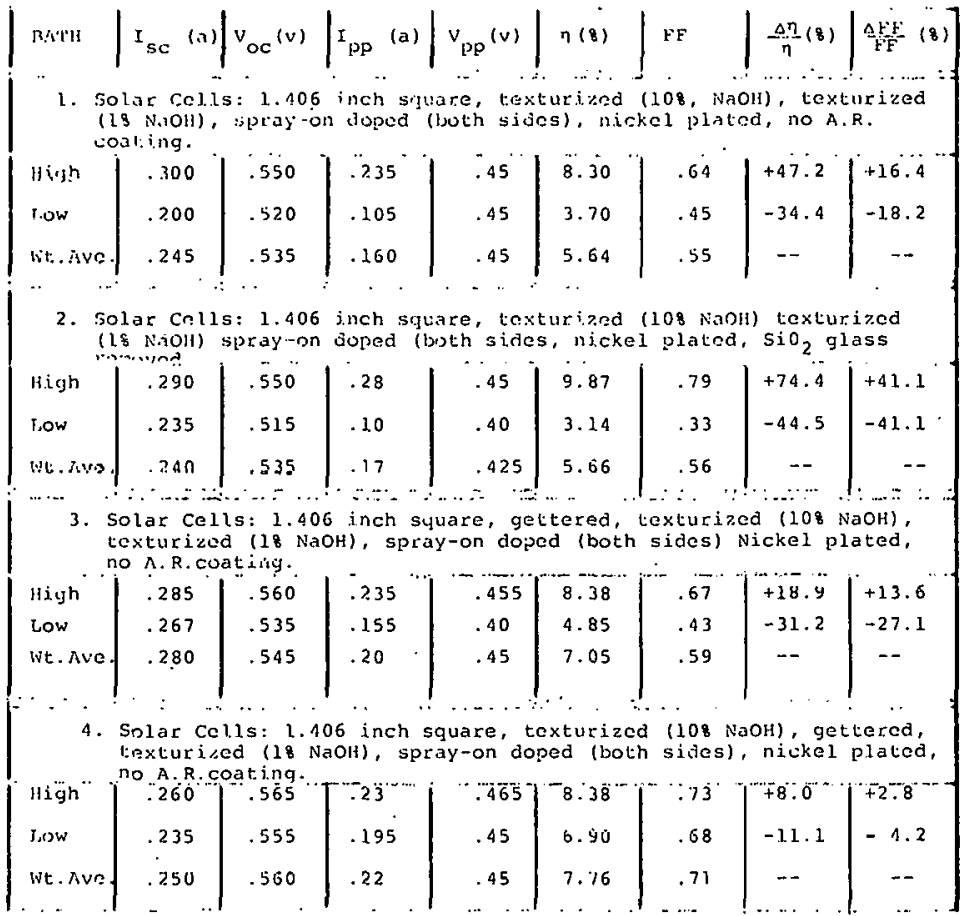




\section{COST OF SPRAY ON DOPANT JUNCTION FORMATION IN CENTS PER PEAK WATT}

\begin{tabular}{|c|c|c|c|c|c|c|c|c|}
\hline Batch & $I_{s c}(A)$ & $v_{\text {oc }}(v)$ & $I_{p p}(a)$ & $v_{p p}(v)$ & $\eta(8)$ & $\mathbf{F} \mathbf{F}$ & $\frac{\Delta n}{n}-(8)$ & $\mathrm{ArF}^{\prime} \mathrm{F}$ \\
\hline$B-1$. & ontrol. & d $\operatorname{ces} 11$ & d. $T$ & Stop $\mathrm{T}$ & , si:d. & $\mathrm{OCl}_{3}$ & f. with & AI Fan:k \\
\hline & & & " & & . & .. & . & \\
\hline High & 1.40 & 0.580 & 1.22 & 0.435 & 12.82 & 0.654 & 16.55 & 15.24 \\
\hline Low & 1.30 & 0.565 & 0.99 & 0.365 & 8.73 & 0.492 & -20.64 & -13.38 \\
\hline wt sue. & 1.38 & 0.582 & 1.20 & 0.38 & 11.00 & 0.568 & - & $\cdots-$ \\
\hline \multicolumn{9}{|c|}{ B-2. Intermediate Gettering } \\
\hline$\ldots$ & & " & . & & & - & &. \\
\hline High & 1.43 & 0.575 & 1.26 & 0.44 & 13.40 & 0.680 & 8.94 & 5.43 \\
\hline Low & 1.43 & 0.555 & 1.20 & 0.37 & 10.71 & פספ & 12.93 & $t=1 \mathrm{~s} .3 \mathrm{~s}$ \\
\hline Wt. Ave. & 1.40 & 0.565 & 1.24 & 0.41 & 12.30 & 0.645 & -- & - \\
\hline \multicolumn{9}{|c|}{ 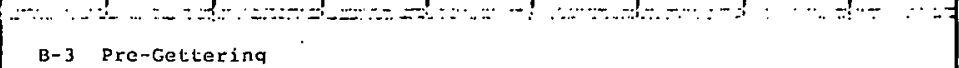 } \\
\hline & 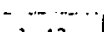 & . & & & $\cdots$ & (n) & $\cdots \cdots$ & $\cdots$ \\
\hline Itigh & J. .42 & 0.575 & 1.25 & 0.420 & 12.68 & 0.643 & 8.10 & 4.72 \\
\hline Jow & 1.37 & 0.560 & 1.10 & 0.370 & 9.83 & 0.531 & -16.20 & -13.52 \\
\hline wt. Ave. & 1.40 & 0.565 & 1.20 & 0.405 & 11.73 & 0.614 & -- & -- \\
\hline$B-4$ & ntermedi & ate Ge & ering wi & h Sio $A R$ & Coating & & & $\cdot$ \\
\hline & & & & & & 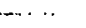 & & $\cdots$ \\
\hline$H \mathrm{j}, \mathrm{gh}$ & 1.45 & 0.573 & 1.30 & 0.455 & 14.29 & 0.712 & 7.61 & 3.79 \\
\hline tow & 1.40 & 0.555 & 1.20 & 0.43 & 12.46 & 0.664 & -6.17 & -3.21 \\
\hline tit five. & 1.42 & 0.565 & 1.28 & 0.43 & 13.28 & 0.686 & -- & -- \\
\hline & .. & & & & & & & \\
\hline
\end{tabular}

\section{COST OF POC13 JUNCTION FÜRATION IN CENTS PER PEAK WATT}

$\begin{array}{lc}\text { Equipment cost } & 2.15 \\ \text { Labor cost } & 0.80 \\ \text { Material } & 9.73 \\ \text { ULility } & 0.01 \\ \quad \text { TOTAL } & 13.39\end{array}$




\section{COST OF SPRAY ON DOPANT JUNCTION FORMATION IN \\ CENTS PER PEAK WATT}

\begin{tabular}{ll} 
Equipment & 0.296 \\
Floor. Space & 0.065 \\
Labor & 0.296 \\
Material & 0.781 \\
Utility & 0.0887 \\
\multicolumn{1}{r}{$\quad$ TOTAL } & 1.5267 cents/peak watt
\end{tabular}

\section{SPRAY ON DOPANT PROCESS}

TYPE OF CELL

$$
\mathrm{N}^{+-}-\mathrm{P}-\mathrm{P}^{+}
$$

Solution for $\mathrm{N}^{+}$junction - water base phosphor.

Film $\quad \mathbf{N}=10^{19} / \mathrm{cm}^{3} \quad$ viscocity $=.5-9$ centipoise

a $28^{\circ} \mathrm{C}$

Solution for $\mathrm{p}^{+}$junction - water base Boron Film

$$
\mathrm{N}=10^{18} / \mathrm{cm}^{3} \text { viscocity } 5-9 \text { centipoise }
$$

Infra Red Oven Temperature $=400^{\circ} \mathrm{F}$

PARAME'TERS

AVG. CELL EFFICIENCY

CONVEYOR SPEED

RECIPROCATOR SPEED

SOLVENT CONSUMPTION/GUN

ATOMIZATION PRESSURE

COATING THICKNESS

COST UF EQUTPMENT

THROUGHPUT/HOUR

DRIVE-IN
PRESENT

$13 \%$

2'/Minute

$90 \mathrm{osc} / \mathrm{min}$.

$7 \mathrm{cc} / \mathrm{min}$.

20 PSI

$2 \pm . \dot{0} .5 \mathrm{u}$

$18,000.00$

450

Furnace Temp $925^{\circ}$
FUTURE

14.58

¿'/minule 90 osc/min.

$7 \mathrm{cc} / \mathrm{min}$.

25 PSI

$2_{-}^{+} 0.5 \mathrm{U}$

$78,790.00$

2800

Investigating new techniques 
COMPARISON OF PROCESS COSTS FOR A FULLY AUTOMATED

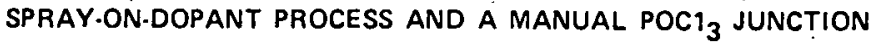
FORMATION PROCESS IN TERMS OF 1975 CENTS PER PEAK WATT

SAMICS RESULTS FOR SPRAY.ON DOPANT PROCESS IN 1975 CENTS PER PEAK WATT

EQUIPMENT

FLOOR SPACE

LABOR

MATERIAL

UTILITY

TOTÁL

SPRAY.ON DOPANT PROCESS

1. SPRAY.ON

2. DRIVE-IN

3. EXCESS DOPANT REMOVAL
SAMICS RESULTS FOR POC1 3 JUNCTION FORMATION PROCESS IN 1975 CENTS PER PEAK WATT

\begin{tabular}{lr} 
EQUIPMENT & 2.644 \\
FLOOR SPACE & 3.969 \\
LABOR & 38.330 \\
MATERIAL & 39.207 \\
UTILITY & 16.810 \\
\hline TOTAL & 100.960
\end{tabular}

POC1 $_{3}$ JUNCTION FORMATION PROCESS
1. PREDIFFUSION CLEANING
2. $\mathrm{POCl}_{3}$ DIFFUSION
3. FRONT SURFACE PRINTING
4. BACK SURFACE ETCHING
5. ALUMINUM EVAPORATION
6. ALUMINUM FIRE-IN 


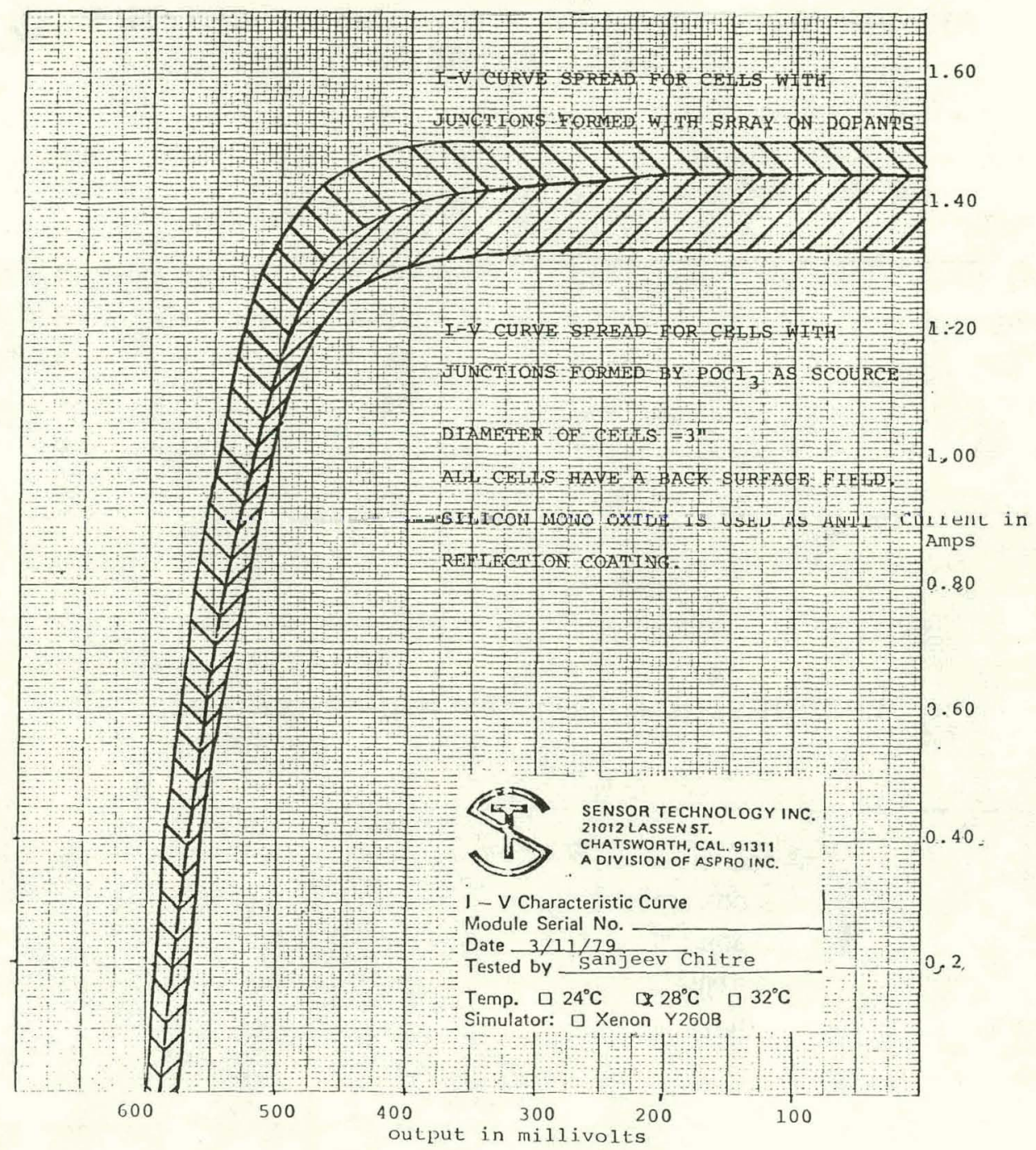

\section{PROCESS COSTS FOR PARALLEL FLOW LASERSCRIBE SYSTEM IN CENTS PER PEAK WATT}

\begin{tabular}{lcccc} 
& 1986 cents & 197 cents \\
\hline Equipinent & Old Value & $\begin{array}{c}\text { Corrected } \\
\text { Value }\end{array}$ & Old Value & $\begin{array}{c}\text { Corrected } \\
\text { Value }\end{array}$ \\
Floor space & 0.5850 & 0.5850 & 0.3049 & 0.3049 \\
Labor & 0.0612 & 0.0612 & 0.0319 & 0.0319 \\
Materials & 0.8449 & 0.8449 & 0.4400 & 0.4400 \\
Utilities & 0.0192 & 0.0192 & 0.0100 & 0.0100 \\
\hline Total & 11.0986 & 0.2783 & 5.7869 & 0.1451 \\
\hline
\end{tabular}




\section{PROCESS COSTS FOR SERIAL FLOW LASERSCRIBE SYSTEM IN CENTS PER PEAK WATT}

\begin{tabular}{lcccc}
\hline & \multicolumn{2}{c}{1986 cents } & \multicolumn{2}{c}{1975 cents } \\
\cline { 2 - 5 } & Old Value & $\begin{array}{c}\text { Corrected } \\
\text { Value }\end{array}$ & Old Value & $\begin{array}{c}\text { Corrected } \\
\text { Value }\end{array}$ \\
\hline Equipment & 0.5219 & 0.5219 & 0.2721 & 0.2721 \\
Floor Space & 0.0564 & 0.0564 & 0.0294 & 0.0294 \\
Labor & 0.5612 & 0.5612 & 0.2926 & 0.2926 \\
Materials & 0.0247 & 0.0247 & 0.0129 & 0.0129 \\
Utilities & 9.1261 & 0.2319 & 4.7580 & 0.1209 \\
\hline TOTAL & 10.2903 & 1.3961 & 5.3650 & 0.7279 \\
\hline
\end{tabular}

COST OF SERIAL FLOW LASERSCRIBE SYSTEM

(1975 CENTS PER PEAK WATT)

\begin{tabular}{ll} 
EQUIPMENT & .270 \\
FLOOR SPACE & .030 \\
LABOR & .350 \\
MATERIAL & .004 \\
UTILITY & .123 \\
\hline TOTAL & $.777^{*}$
\end{tabular}

"TOTAL COST INCLUDES SCRIBING A MODIFIED HEXAGONAL SOLAR CELL WITH CENTRAL HOLE. 
LASERSCRIBING PROCESS

\begin{tabular}{|l|l|l|l|}
\hline Laser Parameters & Existing & Serial & Parallel Flow \\
\hline Mode & TEMoo & TEMoo & TEMoo \\
Beam Size & $0.6 \mathrm{mil}$ & $1 \mathrm{mil}$ & $1 \mathrm{mil}$ \\
Power/Beam & 10 watts & $32 \mathrm{watts}$ & $32 \mathrm{watts}$ \\
Pulse Rate & $10 \mathrm{KHz}$ & $10 \mathrm{KHz}$ & $10 \mathrm{KHz}$ \\
Time Cycle & $45 \mathrm{sec}$. & $19 \mathrm{sec}$. & $31 \mathrm{sec}$. \\
Velocity & $2.5 \mathrm{in} / \mathrm{sec}$. & $10 \mathrm{in} / \mathrm{sec}$. & $10 \mathrm{in} / \mathrm{sec}$. \\
Throughput/hour & 120 & 7200 & 4800 \\
Wafer Resident time & $25 \mathrm{sec}$. & $19 \mathrm{sec}$. & $31 \mathrm{sec}$. \\
Cost of Equipment & $\$ 85,000.00$ & $\$ 520,000.00$ & $\$ 387,000.00$ \\
\hline
\end{tabular}

\section{JUNCTION FORMATION ADD-ON PRICES}

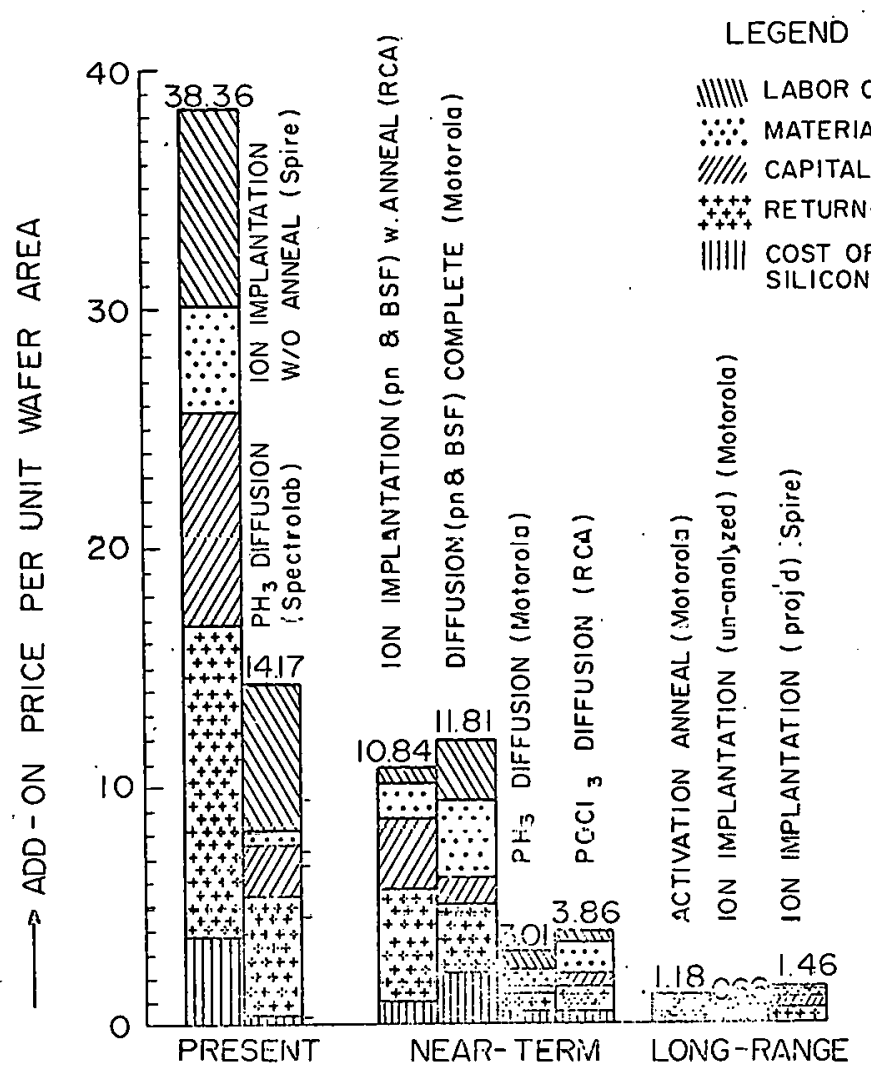




\section{CALTECH STUDY (OCLI)}

- PRODUCED - $12 \%$ AMI CELLS WITH P ${ }_{4}^{+}$(BASELINE)

- WITHIN 10\% OF DIFFUSED CONTROL SAMPLES

- RELATIVELy INSENSItIVE tO beam PaRAMETERS

- PRODUCED $P^{+} \& P_{2}^{+}$IMPLANTED CELLS FOR COMPARISON

- slightly lower than P $_{4}^{+}$IMPLanted samples

- still under study

- IMPLANTED SAMPLES WITH BEAM IMPURITIES

- SUBMITTED TO OCLI FOR PROCESSING

- preliminary Results

- MOLECULAR PHOSPHORUS PROMISING

- $\mathrm{P}_{4}^{+}$IMPLANT MAY INCREASE THROUGHPUT

\section{PRINCIPLES OF ION IMPLANTER DESIGN}

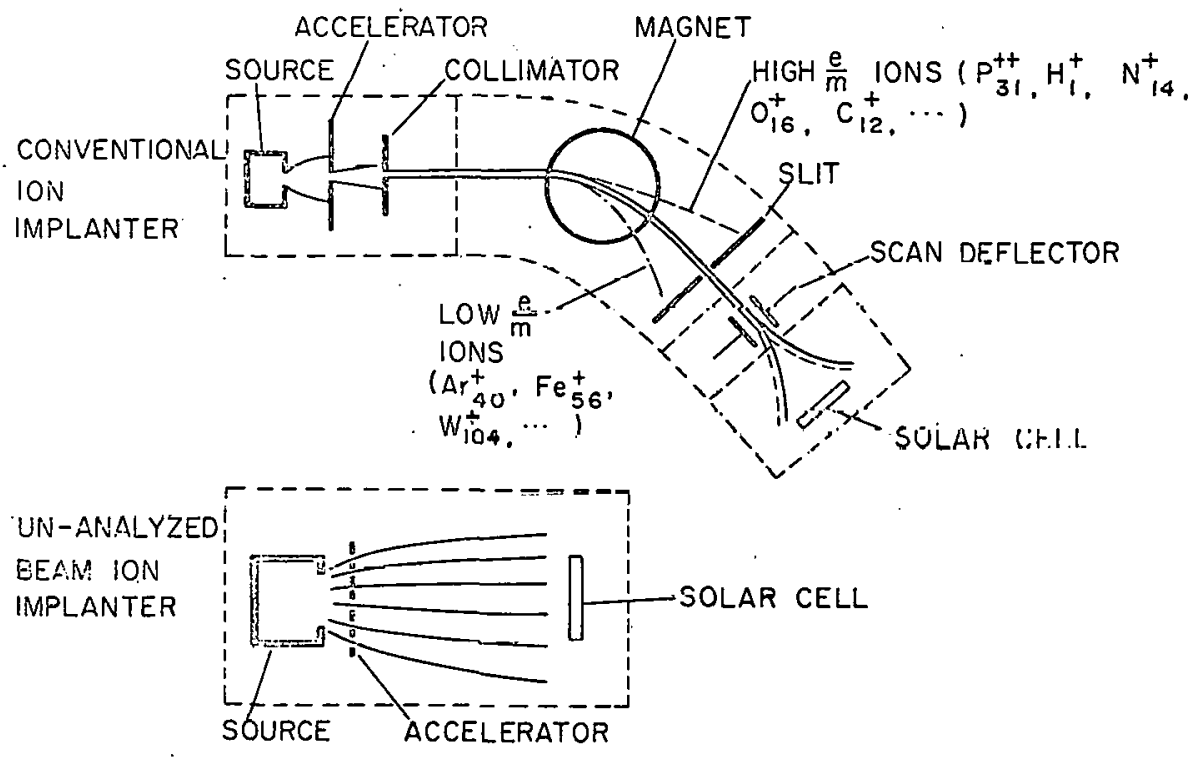



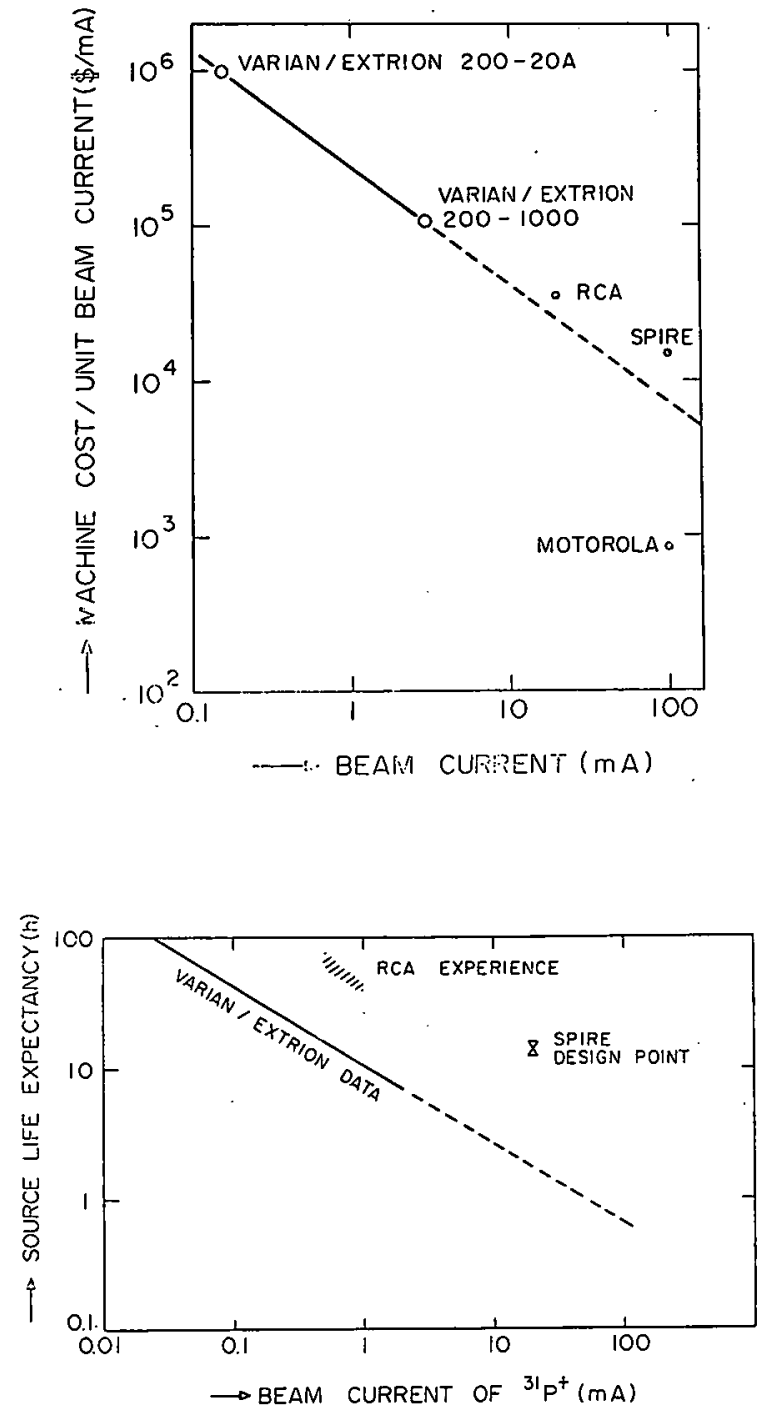


\section{PROCESS ENERGIES FOR JUNCTION FORMATION PROCESSES (kWh/M2)}

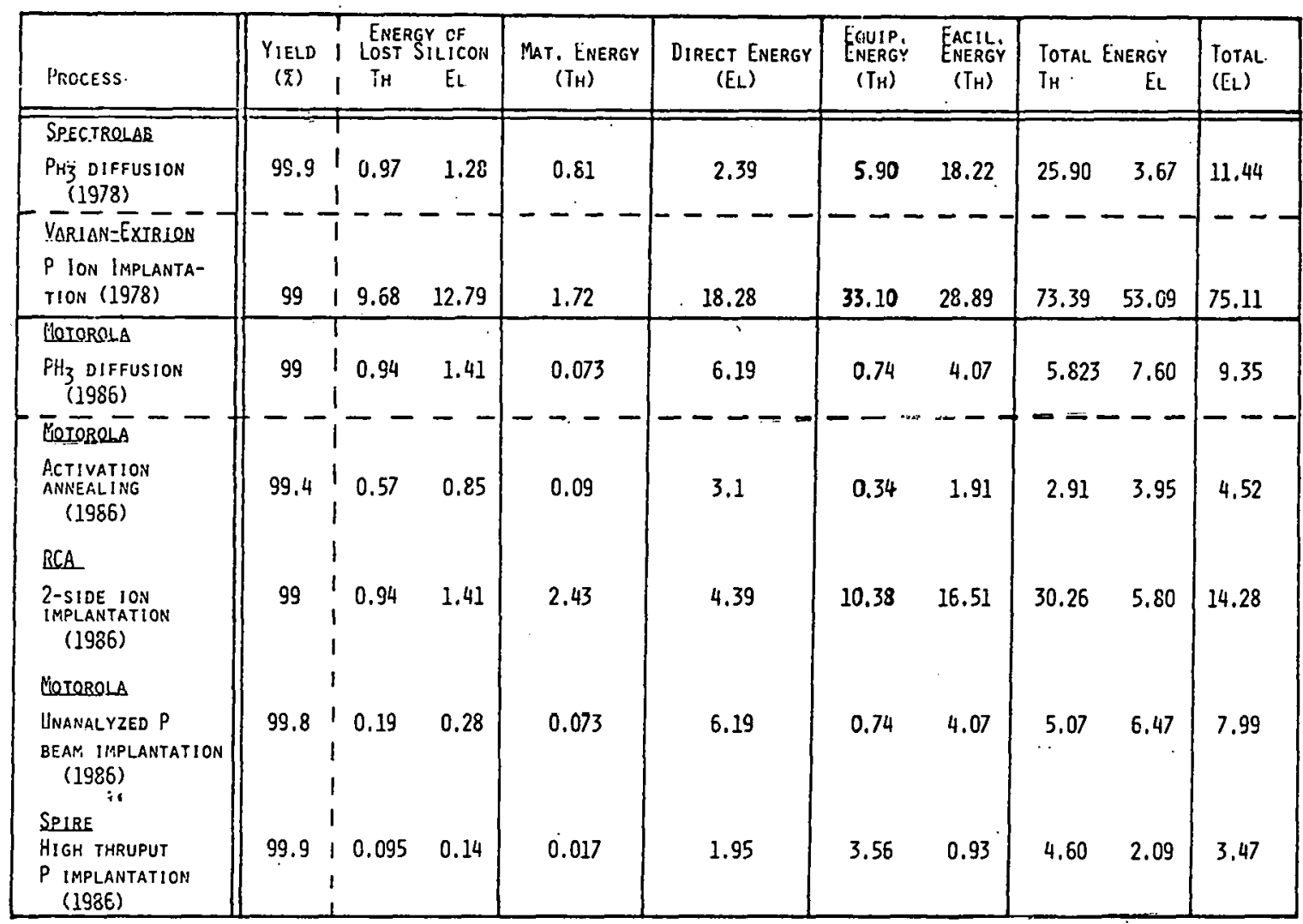

$0.3 \mathrm{KHH}(E L)=1 \mathrm{KWH}(T H)$

EWERGIES UF STARTING MATERIAL

$\begin{array}{ccc} & T H & E L \\ 1978 & 967.89 & 1279.12\end{array}$

$1985 \quad 94.94 \quad 141.29$ 


\section{TECHNICAL AND ECONOMIC COMPARISON OF PRESENT AND PROPOSED JUNCTION FORMATION PROCESSES}

\begin{tabular}{|c|c|c|c|c|c|c|c|c|}
\hline ORGANIZATION & $\begin{array}{l}\frac{\text { Varian-Extrion }}{200-1000 \text { hp }} \\
\text { (Spire) } \\
(1978)\end{array}$ & $\begin{array}{c}\frac{\text { Spectrolab }}{\text { phy dif- }} \\
\text { fubion } \\
(1978)\end{array}$ & $\begin{array}{c}\text { Motorola } \\
\text { PH } 3 \text { dif- } \\
\text { fusion } \\
(1986) \\
\end{array}$ & $\begin{array}{c}\frac{\text { Motorolia }}{5-s t e p} \\
\text { diffusion } \\
\text { process } \\
(1986)\end{array}$ & $\begin{array}{c}\text { RCA } \\
\text { 2-side ion } \\
\text { Implanta- } \\
\text { tion w/an- } \\
\text { nealing } \\
(1986)\end{array}$ & $\begin{array}{c}\frac{\text { Motorola }}{\text { Activation }} \\
\text { annealing } \\
(1986)\end{array}$ & 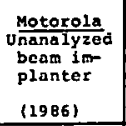 & $\begin{array}{l}\text { Spize } \\
\text { gigh thruput } \\
\text { ion implan- } \\
\text { ter } \\
(1986)\end{array}$ \\
\hline $\begin{array}{l}\text { Throughput/rate (no.h-1/dia. }(\mathrm{cm}) ! \\
\text { 1. Direct Materials } \\
\text { 2. Indircct Materials } \\
\text { 3. Expendible toollng } \\
\text { 4. Electrical Energy }\end{array}$ & $\begin{array}{l}240 / 7.6-\mathrm{cm} \\
0.01 \\
0.75 \\
2.63 \\
0.73\end{array}$ & $\begin{array}{l}129 / 7.6-\mathrm{cm} \\
0.02 \\
0.19 \\
0.28 \\
0.08\end{array}$ & $\begin{array}{l}1000 / 12- \\
\mathrm{cm} \\
0.29 \\
0.28 \\
0.07 \\
0.20\end{array}$ & $\begin{array}{l}2000 / 1.2- \\
\mathrm{cm} \\
2.26 \\
0.25 \\
0.16 \\
0.44\end{array}$ & $\begin{array}{c}2000 / 7.6- \\
\mathrm{cm} \\
6.25 \\
0.69 \\
0.27 \\
0.22\end{array}$ & $\begin{array}{c}2000 / 12-\mathrm{cm} \\
0 . \\
0.03 \\
0.05 \\
0.1 \mathrm{C}\end{array}$ & $\begin{array}{l}4800 / 12-\mathrm{cm} \\
0.03 \\
0.07 \\
0.00 \\
0.02\end{array}$ & $\begin{array}{c}28,000 / 10- \\
\mathrm{cm} \\
0.07 \\
0.02 \\
0.06 \\
0.08\end{array}$ \\
\hline $\begin{array}{l}\text { 5. Total Materials } \\
\left(1.0526^{*}(1,+2,+3,+4.1)\right.\end{array}$ & 4.34 & 0.59 & 0.78 & 3.27 & 1.51 & 0.18 & 0.13 & 0.24 \\
\hline 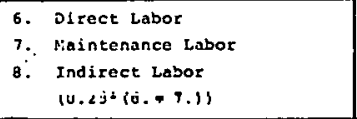 & $\begin{array}{l}5.50 \\
0.70 \\
1.55\end{array}$ & $\begin{array}{c}4.65 \\
:- \\
1.17\end{array}$ & $\begin{array}{l}0.52 \\
0.08 \\
0.15\end{array}$ & $\begin{array}{l}1.68 \\
0.37 \\
0.51\end{array}$ & $\begin{array}{l}0.42 \\
0.14 \\
0.14\end{array}$ & $\begin{array}{c}0.24 \\
-- \\
0.06\end{array}$ & $\begin{array}{l}0.12 \\
0.02 \\
0.03\end{array}$ & $\begin{array}{l}0.07 \\
0.02 \\
0.02\end{array}$ \\
\hline $\begin{array}{l}\text { 9. Total Labor } \\
(1.3158 \cdot(6 .+7 .))\end{array}$ & 9.16 & 6.12 & 0.78 & 2.72 & 0.73 & 0.32 & 0.28 & 0.11 \\
\hline $\begin{array}{l}\text { 10. Equipment } \\
\text { 11. Fasility }\end{array}$ & $\begin{array}{l}7.54 \\
0.39\end{array}$ & $\begin{array}{l}1.61 \\
0.37\end{array}$ & $\begin{array}{l}0.17 \\
0.05\end{array}$ & $\begin{array}{l}0.79 \\
0.19\end{array}$ & $\begin{array}{l}2.45 \\
0.26\end{array}$ & $\begin{array}{r}0.07 \\
-0.03 \\
\end{array}$ & $\begin{array}{l}0.05 \\
0.02 \\
\end{array}$ & $\begin{array}{l}0.40 \\
0.01\end{array}$ \\
\hline 12. Capital $(10 .+11)$. & 7.93 & 1.98 & 0.22 & 0.98 & 2.71 & 0.10 & 0.07 & 0.41 \\
\hline $\begin{array}{l}\text { 13. Overhead } \\
\text { 14. Return-on-equity }\end{array}$ & $\begin{array}{r}0.48 \\
13.45 \\
\end{array}$ & $\begin{array}{l}0.23 \\
5.69 \\
\end{array}$ & $\begin{array}{l}0.02 \\
0.76 \\
\end{array}$ & $\begin{array}{l}0.05 \\
2.96\end{array}$ & $\begin{array}{l}0.17 \\
4.68 \\
\end{array}$ & $\begin{array}{l}0.01 \\
0.31\end{array}$ & $\begin{array}{l}0.005 \\
0.21\end{array}$ & $\begin{array}{l}0.03 \\
0.62 \\
\end{array}$ \\
\hline $\begin{array}{l}\text { 15. Podi-on price of process } \\
\text { 16. Yield (Q) } \\
\text { 17. Yield add-on process price } \\
\text { 18. Cose of sillicon lost-1n- } \\
\text { process }\end{array}$ & $\begin{array}{c}34.45 \\
99 \\
34.83 \\
3.53\end{array}$ & $\begin{array}{l}14.51 \\
99.9 \\
14.52 \\
0.35\end{array}$ & $\begin{array}{c}2.56 \\
99 \\
2.59 \\
0.42 \\
\end{array}$ & $\begin{array}{l}9.98 \\
9 .- \\
9.98 \\
1.78\end{array}$ & $\begin{array}{l}9.90 \\
-. \\
9.90 \\
0.84\end{array}$ & $\begin{array}{l}0.93 \\
99.4 \\
0.93 \\
0.25\end{array}$ & $\begin{array}{l}0.58 \\
99.8 \\
0.58 \\
0.08 \\
\end{array}$ & $\begin{array}{l}1.42 \\
99.9 \\
1.42 \\
0.04\end{array}$ \\
\hline 19. Adti-on price & $\overline{38.36}$ & 14.87 & 3.01 & 21.76 & 10.74 & 1.18 & 0.66 & 2.46 \\
\hline
\end{tabular}

\section{DEVELOPMENT OF ECONOMICAL IMPROVED THICK FILM SOLAR CELL CONTACT}

OBJECTIVES:

1. PROVIDE AN ALL-METAL SCREENABLE INK FOR SCLAR CELL CONTACTS,

2. ELIMINATE GLASS FRIT.

3. SUBSTITUTE LOW MELTING METAL POWDER "FRIT" PROMOTING SiNTERING IN LIQUID PHASE

4. DETERHINE A SCREENABLE OXIDE SCAVENGER, REMOVING NATIVE SILICON OXIDC DURINC FIRING STEP, AND WHICH DNES NOT AFFEC.T MATURED ELECTRODE PROPERTIES.

5. MAINTAIN COGNIZANCE OF LSA COST OBJECTIVES IN MATERIAL AND PROCESS SELECTION. 


\section{ACCOMPLISHMENTS}

1. A LOW TEMPERATURE DEPOLYMERIZING PASTE BINDER HAS BEEN IDENTIFIED,

2. THReE SCREenable OXIDE SCAVengers have BeEn found.

3. LOW TEMPERATURE SINTERING OF AN ALL-METAL PASTE. HAS BEEN ACCOMPLISHED IN A SILVER SYSTEM.

4. ELECTRODES HAVE EXCELLENT METALLURGICAL AND ENVIRONTAL PROPERTIES.

5. TO DATE 61 PASTE FORMULATIONS HAVE BEEN PREPARED AND CHARACTER IZED.

\section{AVERAGE GRAIN DIAMETER VARIATION VERSUS RECIPROCAL TEMPERATURE FOR SEVERAL ALL METAL INKS}

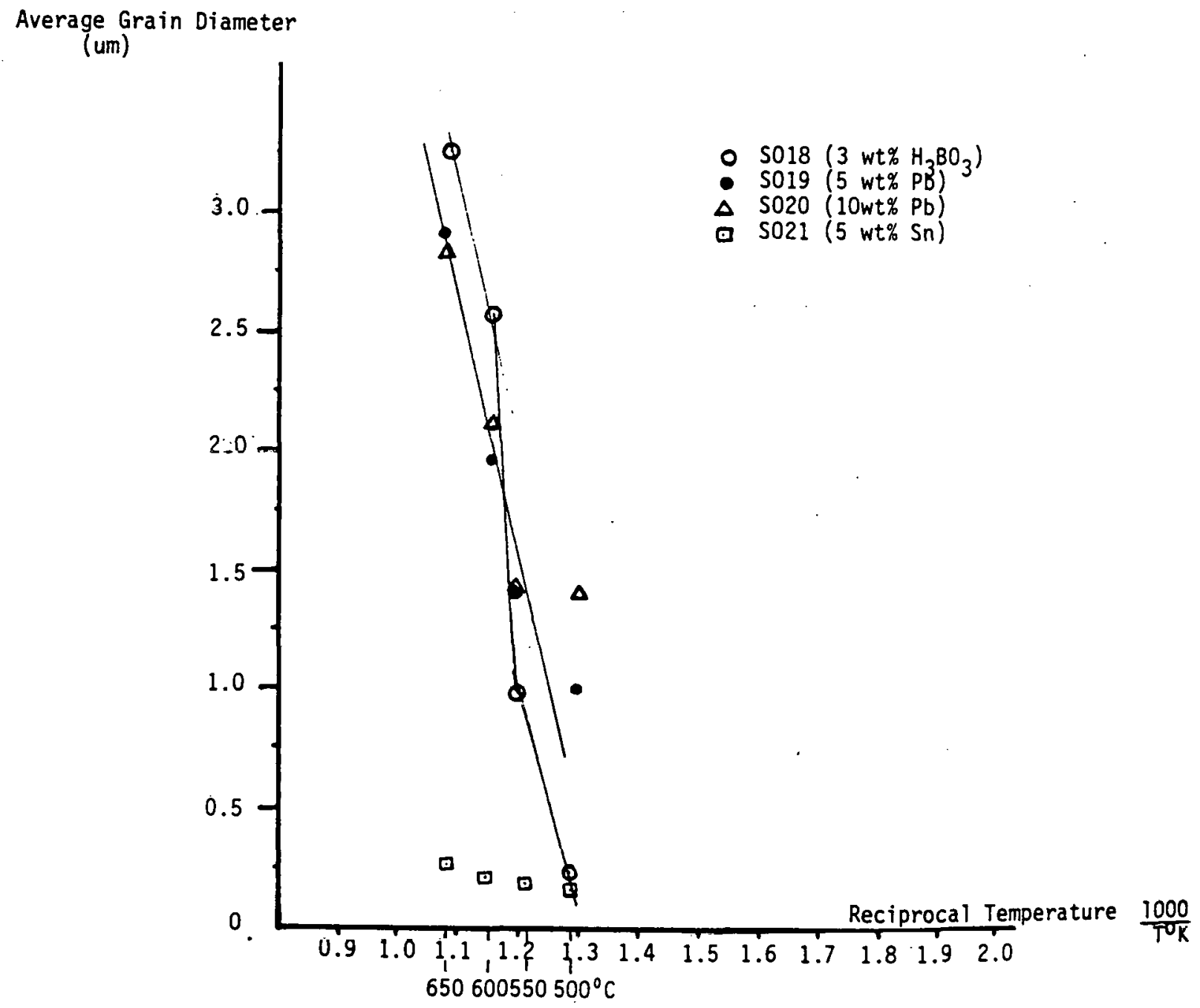




\section{AUGER SURFACE SPECTRA VERSUS ETCH DEPTH \\ OF DECOMPOSED $A_{G} F-S_{\mid}$INTERFACE}

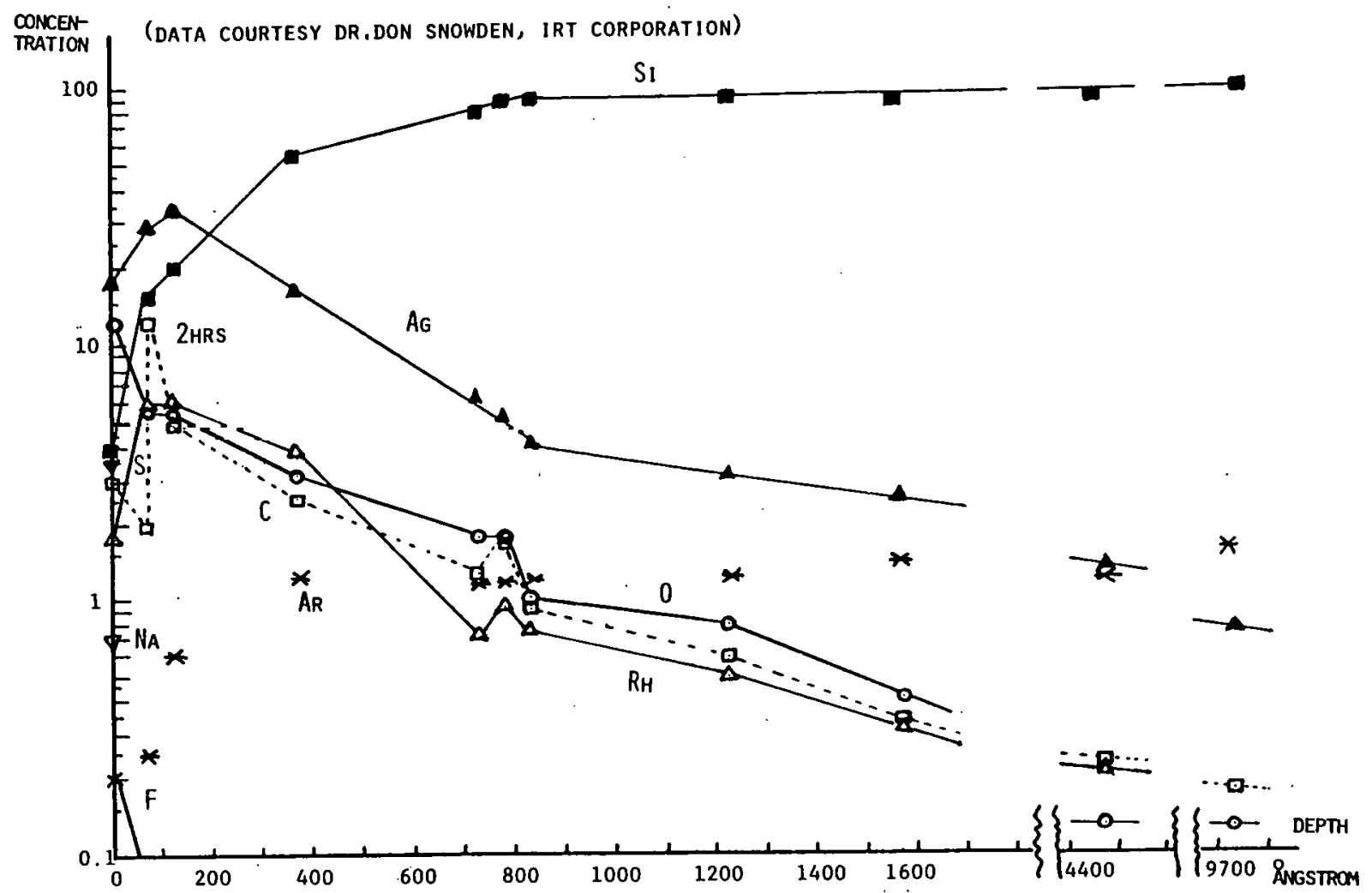

PROBLEM AREAS AND FUTURE PLANS

1. Electrical PROpERTIEs of INKS to daTE are INADEOUATE, CONTACT RESISTANCE OF EARLY SCREENED ALL-METAL CONTACTS AND LOW ENERGY GAP INTERMEDIARY HAS RESULTED IN MARKED ROVEMENT. 2. ADDITIONAL EUTECTIC-DOPANT ALLOYS WILL BE TRIED TO REDUCE
COUTACT RFGI GTANGE FURTHER. 3. ONCE CONTACT RESISTANCE IS ACCEPTABLE, BASE METAL SYSTEM
DEVELOPMENT WILL BEgIN.

\section{AUTOMATED ARRAY ASSEMBLY TANDEM JUNCTION MODULE}

- design largé nren tjc

- VERIFY tJC PROCESS

- design tandem junction module

- fabricate test modules 


\section{LARGE AREA TJC DESIGN}

DESIGN CONSIDERATIONS

SERIES RESISTANCE

- base resistance

- metal finger Resistance $(P+)$

- CONTACT RESISTIVITY $(P+1$

SURFACE RECOMBINATION

- $P+$ REGION

MODULE ASSEMBLY

- Series or parallel interconnect

- P+ ANO N + CONTACTS ON OPPOSITE EDGES

\section{TANDEM JUNCTION MODULE}

LARGE AREA TJC DESIGN

$$
\begin{aligned}
& \text { LOSSES } \\
& F_{f}-\frac{J_{m} d m L^{2}}{24 V_{O C} T_{1}}+\frac{J_{m} \pi m l^{2}}{24 V_{O C} T_{2}} \quad \cdots 1.7 \% \\
& F_{b}=\frac{J_{m} P_{S} d^{2}}{12 V_{0 c}} \quad-2.6 \%
\end{aligned}
$$

OPTIMIZATION

$$
\begin{aligned}
& I_{s c}=\alpha_{n} I_{\lambda \epsilon}+I_{i s} \\
& V_{o c}=\frac{K T}{q} \text { in } \frac{l_{<c}}{l_{c b i o}} \\
& I_{c b o}=I_{c s}\left(1-\alpha_{n} \quad \cdots 1\right)
\end{aligned}
$$

\section{TRANSISTOR MODEL OF TANDEM JUNCTION CELL}

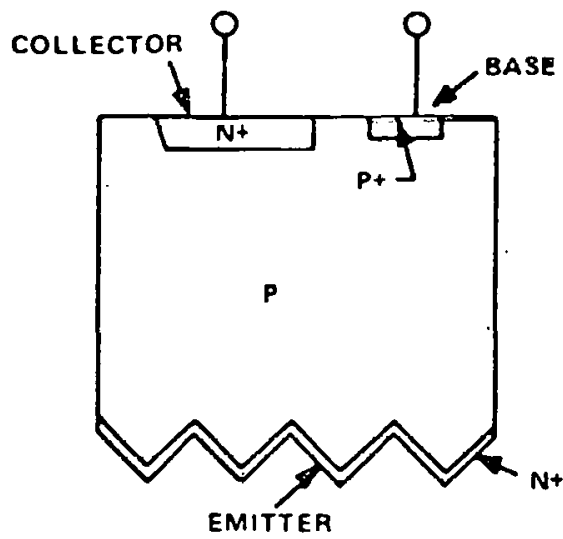

(a) TJC CROSS SECTION

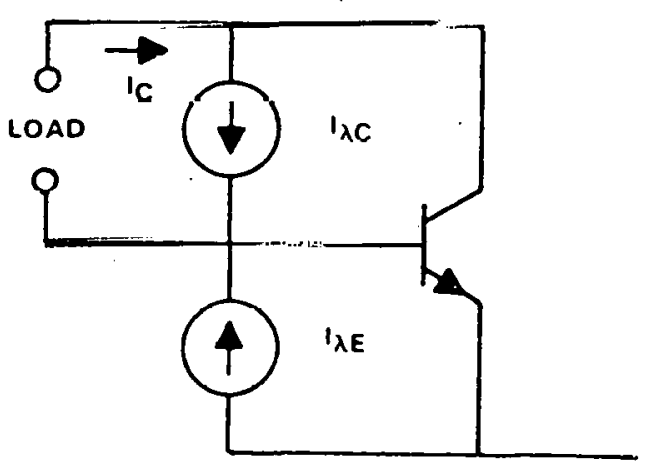

(b) EOUIVALENT CIRCUIT 


\section{TJC METAL PATTERN}

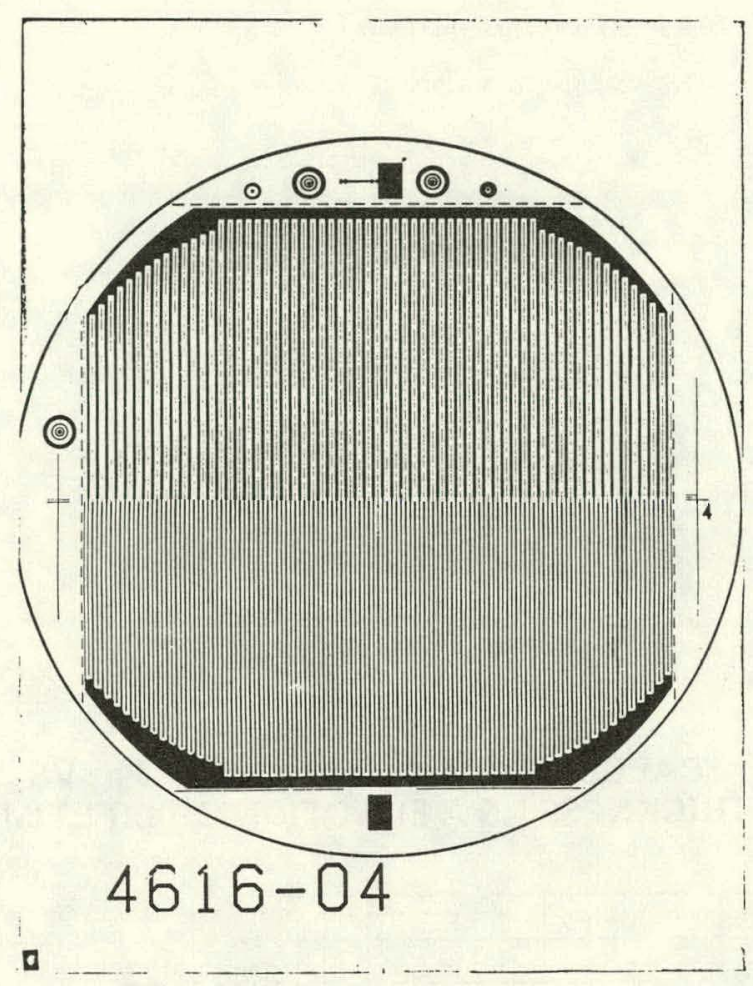

TANDEM JUNCTION MODULE

PROCESS VERIFICATION

P+ CONTACT RESISTIVITY

$\begin{array}{lcc} & \text { AI ALLOY } & \text { TEMPERATURE } \\ \text { AI THICKNESS } & 650^{\circ} \mathrm{C} & 850^{\circ} \mathrm{C} \\ 2000 \AA & 1.2 \times 10^{-3}: \mathrm{Cm}^{2} & \\ 4000 \AA & & \end{array}$

CELL THICKNFSS

- key factor is lifetime after pRocessing

- taRgei thICKNESS $125-140 \mathrm{~m}$ 


\section{TANDEM JUNCTION MODULE}

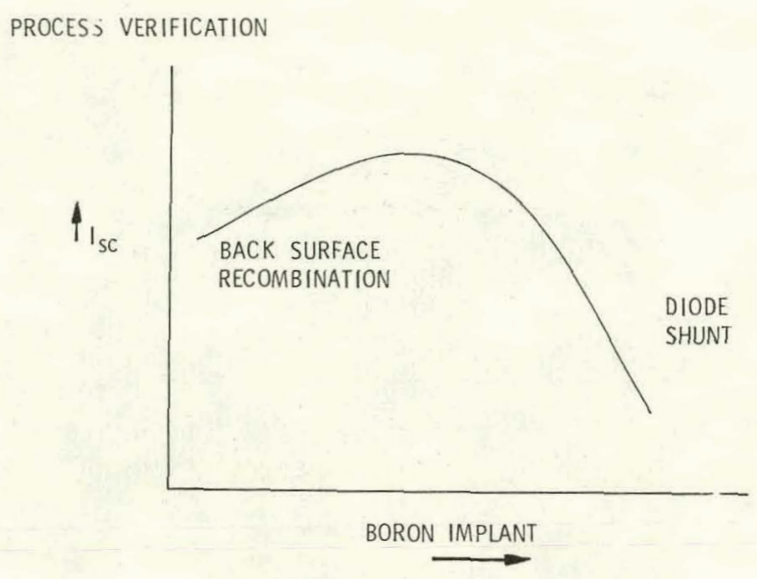

EFFECT OF BORON IMPLANT ON TJC

\section{CALCULATED VS MEASURED JSC VS THICKNESS AS A FUNCTION OF LIFETIME}

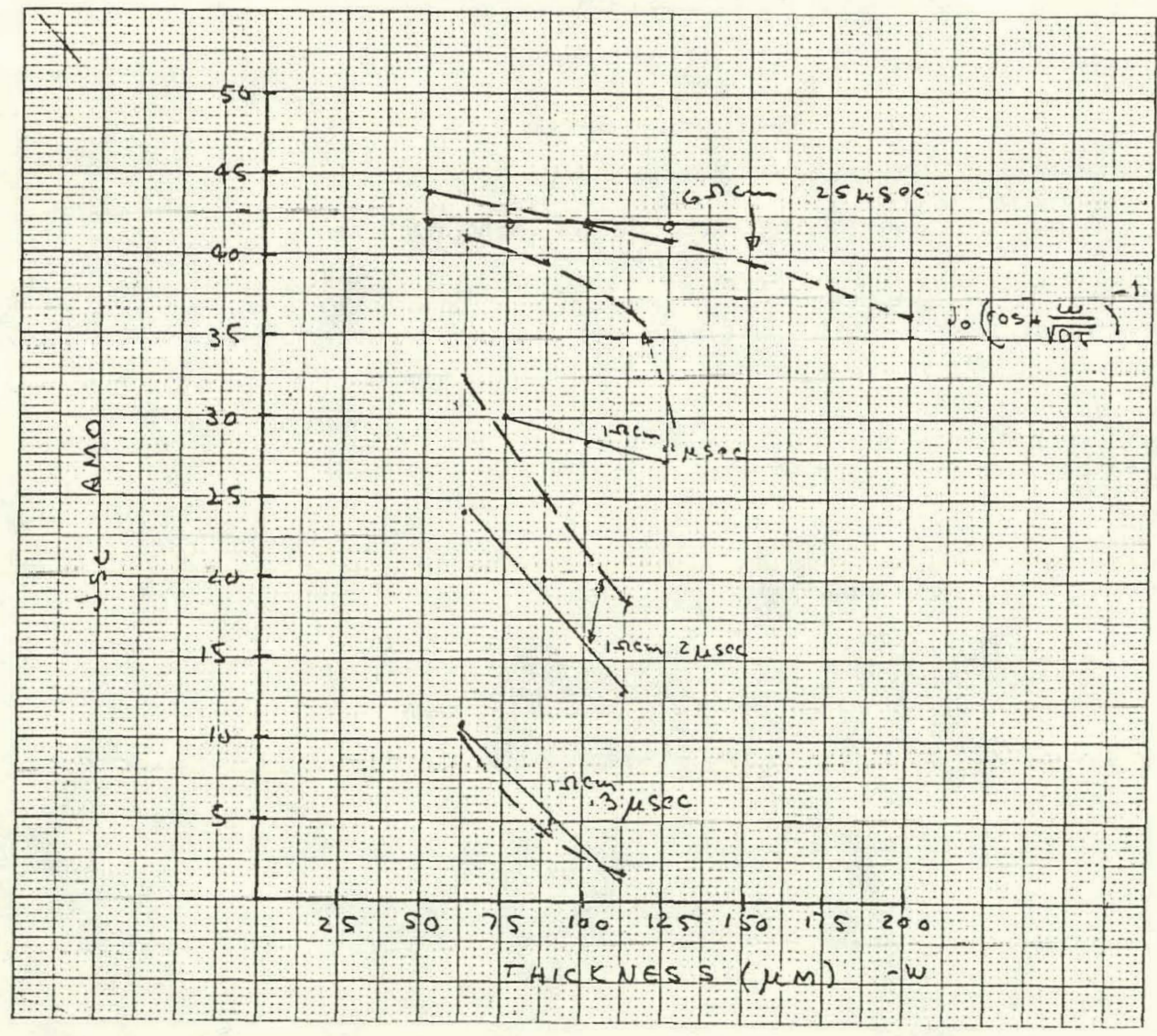




\title{
TANDEM JUNCTION MODULE
}

\author{
MODULE DESIGN
}

- Single n+ AND P+ CONTACT

- parallel - series interconnect

- porcelainized steel - glass

- copper clad invar interconnects

- 30 cell sample modules

OPTICAL COATING LABORATORY, INC.

\section{DEVELOPMENT OF HIGH EFFICIENCY (14\%) SOLAR CELL ARRAY MODULE}

\begin{abstract}
OBJECTIVE
THE INITIAL PHASE OF THIS PROGRAM IS TO DESIGN AND DEVELOP 3" DIAMETER, P/N SOLAR CELLS WITH THE CONVERSION EFFICIENCY OF $16.5 \%$ OR BETTER AT AMI ANO $28^{\circ} \mathrm{C}$. UPON COMPLETION OF THE CELL DEYELOPMENT PHASE. OCLI IS TO DESIGN, FABRICATE, AND DELIVER SIX (6) HIGH EFFICIENCY MODULES, APPROXIMATELY $2^{\prime} \times 4^{\prime}$, NITH A MINIMUM OUTPUT OF 90 WATTS AT AMI ANO $28^{\circ} \mathrm{C}$ AND WITH THE DESIGN GOAL OF $14 \%$ OVERALL EFFICIENCY.

THE SECOND PHASE OF THIS PROGRAM IS TO DESIGN AND FABRICATE PRODUCTION TOOLING FOR THE MANUFACTURE OF THE HIGH EFFICIENCY CELLS AND MODULES. THENTY (20) VERIFICATION MODULES ARE TO BE FABRICATED AND DELIVERED TO JPL.
\end{abstract}




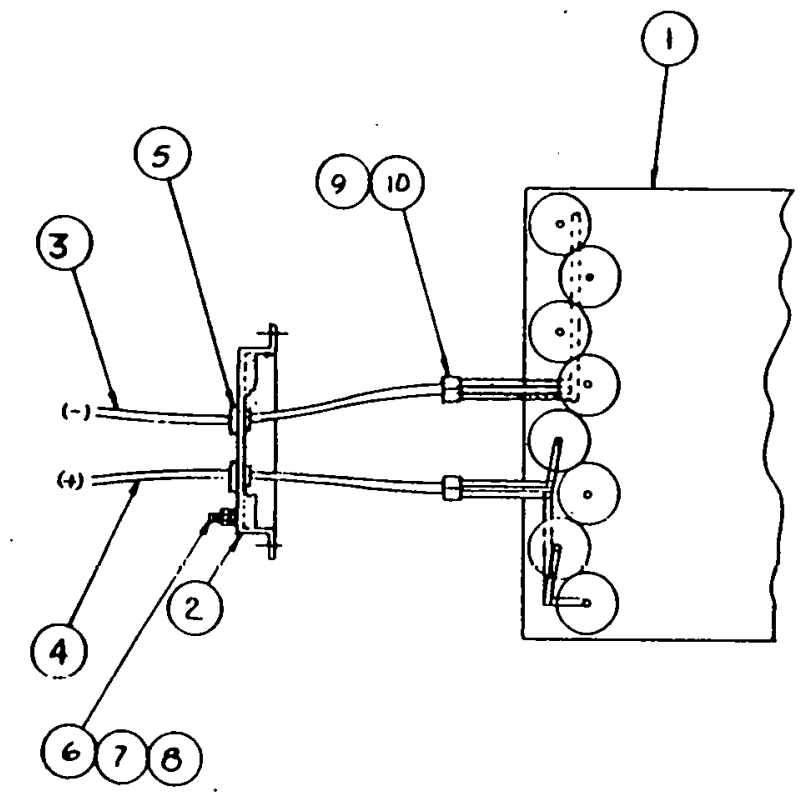

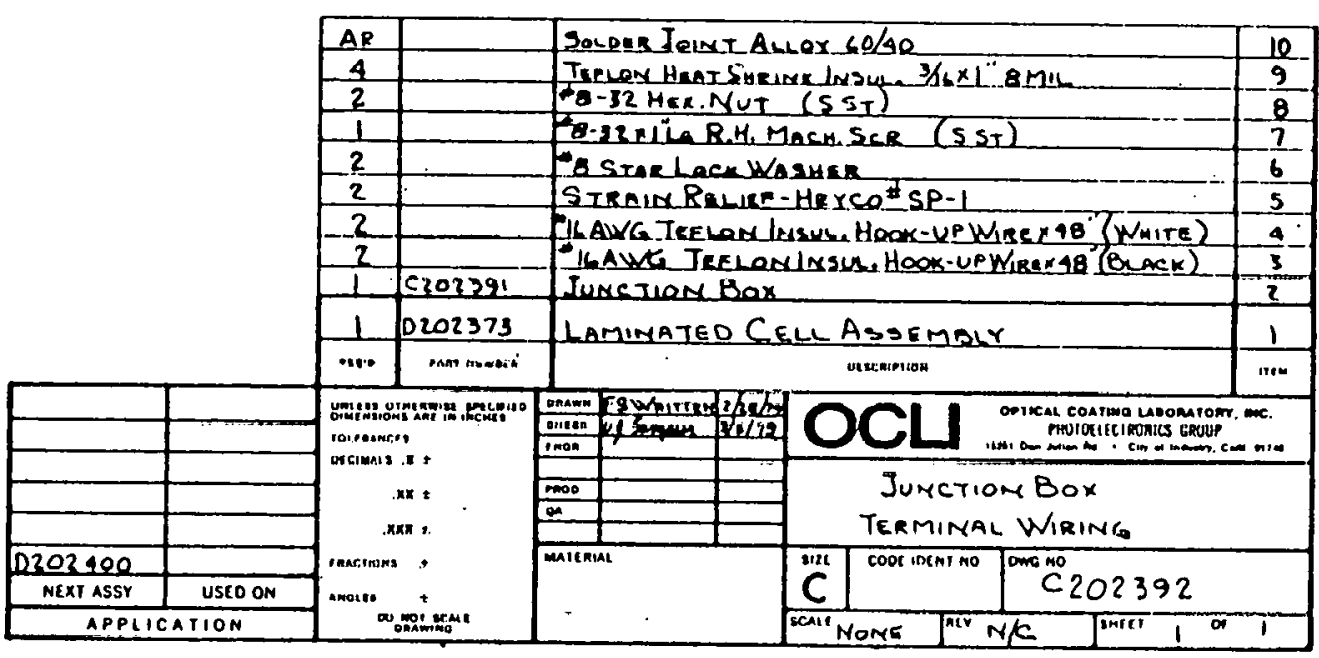



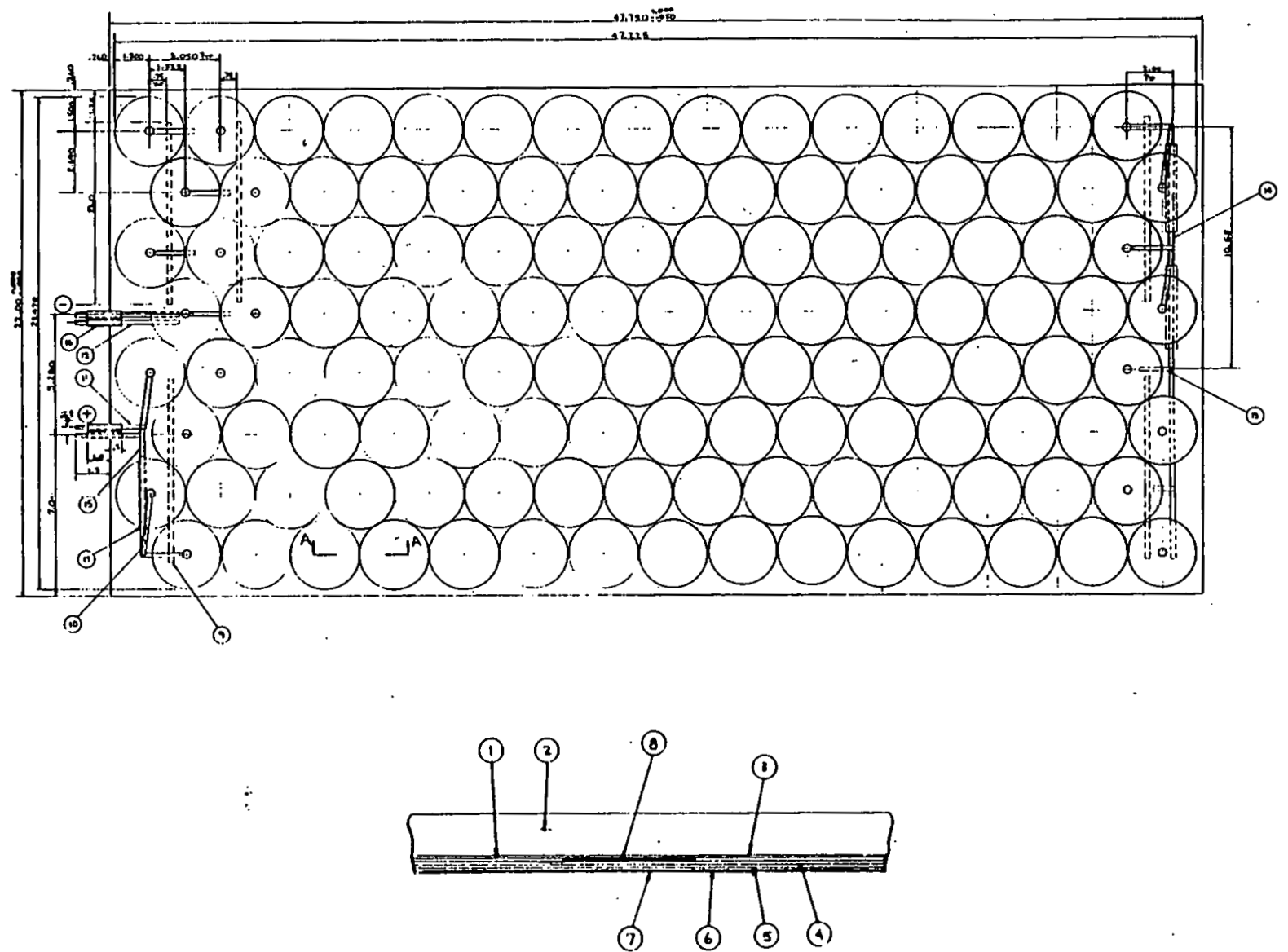

Sicruan A-A

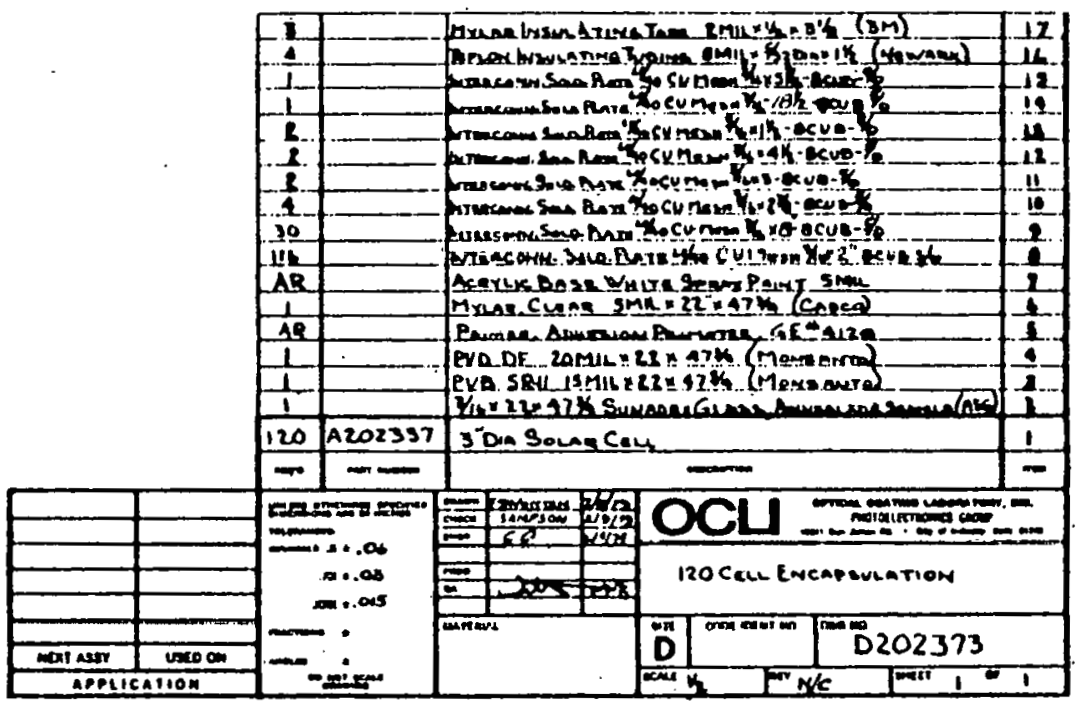




\section{FLOW CHART FOR HIGH EFFICIENCY P + N N+ CELLS}

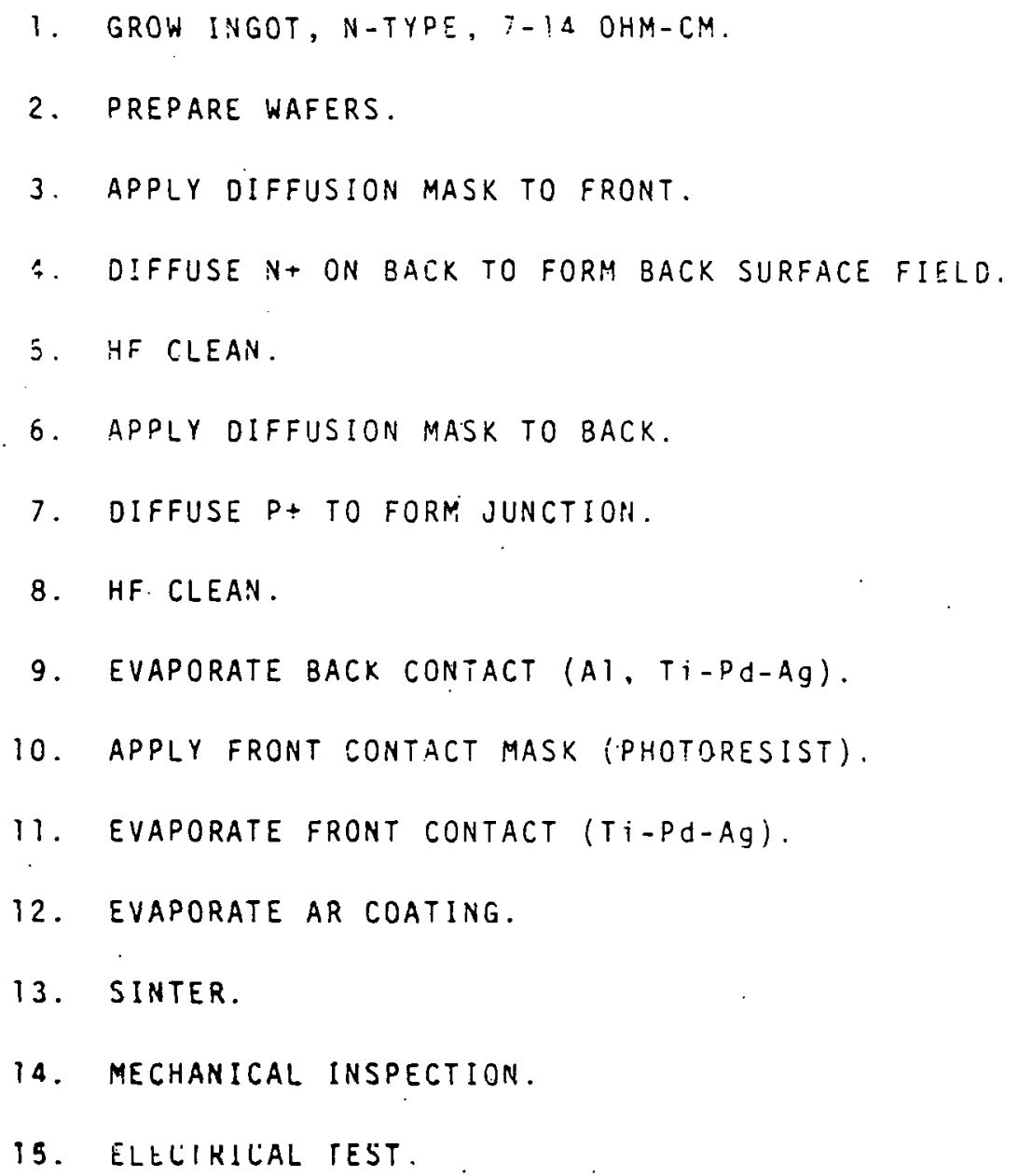

\section{PROBLEM AREAS}

ONLY ONE MAJOR PROBLEM IS ANTICIPATED: THAT IS THE -DEVELOPMENT OF. A LARGE AREA, HIGH EFFICIENCY, P/N SOLAR CELL. TO ACHIEVE AN AVERAGE CELL EFFICIENCY OF $16.5 \%$ AT AMI ANO $28^{\circ} \mathrm{C}$, A GO0D PROCEDURE TO PROVIDE AN EFFECTIVE BACK SURFACE FIELD MUST BE DEVELOPED. PRESENTLY, PHOSPHORUS DIFFUSION WITH PHOSPHORUS OXYCHLORIOE AS THE SOURCE MATERIAL IS BEING IMVESTIGATED. ALL OTHER PROCESSIHG STEPS ARE WELL IN HAND. 


\section{SPIRE CORPORATION}

PULSE PROCESSING FOR SOLAR CELLS

SPIRE CORPORATION

BEDFORD, MA

LSA PRODUCTION PROCESSES

JPL APRIL 4, 1979

\section{SOLAR CELL PROCEESS SEUUUENẼE}

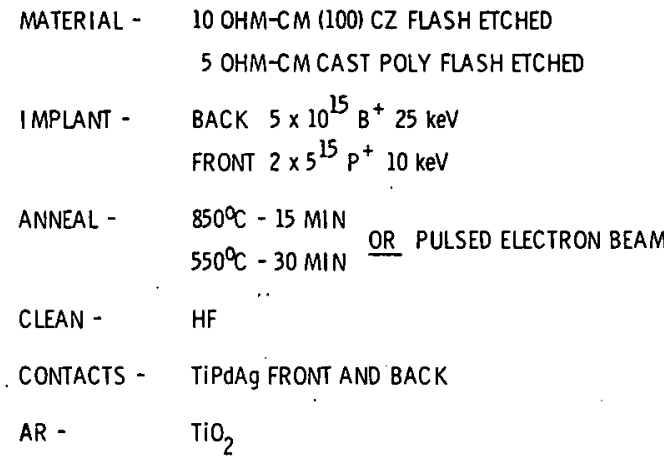

PERFORMANCE DISTRIBUTION FOR ION IMPLANTED SOLAR CELLS DELIVERED TO JPL

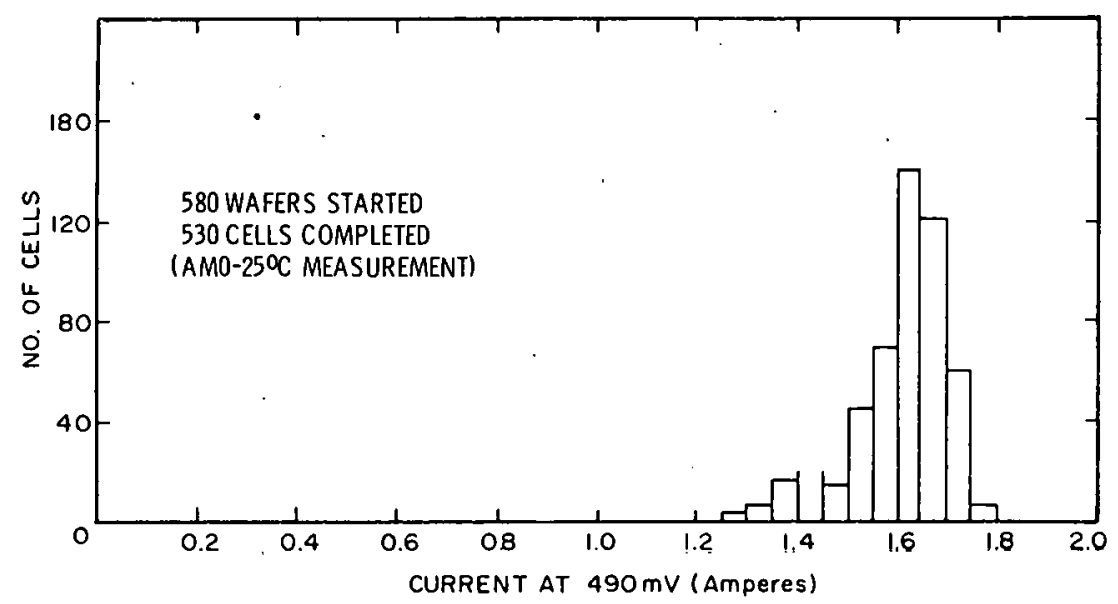


ANNEAL MATRIX SUMMARY

\begin{tabular}{|c|c|c|c|c|c|c|c|}
\hline \multirow{2}{*}{$\begin{array}{l}\text { ANNEAL } \\
\text { TYPE } \\
\text { Standard }\end{array}$} & \multicolumn{2}{|c|}{$P_{\max }(W)$} & \multicolumn{2}{|c|}{$v_{\infty}(N)$} & \multicolumn{2}{|c|}{$I_{s c}(A)$} & \multirow{2}{*}{$\frac{\mathrm{FF}}{.74(3.1 \%)}$} \\
\hline & .766 & B. $8 \%$ ) & .587 & $(0.2 \%)$ & 1.760 & $(1.5 \%)$ & \\
\hline 1 & .761 & (2.4) & .585 & $(0.3)$ & 1.753 & (1.3) & $.74(1.4)$ \\
\hline 2 & .767 & $(1.8)$ & .586 & $(0.3)$ & 1.744 & (1.4) & $.75(1.3)$ \\
\hline 3 & .682 & $(19,4)$ & .579 & $(0.8)$ & 1.703 & $(8.2)$ & $.69(14.6)$ \\
\hline 4 & .699 & (12.7) & .567 & $(0.2)$ & 1.710 & $(2.5)$ & $.72(10.8)$ \\
\hline 5 & .738 & (2.1) & .581 & $(0.4)$ & 1.709 & $(1.0)$ & $.74(1.4)$ \\
\hline 0 & .720 & (4.3) & .586 & $(0.4)$ & 1.732 & $(1.9)$ & $.71(2.8)$ \\
\hline 7 & .743 & (2.4) & .585 & $(0.7)$ & 1.741 & $(0.7)$ & $.73(1.5)$ \\
\hline
\end{tabular}

- $7.6 \mathrm{CM} \mathrm{n}^{+} \mathrm{p} \mathrm{p}^{+}$ION IMPLANTED CELLS

- 10 o-CM CZ flash etched silicon

- percent StD. deVIation IS IN PaRenthesis (\%)

TIME AT TEMPERATURE FOR IMPLANT ANNEAL TESTS

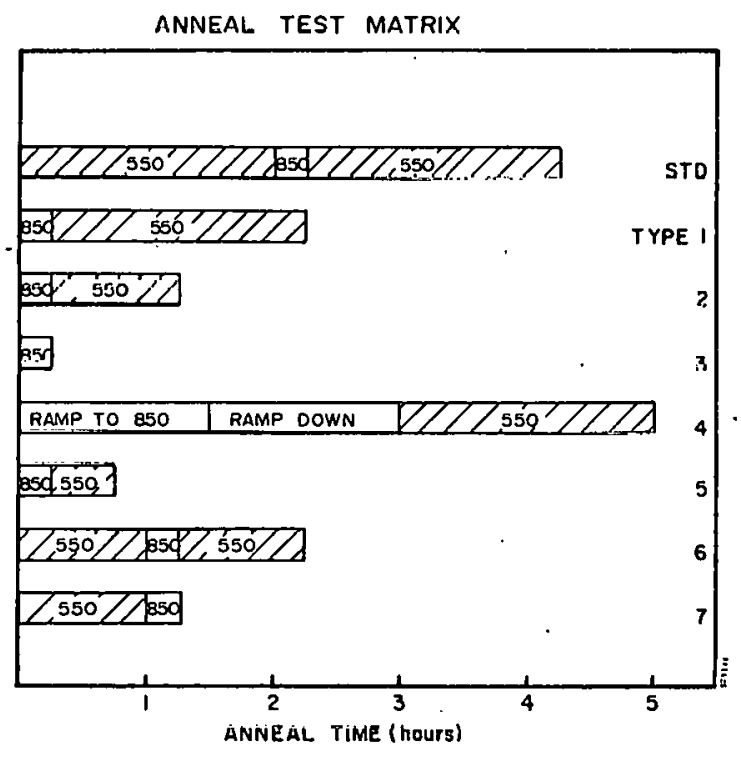


PERFORMANCE DISTRIBUTION: POLYCRYSTALLINE SILICON

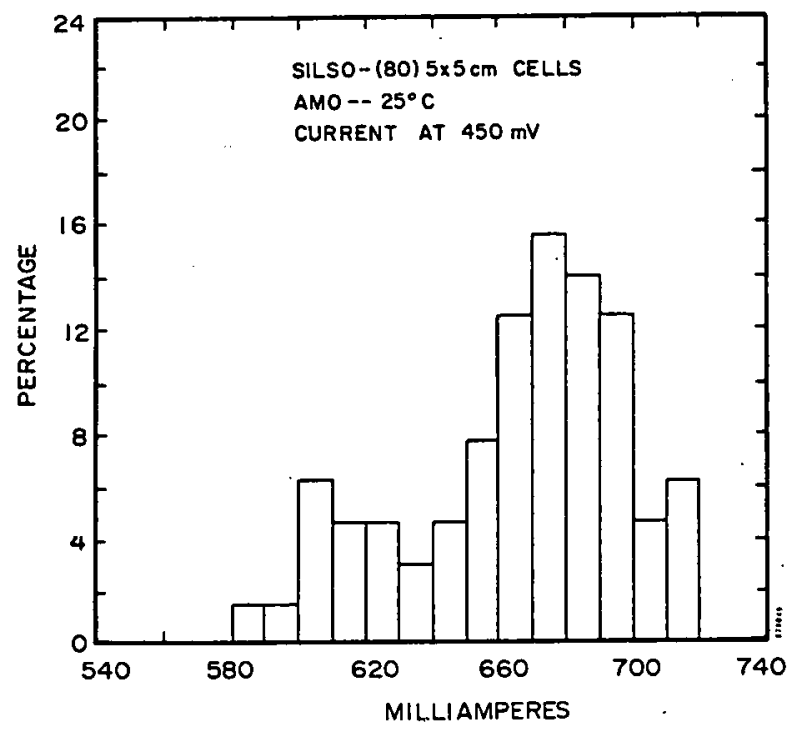

SPECTRAL RESPONSE FOR SINGLE AND POLYCRYSTALLINE ION IMPLANTED CELLS

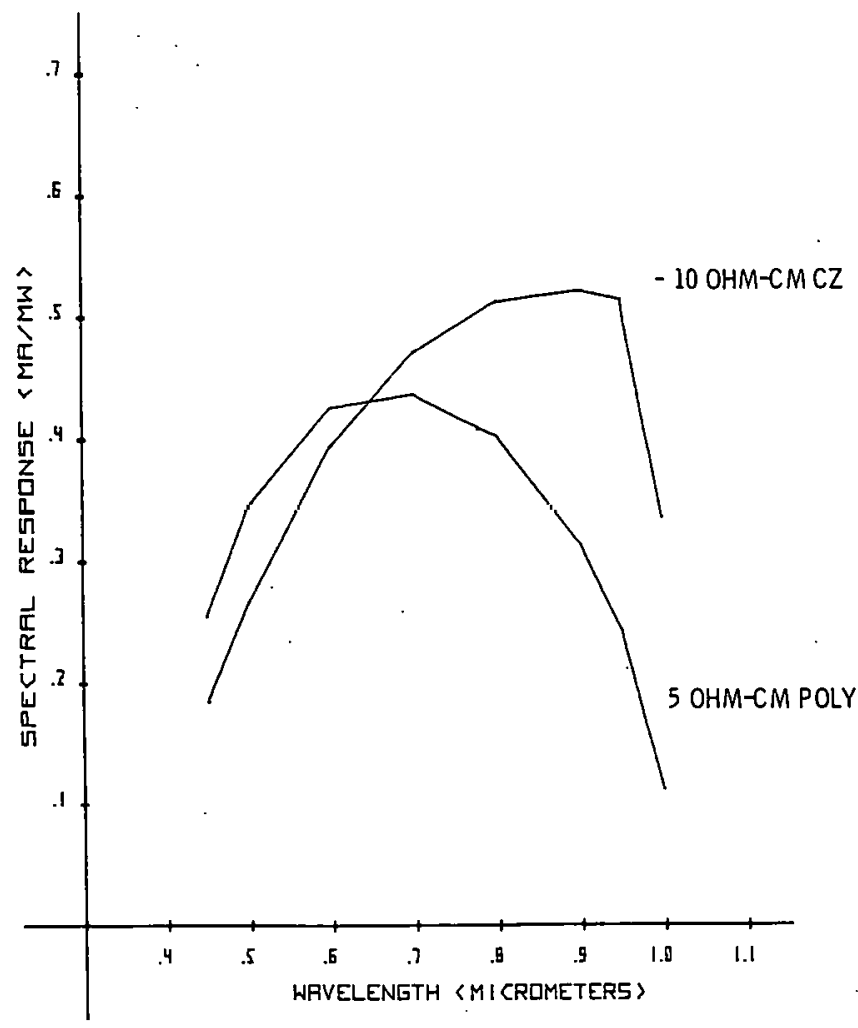


SHEET RESISTANCE MAP FOR 2" ELECTRON BEAM

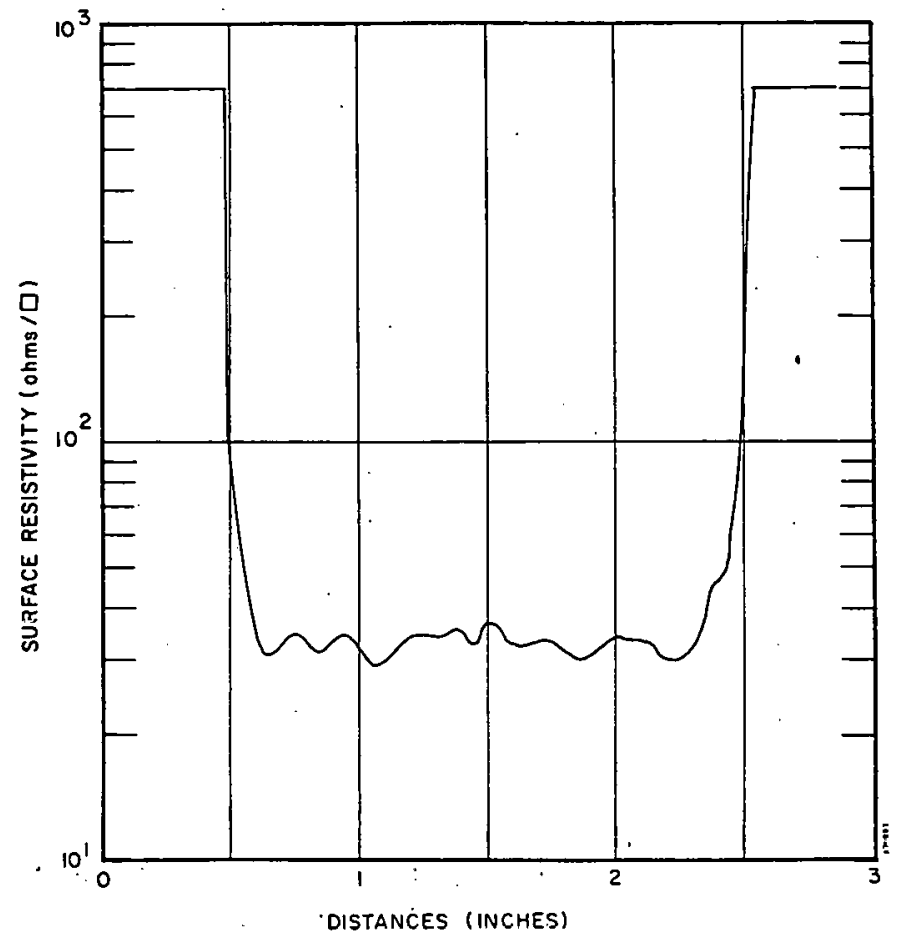

SHEET RESISTANCE MAP FOR 3" ELECTRON BEAM

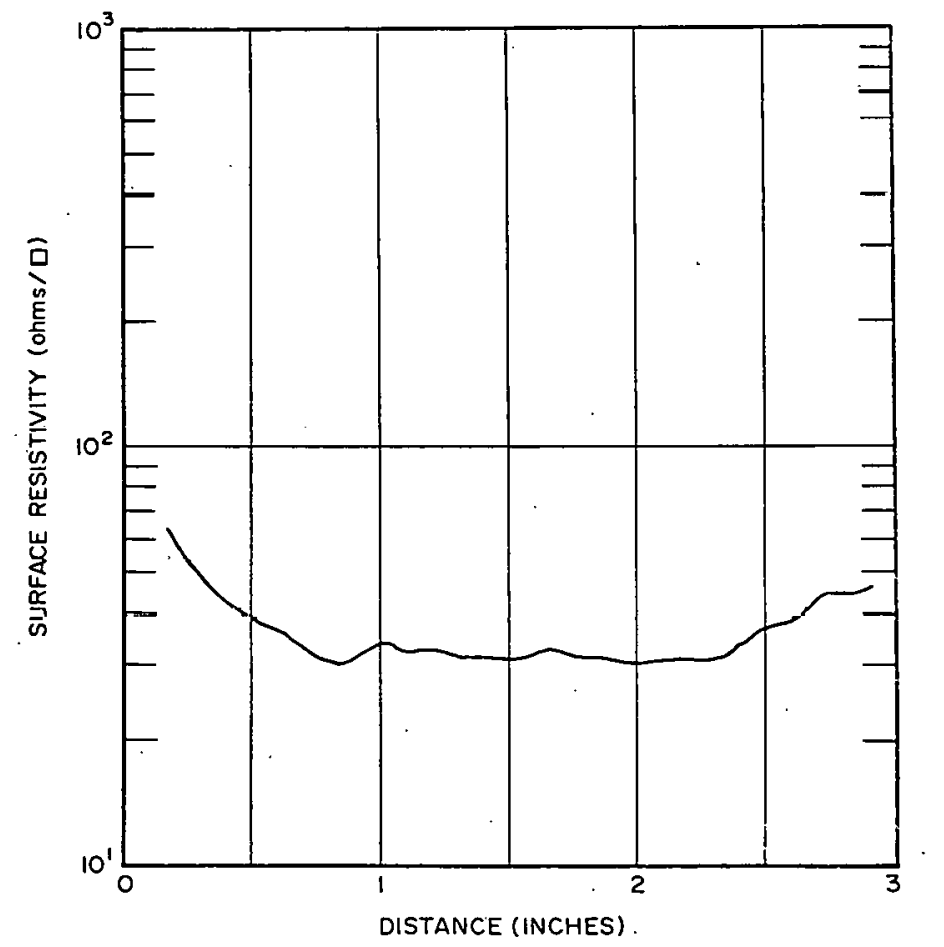




\section{PULSED ELECTRON BEAM CHARACTERISTICS}
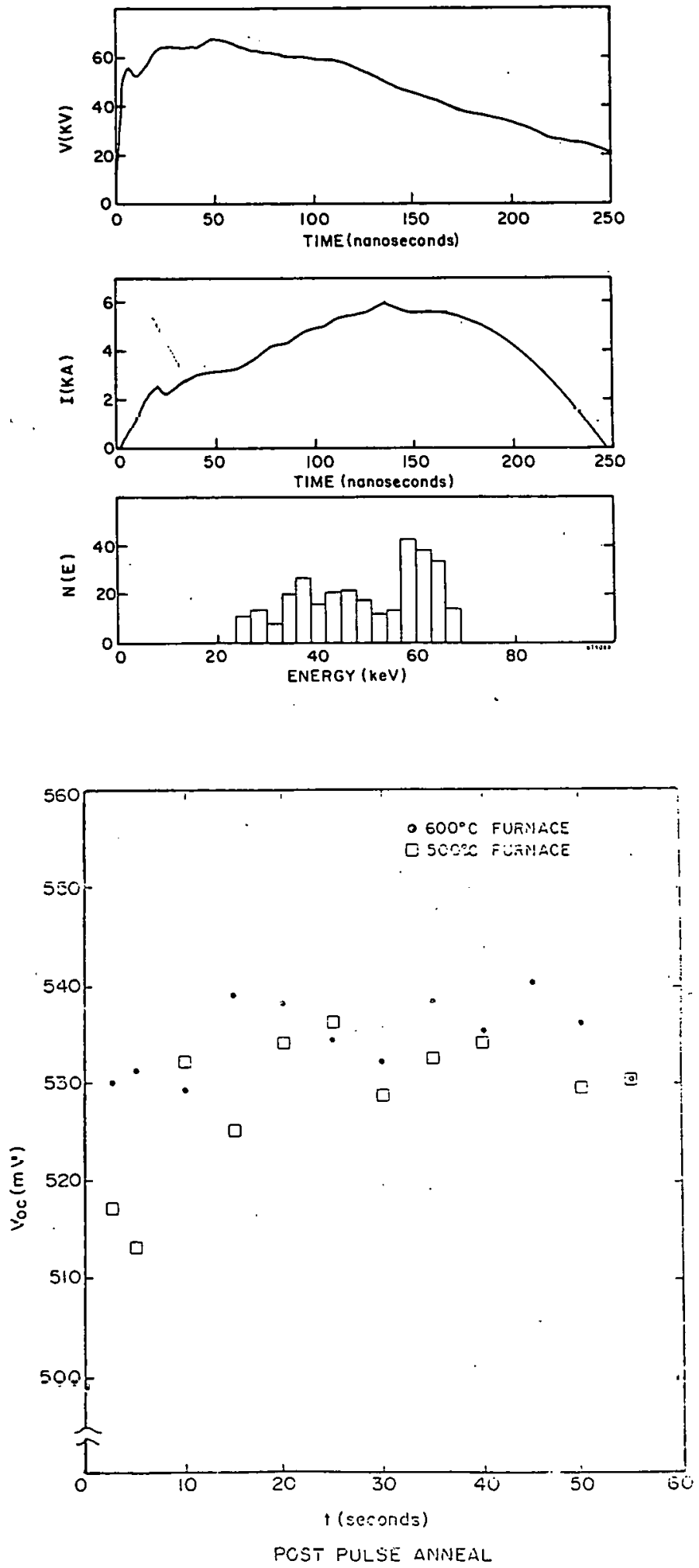

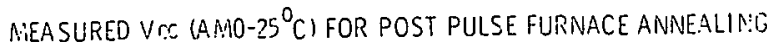




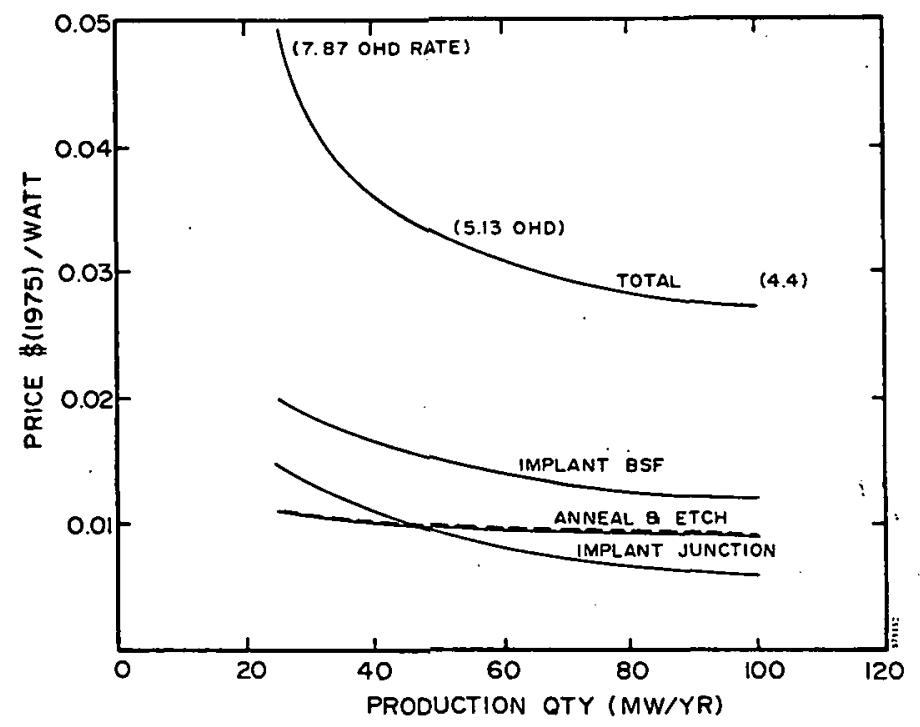

SAMIS III COST ELEMENTS (JUNCTION AND BSF FORMATION)

\begin{tabular}{|c|c|c|c|c|c|c|}
\hline \multirow[t]{2}{*}{ PROCESS ELEMENT } & \multicolumn{6}{|c|}{ COST (1975 \$NATT) } \\
\hline & $\begin{array}{l}\text { CAPITAL } \\
\text { COSTS }\end{array}$ & $\begin{array}{l}\text { DIRECT } \\
\text { LABOR }\end{array}$ & MAT'LS & UTILITIES & $\begin{array}{c}\text { INDIRECT } \\
\text { (incl. taxes) }\end{array}$ & $\begin{array}{l}\text { TOTAL } \\
\text { VALUE ADDED }\end{array}$ \\
\hline $\begin{array}{l}\text { Phosphorus I mplant } \\
\text { Junction }\end{array}$ & 0.0053 & 0.0004 & 0.0012 & 0.0003 & 0.0087 & 0.0101 \\
\hline $\begin{array}{l}\text { Aluminum I mplant } \\
\text { BSF }\end{array}$ & 0.0061 & 0.0008 & 0.0015 & 0.0006 & 0.0012 & 0.0102 \\
\hline Furnace Anneal & 0.0009 & 0.0004 & -- & -- & 0.0009 & 0.0022 \\
\hline Plasma Etch & 0.0027 & 0.0002 & 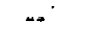 & 0.0001 & 0.0035 & $\underline{0.0065}$ \\
\hline TOTAL & & & & & & $\$ 0.0290$ \\
\hline \multicolumn{7}{|c|}{ - jon mwinR impLanter } \\
\hline \multicolumn{7}{|c|}{ - $7.5 \times 10 \mathrm{CM}$ SHEET, $11 \%$ AMI CELLS } \\
\hline
\end{tabular}

MOTOROLA, INC. 


\section{PATTERNED WAX MASKING}

A. ATTEMPT TO REPLACE PHOTORESIST PROCESSING WITH A PATTERN PRINTING TECHNIOUE.

B. PHOTORESIST DISADVANTAGES
1. HIGH COST
2. SPECIAL FACILITIES AND EOUIPMENT
3. SOLVENT FUMES
4. LIMITED SHELF LIFE
5. TIME-CONSUIIIIG EXPOSE-DEVELOP-BAKE CYCLE

C. REPLACEMENT TECHHIOUE

1. REPLACE PHOTORESIST HITH INERT WAX.

2. APPLY WAX WITH A PRINTING PLATE.

D. ADVANTAGES

1. LOH COST

2. NO SPECIAL SAFETY ILLUMINATION, HUMIDITY CONTROL, ETC.

3. NO SOLVENT FUMES

4. INDEF INITE SHELF LIFE

5. SIMPLE AND OUICK PROCESSING

E. PRINTING TECHNIQUES

1. LETTERPRESS - RAISED PLATE AREAS BEAR WAX AND TRAIISFER ON CONTACT WITH HAFER.

2. INTAGLIO - WAX IS BORME BY DEPRESSIONS IN PLATE, SURFACE TENSION CAUSES BEADING OF WAX. TRANSFER OCCURS ON CONTACT.

3. LITHOGRAPHY - HAX SELECTIVFLYY METS DEFINED PLATE AREAS. NO PLATE CONTOUR,

F. DISADVANTAGES

1. INTAGLIO PRIITING REQUIRES A WAX SURFACE TENSION NOT EASILY OBTAINED.

2. LITHOGRAPHIC PLATE PREPARATION IS TIME CONSUMING. PLATES ARE DIFFICULT TO REPLALE. 


\section{PRINTING TECHNIQUES}

PRODUCE PRINTING PLATES IN QUANTITY FROM DURABLE MASTERS

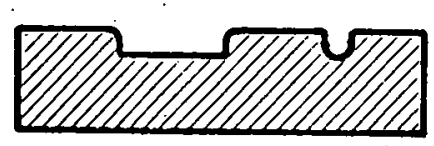

DURABLE MASTER

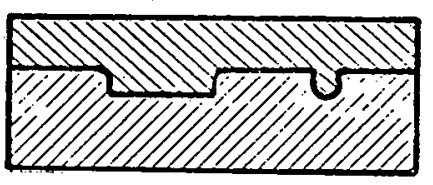

CURABLE PLATE MATERIAL MOLDED

BY MASTER PLATE

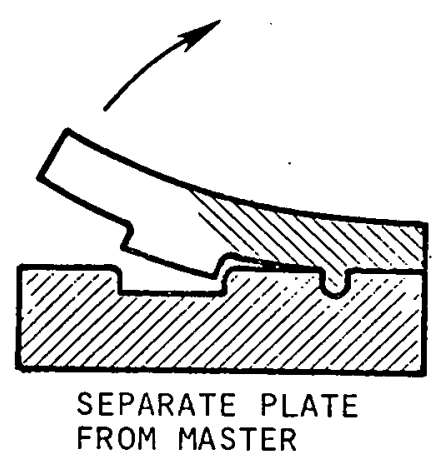

SEPARATE PLATE FROM MASTER

PRINT BY LETTERPRESS TECHNIQUE

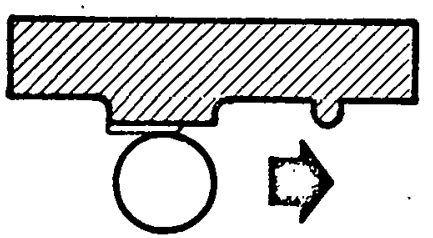

APPLY WAX

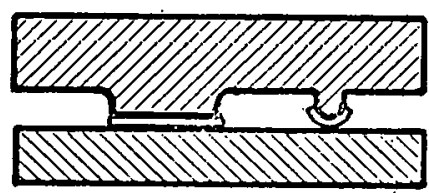

IMPR INT
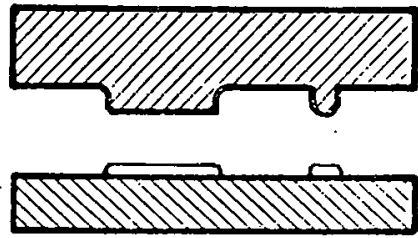

PATTERN TRANSFERRED

G. AREAS OF RESEARCH
1. PRINTING PLATE MATERIAL
2. TYPE OF MASKING WAX
3. PRINTING DEVICE CONF!GURATIOH!
4. FATTCRN DCTIMITIOH
5. COST

H. PROJECT TASKS
1. PRODUCT MASTER PLATE MOLDS.
2. PRODUCT PRINTING PLATES.
3. RESEARCH MASKING HAX PROPERTIES.
4. DESIGN AND CONSTRUCT PRINTING DEVICE.
5. FVAI IIATE. PRINTING PERFORMANCE.
6. DETERMINE WAX ETCH RESIST BEHAVIOR.
7. COST ANALYSIS. 


\section{THE PROCESS SEQUENCE}

1. Plasma silicon etch (one side)

2. Apply waX MASK

3. Texture etch (ONE SIDE)

4. Remove waX mask

5. ION IMPLANT BACK SURface FIELD

6. ION IMPLANT P-N JUNCTION

7. Activation anneal of implant*

8. Deposit silicon nitride (lacvd)

9. Plasma pattern Nitride

10. Plate metal and solder coat

11. CELL test AND InterconNect

12. Encapsulate

- Mar be combined

\section{PROCESS SPECIFICATIONS}

1. Plasma silicon etching to remove sah damage.

2. HaX MASKING.

3. ION IMPLANTATION

4. VACUUM SILICON NITRIDE DEPOSITION,

5. Plasma metal pattern definition.

6. Metallization

\section{PLASMA PATTERNING:}

\section{A MAJOR TECHNOLOGY ADVANCEMENT}

1. ALL DRY PROCESS.

2. Mechanically masked.

3. REPLACES PHOTORESIST PATTERNING

- Reduces materials consumption

- Reduces floor space reguirements

- Reduces capital costs

- Reduces environmental control RenUirements

\section{PHOTORESIST VS PLASMA COMPARISON}

\section{PHOTORESIST}

1. APPLY PHOTORESIST*

2, BAKE

3. EXPOSE

4. BAKE

5. DEVELOP*

6. $\mathrm{ETCH}^{\circ}$

7. REMOVE PHOTORESIST*

-materialas consumied
DLLASMA PAULERH

1. ALIGN TO MASK

2. LOAD IN CHAMBER

3. PLASMA ETCH*

4. UNLOAD 


\title{
EXTENSION PROGRAM
}

1. Optimization of plasma silicon etching.

2. Feasibility of plasma texture etching.

3. AdVANCED ION IMPLANTATION AND anNEALING analysis.

4. Optimization of plasma etching of silicon nitride.

5. Metallization cost reduction.

6. Cost analysis,

7. Process verification.

\section{METALLIZATION COST REDUCTION}

1. Lliminate electroless palladium layer.

2. REPLACE SOLDER CONDUCTOR LAYER.

\section{COMPARISON OF METAL CONDUCTOR LAYERS}

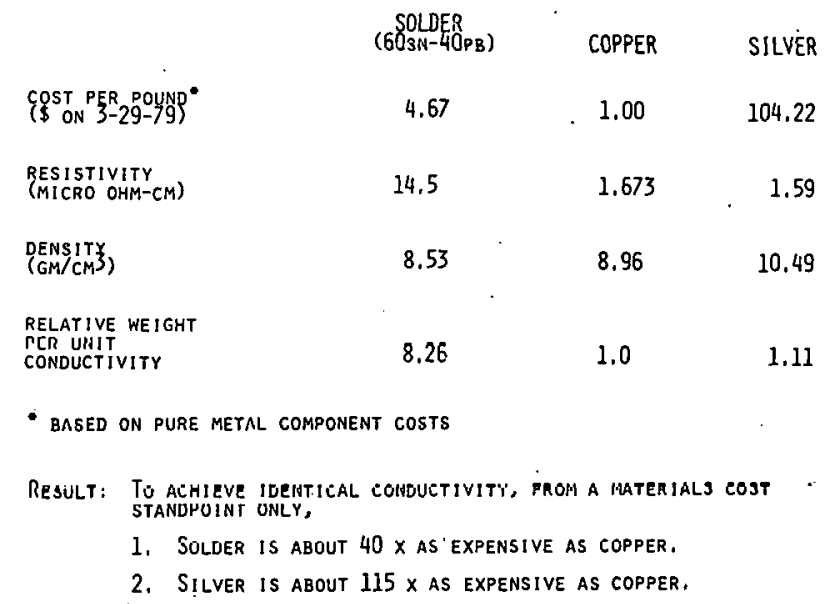

\section{THE ESTABLISHMENT OF A PRODUCTION-READY MANUFACTURING PROCESS UTILIZING THIN SILICON SUBSTRATES FOR SOLAR CELLS}

\author{
PRIHCIPAL INVESTIGATOR: R.A. PRYOR
}




\section{TECHNICAL OBJECTIVES}

1. INVESTIGATE, DEVELOP, AND CHARACTERIZE METHODS TO ESTABL ISH A MANUFACTURING PROCESS WHICH UTILIZES ESTABLISH A MANUFACTURING PROCESS WHICH

2. BY PROCESS VERIFICATION TESTS AND ANALYSES, DEMONSTRATE IHAT AT ANNUAL PRODUCT ION VOLUME OF 15 MEGANATTS AND A WAFER THICKNESS
AS-SAWED

15 MiLs

8 MILS

5 MILS

\begin{tabular}{llll} 
KERE & $\begin{array}{c}\text { COST PER } \\
\text { CAPUIAL }\end{array}$ & $\begin{array}{c}\text { PEAK WATT } \\
\text { IABOR }\end{array}$ \\
\hline 12 MILS & $: 0.35$ & $\$ 0.135$ \\
$7.5 \mathrm{MILS}$ & $: 0.20$ & $\$ 0.080$ \\
$7.5 \mathrm{MILS}$ & $: 0.16$ & $\$ 0.965$
\end{tabular}

\section{TEC.HNIC.AI. APPROACH}

1. Standard (15 MIL) ano thin (9 MIL and 5 MIL) as-Sawed SUBSTRATES WILL BE CHEMICALLY ETCHED TO REMOVE SAW DAMAGE,

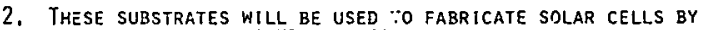
STANDARD PROCESSING TECHNI AUES.

3. PARTICULAR PROCESSINE PROBLEMS WILL BE DIAGNOSED AND
PROCESSES WILL BE MODIFIED TO ACCOMMODATE THIN. SUBSIRATES, 4. OPTIMUM SAW DAMAGE REMOVAL WIILL BE DETERMINTS THROUGH

5. DPtimum substrate thinness hill. be evaluated.

6. VARIOUS PROCESS SERUENCES WILL BE CONSINERED.

\section{CONTRACT TASKS}

TASK 1. Fabrication and EVALUAJION OF SOLAR CELLS ON 8 MIL WIRE-SAWED WAFERS ETCHED TO 7 MILS.

TASK 2. FABRICATION AND EVALUATION OF SOLAR CELLS ON 5 MIL WIRE-SAWED WAFERS ETCHED TO L! MILS.

task 3. Evaluate possibility of, thinner cells,

TASK 4, DETERMINE OPTIMUM THICKNESS OF SAW DAMAGE REMOVAL.

TASK 5, SPECIFY A PILOT LINE PROCESS.

task 6. Demonstrate pilot line capability,

TASK $\%$, PREPARE PROCESS SPECIFICATION SHEETS.

TASK 8, COST ANALYSIS,

TASK 9. SPECIFY PRODUCTION PROCESS. 


\section{A BASELINE PROCESS (NO BSF)}

START WITH SAWED AND ETCHED WAFER

1. TEXTURE ETCH - BOTh SIDES,

2. $\mathrm{PH}_{3}$ DIFFUSE, $900^{\circ} \mathrm{C}-\mathrm{BOTH}$ SIDES.

3. ETCH BACK, MESA ETCH FRONT.

4. Silicon nitride AP. COAT.

5. ETCH BACK, PATTERN ERONT.

6. Metallize.

Evaluate

\section{WIRE SAW PARAMETERS}

PRIEIARY

PITCH (WIRE SPACING) $-0.3,0.4,0.6 \mathrm{MM}$

ABRASIVE - 5, 10, 15, 20, 30 m

WIRE DIAMETER $-.075, .10, .15, .20 \mathrm{MM}$

SECONDARY

WIRE FEED RATE

WIRE SPEED

WIRE LOADING 


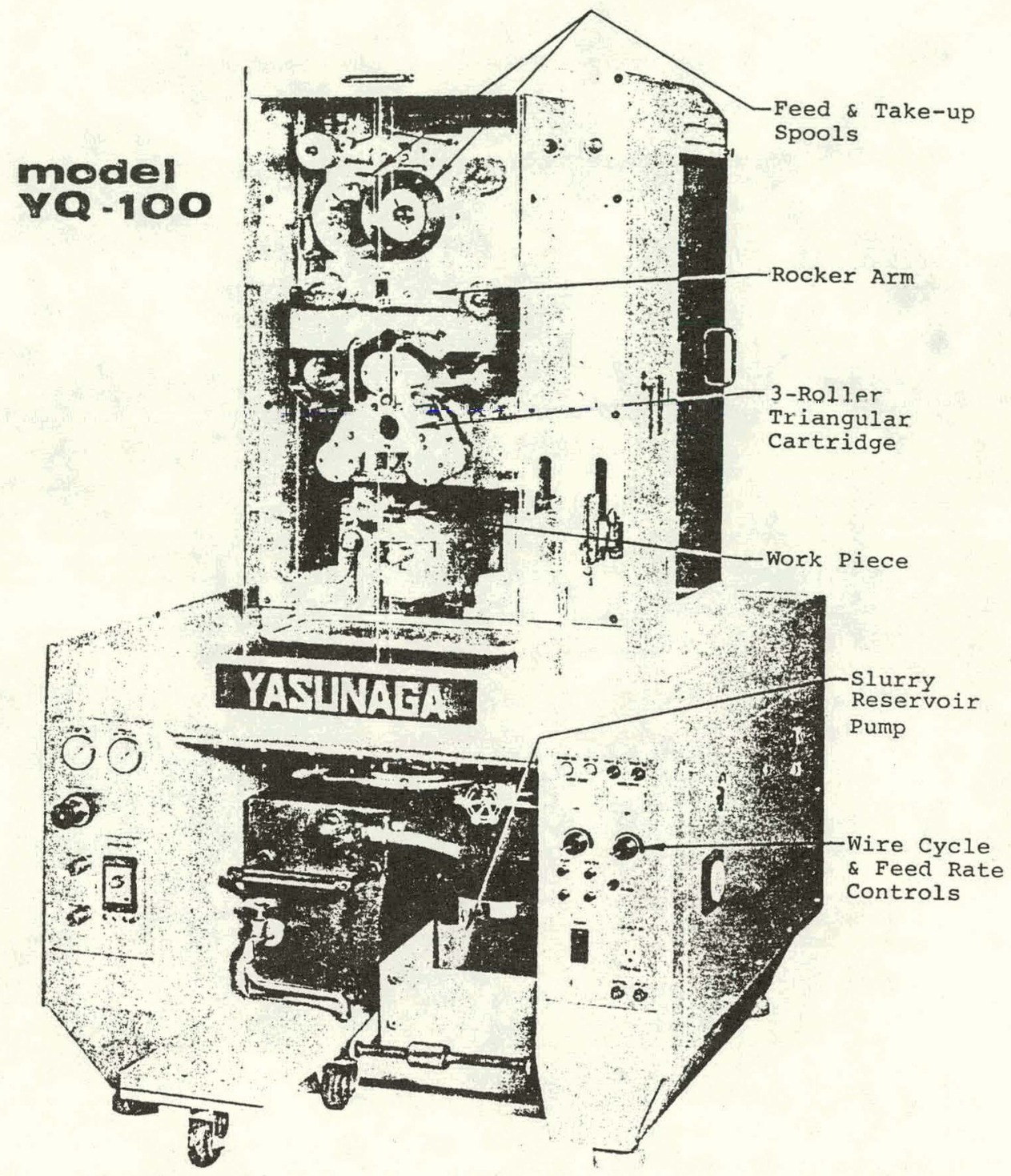

\section{PITCH}

- wire spacing

- COMPLETELY DETERMINES WAFERS/KG

- $0.3,0.4,0.6$ mM AVAILABLE

$\begin{array}{lllc}\text { PITCH } & \text { TOTAL VOLUME } & \text { MEIGHT } & \text { SILICON COST } \\ 0.3 \mathrm{MM} & 1.37 \mathrm{~cm}^{3} & 3.19 \mathrm{G} & \$ .573 \\ 0.4 \mathrm{MM} & 1.82 \mathrm{~cm}^{3} & 4.25 \mathrm{G} & .764 \\ 0.6 \mathrm{MM} & 2.74 \mathrm{~cm}^{3} & 6.37 \mathrm{G} & 1.147\end{array}$


- ABRASIVE

- $5,10,15,20,30$ UM USED

- Kerf loss approximately three-four times abrasive diameter

- Saw time inversely proportional to abrasive size

- surface damage proportional to abrasive size

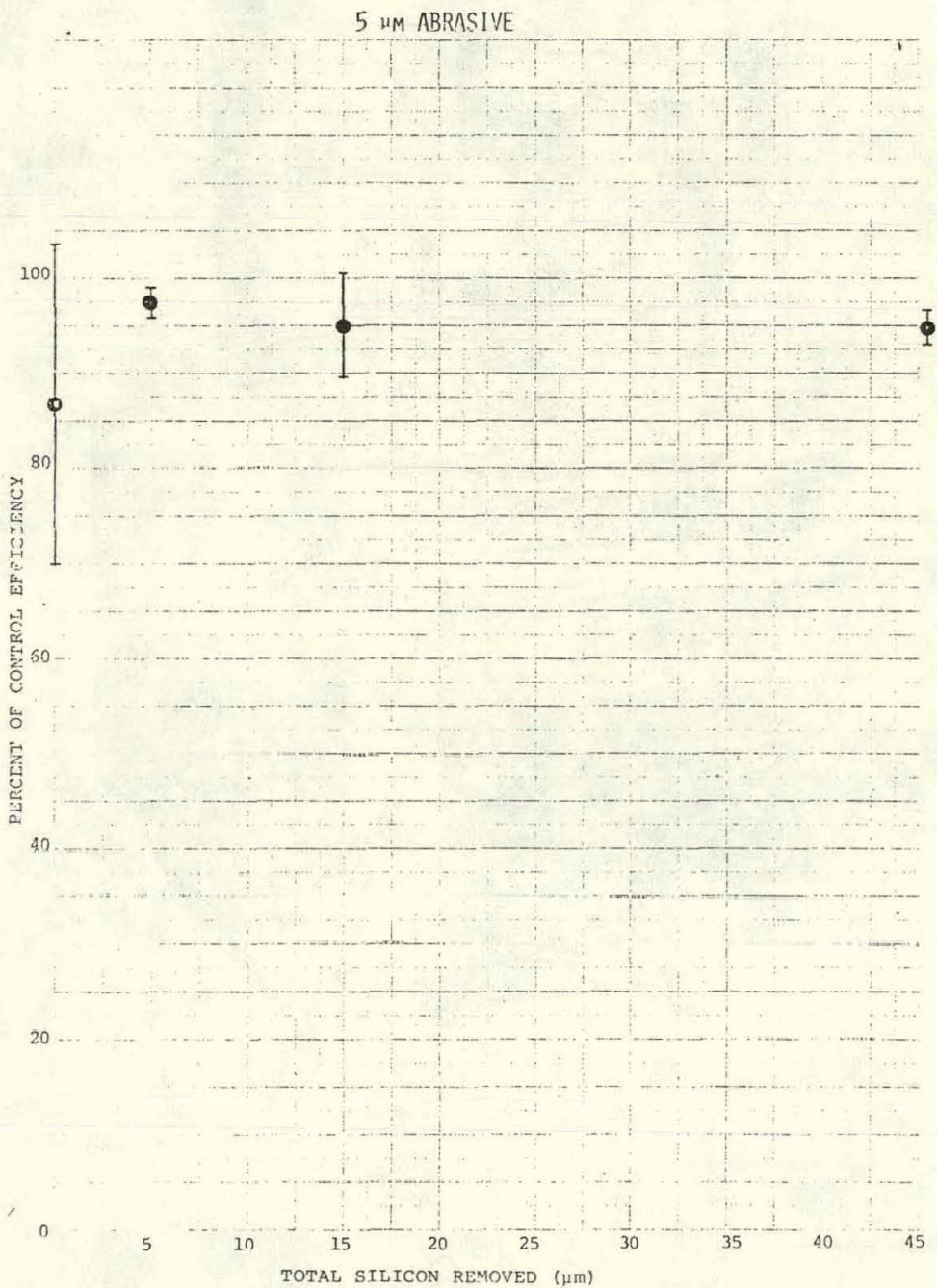




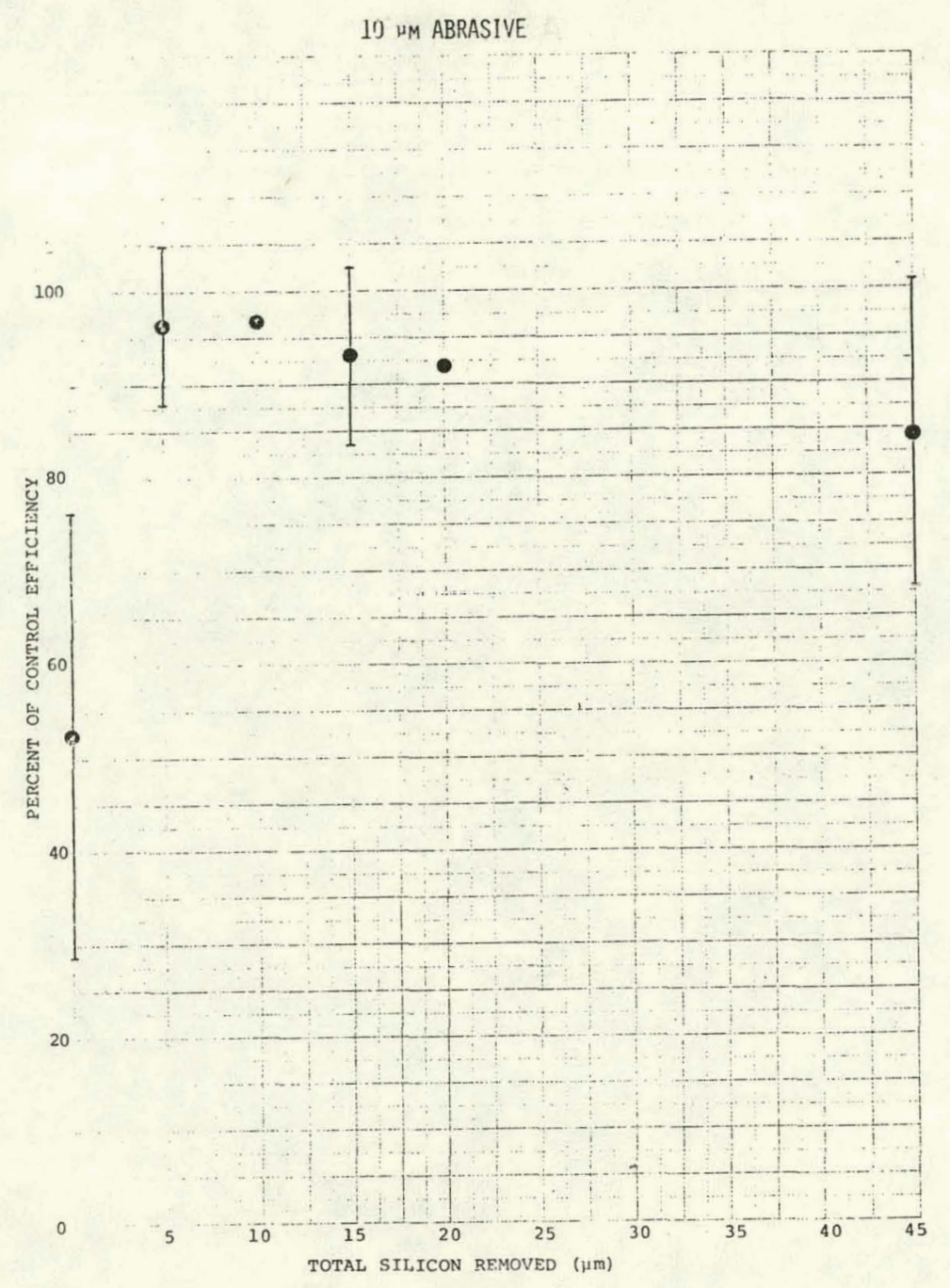

3-203 


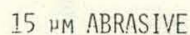

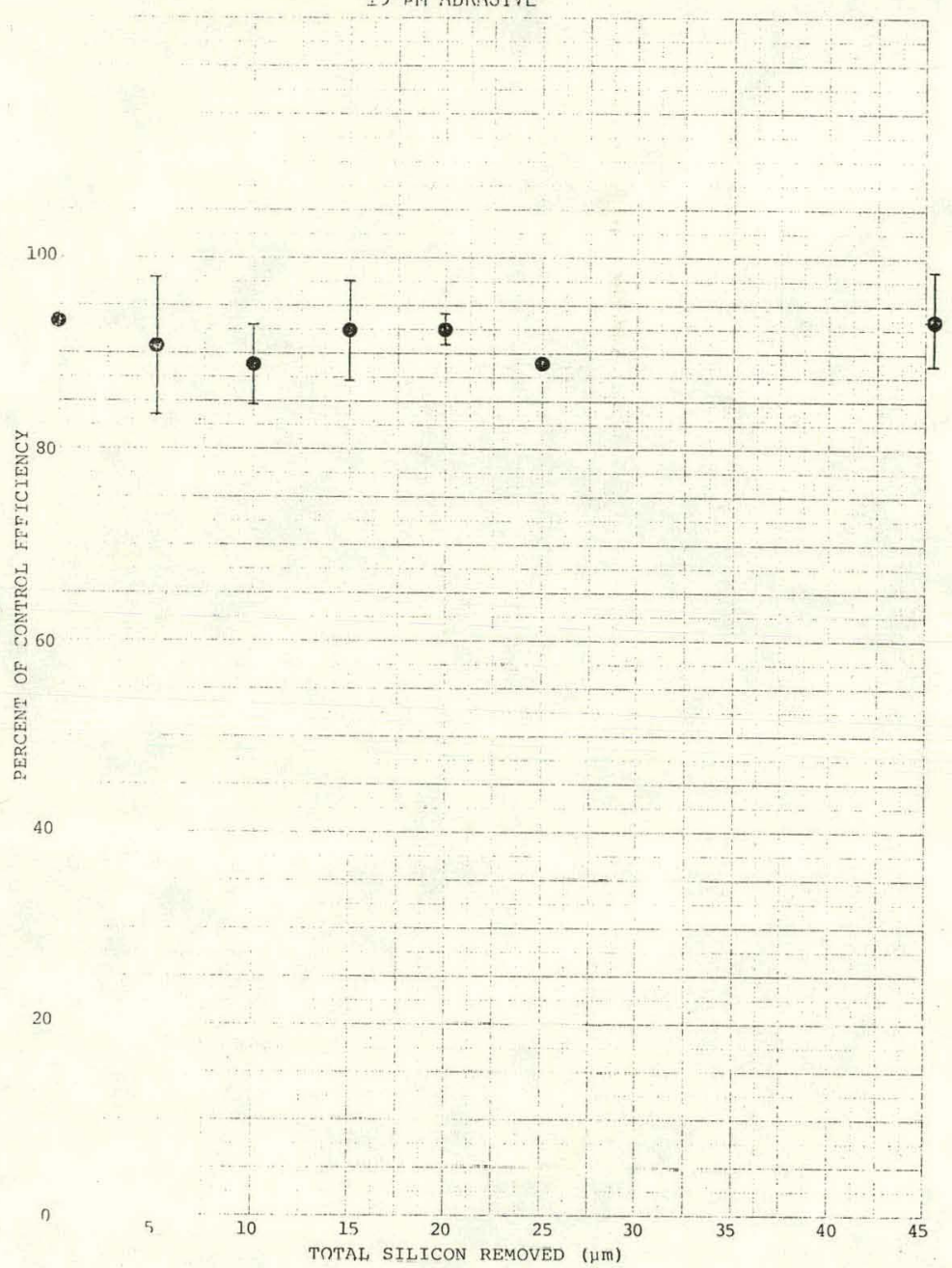




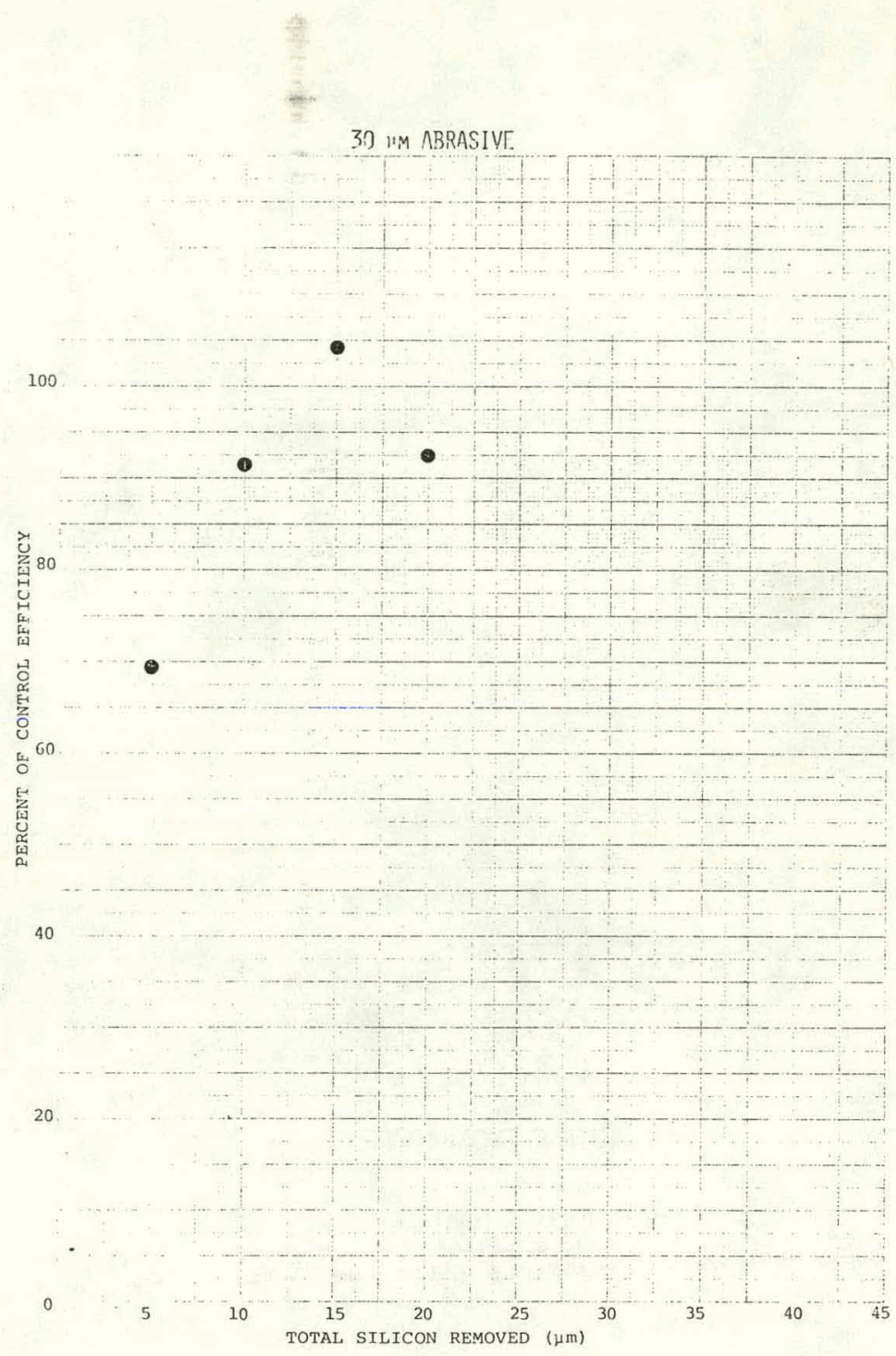




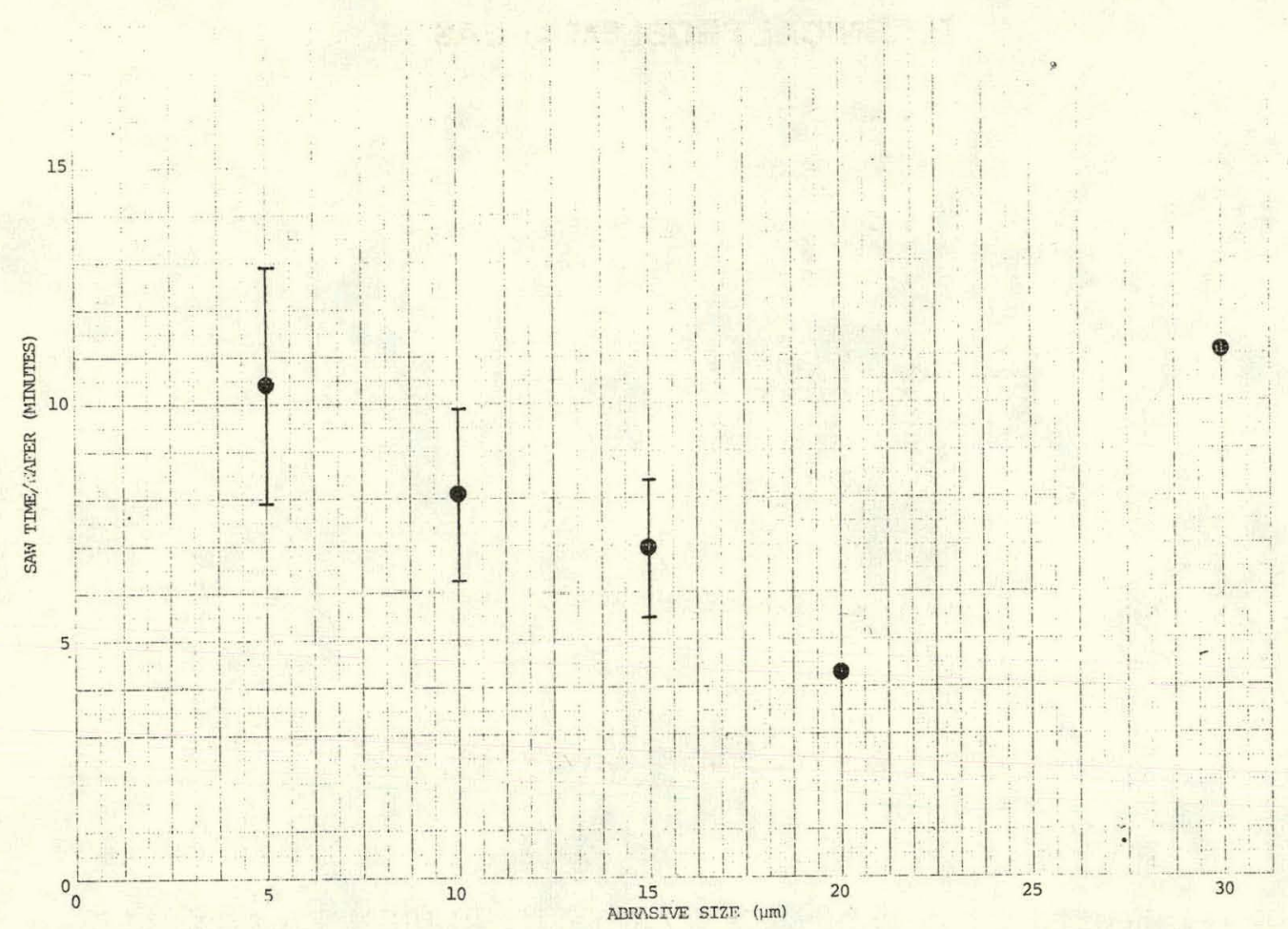

\section{WIRE DIAMETER}

- major contributor to kerf loss

- yasunaga ADVERTISES 3 MIL (U.U/5 MM) MAY BE USLD

- $0.075,0.10,0.15,0.20$ mM DIAPIETER TRIED

\section{WAFERING COST ESTIMATE}

ASSUMPTIONS:

- ONE OPERATOR FOR THREE MACHINES

- $0.3 \mathrm{MM}$ PITCH

- 0.15 mM WIRE

- 0.00 's mir ADRAsive

- 3 INCII INGOT

COSTS

$\begin{array}{lc}\text { SILICON } & \$ 0.573 / \text { WAFER } \\ \text { LABOR } & 0.1 / \text { JI/WIFER } \\ \text { MATERIAL } & 0.177 / \text { WAFER } \\ \text { EQUIPIIFNT } & 0.041 / \text { WAFER } \\ & \\ \text { IUIAL } & \$ 0.970 / \text { WAFFR } \\ & \$ 213 / \text { METER } \\ & \$ 1.997 / \text { WATT }\end{array}$




\title{
TECHNICAL PROBLEM AREAS
}

\author{
- vire SPOOL BREAKAGE \\ - heAK RESPOOLER MOTOR \\ - URSYNCHRONIZED TRAVERSING HOTOR \\ - hon-UNIFORM cutting rate \\ - loading variations \\ - eXcessive air usage \\ - SLURRY HOSE RUPTURE \\ - abrasive settles out of sluRRY \\ - thin wiRes aRe nOt eCONOMICALlY USABLE \\ - UNEVEN EILICON SURTACE
}

OPTICAL COATING LABORATORY, INC. (PCA)

\section{DEVELOPMENT OF LOW COST CONTACTS TO SILICON SOLAR CELLS}

\author{
(4) December 1978 - April 1979 )
}

\begin{abstract}
'The yoal of the contract is to test the technical feasibility and effective cost of a copper plating system for the manufacture of solar cells for high volume production of low cost solar array modules.
\end{abstract}

A sequence has been developed to plate electrolessly. ihromium-copper contacts onto the very thin palladium layer formed by the Motorola Pd-immersion bath. Contacts to both $\mathrm{Pt}$ and $\mathrm{Nt}$ surfaces of slices were formed by simultaneous deposition. These plated $\mathrm{Cr}-\mathrm{Cu}$ contacts were compared to cr-Cu contacts formed by vacuum evaporation.

For both systems, the contact thickness was built up using electrolytic copper depnsition. Good adhesion and yuud cell performance was obtained for both systems. However, there was cell degradation after repeated heat treatments. Attempts were made to decrease. the degradation by using more effective masking methods during plating.

In addition cellg have been made by depositing copper (electrolessly). directly onto Pd formed by the Motorola immersion method and electroless bath. These cells also had contact build up by electrolytic Cu plating. Preliminary results show that the overall cell properties resemble those made using the $\mathrm{Pd}-\mathrm{Cr}-\mathrm{Cu}$ sequence. 
PLATED PALLADIUM-PALLADIUM-COPPER

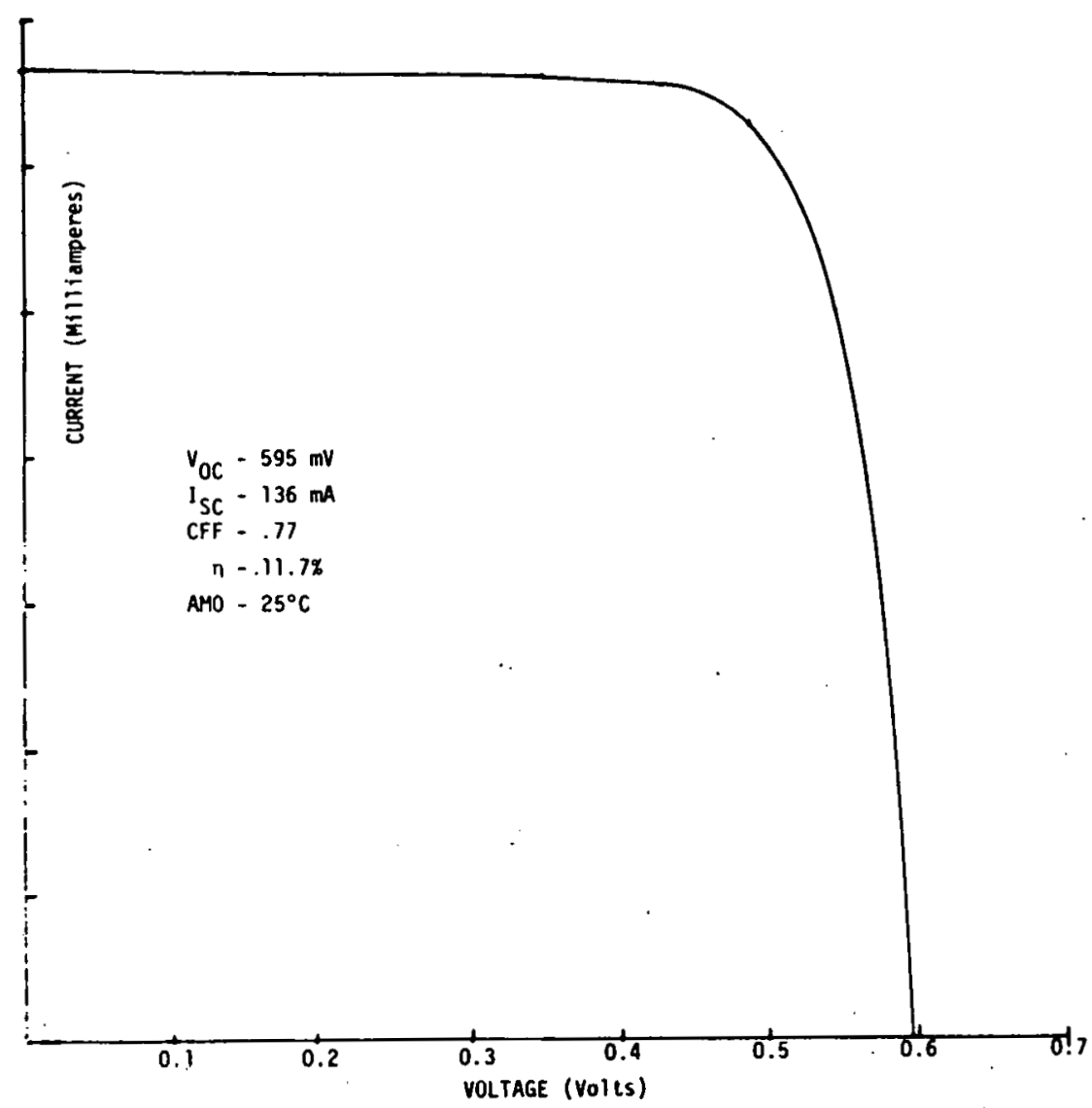




\section{PLATED PALLADIUM-CHROMIUM-COPPER}

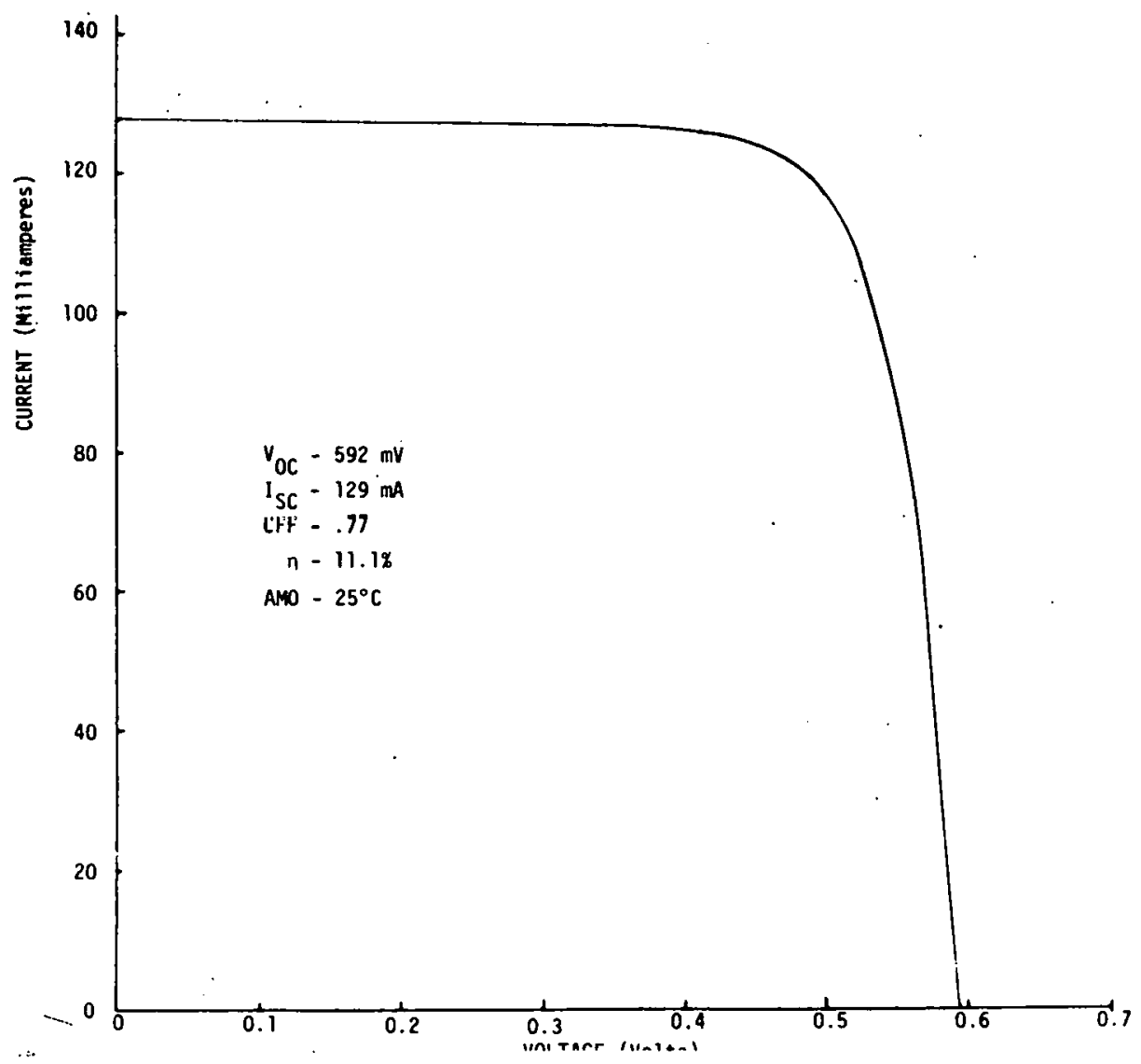

EVAPORATED CONTACT TEST

\begin{tabular}{|c|c|}
\hline GROUP NO. & CONTACT TYPE \\
\hline 1 & $\mathrm{Cr}-\mathrm{Cu}\left(1000 \AA \mathrm{C} \mathrm{Cr}-5000 \mathrm{~A}^{\circ} \mathrm{Cu}\right)$ \\
\hline 2 & Cr-Cu-Plated Cu (4-6 microns) \\
\hline 3 & TH-Pd-Ag (only 2000A Ag) \\
\hline 4 & Ti-Pd-Ag-Plated Ag (4-6 microns) \\
\hline
\end{tabular}

Sets from each group were heated at $400^{\circ} \mathrm{C}$, $450^{\circ} \mathrm{C}$, and $500^{\circ} \mathrm{C}$ for 5 minutes in $\mathrm{Hitrogen}$.

Groups 1 and 3 plated-up after heat treatments for proper comparison: 


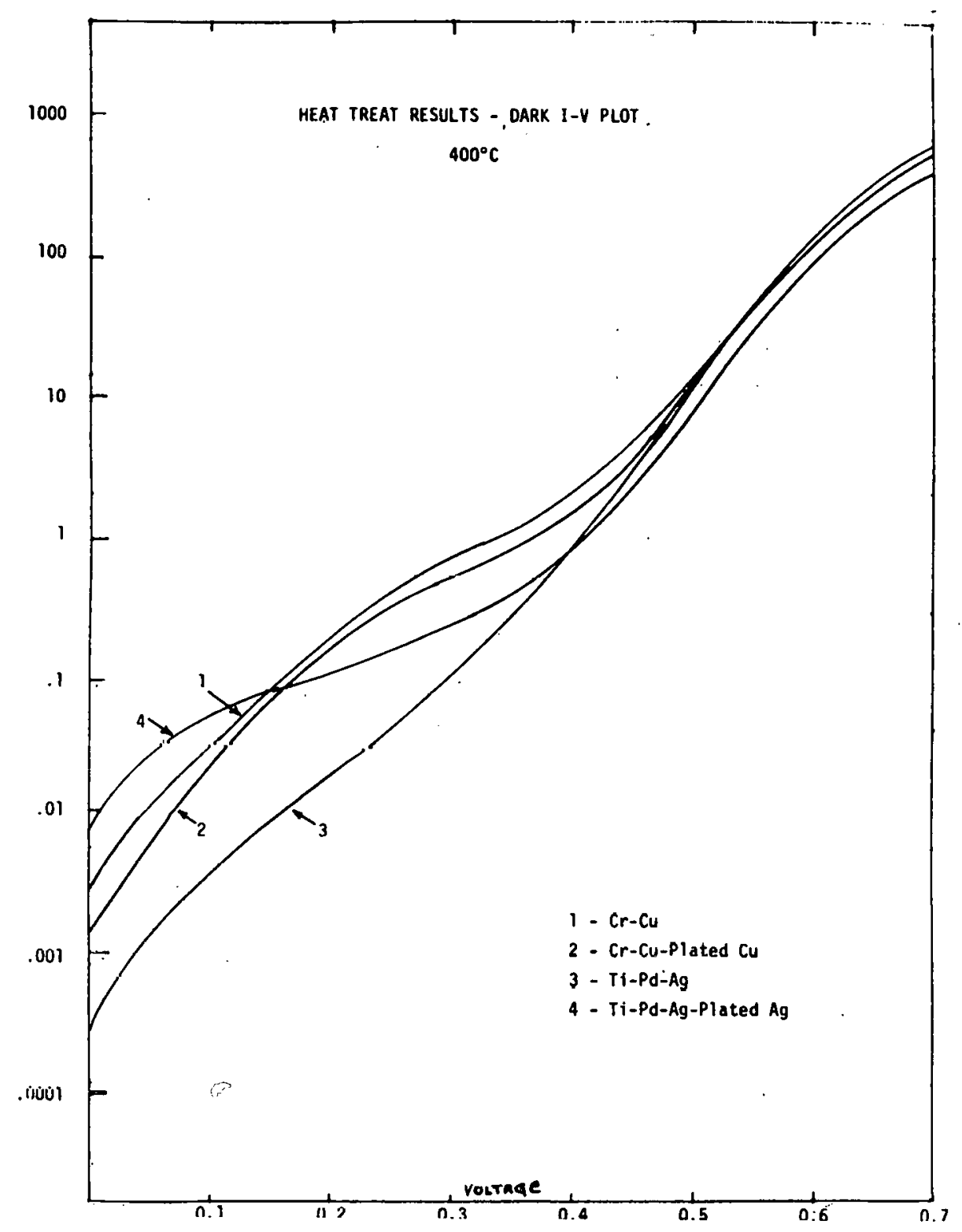




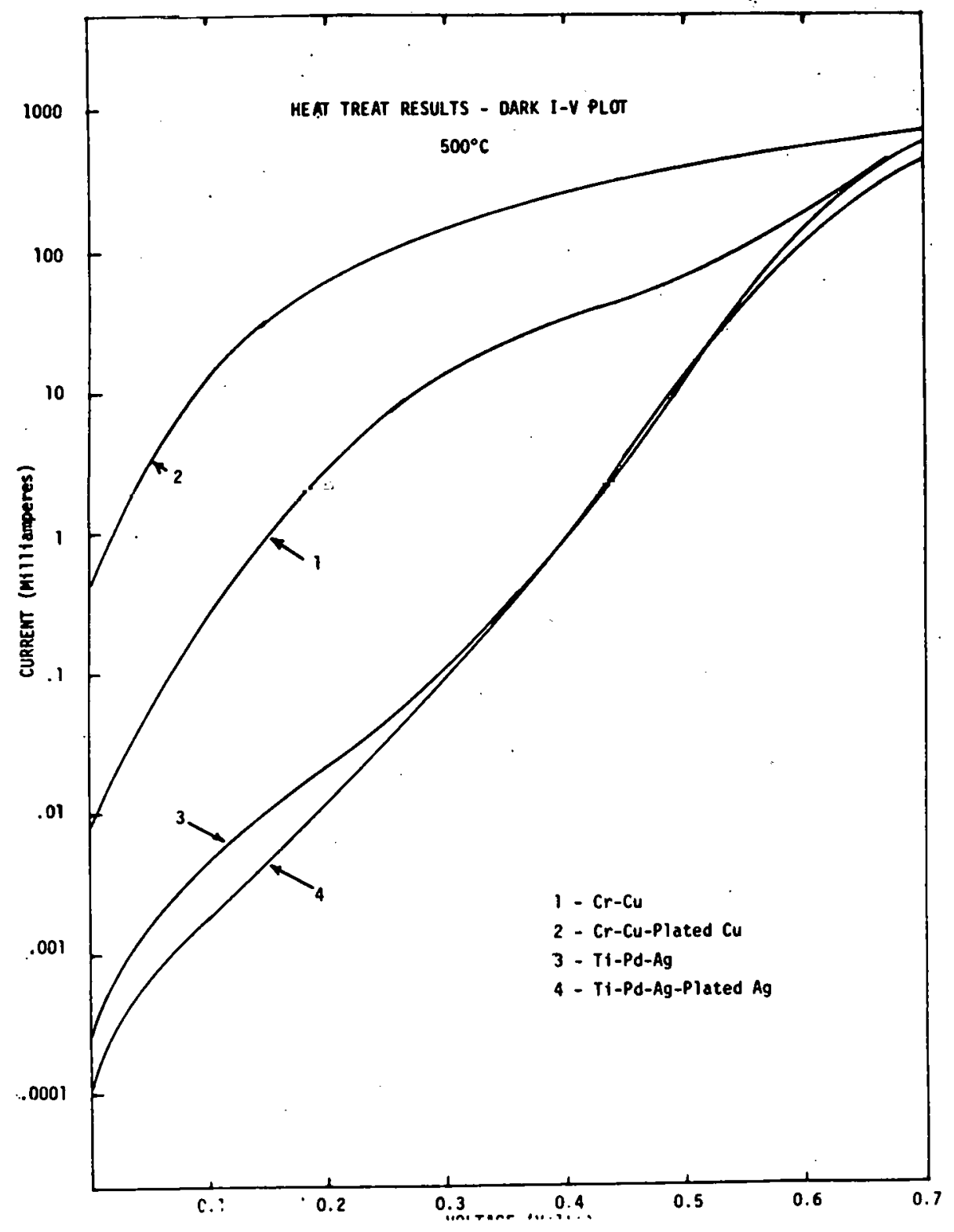




\section{SOLAR CELL ELECTRICAL DATA}

CELL OESCRIPTION: Chrowiun-Copper Evaporated Heat Treat Tests

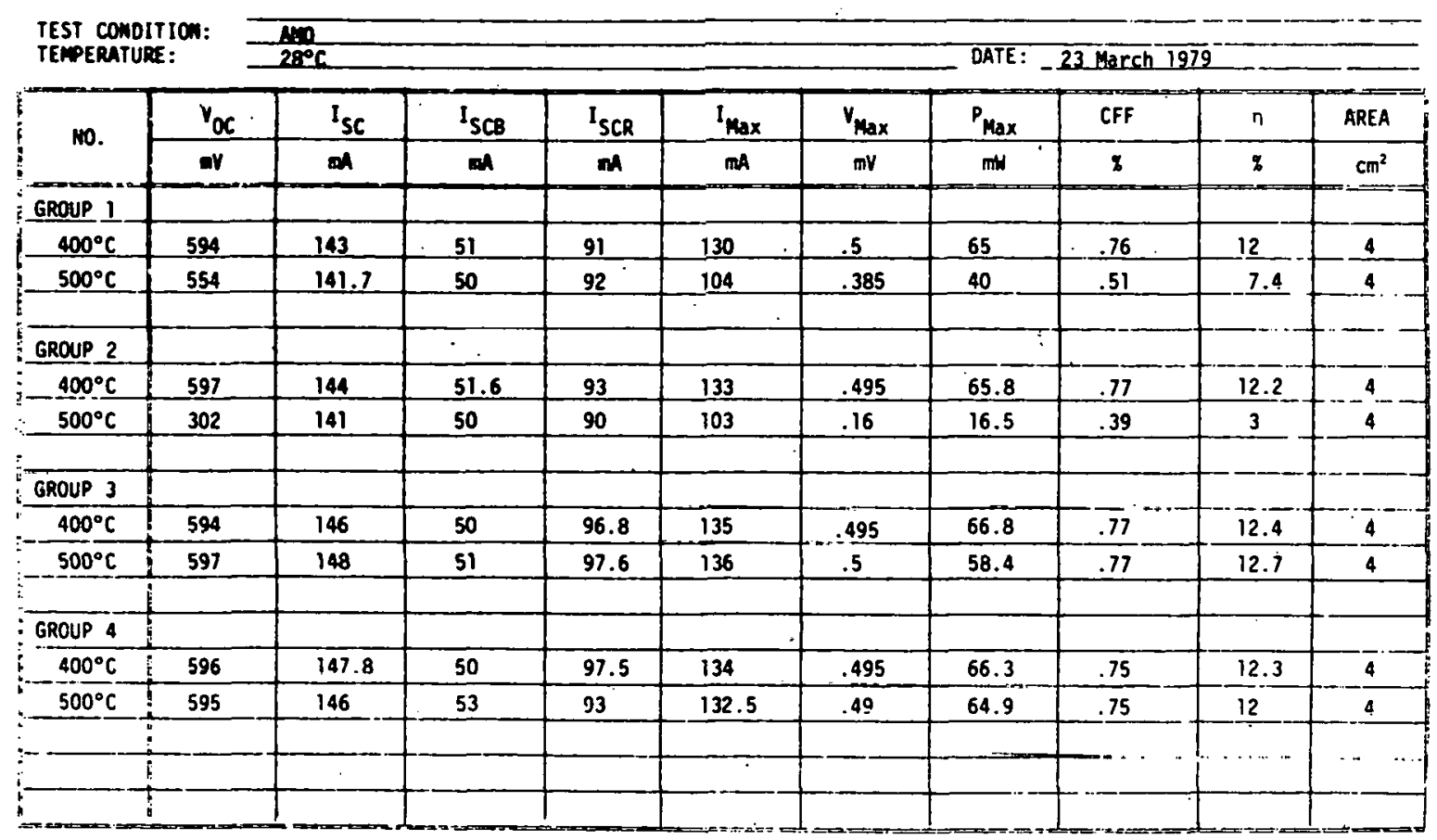

CONTACT ADHESION

\begin{tabular}{|c|c|c|c|c|}
\hline CONTACT TYPE & MODE & AREA & FROAI & Bink \\
\hline Ti-Pd-Ag & Evaporated & $.02 \mathrm{~cm}^{2}$ & $200 g^{*}$ & $236 \mathrm{git}^{\dagger}$ \\
\hline $\mathrm{Cr}-\mathrm{Cu}$ & Evaporated & $.02 \mathrm{~cm}^{2}$ & $117 \mathrm{gnt}$ & $250 \mathrm{gm}^{+}$ \\
\hline $\mathrm{Pd}-\mathrm{Cr}-\mathrm{Cu}$ & Plated & $.02 \mathrm{~cm}^{2}$ & $83 \mathrm{gm} *$ & $220 \mathrm{gm}^{+}$ \\
\hline$P d-P d-C u$ & Plated & $.02 \mathrm{~cm}^{2}$ & $170 \mathrm{gm}$ & $280 \mathrm{gm}^{+}$ \\
\hline
\end{tabular}

* Pulled Some Silicon

†Cell Broke

Cell Substrate: 7-14 ohm-cm P-Type - Chemically Polished Front Al Alloyed Dack 
ARCO SOLAR, INC.

\title{
AUTOMATED SOLAR PANEL ASSEMBLY LINE
}

\author{
OBJECTIVES
}

1. ESTABLISH MODULE DESIGN COMPATIBLE WITH AUTOMATED MODULE FABRICATION TECHNIQUES.

2. DESIGN AND FABRICATE AUTOMATED SOLAR CELL SOLDERING MACHINE CAPABLE OF ASSEMBLING 12 CELLS/MINUTE.

3. UEZIGL MND FRRRTCATF, AUTOMATED MODULE LAMINATING MACHINE CAPABLE OF 12 MODULES/HOUR.

4. INSTALL EQUIPMENT INTO PRODUCTION LINE AND OPERATE AUTOMATED PILOT LINE.

APPROACH

MODULE DESIGN

100 MM SOLAR CELL WITH FULLY REDUNDANT INTERCONNECTS COMPATIBLE WITH AUTOMATION. FIELD PROVEN ENCAPSULATION SYSTEM.

SOLDERING MACHINE

DEVELOP SIMPLE, RELIABLE MECHANISMS. SIMULTANEOUS SOLDERING OF TOP AND BOTTOM CELL INTERCONNECTS.

LAMINATION SYSTEM

VACUUM LAMINATION CHAMBER USING INFRARED HEATING, DIAPHRAGM SEALING AND FORCED COOIING. 

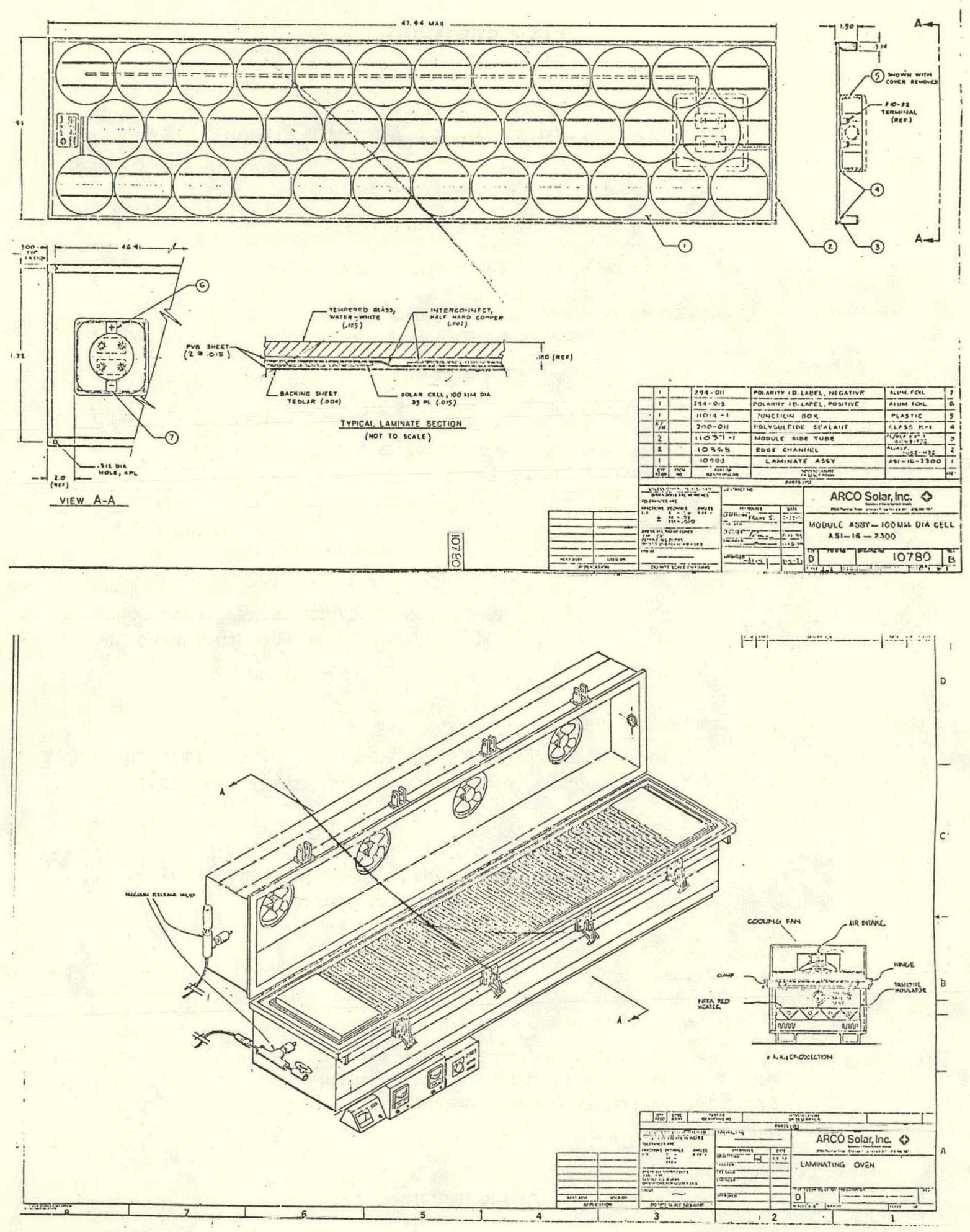


\section{CELL STRINGER}

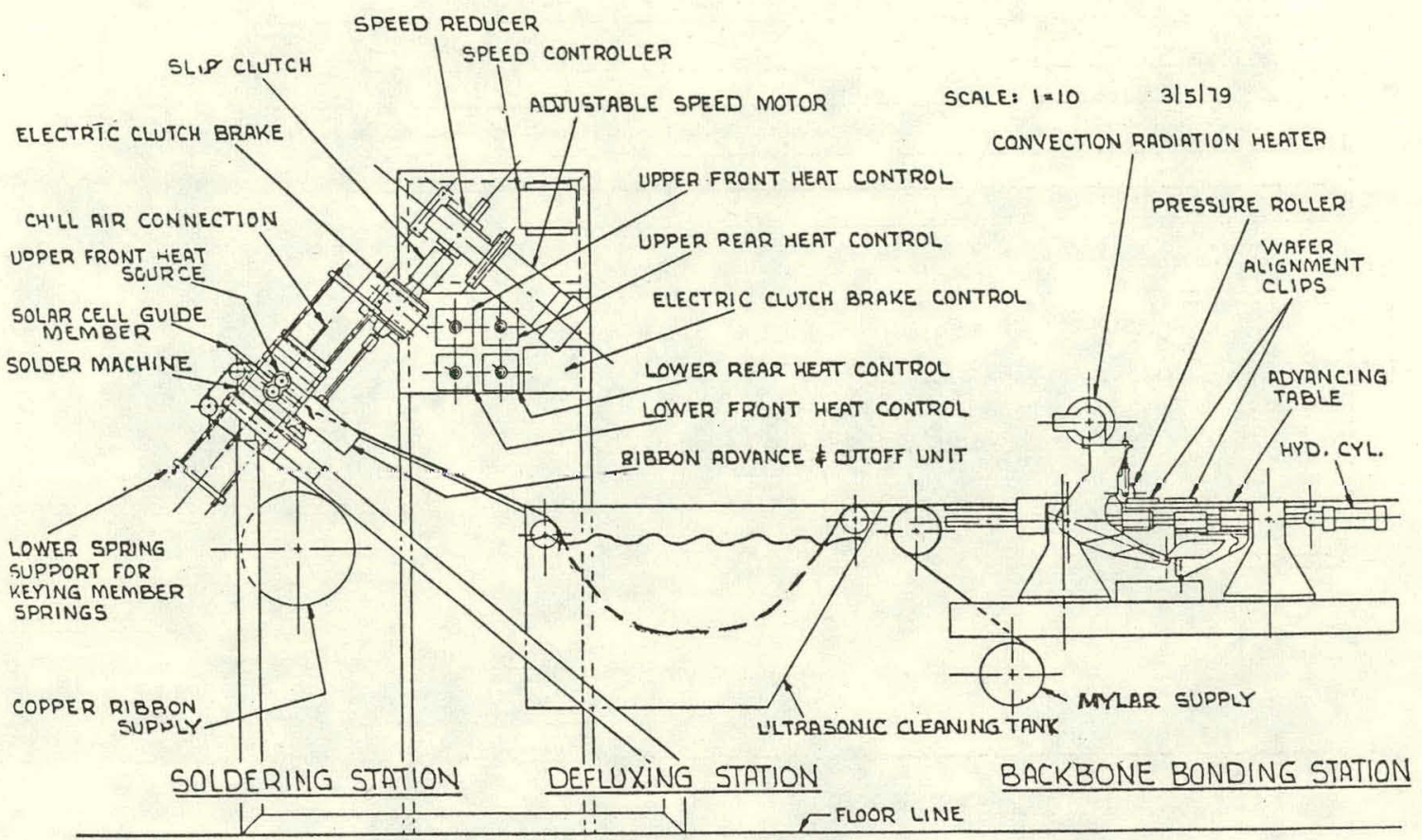

\section{STATUS}

MODULE DESIGN AND TESTING

DESIGN COMPLETE; DESIGN LIMIT THERMAL CYCLING COMMENCED

SOLDERING MACHINE

1. SOLDERING HEAD DESIGNED AND MECHANICALLY TESTED

2. a. CELL ALIGNMENT AND TRANSPORT IN DESIGN

b. RIBBON FEED AND ADVANCE IN DESIGN

3. CELL CLEANING SYSTEM DESIGNED

4. MYTAR STRIP ATTACHMENT DESIGN NEAR COMPLETION

LAMINATION SYSTEM

5. PRODUCTION LAMINATION CHAMBER DESIGNED

6. INSTRUMENTATION AND CONTROL IN DESIGN

7. LAMINATION ROTARY IN DESIGN

\section{OPEN ISSUES}

1. SOLDERING PROOF OF DESIGN TO BE DEMONSTRATED

2. THINNER LAMINATION PROCESS TO BE DEVELOPED 


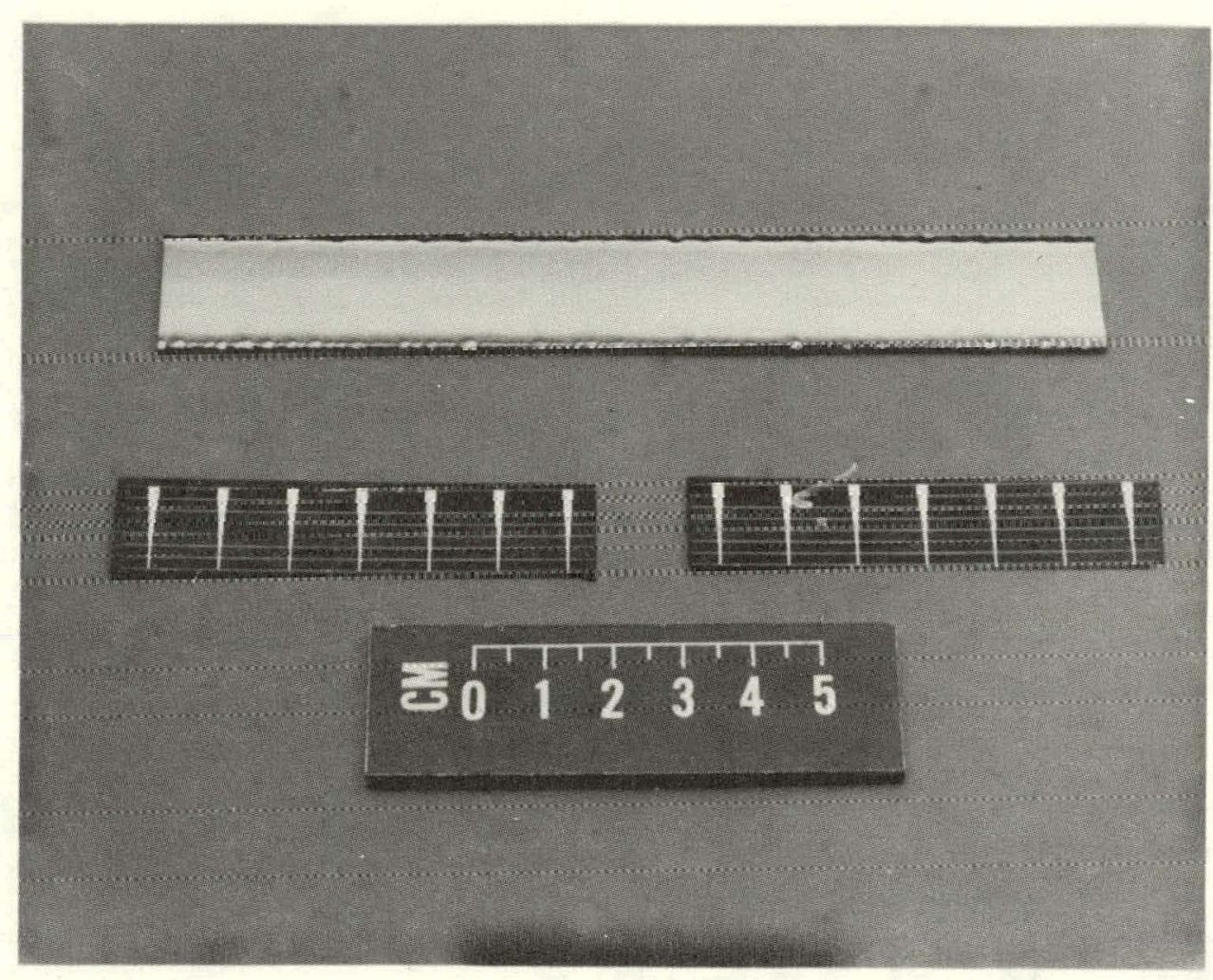

\section{AR COATING BY WITHDRAWAL FROM SOLUTION}

- $88 \% \mathrm{TrO}_{2}-12 \% \mathrm{SiO}_{2}$

- rFsiII ta DEPENDENT ON - Viscositi

- concentration

- RATF OF WITHDRAHAL

- efficiency enhancement up to $48 \%$

- cost effective 


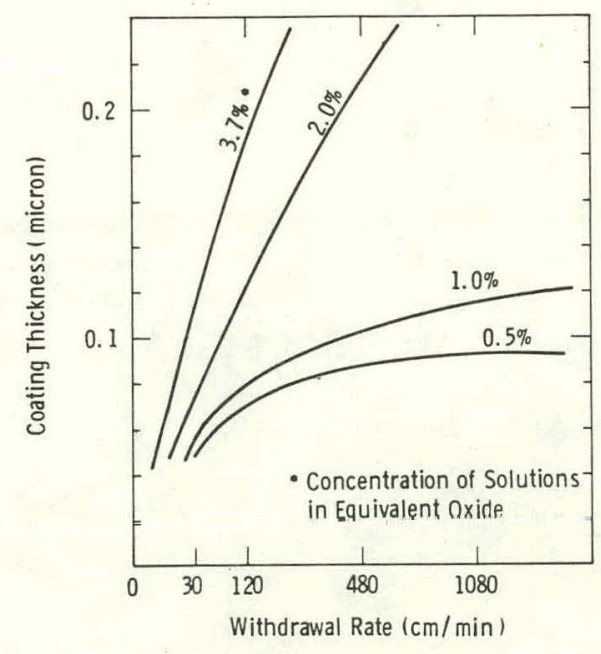

Coating thickness as a function of solution concentration and withdrawal rate in dipping application.

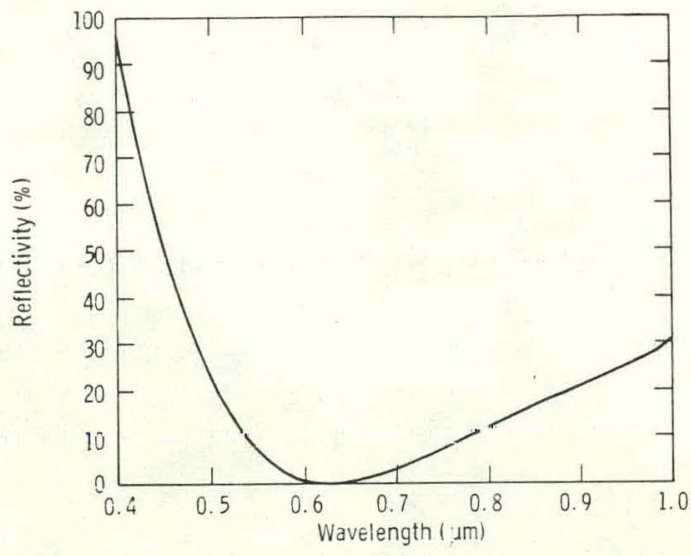

Spectral reflectivity of a AR coating on a web silicon solar cell (composition-88\% $\mathrm{TiO}_{2}-12 \% \mathrm{SiO}_{2}$, heat treated at $450^{\circ} \mathrm{C}$ )

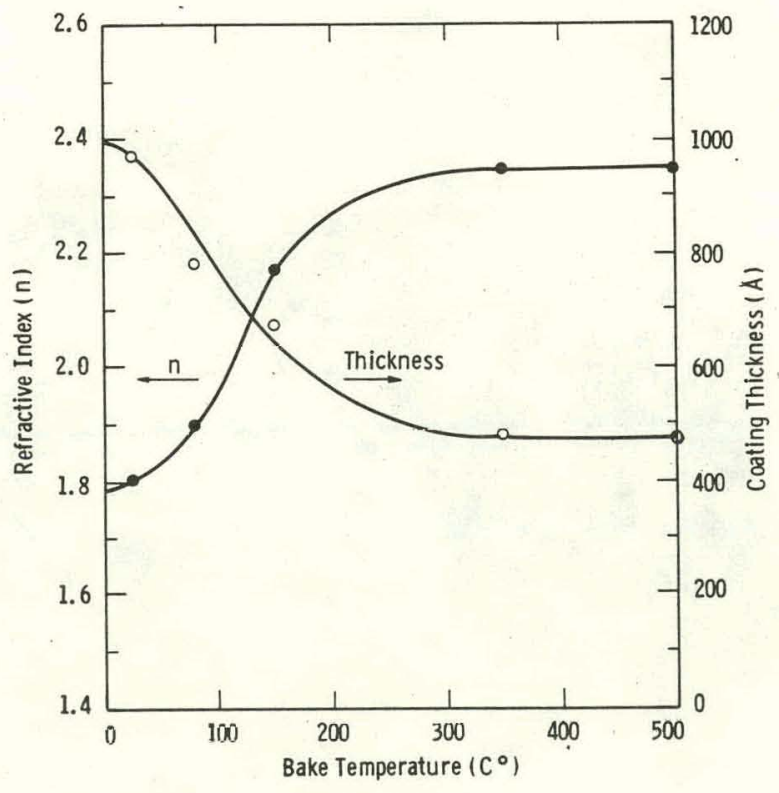

Change in index of refraction and coating thickness during heat treatment 


\section{EFFECT OF METAL-ORGANIC DERIVED AR COATINGS ON SOLAR CELL PERFORMANCE}

\begin{tabular}{llcrc} 
Cell & Coating & \multicolumn{2}{c}{ Efficiency $(\%)$} & Enhancement \\
& & Uncoated & CoAted & \\
$1009 \mathrm{~B} 3$ & $\mathrm{TAO}_{2}$ (BASELINE) & 8.95 & 12.70 & $42 \%$ \\
$1012 \mathrm{~B} 3$ & $\mathrm{TrO}_{2}+\mathrm{S}_{1} \mathrm{C}_{2}$ & 8.65 & 12.82 & $48 \%$
\end{tabular}

\section{ANTIREFLECTION FILM THICKNESS VS ENHANCEMENT FACTOR}
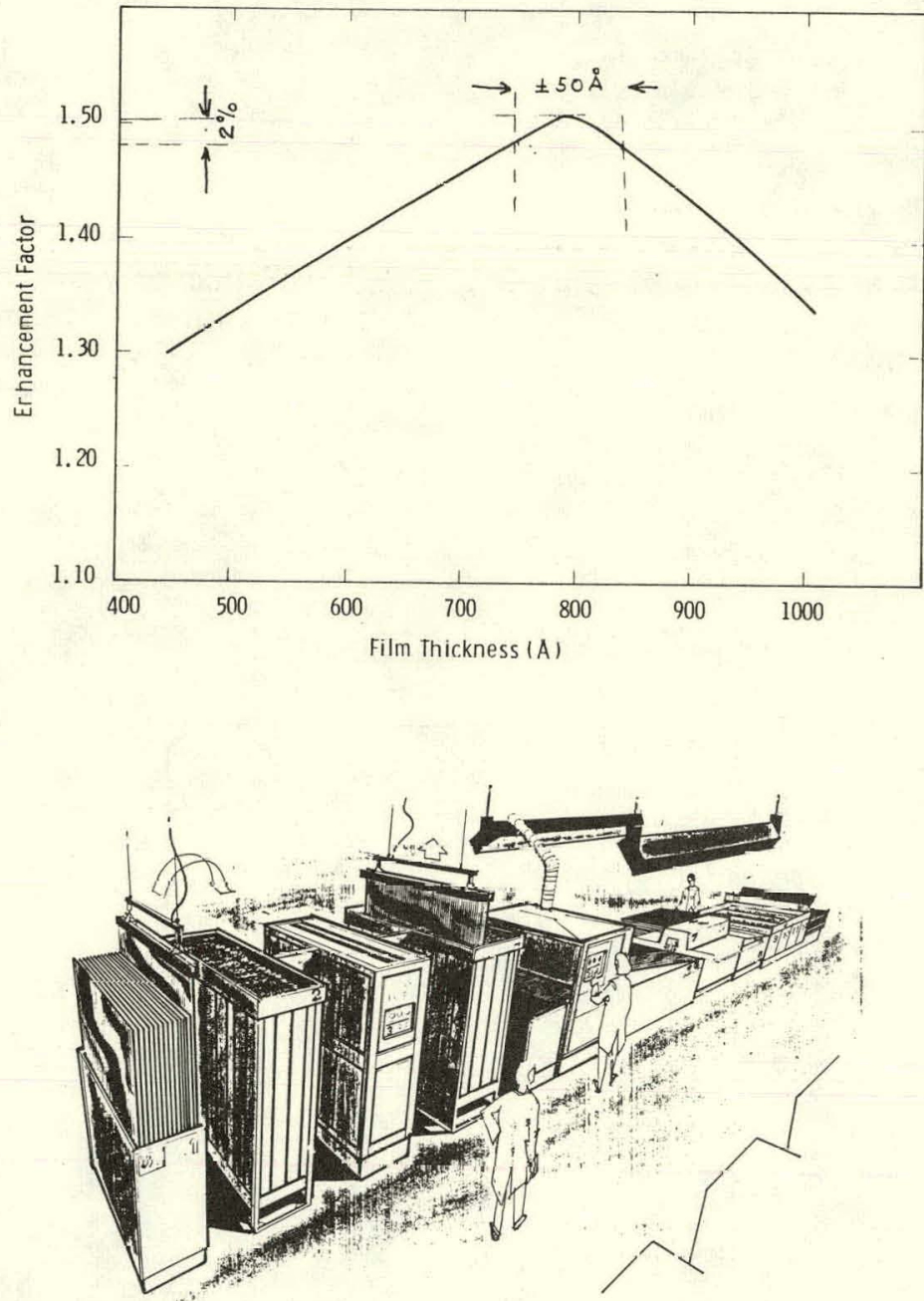


\title{
PRESENT PROCESS FOR DIP COATING AR
}

\author{
CONDITIONS: 1 WEB WITHDRAWN AT A TIME \\ $30 \mathrm{cM} /$ MIN $=0.5$ WATTS \\ YEARLY OUTPUT $-0.25 \times 10^{E}$ WATTS \\ COSTS: 4 TECHNICIANS + SUPERVISION \\ - $65 \mathrm{k} \$$ \\ Utilities \\ $\$ 125$ \\ Materials \\ $\$ 750$ \\ LAB SPACE \\ $\$ 2500$ \\ CAPITAL \\ $\$ 2000$
COST/WATT -- .28.WATT PEAK (1986\$)
LABOR INTENSIVE

\section{AR COATING BY DIPPING COST INPUTS}

\begin{tabular}{|c|c|c|}
\hline 2.01 & $\begin{array}{l}\text { BUFFER } \\
\text { (HOLDING AREA FOR } \\
\text { MATERIAL FROM } \\
\text { JUNCION FORMATION } \\
\text { PROCESS) }\end{array}$ & $\begin{array}{l}\text { LABOR - } 0.1 \text { PY CAPITAL - 10K\$ } \\
\text { FLOOR SPACE }-97 \mathrm{FT}^{2}-\text { UTILITIES } 0.5 \mathrm{KW}\end{array}$ \\
\hline 2.02 & $\begin{array}{l}\text { AR - DIP \& DRAIN } \\
\text { (WEB - HELD IN } \\
\text { FRAMES DIPPED IN } \\
\text { VAT OF SOLUTION) }\end{array}$ & $\begin{array}{l}\text { LABOR - } 0.25 \text { PY CAPITAL - EOK\$ } \\
\text { FLOOR SPACE } 17 \mathrm{FT}^{2}-\text { UTILITIES } 0.5 \mathrm{KM} \\
\text { COMMODITIES: } \\
\text { AR SOL'N } 1.33 \times 10^{-5} \text { L/MIN } \\
\text { ISOPROPYL } 6.3 \times 10^{-3} \text { L/MIN } \\
\text { ALCOHOL }\end{array}$ \\
\hline 2. & $\begin{array}{l}\text { BAKE AND COOL } \\
\text { (WEB BAKED AT } \\
400^{\circ} \mathrm{C} \text { FOR } 5 \text { MIN, } \\
\text { AND COOLED FOR } \\
10 \text { MIN.) }\end{array}$ & $\begin{array}{l}\text { LABOR }-0.25 \text { PY CAPITAL }-20 \mathrm{KS} \\
\text { FLOOR SPACE } 48 \mathrm{FT}^{2} \text { UTILITIES }-4.5 \mathrm{KW}\end{array}$ \\
\hline
\end{tabular}




\section{BASIC PROCESS STEPS}

(P ON N CELL - BORON IMPLANTED JUNCTION)

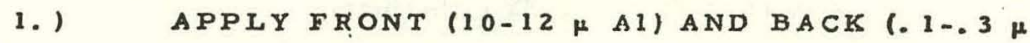
OF A\& DOPED Ag + $2-3 \mu$ Ni) CONTACTS

THROUGH APPROPRIATE MECHANICAL MASKS.

2.) APPLY COMBINED COATING (AR, HERMETIC SEAL, IMPLANTATION OXIDE) OF $\mathrm{Al}_{2} \mathrm{O}_{3}$ OVER FRONT SURFACE AND EDGE.

3.) ION-IMPLANT FRONT JUNCTION USING MECHANICAL EDGE MASK TO PROVIDE PASSIVATED STRUCTURE.

4. $)$ HEAT TREAT TO SIMULTANEOUSLY ELECTRICALLY ACTIVATE IMPLANTED IONS AND ALLOX CONTACTS,

\section{MANUFACTURING PROCESS SEQUENCE}

STEP 1

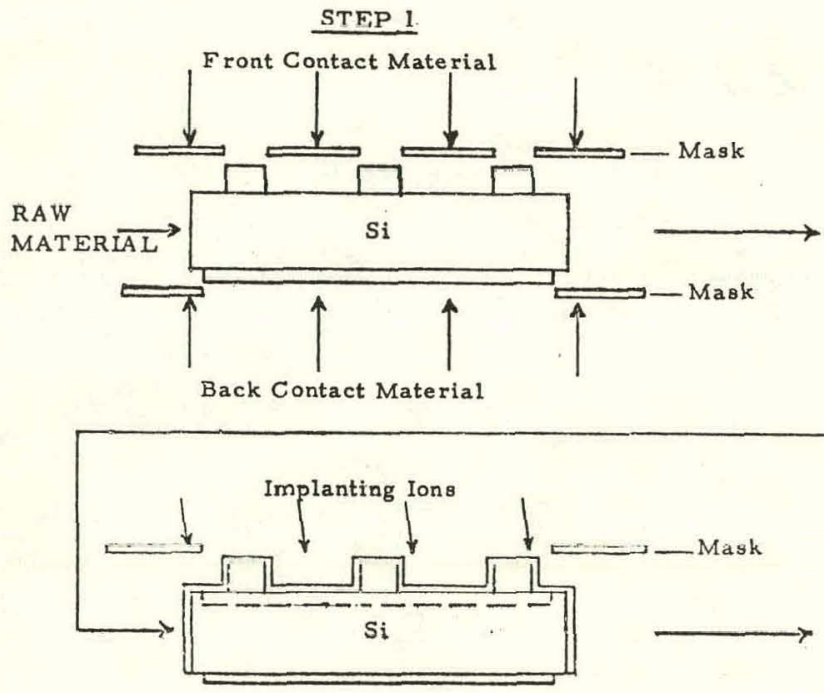

$\operatorname{STEP} 3$
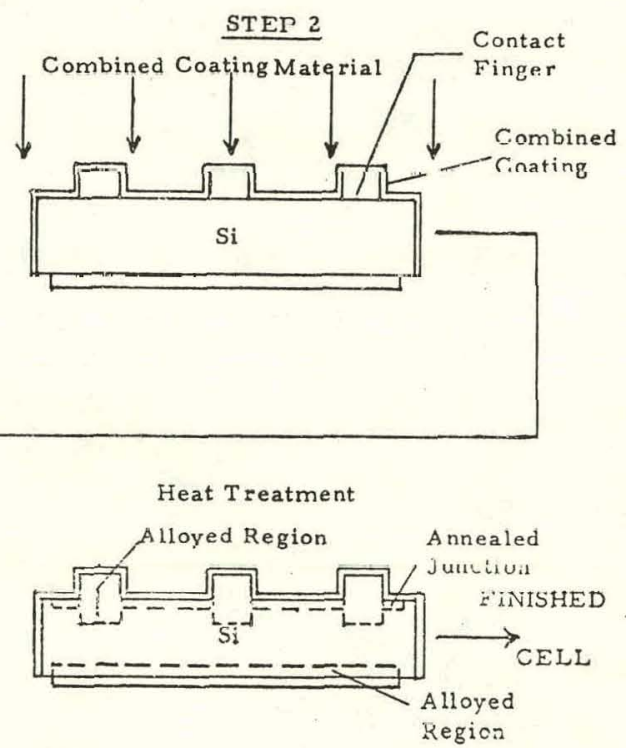

STEP 4 


\section{MANUFACTURING ADVANTAGES}

1) EXTREME SIMPLICITY - ONLY 4 MAJOR MANUFACTURING STEPS INCLUDING ENCAPSULATION SIMPLE CELI CONFIGURATION.

2) COMPLETELY INTEGRAL CELL - NO SURFACE BONDED INTERFACES - WELDABLE CONTACTS.

3) FOOLPROOF PROCESSING - HIGH YIELD

4) COMPLETELY AUTOMATABLE AND CAPABLE OF VERY LARGE SCALE PRODUCTION.

5) ALL CONVENTIONAL SILICON STARTING MATERIALS USEABLE(Cz, FLOAT-ZONED, DENDRITIC, EFG ETC.COULD BE PREFERRED METHOD FOR THIN FILM MATERIALS).

6) ALL MATERIALS USED READILY AVAILABLE AND CONSISTENT WITH LOW COST PROCESSING.

7) CELL CONFIGURATION FOR LINEAR MATERIALS CONSISTENT WITH LOW COST ARRAY FABRICATION. 
FRONT CONTACT SHEET RESISTIVITY

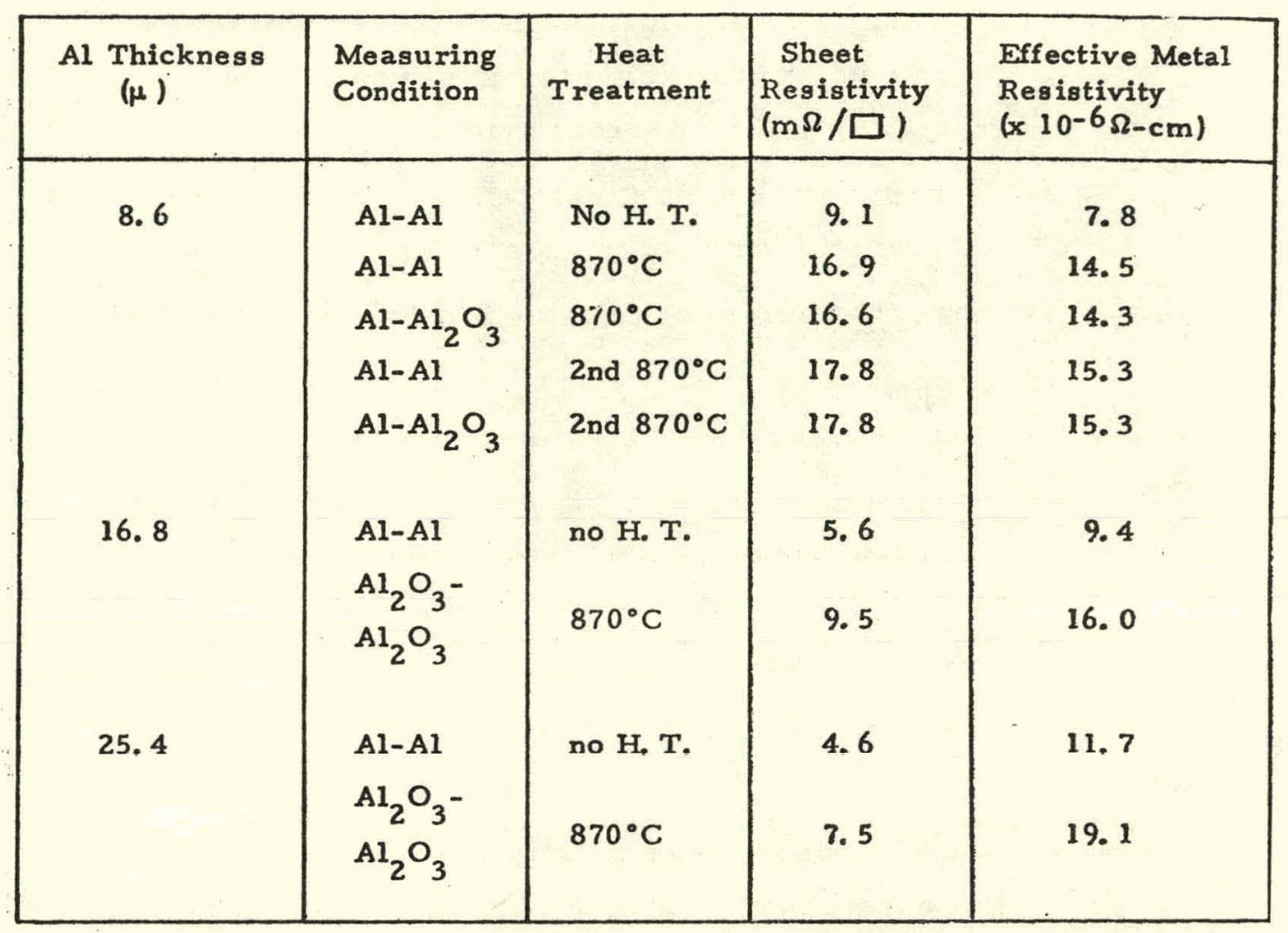

FRONT CONTACT RESISTANCE

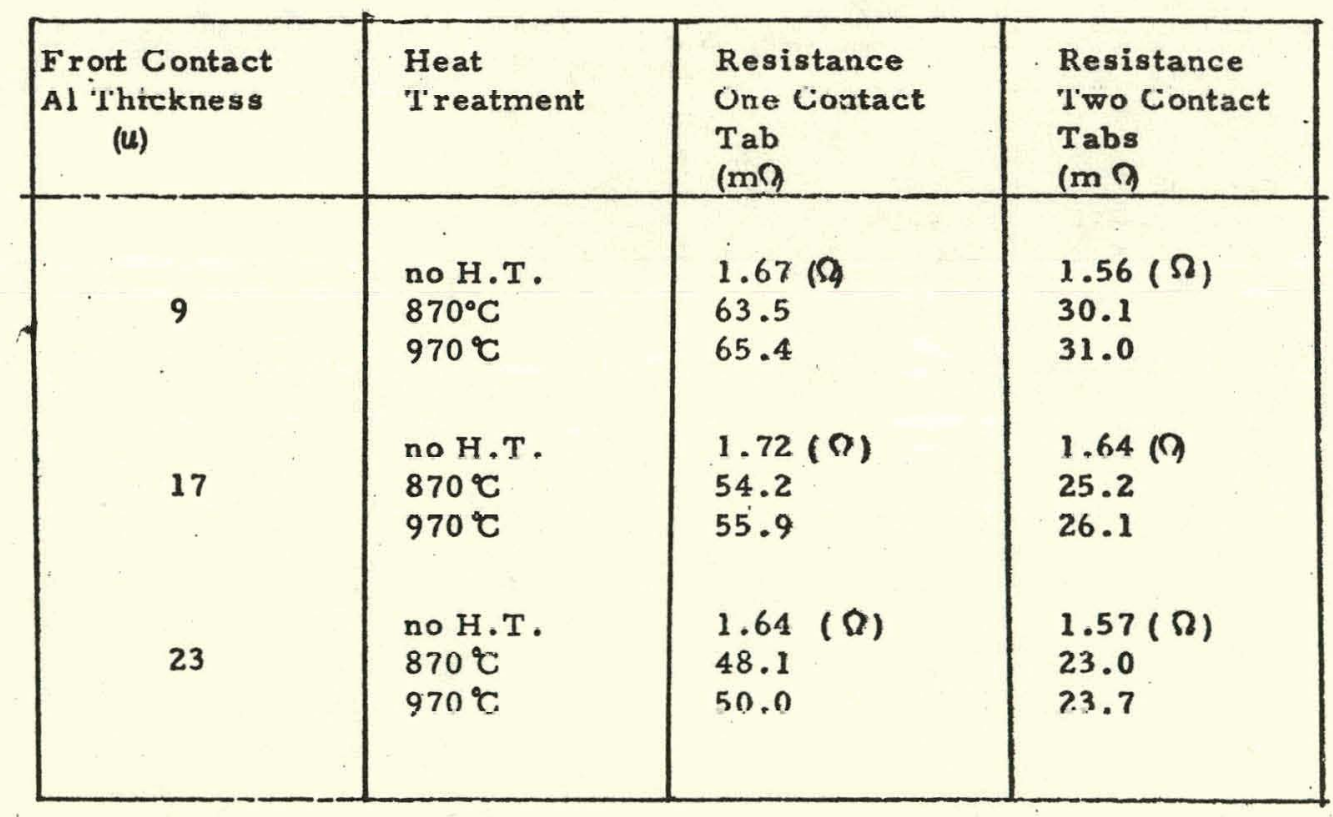




\section{LARGE AREA ALLOYED DIODE CHARACTERISTICS}

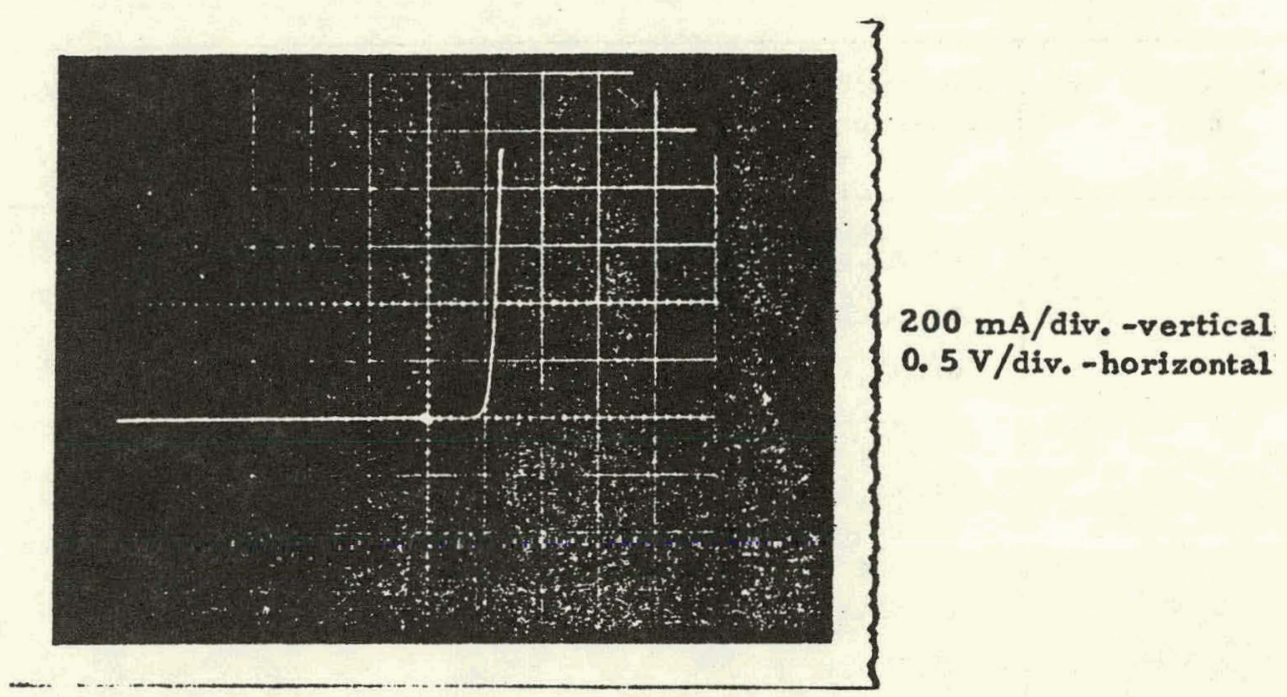

1 (a) $0.9 \times 1.6 \mathrm{~cm}$ Diode

KINETIC COATINGS, INC.

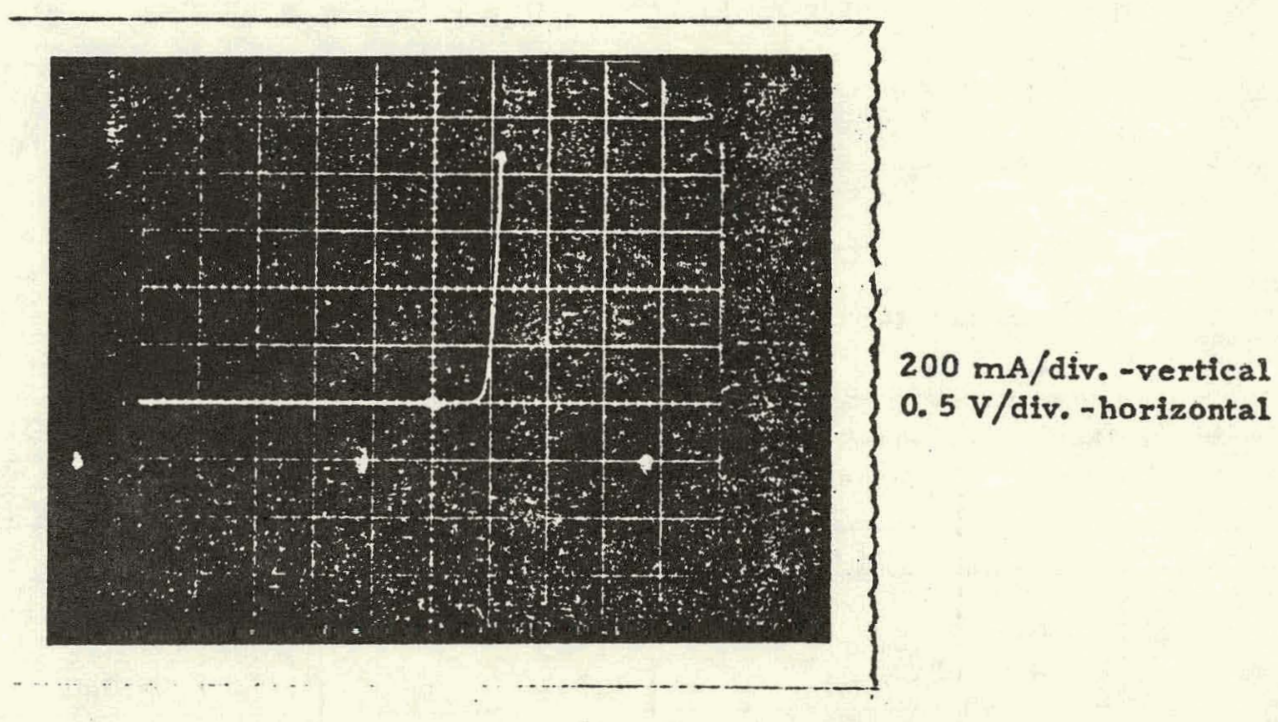

1 (b) 2" $\times 2$ " Diode 


\title{
SECTION I - INTRODUCTION
}

\author{
K \& S to Design, Build, \& Deliver an Automated \\ Assembly Line With the Following Goals: \\ 1. Flexible Design - adaptable to variety of \\ APPLICATIONS \\ - Assemble up to a 6 string module \\ - Permit strings to be assembled in series \\ OR SERIES/PARALLEL RELATIONSHIP \\ 2. Machine to be Built - \\ - to assemble a typical solar cell and module \\ - Machine cycle time - 5 seconds \\ - Index TIMe - 1 - 1.5 seconds \\ - Operation time - 3.5 - 4 seconds \\ - YIELD - 95\% OR BetTER
}

\section{SECTION III - MACHINE CONSIDERATIONS AND DESIGN APPROACH}

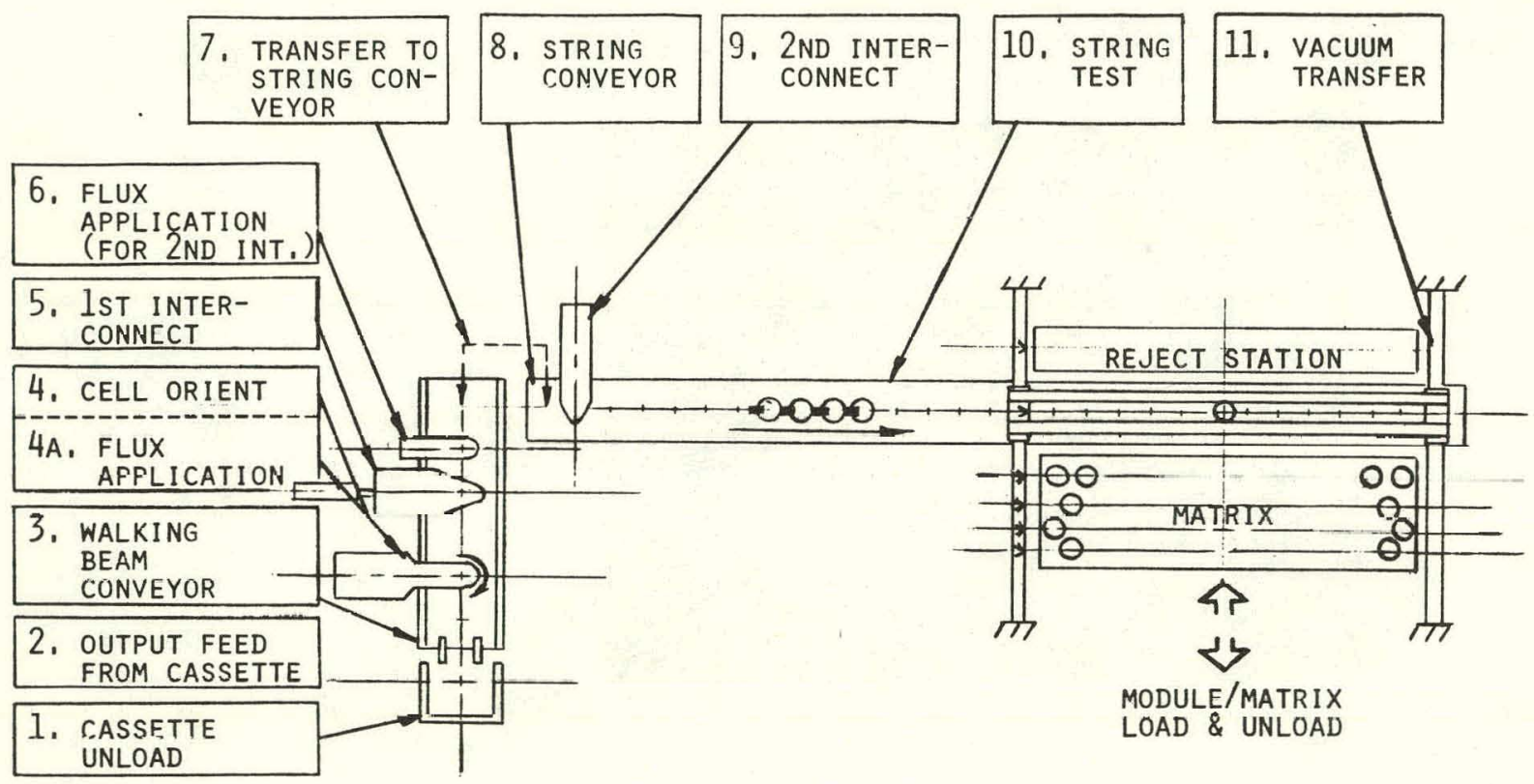




\section{SECTION III STRING TESTING STATION}

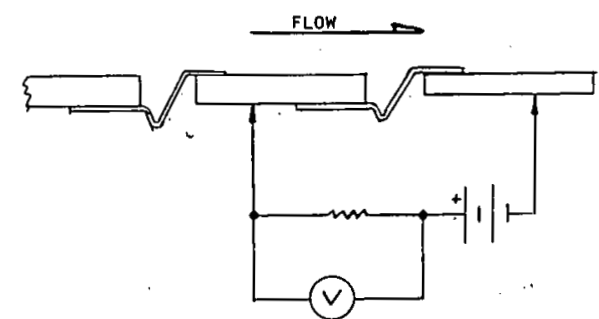

Formard Bias Test - after each 2ND interconnect is made

STATION 11 - VACUUM TRANSFER

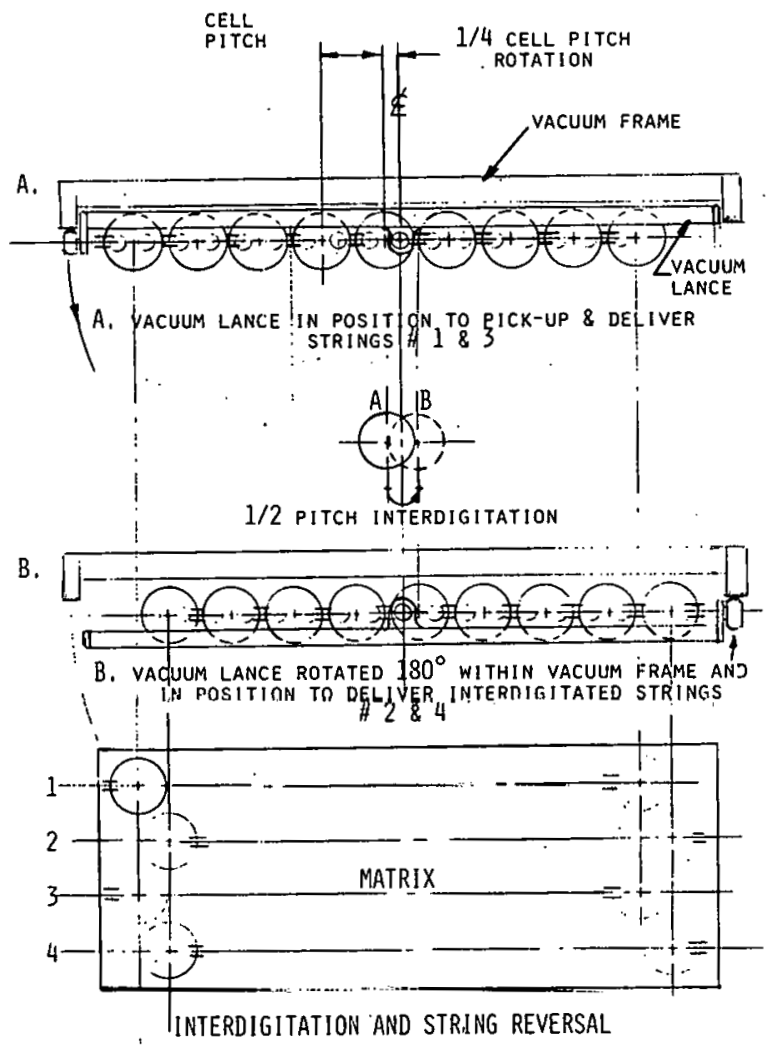


PRODUCTION PROCESS AND EQUIPMENT AREA

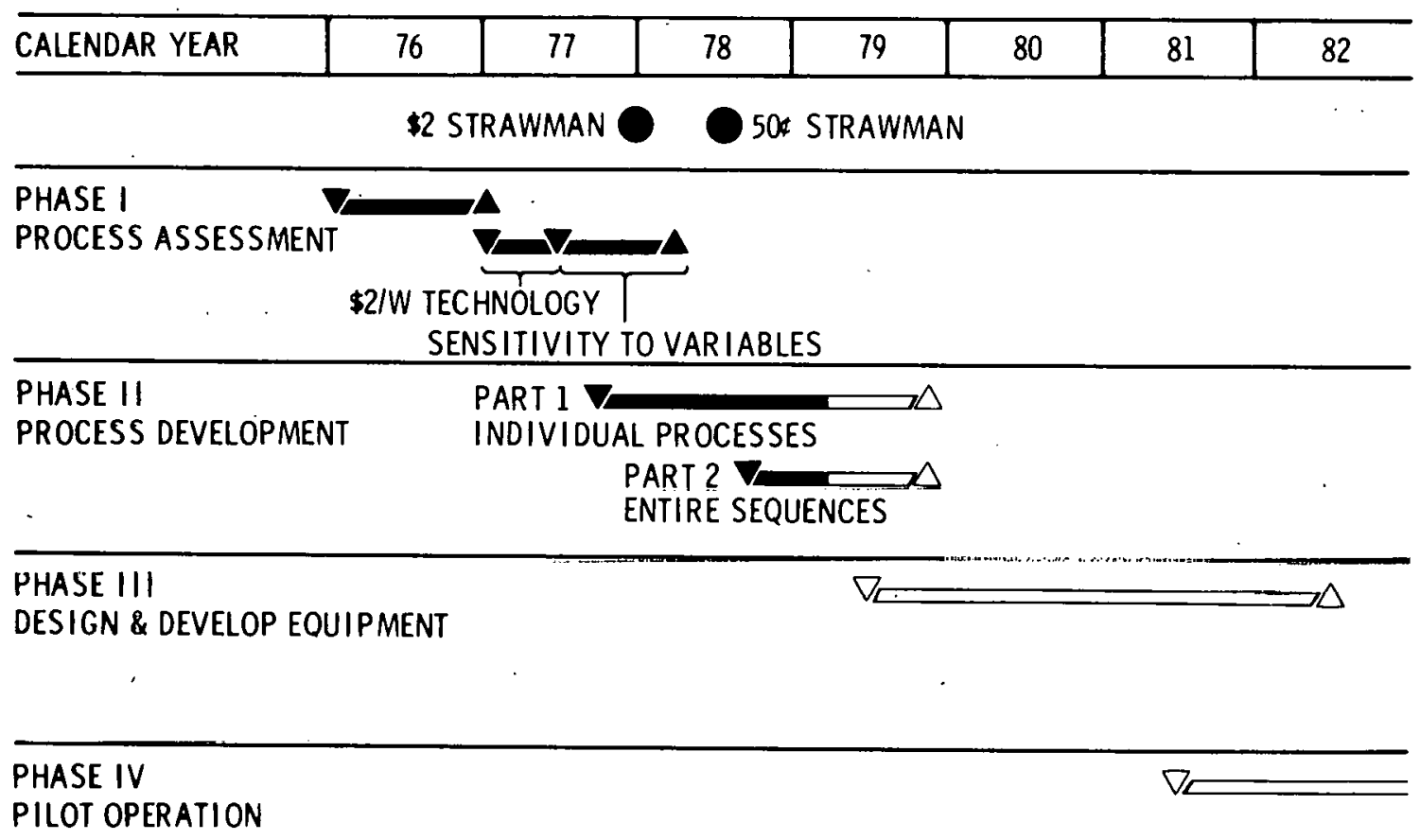

\section{AUTOMATED PROCESSING EQUIPMENT CURRENT PERFORMANCE}

\begin{tabular}{lll}
\multicolumn{1}{c}{ SPFAKFR } & \multicolumn{1}{c}{ COMPANYY } & \multicolumn{1}{c}{ SUBJECI } \\
W. KERN & RS.A & SPRAY AMTIRELLEGTION S.MATING. \\
R.V. D'AIELLO & RCA & THICK FILM METALLIZATION \\
S. CHITRE & SENSOR TECH & LASER SCRIBER \\
S. CHIIRE & SENSOR TËCH & SPRAY-ON JUNCTION \\
R. B. CAMPBELL & WESTINGHOUSE & DIP ANTIREFLECTION COATING
\end{tabular}




\section{SURFACE PREPARATION}

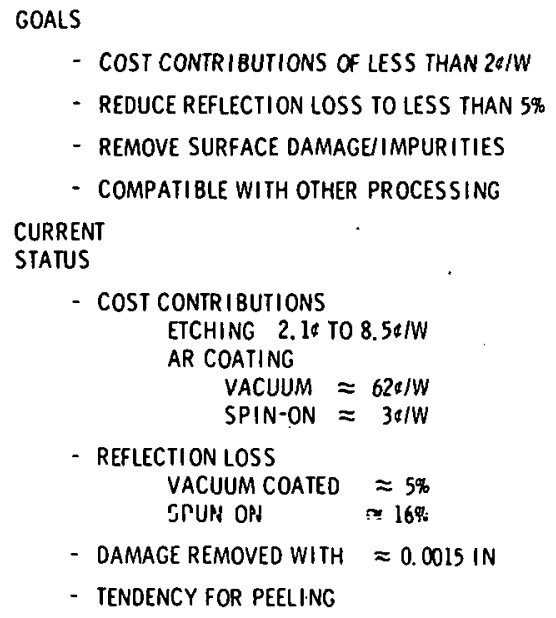

- TENDENCY FOR PEELING

\section{JUNCTION FORMATION}

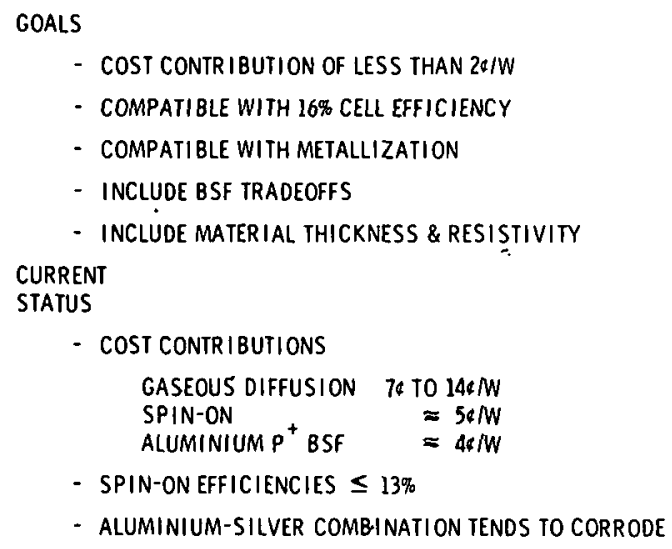




\title{
METALLIZATION
}

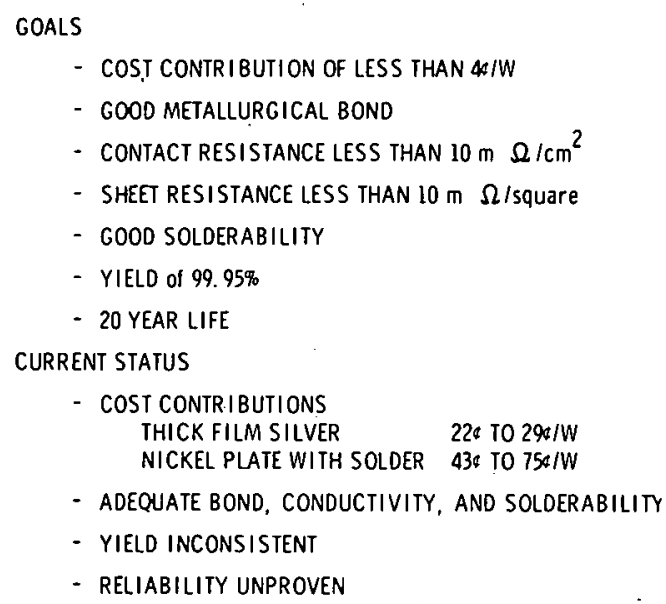

- adeQUate BOND, CONDUCTIVITY, AND SOlOERABILITY

- YIELD INCONSISTENT

- RELIABILITY UNPROVEN

\author{
ASSEMBLY \\ GOALS \\ - COST CONTRIBUTION OF LESS THAN 17\&/W \\ - YIELD GREATER.THAN $99.9 \%$ \\ - 20-YEAR LIFE \\ - COMPATIBILITY WITH VARIOUS SHEET FORMS \\ CURRENT \\ STATUS \\ - COST CONTRIBUTION OF $\$ 1$ TO $\$ 4.60 / \mathrm{W}$ \\ - YIELD HIGH WITH REWORK \\ - LIFE NOT KNOWN
}


4. Engineering Area

\title{
ENGINEERING DEVELOPMENTS POTPOURRI
}

\author{
R. ROSS
}

5 APRIL 1979

\section{MAJOR UNREPORTED ENGINEERING ACTIVITIES}

- cell reliabil ity testing (Clemson)

- electrical termination study (motorola)

- electrical safety requirements (UL)

- arRay structural anal ysis (BeChtel/ JPL)

- EnVIRONMENTAL teSt DEVELOPMENT (JPL)

- SOIll ING

- insulation ourabiliti

\section{ENGINEERING AREA P.RESENTATIONS}

- CENTRAL station WIND lOAdS (BOEING)

- RESIDENTIAL MODULE REQUIREMENTS (BURT HILL)

- module electrical insUlation REQ. (BECHTEL)

- golar cell fRActure gtrength (JPI)

- ir camera hOt-SPOt test Results (JPL)

- SERIES-PARALLEL ANALYSIS UPDATE (JPL)

- MISMATCH LOSS FIELD EXPERIENCE (MIT/LL)

- ARRAY STANDARDS UPDATE (JPL) 
PHOTOVOLTAIC ENERGY CALCULATION CONSIDERATIONS

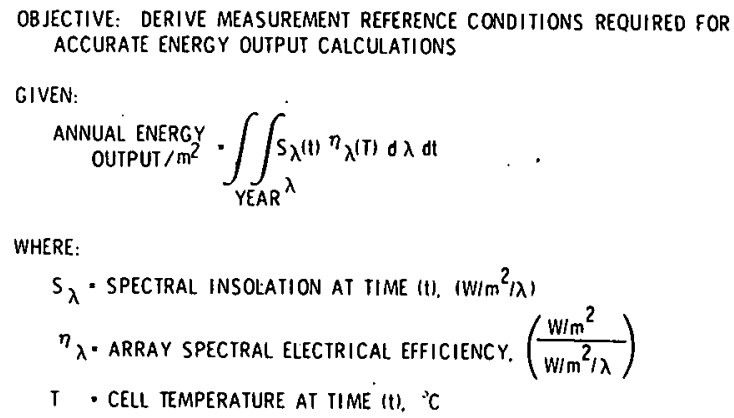

\section{CALCULATION SIMPLIFICATION IMPLICATIONS}
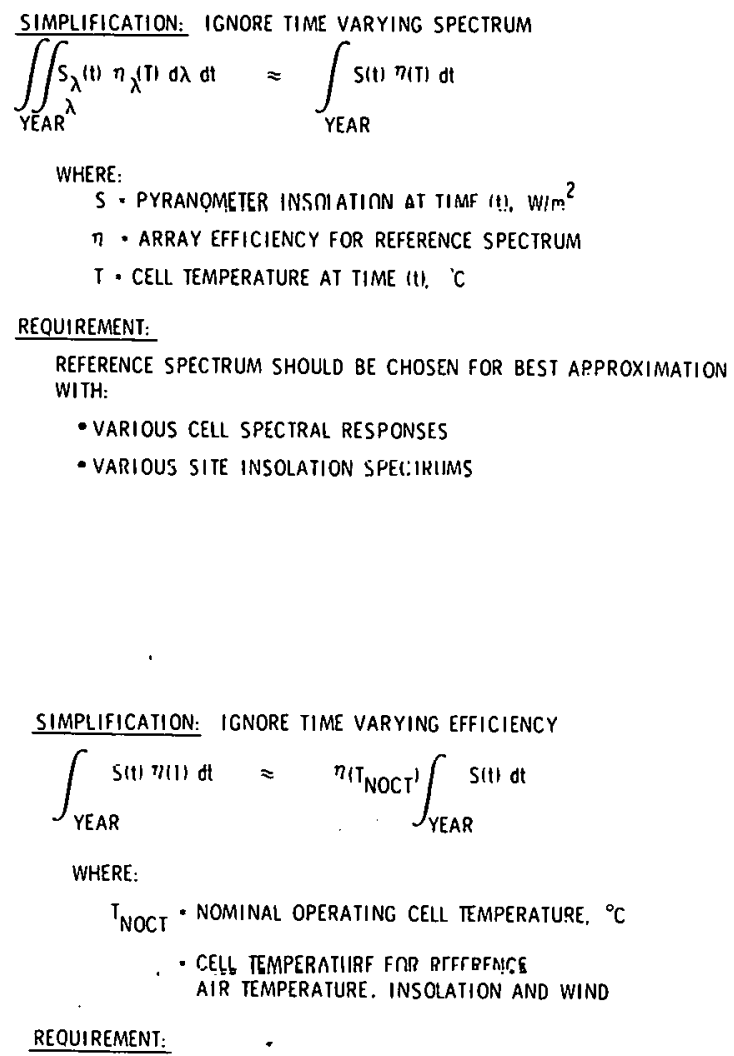

REFERENCE AMBIENT CONOITIONS SHOULD BE CHOSEN FOR BES APPROXIMATION WITH;

- Various arrai thermal designs

- VARIOUS SITE AMBIENT CONDITIONS 
ENERGY OUTPUT VS CELL TEMPERATURE-

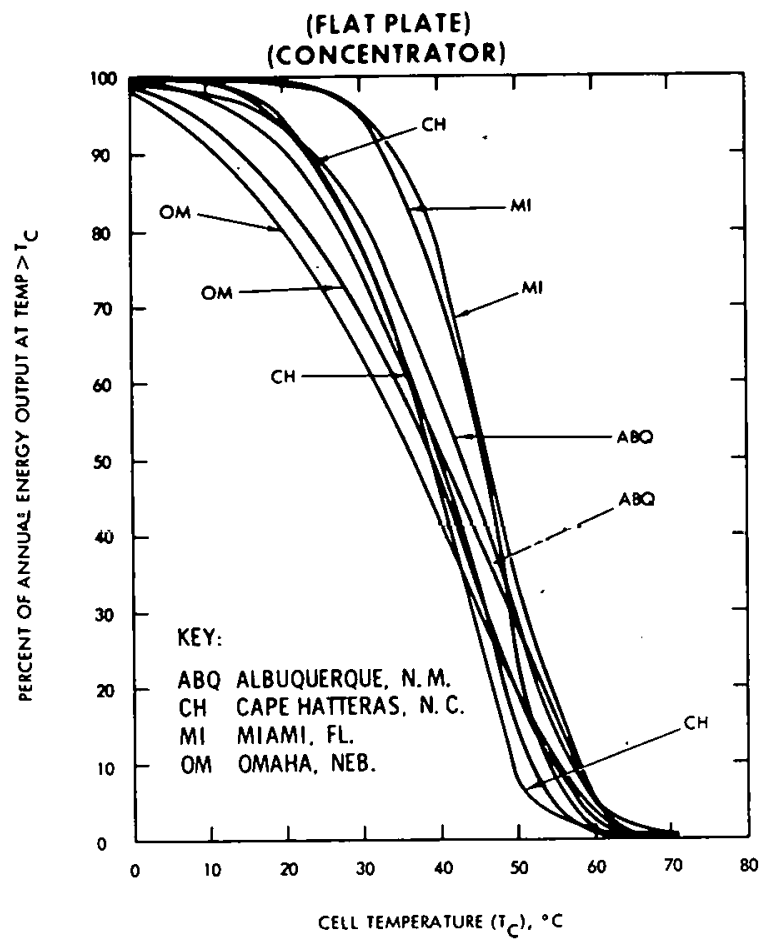

ENERGY OUTPUT VS INSOLATION LEVEL

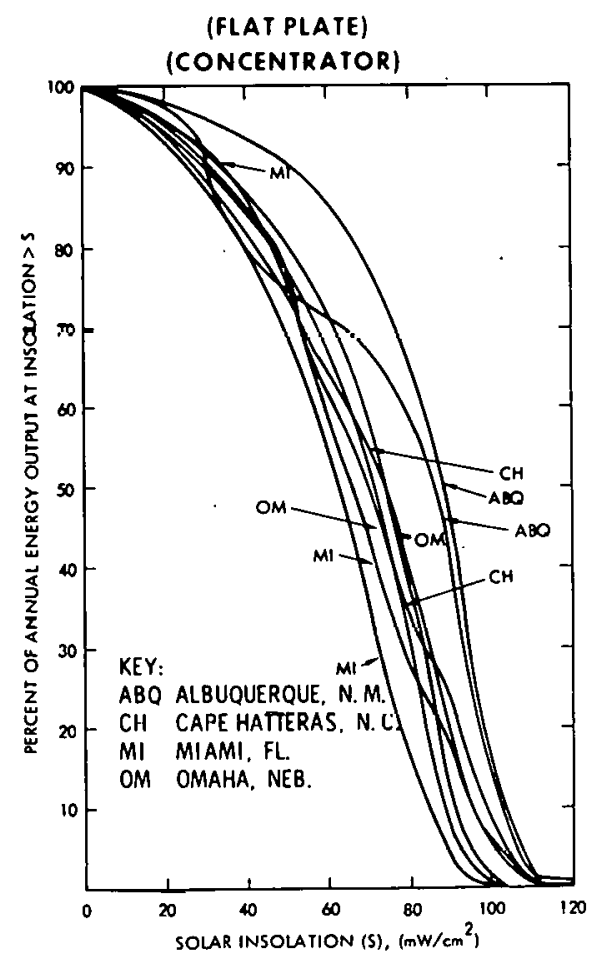




\section{CELL EFFECTIVE OPERATING TEMPERATURE}

VS EFFECTIVE INSOLATION LEVEL

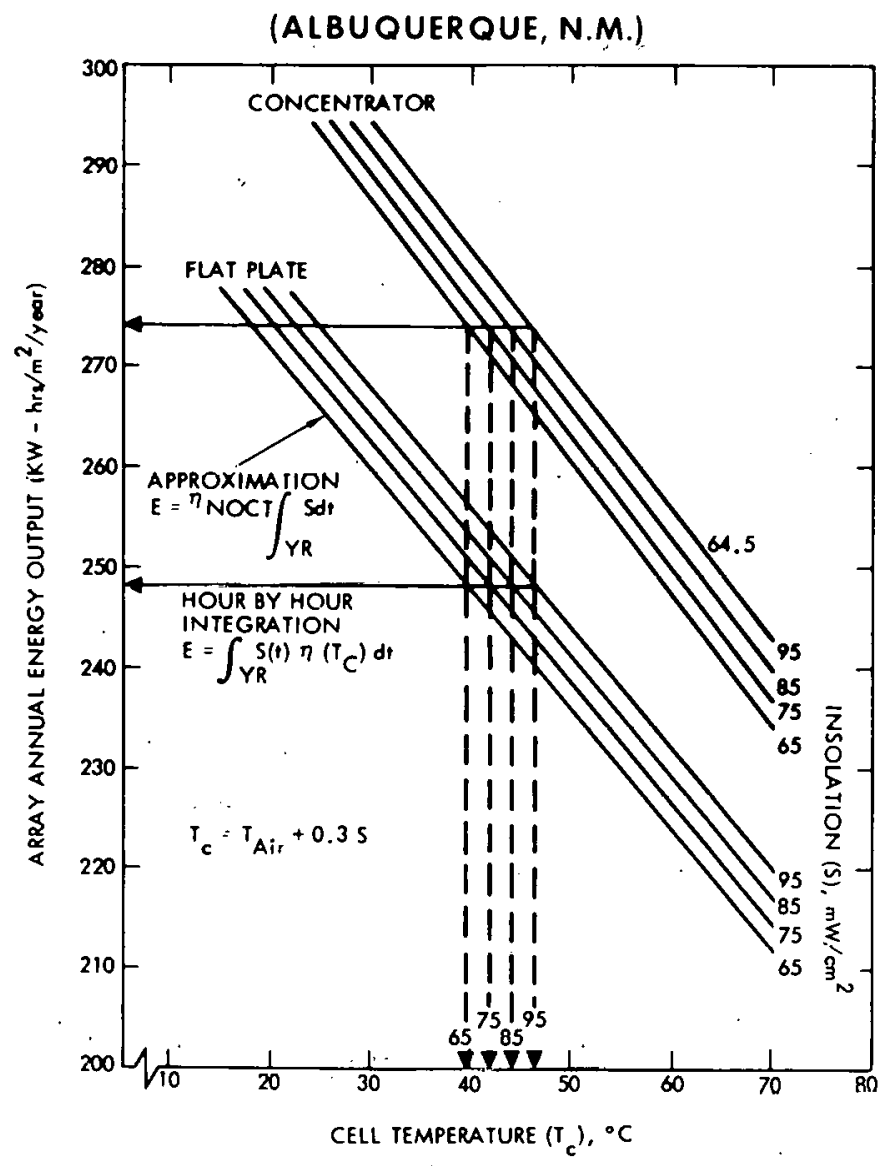


CELL EFFECTIVE OPERATING TEMPERATURE

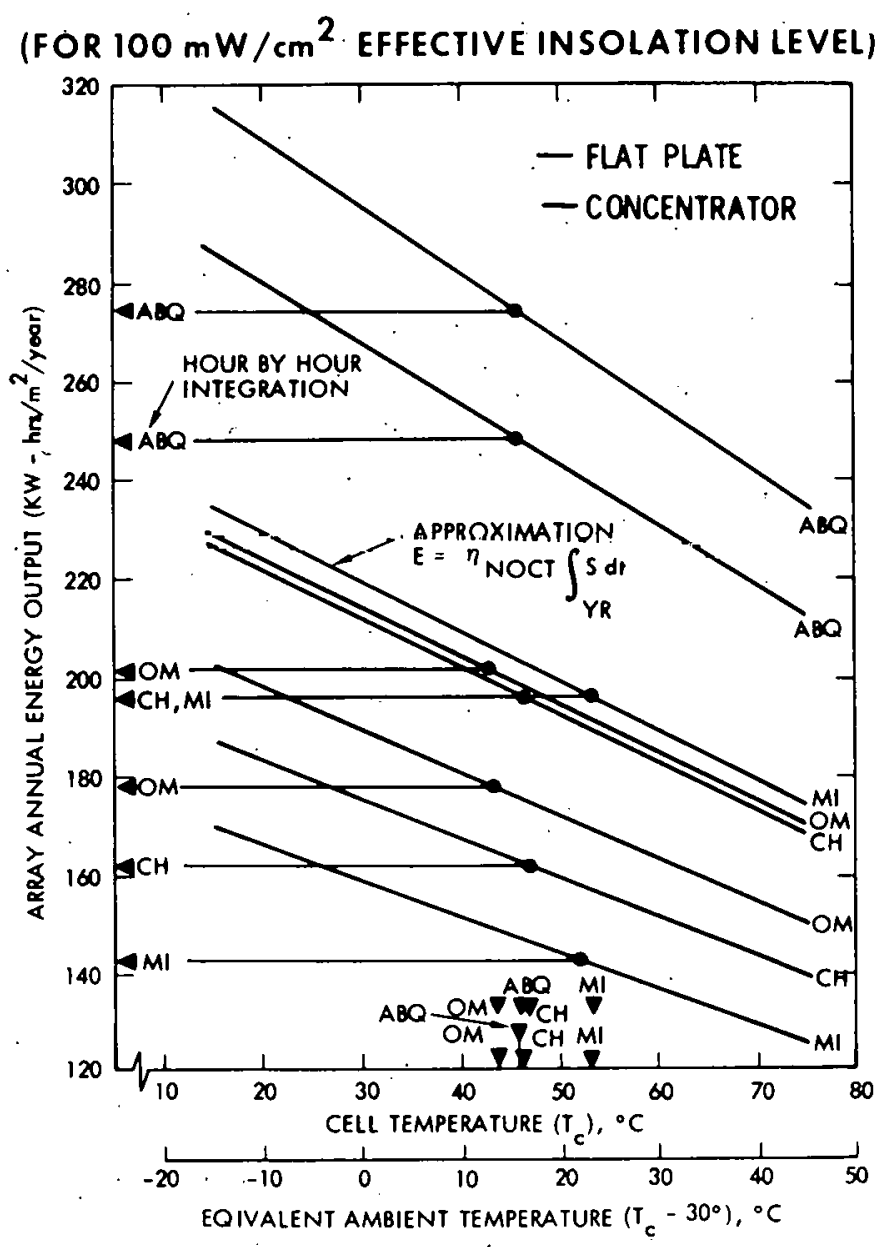


CELL EFFECTIVE OPERATING TEMPERATURE (FOR $80 \mathrm{~mW} / \mathrm{cm} 2$ EFFECTIVE INSOLATION LEVEL)

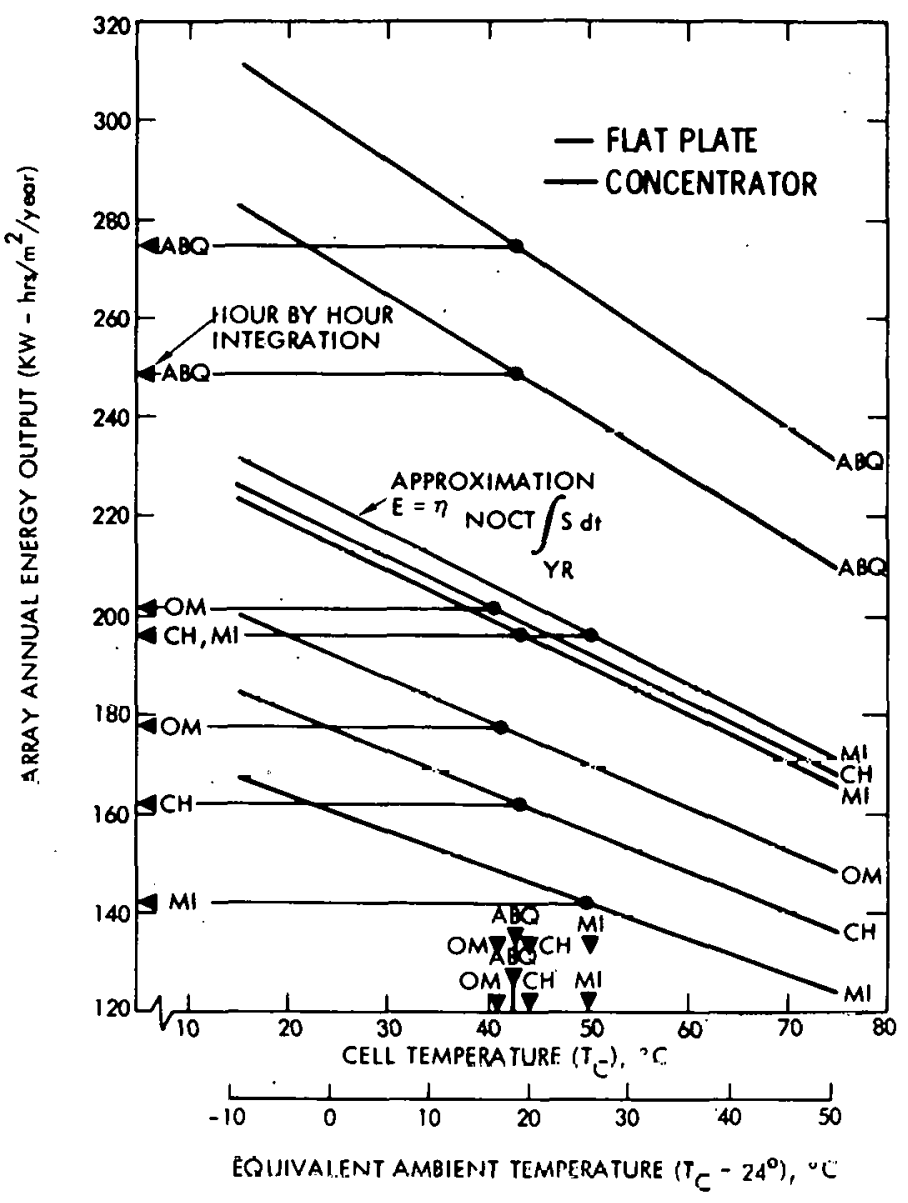

SIMPLIFIED ENERGY CALCULATION SUMMARY

\begin{tabular}{|c|c|c|c|c|c|c|c|}
\hline $\begin{array}{l}\text { ARRAYY } \\
\text { TYPE }\end{array}$ & $\begin{array}{c}\text { SITE } \\
\text { LOCATION }\end{array}$ & $\begin{array}{l}\text { TOIAL } \\
\text { INSOL. } \\
\text { WW-HrS } \\
\frac{m^{2}-Y R}{}\end{array}$ & $\begin{array}{l}\text { ACTUAL } \\
\text { ARRAY } \\
\text { OUTPUT } \\
\frac{k W-H r S}{m^{2}-Y R}\end{array}$ & $\begin{array}{c}5: 80 \\
T: 80,20\end{array}$ & $\mathrm{OCT} \int_{\substack{\mathrm{YR} \\
\mathrm{S}, 100 \\
\mathrm{~T}: \infty 0,20}}^{S \mathrm{dt}} /$ & $\begin{array}{l}\text { ACTUAL } \\
\text { ARRAY } \\
\text { OUTPUT } \\
\text { S: IUU } \\
\text { T: } 100.20\end{array}$ & $\begin{array}{c}5: 100 \\
\text { T: } 100,15\end{array}$ \\
\hline $\begin{array}{l}\text { AVE. } \\
\text { FLAT } \\
\text { I'LATE }\end{array}$ & $\begin{array}{l}\text { ALBUQ. } \\
\text { CAP. HAT. } \\
\text { OMAHAA } \\
\text { MIAMI }\end{array}$ & $\begin{array}{l}2316 \\
1832 \\
1853 \\
1895 \\
\end{array}$ & $\begin{array}{l}248 \\
196 \\
201 \\
196 \\
\end{array}$ & $\begin{array}{l}1.00 \\
0.99 \\
0.99 \\
1.03\end{array}$ & $\begin{array}{l}1.01 \\
1.01 \\
1.00 \\
1.04\end{array}$ & $\begin{array}{l}0.98 \\
0.98 \\
0.97 \\
1.02\end{array}$ & $\begin{array}{l}1.00 \\
1.01 \\
0.99 \\
1.04\end{array}$ \\
\hline $\begin{array}{l}\text { AVG. } \\
\text { 2:AXIS } \\
\text { CON. }\end{array}$ & $\begin{array}{l}\text { ALBUQ. } \\
\text { CAP. HAT. } \\
\text { UMAHA } \\
\text { MIAMI }\end{array}$ & $\begin{array}{l}2552 \\
1512 \\
1638 \\
1372\end{array}$ & $\begin{array}{l}274 \\
162 \\
177 \\
142\end{array}$ & $\begin{array}{l}0.99 \\
0.44 \\
0.99 \\
1.03\end{array}$ & $\begin{array}{l}1.01 \\
1.01 \\
1.00 \\
1.05\end{array}$ & $\begin{array}{l}0.98 \\
0.98 \\
0.97 \\
1.01\end{array}$ & $\begin{array}{l}1.00 \\
1.01 \\
0.99 \\
1.04\end{array}$ \\
\hline $\begin{array}{l}\text { HOT } \\
2-A 1 X S \\
\text { CON. }\end{array}$ & $\begin{array}{l}\text { ALBUQ. } \\
\text { CAP. HAT. } \\
\text { OMAHA } \\
\text { MIAMI }\end{array}$ & $\begin{array}{l}2552 \\
1512 \\
1638 \\
1372\end{array}$ & $\begin{array}{l}757 \\
152 \\
166 \\
134\end{array}$ & $\begin{array}{l}1.00 \\
0.97 \\
0.97 \\
1.01\end{array}$ & $\begin{array}{l}1.01 \\
1.00 \\
0.98 \\
1.02\end{array}$ & $\begin{array}{l}0.90 \\
0.94 \\
0.93 \\
0.96\end{array}$ & $\begin{array}{l}0.98 \\
0.97 \\
0.95 \\
0.99\end{array}$ \\
\hline
\end{tabular}

S. INSOL ATION $\left(\mathrm{mW} / \mathrm{cm}^{2}\right), \quad$ T: INSOL. (mW/ $\left.\mathrm{cm}^{2}\right)$, AIR TEMP. $(0 \mathrm{Cl}$ 


\title{
PHOTOVOLTAIC ARRAY SERIES / PARALLEL STUDIES
}

\section{CHARLES GONZALEZ}

\section{SERIES-PARALLEL STUDIES}

\author{
- OBJECTIVE: \\ DEVELOP GUIDELINES FOR SOLAR CELL CONFIGURATIÜNS \\ WHICH ARE CONSISTENT WITH MINIMUM LIFE-CYCLE \\ COST \\ - APPROACH: \\ - DEFINE CELLIMOdULE faILURE MECHANISMS \\ - USE COMPUTER PROGRAM TO PERFORM PARAMETRIC \\ ANALYSES \\ - aNALYZE RESULTS IN ORDER TO DEVELOP GUIDELINES FOR \\ - DETERMINING OPTIMUM SERIES-PARALLEL \\ COMBINATIONS \\ - APPROPRIATE USE OF BYPASS DIODES
}

\section{CURRENT STAFUS}

- TOPICS PREVIOUSLY COVERED:

- POWER LOSS VS SERIES-PARaLLELING

- misMatch LOSSES

- "HOT-SPOT" HEATING

- USE OF DIODES

- MANUFACTURING YIELD

- ÉX́pansIÓN OF ABOVE IUHICS

- MULTI -CELL FAILURES CONSIDERED

- "HOT-SPOT" HEATING UNDER NON-UNIFORM CELL PARAMETERS

- DIODE VS SERIES-PARALLFLING TRADE-OFFS - MANUFACTURING YIELD CONSIDERATIONS FOR DIFFERENT CELL FAILURE RATES 


\section{MANUFACTURING YIELL STUDY UPDATE}

- PREVIOUS CONCLUSION:

MODULES OF MORE THAN 100 CELLS REQUIRE AT LEAST SIX PARALLEL STRINGS AND TWO SERIES BLOCKS TO IMPROVE YIELD BASED ON CELL FAILURE RATE OF 1 PER 1000

- UPDATED CONCLUSIONS:

IN ADDITION:

- MODULES OF 100 CELLS OR MORE REQUIRE EXTENSIVE SERIES-

PARALLELING TO ATTAIN ACCEPTABLE YIELDS FOR CELL

FAILURE RATES OF 1 PER 100

- MODULES OF MORE THAN 100 CELLS REQIIIRE MINIMAL SERIES-

PARALLELING FOR CELL FAILURE RATES OF I PER 10,000

\section{BRANCH CIRCUIT POWER LOSS VS CELL FAILURE DENSITY}

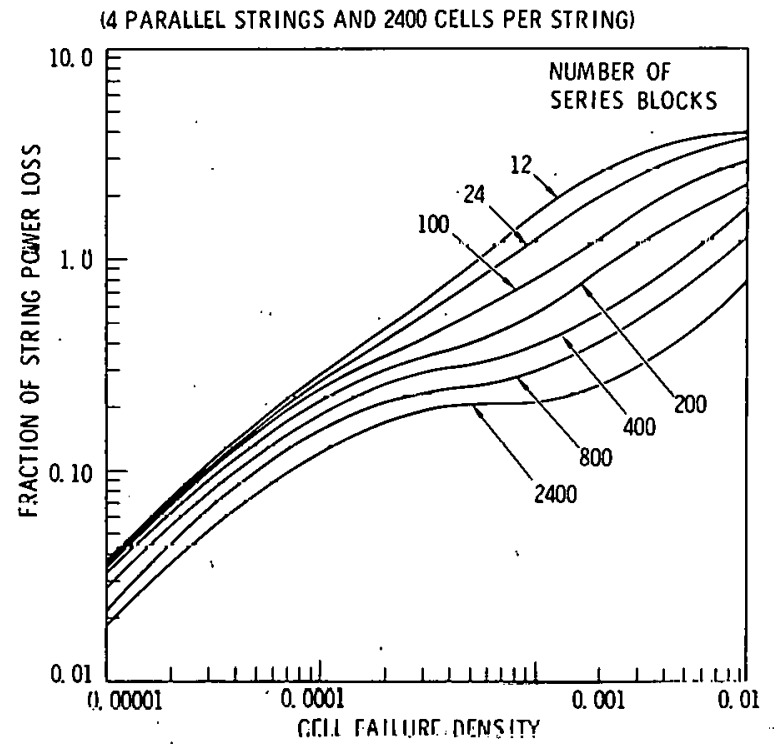

DIODE VS SERIES-PARALLEL TRADE-OFF
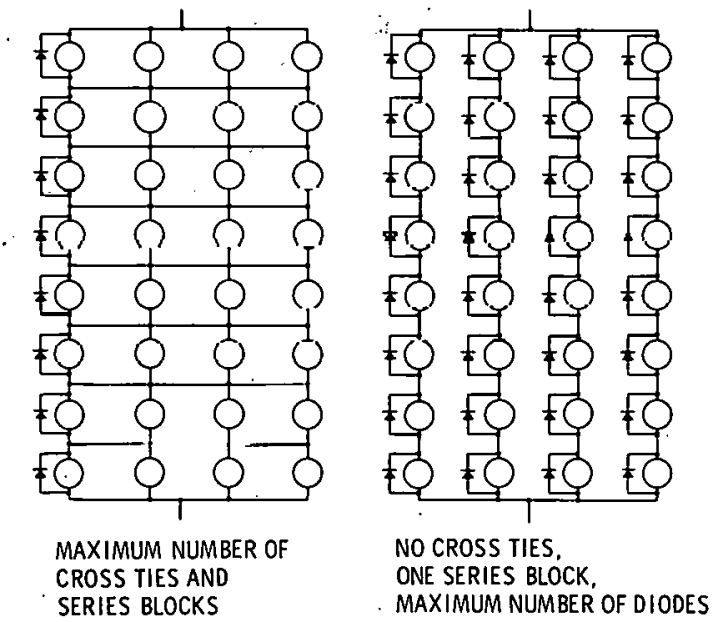
MODULE IV CURVE VS NUMBER OF DIODES

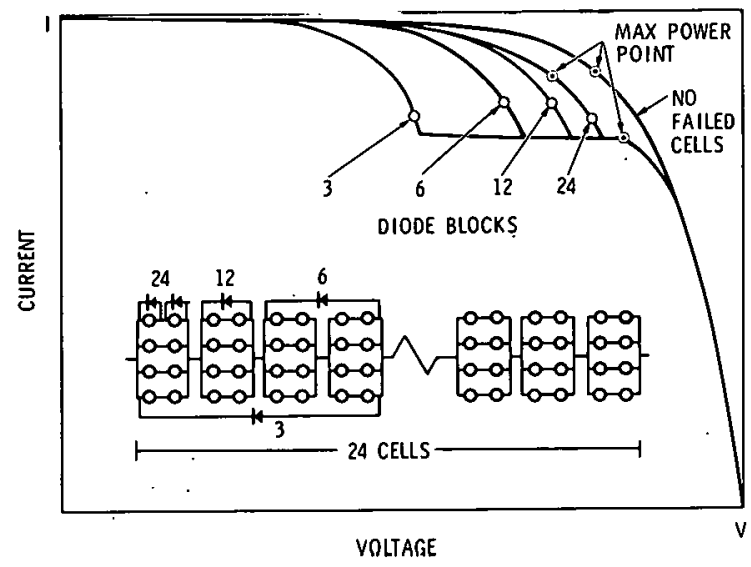

BRANCH CIRCUIT POWER LOSS VS NUMBER OF DIOD'ES PER SUB-STRING

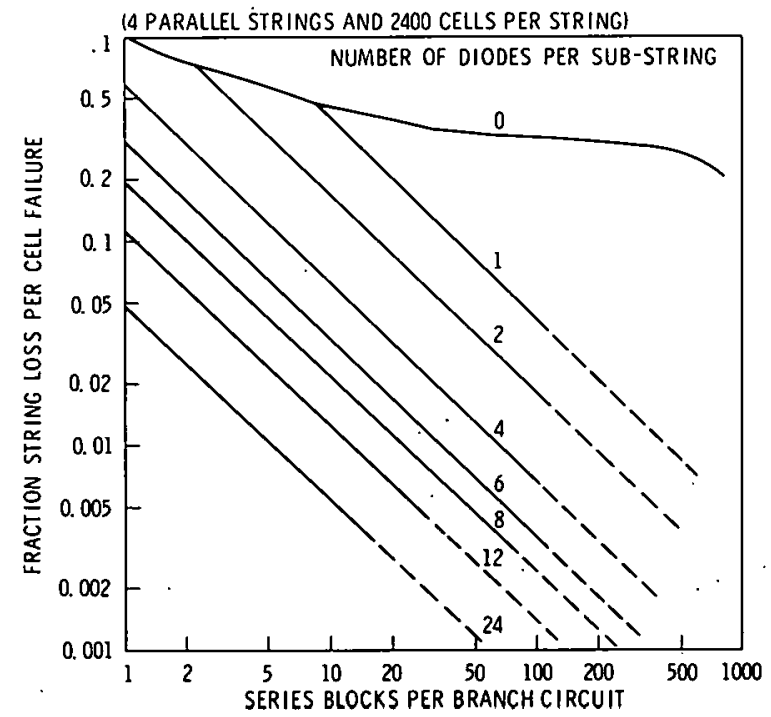

"HOT-SPOT" HEATING CELL SHUNT RESISTANCE

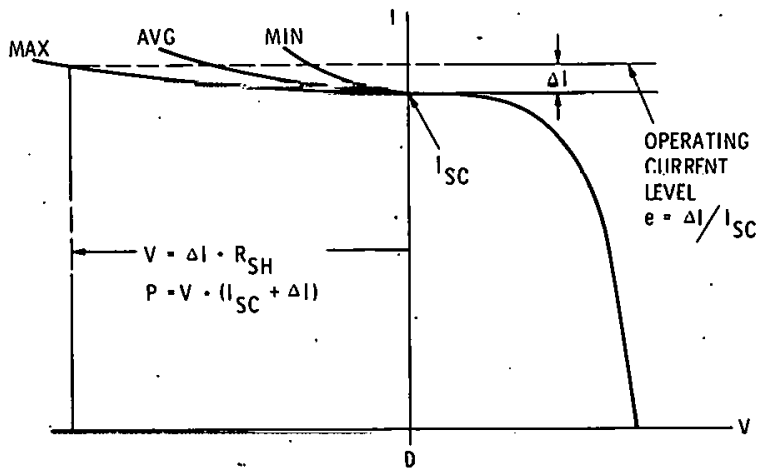




\section{"HOT-SPOT" HEATING VS CELL CONFIGURATION}

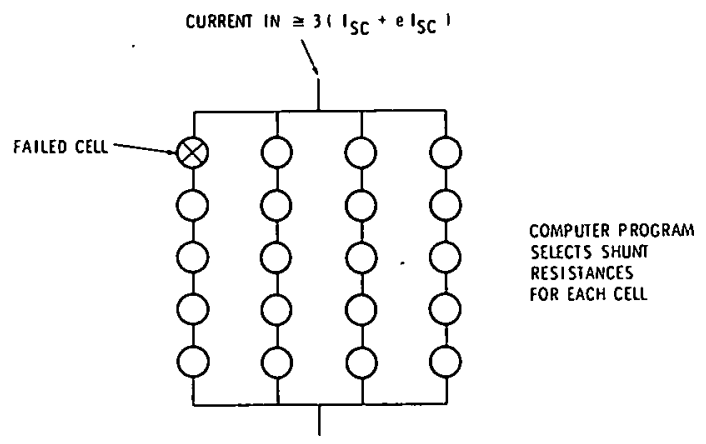

\section{HEATING CONSTANT HISTOGRAM}

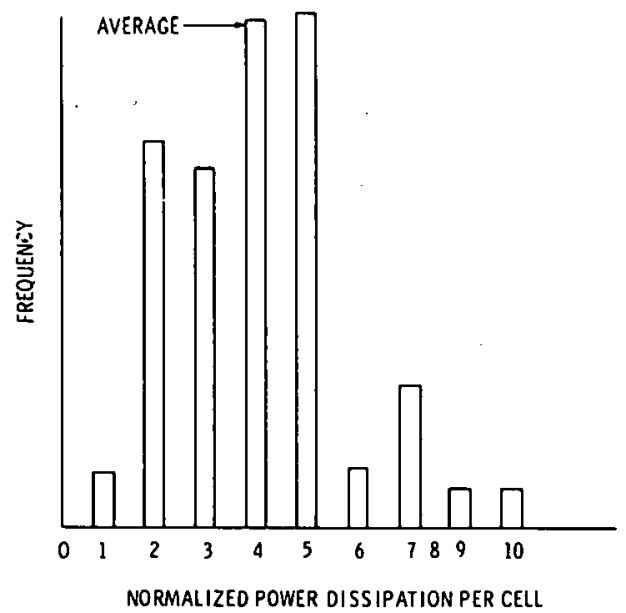

\section{HEATING CONSTANT VS NUMBER OF CELLS IN A SUB-STRING}
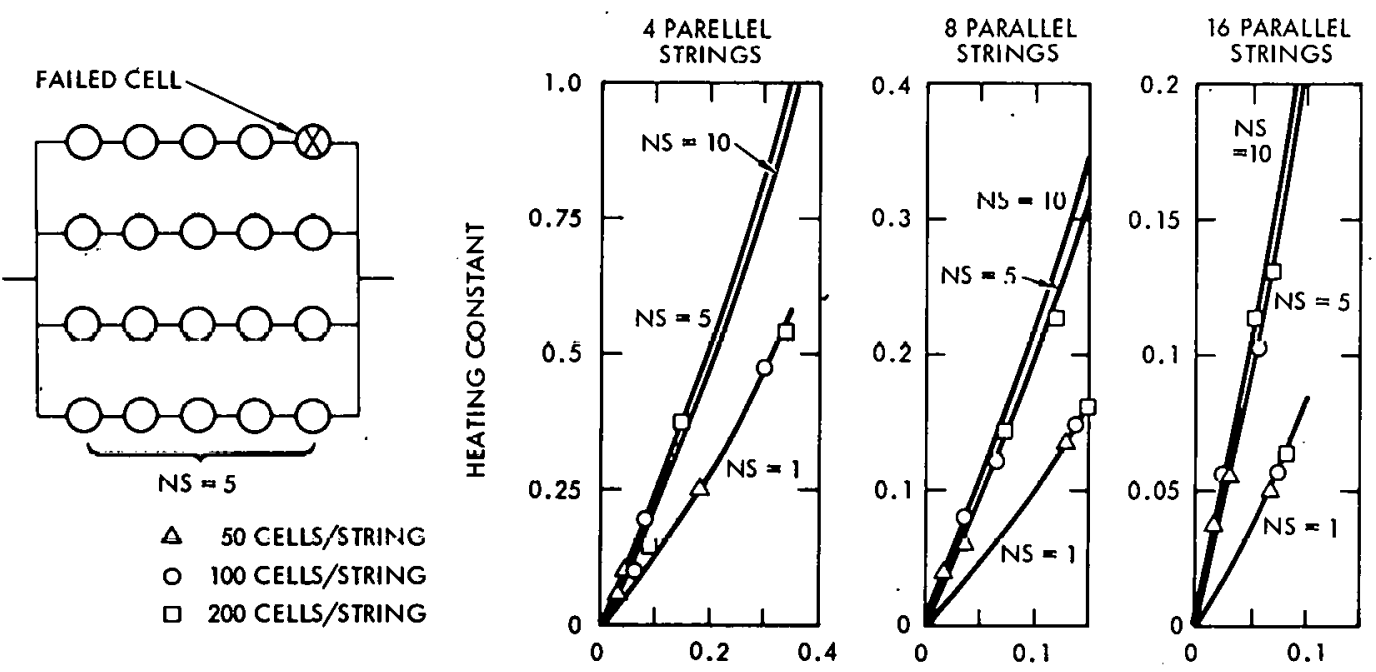

FRACTIONAL OVER CURRENT, a 


\section{CONCLUUSIONS}

- FOR 4 STRINGS IN PARALLEL MULTI-CELL FAILURES LEAD TO A NON-LINEAR POWER LOSS FOR CELL FAILURE DENSITIES GREATER THAN 0.0001

- TRADE-OFFS BETWEEN USE OF DIODES AND USE OF SERIESPARALLELING FAVOR DIODES - ALL THINGS BEING EQUAL

- NON-UNIFORM CELL PARAMETERS REQUIRE THAT THE OPTIMUM

SERIES-PARALLEL ARRANGEMENTS TO REDUCE 'HOT-SPOT' PROBLEMS BE DETERMINED STATISTICALLY

\section{FUTURÉ WORK}

- COMPLETE MULTI-CELL FAILURE ANALYSIS FOR PARALLEL STRINGS GREATER THAN FOUR

- "HOT-SPOT" HEATING

- EXPAND GUIDELINES DEVELOPMENT FOR NON-UNIFORM HEATING BASED ON GIVEN PARAMETER DISTRIBUTIONS

- CORRELATE ANALYTICAL RESULTS WITH EMPIRICAL DATA

- DOCUMENT RESULTS OF ANALYSES TO DATE INCLUDING GUIDELINES AND RECOMMENDATIONS 


\title{
FRACTURE MECHANICS TESTING OF SILICON SOLAR CELLS
}

\author{
by
}

C. P. Chen

\section{OBJECTIVES}

- determine nature and SOURCe of Flaw CONTROLLINg fracture of SILICON SOLAR CELLS

- DETERMine StRENGTH OF SOLAR CELLS AS FUnCTION OF:

- MANUFACTURING PROCESS STEPS - SAWING, CHEMICAL POLISHED, TEXTURE ETCHED . . . COMPLETED CELL

- Cell physical factors - Cell material, Shape, Size, design, . .

- STRESS CONDITIONS - UNIAXIAL, BIAXIAL, SHEAR

- DETERMINE STANDARD TEST METHOD FOR SILICON SHEET MATERIAL

\section{CYLINDRICAL BENDING OF SOLAR CELL}
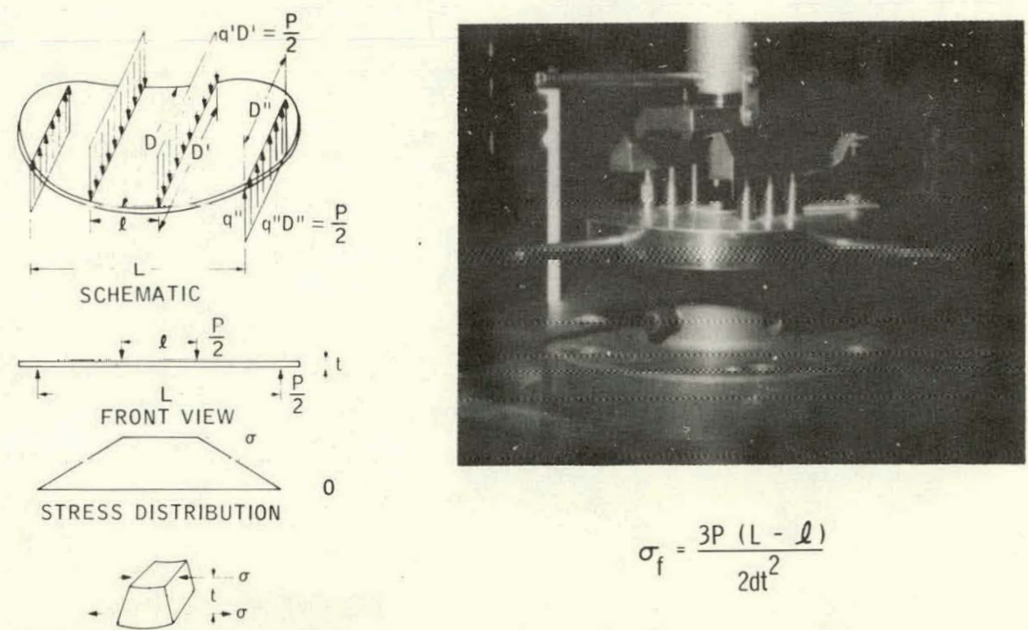

$$
\sigma_{f}=\frac{3 P(L-\ell)}{2 d t^{2}}
$$


BIAXIAL FLEXURE STRENGTH TEST OF SOLAR CELLS
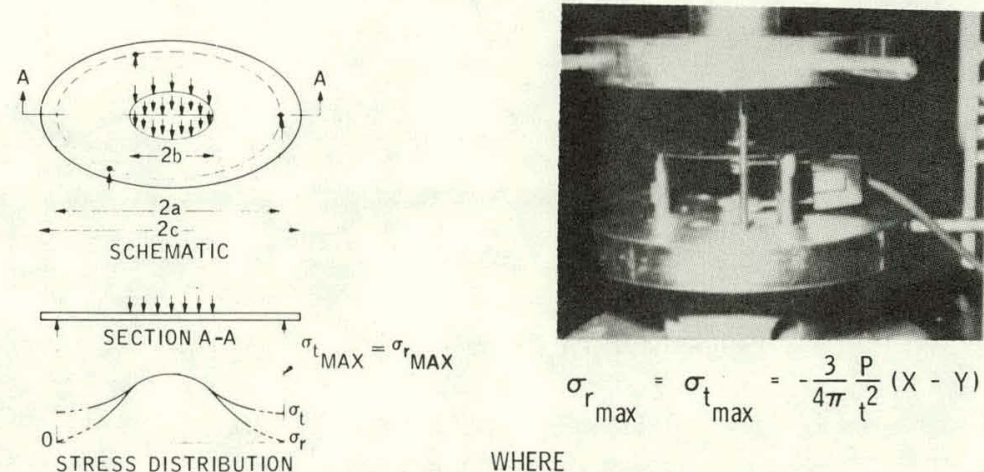

WHERE

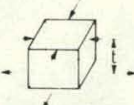

UNIT ELEMENT WITHIN $2 b$ AREA

$$
\begin{aligned}
& X=(1+\nu) \ln \left(\frac{b}{c}\right)^{2}+\frac{1}{2}\left(\frac{b}{c}\right)^{2} \\
& Y=(1+\nu)\left[1+\ln \left(\frac{a}{c}\right)^{2}\right]+(1-\nu)\left(\frac{a}{c}\right)^{2}
\end{aligned}
$$

FOUR-POINT TWISTING OF SOLAR CELL
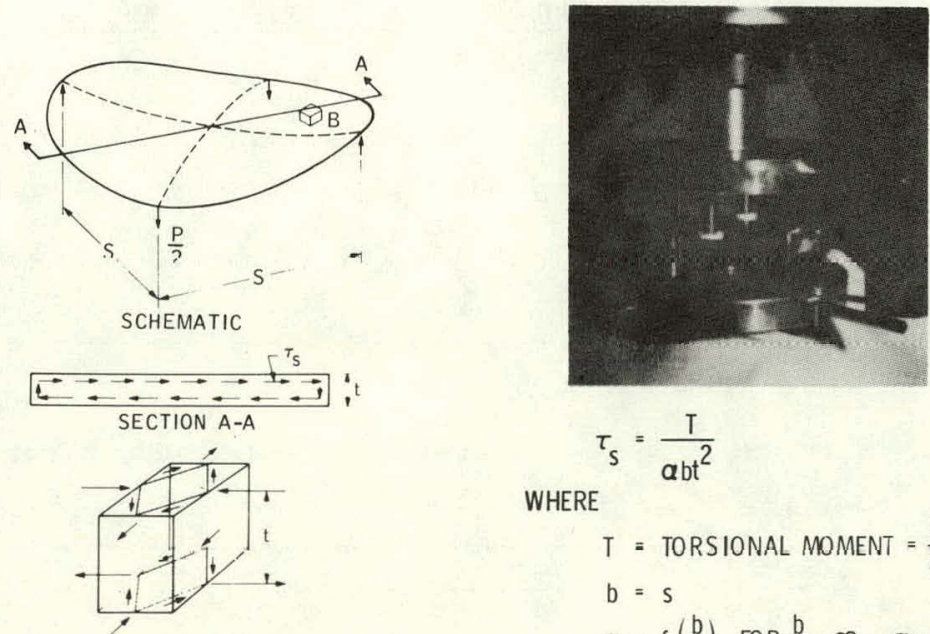

$$
\tau_{s}=\frac{T}{a b t^{2}}
$$

WHERE

$$
\begin{aligned}
& T=\text { TORSIONAL MOMENT }=\frac{P}{2} s \\
& b=s \\
& a-1\left(\frac{b}{t}\right), \text { FOR } \frac{b}{t}-\infty, a-\frac{1}{3}
\end{aligned}
$$


WEIBULL DISTRIBUTION (WEAKEST LINK STATISTICS)

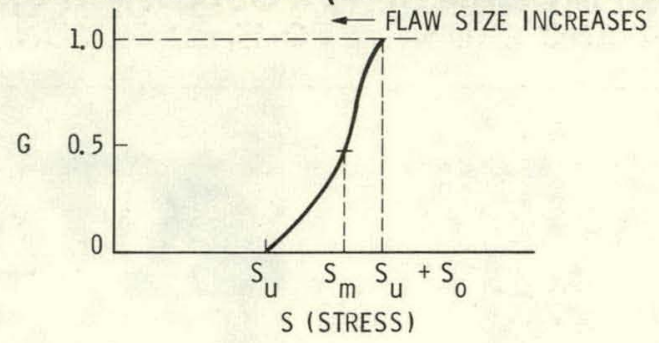

$$
\begin{aligned}
\text { FRACTURE PROBABILITY } G=1-\exp \left[-\int_{V}\left(\frac{S-S_{u}}{S_{0}}\right)^{m} d V\right] \\
S_{u}=\text { STRESS BELOW WHICH NONE WILL FAIL } \\
S_{u}+S_{0}=\text { STRESS ABOVE WHICH ALL WILL FAIL } \\
S=\text { STRESS OF INTEREST } \\
m=\text { WEIBULL MODULUS (RELATE TO SLOPE OF PLOT) } \\
S_{m}=S \text { AT } 0.5 \mathrm{G}, S_{\mathrm{m}} \approx S_{\text {ave }}
\end{aligned}
$$

\section{EFFECT OF TEST METHODS ON THE MEASURED STRFNGTH OF SILICON WAFERS}

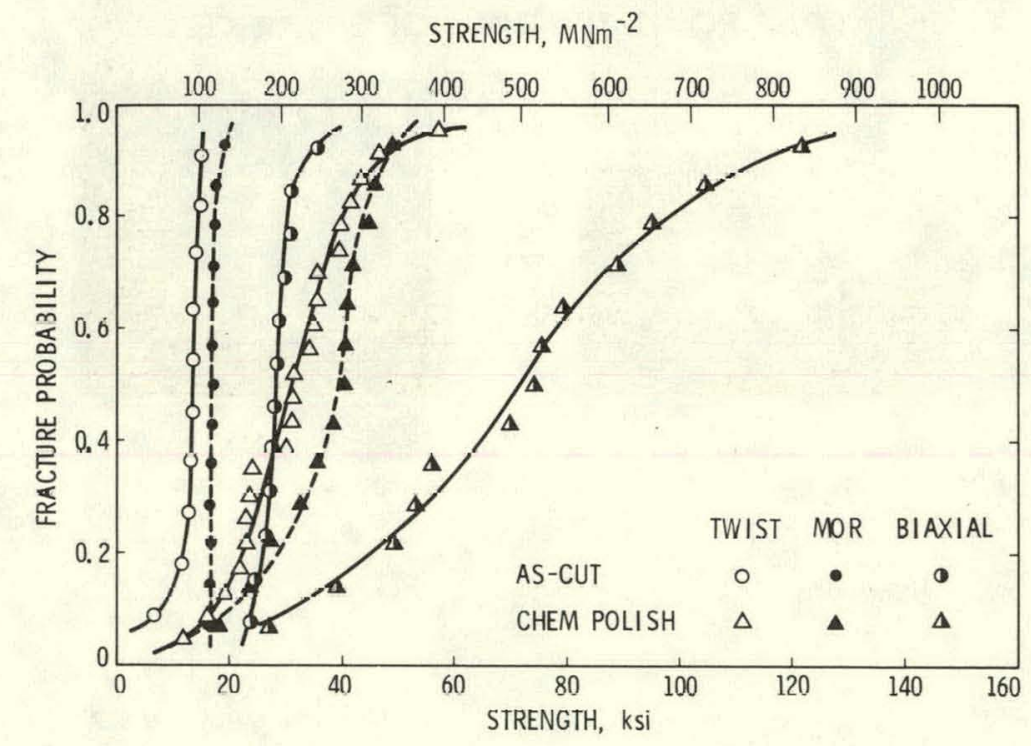


FRACTURE PROBABILITY vS MODULUS OF RUPTURE OF AS-CUT AND CHEMICAL POLISHED SILICON WAFERS

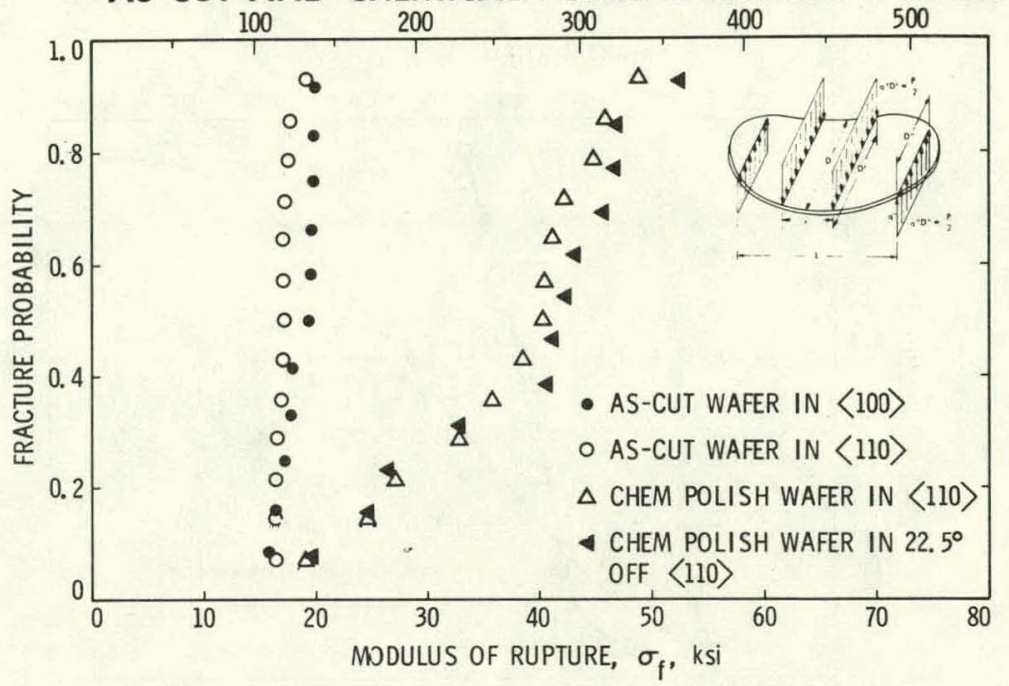

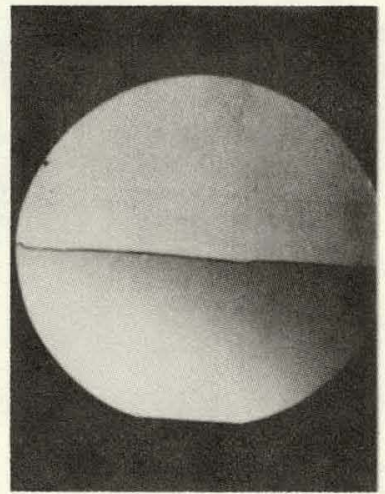

$\langle 110\rangle$

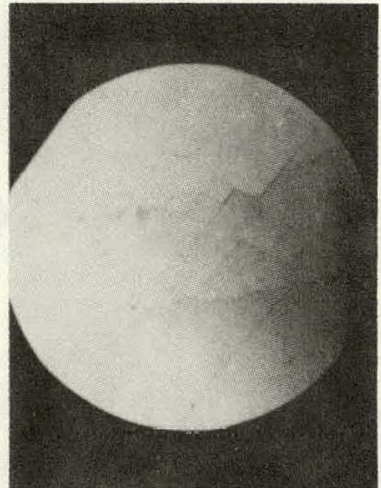

$\langle 100\rangle$ 
FRACTURE PROBABILITY vS BIAXIAL

STRENGTH OF SILICON WAFERS

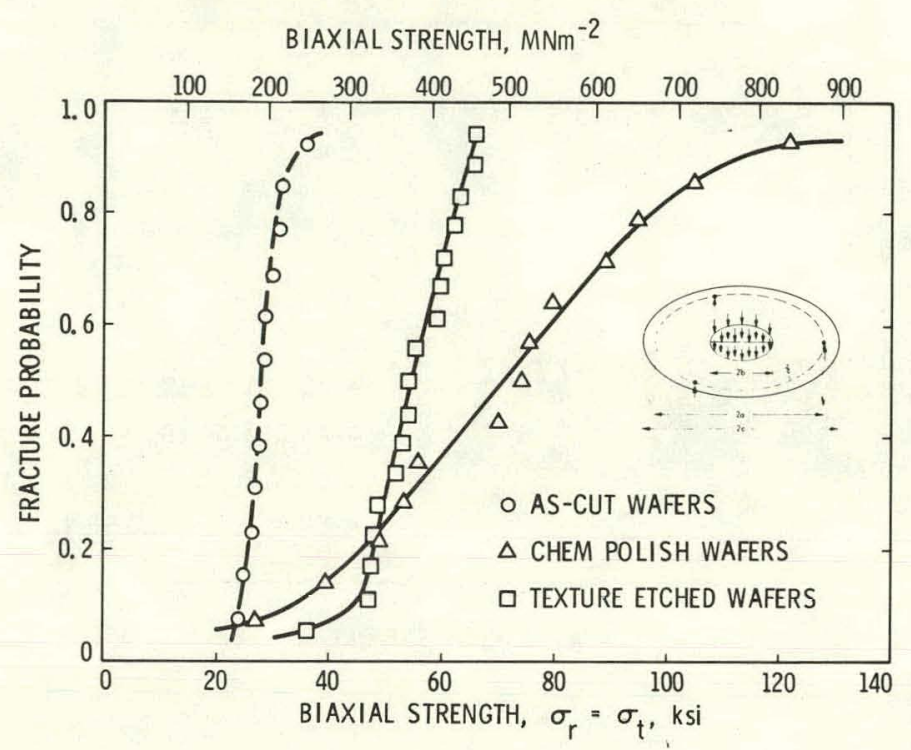

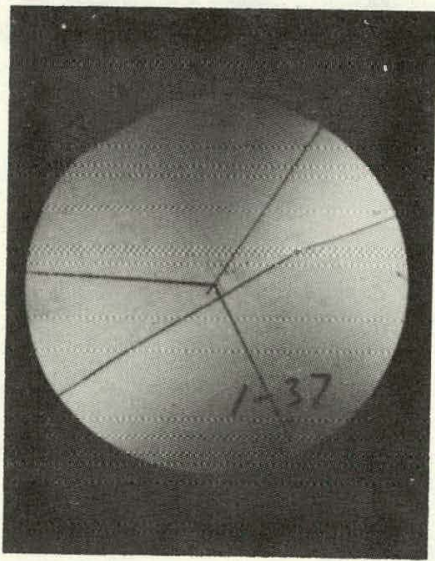

AS-CUT

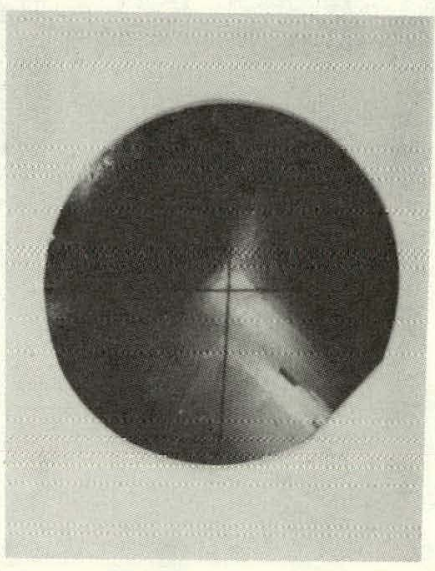

CHEMICAL PULISHEU 


\section{EFFECT OF CELL PROCESSES ON THE}

STRENGTH OF WAFERS
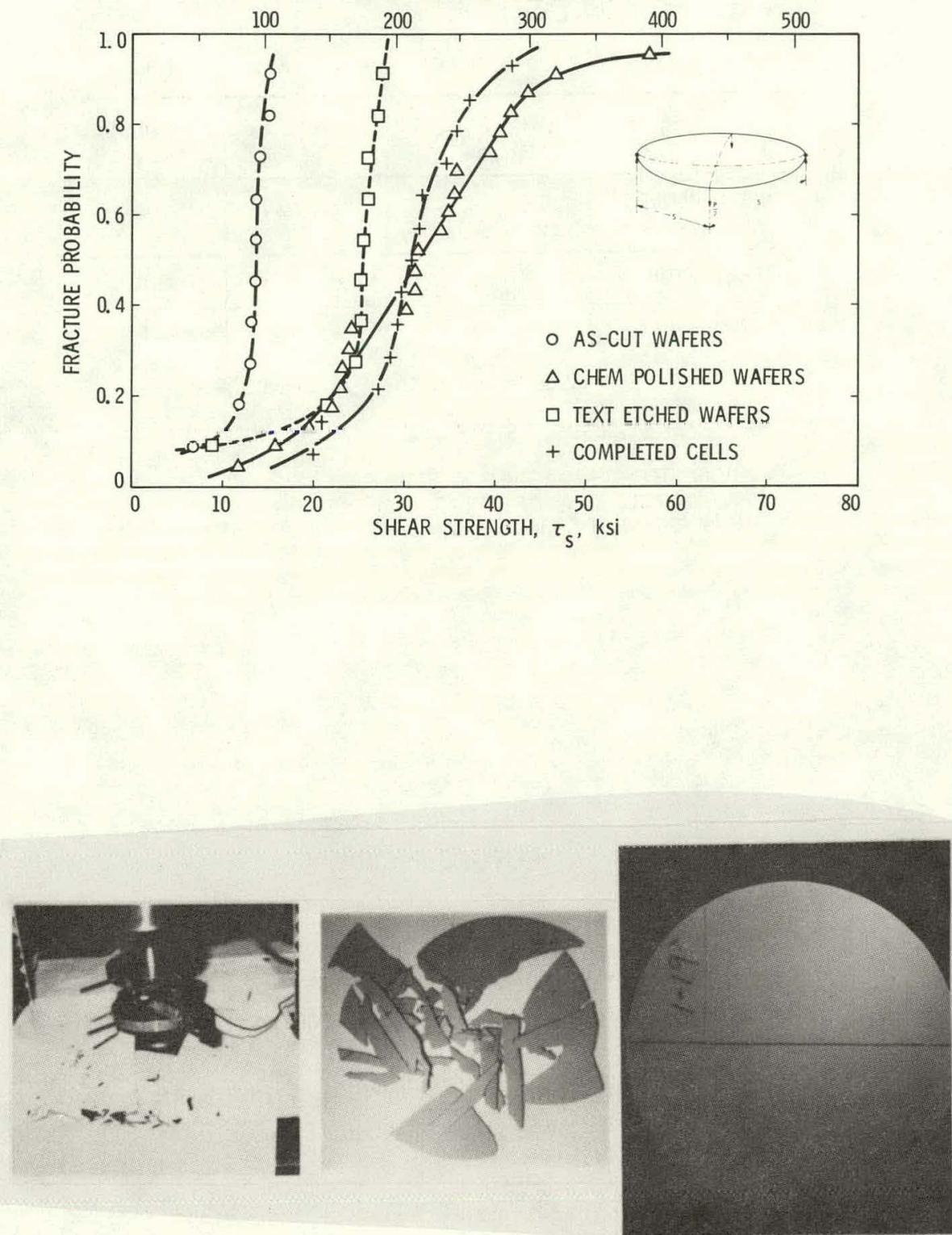

Typical Fracture of Silicon Wafers Subjected to Four-point Twisting 
SUMMARY

- STRENGTH*, (ksi)/DEFLECTION**; (in.)

\begin{tabular}{l|c|c|c} 
CELL PROCESS & UNIAXIAL MOR & BIAXIAL & SHEAR \\
\hline AS-CUT & $\begin{array}{l}16-19 \\
(24-17 \mu) / 0.05\end{array}$ & $24-34 / 0.06$ & $5-15 / 0.09$ \\
\hline CHEM POLISHED & $\begin{array}{l}20-48 \\
(18-3 \mu) / 0.11\end{array}$ & $28-120 / 0.13$ & $14-55 / 0.21$ \\
\hline TEXT. ETCHED & - & $36-65 / 0.09$ & $9-28 / 0.14$ \\
\hline COMPLETED CELL & - & & $17-42 / 0.14$
\end{tabular}

* STRENGTH RANGE IN WHICH 90\% OF FAILURES OCCUR \# MEAN DETLECTION

( ) CALCULATED FLAW SIZE RANGE

- SHEAR STRENGTH MEASURED BY FOUR-POINT TWISTING TEST IS RECOMMENDED AS A STANDARD TEST METHOD FOR STRENGTH MEASUREMENT OF SILICON SOLAR CELLS

\section{FUTURE WORK}

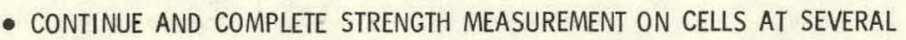
CELL MANUFACTURERS AND MANUFACTURING PROCESSES

- PERPORM TESTS OF CELLS WITH OTHER PHYSICAL CHARACTERISTICS - IN TERMS OF NATURE OF SHEET, SHAPE, SIZE, etc.

- conduct faIluRe analysis to determine nature ANd SOURCE OF FLAW CONTROLLING FRACTURE OF SOLAR CELLS

- PeRForm WeI BULL STATISTICAL analysis 


\title{
MODULE/ARRAY INTERFACE STUDY
}

\author{
Research and Engineering Operation \\ Bechtel National, Inc. \\ San Francisco, California
}

The objectives of this study are to: 1) evaluate the technical and economic feasibility of a curved glass-superstrate module configuration and 2 ) develop voltage isolation requirements for modules.

A previous study, performed by Bechtel, indicated that a clip-supported, slightly curved glass superstrate module would cost substantially less than an equivalent metal-framed module, due to reductions in framing material costs. During the present study a survey of glass manufacturers and fabricators was conducted to determine the cost and practicality of manufacturing the curved superstrate in both test sample and production quantities. Survey results indicate that the design is technically feasible and that prototype curved glass structures are being fabricated for use as mirrors in thermal systems. However, sufficient cost data to permit analysis of large quantity production costs have not been obtained thus far.

In the area of electrical insulation, a literature search was conducted to identify and evaluate existing design practices and test methods applicable to photovoltaic modules. Available data mostly relates to insulation in ac fields and reflects work done by the cable industry. This data indicates that dielectric strength decreases with time and that to ensure acceptable long-term (e.g., 20 years) performance, the maximum stress levels must be kept well below the measured short-time breakdown values. The existing data indicate that short-duration test procedures are useful for quality control purposes, but do not predict long-time performance. Although various types of accelerated aging tests have been proposed, it appears that real-time testing is required to verify insulation system design integrity. This is especially true for novel configurations, such as solar cell encapsulation systems, in which the materials will be stressed by DC and, possibly, inverter ripple-induced AC fields. Also, the long-time effect of voltage stress on extremely thin layers of material (e.g., thin plastic films or primer coats) within the encapsulation system requires further investigation. This is necessary because for insulation systems in DC fields, where the voltage is distributed across a series combination of two or more different insulating materials, the ratio of the field strengths in the materials varies directly with the ratio of their resistivities (as opposed to the materials' permittivities for AC or transient fields). In such multilayer cases, unacceptable stress levels might result.

Viewgraphs detailing this presentation appear on the following pages. 


\section{CURVED GLASS MODULE AND \\ MODULE ELECTRICAL INSULATION REQUIREMENTS \\ DAN ROSEN \\ BECHTEL NATIONAL, INC.}

APRIL 5, 19,79

CURVED GLASS MODULE

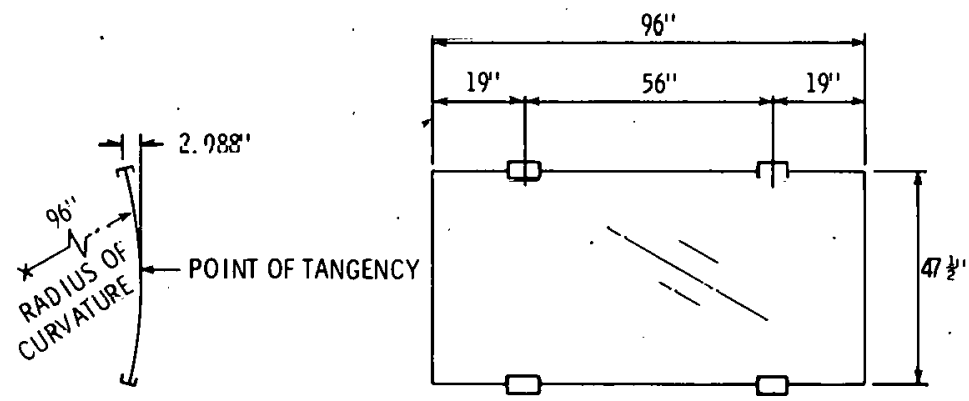

\begin{tabular}{|c|c|c|c|}
\hline \multirow{2}{*}{$\triangle \times 8 \mathrm{FI}$ PANEL TYPE } & \multicolumn{3}{|c|}{ PANEL STRUCTURAL COSTS- $\$ M^{2}(1975 \$ S$} \\
\hline & 35 PSF & $50 \mathrm{PSF}$ & 75 PSF \\
\hline $\begin{array}{l}\text { FLAT PLATE "PICTURE } \\
\text { FRAME" SUPPORT }\end{array}$ & 18.00 & 21.70 & 26.60 \\
\hline $\begin{array}{l}\text { CURVED GLASS } \\
\text { CLIP SUPPORT }\end{array}$ & 6.90 & 6. 90 & 6.90 \\
\hline
\end{tabular}

(1) EXCLUS IVE OF COST FOR CURVING THE GLASS 


\section{CURVED.GLASS MODULE SUPPORT STRUCTURE CONCEPTS}

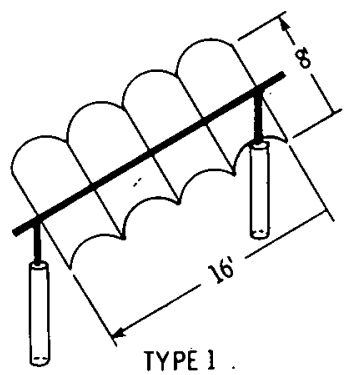

HORIZONTAL TORQUE TUBE, CAISSON FOUNDATION

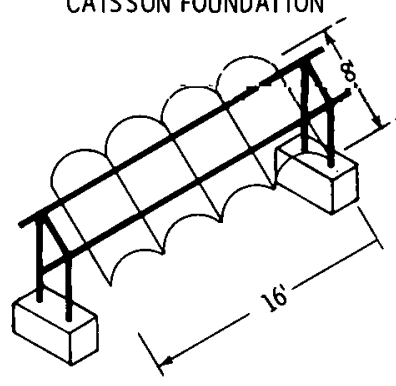

TYPE 3

STANDARD RACK 8 SLANT HEIGHT

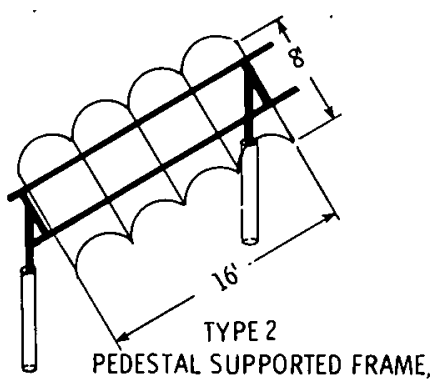

CAISSON FOUNDATION

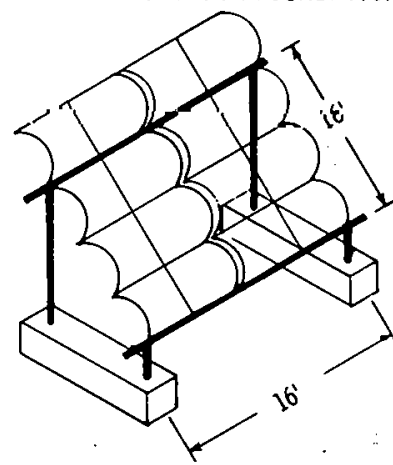

TYPE 4

STANDARD RACK 16 ' SLANT HEIGHT

\section{CURVED GLASS MODULE FUTURE WORK}

WORK TO BE ACCOMPLISHED DURING THE NEXT THREE MONTHS WILL INCLUDE

- EVALUATION OF FABRICATION COSTS FOR CURVING GLASS SHEETS IN COMMERCIAL PRODUCTION QUANTATIES

- deVElopment of designs and estimates of installed COSTS FOR THE CURVED GLASS MODULE AND THE FOUR SUPPORT SIRUCTURC TYPLS TOR UNIFORM LOADINGS OF 20, 35 AND 50 PSI

- COMPUTER AIDED FINITE ELEMENT ANALYSES OF STRESS DISTRIBUTIONS IN THE CURVED GLASS SHEET

- nFVFI.OP a teSt PLAN,TO EVALUATE AND VERIFY tHe FINALIZED CURVED GLASS DESIGN 


\section{ELECTRICAL ISOLATION DESIGN CONCLUSIONS}

- EXISTING INFORMATION RELATES PRIMARILY TO INSULATION IN AC FIELDS.

- MAXIMUM STRESS LEVELS MUST BE KEPT WELL BELOW MEASURED SHORTTIME BREAKDOWN VALUES.

- DESIGN EVALUATION MUST CONSIDER:

- ShORT teRm MATERIAL CHARACTERIStICS

- $\quad$ efFects of ageing on máterial characteristics

- $\quad$ efFects of CONFIGURATION AND CONSTRUCTION ON THE STRESS DISTRIBUTION WITHIN THE ENCAPSULATING MATERIALS

- SHORT-TIME TESTS DO NOT SUB JECT THE MODULE TO THE EFFECTS OF AGEING ENCOUNTERED IN SERVICE AND ARE OF LIMITED USE IN PREDICTING LONG TIME PERFORMANCE

- REAL TIME TESTING UNDER ACTUAL OPERATING CONDITIONS IS NECESSARY TO VERIFY INSULATION DESIGN INTEGRITY

\section{EFFECT OF TIME ON THE DIELECTRIC STRENGTH OF POLYETHYLENE UNDER AC STRESS}
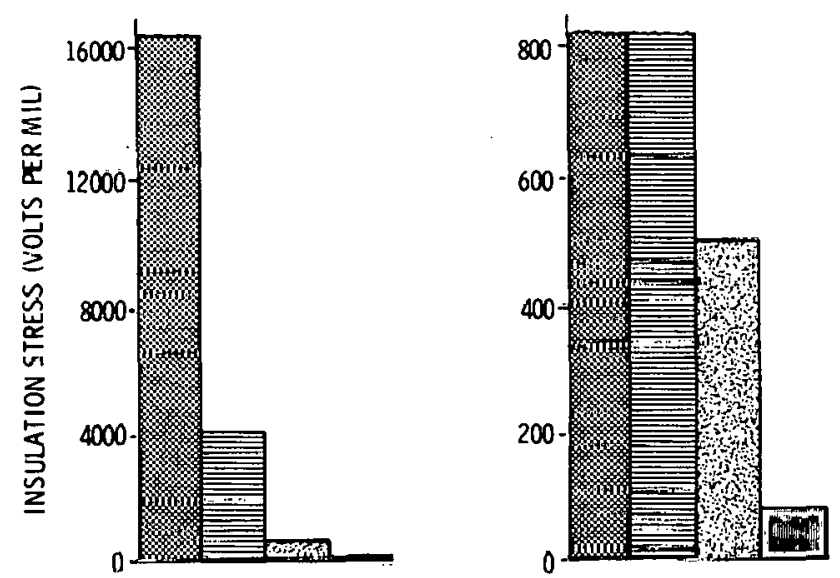

INTRINSIC STRENGTH

IMPULSE STRENGTH (15/ AO MICROSECOND)

SHORI TIME STRENGTH IS MINUTE STEPI

MAXIMUM STRESS PERMITTED BY THE INSULATED POWER CABLE ENG INEERS ASSOCIATION (IPCEA) SPECIFICATION FOR CABLE MANUFACTURING 
FACTORS AFFECTING THE BREAKDOWN LEVEL INCLUDE:

SHORT TIME $\left\{\begin{array}{l}\text { INTRINSIC STRENGTH } \\ \text { RATE OF VOLTAGE RISE } \\ \text { THERMAL B REAKDOWN } \\ \text { MATERIAL THICKNESS } \\ \text { ELECTRODE CONFIGURATION } \\ \text { VOIDS AND IMPERFECTIONS } \\ \text { CORONA } \\ \text { TREEING } \\ \text { ULTRA VIOLET DEGREDATION } \\ \text { OTHER AGEING AFFECTS }\end{array}\right.$

\section{MODULE VOLTAGE ISOLATION DESIGN LEVELS}

REQUIREMENTS

THE MODULE ENCAPSULATING SYSTEM MUST MAINTAIN ACCEPTABLE ELECTRICAL INSULATING PROPERTIES THROUGHOUT THE MODULES USEFUL LIFE, BOTH TO PREVENT PREMATURE FAILURE AND TO PROTECT PERSONNEL AGAINST SHOCK HAZARDS.

SOURCES OF ELECTRICAL STRESS

THE MODULE ENCAPSULATING SYSTEM WILL BE STRESSED BY ELECTRIC FIELDS RESULTING FROM:

(1) DC SYSTEM VOLTAGE

(A) MAXIMUM OPEN-CIRCUIT VOLTAGE

(B) OPERATING VOLTAGE (VARIES WITH TEMPERATURE)

(2) TRANSIENT VOLTAGE

(A) LIGHTNING INDUCED

(B) INVERTER (IF USED) CAUSED

(3) AC RIPPLE (IF INVERTIER IS USED) 
THE DIELECTRIC STRENGTH OF AN INSULATTING

MATERIAL DECREASES WITH INCREASING TIME UNDER STRESS

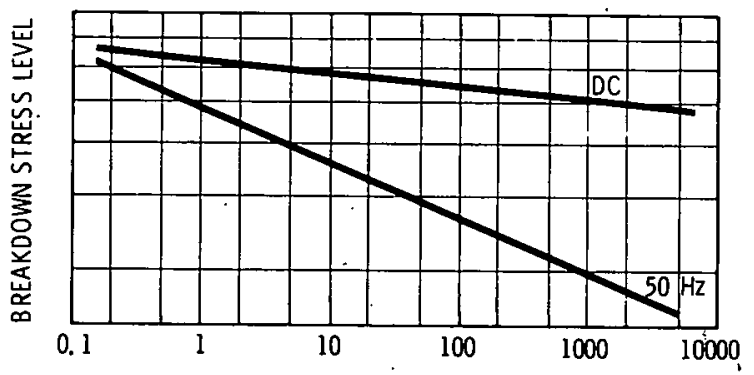

TIME TO BREAKDOWN (MINUTES)

\section{VOLTAGE DISTRIBUTION VERSUSS TIME FOR DIELECTRIC IN SERIES}

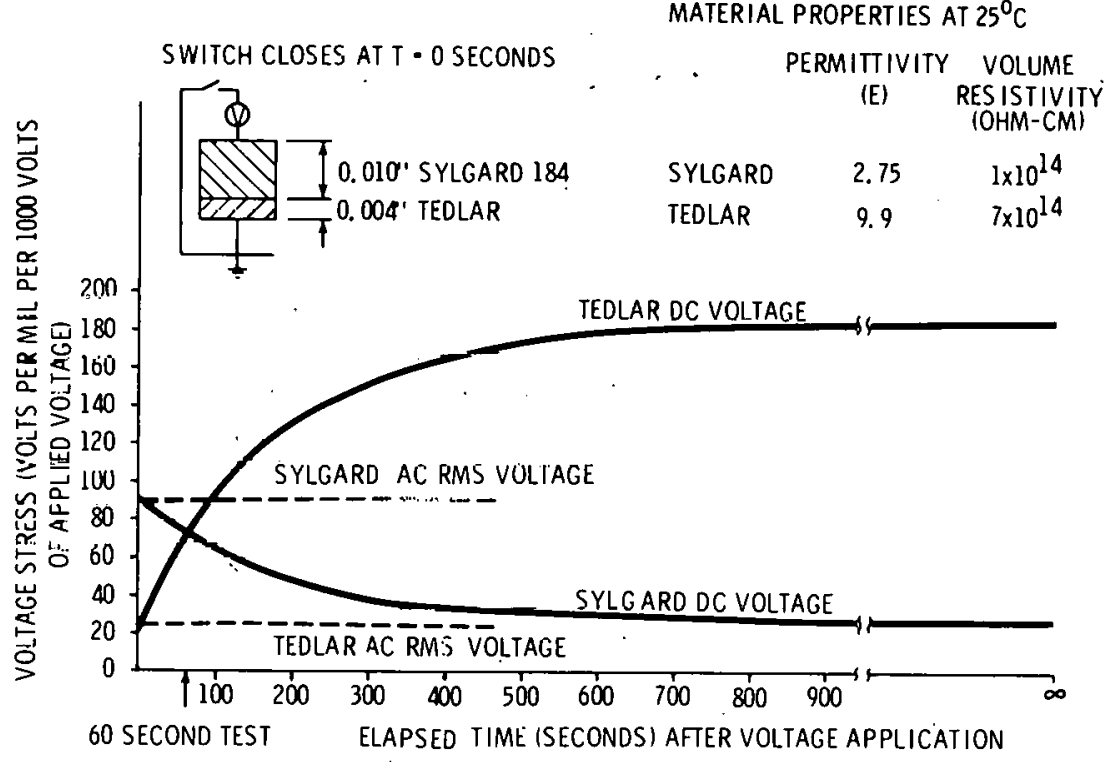




\section{ELECTRICAL ISOLATION DESIGN CONSIDERATIONS}

- EACH DES IGN MUST BE INDIVIDUALLY EVALUATED to ASSESS ITS LONG IERM ISOLATION CAPABILITIES

- DESIGN EVALUATION MUST CONSIDER

- SHORT IIME MATERIAL CHARACTERISTICS

- efFECTS OF AGEING ON MATERIAL CHARACTERISTICS

- EFFECTS OF CONFIGURATION AND CONSTRUCTION ON THE STRESS DISTRIBUTION WITHIN THE ENCAPSULATING MATERIALS

- IF PROPFRIYY APPLIED, SHORT TIME TESTS SUCH AS THE UL DIELECTRIC WITHSTAND TEST PROCEDURE CAN BE USEFUL IN ASSESSING MANUFACTURING QUALITY

- Short time tests do not Subject the module to the efFects OF AGEING ENCOUNTERED IN SERVICE AND ARE OF LIMITED USE IN PREDICTING LONG TIME PERFORMANCE 


\section{RESIDENTIAL PHOTOVOLTAIC MODULE REQUIREMENTS STUDY \\ Burt Hill Kosar Rittelmann Associates \\ Butler, Pennsylvania}

The objective of this almost-completed study was to investigate the requirements that would be placed upon modules integrated into a residence. The study was divided into four sections. The first section was a review of building codes and their referenced standards. This portion of the task was completed at the end of December.

The second section of the study was the investigation of module size and installation procedures. It was determined that the best approach was to deal with the module as a "black box" and ignore module construction. Four mounting types were identified: rack mount, stand-off mount, direct mount, and integral mount. Cost breakdowns were developed for the identified module sizes for each of these mounting types.

Upon completion of the second section of the study, the contractor began analyzing the effect of the electrical code upon the module design and also upon the associated wiring and terminal requirements.

The final section of the study was the cost analysis of installed arrays for the difference mounting configurations, module sizes, and module wiring schemes.

The final report will be developed as a series of studies to show the particular concerns each of the mounting types must face in reference to the building industry. It will also be a preliminary document for the development of appropriate standurds and test methods to assist in the penetration of the residential market with photovoltaic modules.

The draft final report is in preparation. The final report is expected to be available in July, $1 \dot{9} \overline{7} \dot{y}$.

Viewgraphs detailing this presentation appear on the following pages. 


\title{
RESIDENTIAL MODULE REQUIREMENTS
}

\author{
P.R. RITTELMANN/J. OSTER \\ BURT HILL KOSAR RITTELMANN ASSOCIATES \\ APRIL 5, 1979
}

CODE DEVELOPMENT AND USAGE

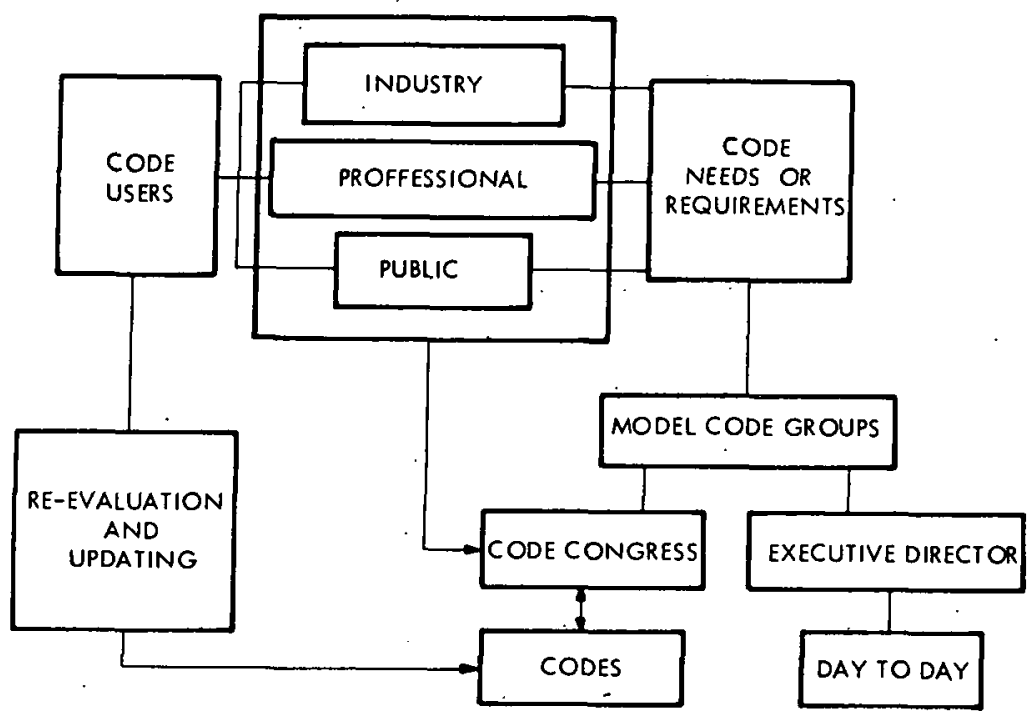

STANDARDS AND TESTING AGENCIES REVIEWED

- American Society of Testing and Materials (astm)

- American national Standards institute (ANSi)

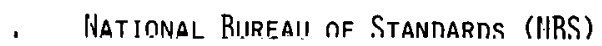

- Federal Standards and Specifications

- ilational fire Protection association (NFPa)

. Underviriters LiBORATORIES (UL) 
BUILDING OFFICIALS AND CODE ADMINISTRATORS INT. INC. (BOCA)

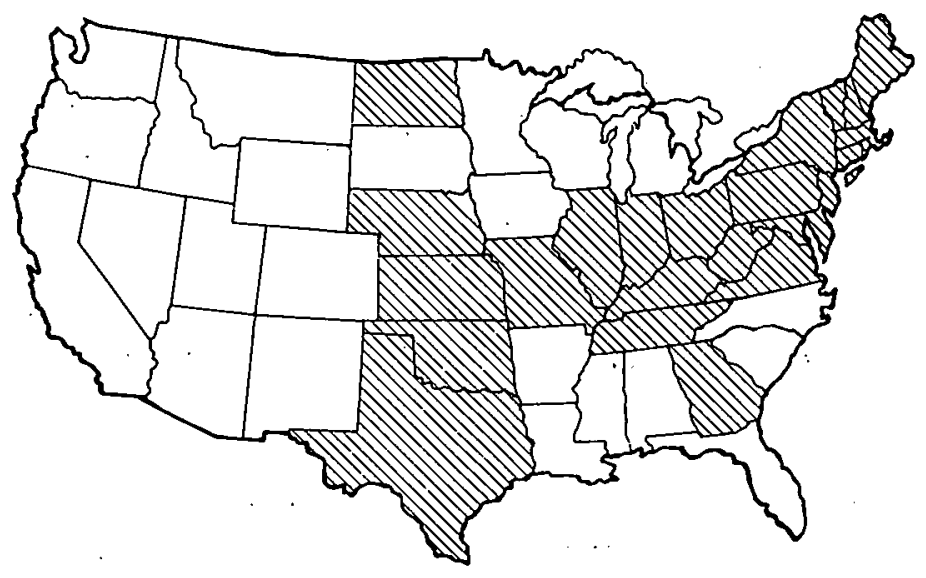

INTERNATIONAL CONFERENCE OF BUILDING OFFICIALS

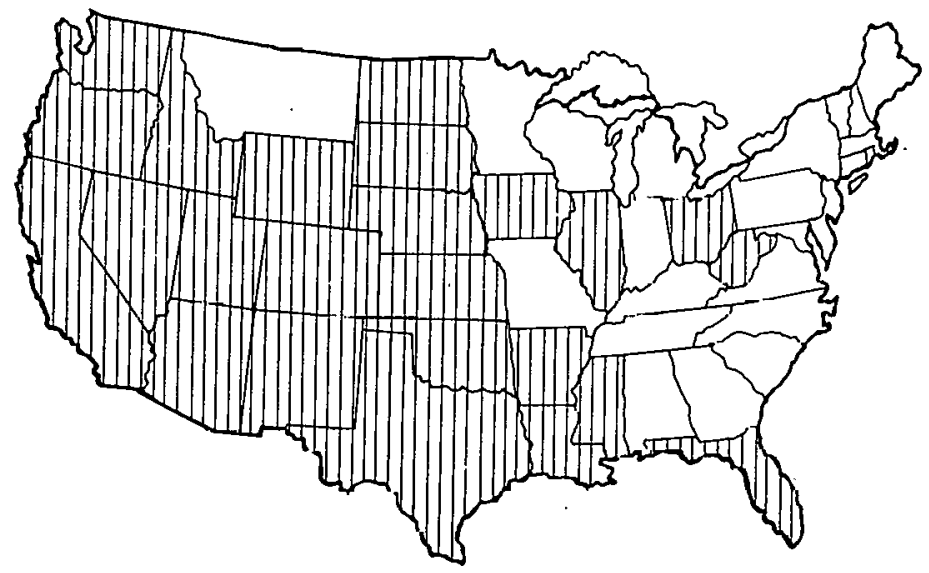

SOUTHERN BUILDING CODE CONGRESS INTERNATIONAL (SBCC)

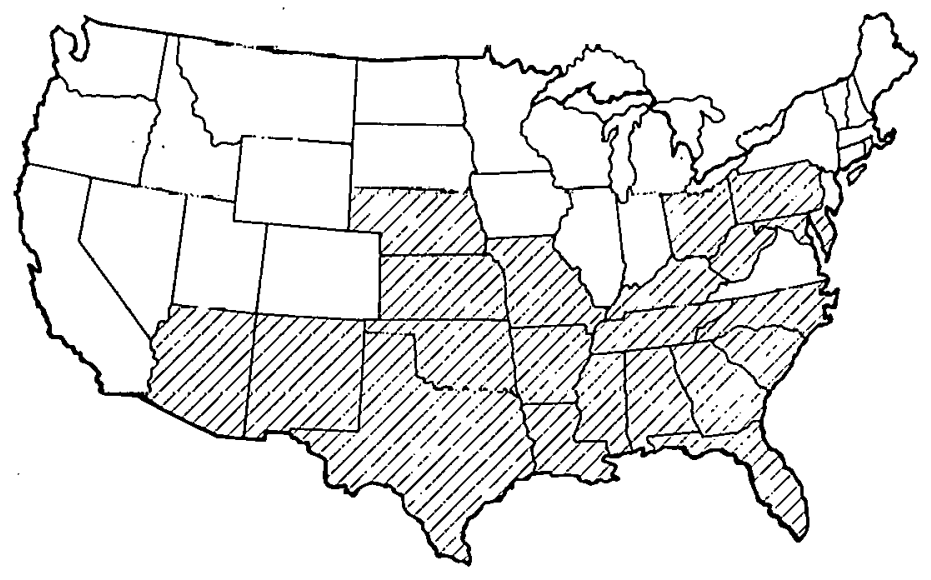




\section{PLASTIC LAMINATIONS}

BOCA

$$
\text { CLASSIFICATION }
$$

MAX. PAMEL AREA

(INDIVIDUAL UNIT)

CLASS A

CLASS B

CLASS C

SBC

CLASS CCl

CLASS CC2
300 S.F.

200 S.F.

100 S.F.

300 S.F.

100 S.F.
TOTAL AREA OF PLASTIC ON ROOF

(\% OF FLoOR AREA)

$30 \%$

$25 \%$

$20 \%$.

$30 \%$

$25 \%$

\section{CODE CONCLUSIONS}

BoCA, uBC, SSBC all agree that Residential Photovoltaic

Modules need not be incombustible.

- Codes place severe restrictions on the use of plastics IN ROOF Materials. THE statements are seVER ENOUGH to PROHIBIT ITS USE,

- Photovoltaic MOdules in RACK OR STAND-OfF MOUNT Will MOST LIKELY BE CONSIDERED AS ROOF STRUCTURES BY THE CODE AND SUBJECTED TO ALL THE ASSOCIATED CODE RESTRICTIONS.

- Applications which may place PV panels in pedestrial areas MUST BE TEMPERED OR WIRED FOR GLASS IF GLASS IS USED.

- PV MOdULES WHICH Become PART OF the BUILDING STRUCTURE, I.E., INTEGRAL, MUST COMPLY WITH ALL CODE MANDATED LOADING REQUI REMENTS.

NOTES: CODEs ARE WRITTEN ON A NATIONAL LEVEL AND ARE THEORETICALLY UNIFORM THROUGHOUT THE II.S. HOWEVER, EACH CODE MUST BE LOCALLY INTERPRETED. THIS LOCAL INTERPRETATION ALLOWS FOR GREAT DISCREPANCIES. THE MANUFACTURER MUST BE AWARE OF THIS, BUT CANNOT COUNI ON THEM. 


\section{NATIONAL ELECTRICAL CODE SUMMARY}

GENERAL

THE PURPOSE OF THE CDDE IS PRACTICAL SAFEgUARDING OF PERSONS AND PROPERTY.

SAFETY

LIVE PARTS OPERATING AT 50 VOLTS OR MORE SHALL BE GUARDED AGAINST ACCIDENTIAL CONTACT DURING INSTALLATION. THIS MAY BE NECESSARY AT ALL VOLTAGE LEVELS.

GROUNDING

Metal framed panels Will require grounding unLess SPecial provisions for isolating Live Wires are made. Metal frames USED AS CONDUCTOR RACEWAYS REQUIRE GROUNDING.

\section{TERMINALS}

QUICK CONNECT TERMINALS, ALTHOUGH NOT SPECIFICALLY MENTIONED IN THE CODE, ARE A RECOGNIZED METHOD FOR MAKING ELECTRICAL CONNECTIOIIS. SOME MUNICIPALITY CODES DO NOT RECOGNIZE QUICK CONNECT SPLICES WHERE INSTALLATIONS ARE CONSIDERED TO BE PERMANENT.

\section{WIRING}

FACTORY INSTALLED INTERNAL WIRING OF EQUIPMENT DOES NOT COME UNDER THE JURISDICTION OF THE CODE, IF THE EQUIPMENT HAS BEEN LISTED BY AN ELECTRICAL TESTING LABORATORY,

ALL CONDUCTORS USED FOR GENERAL WIRING SHALL NOT BE SMALLER THAN \#14 COPPER. WIRING USED IN LIGHTING FIXTURES AND SIMILAR FOUIPMENT SHALL NOT BE SMALLER THAN \#18 COPPER. PV PANELS MAY BE CONSIDERED TO BE SIMILAR TO LIGHTING FIXTURES.

CONDUCTOR. OPERATING TEMPERATURES FOR SPECIFIC MOUNTING TYPES MUST BE DETERMINED SO THAT CONDUCTORS CAN BE PROPERLY SIZED.

MODULE WIRING SYSTEMS, I.E. FACTORY LUBRICATED CABLE/TFRMINAL ASSEMBLIES INTENDED TO MINIMIZE FIELD LABOR ARE RECOGNIZED BY THE CÓDE. 


\section{BUILDING MODULE INTEGRATION TYPES}

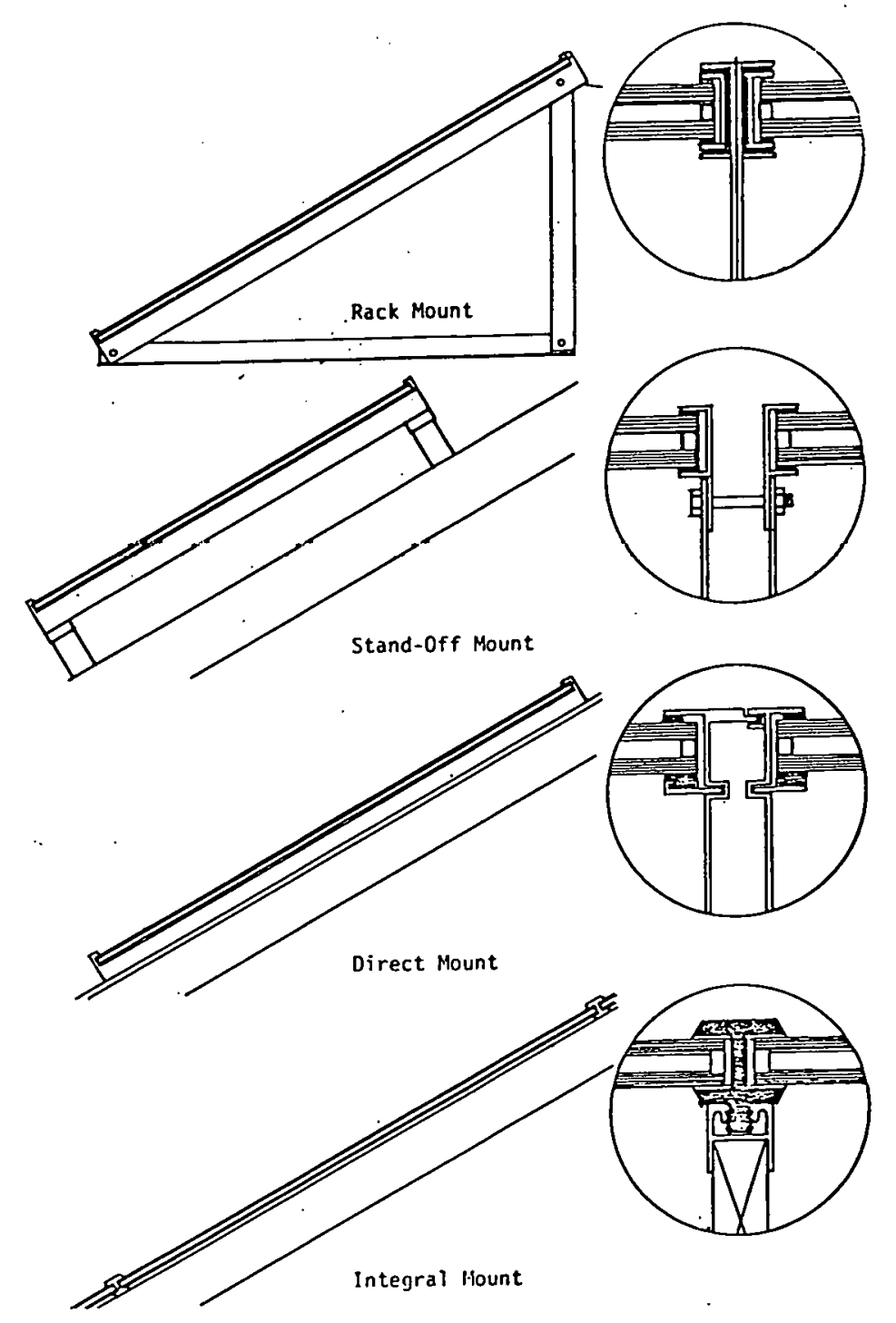

\section{ELEMENTS OF STUDY MATRIX}

PANEL SIZE

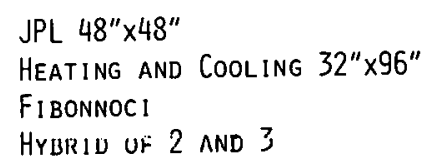

ARRAY ASPECT RATIO

$$
\begin{array}{ll}
1: 1 \\
1: 2 \\
1: 3 \\
1: 4 \\
1: 7 \\
1,15
\end{array}
$$

MOUNTIIIG TYPE

$$
\begin{array}{ll}
\text { Integral } \\
\text { Direct } \\
\text { - } & \text { Standoff } \\
& \text { Rack }
\end{array}
$$

MODULE CONSTRUCTION

SUBStrate/SUPERstrate

$$
\text { Nlone/GLASS }
$$$$
\text { Mone/Plastic }
$$

Hone/Sillicon Encapsulant

PLASTic/glass

Plastic/Plastic

Plastic/Silicon Encapsulant

ETC. 
MODULE SIZE

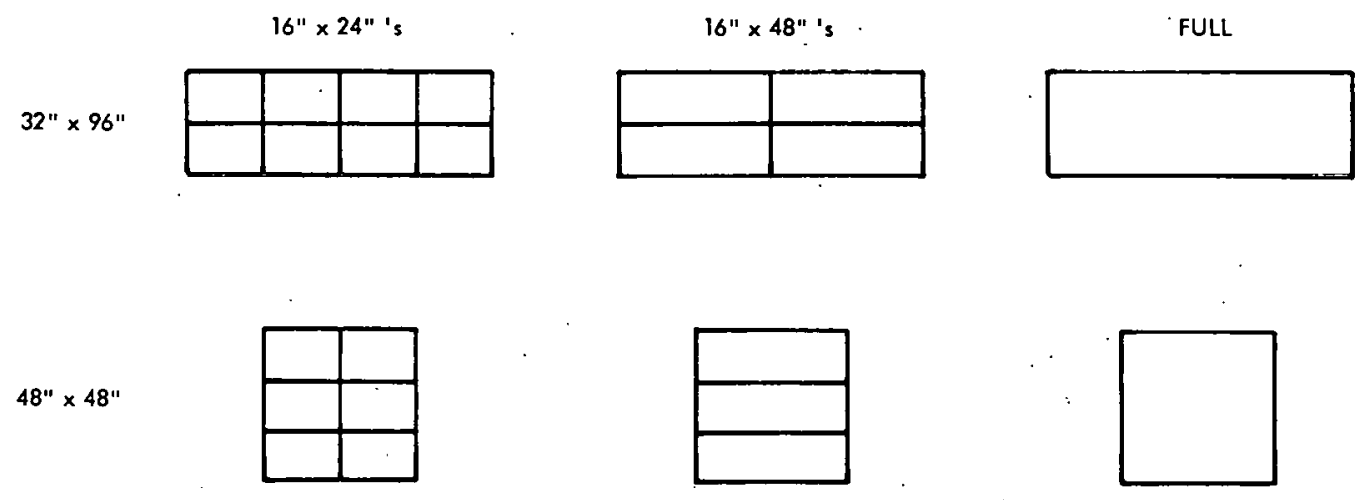

ARRAYS USING 48" X 48"' PANELS
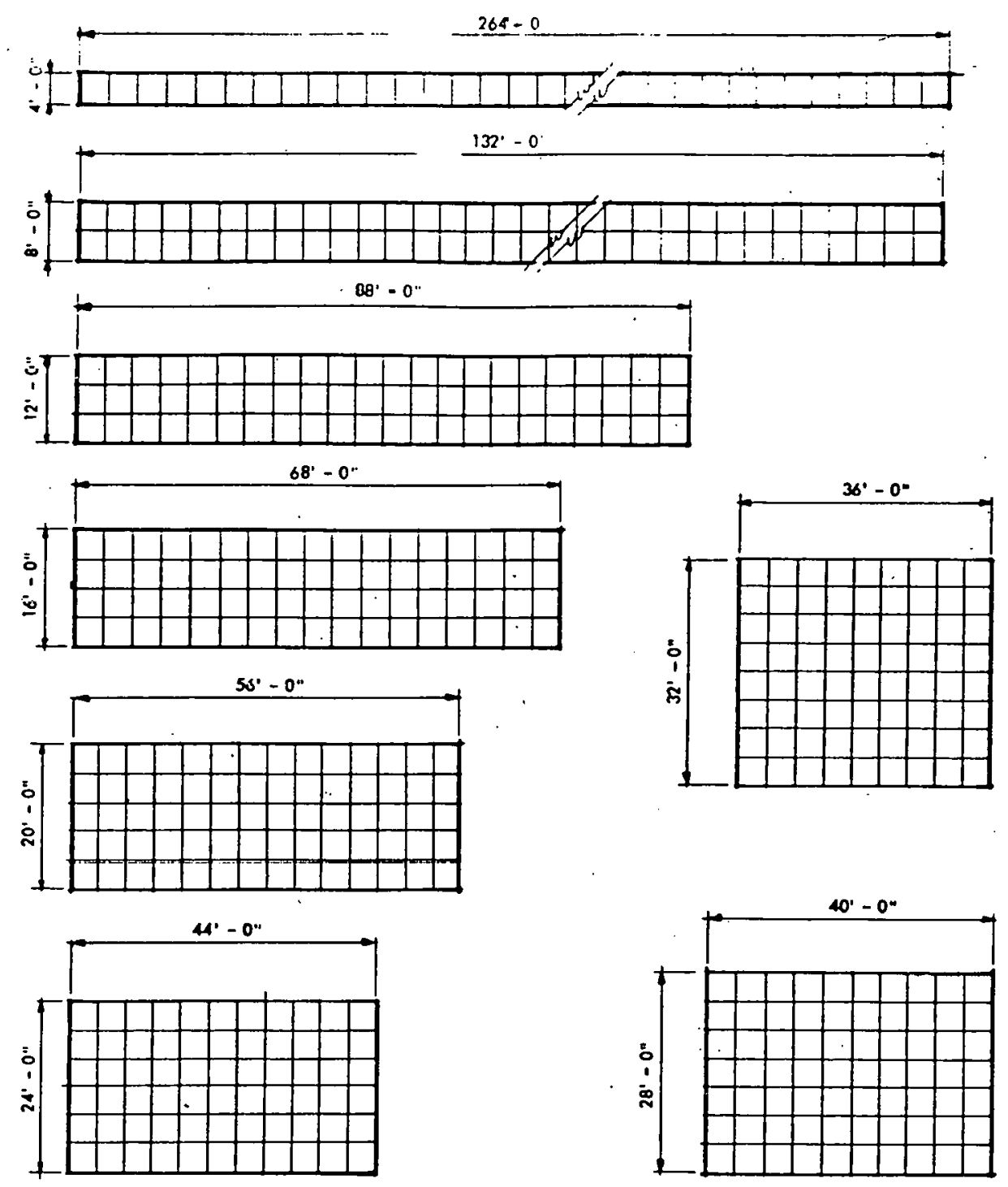
ARRAYS USING 32" X 96" PANELS
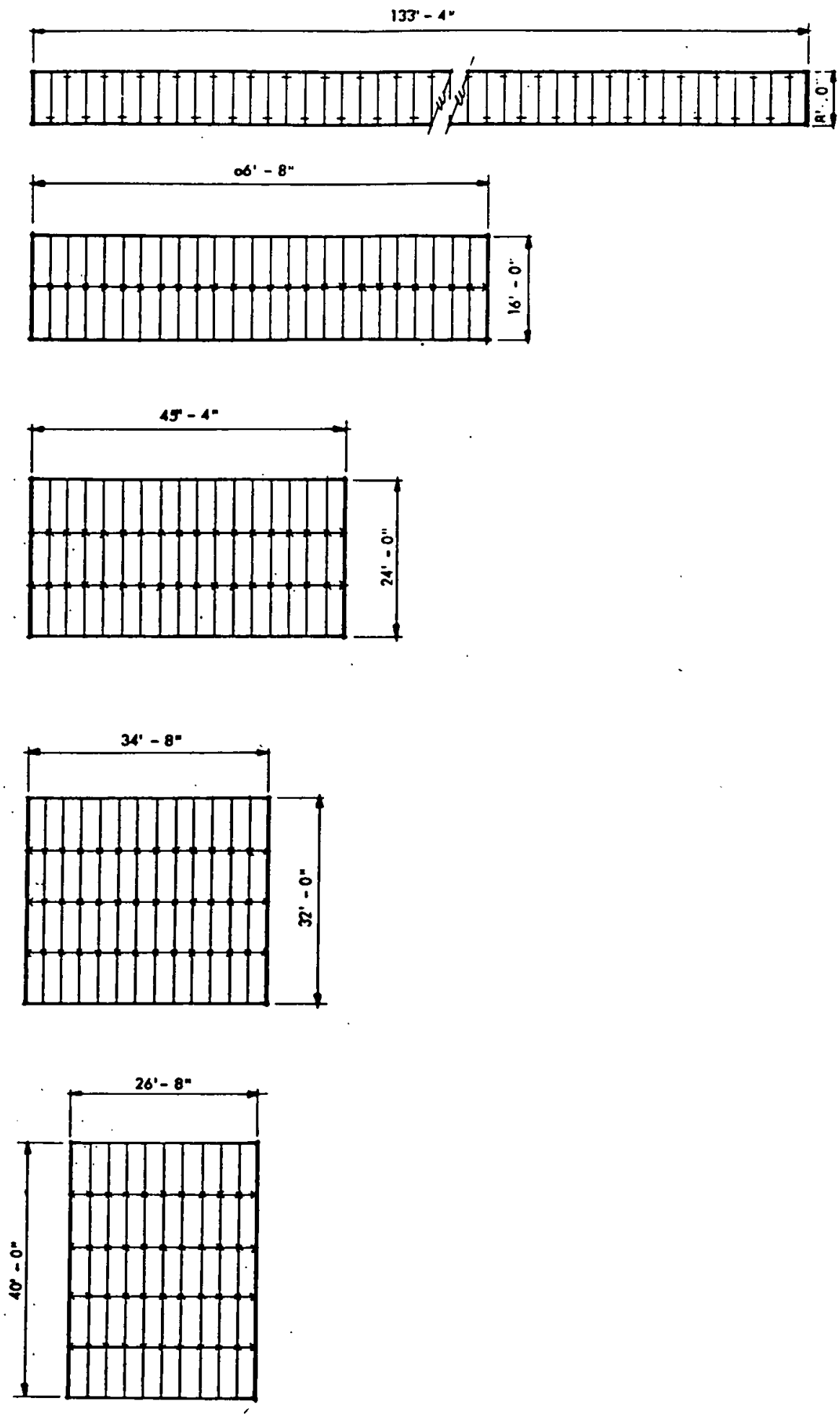
48" X 48" PANEL

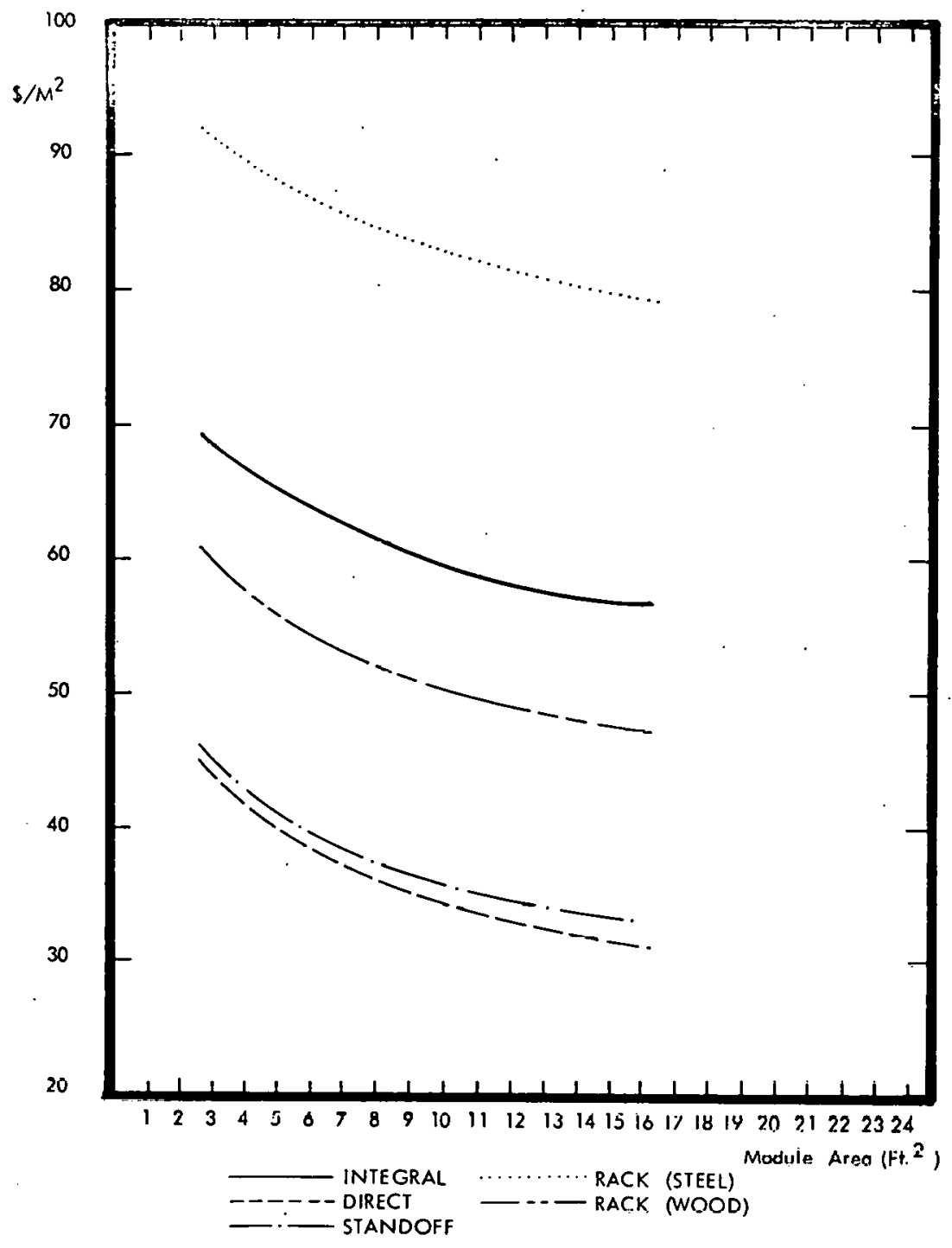


32" X 96" PANEL

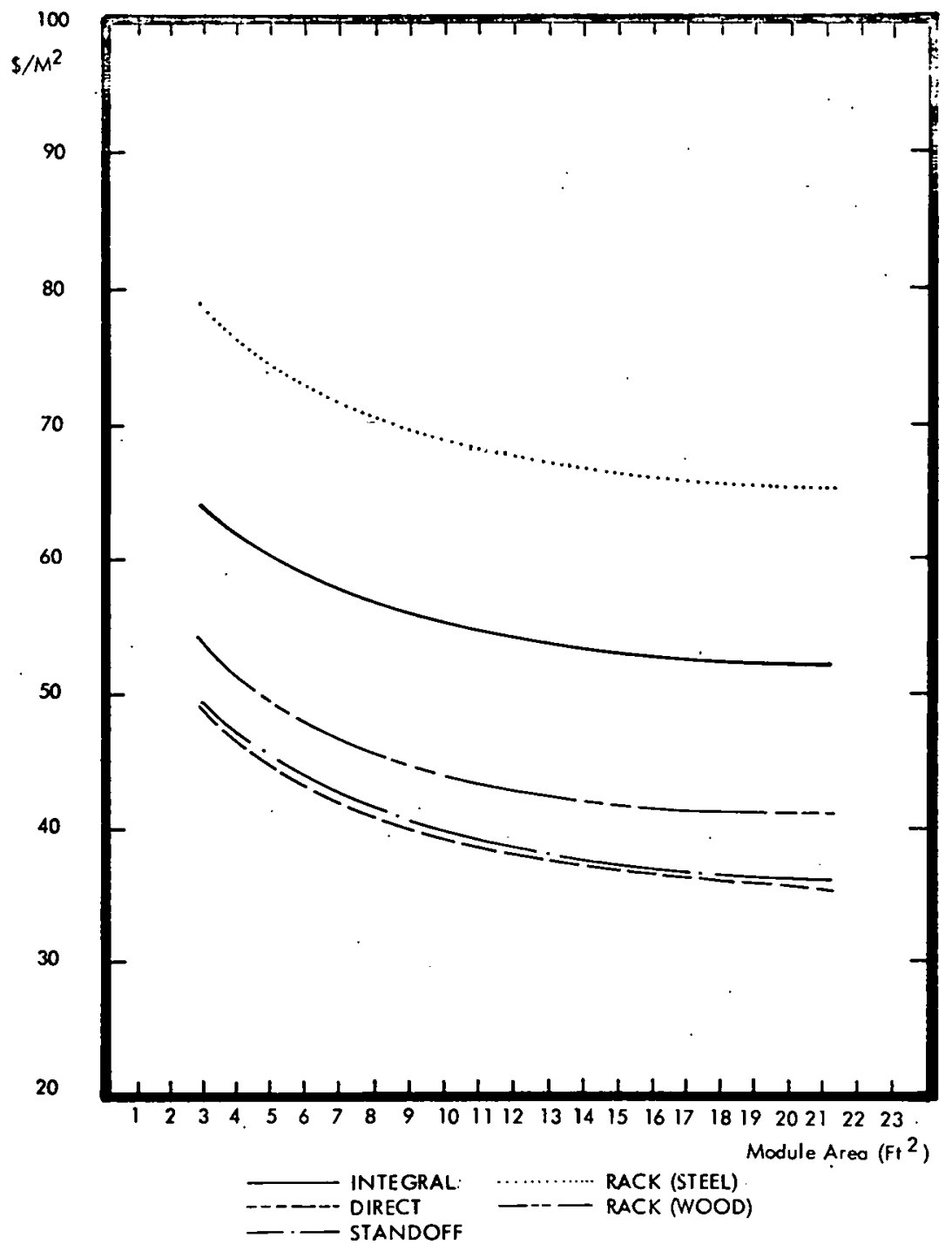


WIRING COSTS

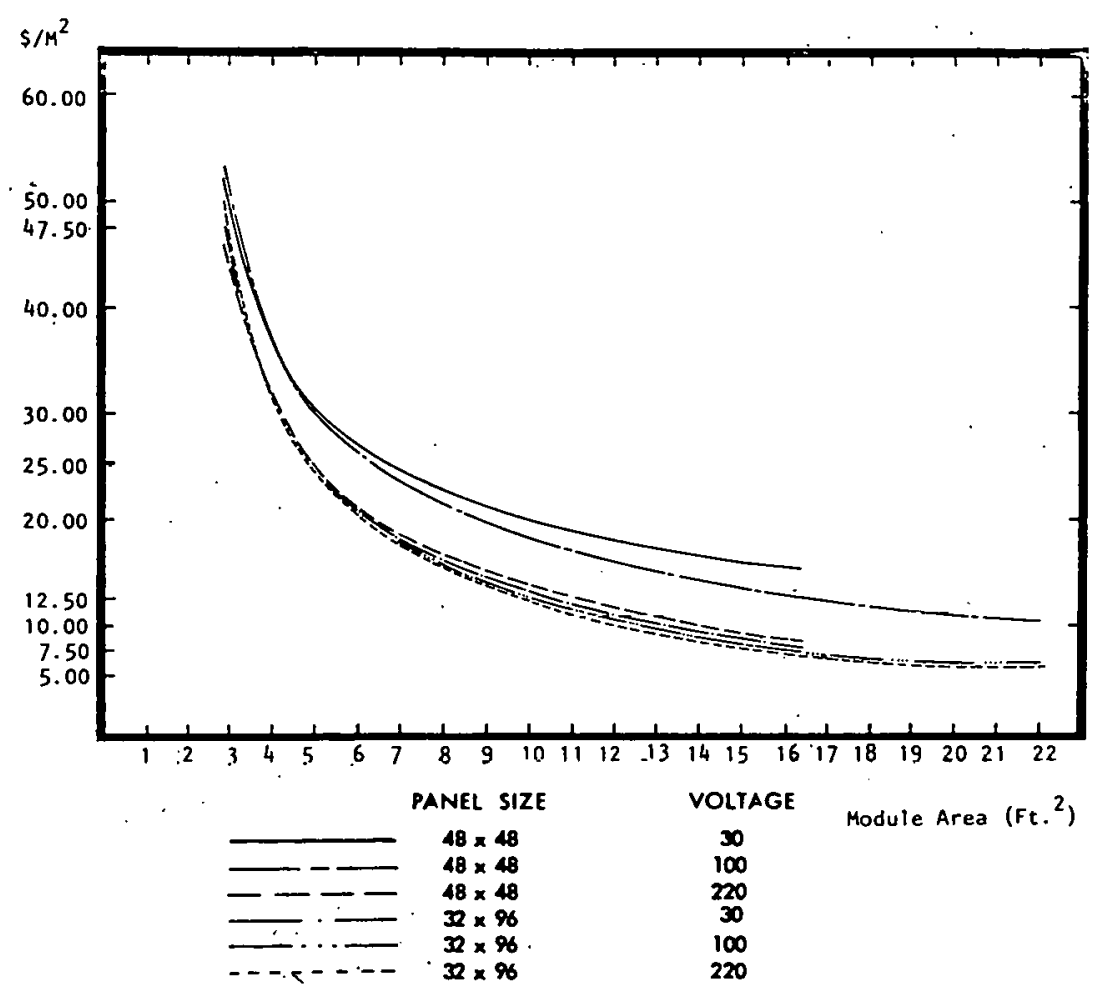

G. E. SHINGLE MODULE
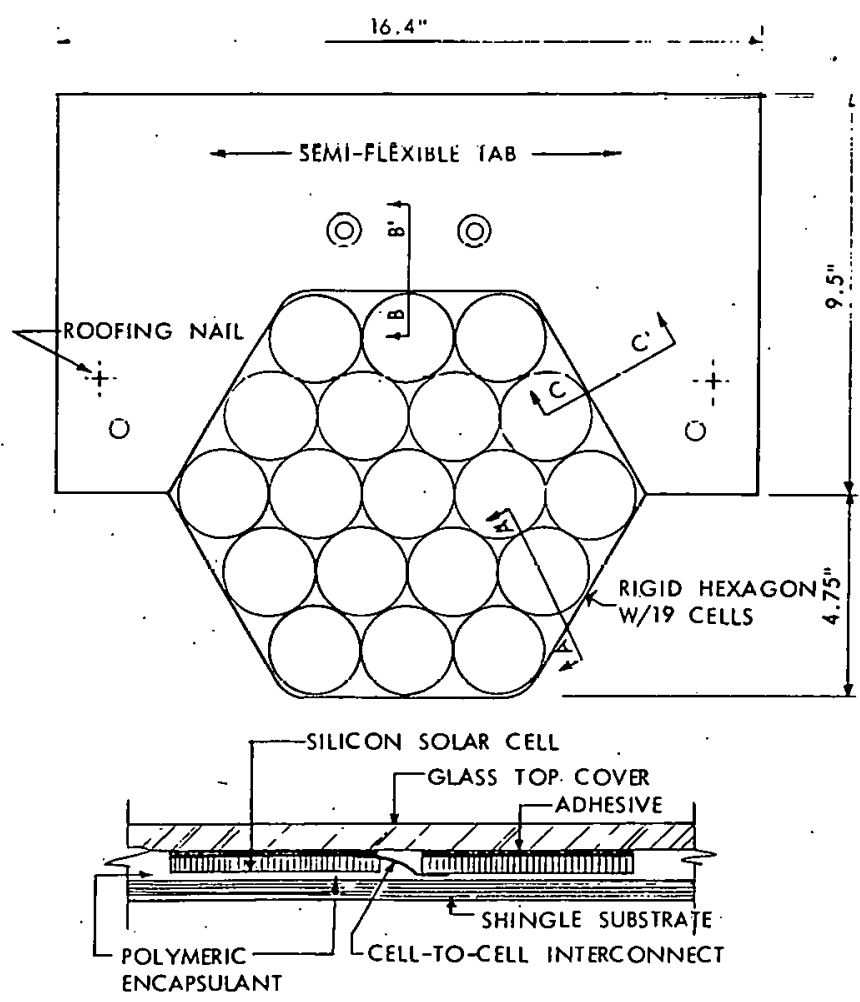


\section{COMPARISON OF PV SHINGLE PROPERTIES VS. FLAT PANEL PROPERTIES}

ELAT PANEL

1. Larger Area per panel. Awkward for one man. May need a crane.

2. LARGER AREA MEANS FEWER JOINTS.

3. PANel/SKYlight TECHNOLOGY MUST ADAPT TO CONVENTIONAL RESIDENTIAL ROOF-TRUSS TECHNOLOGY,

4. SLICK SURFACE TO SHED RAIN AND SNOW.

5. FEWER ELECTRICAL CONNECTIONS - LESS VULNERABILITY. CONNECTIONS CAN BE PROTECTED BEHIND PANEL IN WEATHERPROTECTED SPACE,

6. Panels can be adapted to different MOUNTING TYPES: INTEGRAL, FLUUS, STANDOFF, VERTICAL OR FLAT,
SHINGLES

1. A SHINGLE CAN BE HANDLED BY ONE MAN,

2. Many joints, many COnNECTIONS.

3. SHINGLES ARE AN ATTEMPT TO MAKE AN EASY TRANSITION INTO HOUS ING MARKET.

4. TOOTHED SURFACE OF SHINGLES MAY PROMOTE ICE BUILDUP.

5. Many electrical CONNections FROM SHINGLE TO SHINGLE MORE CHANCE OF ELECTRICAL FAILURE', CONNECTIONS ARE ALL ABOVE PLYWOOD SUBSTRATE,

6. SHINGLES GO ON THE ROOF IN ONLY ONE WAY AND WITHIN CERTAIN LIMITS OF PITCH.

\section{RETROFIT GARAGE OPTIONS}
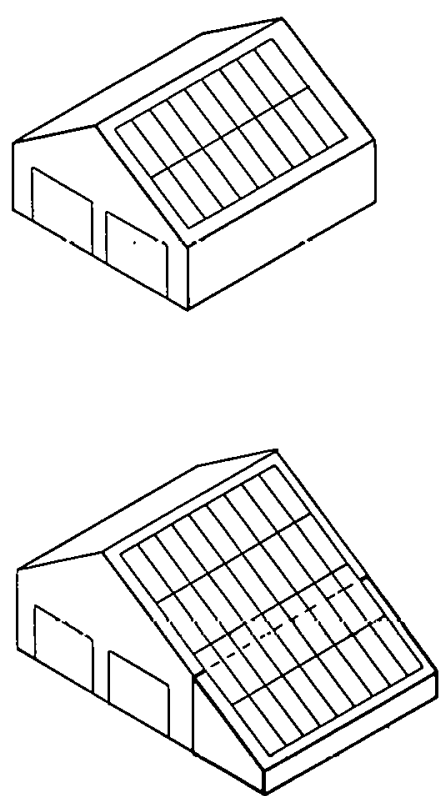
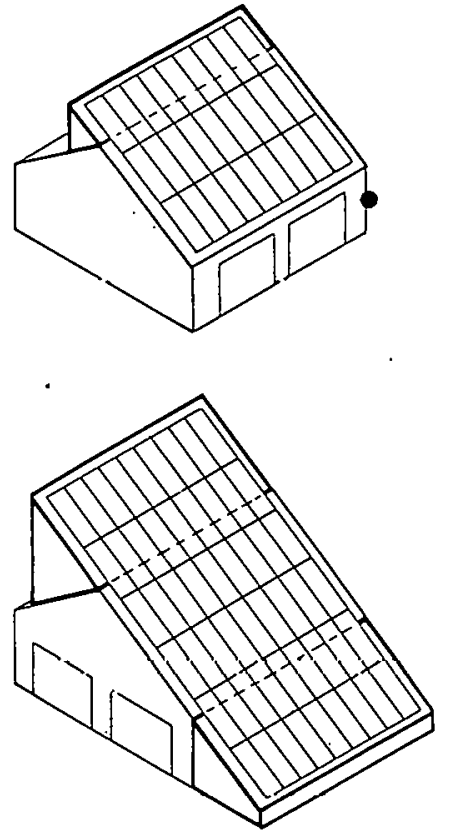


\section{PRELIMINARY CONCLUSIONS}

- PV Not AdDRESSEd IN NEC

- Possible inclusion In NeC 1984 Edition. Draft Required By MID - 1982.

- Premanufactured Wiring Systems Adventageous

- Voltage Level $110-220 \mathrm{~V}$ (Based On Cost Of Wiring)

- Ul testing And Approval Necessary

- Further Work Required On Optimum Size

- No Major Or Insurmountable Problems

- Design investigation For lower Cost Direct And Intęgral Mount PV Modules.

- Standard Investigation Is Anticipatory And Currently Underway BY SERI AND ANSI.

- Code investigation Required for each Application, 


\title{
WIND LOADS ON FLAT PLATE ARRAY FIELDS
}

\author{
Boeing Engineering and Construction Company \\ Seattle, Washington
}

The objective of this study is to develop more refined estimates of wind loading on flat-plate photovoltaic modules and array support structures.

A prototype two-dimensional separated flow analysis program was used to calculate front and base pressures on flat plates at large angles of attack and close proximity to the ground. Pressure distributions on photovoltaic modules due to wind can be obtained using this program. The wind loads that the supporting structure is subjected to were determined by integrating the pressures over the area of the module. The pressures generated on the photovoltaic modules and the total force transmitted to the array structure are strongly dependent on the array angles to the wind and ground and the array elevation above the ground. This dependency is partly because the height of the array is a function of the angle at which the array is positioned and that the wind velocity affecting the array decreases near the ground.

"Barriers such as fences can effectively reduce the wind velocity behind the barriers and so reduce the wind loading on photovoltaic arrays positioned behind the barriers. The wind velocity profile is affected by the porosity of the barrier and the distance away from the barrier.

Other devices besides fences can be used to decrease the wind loading on a photovoltaic array, but are difficult to analyze theoretically. A wind tunnel study is being planned to validate the theoretical results and to investigate wind load reducing techniques that defy theoretical solutions.

Final documentation of the study is underway.

Viewgraphs detailing this presentation appear on the following pages. 


\section{Wind Loads on Flat Plate Array Fields}

Objective: Develop more refined estimates of wind loading on flat-plate photovoltaic modules and array support structures

Study plan:

\begin{tabular}{|l|l|}
\hline Literature \\
search
\end{tabular}$\left[\begin{array}{l}\begin{array}{l}\text { Calculate theoretical } \\
\text { aerodynamic pressures } \\
\text { on plate arrays } \\
\text { - Attached flow } \\
\text { - Seperated flow }\end{array} \\
\hline\end{array}\right.$

\begin{tabular}{|l|l|}
\hline $\begin{array}{l}\text { Determine } \\
\text { plate and } \\
\text { support } \\
\text { structure } \\
\text { loads }\end{array}$ & $\begin{array}{l}\text { Identify } \\
\text { key } \\
\text { parameters } \\
\text { affecting } \\
\text { loads }\end{array}$ \\
\hline
\end{tabular}

\section{Plate Array Conditions and Environment}

Wind environment:

- Steady state - frequency independent

- Unsteady - frequency dependent
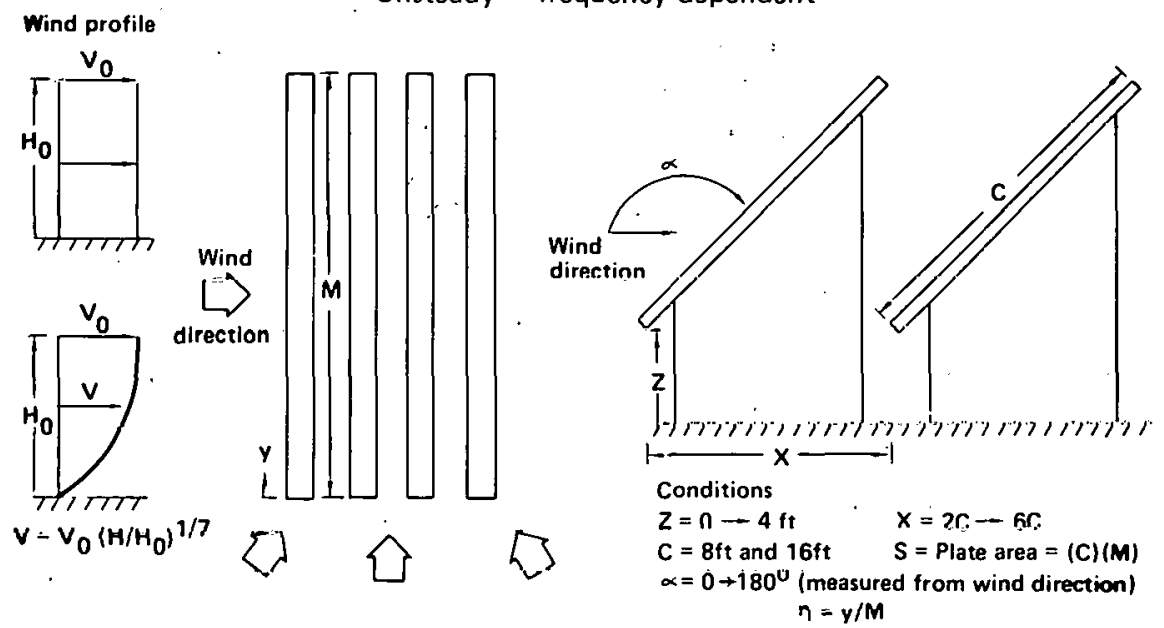

Panel Theoretical Aerodynamic Loads

(Separated Flow Analysis)
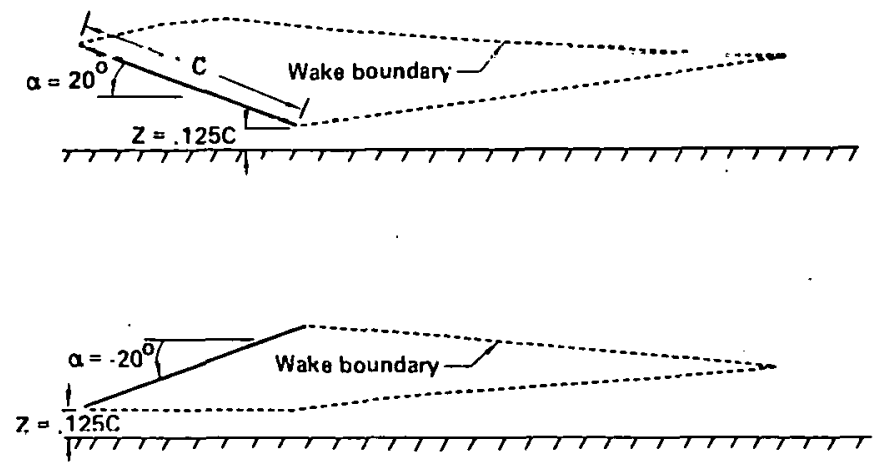
Array Pressure Distribution

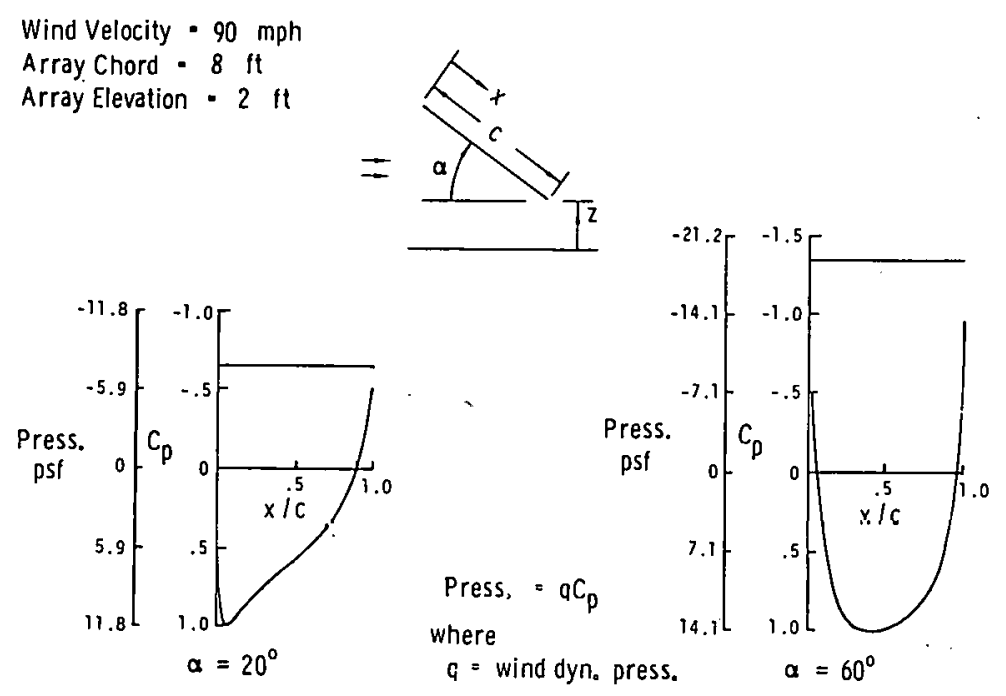

Two-Dimensional Plate Normal Force

Coefficient in Close Ground Proximity

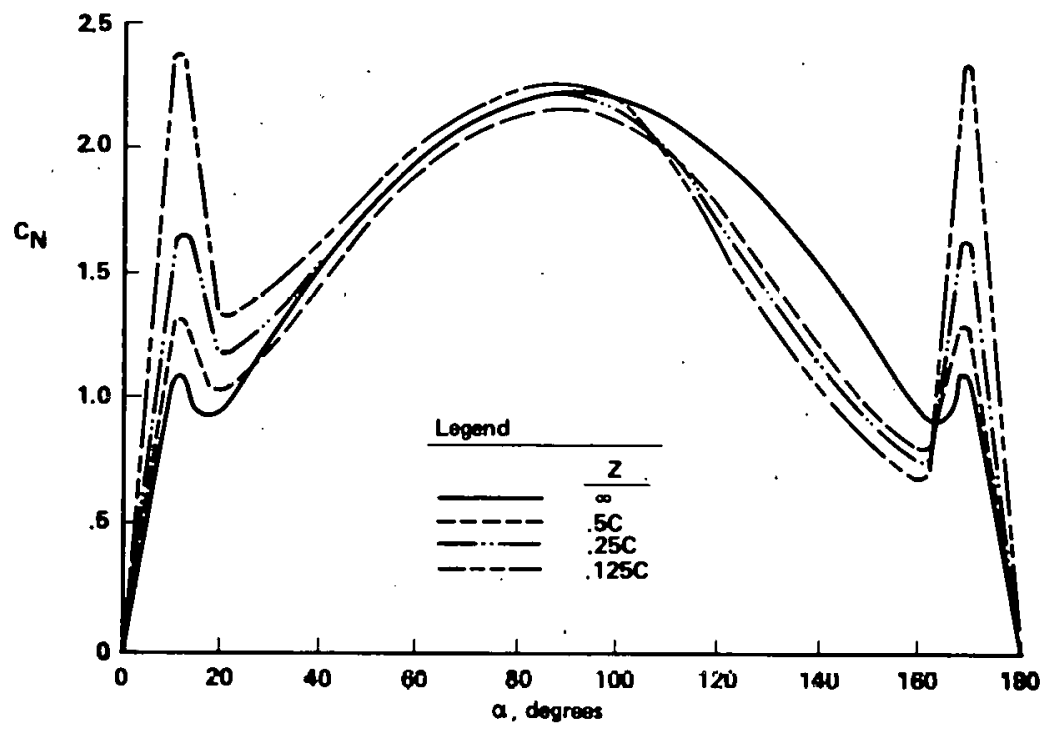




\section{Envelope of.Wind Forces on Arrays}

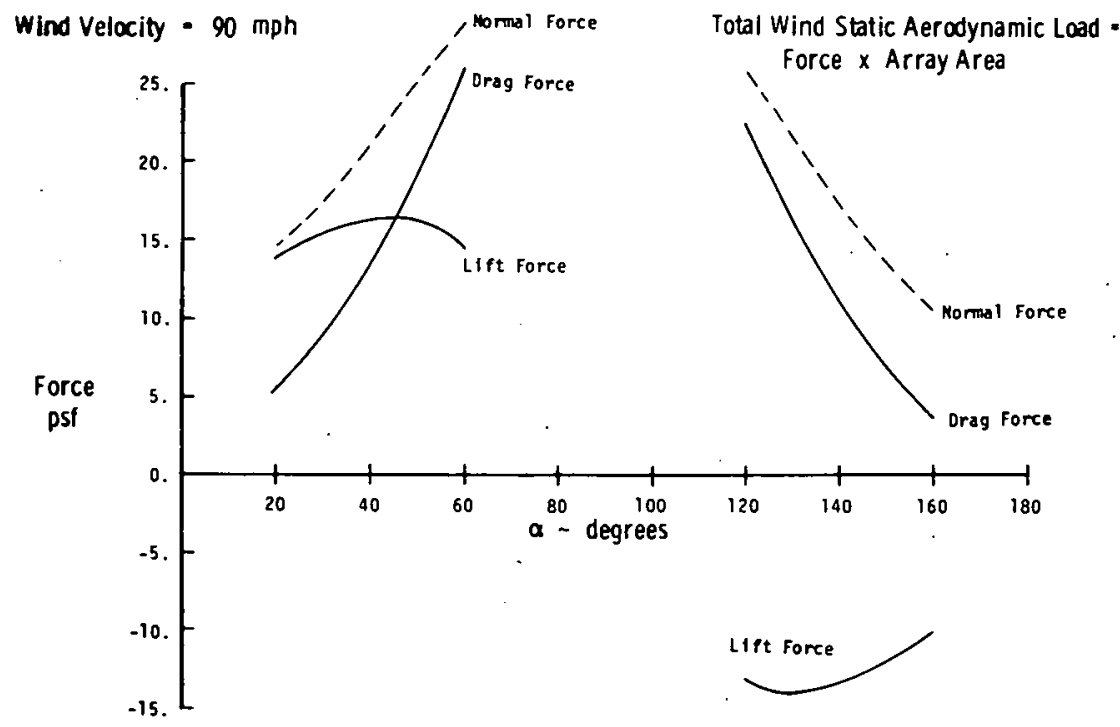

Protective Barriers

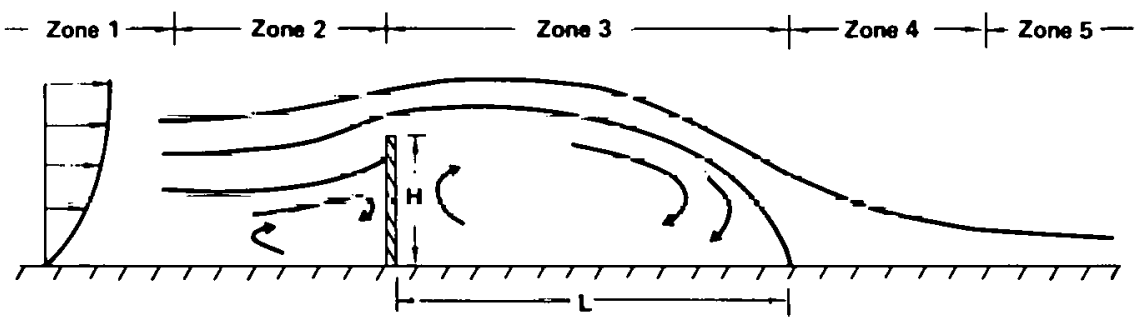

Zone 1: Zone of unobstructed flow

Zone 2: Zone of pressure rise

Zone 3: Standing eddy zono

Zone 4: Zone of redovelopment

Zon 3:

- Zone of reduced steaty state flow

Zone 5: Zone of redeviloped flow

- Zone of increased turbulence

- $L=12 \mathrm{~h}-16 \mathrm{~h}$ 


$$
x \stackrel{2}{=} 4 \mathrm{~m}
$$

CONDITIONS:

- Free stream velocity $=\mathbf{4 0} \mathrm{m} / \mathrm{sec}$

- Fence height $=2.5 \mathrm{~m}$

- Steady state wind

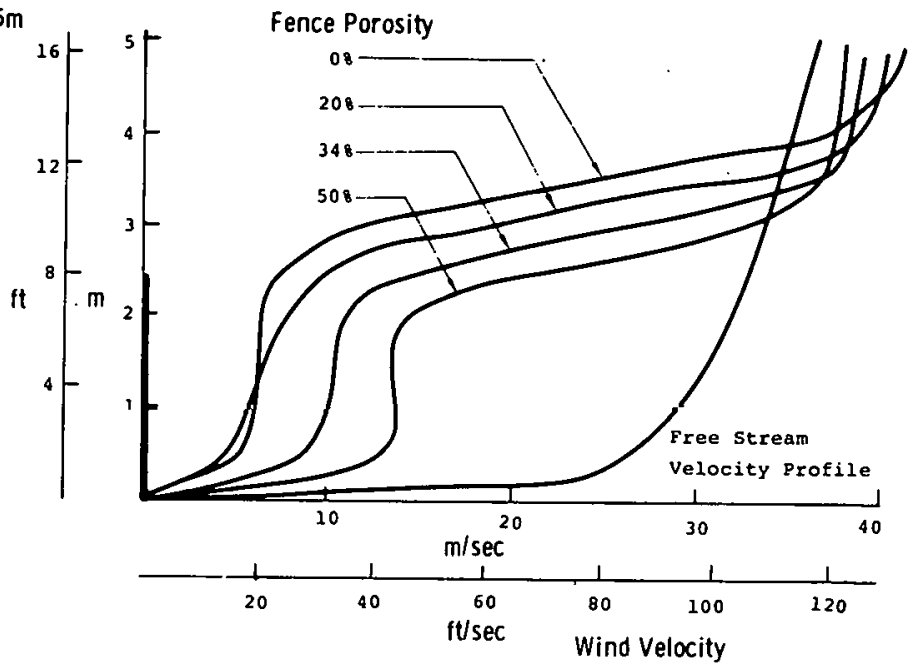

\section{Effect of Fence Porosity on Wind Velocity Profile}

$$
X=7.5 \mathrm{~m}
$$

CONDITIONS:

- Free stream velocity $=\mathbf{4 0} \mathrm{m} / \mathrm{sec}$

- Fence height $=2.5 \mathrm{~m}$

- Steady state wind
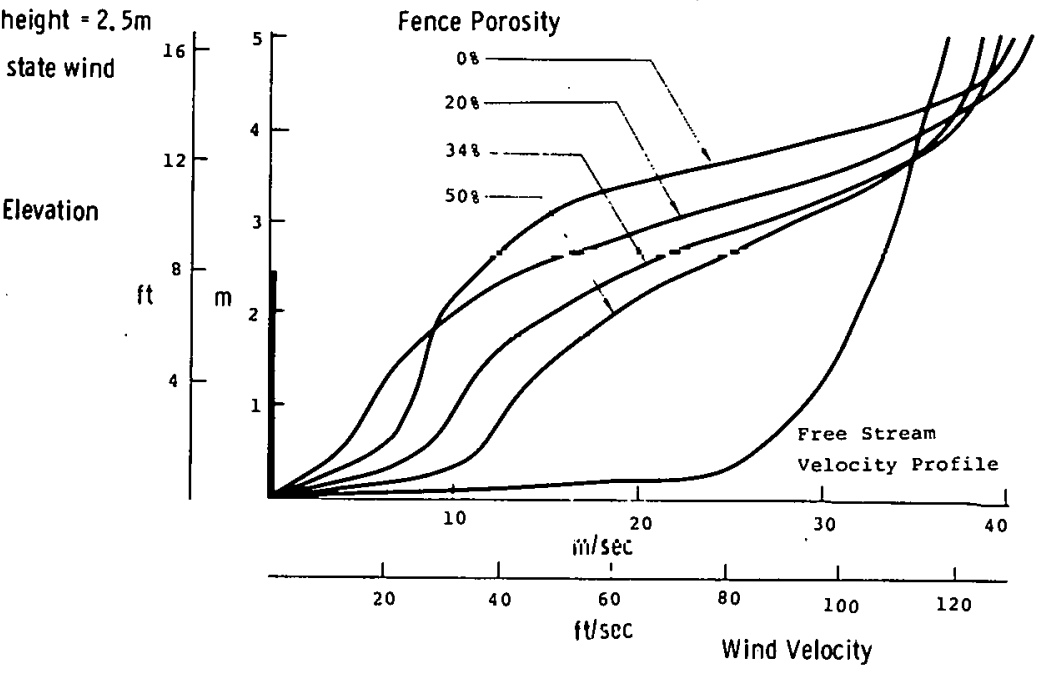
Wind Tunnel Test Plan

\author{
Location: Colorado State University \\ Timing: Late Summer, Fall \\ Tunnel Type: Environmental Wind Tunnel \\ test section $12^{\prime} \times 7^{\prime}$ to $9^{\prime}$ \\ Models: $\quad 10$ flat plate arrays \\ fences with porosity of \\ $0 \%, 35 \%, 50 \%$
}

\title{
I est Hequirements
}

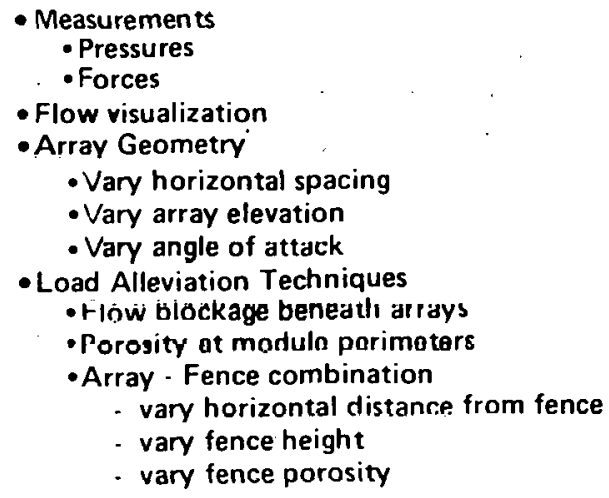




\author{
PHOTOVOLTAIC MODULE ELECTRICAL TERMINATION \\ DESIGN REQUIREMENT STUDY \\ Motorola Semiconductor Group \\ Phoenix, Arizona \\ and \\ ITT Cannon Electric Division \\ Santa Ana, California
}

An important step in meeting LSA Project goals is the selection and improvement, where needed, of 1 ife-cycle cost effective electrical termination hardware for modules and arrays. The objective of this study is to develop information to facilitate this selection and improvement.

This study draws upon the information base for the vast quantity of existing outdoor electrical termination hardware. Results will be presented in parametric form to the fullest extent possible and in a form to allow updating as the LSA Project progresses. Results expected from this study include:

1. Termination hardware requirements, including environmental, system interface, design, production, and application requirements.

2. A catalog of existing termination hardware with its attributes.

3. A summary of the attribute cost dependencies and cost-driven sensitivities.

4. A listing of candidate electrical termination hardware.

5. Areas for cost improvement.

Cost is an important selection factor in conducting this study. - With an allocation of $\$ 0.50 / \mathrm{Wp}$ for the whole module, termination hardware cost should not be a significant fraction of that amount. One emphasis of the study is to sepk nut. and fescribe the cost dependencies of each attribute or property important to the selection of electrical termination hardware for solar cell modules and arrays. By doing so, it is anticipated that cost drivers can be identified. Life-cycle cost is to be used throughout the study. Included in the life-cycle cost are the costs of installation and maintenance, as well as the first cost of the hardware. 


\title{
INVESTIGATION OF RELIABILITY ATTRIBUTES AND ACCELERATED STRESS FACTORS ON TERRESTRIAL SOLAR CELLS
}

\author{
Clemson University \\ Clemson, South Carolina
}

The objective of this study is to a) develop test methods for evaluation of solar cells, b) perform investigations of factors involved in the reliability of terrestrial solar cells and c) to develop specifications for the accelerated stress testing of solar cells. The overall program approach involves determining the reliability characteristics of currently available comercial cells by accelerated stress testing. In order to do this consideration was given to defining cell failure in terms of changes in a cell's measured parameters ( $\mathrm{I}_{\mathrm{Sc}}, \mathrm{V}_{\mathrm{OC}}, \mathrm{FF}$, etc.). Degradational failures are expected to predominate. One major objective is to identify life-limiting failure mechanisms that occur during accelerated stress testing. The information gained from time-to-failure distributions and failure mechanism identitication will be urflized to gelletale a preliminary cell qualification test schedule.

A cell reliability test facility was established and jigs designed and constructed for testing three different cell sizes. The capability for reproducible measurements of $\mathrm{I}_{\mathrm{sc}}, \mathrm{V}_{\mathrm{oc}}, \mathrm{I}_{\mathrm{m}}, \mathrm{V}_{\mathrm{m}}$, $F F, R_{S}, R_{S h}$ was demonstrated. Stress test equipment is in place and operational for temperature-voltage $(T-V)$ stress, temperaturehumidity-bias under pressure (T-H-B) stress, pulsed power-temperature stress, temperature-voltage-humidity (atmospheric $85^{\circ} \mathrm{C}-85 \mathrm{RH}$ ) and thermal cycle.

A cell stress-testing schedule was developed, with two phases. During Phase 1 small quantities were tested for limited times to generate data necessary for proper design of Phase 2, which was the large-scale testing program. A quantity of $200 \mathrm{Si}$ solar cells from each of four manufacturers was made available for the Phase 2 testing requirements.

Results of the first year of testing are now being documented in a final report to be released by the end of April 1979. Meanwhile, the second year's testing effort is getting under way. In the follow-on phase new types of cells. i.e., cells made of polycrystalline material, cells with ion-implanted junctions, and cells made with different metallization systems will be added to the clemson test prugram. 


\section{ACCELERATED SUNLIGHT ENDURANCE TESTING OF SOLAR CELL MODULES \\ DSET Laboratories, Inc. Phoenix, Arizona}

The accelerated aging of Block II mini-modules was continued using DSET's Super-MAQ Fresnel-concentrating accelerated weathering machine. Through March 19, 1979, five of the modules had been subjected to approximately 1,300,000 langleys of radiation, one module to $1,200,000$ langleys, and two modules to 500,000 langleys.

Weekly visual inspections have revealed the development of delamination, cracked cells, carbonation, and contact corrosion within some modules. The weckly reports are supplewented by munthly slide photos of all modules.

I-V measurements are made for each module on a monthly basis. Global insolation measurements are made with a WMO Class I pyranometer. Normal incident (direct) measurements are made with a pyrheliometer for reference. An $A / D$ buffer has been added to DSET's computer facility and now is employed in obtaining $I-V$ measurements. This permits the computerization of all data and digital plotting of the un-normalized I-V curves. JPL algorithms are being programmed into DSET's computer for plotting normalized I-V curves.

is

Cooling studies on Super-MAQ aimed at maintaining modules at or near NOCT during exposure are contemplated for the immediate future. 
5. Operations Area

\section{FIELD EXPERIENCE UPDATE \\ LARRY DUMAS \\ OPERATIONS MANAGER}

\section{ANTONIAK'S SECOND LAW}

"THERE'S TOO MUCH DATA AND NOT ENOUGH THINKING"

DATA BASE: MODULES

BLOCK BUY HISTORY

\begin{tabular}{|c|c|c|c|c|}
\hline & BLOCK I & BLOCK II & BLOCK III & BLOCK IV \\
\hline FROM: & JAN 1976 & JUL 1976 & DEC 1977 & MAY 1979 \\
\hline TO: & UL1 $19 / 6$ & MAK IY'78 & JUINE 1979 & JUL 1980 \\
\hline POWER (kW) & 58 & 110 & 213 & TBO \\
\hline NUMBER OF CONTRACTORS & 4 & 4 & 5 & 8 \\
\hline LARGEST DELIVERY (KWIMO) & $\ln .5$ & 23.4 & 36.0 & - \\
\hline PRICE $1975 \$ \mathrm{\$ W}$ & 21.0 & 13.7 & 10.4 & - \\
\hline
\end{tabular}




\section{BLOCK BUY MODULE UTILIZATION (kW)}

\begin{tabular}{|c|c|c|c|c|}
\hline $\mathrm{CK}$ & BLOCK II & BLOCK III & DAT & LEVEL OF \\
\hline
\end{tabular}

MITLL

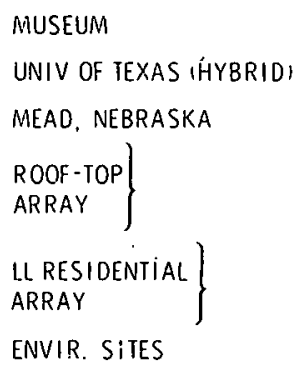

OTHER
1.6

$$
\begin{array}{r}
8.0 \\
28.2
\end{array}
$$

4.7

$$
\text { 4. } 4
$$

7.0

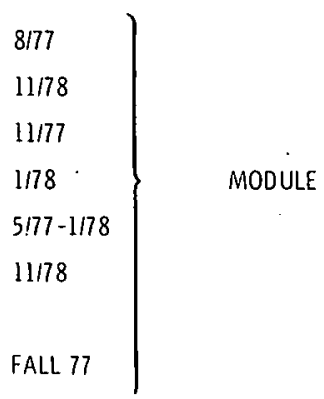

$4 / 77-10 / 77$

11176

7/76-12/78

10176-SUM 78

$4 / 77-10177$

\section{BLOCK BUY MODULE UTILIZATION (kW)}

$\begin{array}{llll}\text { BLOCK I BLOCK II BLOCK III } & \text { DATE } & \text { LEVEL OF } \\ \text { SIELDED } & \text { SURVEILLANCE }\end{array}$

DOD

BATTERY CHARGERS

REMOTE RADAR

TELEPHONE VAN

WATER PURIFICATION"

RADIO SYSTEMS

JPL FIELD TEST SITES

$\begin{array}{ll}\text { PASADENA } & \left\{\begin{array}{l}0 . \\ \text { TABLE MOUNTAIN }\end{array}\right. \\ \text { GOLDSTONE } & \left\{\begin{array}{l}0 . \\ 0 .\end{array}\right.\end{array}$

POINT VICENTE

JPLILERC ENUURANCE TEST SITES

VARIOUS LOCATIONS
0.6
8. 1
2.7
10.6
0.3

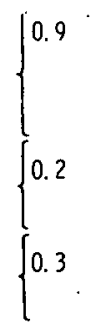

1.4

DECOMISSIONED

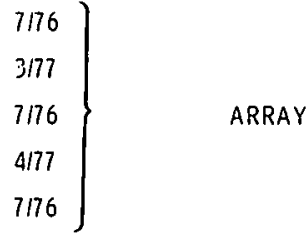

SPRING 77

FALL 77

$1 / 79$

$11 / 76-3 / 77$

1/77-10/77

4/76-12176

$4 / 77-9 / 77$

8178

MODULE

$10177-5 / 78 \quad$ MODULE 
FORMS OF FIELD DEGRADATION

- electrical faILuRe

- PHYSICAL DEgRAdation

- ELECTRICAL DEgRADATION

PROBLEM/FAILURE REPORT (P/FR) FLOW PLAN

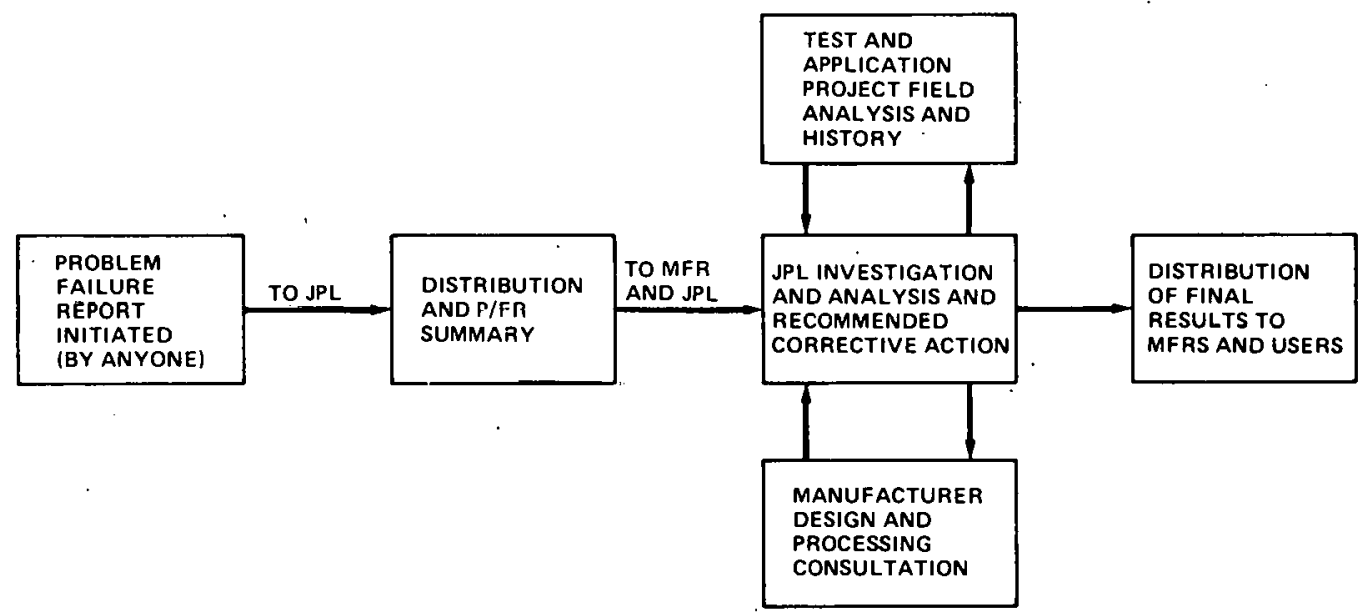

PROBLEM/FAILURE REPORT (P/FR) STATUS

\begin{tabular}{|l|c|c|c|c|c|}
\hline PROCUREMENT & $\begin{array}{c}\text { NUMBER } \\
\text { OF } \\
\text { PIFR'S }\end{array}$ & $\begin{array}{c}\text { NUMBER } \\
\text { OF PIFR'S } \\
\text { CLOSED }\end{array}$ & $\begin{array}{c}\text { ENVIRONMENTAL } \\
\text { TEST }\end{array}$ & $\begin{array}{c}\text { JPL } \\
\text { FIELD } \\
\text { TEST }\end{array}$ & $\begin{array}{c}\text { FIELO TESI \& } \\
\text { APPLICATION } \\
\text { PROIECTS }\end{array}$ \\
\hline BLOCK I & 173 & 159 & 100 & 34 & 39 \\
BLOCK II. & 145 & 119 & 105 & 3 & 37 \\
BLOCK III & 54 & 43 & 54 & 0 & 0 \\
DEVELOPMENTAL & 46 & 30 & 43 & 3 & 0 \\
COMMERCIAL & 41 & 25 & 41 & 0 & 0 \\
MISC. & 38 & 3 & 38 & 0 & 0 \\
\hline TOTAL & 497 & 379 & 381 & 40 & 76 \\
\hline
\end{tabular}


FIELD TEST \& APPLICATION P/FR SUMMARY

\begin{tabular}{|c|c|c|c|c|c|c|c|}
\hline & $\begin{array}{c}\text { INTERCONNECT } \\
\text { FRACTURES }\end{array}$ & $\begin{array}{c}\text { UNSOLDERED } \\
\text { INTERCONNECTS }\end{array}$ & $\begin{array}{c}\text { HAIL } \\
\text { DAMAGE }\end{array}$ & $\begin{array}{c}\text { CRACKED } \\
\text { CELLIS }\end{array}$ & $\begin{array}{c}\text { WIRE \& } \\
\text { TERMINAL } \\
\text { CORROSION }\end{array}$ & $\begin{array}{c}\text { GROUNDED } \\
\text { CELL } \\
\text { STRING }\end{array}$ & $\begin{array}{c}\text { ENCAPSULANT } \\
\text { DELAMINATION }\end{array}$ \\
\hline BLOCK I & 31 & 7 & 2 & 10 & 3 & 2 & 16 \\
\hline BLOCK II & 0 & 8 & 9 & 16 & 0 & 4 & 5 \\
\hline TOTAL & 31 & 15 & 11 & 26 & 3 & 6 & 21 \\
\hline
\end{tabular}

\section{FAILURE MODE-INTERCONNECT FRACTURES}

- Number of occurRences

- NUMBER OF MANUfACTURERS INVOLVED

- EFFECT: OPEN CIRCUIT; ELECTRICAL OUTPUT DEGRADATION; HOT SPOTS AND OVERHEATING

- Probable cause: design/WORKMANSHIP

- CORRECTIVE ACTION: STRESS RELIEF DESIGN.AND PRODUCTION CONTROL
31

4

\section{FAILURE MODE-UNSOLDERED INTERCONNECT}

- NUMBer of ocCURRENCES

15

- NUMBER OF MANUFACTURERS

- EFFECT: OPEN CIRCUIT

- PROBABLE CAUSE: WORKMANSHIP

- CORRECTIVE ACTION: PROCESS CONTROL

\section{FAILURE MODE-HAIL. DAMAGE}

- NUMBER Of OCCURRENCES

- NUMBer of manufacturers

2

- efFect: open circuit; electrical degradation

- frobable cause: design

- CORRECTIVE ACTION: DESIGN FOR ENVIRONMENT

REFERCNCE: ENVIRONMENTAL HAIL MODEL FOR ASSESSING RISK TO SOLAR COLLECTORS, LSA $5101-45$

PHOTOVOLTAIC SOLAR PANEL RESISTANCE TO SIMULATED HAIL, LSA S101-62 


\title{
FAILURE MODE-CRACKED CELLS
}

- Number of occurrences

- number of manufacturers

- effect: open cIRCuIt; electrical degradation; local overheating

- PROBABLE CAUSE: DESIGNIWORKMANSHIP

- CORRECTIVE ACTION: ·

(a) DESIGN TO MINIMIZE THERMAL AND MECHANICAL SIRESSES ON CELLS

(b) IMPROVE INPROCESS INSPECTION AND HANDLING TO AVOID BADLY CHIPPED OR PARTIALLY CRACKED CELLS IN COMPLETED PRODUCT

REFERENCE: REJECIION CRITERIA FOR JPL LSA MODULES, LSA 510I-21 REV A

\section{FAILURE MODE-WIRE AND TERMINAL CORROSION}

- NUMBER of OCCURRENCES

- Number of manUfacturers

- EFFECT: electrical degradation

- PROBABLE CAUSE: DESIGN/WORKMANSHIP

- CORRECTIVE ACTION: IMPROVE MATERIAL SELECTION; TORQUE SPECS FOR MECHANICAL CONNECTION

\section{FAILURE MODE-GROUNDED CELL STRING}

\author{
- number mf nc.culRrences 6 \\ - NUMBER Óf MANUFAC:HIKR.RS 3 \\ - EFFECT: SAFETY hAZARD \\ - Probable cause: workmanship \\ - CORRECTIVE ACTION: IMIPROVE ASSEMBLY TECHNIQUES
}

FAILURE MODE-ENCAPSULANT DELAMINATIUN

- number of ocCuRrenCes

- nlimber ur mainufacturers ínvolved 3

- eFfFct: moIstuRe penetration and entRapment

- probable cause: oesicniworkmanship

- CORRECTIVE action: more eXACTING PREPaRation of asSEmbly SURFACES DURING MANUFACTURE AND SELECTION OF COMPATIBLE MAIËKIALS

REFERENCE: EXPERIENCE W!TH SILICONES IN PHOTOVOLTAIC MODULES. DOEIJPL - $1012-79 / 8$

PHOTODEGRADATION OF POLYMERIC ENCAPSULANTS OF SOI.AR CELL MODULES, LSA 5101-77. 
FAILURE OBSERVATIONS: PROBLEMS AND RECOMMENDATIONS

\begin{tabular}{|c|c|}
\hline PROBLEM & POTENTIAL SOLUTIONISI \\
\hline $\begin{array}{l}\text { - FAILURES DIFFICULT TO } \\
\text { DETECT IN AN ARRAY : }\end{array}$ & $\begin{array}{l}\text { - MODULE LEVEL TESTING } \\
\text { - IMPROVED DETECTION METHODS }\end{array}$ \\
\hline $\begin{array}{l}\text {-FAILURES DIFFICULT TO } \\
\text { ISOLATE IN AN ARRAY }\end{array}$ & $\begin{array}{l}\text { - IMPROVEO DETECTION METHODS } \\
\text { - TEST POINT ACCESS }\end{array}$ \\
\hline - UNCERTAIN DATA BASE & $\begin{array}{l}\text { - FOCUS ON WELL INSTRUMENTED AND } \\
\text { ATTFNOEN SITES }\end{array}$ \\
\hline
\end{tabular}

\section{PHYSICAL DEGRADATION}

- DEPENDENT ON VISUAL OBSERVATIONS

- RESULTS REPORTED IN VARIOUS JPL, LeRC, AND MITILL

PUBLICATIONS

- typically little correlation with failure data

\section{PHYSICAL DEGRADATION OBSERVATIONS: PROBLEMS AND RECOMMENDATIONS}

\begin{tabular}{|l|l|}
\hline PROBLEM & POTENTIAL SOLUTIONISI \\
\hline $\begin{array}{l}\text { INCONSISTENCIES IN } \\
\text { REPORTED VISUAL } \\
\text { OBSERVATIONS }\end{array}$ & $\begin{array}{l}\text { DEVELOP UNIFORM INSPECTION } \\
\text { METHODOLOGIES AND DEGRADATION } \\
\text { CLASSIFICATION }\end{array}$ \\
\hline -LACK OF CORRELATION & IMPROVE INSPECTION METHODOLOGY \\
WITH RELIABILITYI & AND DEGRADATION CLASSIFICATION \\
LIFETIME DATA & BASED ON FIELD EXPERIENCE AND \\
& RELIABILITYILIFETIME STUDIES \\
& OEVVELOP IAPPLY NON-VISUAL TECHNIQUES \\
\hline
\end{tabular}

\section{ELECTRICAL DEGRADATION}

- DEPENDS ON DETECTION, ISOLATION, AND OUANTITATIVE. MEASUREMENTS

- TYPically unREPORTEd

- COMMON CAUSES:

- CRACKEO CELLS

- CORRODED CIRCUITRY

-DIRT

-AND. ..? 
CORRECTED ISC HISTORY FOR A REPRESENTATIVE BLOCK II MODULE

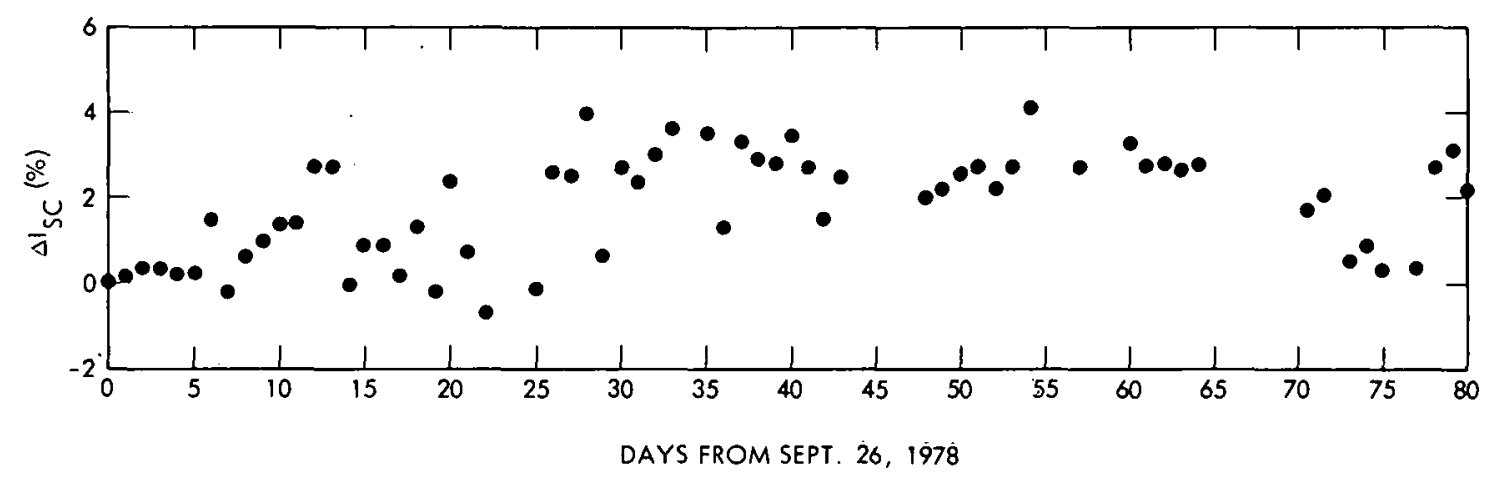

ELECTRICAL DEGRADATION OBSERVATIONS:

PROBLEMS AND RECOMMENDATIONS

\begin{tabular}{|c|c|}
\hline PROBLEM & POTENTIAL SOLUTIONISI \\
\hline $\begin{array}{l}\text { - LACK OF QUANTITATIVE } \\
\text { DATA }\end{array}$ & $\begin{array}{l}\text { - IMPROVED IN-SITU MEASUREMENT } \\
\text { TECHNIQUES ANO EQUIPMENT } \\
\text { - LABORATORY MEASUREMENTS OF SAMPLES } \\
\text { - MODULE AND SUB -MODULE FIELO } \\
\text { EXPERIMENTATION }\end{array}$ \\
\hline
\end{tabular}

\section{OVERALL CONCLUSIONS/RECOMMENDATIONS}

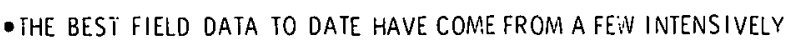
MUUNI TUREU SITES

- FNILURE RATES ARE LUW!

- CORRELATION WIIH ENVIRONMENTAL STRESS LEVELS IS LACKING

- PROBLEMIFAILURE REPORTING ANU ANALYSIS SYSTEM HAS PROVEN

VALUABLE AND SHOULD BE EXPANDED BEYOND LSA PROCUREMENTS

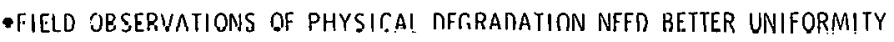
AND INTEGRATION WITH RELIABILITYILIFETIME EFFORTS

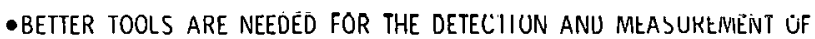
FIELD OEGRAUATION

- an overall plan for data acquisition is neEOed 